\title{
EDUCAÇÃO: VISÕES E ESTRUTURAS
}




\section{PEMBROKE COLLINS CONSELHO EDITORIAL}

PRESIDÊNCIA Felipe Dutra Asensi

CONSELheiros Adolfo Mamoru Nishiyama (UNIP, São Paulo)

Adriano Moura da Fonseca Pinto (UNESA, Rio de Janeiro)

Adriano Rosa (USU, Rio de Janeiro)

Alessandra T. Bentes Vivas (DPRJ, Rio de Janeiro)

Arthur Bezerra de Souza Junior (UNINOVE, São Paulo)

Aura Helena Peñas Felizzola (Universidad de Santo Tomás, Colômbia)

Carlos Mourão (PGM, São Paulo)

Claudio Joel B. Lossio (Universidade Autónoma de Lisboa, Portugal)

Coriolano de Almeida Camargo (UPM, São Paulo)

Daniel Giotti de Paula (INTEJUR, Juiz de Fora)

Danielle Medeiro da Silva de Araújo (UFSB, Porto Seguro)

Denise Mercedes N. N. Lopes Salles (UNILASSALE, Niterói)

Diogo de Castro Ferreira (IDT, Juiz de Fora)

Douglas Castro (Foundation for Law and International Affairs, Estados Unidos)

Elaine Teixeira Rabello (UERJ, Rio de Janeiro)

Glaucia Ribeiro (UEA, Manaus)

Isabelle Dias Carneiro Santos (UFMS, Campo Grande)

Jonathan Regis (UNIVALI, Itajaí)

Julian Mora Aliseda (Universidad de Extremadura. Espanha)

Leila Aparecida Chevchuk de Oliveira (TRT 2a Região, São Paulo)

Luciano Nascimento (UEPB, João Pessoa)

Luiz Renato Telles Otaviano (UFMS, Três Lagoas)

Marcelo Pereira de Almeida (UFF, Niterói)

Marcia Cavalcanti (USU, Rio de Janeiro)

Marcio de Oliveira Caldas (FBT, Porto Alegre)

Matheus Marapodi dos Passos (Universidade de Coimbra, Portugal)

Omar Toledo Toríbio (Universidad Nacional Mayor de San Marcos, Peru)

Ricardo Medeiros Pimenta (IBICT, Rio de Janeiro)

Rogério Borba (UVA, Rio de Janeiro)

Rosangela Tremel (UNISUL, Florianópolis)

Roseni Pinheiro (UERJ, Rio de Janeiro)

Sergio de Souza Salles (UCP, Petrópolis)

Telson Pires (Faculdade Lusófona, Brasil)

Thiago Rodrigues Pereira (Novo Liceu, Portugal)

Vania Siciliano Aieta (UERJ, Rio de Janeiro) 


\section{ORGANIZADORES:}

CRISTINA ROLIM WOLFFENBÜTTEL, JANILTON DE LIMA ALMEIDA,

JOSÉ MORAIS SOUTO FILHO, KARINA MEDEIROS PIRANGY DE SOUZA

\section{EDUCAÇÃO: VISÕES E ESTRUTURAS}

PEMBROKE COLLINS

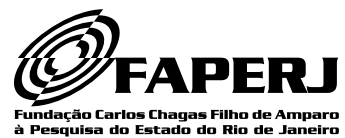

à Pesquisa do Estado do Rio de Janeiro

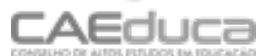

PEMBROKE COLLINS

Rio de Janeiro, 2021 


\section{Copyright @ 2021 $\mid$ Cristina Rolim Wolffenbüttel, Janilton de Lima Almeida, José Morais Souto Filho, Karina Medeiros Pirangy de Souza (orgs.)}

DIREÇÃO EDITORIAL Felipe Asensi

ediçăo e editoração Felipe Asensi

REvIsÃo Coordenação Editorial Pembroke Collins

projeto grafico e capa Diniz Gomes

diagramaÇåo Diniz Gomes

DIREITOS RESERVADOS A

\section{PEMBROKE COLLINS}

Rua Pedro Primeiro, 07/606

20060-050 / Rio de Janeiro, RJ

infoapembrokecollins.com

www.pembrokecollins.com

TODOS OS DIREITOS RESERVADOS

Nenhuma parte deste livro pode ser utilizada ou reproduzida sob quaisquer meios existentes sem autorização por escrito da Editora.

FINANCIAMENTO

Este livro foi financiado pela Fundação de Amparo à Pesquisa do Estado do Rio de Janeiro, pelo Conselho Internacional de Altos Estudos em Direito (CAED-Jus), pelo Conselho Internacional de Altos Estudos em Educação (CAEduca) e pela Pembroke Collins.

Todas as obras são submetidas ao processo de peer view em formato double blind pela Editora e, no caso de Coletânea, também pelos Organizadores.

E24

Educação: visões e estruturas / Cristina Rolim Wolffenbüttel, Janilton de Lima Almeida, José Morais Souto Filho e Karina Medeiros Pirangy de Souza (organizadores). - Rio de Janeiro: Pembroke Collins, 2021.

$564 \mathrm{p}$

ISBN 978-65-89891-26-0

1. Educação básica. 2. Educação de jovens e adultos. 3. Educação superior. I. Wolffenbüttel, Cristina Rolim (org.). II. Almeida, Janilton de Lima (org.). III. Souto Filho, José Morais (org.). IV. Souza, e Karina Medeiros Pirangy de (org.). 


\section{SUMÁRIO}

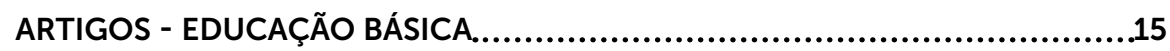

PROGRAMA DE ESCOLAS ESTADUAIS DE ENSINO MÉDIO EM TURNO ÚNICO. AS "ESCOLAS VIVAS" (2015-2019) DO ESPÍRITO SANTO, BRASIL. UMA ANÁLISE EPISTEMOLÓGICA: REFLEXÕES SOBRE PARADIGMA EDUCACIONAL

Vitor Martins Graciliano

A ATUAÇÃO DO PROFESSOR COMO MEDIADOR NO PROCESSO DE ENSINO-APRENDIZAGEM NA EDUCAÇÃO INFANTIL.................................27 Yasmim Lorena Nunes Barbosa

O PAPEL DAS GARATUJAS PARA AS CRIANÇAS DE 0 A 3 ANOS NA EDUCAÇÃO INFANTIL: UMA REVISÃO. .40

Gisleine Cristina da Silva

A LEITURA NA PRIMEIRA INFÂNCIA E O NASCIMENTO DE NOVOS LEITORES NA EDUCAÇÃO INFANTIL. .55

Gisleine Cristina da Silva

ENSINO E APRENDIZAGEM: REFLEXÕES SOBRE OS IMPACTOS DO ENSINO REMOTO NA PANDEMIA DE COVID-19. .68

Diego Neves Sampaio

Débora Karpowicz

PROCESSOS DE INDUÇÃO DE PROFESSORES INICIANTES NA ESCOLA BÁSICA: UMA REVISÃO. .85 Aurineide Maria de Almeida Castro Islane Cristina Martins 
O IDEB E O INCENTIVO A UMA POLÍTICA PÚBLICA DESIGUAL: UMA ANÁLISE DA EVOLUÇÃO DA QUALIDADE EDUCACIONAL NAS CAPITAIS BRASILEIRAS A PARTIR DA INSERÇÃO DO NÍVEL SOCIOECONÔMICO. .102 Heloisa Borella Zamboim

PROCESSOS DE ACOMPANHAMENTO QUE POTENCIALIZAM APRENDIZAGENS: CASE DE DUAS ESCOLAS DE PORTO ALEGRE .120 Fernando Degrandis

PARECER DOCENTE SOBRE A EDUCAÇÃO INCLUSIVA DE ALUNOS NECESSITADOS ESPECIAIS (NEE) NAS ESCOLAS DO ENSINO INFANTIL E FUNDAMENTAL .132

Kleber Lima de Souza

Loana Patrícia Lopes Souto

Odvan Pereira de Gois

Marcos Antônio Medeiros do Nascimento

ALFABETIZAÇÃO CIENTÍFICA E TECNOLÓGICA: POSSIBILIDADES NO ENSINO DA EDUCAÇÃO BÁSICA....................................................145 Lesly Diana Pimentel Yong Hendy Barbosa Santos

OS PROFESSORES E A EDUCAÇÃO PARA O TRÂNSITO NAS ESCOLAS.............158 José Carlos Teixeira Pistilli

Fabiana Mabel Azevedo de Oliveira

"A CAUSA SECRETA" DE MACHADO DE ASSIS: IDEOLOGIAS E COMPORTAMENTOS 172 Maria Eliete Silva Pereira

A BASE NACIONAL COMUM CURRICULAR (BNCC) NO ENSINO DA MATEMÁTICA ANOS INICIAIS: AVANÇO E/OU RETROCESSO? .182 Heidyani Leão de Souza

PERFIL DOCENTE NA EDUCAÇÃO INFANTIL: COMPETÊNCIA PROFISSIONAL OU QUESTÃO DE GÊNERO?. 199 Eduardo Gasperoni de Oliveira Daiane Nonato de Lima José Morais Souto Filho 
INTERFACES DO ENSINO DE GEOGRAFIA: O CURRÍCULO E O MATERIAL OFICIAL DA REDE PÚBLICA PAULISTA DE ENSINO REGULAR - ANOS FUNDAMENTAIS 228

Jefferson Luis Brentini da Silva

UM BREVE RELATO DA VALORIZAÇÃO DA EDUCAÇÃO INFANTIL NA HISTÓRIA DA HUMANIDADE. 245

Michele Padilla Pedroso Vígari

REFLEXIVIDADE E PRÁTICA DOCENTE: NARRATIVAS DE PROFESSORAS ALFABETIZADORAS .259

Liliana Monteiro Carcará

LEGISLAÇÃO E POLITICAS PÚBLICAS PARA A EDUCAÇÃO INFANTIL: DA LEI DE DIRETRIZES E BASES DA EDUCAÇÃO (LDB 9394/96) AOS DIAS ATUAIS 267 Camila Mourão Borges

A GESTÃO DO RISCOS NA EDUCAÇÃO BÁSICA BRASILEIRA.........................280 Solange Feliciano Pires

\section{ARTIGOS - EDUCAÇÃO PROFISSIONAL, TECNOLÓGICA E DE JOVENS E ADULTOS}

CARACTERÍSTICAS PEDAGÓGICAS DAS POLITITICAS PÚBLICAS APLICADAS AO EXTENSIONISMO RURAL: UMA ANÁLISE DO ESTADO DE SÃO PAULO.......299 Júlia Garcia da Silva João Paulo Pereira Duarte

A FORMAÇÃO DO PROFESSOR DA EJA: A CONCEPÇÃO FREIREANA NA CONSTRUÇÃO DO PERFIL DO EDUCADOR-TRANSFORMADOR....................316 Herson Conceição

Rosana Assis dos Santos

INFOEJA: UMA PROPOSTA DE PRODUTO EDUCACIONAL NO ENSINO DE INFORMÁTICA DO CURSO DE ADMINISTRAÇÃO DO PROEJA. 332 Aline Carla de Sousa Leite Cipriano

A AÇÃO SUPERVISORA NO SUCESSO/INSUCESSO ESCOLAR DA EJAI NAS ESCOLAS MUNICIPAIS DE NINA RODRIGUES-MA. 349 Silvia de Fátima Nunes da Silva 
CONCEPÇÕES DE PROFESSORES BRASILEIROS E FINLANDESES SOBRE COMUNIDADE DE APRENDIZAGEM .367

Azenaide Abreu Soares Vieira

Paula Renata Cameschi de Souza

ARTIGOS - ENSINO SUPERIOR. 388

ENSINO SUPERIOR PRIVADO NO BRASIL E AGENDA 2030. 390 André Serotini

A EXPANSÃO DO SABER: O PAPEL DA MÚSICA EM UNIVERSIDADES CONFESSIONAIS. .403 Jetro Meira de Oliveira

AFETIVIDADE E EDUCAÇÃO: A NECESSIDADE DO ENSINO AFETIVO NA EDUCAÇÃO UNIVERSITÁRIA. .422

Walfrido Monteiro Júnior

OS DESAFIOS DO ENSINO JURÍDICO E O PROFESSOR COMO MEDIADOR EM TEMPOS DE COVID-19. .441

Gabrielle Apoliano Gomes Albuquerque Pearce

Luiz Alberto Gomes Barbosa Neto

A BASE NACIONAL COMUM CURRICULAR E A EDUCAÇÃO FINANCEIRA. .458 Jefferson Florencio Rozendo

A EDUCAÇÃO E A PSICANÁLISE NA GESTÃO DOS CONFLITOS. .468 Jefferson Florencio Rozendo

\section{RESUMOS}

O ALUNO NÃO É O PROBLEMA: O PROTAGONISMO DA TERAPIA OCUPACIONAL EM EDUCAÇÃO JUNTO À COMUNIDADE ESCOLAR. .482 Victor Matheus Marinho Dutra

PROFESSORES DE EDUCAÇÃO FÍSICA E BNCC: ALGUMAS REFLEXÕES. .488 Anderson José de Oliveira

RELAÇÕES ÉTNICO-RACIAIS E AUTOCONHECIMENTO NO ENSINO FUNDAMENTAL I: COMO OS EDUCANDOS PERCEBEM/SENTEM O RACISMO ESTRUTURADO (ESTUDO DE CASO). .492 Vitor Martins Graciliano 
MULTICULTURALISMO, RELAÇÕES ÉTNICO-RACIAIS: UMA POSSIBILIDADE DE INTERVENÇÃO NO COMPONENTE CURRICULAR EDUCAÇÃO FÍSICA .496 Anderson José de Oliveira

O CONTEXTO DE PRODUÇÃO DA BNCC E SEUS REFLEXOS PARA A EDUCAÇÃO BÁSICA: APONTAMENTOS HISTÓRICOS.... .502 Luan Tarlau Balieiro

ENSINO E APRENDIZAGEM EM GEOGRAFIA: REFLEXÕES A PARTIR DA PANDEMIA DA COVID-19. 508 Diego Neves Sampaio

DESAFIOS DA EDUCAÇÃO BÁSICA EM TEMPOS DE ENSINO REMOTO...........516 Laiane Michele Silva Souza

EJA NO SISTEMA PRISIONAL BRASILEIRO. .521 Lanita Helaine S. N. Sizanosky

UTILIZAÇÃO DO DIÁRIO DE BORDO PARA DESENVOLVIMENTO DE COMPETÊNCIAS E AUTONOMIA COM ALUNOS DO PROEJA. .526 Leonardo do Monte Rabelo

POLITICAS PÚBLICAS PARA EDUCAÇÃO DE JOVENS E ADULTOS: UM ESTUDO SOBRE A IMPLANTAÇÃO EM GOIÁS.

César de Araújo Pires

Daniella Couto Lôbo

A FALTA DA EDUCAÇÃO FINANCEIRA E MARKETING NOS CURSOS DE DIREITO EM SERGIPE .538 Lavinia de Almeida Souza

ESTABELECIMENTO E DESENVOLVIMENTO DA MICROBIOTA INTESTINAL EM IDADE PEDIÁTRICA. .543

Amanda do Nascimento Souza

EFEITOS DOS NUTRIENTES ANTIOXIDANTES NO ESTRESSE OXIDATIVO INDUZIDO PELO EXERCÍCIO FÍSICO..................................................546 Amanda do Nascimento Souza 
PERSPECTIVAS COM O LETRAMENTO DIGITAL E REMOTO NA PRÁTICA PROFISSIONAL JURÍDICA INTRODUZIDA PELA RESOLUÇÃO № 2 DO CNE/CES

Thiago de Souza Modesto

A PERCEPÇÃO DOS PROFESSORES UNIVERSITÁRIOS SOBRE O

TRABALHO REMOTO: LIMITES E POSSIBILIDADES....................................556

Otília Maria A. N. A. Dantas

Lidiane Oliveira Eduardo Mota

Pauliane Duarte de Almeida

Rafael Rodrigues de Melo 


\section{CONSELHO CIENTÍFICO DO CAEdUCa}

Adriano Rosa (USU)

Antonio Gasparetto (IFSMG)

Cristiane Barroncas Maciel Costa Novo (UEA)

Fabiana Eckhardt (UCP)

Felipe Asensi (UERJ)

Glaucia Ribeiro (UEA)

Jardelino Menegat (UniLassale)

Jose Miranda (UNIMB)

Marcelo Mocarzel (UniLassale)

Marcia Cavalcanti (USU)

Rafael Bastos de Oliveira (UCP)

Robert Segal (Unirio)

Rosangela Tremel (Unisul)

Sergio Salles (UCP)

Thiago Mazucato (FUNEPE) 



\section{SOBRE O CAEduca}

\section{O Conselho Internacional de Altos Estudos em Educação}

(CAEduca) é iniciativa consolidada e reconhecida de uma rede de acadêmicos para o desenvolvimento de pesquisas e reflexões interdisciplinares de alta qualidade em educação.

O CAEduca desenvolve-se via internet, sendo a tecnologia parte importante para o sucesso das discussões e para a interação entre os participantes através de diversos recursos multimídia.

O evento é um dos principais congressos acadêmicos do mundo e conta com os seguintes diferenciais:

- Abertura a uma visão multidisciplinar e multiprofissional sobre a educação, sendo bem-vindos os trabalhos de acadêmicos de diversas formações;

- Democratização da divulgação e produção científica;

- Publicação dos artigos em livro impresso no Brasil (com ISBN), com envio da versão virtual aos participantes;

- Galeria com os selecionados do Prêmio CAEduca de cada edição;

- Interação efetiva entre os participantes através de ferramentas via internet;

- Exposição permanente do trabalho e do vídeo do autor, durante o evento, para os participantes;

- Coordenadores de GTs são organizadores dos livros publicados.

O Conselho Científico do CAEduca é composto por acadêmicos de alta qualidade no campo da educação em nível nacional e internacional. 
Em 2021, o CAEduca organizou o seu tradicional Congresso Internacional de Altos Estudos em Educação (CAEduca 2021), que ocorreu entre os dias 26 e 28 de maio de 2021 e contou com 10 Grupos de Trabalho com mais de 350 artigos e resumos expandidos de 31 universidades e 19 programas de pós-graduação stricto sensu. A seleção dos trabalhos apresentados ocorreu através do processo de peer review com double blind, o que resultou na publicação dos 7 livros do evento.

Os coordenadores de GTs organizaram os respectivos livros, e no caso de GTs que não tenham tido ao menos 18 trabalhos aprovados, estes foram realocados em outro GT, conforme previsto em edital específico. Os coordenadores de GTs também indicaram artigos para concorrer ao Prêmio CAEduca 2021. A Comissão Avaliadora foi composta pelas professoras Dras. Ana Maria Paula Marques Gomes (Escola Superior de Educação de Paula Frassinetti - Porto - Portugal), Juliana Fernandes Teixeira (Universidade Federal do Piauí) e Maria de Lourdes Borges (Unilasalle). O trabalho premiado é de autoria de José Roberto Limas da Silva, intitulado "O topocídio e o esvaziamento das memórias afetivas: agravamentos e repercussões em face da pandemia da covid- 19”.

Esta publicação é financiada por recursos da Fundação de Amparo à Pesquisa do Estado do Rio de Janeiro (FAPERJ), do Conselho Internacional de Altos Estudos em Direito (CAED-Jus), do Conselho Internacional de Altos Estudos em Educação (CAEduca) e da Editora Pembroke Collins e cumpre os diversos critérios de avaliação de livros com excelência acadêmica nacionais e internacionais. 


\section{ARTIGOS - EDUCAÇÃO BÁSICA}





\section{PROGRAMA DE ESCOLAS ESTADUAIS DE ENSINO MÉDIO EM TURNO ÚNICO. AS "ESCOLAS VIVAS" (2015- 2019) DO ESPÍRITO SANTO, BRASIL. UMA ANÁLISE EPISTEMOLÓGICA: REFLEXÕES SOBRE PARADIGMA EDUCACIONAL}

Vitor Martins Graciliano ${ }^{1}$

INTRODUÇÃO

O Programa de Escolas Estaduais de Ensino Médio em Turno Único, denominado "Escola Viva". Teve como principal teórico Antônio Carlos Magalhães e base metodológica a "Escola da Escolha", que no Brasil teve seu início nos anos de 2000, em Recife-PE (PETERLE, 2015, p. 137). A implantação desse modelo educacional em Pernambuco foi protagonizada pela parceria do Instituto de Corresponsabilidade pela Educação (ICE) e o Governo do Estado de Pernambuco. O ICE é uma entidade sem fins econômicos e foi criado em 2003 por um grupo de empresários que idealizavam um novo modelo de escola para resgatar a antiga excelência do

1 Bacharel em Direito, Licenciado em geografia, Especialista em Psicopedagogia e Educação Ambienta. Pesquisador da área de Educação: currículo, práticas escolares e relações étnico-raciais. 
então decadente e secular Ginásio Pernambucano, localizado em Recife. (ICE 2021).

A Lei Complementar n. 799/2015 criou o Programa Escola Viva. Foi aprovada em regime de urgência, sem as devidas deliberações na Assembleia Legislativa do Espírito Santo (ALES), sem a discussão prévia com a sociedade capixaba. Teve o ICE como principal parceiro e organizador do projeto, nesses termos, foi vista, pela primeira vez na rede estadual de ensino, uma política pública de educação tão ampla e impactante pautada na relação entre o público e o privado. O projeto Escola Viva foi implantado, ampliado e extinto em quatro anos e meio. Nos anos 2015 a 2019, o Programa foi implantado em 36 unidades escolares, ultrapassando a meta estabelecida de 32 unidades, proposta pelo Governo capixaba e pela ONG Espírito Santo em Ação (TEIXEIRA, 2017).

Substituído no ano de 2020 pelo Programa de Ensino Integral, criado pelo Projeto de Lei Complementar (PLC) n. 58/2019, do governador Renato Casagrande, também foi aprovado em regime de urgência na ALES. O programa Escola Viva foi extinto deixando inúmeros questionamentos, indagações e um legado significativo no currículo da educação básica da Rede Estadual de Ensino do Espírito Santo. Dentre as mudanças iniciadas na Rede Estadual de Ensino Básico com o advento da Escola Viva, destacamos: a criação de uma nova figura na organização hierárquica gestora, o Professor Coordenador de Área (PCA) e as novas disciplinas: eletivas, Projeto de Vida (que no novo currículo substituirá as aulas de filosofia e sociologia no terceiro ano do Ensino Médio) e Estudo Orientado, por exemplo. As duas últimas foram implantadas também nas séries finais do Ensino Fundamental em 2021.

Esta pesquisa apresenta-se proeminente para que se entenda como o programa Escola Viva, oriundo de uma parceria público-privada, conseguiu influenciar tão significativamente os novos currículos estaduais da Educação Básica. Entender os meandros ideológicos e sua influência nas políticas públicas de educação é crucial para a compreensão, de que direção segue a política educacional do nosso estado, se a caminho da emancipação ou da alienação.

A temática educacional é sempre relevante, ainda mais aquela que almeja estudar questões curriculares, fator condicionante do trabalho de professores e desenvolvimento dos alunos, objeto de disputa entre diferen- 
tes grupos sociais (ARROYO, 2013). Diante disto, pretende-se apresentar os impactos curriculares que a Escola Viva trouxe aos novos currículos estaduais e, por consequência, a todo sistema educacional da rede estadual capixaba.

Neste contexto, nossos objetivos são apresentados de forma geral: no pensar, problematizar o significado e efeitos do projeto Escola Viva no cenário educacional estadual e para as demais redes da Educação Básica do Espírito Santo.

Consequentemente, são definidos como objetivos específicos os seguintes: Apresentação de uma análise do programa Escola Viva segundo aspectos epistemológicos e parâmetros quantitativos e qualitativos. Viabilização uma leitura comparativa do programa Escola Viva a partir de trabalhos acadêmicos e literatura cientifica sobre os temas em análise. E por fim, desenvolver o debate sobre o projeto educacional do governo do Espírito Santo e a participação dos seus atores nesse projeto.

\section{PRESSUPOSTOS METODOLÓGICOS}

Pela complexibilidade do projeto e suas múltiplas vertentes, entendemos que segundo a classificação de pesquisas de Gil (2002) a mais adequada para os fins almejados seja a Pesquisa Exploratória a partir de levantamento bibliográfico e análise de exemplos que "estimulem a compreensão” (SELLTIZ et al., 1977, p. 63, citado por GIL, 2002, p. 41).

Por se tratar de uma pesquisa cuja abordagem principal é qualitativa, propomos usar como procedimentos de coleta/produção de dados: a pesquisa documental e revisão de literatura, conforme delimita Gil (2002, p. 43). Segundo os princípios do acompanhamento cartográfico discursivo que permeia as forças que afetam as práticas políticas curriculares e que dialoga com a filosofia da diferença como potência para a análise dos complexos fios que tecem essas enunciações. (SILVA; MOREIRA, 2018, p. 1).

Foi desenvolvido uma pesquisa no banco de dados da CAPES e da UFES, com o recorte de dez (10) anos, buscando as principais produções acadêmicas relacionadas ao objeto de pesquisa e materiais que apresentassem dados ou pontos de convergência relevantes. Em seguida foi realizado o fichamento de livros, catálogos e artigos que compõem a revisão 
bibliográfica e o quadro teórico, necessários à fundamentação da pesquisa. Contribuirão tanto para a análise de nosso objeto de estudo, quanto na identificação dos fatores contextuais responsáveis pela temática.

No passo seguinte, foi desenvolvida uma "Redes de conversações" (CARVALHO; HOLZMEISTER, 2013) com profissionais que atuaram no programa ou pesquisaram e escreveram sobre ele. Buscando conhecer os discursos elaborados sobre seus objetos, por seus diferentes intérpretes, para então selecionar aqueles textos pertinentes à pesquisa ou que discorram sobre a problemática em pauta. "A diretriz cartográfica se faz por pistas que orientam o percurso da pesquisa sempre considerando os efeitos do processo do pesquisar sobre o objeto da pesquisa, o pesquisador e seus resultados”. (BARROS; PASSOS, 2009, p. 17). Esse alinhamento metodológico apresentou-se com maior potencial de contribuição, por apresentar os melhores subsídios epistemológicos para essa pesquisa e os suportes necessários.

\subsection{REVISÃO DE LITERATURA}

Por se tratar de um recorte/fato histórico muito recente os principais trabalhos que encontramos abordam principalmente o cenário de idealização e movimentos de implantação do programa Escola Viva no estado do Espírito Santo. Abordando esta temática é possível relacionar as dissertações de mestrado de: Ronan Salomão Gaspar (2016) com o título “As figurações na política estadual de educação em tempo integral no Espírito Santo" e Tatiana Gomes dos Santos Peterle cujo título foi: "A política estadual de educação no Espírito Santo: o papel do projeto 'Escola Viva' o direito social à educação básica e profissional”.

Na dissertação de mestrado, Peterle (2015) desenvolveu uma análise crítica das bases metodológicas e epistemológicas do referido programa. Apresentando ainda os aspectos das fases de instituição e de implantação da Escola Viva. Em suas conclusões, a pesquisadora afirma que a política do então governador Paulo Hartung na implantação do programa foi muito pouco dialógica e instituiu projetos que desintegraram o direito a uma Educação Básica e Profissional pública, integral e integradora, assumindo, assim, uma lógica empresarial de gestão privatizante da educação (PETERLE, 2015, p.190). 
Gaspar (2016) analisou as políticas públicas relacionadas ao sistema educacional tendo como objeto de estudo o compromisso do Estado com os princípios e fundamentos constitucionais: igualdade, equidade, isonomia, promoção social e transparência/publicidade. No referido trabalho, o autor concluiu que na implantação e primeiro ano do programa houve demasiada influência do setor privado em todos os processos, ferindo desta forma, os princípios constitucionais e democráticos supracitados, que devem reger as políticas públicas dos entes federativos e do Estado. Assim, em suas conclusões, o pesquisador classifica o programa como retrógrado e antidemocrático. Destarte, carece de debate e de ações coletivas para sua superação. (GASPAR, 2016, p.160).

As conclusões apresentadas pelos autores, convergem e são ratificadas pela afirmação dos pesquisadores que afirmam:

[...] o setor privado, ao obter o protagonismo, reduz a autonomia dos professores, com a pretensão, a um só tempo: melhorar os resultados nas avaliações em larga escala e nortear a gestão sob uma matriz gerencialista, a partir de modelos padronizados em valores empresariais, pautados na produtividade, eficiência e eficácia. (ALCÂNTARA; MATOS; COSTA, 2020, p.16).

Destarte, as deliberações argumentações e conclusões que os pesquisadores apresentaram. Torna-se imperioso que se pense, problematize e reflita-se, sobre os efeitos de práticas discursivas hegemônicas de políticas que reflitam esse discurso e as consequências desse tipo de programa para os cofres públicos e a eficiência das práticas pedagógicas do programa em análise para o desenvolvimento dos educandos segundo os constitucionais de democracia participativa onde o ser cidadão se concretiza por sua construção política.

\subsection{REFERENCIAL TEÓRICO}

Ao analisar o currículo do programa Escola Viva, a luz dos fundamentos curriculares de Arroyo a partir de sua obra "Currículo, território em disputa" (2013), onde o autor apresenta práticas pedagógicas desenvolvidas no espaço escolar que são desvalorizadas pelas organizações curricu- 
lares verticalizadas, produzidas de forma autoritária sem participação dos docentes e alunos que buscam uma formação para o trabalho, sobretudo.

Sabendo-se que todas políticas são derivadas de práticas discursivas permeadas por relações de poder que se origina a partir de uma construção psicossocial, assim sendo, para que se compreenda a essência de um projeto político pedagógico é imperativo estudá-lo a partir da filosofia que foi utilizada como sua base teórica como afirma Newton Duarte ao analisar um dos pilares do programa o "aprender a aprender" segundo Vigotski, afirma o autor que:

[...] à forma alienada e esvaziada pela qual é captada, no interior do universo ideológico capitalista, a necessidade de superação do caráter estático e unilateral da educação escolar tradicional, com seu verbalismo, seu autoritarismo e seu intelectualismo (DUARTE, 2001, p. 28).

Neste sentido, torna-se indispensável a análise do projeto segundo o viés da sociologia, com Christian Laval que discute no livro "A escola não é uma empresa" (2004), a crise de legitimidade da escola em tempos de avanço neoliberal e coloca em xeque os valores embutidos em termos hoje correntes na educação, como 'inovação' e 'eficiência'. A obra faz um diagnóstico geral das mudanças nos sistemas educacionais, influenciadas pelo chamado neoliberalismo escolar. Laval destaca a atuação das Organizações Internacionais que pressionam os sistemas de educação nacionais a fazer com que as instituições de ensino e os profissionais que nelas trabalham se moldem às necessidades do capitalismo contemporâneo. Vendidas como modernizadoras, medidas como as provas padronizadas e ideias como as de capital humano e de competências e habilidades se prestam mais a atender interesses do mercado que à formação e emancipação dos estudantes. "Entretanto, é preciso indicar que a realização de exames gerais uniformizados tomados como avaliação de sistemas de ensino podem levar ao estreitamento do currículo e à destituição dos sujeitos escolares de sua tarefa de maior responsabilidade e nobreza: elaborar currículo" (SILVA, 2019, p. 108).

Convergindo com Laval e Silva, identifica-se a crítica ao sistema educacional burocrático de Moacir Gadotti no livro "Escola Cidadã” (2004), 
em que o autor apresenta sua preocupação com a autonomia da escola, que para ele, trata-se da própria natureza da educação. Destaca ainda que: "A escola que está perdendo a sua autonomia também está perdendo sua capacidade de educar para a liberdade". (GADOTTI, 2004, p. 9). Gadotti salienta que a comunidade escolar, a partir da sua autonomia, é a única capaz de produzir real desenvolvimento da escola como instrumento de promoção social e combate às desigualdades do atual sistema capitalista neoliberal que utiliza o sistema educacional como instituição de controle e reprodutor de preconceitos, que amplia o abismo social e a opressão.

\section{CONSIDERAÇÕES FINAIS}

Importante destacarmos que o programa em análise foi um dos alvitres do projeto de governo que se desenvolveu em dois mandatos do ex-governador Paulo Hartung (2003-2010), mantida no primeiro mandato de Renato Casagrande (2011-2014) e retomada no terceiro mandato de 2015-2018 fase intensa de políticas neoliberais e unilaterais denominada "Era Paulo Hartung (2003-2016)". (OLIVEIRA; LIRIO, 2017)

Nesses termos, como apresentado pelos pesquisadores a:

Escola Viva faz parte de um conjunto de políticas que tem por finalidade passar adiante a responsabilidade da educação pública para a iniciativa privada. $O$ segundo é que tal projeto evidencia uma face autoritária da gestão Hartung que nega abrir canais de diálogo com a sociedade civil organizada na construção desse e de outros projetos que envolvam a educação (OLIVEIRA; LIRIO, 2017, p. 292).

Como docente desta Rede desde 2011, trabalhei por três anos no programa em análise. Desta forma, vivenciei esse paradigma educacional: neoliberal, antidemocrático e totalmente centrado verticalmente, com políticas de alteridade, com muitas restrições para alguns setores e gastos astronômicos para outros. Sobretudo, o mais relevante para esse trabalho são as análises realizadas a partir dos estudos e escritos dos pesquisadores aqui apresentados que apresentam e até denunciam que as políticas que convergiram no programa Escola Viva foram políticas: antidemocráticas e anticonstitucionais, tendo essa última constatação implicações jurídi- 
cas que deveriam ter sido questionadas nas esferas judiciais pelos órgãos competentes. No entanto, aconteceu mais uma vez, uma das "virtudes" políticas destes governadores: a hegemonia, e aprovação de todos os orçamentos e projetos em tempo recorde, sem oposição, e nem sequer questionamentos.

Desta forma, temos como considerações finais, e até mais do que isso, a esperança, mas uma esperança ativa, que através da nossa organização como docentes, pesquisadores e cidadãos que somos, novos ventos hão de soprar por essas terras capixabas e trarão a verdadeira democracia e o diálogo na gestão pública e uma política educacional pautada nos princípios constitucionais para a formação de cidadãos conscientes dispostos a lutar por uma sociedade mais justa e igualitária.

\section{REFERÊNCIAS}

ALCÂNTARA, A. B.; MATOS, L; COSTA, R. Programa Escola Viva no Estado do Espírito Santo: reflexões acerca da gestão educacional. Roteiro, v. 45, p. 1-20, 18 ago. 2020.

ARROYO, Miguel González. Currículo, território em disputa. Petrópolis, RJ: Vozes, 2013.

CARVAlHO, Janete Magalhães. HOLZMEISTER, Ana Paula Patrocínio. Potência das redes de conversações no cotidiano escolar: entre formas, forças e modos de constituição. Disponível em: https://periodicos.ufff.br/index.php/revistainstrumento/ article/ view/18869. Acesso em: 07 mar. 2021.

DUARTE, Newton. Vigotski e o "aprender a aprender": crítica às apropriações neoliberais e pós-modernas da teoria vigotskiana. Campinas, SP: Autores Associados, 2001. (Coleção educação contemporânea).

GADOTTI, Moacir. Escola Cidadã. 10ª ed. São Paulo: Cortez, 2004.

GASPAR, Ronan Salomão. As figurações na política estadual de educação em tempo integral do Espírito Santo / Ronan Salomão Gaspar. Dissertação (Mestrado em Educação) - UFES, Centro de Educação, 2016. 
GIL, Antônio Carlos. Como elaborar projetos de pesquisa. Antônio Carlos Gil. São Paulo: Atlas, 2002.

LAVAL, Christian. A Escola não é uma empresa. O neoliberalismo em ataque ao ensino público. Christian Laval. trad. Mana Luiza M. de Carvalho e Silva, Londrina: Editora Planta, 2004. XXI, 324p.

OLIVEIRA, Ueber José de. LIRIO, Marcos Marcelo. O projeto escola viva: a política de educação neoliberal de Paulo Hartung, no Espírito Santo (2003-2016). Disponível em https://periodicos.ufpe.br/revistas/revistaclio/article/view/25043. Acesso em: 12 abr. 2021.

PASSOS, Eduardo; BARROS, Regina Benevides de. A cartografia como método de pesquisa-intervenção. In: PASSOS. Eduardo; KASTRUP, Virgínia e ESCÓSSIA, Liliana da (orgs). Pistas do método da cartografia: pesquisa-intervenção e produção de subjetividade. Porto Alegre: Sulina, 2009. Disponível em https:// docplayer.com.br/8183856-Pistas-do-metodo-da-cartografia--e-producao-de-subjetividade.html. Acesso em: 02 mar. 2021.

PETERle, Tatiana Gomes dos Santos. A política estadual de educação no Espírito Santo: o papel do projeto "Escola Viva" no direito social à educação básica e profissional / Tatiana Gomes dos Santos Peterle. - 2015. 247 f.: il. Orientador: Marcelo Lima. Dissertação (Mestrado em Educação) - Universidade Federal do Espírito Santo, Centro de Educação.

SILVA, Itamar Mendes da. Gestão e avaliações sistêmicas. In: OLIVEIRA, Eduardo Augusto Moscon de; SILVA, Itamar Mendes da; LIMA, Marcelo (Orgs.). Política educacional e gestão na escola básica: perspectivas. Artigo de São Carlos SP: Pedro \& João Editores, 2019. $2^{\underline{a}}$ edição. 145 p.

SILVA, Sandra Kretli da. MOREIRA, Priscila dos Santos. Cartografia discursiva das forças que movimentam as práticas políticas curriculares e a formação de professores nos dossiês da abdc publicados na e-curriculum. Disponível em <http://dx.doi.org/10.23925/1809-3876.2018v16i4p1358-1380. Acesso em 02 mar. 2021. 
SOBRE o programa. Instituto de Corresponsabilidade pela Educação. Disponível em: <http://icebrasil.org.br/sobre-o-ice/. Acesso em: 25/01/2021.

. Escola da Escolha. Instituto de Corresponsabilidade pela Educação (ICE) em 2015. Disponível em: <http://www.arcoverde. pe.gov.br/zaap/kcfinder/u pload/arquivos/processo-seletivo/introducao-as-bases-do-modelo.pdf. Acesso em: 25 jan. 2021.

TEIXEIRA, A. Relatório Educação em tempo integral 2017. Educação: construindo um futuro promissor. Atividades do Programa Escola em Tempo Integral 2014-2017. ES. 2017. 


\section{A ATUAÇÃO DO PROFESSOR COMO MEDIADOR NO PROCESSO DE ENSINO-APRENDIZAGEM NA EDUCAÇÃO INFANTIL}

Yasmim Lorena Nunes Barbosa $a^{2}$

\section{INTRODUÇÃO}

A Pedagogia Tradicional centraliza a ideia de que o professor é o ser dotado de conhecimento e que somente ele é capaz de repassar o conhecimento de forma sistematizada, mecânica e generalizada aos seus educandos (LEÃO, 1999).

Portanto, este estudo almeja desvincular a centralização da pedagogia somente no professor e focar o planejamento no educando, dando atenção a esses detalhes e conceder equidade no tratamento pedagógico em sala de aula, porque o ideal é que se deve dar maior importância ao indivíduo que está recebendo o repasse de conhecimento. É com o aluno que deve-se ter em mente como planejar uma prática pedagógica para englobar todos os alunos da turma, em todos os sentidos, levando-se em consideração que os alunos são crianças e em sua maioria possuem determinadas carências, e porque a escola também se tornará um lugar novo e repleto de pessoas novas e experiências diferenciadas que a criança irá vivenciar, e para isso ela deve se sentir segura e confiante para se abrir e permanecer com

2 Pós-Graduanda em Docência no Ensino Superior - FAVENI 
o professor no decorrer de sua jornada da descoberta do conhecimento (GÔNGORA, 1985).

\section{O PAPEL DO PROFESSOR NA EDUCAÇÃO INFANTIL}

Entende-se que o professor é o detentor do conhecimento e que, a partir dele, os alunos serão capazes de receber uma orientação adequada perante assuntos abordados desde o contexto histórico, como também o social e político. Isso é explanado para alunos do ensino básico, mas com certa maturidade para saber absorver tais conteúdos ministrados em sala de aula e aprender a dialogar e discutir para formar uma opinião sobre tal discussão (MARTINS; DUARTE, 2010).

Porém, quando se trata de alunos das séries iniciais, o conceito de professor é compreendido como sendo aquele que vai substituir alguém próximo da criança, e vai contribuir para o seu desenvolvimento intelectual e cognitivo, fato esse aderido aos professores das turmas de Maternal e Jardim de Infầncia, que ficam responsáveis em ensinar os valores de se conviver em sociedade, ou em grupos sociais, com as brincadeiras feitas com a própria turma. Esse ato auxilia aquela criança que é tímida e envergonhada e instiga nela o sentimento de curiosidade, ao passo que a vontade de participar das atividades em grupo aumenta. Outro aspecto muito importante é que esse trabalho é inteiramente voltado para a questão social, com os ensinamentos de respeito e valorização pelas culturas diversificadas (MARTINS; DUARTE, 2010).

O papel do professor nessas séries iniciais é desempenhado envolvendo diversos fatores como os já supracitados, e também é responsável pelo desenvolvimento da criança, como também já foi mencionado. É por esse e outros motivos que o professor tem que ter empatia e amor ao que faz. É ele quem vai conviver com a criança pela primeira vez longe de casa e dos pais. É ele quem vai atuar no seu ensinamento e orientação acerca das questões acadêmicas e sociais. Em vista disso, o modo de falar e de agir do professor, tanto com a família da criança como para com ela mesma, pode abrir caminhos para o desempenho de um ótimo trabalho. E não basta apenas ser consciente na hora de falar e agir, pois o amor à profissão leva o profissional a abraçar seu trabalho e a exercer a profissão de modo conjunto e íntegro (BROLEZZI, 2014). O professor de maternal utiliza-se 
de aspectos adquiridos com o convívio e criação de crianças, ou de seus próprios filhos, tais como: paciência, afetividade e pulso firme.

O desenvolvimento da criança está aliado tanto às questões sociais, voltadas para o conhecimento das diferenças existentes entre as pessoas e a valorização e o respeito pelas diversas culturas e costumes que todos adotam para si, como também se associa à instrumentos de avaliação escolhidos e utilizados pelo professor. Esses instrumentos abordam todo o planejamento de trabalho e como o professor irá agir para mensurar o nível de complexidade a que a criança está submetida, e se essa condição é válida ou suficiente para avaliar se o aluno está apto a ser submetido a novas abordagens oriundas de séries superiores (RIBEIRO, 2018).

Mas para que o professor tenha tais técnicas de abordagem para observação e avaliação da criança é necessário que ele tenha uma formação pedagógica e um treinamento prévio para melhor compreender de que modo ele pode empenhar seu trabalho para obter resultados satisfatórios (NOGUEIRA, 2013). Contudo, essa formação de professores é constantemente danificada por questões político-econômicas, podendo ser encontrados diversos relatos no decorrer da história de como os professores têm tido uma certa desvalorização porque o Estado não coopera para que o ensino, tanto para crianças como para jovens e adultos, seja alcançado em sua totalidade, tendo como base histórica para exemplificar esse fato os impactos da educação no Brasil ocorridos durante o período da Ditadura Militar, entre 1964-1985 (LUZURIAGA, 1981).

\section{OS DESAFIOS ENFRENTADOS PELA EDUCAÇÃO INFANTIL}

As instituições voltadas para o ensino infantil devem oferecer meios e instrumentos para ajudar o professor na sua jornada. Porém, a concepção de escola infantil remete que o aluno tem que brincar, desenvolver atividades leves e participar de pequenas convenções sociais denominadas festas que são destinadas à comemoração de algum marco com fins recreativos. Como foi mencionado no início desta explanação, o convívio social de crianças com outras crianças é muito importante porque é ali que ela vai aprender como agir no meio, como interagir com outro colega e, até mesmo, aprender que todas as crianças têm uma personalidade caracterís- 
tica delas próprias. Só que isso fere o que os educadores batalharam para conquistar ao longo da história, que foi a autonomia da escola infantil, com os objetivos voltados para o ensino e a aprendizagem significativa de crianças na primeira infância, explanando as letras do alfabeto e os números, além do que influencia aquelas crianças com múltiplas inteligências consideradas crianças com altas habilidades ou superdotação, que conseguem aprendem a ler e a escrever muito cedo, e o seu desenvolvimento se torna rápido à medida que o professor, em conjunto com a instituição, fornece meios e caminhos adequados para esse fim, em sua grande maioria através de uma avaliação mediadora (SILVA, 2014).

Mas, a sociedade infere que a pré-escola não é uma escola de grande importância. É nesse ponto que a argumentativa merece uma explicação. A criança do século XXI desenvolve-se mais rápido do que as crianças que viveram em tempos remotos. Isso deve-se ao fato de que, atualmente, a evolução da tecnologia tem avançado no tocante à melhorias na vida do ser humano. Algumas dessas melhorias são adeptas de necessidades que o próprio homem viu na tentativa de satisfazer para obter uma melhoria na sua qualidade de vida. E como a tecnologia está presente em todo lugar, a criança rapidamente aprende a lidar com ela devido a sua curiosidade (FEITOSA, 2003).

Por isso a pré-escola é um ambiente onde a criança vai expandir seus horizontes, vai conhecer coisas novas e, com os estímulos certos, ela vai adquirir qualidades que irão auxiliar no decorrer de sua jornada no fundamental menor e maior, ensino médio e jornada acadêmica no ensino superior. Tudo isso depende inteira e primariamente de como a atuação do professor nas séries iniciais é colocada em prática.

Para suprir as necessidades de evasão escolar por falta de progresso no desenvolvimento das crianças, passou-se a investir mais na pré-escola, principalmente para diminuir os níveis de analfabetização. Para isso, o governo criou medidas como a adesão à Formação Continuada para profissionais da educação de todas as séries, além de elaborar metodologias de avaliação e criar os Parâmetros Curriculares Nacionais para o ensino básico (BRASIL, 2013).

Atualmente, o professor da educação infantil deve ser polivalente, pois ele atua tanto na área assistencial como na área educativa. Em vista disso, trazendo inicialmente o que foi explanado neste estudo, o pedagogo 
se torna o mediador do conhecimento, assim como era feito na Grécia Antiga quando os paidagogos pegavam nas mãos das crianças e as levavam para os detentores do conhecimento (LUZURIAGA, 1981). O professor da educação infantil tem que ter em mente que todo o conhecimento é assimilado com o tempo, e cada criança tem o seu tempo de aprender. Algumas aprendem mais rápido que outras, o que se deve ficar atento para com elas, mas no fim, o objetivo é alcançado com êxito através da aprendizagem significativa de acordo com a idade da criança e o nível de complexidade do que está sendo trabalhado.

Essa mediação é feita criando-se laços de convivência com a criança. A ideia do professor fixo está atrelada ao fato de que o professor será uma pessoa diferente dos seus pais que a criança vai ter em sua rotina, situada em um ambiente diferente de sua casa. Para que a criança adquira o sentimento de confiança em uma pessoa totalmente estranha, é necessário que essa pessoa mostre para a criança que ela pode confiar sem ter medo. Esse é um longo processo, mas, no fim, a criança acaba por ceder e até gostar do novo ambiente. Quando essa etapa de convivência é concluída, vem a etapa de socialização dos alunos com a passagem de conhecimentos prévios através de atividades lúdicas, incentivando a criança a descobrir as respostas para problemas que ela julga difícil através da problematização de situações, o que vai estimular o seu cognitivo.

\section{A FORMAÇÃO SOCIAL NO CONTEXTO DA EDUCAÇÃO INFANTIL}

A educação é uma fonte transformadora de futuro. É através dela que o ser humano se molda e se constrói. Permitir que todos tenham total acesso a ela é garantir a construção de uma sociedade mais justa e igualitária para todos, onde todos os cidadãos possuem o acesso a cultura e conhecimentos que são julgados importantes e, a partir disso, possam ser capazes de construir e promover um futuro melhor (LUZURIAGA, 1981).

A partir disso, é possível observar a importância da educação no processo de formação de identidade de um indivíduo e no seu desenvolvimento como pessoa. A educação é capaz de mudar a cultura de uma sociedade e transformar os seus cidadãos com o objetivo de remover a alienação 
imposta às pessoas pela falta de oportunidades e atenção no seu processo de desenvolvimento (MENEZES, 2010).

No que tange à educação infantil, a visão tradicionalista é aquela em que existe uma hierarquia entre professor e aluno e que essa hierarquia tinha que ser preservada: o professor era o ser dotado de conhecimento capaz de transmiti-lo para as crianças de forma sistemática e generalizada, não atentando-se para observar e analisar qual o tipo de turma na qual ele estava trabalhando (LUZURIAGA, 1981).

Pesquisadores contemporâneos têm trabalhado em uma forma de descentralizar a pedagogia do professor para a criança para construir uma educação que garanta uma melhor formação pessoal e social infantil. A construção do conhecimento da criança se dá por meio da interação com o meio na qual ela está inserida. Sendo assim, a escola de educação infantil não é o primeiro local de interação dessa criança, pois ela começa a interagir com os pais e a família em casa desde o seu nascimento. A escola é apenas um dos locais onde ela vai estruturar as relações sociais aprendidas no momento pedagógico mediado pelo professor de educação infantil, onde irá proporcionar essa interação de forma estruturada, construtiva e planejada (LUZURIAGA, 1981).

É sabido que a criança vive em uma contradição social ao ingressar na educação infantil. Ela sai de uma realidade onde está em casa, tendo uma educação paralela, e ingressa na educação infantil em um meio social diferente que possui objetivos educacionais e regras de conduta diferentes. Isso demonstra que a maioria das crianças saem de casa para vivenciar essa nova etapa da vida delas com uma certa apreensão devido ao impacto da adesão de novas regras, principalmente as de convivência. Então o professor já instiga a criança a responder algo e é demonstrado que nem sempre é quando ela quer. Essas regras de conduta serão levadas com o indivíduo pelo resto de sua vida (GÔNGORA, 1985).

Por conta disso, existe essa contradição da socialização, que se torna difícil e complicado no relacionamento professor/aluno evidenciado logo no primeiro dia de aula. O desapego dos familiares pela criança é um processo lento e conjunto e por isso os pais ficam com eles por um breve período inicial de duas semanas e, passado esse período, a criança tem que se acostumar a ser independente e a conviver sem os pais, desenvolvendo o sentimento de se sentir à vontade para conviver dentro da sala de aula com 
a conquista da confiança do professor. Só que também existe o processo da conquista e confiança individual oriundo da criança: ela tem que se sentir confiante e segura naquele ambiente, percebendo afinal que a escola é a sua segunda casa, e o professor é diretamente responsável por essa conquista porque ele vai propor situações em que esse processo vai acontecer dentro de um ambiente educativo (LẼ̃O, 1999).

Percebe-se que ser professor da educação infantil não é uma tarefa simples como aparenta ser. O professor deve lidar com certas falas, com certos pensamentos que, em algum momento em sua carreira, irá em desacordo com a atuação dele em sala de aula, na qual requer uma atuação profissional e qualitativa dentro desse ambiente. Levando em consideração a construção desse conhecimento pelas crianças, é importante que o educador saiba que é necessário que haja a defesa da ideia centrada do ensino e da prática docente com a proposta contemporânea de derrubar as visões tradicionalistas do ensino e se adequar com algumas concepções de movimentos educacionais que prezam pela oferta de educação de qualidade para seus alunos, como o movimento escolanovista, por exemplo (LẼ̃O, 1999).

A desconstrução da proposta de ensino centrado no professor é um tema que vem sendo trabalhado no atual cenário de práticas pedagógicas contemporâneas. Essa visão vai contra o ensino tradicional por não ser a prática mais ideal e mais aplicada contemporaneamente dentro da sala de aula. A permanência da visão tradicionalista se torna uma grande problemática porque o educador não permite que a criança tenha o seu espaço para questionar e expor suas emoções e necessidades de aprendizado (LẼ̃O, 1999).

É importante que a criança tenha esse espaço e a oportunidade de fala, visto que o professor não só ensina, mas também aprende com a criança através do processo de ensino-aprendizagem, e onde essa desconstrução irá acontecer não só na vida, mas também na sociedade por meio das nossas ações. Então é importante que a criança tenha seu espaço e seu momento de brincadeiras, de socializar com os colegas, para que ela produza e desenvolva formas de interatividade com outras crianças, para que ela observe, para que ela questione mais uma vez o porquê das coisas. São situações de extrema importância porque vão contribuir para o processo de desenvolvimento da criança por meio da aprendizagem. 
O conhecimento de mundo vai surgindo por meio do contato e da expressão das necessidades que a criança vai apresentar no decorrer do cotidiano. Percebe-se que atualmente existem muitos educadores que não dão oportunidade para que isso aconteça, e isso se torna prejudicial no desenvolvimento do educando. É válido ressaltar que é necessário que haja o entendimento de que a criança tem o seu individualismo e suas limitações, então as perguntas que são feitas por ela devem ter uma resposta clara e concisa, mas de pronúncia simples e entendimento fácil, tudo isso voltado para uma necessidade de reflexão por não deixar somente o contexto de transmissão do conhecimento, mas sim de permitir que a criança aplique o conhecimento que está sendo adquirido.

A proposta então seria ensinar o conteúdo e, posteriormente, fornecer meios para que essa criança entenda e compreenda o sentido do conteúdo aprendido, seja por meio de estimulação visual com amostragens de objetos significativos, como contagem de frutas, ou seja por meio de estimulação sonora, como por exemplo através da música. Mas deve-se ter em mente que o objetivo primordial é construir o conceito de compreensão por parte da autonomia da criança de descobrir o mundo e encontrar um sentido nele, logicamente visando sempre trabalhar dentro da realidade socioeconômica e cultural e das particularidades de cada criança, porque é sabido que a educação infantil é responsável tanto pelo processo de ensino-aprendizagem como também da estruturação pedagógica da construção do conhecimento, bem como mescla a educação especial como garantia de oportunidade de educação para todos.

O planejamento do professor deve embasar as teorias que compreendem que a criança modifica o ambiente e é por ele também modificada. Esse planejamento deve ser voltado para uma observação de que a criança de fato se modifica a cada momento, a cada interação social e a cada proposta educacional proporcionada, então ela também em algum momento no decorrer dessa prática proporciona a possibilidade de outra pessoa se modificar pelo que ela está apresentando (BRASIL, 1998). Isso se torna muito evidente no cotidiano das atividades interativas em sala de aula: há momentos em que as crianças trazem coisas novas para a sala de aula e o professor tem o seu momento de interação com elas onde ele também irá aprender com ela.

A criança faz parte desse processo de modificar. E isso tem que estar expresso de maneira claro e concisa no embasamento teórico no 
planejamento do professor de educação infantil, no sentido de sempre dar a oportunidade para que a criança faça as coisas que irão permitir sua formação pessoal e social possibilitando a ela o espaço para exposição de algo novo que vai agregar coisas boas em seu desenvolvimento. Deve ter ações qualitativas que promovam e desenvolvam esse processo de construção e evolução da criança, não somente no meio educacional, mas como indivíduo pensante que terá ações aplicadas dentro da sociedade, formando cidadãos aptos para atuar no meio social de forma construtiva e qualitativa.

O professor deve se envolver com seus alunos e entender que ele é o integrante do grupo mais experiente. Percebe-se aqui que a proposta didática de o ensino ser centrado no professor não se torna uma prática eficaz no sentido de promover o desenvolvimento educacional infantil, principalmente porque é visto que o educador também aprende com a criança em alguma etapa no decorrer do seu trabalho, o que corrobora a afirmação de que o professor é o detentor do conhecimento. Ele de fato é o mediador do conhecimento para as crianças, na qual conduz as situações de aprendizagem, mas ele não deve ser visto como a figura máxima que transmite o conhecimento pois ele é apenas mais um integrante do grupo que possui um saber e experiência e propostas pedagógicas para a aprendizagem (AZAMBUJA; CONTE; HABOWSKI, 2017).

$O$ ensino deve ser voltado integralmente para a criança, para que ela construa o seu conhecimento através das descobertas realizadas em momentos de socialização propostas pelo mediador. O professor não pode trazer as respostas prontas para os alunos. O professor deve instigar que o aluno busque e responda suas dúvidas desde cedo. Esse processo é muito trabalhoso e por isso muitos educadores terminam por adotar um sistema de rotina que é aplicado em todas as turmas por onde ele passa, não se permitindo abrir o leque de possibilidades para adentrar no mundo prazeroso de descobertas experimentado pelas crianças. Não se trata somente de levar as propostas de pesquisas e deixar que a criança trabalhe por conta própria. É necessário que haja a condução desse aluno, mostrando caminhos para que ele consiga chegar até aquela resposta ao qual almeja encontrar.

O planejamento também deve incluir etapas de ação e criatividade para promover práticas pedagógicas lúdicas e interativistas que 
despertem na criança o olhar de curiosidade para adentrar naquilo que é novo e desconhecido para ela. Para que isso aconteça, é necessário que o docente esteja em constante acesso às informações e trabalhe no seu desenvolvimento profissional, buscando sempre novas fontes de pesquisas e compartilhando experiências com outros colegas da área.

Escutar e observar as crianças é fundamental para que o processo de desenvolvimento se dê de maneira eficaz. É necessário dar ouvidos ao que a criança está expressando para que ela reproduza sua necessidade. Observar as práticas daquele indivíduo para entender a forma como ele aplica tal coisa é uma proposta que o educador pode levar em consideração para que isso se encaixe no seu planejamento. E, mediante a tudo o que foi discutido, a educação tem como objetivo promover conhecimento de forma gradual, ou seja, é necessário dar continuidade a algo para que o objetivo final seja alcançado, e esse objetivo centralizado na educação infantil se trata do desenvolvimento da criança como indivíduo incluso na sociedade. Se o professor não destinar uma parte do seu tempo para analisar e refletir acerca das ações realizadas pelas crianças no dia a dia, ele não saberá o que a criança já sabe e o que ela já conhece. Sendo assim, neste sentido, a observação é um item fundamental para incluir dentro do planejamento qualitativo do professor (ABUCHAIM, 2016).

\section{CONSIDERAÇÕES FINAIS}

Evidenciar de que maneira o planejamento pedagógico, centralizado primariamente no educando, pode contribuir para que haja o seu pleno desenvolvimento, tanto cognitivo como social, adequando um método de observação voltado para os esforços da criança, objetivando o processo de ensino-aprendizagem, além de elucidar um novo olhar para a educação infantil de forma que seja integralmente voltada para a criança, trazendo uma visão contemporânea da sua formação pessoal e social perante o meio ao qual está inserida. É necessário propor novas formas de lecionar os conteúdos primários de maneira que a criança seja instigada a buscar as respostas para suas perguntas e não as receber prontas, além de evidenciar que a criança se desenvolve no meio educacional de forma que ela modifica o ambiente ao qual está inserida e é modificada pelos mesmos conceitos 
já estabelecidos. Deve-se, portanto, promover a concepção de que o professor não é o centro do conhecimento, mas sim uma parte integrante de um grupo que está em constante desenvolvimento dentro do processo de ensino-aprendizagem. Este trabalho tem o seu desenvolvimento com base nas pesquisas bibliográficas a respeito das práticas pedagógicas, bem como almeja fundamentar a importância da educação na formação da criança em um indivíduo pensante e capaz de modificar o meio ao qual está inserido.

A realidade dos cursos superiores no Brasil, principalmente os voltados para as áreas de licenciatura, tem sofrido bastante principalmente pela falta de material atualizado que auxiliem na formação do docente. Uma formação adequada para o pedagogo implica que ele terá autonomia para organizar uma sala com as crianças e ainda passar o sentimento de confiança mútua para iniciar o processo de aprendizagem. Tendo em vista os diversos problemas enfrentados em sua jornada, o professor deve estar ciente também de que a realidade da educação brasileira ainda está dividida em grupos sociais, o que inicia pontos de desigualdade entre classes. Isso tem se tornado uma problemática que levanta questões recorrentes associadas a políticas educacionais e programas de educação infantil, na qual devem conceder pelo menos o benefício da qualidade do ensino para todas as crianças.

Assim, a formação do professor vai muito além dos quatro anos em que ele passa na graduação. É por isso que se chama formação continuada, porque continua no período de estágio, onde acontece o primeiro contato com o futuro ambiente de trabalho, no convívio com as crianças, no convívio com os pais das crianças e com os colegas de profissão, além das demais oportunidades de formação de nível acadêmico.

\section{REFERÊNCIAS}

ABUCHAIM, Beatriz de Oliveira. Pedagogical planning in early chilhood education: perceptions of teachers, principals and pedagogical coordinators. Revista Veras, São Paulo, v.6, n.2, p. 156-179, jul-dez, 2016.

AZAMBUJA, Paula Lima; CONTE, Elaine; HABOWSKI, Adilson Cristiano. O planejamento docente na educação infantil: metamor- 
foses e sentidos ao aprender. PESQUISA EM FOCO, v. 22, n. 2, 2017.

BRASIL. Ministério da Educação. Referencial curricular nacional para a educação infantil. Brasília: MEC/SEF, 1998.

- Ministério da Educação. Secretaria de Educação Básica. Diretrizes Curriculares Nacionais Gerais da Educação Básica. Diretoria de Currículos e Educação Integral. Brasília: MEC, SEB, DICEI, 2013. 562p.

BROLEZZI, Antônio Carlos. Empatia na relação aluno/professor/conhecimento. Revista de Psicologia, v. 17, nº 27, ano 2014.

FEITOSA, Juliana Biazze. SILVA, Mariita Bertassoni. Desenvolvimento infantil e tecnologia: um estudo psicológico. Psicologia Argumento, Curitiba, v. 21, n. 35, p. 33-38, out./dez. 2003.

GÔNGORA, Francisco Carlos. Tendências pedagógicas na prática escolar. Edições Loyola. São Paulo, 1985.

LEÃO, Denise Maria Maciel. Paradigmas contemporâneos de educação: escola tradicional e escola construtivista. Cadernos de pesquisa, $\mathrm{n}^{-}$ 107, p. 187-206. Julho/1999.

LUZURIAGA, Lorenzo. História da educação e da pedagogia. 13 ed. São Paulo: Nacional, 1981.

MARTINS, L.M; DUARTE, N. (Orgs. Formação de professores: limites contemporâneos e alternativas necessárias (on-line). São Paulo: Editora UNESP; São Paulo: Cultura Acadêmica, 2010. $191 \mathrm{p}$.

MENEZES, César. BAHIENSE, Jorge. ROCHA, Willians. História. 2 ed. Rio de Janeiro: Gráfica GPI, 2010.

NOGUEIRA, Gabriela Medeiros et al. Práticas pedagógicas na Educação Infantil e nos anos iniciais do Ensino Fundamental: diferentes perspectivas. Rio Grande: Editora da FURG, 2013. 
RIBEIRO, Bruna. Avaliação da aprendizagem na educação infantil: um estudo exploratório em 125 municípios brasileiros. Revista Linhas, Florianópolis, v. 19, n. 40, p. 218-245, maio/ago. 2018.

SILVA, Juliana Pereira da. URT, Sonia da Cunha. Educação Infantil e avaliação: uma ação mediadora. Nuances: estudos sobre Educação, Presidente Prudente-SP, v. 25, n. 3, p. 56-78, set/dez. 2014. 


\section{O PAPEL DAS GARATUJAS PARA AS CRIANÇAS DE 0 A 3 ANOS NA EDUCAÇÃO INFANTIL: UMA REVISÃO}

Gisleine Cristina da Silva ${ }^{3}$

\section{INTRODUÇÃO}

O desenho infantil pode ser entendido como uma forma própria de expressão da criança constituindo uma língua que possui vocabulário. E, ele possibilita a criança um contato consigo e com o mundo, sendo uma maneira de compreender o contexto ao seu redor e relacionar-se com ele, bem como, demonstrar o seu mundo interior, seus conflitos, medos, desejos, alegrias, tristezas e a partir disso trabalhar os seus sentimentos (BOTELHO, 2018).

Desse modo, o desenho infantil está diretamente relacionado com a comunicação do ser humano e ocorre de diversas maneiras de acordo com o com o meio que o sujeito está inserido. Assim, a partir do modo como os pequenos são educados eles vão construindo a sua identidade e desenvolvendo a comunicação, seja verbalmente ou por outras maneiras como os gestos, os movimentos corporais ou os sinais (SANTOS, RADVANSKEI e BACHMANN, 2016).

Nesse sentido, segundo Santos, Radvanskei e Bachmann (2016) nos primeiros anos de vida a criança aprende a se comunicar por meio do seu corpo, da fala, dos sons e busca explorar e compreender o mundo ao seu redor assim paulatinamente descobre novas formas de estar e de interagir

3 Especialista em Psicopedagogia Clínica e institucional pela Universidade Estadual de Maringá. 
com o meio em que está inserida. Dessa forma, é extremamente necessário que o professor da educação infantil tenha compreensão e conhecimento a respeito do desenho infantil e a sua relação com a evolução do desenvolvimento humano. Assim como, saber que o desenho diz respeito as manifestações das necessidades vitais pelas quais as crianças passam na medida em que conhecem e agem sobre o mundo e comunicam-se com esse mundo.

Assim, para que a criança de zero a três anos aprenda, se faz necessário que o ambiente de interação social favoreça as vivências significativas e a arte apresenta-se como um poderoso instrumento de expressão e comunicação que os docentes podem lançar mão para propor situações ricas de aprendizagens (HAWTHORNE, 2021).

Em virtude disso, o estudo foi movido por inquietações que despertaram o interesse em aprofundar o assunto no que toca a importância das garatujas no desenvolvimento da criança de zero a três anos de idade. Nesse sentido, questiona-se: pode este estudo contribuir com o entendimento dos professores da educação infantil da importância do desenho para a criança pequena? Como garantir um ambiente rico em recursos e ensino voltado para aspectos mais livres, mais criativos, ou seja, de manipulação e de exploração de materiais, nessa faixa etária?

Assim sendo, esse estudo justifica-se pela grande importância que o desenho tem para a criança e pela a necessidade de enxergar as garatujas das crianças por meio de uma observação atenta, sútil e sensível, a fim de compreender o grafismo infantil e o seu simbolismo como um forma de expressão infantil mantendo o foco da observação no processo de produção do desenho e não apenas no produto, isto é, romper com o vício de valorização apenas no resultado em detrimento do processo e no contexto em que se deu a produção.

Nesse sentido, o presente artigo trata-se de um estudo sistemático cujo objetivo foi apresentar uma revisão de artigos, a fim de discutir o papel das garatujas para as crianças de 0 a 3 anos na educação infantil.

O presente estudo organiza-se em três partes articuladas entre si, sendo que na introdução discute-se a temática no geral e é apresentado o objetivo da pesquisa, a problematização e a justificativa.

$\mathrm{Na}$ segunda parte, é apresentado o desenvolvimento do estudo que está subdividido em: metodologia, resultados, discussão. E, a terceira parte refere-se as considerações finais na qual busca-se discutir e fazer uma reflexão diante da temática em questão. 


\section{MATERIAIS E MÉTODOS}

Foi feito um levantamento da literatura em março de 2021, nas bases de dados Periódicos CAPES e Google Acadêmico. Os descritores utilizados foram os seguintes: "Garatujas" AND "Crianças de zero a três anos" AND "e "Educação Infantil" AND "Doodles" AND "Children from zero to three Years" AND "Early childhood education" em todas as bases de dados. Foram selecionados 10 artigos sendo incluídos segundo os critérios de elegibilidade conforme a Figura 1. Os critérios de inclusão foram: artigos nos idiomas inglês e português, nos últimos cinco anos, envolvendo o papel das garatujas para s crianças de 0 a 3 anos na educação infantil. Os critérios de exclusão foram artigos de revisão de literatura.

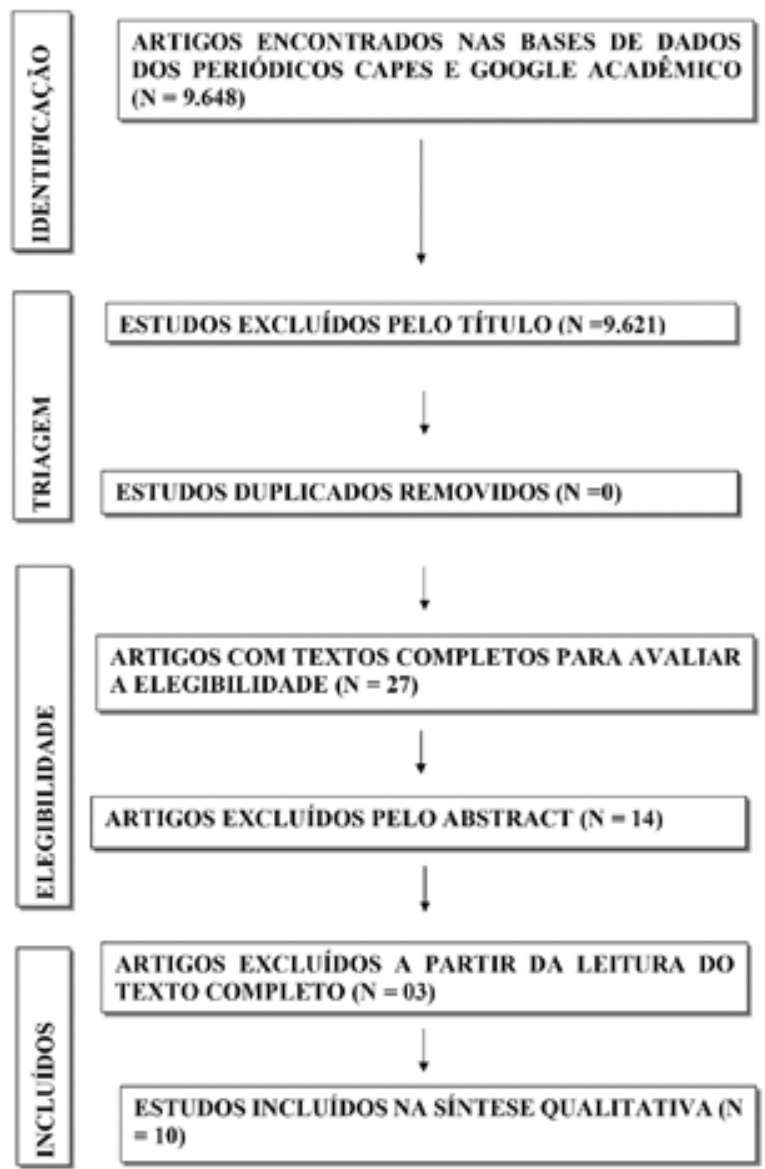

Figura 1. Fluxograma e critérios de seleção e inclusão dos Artigos 


\section{RESULTADOS}

Os resultados do presente estudo encontram-se na tabela 1.

Tabela 1 - Demonstrativo dos artigos que integram a Revisão Integrativa

\begin{tabular}{|c|c|c|c|c|c|c|}
\hline$\# \mathbf{N}$ & Data & Título & Autores & Periódico & Objetivos & Resultados \\
\hline 1 & 2021 & $\begin{array}{l}\text { Arte no berçário: } \\
\text { Explorando, } \\
\text { criando e } \\
\text { aprendendo }\end{array}$ & $\begin{array}{c}\text { Julia } \\
\text { Galvani } \\
\text { Hawthorne }\end{array}$ & $\begin{array}{c}\text { TCC } \\
\text { apresentado } \\
\text { ao Centro } \\
\text { de Ciências } \\
\text { Humanas e } \\
\text { Biológicas da } \\
\text { UFSCar. }\end{array}$ & $\begin{array}{c}\text { Compreender } \\
\text { como a arte é } \\
\text { trabalhada nas } \\
\text { salas de berçário } \\
\text { e quais propostas } \\
\text { pedagógicas } \\
\text { podem favorecer } \\
\text { a imersão } \\
\text { dos bebês nas } \\
\text { linguagens } \\
\text { artísticas, } \\
\text { possibilitando- } \\
\text { lhes experiências } \\
\text { e aprendizados de } \\
\text { si e do mundo. } \\
\end{array}$ & $\begin{array}{c}\text { Para que as vivências } \\
\text { com as artes sejam } \\
\text { significativas para os } \\
\text { bebês, é preciso que o } \\
\text { professor possa } \\
\text { participar da construção } \\
\text { de um currículo } \\
\text { emancipador, } \\
\text { abandonando } \\
\text { práticas tecnicistas e } \\
\text { instrumentais e criando } \\
\text { saberes contextualizados } \\
\text { às culturas das } \\
\text { comunidades. }\end{array}$ \\
\hline 2 & 2020 & $\begin{array}{c}\text { Rabiscos e } \\
\text { Emoções: Nova } \\
\text { Perspectiva } \\
\text { sobre o } \\
\text { Desenvolvimento } \\
\text { do Desenho }\end{array}$ & $\begin{array}{c}\text { Evelyn de } \\
\text { Oliveira1, } \\
\text { Sonia } \\
\text { Grubits }\end{array}$ & $\begin{array}{c}\text { Avaliação } \\
\text { Psicológica. }\end{array}$ & $\begin{array}{c}\text { Apresentar } \\
\text { uma nova } \\
\text { teoria sobre o } \\
\text { desenho infantil, } \\
\text { denominada } \\
\text { como Perspectiva } \\
\text { Dinâmica e } \\
\text { Estética. }\end{array}$ & \begin{tabular}{|c|} 
A Perspectiva Dinâmica \\
e Estética apresenta \\
uma nova forma de \\
conceber o processo de \\
desenvolvimento do \\
desenho, especialmente \\
no que tange à fase do \\
rabisco expressivo que, \\
de forma inovadora, \\
pressupõe a expressão \\
de estados emocionais \\
já nos rabiscos iniciais, \\
e não somente após o \\
desenho esquemático. \\
\end{tabular} \\
\hline 3 & 2020 & $\begin{array}{c}\text { Artes Visuais na } \\
\text { educação infantil: } \\
\text { O desenho e } \\
\text { o seu papel no } \\
\text { desenvolvimento } \\
\text { da criança }\end{array}$ & $\begin{array}{l}\text { Tamara } \\
\text { Cristina } \\
\text { Ferreira }\end{array}$ & $\begin{array}{c}\text { Monografia } \\
\text { apresentada ao } \\
\text { Especialização } \\
\text { em Ensino de } \\
\text { Artes Visuais } \\
\text { e Tecnologias } \\
\text { Contemporâneas } \\
\text { da UFMG }\end{array}$ & $\begin{array}{c}\text { identificar as } \\
\text { contribuições do } \\
\text { ensino da arte } \\
\text { no âmbito da } \\
\text { educação infantil, } \\
\text { evidenciando } \\
\text { novas } \\
\text { possibilidades } \\
\text { didáticas de } \\
\text { ensino, avaliação } \\
\text { e interpretação, } \\
\text { por meio de uma } \\
\text { maior atenção e } \\
\text { cuidado com o } \\
\text { papel mediador } \\
\text { do professor. }\end{array}$ & \begin{tabular}{|c|} 
O desenho tem papel \\
importante como \\
instrumento de \\
comunicação. Mas não \\
adianta ter essa clareza \\
se minhas atitudes \\
enquanto professora \\
não condiz com minha \\
prática e teoria. É \\
preciso fazer, É preciso \\
colocar em prática e \\
exercitar a cada dia esse \\
olhar perante o aluno, \\
sem focar no certo ou \\
errado, sem focar na \\
maneira correta de \\
desenhar.
\end{tabular} \\
\hline
\end{tabular}




\begin{tabular}{|c|c|c|c|c|c|c|}
\hline$\# \mathbf{N}$ & Data & Título & Autores & Periódico & Objetivos & Resultados \\
\hline 4 & 2019 & $\begin{array}{c}\text { A importância das } \\
\text { Artes Visuais na } \\
\text { aprendizagem das } \\
\text { crianças }\end{array}$ & \begin{tabular}{|c|} 
Eliane \\
Maria \\
Fogliarini \\
Moura, \\
Marilane \\
Wolff Paim
\end{tabular} & $\begin{array}{l}\text { Revista } \\
\text { Apotheke }\end{array}$ & $\begin{array}{c}\text { Compreender } \\
\text { de que maneira } \\
\text { a linguagem } \\
\text { artística } \\
\text { contribui para } \\
\text { a aprendizagem } \\
\text { da criança, } \\
\text { identificar } \\
\text { as possíveis } \\
\text { metodologias } \\
\text { que podem } \\
\text { ser trabalhadas } \\
\text { e relacionar a } \\
\text { interação da } \\
\text { criança com o } \\
\text { mundo que a } \\
\text { cerca. }\end{array}$ & $\begin{array}{c}\text { E possível dizer que } \\
\text { o desenho antecede à } \\
\text { escrita, mas que ambos } \\
\text { possuem uma relação } \\
\text { de interdependência, } \\
\text { tendo em vista } \\
\text { que quanto mais } \\
\text { oportunidades a criança } \\
\text { tiver para representar e } \\
\text { transcrever para o papel } \\
\text { sua impressão sobre } \\
\text { o mundo à sua volta, } \\
\text { considerando também } \\
\text { seus sentimentos e } \\
\text { emoções, mais ela estará } \\
\text { apta para desenvolver } \\
\text { o sistema de escrita, } \\
\text { visto que o mesmo, } \\
\text { assim como o desenho, } \\
\text { também é uma forma } \\
\text { de representação. } \\
\end{array}$ \\
\hline 5 & 2019 & $\begin{array}{c}\text { Arte na educação } \\
\text { infantil: } \\
\text { possibilidades e } \\
\text { limites }\end{array}$ & \begin{tabular}{|c|} 
Kalyne \\
Madeira \\
Furtado, \\
Gil Camelo \\
Neto
\end{tabular} & Revista Plus FRJ & $\begin{array}{c}\text { Compreender } \\
\text { como se dá a } \\
\text { abordagem da } \\
\text { Arte na sala de } \\
\text { aula da educação } \\
\text { Infantil. }\end{array}$ & $\begin{array}{c}\text { Através das leituras } \\
\text { de livros e periódicos, } \\
\text { ficou claro que existe } \\
\text { um longo processo } \\
\text { para a incorporação da } \\
\text { Arte nas escolas como } \\
\text { sugere o Referencial } \\
\text { Curricular para a } \\
\text { Educação Infantil. } \\
\end{array}$ \\
\hline 6 & 2019 & $\begin{array}{c}\text { Os (entre) } \\
\text { lugares da arte na } \\
\text { educação infantil11 }\end{array}$ & $\begin{array}{c}\text { Marisete } \\
\text { Machado } \\
\text { Colbeich, } \\
\text { Carolina } \\
\text { Ramos } \\
\text { Nunes }\end{array}$ & $\begin{array}{l}\text { Revista } \\
\text { Apotheke }\end{array}$ & $\begin{array}{c}\text { Evidenciar a arte } \\
\text { como um campo } \\
\text { de conhecimento } \\
\text { que contribui } \\
\text { para as práticas } \\
\text { pedagógicas. }\end{array}$ & $\begin{array}{c}\text { Consideramos que } \\
\text { de modo geral falta } \\
\text { reconhecimento da } \\
\text { importância do ensino } \\
\text { da Arte na formação } \\
\text { dos professores da } \\
\text { educação infantil. É } \\
\text { necessário às formações } \\
\text { em pedagogia, que } \\
\text { se amplie a reflexão e } \\
\text { potencialidade do papel } \\
\text { da arte na educação. } \\
\end{array}$ \\
\hline 7 & 2019 & $\begin{array}{l}\text { As crianças e os } \\
\text { seus desenhos } \\
\text { na educação } \\
\text { infantil: o papel } \\
\text { da professora }\end{array}$ & $\begin{array}{c}\text { Ana Karina } \\
\text { Corrêa } \\
\text { Hoeller, } \\
\text { Maria } \\
\text { Laura } \\
\text { Pozzobon } \\
\text { Spengler }\end{array}$ & $\begin{array}{l}\text { Pedagogia em } \\
\text { foco }\end{array}$ & $\begin{array}{c}\text { analisar e refletir } \\
\text { sobre a ação da } \\
\text { professora, como } \\
\text { agente facilitador } \\
\text { do processo } \\
\text { da criança se } \\
\text { descobrir e } \\
\text { descobrir o } \\
\text { mundo da arte } \\
\text { por meio do } \\
\text { desenho. }\end{array}$ & $\begin{array}{l}\text { Analisando e refletindo } \\
\text { sobre o posicionamento } \\
\text { de vários autores da área } \\
\text { da educação e artes, a } \\
\text { professora que altera o } \\
\text { trabalho da criança está } \\
\text { interferindo de forma } \\
\text { negativa na ação autoral } \\
\text { e no desenvolvimento } \\
\text { criativo da mesma.. }\end{array}$ \\
\hline
\end{tabular}




\begin{tabular}{|c|c|c|c|c|c|c|}
\hline$\# \mathbf{N}$ & Data & Título & Autores & Periódico & Objetivos & Resultados \\
\hline 8 & 2019 & $\begin{array}{c}\text { Por onde caminha } \\
\text { o desenho na } \\
\text { escola: pensando } \\
\text { seus espaços }\end{array}$ & $\begin{array}{l}\text { Érico } \\
\text { Vinicius } \\
\text { Fonseca } \\
\text { dos Santos }\end{array}$ & $\begin{array}{c}\text { TCC } \\
\text { apresentado } \\
\text { ao Centro } \\
\text { de Ciências } \\
\text { Humanas e } \\
\text { Biológicas da } \\
\text { UFSCAR }\end{array}$ & $\begin{array}{c}\text { Identificar } \\
\text { os espaços } \\
\text { percorridos pelo } \\
\text { desenho infantil } \\
\text { no contexto } \\
\text { escolar, suas } \\
\text { possibilidades } \\
\text { criadoras e seus } \\
\text { significados } \\
\text { relacionados ao } \\
\text { desenvolvimento } \\
\text { psicológico, } \\
\text { sensível e } \\
\text { interpretativo do } \\
\text { contexto em que } \\
\text { a criança vive. }\end{array}$ & \begin{tabular}{|c} 
Verificou-se que, as \\
linguagens artísticas \\
podem permear o \\
cotidiano da Educação \\
Infantil, desde que \\
pedagogas/os tenham \\
garantido o seu direito \\
de serem formados em \\
Arte durante os cursos \\
de Licenciatura, a fim \\
de compreender o valor \\
da dimensão artística \\
no desenvolvimento \\
infantil, a qual é uma \\
das dimensões da \\
imaginação criativa, do \\
jogo e do aprender. \\
\end{tabular} \\
\hline 9 & 2018 & $\begin{array}{c}\text { O desenho no } \\
\text { processo de } \\
\text { desenvolvimento } \\
\text { cognitivo }\end{array}$ & $\begin{array}{l}\text { Fernanda } \\
\text { Bahena } \\
\text { Soares, } \\
\text { Stela Maris } \\
\text { Brito } \\
\text { Maziero }\end{array}$ & $\begin{array}{c}\text { TCC } \\
\text { apresentado } \\
\text { curso de } \\
\text { Licenciatura em } \\
\text { Artes Visuais da } \\
\text { UNINTER }\end{array}$ & $\begin{array}{c}\text { Apresentar } \\
\text { a função do } \\
\text { contexto escolar } \\
\text { e o que se é } \\
\text { esperado deste } \\
\text { ambiente, em } \\
\text { relação ao } \\
\text { processo de } \\
\text { socialização e no } \\
\text { desenvolvimento } \\
\text { do aluno, } \\
\text { intercalando- } \\
\text { se com a } \\
\text { importância do } \\
\text { ensino da arte no } \\
\text { currículo escolar. }\end{array}$ & $\begin{array}{l}\text { Pôde-se observar que } \\
\text { a escola e as aulas de } \\
\text { artes devem ser atuantes } \\
\text { em um contexto que } \\
\text { ofertam estímulos para } \\
\text { os alunos de modo que } \\
\text { seja rico em impulsos } \\
\text { preparando o aluno para } \\
\text { a vida em sociedade. }\end{array}$ \\
\hline 10 & 2017 & $\begin{array}{l}\text { O desenho e sua } \\
\text { contribuição para } \\
\text { a aprendizagem }\end{array}$ & & $\begin{array}{c}\text { Artigo } \\
\text { apresentado } \\
\text { como TCC } \\
\text { ao Curso de } \\
\text { Pedagogia da } \\
\text { UFRN }\end{array}$ & $\begin{array}{c}\text { Mostrar a } \\
\text { contribuição do } \\
\text { desenho infantil } \\
\text { como forma de } \\
\text { oferecer muitas } \\
\text { oportunidades } \\
\text { para a } \\
\text { aprendizagem, } \\
\text { contribuindo } \\
\text { para a aquisição } \\
\text { da leitura e } \\
\text { da escrita na } \\
\text { alfabetização } \\
\text { e para o } \\
\text { desenvolvimento } \\
\text { da criança. } \\
\end{array}$ & $\begin{array}{c}\text { O desenho infantil } \\
\text { enquanto linguagem } \\
\text { gráfica e artística } \\
\text { contribui de forma } \\
\text { significativa não só para } \\
\text { o desenvolvimento da } \\
\text { escrita, como também } \\
\text { auxilia na coordenação } \\
\text { motora da criança e } \\
\text { demais aprendizados } \\
\text { durante o processo } \\
\text { alfabetização. }\end{array}$ \\
\hline
\end{tabular}




\section{GRAFISMO INFANTIL: AS GARATUJAS COMO MARCAS DE COMUNICAÇAO E EXPRESSÃO}

Os primeiros traços realizados pelas crianças expõem muito sobre suas etapas de acesso ao conhecimento e suas vivências com o universo da linguagem escrita. Bem como, a apropriação da escrita e da leitura, sendo por meio do desenho o modo como expressam suas necessidades, identidades e experiências sociais que ainda se encontram em fase de construção (Sousa, 2020).

Desse modo, o presente estudo teve por objetivo apresentar uma revisão de artigos, a fim de discutir o papel das garatujas para as crianças de 0 a 3 anos na educação infantil.

Nesse sentido, se faz extremamente necessário que o professor da Educação Infantil tenha compreensão e conhecimento a respeito do desenho infantil e a sua relação com a evolução do desenvolvimento humano. Assim como, saber que o desenho diz respeito as manifestações das necessidades vitais pelas quais as crianças passam na medida em que conhecem e agem sobre o mundo e comunicam-se com esse mundo.

Dito isso, vale recordar que a comunicação humana vem desenvolvendo-se desde a pré-história, resultando em diversos tipos de linguagem verbal e não-verbal. E, antes mesmo da comunicação verbal existir, o homem primitivo, já revelavam sinais de comunicação por meio da linguagem elementar desenvolvida a partir de gestos, sons, expressões e grunhidos (MOURA e PAIM, 2019).

Nesse sentido, de acordo Parellada (2009) citado por Moura e Paim (2019), à medida que homens deixaram de ser nômades e fixaram-se em uma determinada região tiveram mais tempo para dedicar-se a arte da comunicação. E, essas marcas de comunicação estão nos desenhos rupestres nas paredes das cavernas e rochas ao ar livre que foram encontrados por pesquisadores em diferentes sítios arqueológicos. Assim, as expressões artísticas produzidas pelo homem ao longo dos tempos nas diferentes culturas são conhecimentos adquiridos por ele por meio de diferentes formas de expressão, tais como: desenho, pintura, fotografia, modelagem, escultura, gravura, arquitetura e bordado, etc. E, a arte trata-se da experiencia e da cultura envolvendo ainda conhecimentos e saberes adquiridos de geração em geração por meio do desenvolvimento individual e social (FERREIRA, 2020). 
Com isso, o desenho gravado na história humana é a primeira forma de comunicação e expressividade simbólica de suas relações com o mundo, construindo a partir dele uma ligação entre a realidade e as abstrações daquilo que se pretende registrar (SANTOS, 2019). E olhando para os desenhos na atualidade e os enxergando como expressões gráficas que demonstram uma significação de ideias de quem os faz sujeita uma interpretação direta de quem os comtempla, evidenciando que diz respeito a uma linguagem explorada desde muito cedo pelas crianças (SANTOS, 2019).

Nesse contexto, o desenho trata-se de um modo de expressão que vai muito além do lápis e do papel, sendo que diferentes artefatos e materiais foram usados pelo homem para registro ao longo da história. E, ele pode ser considerado universal de modo que a comunicação realizada a partir dele é um dos meios mais antigos utilizado pelo homem (OLIVEIRA e GRUBITS, 2020).

Além do mais, desenhar é um ato espontânea adquirido pelo ser humano durante seu desenvolvimento é uma ação espontânea adquirida pelo ser humano durante o seu desenvolvimento sendo na infância que a criança realiza seus primeiros traços de expressão e comunicação. Tais desenhos compõem o universo humano de construção do conhecimento (OLIVEIRA e GRUBITS, 2020).

Nesse sentido, a criança é um ser produtor de cultura e o ato de se expressar por meio da arte, como por exemplo, o desenho, pintura, a escultura, a dança e a música precisar ter um espaço assegurado no cotidiano da educação infantil. O desenho, é uma linguagem tão importante quanto a linguagem oral e escrita. Além de ser, uma forma de se comunicar com o mundo e de registro (HOELLER; SPENGLER, 2019).

Sabe-se que a educação infantil diz respeito ao primeiro nível da educação básica sendo um direito da criança e um dever do Estado como está estabelecido na Constituição Federal de 1988. Assim sendo, a educação infantil divide com as famílias a função de educar e cuidar de crianças pequenas. E, nos primeiros anos de vida as crianças estão num período de descoberta do mundo ao seu redor. Elas interagem com o meio e com as pessoas e aprendem a se comunicar por meio diferentes linguagens, como: oral, corporal, musical, plástica etc. (HOELLER; SPENGLER, 2019).

Posto isso, desde muito cedo a criança é apresentada a situações sociais e culturais ricas de símbolos e significados. E, a participar das práticas 
sociais e culturais ao seu redor é requisitada constantemente a reconstruí-las no seu dia a dia na interação com o outro (COLBEICH; NUNES, 2019). Nessa visão, para que a criança de zero a três anos aprenda se faz necessário que o ambiente de interação social favoreça vivências significativas e a arte apresenta-se como um poderoso instrumento de expressão e comunicação que os docentes podem lançar mão para propor situações ricas de aprendizagens (HAWTHORNE, 2021).

Desse modo, segundo Hawthorne (2021) as linguagens decorrentes das artes utilizam sons, cores e movimentos precedem o aprendizado da linguagem escrita. E, a partir da compreensão de que a arte tornar mais eficaz o processo de desenvolvimento da criança de zero a três anos é possível desconstruir o pensamento de que a alfabetização diz respeito apenas a um processo que ocorre por meio das palavras.

Nesse seguimento, de acordo com Rosa (2016) citado por Hoeller e Espengler (2019) o desenho trata-se da primeira manifestação gráfica humana sendo um instrumento para se comunicar e contar histórias. Além do mais, de acordo com a BNCC (Base Nacional Comum Curricular), homologada no fim de 2017, estabelece-se que para a educação infantil objetivos e aprendizagem e desenvolvimento no campo de experiências Traços, sons, cores e formas: "Expressar-se livremente por meio de desenho, pintura, colagem, dobradura e escultura, criando produções bidimensionais e tridimensionais" (BRASIL, 2017, p. 46). Tal fato, reforça o entendimento de que o desenho é importante na vida e no desenvolvimento global infantil.

Em vista disso, o professor ao proporcionar um ambiente que possibilita a ampliação das potencialidades perceptivas, valorizando e resgatando conhecimentos e práticas artísticas enriquece as vivências infantis, bem como, sua compreensão do mundo que à cerca (COLBEICH e NUNES, 2019). O ser humano deve ser visto como um ser que está em constante desenvolvimento em que cada fase da sua vida adquire conhecimentos e experiências. E, toda atividade executada por ele serve para auxiliá-lo em determinadas áreas da sua vida, dando sentido a sua vida (SOARES e MAZIERO, 2018). Um exemplo é o desenho, que possibilita a observação de resultados no desenvolvimento humano nas áreas cognitivas, afetivas, motoras, bem como, na exploração da criatividade e na subjetividade (SOARES e MAZIERO, 2018). 
Os rabiscos são as primeiras manifestações das crianças sobre o papel, ou seja, é a primeira expressão significativa da criança. Por isso, tal estágio pode ser considerado a evolução do desenho informal em que a criança não tem a intenção de traçar no papel com precisão no plano plástico, isto é, o borrão ou aglomerado e no plano gráfico, que são os rabiscos (BOMBONATO e FARAGO, 2016).

Dessa maneira, os borrões que as crianças fazem de acordo com Méredieu (2006) citado por Bombonato e Farago (2016) estão relacionados com os jogos e manipulações que ocorrem quando os bebês estão em contato papinhas ou outros alimentos e sentem a necessidade de se sujarem, o que causa um grande sentimento de prazer.

Assim, ainda segundo Méredieu (2006), os rabiscos acontecem a partir de expressões num ritmo biopsíquico próprio de cada criança, ou seja, os rabiscos aparecem em meio a aprendizagem do andar e do sentido de equilíbrio. Tal fato possibilita as análises psicomotoras do gesto gráfico e conduz a percepção de que tudo depende da apreensão do eixo corporal. $\mathrm{E}$, antes de descobrir o traço voluntário a criança desenha pelo prazer e satisfação que o movimento the proporciona. (BOMBONATO e FARAGO, 2016).

Além disso, Edith Derdyk (1989) citada por Bombonato e Farago (2016), defende que a criança não desenha apenas pela questão do prazer que o traçado lhe proporciona, mas que o desenho surge de modo espontâneo ao mesmo tempo que o seu desenvolvimento e que é uma ação inteligente, sensível, de autonomia, conhecimento e comunicação. E, isso quer dizer que os traços infantis é um meio que as crianças encontram para se comunicar por meio da representação e simbolização do que ela não consegue expressar por outras linguagens. E Piaget e Vygotsky, citados por Costa (2017), compreendem a criança como um ser ativo, atento, que está sempre criando hipóteses sobre o seu meio. Entretanto, há grandes diferenças na maneira de entender o seu processo de desenvolvimento.

Em vista disto, segundo Vygotsky (1998), ao desenhar a criança utiliza a memória e não desenha o que vê, mas sim o que conhece, ela o faz do mesmo jeito como faz com a fala, ou seja, como se contasse uma história. Sendo assim, o desenho é entendido como uma linguagem gráfica que surge baseado na linguagem verbal. Além disso, o autor interpreta o 
desenho como um estágio que antecede a linguagem escrita. Tal autor classificou o desenho em quatro etapas, são elas:

- Simbólica: é o momento em que as crianças desenham os objetos a partir da memória, sem aparente preocupação com fidelidade à coisa representada;

- simbólico-formalista: momento que se percebe maior elaboração dos traços e formas do grafismo infantil. E, a criança começa sentir a necessidade de não se limitar somente à enumeração dos aspectos concretos do objeto que representa estabelecendo maior número de relações entre o todo representado e suas partes;

- formalista veraz: as representações gráficas são fiéis ao aspecto observável dos objetos representados, buscando ficar mais próximo da realidade e se encerrando os aspectos mais simbólicos presentes nas etapas anteriores;

- formalista plástica: diz respeito a uma nova forma de desenhar, em que se acaba utilizando de técnicas projetivas e mais realistas. E, o grafismo deixa de ser uma atividade com fim em si mesma e pra ser um trabalho criador.

E, já para Piaget (2006), o desenho é precedido pela garatuja, etapa inicial do grafismo que, assim como, o brincar tem como característica inicial o exercício da ação, sendo reconhecido assim, a partir do reconhecimento pela criança de um objeto no traçado que realizou (COSTA, 2017). Nessa fase inicial, a assimilação é predominante no desenho, ou seja, o objeto é modificado em função do significado que lhe foi atribuído. E, na continuidade do processo de desenvolvimento, o movimento de acomodação vai permanecendo, ou seja, cada vez mais ocorre uma aproximação com o real e a preocupação com a semelhança ao objeto representado (BOTELHO, 2018).

Assim, segundo Piaget (2006), citado por Costa (2017), o desenho nessa fase inicial chamado de garatuja, faz parte do estágio sensório motor (0 a 2 anos) e do estágio pré-operacional (2 a 7 anos), indo aproximadamente até os três ou quatro anos.

E, ainda segundo as fases do desenho infantil até os três anos podem ser divididas em 2 momentos (COSTA, 2017): 
- Garatuja desordenada: os primeiros traços são casuais em que a criança não pode fazer o que quer com eles. E, são movimentos sem intencionalidade, amplos e assemelham-se a um movimento motor.

- Garatuja ordenada ou controlada: os movimentos aparecem como traços longitudinais e circulares e a figura humana ainda surge apenas na imaginação, podendo começar a surgir o interesse pelas formas. Nessa fase, entre o que a criança diz que vai desenhar e o que ela registra não existe uma relação fixa. Por isso, ela pode dizer que um círculo é ovalado é uma coisa e ao terminar dizer que é outra.

Embora Vygotsky tenha a atenção voltada para o ponto de vista social e Piaget dando atenção ao ponto de vista epistêmico ambos se aproximam ao afirmarem à importância do desenho para o desenvolvimento infantil e o fato da criança desenhar o que lhe interessa, representando o seu conhecimento acerca de um objeto (COSTA, 2017) .

Diante do exposto, cabe ressaltar que quanto mais ricas forem as vivências infantis maior a possibilidade de desenvolvimento da criatividade e imaginação. E, é dever da escola proporcionar um ambiente seguro, afetivo, com recursos variados e comprometido com o desenvolvimento integral das crianças, bem como, garantir um ensino eficaz, significativo e humanizado (FURTADO e NETO, 2019). Portanto, a educação infantil deve apresentar um ensino adequado e de qualidade para o desenvolvimento da expressão criadora, pois diz respeito a um espaço propício para a emersão da criatividade, imaginação, fantasia e possibilidades.

\section{CONSIDERAÇÕES FINAIS}

No decorrer do presente estudo, que esteve voltado em apresentar uma revisão de artigos, a fim de discutir o papel das garatujas no desenvolvimento da criança de zero a três anos, foi possível verificar que o desenvolvimento do grafismo é a revelação da natureza emocional e psíquica da criança. E, é por meio da sua linguagem gráfica que deixa registrado suas ideias, vontades, sentimentos e fantasias. Nessa visão, o desenho é um meio de comunicação utilizado pela criança desde muito cedo para 
compreender e interagir com mundo que a cerca. E, ele marca o desenvolvimento da infância e em cada etapa o desenho infantil assume um caráter próprio. Assim, tais etapas definem as formas de desenhar que são muito semelhantes em todas as crianças, apesar das diferenças individuais.

Portanto, o desenho infantil é uma etapa muito importante na formação dos seres humanos cabendo aos docentes na educação infantil garantir às crianças de zero a três anos um ambiente rico em experiência, aprendizagem e com recursos variados e um ensino voltado para aspectos mais livres de manipulação e exploração de materiais.

\section{REFERÊNCIAS}

BRASIL. Base Nacional Comum Curricular: Educação é a Base. Ministério da Educação Básica. Brasília: MEC/SEF, 2018.

BOMBONATO, Giseli Aparecida; FARAGO, Alessandra Corrêa. As etapas do desenho infantil segundo autores contemporâneos. Disponível em: < https://www.unifafibe.com.br/revistason-line/ arquivos/cadernodeeducacao/sumario/40/30042016104546.pdf> Acesso em: 24 mar. 2021.

BOTELHO, Angela Maria Camelo da Silva. O Grafismo Infantil: As formas de interpretação dos desenhos das crianças. Curitiba: Appris, 2018.

COLBEICH, Marisete Machado; NUNES, Carolina Ramos. Os (entre) lugares da arte na educação infantil. 2019. Disponível em: < https://www.revistas.udesc.br/index.php/apotheke/article/ view/16501> Acesso em: 17 mar. 2021.

COSTA, Manuella Fahianny Medeiros. O desenho e sua contribuição para a aprendizagem. 2017. Disponível em: < https://monografias. ufrn.br/jspui/handle/123456789/5895 > Acesso em: 17 mar. 2021.

FERREIRA, Tamara Cristina. Artes Visuais na educação infantil: $O$ desenho e o seu papel no desenvolvimento da criança. 2020. Disponível em: < https://repositorio.ufmg.br/handle/1843/33780> Acesso em: 17 mar. 2021. 
FURTADO, Kalyne Madeira; NETO, Gil Camelo. Arte na educação infantil: possibilidades e limites. 2019. Disponível em: < https://faculdadeplus.edu.br/site/wp-content/uploads/2020/02/ 3-ARTE-NA-EDUCA\%C3\%87\%C3\%83O-INFANTIL-POSSIBILIDADES-E-LIMITES.pdf> Acesso em: 17 mar. 2021.

HAWTHORNE, Julia Galvani. Arte no berçário: Explorando, criando e aprendendo. 2021. Disponível em: <https://repositorio.ufscar.br/ handle/ufscar/13961> Acesso em: 17 de mar. de 2021.

HOELLER, Ana Karina Corrêa; SPENGLER, Maria Laura Pozzobon. As crianças e os seus desenhos na educação infantil: o papel da professora. 2019. Disponível em: <https://www.researchgate.net/ publication/334266617_AS_CRIANCAS_E_OS_SEUS_DESENHOS_NA_EDUCACAO_INFANTIL_O_PAPEL_DA_PROFESSORA\#: : text=Na\%20Educa\%C3\%A7\%C3\%A3o\%20 Infantil $\% 2 \mathrm{C} \% 20$ as $\% 20$ professoras,as $\% 20$ teorias $\% 20$ no $\% 20$ campo\%20das> Acesso em: 17 mar. 2021.

MOURA, Eliane Maria Fogliarini. PAIM, Marilane Wolff. A importância das Artes Visuais na aprendizagem das crianças. 2019. Disponível em: <file://C:/Users/User/Dropbox/My\%20PC\%20 (DESKTOP-PEML98F)/Downloads/16492-Texto\%20do\%20artigo-58404-1-10-20191231\%20(2).pdf> Acesso em: 17 mar. 2021.

OLIVEIRA, Evelyn de; GRUBITS, Sonia. Rabiscos e Emoções: Nova Perspectiva sobre o Desenvolvimento do Desenho. 2020. Disponível em: <http://pepsic.bvsalud.org/scielo.php?script=sci_arttext\&pi$\mathrm{d}=$ S1677-04712020000200013> Acesso em: 17 mar. 2021.

SANTOS, Érico Vinicius Fonseca dos. Por onde caminha o desenho na escola: pensando seus espaços. 2019. Disponível em: < https:// repositorio.ufscar.br/handle/ufscar/13626 > Acesso em: 17 de mar. de 2021.

SANTOS, Rodrigo Otávio dos; RADVANSKEI, Sonia de Fatima. BACHMANN, Vanessa da Silveira. Desenho na educação infantil: a importância e sua contribuição para o desenvolvimento cognitivo e para a alfabetização. 2016. Disponível em: < DESENHO NA EDU- 
CAÇÃO INFANTIL: a importância e sua contribuição para o desenvolvimento cognitivo e para a alfabetização | Santos | Cadernos Cajuína (cadernoscajuina.pro.br)> Acesso em: 24 mar. 2021.

SOARES, Fernanda Bahena; MAZIERO, STELA Maris Brito. O desenho no processo de desenvolvimento cognitivo. 2018. Disponível em: <https://repositorio.uninter.com/bitstream/handle/1/413/TCC-FERNANDA\%20SOARES\%20RU\%201326325.pdf?sequence=1\&isAllowed=y > Acesso em: 17 de mar. de 2021 .

SOUSA, Ivan Vale de. Da garatuja à escrita infantil. 2020. Disponível em: <https://revista.unitins.br/index.php/humanidadeseinovacao/ article/view/2488>Acesso em: 17 de mar. de 2021.

VYGOTSKY, L. S. A formação social da mente. São Paulo: Martins Fontes, 1998. 


\section{A LEITURA NA PRIMEIRA INFÂNCIA E O NASCIMENTO DE NOVOS LEITORES NA EDUCAÇÃO INFANTIL}

Gisleine Cristina da Silva ${ }^{4}$

\section{INTRODUÇÃO}

A leitura pode ser entendida como um ato de grande importante para formação pessoal e para a vida do ser humano, pois ao realizá-lo desenvolve saberes necessários à sua formação educativa. Além disso, a leitura está presente na organização do convívio social, seja no ambiente escolar ou em atividades sociais e familiares. E, sabendo-se que a infância é um período de preparação sujeito para o futuro cabendo a família e a escola o incentivo e o estímulo a leitura (SILVA, 2018).

Desse modo, de acordo com a Base Nacional Comum Curricular (BNCC) na educação infantil, a imersão da criança no mundo da linguagem escrita deve acontecer, a partir dos seus conhecimentos, curiosidades e interesses mais perceptíveis por parte do professor. Desse modo, as vivências com a literatura infantil, oportunizadas pelo docente por meio das mediações realizadas entre os textos e as crianças, contribuem de modo significativo no desenvolvimento do gosto pelo ato de ler, bem como, estimula à imaginação e amplia seu conhecimento de mundo (BRASIL, 2017).

Assim, o presente estudo é resultado das reflexões realizadas a respeito do papel da leitura no contexto da Educação infantil. Desse modo, o

44 Especialista em Psicopedagogia Clínica e institucional pela Universidade Estadual de Maringá. 
estudo pauta-se por uma revisão narrativa e teve como propósito discutir e evidenciar a importância da leitura na Educação Infantil e na Primeira Infầncia para a formação de novos leitores. O estudo justifica-se pelo fato da leitura consistir num instrumento de desenvolvimento do ser humano, pois durante o processo de leitura ou mesmo a audição de uma história a criança desenvolve-se cognitivamente, emocionalmente, culturalmente além de contribuir na compreensão do mundo ao seu redor.

A leitura ou contação de história estimula a imaginação, contribui na aquisição da linguagem oral e escrita, no desenvolvimento da afetividade e da formação crítica do indivíduo e quanto mais cedo à criança for apresentada a esse mundo mais facilmente ela desenvolverá o gosto pela leitura e se tornará um novo leitor, com possibilidade de ampliar cada vez mais a sua visão de mundo. Assim sendo, o estudo é movido por inquietações que despertam o interesse em aprofundar o assunto no que toca a importância da leitura na educação infantil e na primeira infância, uma vez que, ler, contar ou inventar e ouvir histórias exerce sempre grande fascínio e alegria nas crianças. E quando essas vivências são oportunizadas, as crianças enriquecem e potencializam as suas experiências, desenvolvem e aprimoram a sua imaginação e criatividade, bem como, a sua linguagem oral e escrita.

Nesse sentido, questiona-se: em que medida as práticas lúdicas de leitura na educação infantil podem contribuir com o desenvolvimento do gosto pelo ato de ler? De que maneira a literatura infantil pode contribuir de forma positiva no desenvolvimento global infantil? Como o aprendizado por meio do lúdico pode tornar-se mais significativo, prazeroso e eficaz para as crianças?

Para efeitos de sistematização, o presente texto está organizado em três partes, porém articuladas entre si. A primeira diz respeito a introdução em discute-se a temática no geral e é apresentado o objetivo do estudo, a problematização e a justificativa. Na segunda parte é apresentado o desenvolvimento do estudo, que se constitui nos seguintes tópicos: A importância da leitura para a primeira infância; Literatura infantil e desenvolvimento a partir da Teoria Histórico-Cultural; Leitura, literatura e ludicidade na escola; Leitura na Educação Infantil e O papel do professor no processo de aquisição da leitura na educação infantil. Já, na terceira parte refere-se a metodologia do estudo. E, a quarta é destinada as considerações finais. 


\section{A IMPORTÂNCIA DA LEITURA PARA A PRIMEIRA INFÂNCIA}

O ator de ler para Paulo Freire diz respeito a um meio de se conhecer o mundo, isto é, se expressa de diversas maneiras, pois mesmo antes de ser alfabetizada uma criança já lê o mundo que a rodeia. Desse modo, a participação dos pais na formação de um novo leitor é de grande relevância, assim como, é fundamental também o papel do educador nesse processo e em sua maneira de se posicionar frente aos educandos (ROQUE E CANEDO, 2015).

Por essa razão, a família e o professor são essenciais na formação de um novo leitor. Além do que, a leitura contribui de forma significativa para o desenvolvimento de vários aspectos infantis como a imaginação e a fantasia, como também, aspectos ligados ao ensino tais como o senso crítico, a ampliação da habilidade de criação e conhecimentos gerais. Assim, segundo Roque e Canedo (2015, p. 5):

A introdução da criança no mundo da leitura deve acontecer mesmo antes de ser iniciado o processo de alfabetização, através de estratégias de leituras estimulantes e criativas, realizadas pelos professores e pela família. Por isso, a família exerce um papel crucial, pois a criança pode ser estimulada e incentivada a ler desde o nascimento e ao longo de toda sua infância. Ao ingressar na escola, cabe aos professores dar continuidade ao trabalho de valorização da leitura.

Nesse contexto, podemos afirmar que o ato de ler é extremamente importante e necessário para o desenvolvimento de várias habilidades nas crianças. Desse modo, se faz necessário trabalhar a leitura com os pequenos desde muito cedo de modo a inseri-las nessa prática. Entretanto, nem sempre as famílias incentivam o hábito de ler por diferentes motivos transferindo essa responsabilidade para a escola. Por isso, muitas crianças ingressam na escola sem que já tenham desenvolvido o gosto pelo ato de ler e ao longo dos anos iniciais continuam mostrando pouco interesse pelo mundo da leitura. 
Diante desse fato, o papel do educador e da escola torna-se ainda mais crucial na construção do gosto e do prazer pelo ato de ler. Assim, é fundamental que os docentes leiam para seus alunos e que tenham desimpedimento para efetivar leituras diversificadas. Nesse sentido, "precisa-se sempre de incentivos e diversificação de livros, revistas, textos, histórias infantis, para chamar a atenção do aluno, para despertar a curiosidade e desenvolver o gosto pela leitura" (NUNES et al. 2012, p. 15).

Entretanto, ainda há muitos professores sem a formação adequada para trabalhar com o público infantil, o que demonstra que se faz necessário avançar em diferentes aspectos em relação a educação e a formação dos professores. Por essa razão, os cursos de formação continuada são essenciais para os professores, bem como, o apoio da direção e equipe pedagógica para realizar cada vez melhor o seu trabalho docente.

\subsection{LITERATURA INFANTIL E DESENVOLVIMENTO NA TEORIA HISTÓRICO-CULTURAL}

O ser humano e o seu processo de humanização, segundo a concepção da Teoria Histórico-Cultural defendida por Vigotski e seus colaboradores, é resultado da história criada pelo próprio homem no decorrer da história (CHAVES et al., 2014). Desse modo, podemos dizer que não nascemos humanos, mas à medida que nos apropriamos dos conhecimentos, da cultura e das experiências produzidas ao longo da história pelo meio social nos tornamos seres humanizados, ou seja, é por meio das vivências com sujeitos mais experientes que nos apropriamos dos comportamentos essencialmente humanos.

Nesse contexto, sabemos que o meio social é essencial no desenvolvimento de todos os aspectos humanos, porém não podemos desconsiderar o papel do biológico, pois este caráter biológico no processo de desenvolvimento do ser humano é algo básico e condição elementar necessária para que os seres humanos avancem e desenvolvam-se historicamente e socialmente alcançando assim as funções psicológicas superiores. Assim, segundo Chaves et al. (2014, p. 153):

[...] ao nos apropriarmos do conhecimento e experiências humanas acumuladas no decorrer da história da sociedade. Por meio das 
relações com parceiros mais experientes nos apropriamos de comportamentos humanos, como a fala, o pensamento, a autonomia, a imaginação, a percepção e a criatividade, fatores importantes para o desenvolvimento da inteligência e da personalidade.

Desse modo, as relações sociais e históricas são fundamentais no processo de desenvolvimento. Em virtude disso, a interação dos adultos com as crianças é um fator essencial desde os primeiros dias de vida dos pequenos e os momentos de cuidados não devem se separar das situações educativas, ou seja, do ensino intencional junto as crianças.

Nesse seguimento, é essencial oportunizar situações de desenvolvimento pleno e humanizador no processo educativo com o intuito de desenvolver de forma plena todas as funções psíquicas superiores na constituição humana por meio do aprendizado, sendo que na escola o dever de ensinar cabe aos educadores (CHAVES et al., 2014).

Posto isso, se faz necessário oportunizar aos educandos as máximas elaborações humanas, construídas e desenvolvidas ao longo dos tempos com o objetivo de desenvolvimento pleno das crianças (PASTRE et al., 2016).

A literatura infantil é um recurso importante para a construção humana e também para o desenvolvimento emocional, social e cognitivo dos pequenos. Além disso, a literatura infantil é essencial no processo de uma educação humanizadora, pois à medida que é proposta como conteúdo, estratégia e recurso de ensino de maneira adequada numa prática de ensino de qualidade permite o desenvolvimento da atenção, da memória, da percepção, ou seja, uma prática pedagógica fortalecedora das funções psíquicas superiores (CHAVES et al., 2014). Ainda, a literatura infantil permite aos pequenos a formação de conceitos científicos e sistematizados, a ampliação do vocabulário, o desenvolvimento do raciocínio, a organização do pensamento e a interpretação do mundo, bem como, o estabelecimento de relações de sentimentos, emoções e afetividade.

Diante disso, se faz necessário oportunizar o contato dos pequenos com a literatura infantil, seja por meio da arte, da música, dos poemas e poesias ou nas contações de histórias. Desse modo o "trabalho deverá ser intencional e planejado pelos professores com o intuito de desenvolver as habilidades humanas, bem como, a promoção intelectual, emocional e afetiva dos educandos" (PASTRE et al., 2016, p.3). Entretanto, segundo 
essa autora não é suficiente apenas proporcionar as crianças o contato com a Literatura Infantil é preciso que a escolha do material seja feita de maneira intencional e criteriosa.

Então, fundamentados pela concepção da Teoria Histórico-Cultural na qual Vigotsky (1999) defende que as funções psíquicas superiores possuem condições de se desenvolver à medida que ocorre a aquisição e a apropriação dos conhecimentos pela criança e isso só é possível quando há a mediação de indivíduos mais experientes culturalmente, sendo que, na escola, o educador assume tal papel, pois, diante da criança ele é a pessoa mais desenvolvida culturalmente.

Cabe ao docente contribuir para a formação e humanização das crianças, criando assim oportunidades de apropriação dos objetos culturais construídos pela humanidade, tais como: as diversas formas de artes, ciências, filosofia e em especial a literatura, que apresenta muitas possibilidades para o desenvolvimento das funções psíquicas superiores dos pequenos. Vale ainda ressaltar "a falta de oportunidade de desenvolvimento das funções psicológicas superiores, como a imaginação, a atenção, a memória, a fala, a criatividade e a percepção, pode resultar nas dificuldades de aprendizagem" (CHAVES et al., 2014, p. 155).

\subsection{LEITURA, LITERATURA E LUDICIDADE NA ESCOLA}

$\mathrm{O}$ ato de ler consiste em saber utilizar a leitura e a escrita de acordo com a sua função social no seu cotidiano tornando assim o sujeito apto a questionar e a utilizar as informações que recebe do mundo (BUENO e STEINDEL, 2006). Quando lemos, construímos nossos próprios significados, elaboramos nossas próprias questões e também rejeitamos, confirmamos ou reelaboramos nossas próprias respostas. Além disso, a leitura tem o poder de nos modificar e também mudar o modo como nos relacionamos com o mundo permitindo assim a possibilidade de mudanças coletivas, bem como, incentiva a reflexão, a crítica e possibilita questionamentos próprios ou coletivos que podem ser explicados ou não dependendo essencialmente do estímulo dado a criança (BUENO e STEINDEL, 2006).

Nessa perspectiva, a leitura diz respeito a um processo de ensino em que os agentes necessitam interagir mutuamente, a fim de obterem sucesso. Logo, o leitor aprendiz e o leitor mais experiente precisam trocar 
experiências para que consequentemente adquira autonomia e com essa autonomia construa o seu saber (FERREIRA E DIAS, 2002).

$\mathrm{O}$ ato de ouvir histórias é a primeira etapa para se tornar um leitor e descobrir que por meio do livro é possível encontrar ideias, satisfazer a curiosidade, encontrar soluções, compreender a realidade, identificar-se com os personagens, superar conflitos e dificuldades, bem como, descobrir novos lugares (BUENO e STEINDEL, 2006). Com isso, ouvir histórias também corresponde a provocar diferentes sentimentos, estimular a vontade de ler por conta própria de modo a nutrir o senso crítico. Assim, de acordo com Abramovich (1994):

[...] o processo natural de contato da criança com o texto literário passa pelas seguintes fases: ouvir histórias, ver ilustrações, fazer associação/ligação dos signos. Portanto, o primeiro contato se faz pelo meio auditivo e visual. Apesar de existir, o texto escrito ainda não faz parte do entendimento, as ilustrações, os formatos diferentes, a criatividade contam a sua história sem precisar de uma única palavra escrita (Bueno e Steindel, 2006, p. 12).

A literatura também é um meio de informação e por meio dela as crianças podem aprender as diferentes relações humanas, problemas e conflitos da vida em sociedade, bem como, conhecer as formas do comportamento humano. O "lúdico não está apenas no ato de brincar, mas também no ato de ler, no apropriar-se da literatura como instrumentos de compreensão do mundo" (BUENO E STEINDEL, 2006, p. 13). E, as práticas lúdico-criativas despertam a atenção dos pequenos podendo assim ser um instrumento potencializador da aprendizagem.

Portanto, as atividades lúdicas favorecem o desenvolvimento motor e psicomotor dos pequenos, bem como, são atividades que permanecem no tempo e quando são significativas elas possuem o poder de ficar marcada na lembrança da vida da criança.

\subsection{LEITURA NA EDUCAÇÃO INFANTIL}

O hábito de ler para a formação psicológica, cognitiva e psicomotora de quem o pratica e proporciona aos pequenos a oportunidade de viajar 
pelo mundo do faz de conta, pois o universo infantil é repleto de ludicidade e é por meio do lúdico que os educadores e educandos se integram no processo ensino-aprendizagem (COELHO, 2015). Assim, a infância é um período em que as crianças estão mais abertas a desenvolver hábitos que serão seguidos futuramente. Assim, é essencial incentivar o gosto pela leitura desde cedo nas crianças, pois esses novos leitores levarão esse hábito construído na infância para toda a sua vida.

Por consequência, se faz necessário mostrar aos pequenos que o ato de ler diz respeito a um meio de obtenção de informações, além de ser uma ação prazerosa e fascinante. E, apesar de nos primeiros anos de vida os pequenos ainda não saberem ler, eles podem ouvir história, observar, manusear e folhear os livros, observar as gravuras o que consequentemente contribui com o desenvolvimento do gosto pelo ato de ler. A leitura na Educação Infantil pode e deve ser realizada em conjunto de modo que a criança segue o leitor na leitura como parceiros de viagem. Seja por meio do tato, pela visão ou simplesmente pelo ato de ouvir a história. Os pequenos de alguma maneira percebem desde cedo que o livro é algo bom e prazeroso (CASTRO E WINKELER, 2011).

Posto isso, o gosto pelos livros não é algo que surge de uma hora para outra. E, é necessário ajudar os pequenos a descobrir as possiblidades que um livro pode oferecer. Por isso, tanto pais como educadores têm um papel essencial nessa descoberta atuando como estimuladores e incentivadores da leitura (CASTRO E WINKELER, 2011).

Por esse prisma, o incentivo à leitura é de grande importância desde muito cedo, porém se faz necessário que compreendam que o ato de ler não se trata de um ato puramente mecânico. Diante disso, para Lerner (2002) a aprendizagem:

[...] começa a partir do momento em que o indivíduo passa a ter contato com o objeto, em questão. A instrumentalização das atividades de ensino, quanto à leitura é o livro. O importante mesmo é que a criança esteja em contato com todo tipo de obra da literatura e façam, quando passarem a tomar ciência do conteúdo, as suas próprias opções de gênero literário (COELHO, (2015, p. 8). 
Nesse contexto, o educador na educação infantil é o principal responsável pelo trabalho com a leitura em sua prática pedagógica em sala de aula e exerce grande influência sobre as crianças no que diz respeito ao gosto pelo mundo da leitura. Além disso, é na Educação Infantil que os educandos passam a ter o contato com leitura de maneira formal e sistematizada. E, o incentivo à leitura necessita ser um propósito compartilhado entre a escola e a família, pois ambas são modelos muito importantes para a formação de um novo leitor. Entretanto, se a criança na educação infantil não trouxer de casa esse hábito é papel da escola estimular, conquistar e encantar os novos leitores por meio de prática de leitura lúdicas, prazerosas, de qualidade e de sentido para as crianças.

Vale ressaltar que nessa etapa do ensino as crianças possuem um nível de concentração muito baixo e dispersam com muita facilidade e rapidez. Por isso, se faz necessário estratégias e planejamentos adequados, a fim de que o aprendizado para as crianças seja repleto de brilho e prazer. Diante disso, ler é algo importante para o cotidiano do ser humano uma vez que envolve questões referentes tanto à vida doméstica, bem como, questões intelectuais e profissionais. Na Educação infantil, é essencial garantir as crianças um ambiente rico em aprendizagens e propício ao desenvolvimento tendo em mente que a criança é um ser ativo e em processo de formação cabendo a escola criar espaços em que ela possa explorar, pesquisar e tirar suas próprias conclusões e a partir disso adquirir novas habilidades frente ao ato de ler.

\subsection{O PAPEL DO PROFESSORE NO PROCESSO DE AQUISIÇÃO DA LEITURA NA EDUCAÇÃO INFANTIL}

Os primeiros anos de vida é um momento da infância em que os pequenos estão muito abertos a conhecer e descobrir o mundo que os cercam. Deste modo, esse é um período ideal para as aprendizagens que acompanharão todo o desenvolvimento humano (SANTOS, 2009). Nesse contexto, na educação de crianças pequenas o fazer compartilhado é essencial no processo de apropriação de conhecimentos que impulsionam o desenvolvimento infantil de uma forma global. Os contatos iniciais das crianças com os livros ocorrem por meio da curiosidade e pelo formato que eles possam possuir. Dessa maneira, é papel do docente oportunizar 
a ampliação de seus conhecimentos de leitura possibilitando que os pequenos tenham acesso a diversos tipos de textos cabendo assim à escola a formação crítica dos novos leitores (RODRIGUES, 2015).

Logo, no processo de formação de leitores os professores necessitam ter conhecimento sobre os livros mediando da melhor forma possível o processo de aprendizagem e transformando esse momento em uma experiência agradável, a fim de construir um vínculo afetivo que leve a confiança e a responsabilidade mútua entre educadores e educandos, bem como, ao desenvolvimento da sensibilidade. O educador precisa trabalhar de maneira diferenciada transformando o tempo de leitura em um momento agradável desenvolvendo assim a sensibilidade e a inteligência e principalmente incentivando e inserindo as crianças no mundo da leitura.

Nesse seguimento, para Cunha (1998), "gostar ou não da literatura, como de qualquer outra experiência, não é um dado biológico de nascença. Se essa característica é da história de cada um, cabe-nos, como educadores, influir o melhor que pudermos nesse dado cultural" (RODRIGUES, 2015, p. 243). É papel do educador despertar nos pequenos o desejo pela leitura desde muito cedo para que enxerguem a literatura como um meio de aquisição de conhecimentos necessários não somente para a formação escolar, mas também para a vida reconhecendo-se como cidadãos com direitos e deveres. Consequentemente, o docente deve promover as práticas de leitura, a fim de contribuir com a inserção dos pequenos na cultura letrada. Desse modo, é essencial que esse hábito seja estimulado na infância por meio de práticas lúdicas que levem as crianças a encontrar sentido e despertando nelas o desejo por novas leituras.

\section{METODOLOGIA}

O presente estudo é de natureza teórica e pauta-se por uma revisão narrativa. Assim, a revisão narrativa diz respeito aos "artigos de revisão narrativa são publicações amplas apropriadas para descrever e discutir o desenvolvimento ou o 'estado da arte' de um determinado assunto, sob ponto de vista teórico ou conceitual” (ROTHER, 2007, p. 1). Assim, tal tipo de revisão não estabelece a metodologia para a busca das referências nem os critérios para elegibilidade dos trabalhos. Ou seja, esse tipo de 
revisão constitui-se da análise da literatura, da interpretação e análise crítico-pessoal do pesquisador (BERNARDO; NOBRE; JANETE, 2004).

Os procedimentos metodológicos envolveram seleção da literatura básica, leitura e fichamento das obras selecionadas, encontros de estudo, discussões e reflexões e elaboração da redação em forma de artigo.

\section{REFLETINDO E CONCLUINDO}

A leitura, a contação de história e a brincadeira estimulam a imaginação, colabora na aquisição da linguagem oral e escrita, desenvolve a afetividade e a formação crítica do indivíduo. E, quanto mais cedo à criança for apresentada a esse mundo, mais facilmente desenvolverá o gosto pela leitura e se tornará um novo leitor, com a possibilidade de ampliação de visão de mundo. Assim, cabe à família, mas sobretudo ao educador, que tem como função primordial fornecer meios para o desenvolvimento da criança e introduzir diferentes atividades lúdicas na sua prática pedagógica. Além disso, o contato com os livros deve ser incentivado desde os primeiros meses de vida da criança, por isso é muito importante organizar um espaço onde as crianças possam ver, tocar, cheirar, manusear, etc.

O contato com os livros possibilita inúmeras possibilidades, como a convivência, o toque, o desenvolvimento da linguagem oral, a percepção tátil, a observação de semelhanças e diferenças de acordo com as gravuras, conhecimento de mundo porque as histórias trazem para os pequenos experiências distintas daquelas que já vivem ou conhecem. $\mathrm{O}$ ato de ler é uma necessidade importantíssima para a vida dos sujeitos. E, a falta de estímulo à leitura é um dos fatores determinantes das dificuldades na leitura e na escrita, bem como, o fracasso escolar.

Portanto, o contato com o universo da leitura instiga nos pequenos a descoberta e o aprimoramento da linguagem, da imaginação, da autonomia contribuindo assim com a formação de novos leitores.

\section{REFERÊNCIAS}

BRASIL. Base Nacional Comum Curricular. 2017. Disponível em: <http://basenacionalcomum.mec.gov.br/images/BNCC_EI_ EF_110518_versaofinal_site.pdf〉. Acesso em: 28 abr. 2021. 
BERNARDO, Wanderley Marques. NOBRE, Moacyr Roberto Cuce. Jatene, Fábio Biscegli. A prática clínica baseada em evidências. Parte II: buscando as evidências em fontes de informação. 2004., São Paulo: Revista da Associação Médica Brasileira.

BUENO, Silvana Beatriz. STEINDEL, Gisela Eggert. A biblioteca e a brinquedoteca: mediadores do livro, objeto prazeroso de saber e lazer no ambiente escolar. Florianópolis- SC: Ciência \& Cognição. v. 8. p.10-21. 2006. Disponível em:<http://www.cienciasecognicao. org/pdf/v08/m32697.pdf> Acesso em: 20 mar. 2021.

CASTRO, Gisele Yumi Freitas de. WINKELER, Maria Sílvia Bacila. A Importância Da Leitura Na Educação Infantil: Relato De Experiência Em Um CEI De Curitiba - PR. 2011. Disponível em: <https://educere.bruc.com.br/CD2011/pdf/5360_3477.pdf> Acesso em: 21 mar. 2021.

CHAVES, Marta et al. Aprendizagem e desenvolvimento: uma perspectiva pedagógica e psicopedagógica com literatura infantil. 2014. Disponível em: <http://pepsic.bvsalud.org/scielo. php?script=sci_arttext\&pid=S0103-84862014000200008> Acesso em: 20 mar 2020.

COELHO, Kesia. A Importância Da Leitura Na Educação Infantil: Um Estudo Teórico. 2015. Disponível em: <https://fapb.edu.br/ wp-content/uploads/sites/13/2018/02/especial/4.pdf> Acesso em: 21 mar. 2021.

FERREIRA, Sandra Patrícia Ataíde. DIAS, Maria da Graça Bompastor Borges. A escola e o ensino da leitura. Maringá-Pr: Psicologia em Estudo. v. 7, n. 1, p. 39-49. 2002. Disponível em: <https://www. scielo.br/pdf/pe/v7n1/v7n1a05.pdf> Acesso em: 21 mar. 2021.

NUNES, Izonete et al. A importância do incentivo à leitura na visão dos professores da escola Walt Disney. 2012. Disponível em: <http://www.faflor.com.br/revistas/refaf/index.php/refaf/article/ view/53/pdf $>$ Acesso em: 24 mar. 2021.

PASTRE, Cristiane Aparecida da Silva et al. Literatura Infantil: Possibilidades de Encantos E Desenvolvimento nos Anos Iniciais. 
2016. Disponível em: <http://www.ppe.uem.br/semanadepedagogia/2016/T02/28.pdf> Acesso em: 20 mar. 2020.

RODRIGUES, Suzana Machado. A Prática De Leitura Na Educação Infantil Como Incentivo Na Formação De Futuros Leitores. 2015 p. 241-249, v.6, n.2(15. ed.). Revista Eventos Pedagógicos. Disponível em: <https://docplayer.com.br/18256865-A-pratica-de-leitura-na-educacao-infantil-como-incentivo-na-formacao-de-futuros-leitores-resumo.html> Acesso em: 24 mar 2021.

ROQUE, Cássia Lina Bittencourt; CANEDO, Maria Luiza. A Importância Do Incentivo À Leitura Nos Primeiros Anos Da Infância. 2015. Disponível em: <http://www.puc-rio.br/ensinopesq/ccg/ licenciaturas/pibid/download/seminario_pibid_sudeste_201510_cassia_roque.pdf> Acesso em: 23 mar 2021.

ROTHER, Edna Terezinha. Revisão sistemática X Revisão Narrativa. 2007. Disponível em: <https://www.scielo.br/pdf/ape/v20n2/ a01v20n2.pdf> Acesso em: 28 abr. 2021.

SANTOS, Maria Cristina dos. Ler para crianças pequenas: Saberes do Professor. 2009. Disponível em: <http://paraalmdocuidar-educaoinfantil.blogspot.com.br/2009/06/blog-post.html> Acesso em: 24 mar. 2021.

SILVA, Sheila da Rocha. A importância da Leitura na Educação Infantil. 2018. Disponível em: <https://bdm.unb.br/bitstream/10483/24530/1/2018_ScheiladaRochaSilva_tcc.pdf> Acesso em: 28 abr. 2021.

VIGOTSKI, L. S. Psicologia pedagógica. São Paulo: Martins Fontes. 1999. 


\section{ENSINO E APRENDIZAGEM: REFLEXÕES SOBRE OS IMPACTOS DO ENSINO REMOTO NA PANDEMIA DE COVID-19}

Diego Neves Sampaio ${ }^{5}$

Débora Karpowicz ${ }^{6}$

INTRODUÇÃO

Dia 17 de março de 2020, o inimaginável aconteceu: o Brasil parou, as escolas fecharam, estudantes, professores e famílias estavam diante de um desafio até então não vivenciado na história da educação. A educação "tradicional", outrora herdada do modelo escolástico, com pitadas do humanismo, porém disfarçada com um discurso crítico e emancipador, foi posta à prova. O velho modelo escolar do século XVIII, com alunos, professores, carteiras enfileiradas e o método tradicional de ensino aprendizagem foi desafiado por novas formas de ensinar e aprender. Um micro-organismo, invisível - SARS-CoV-2, ou Covid-19 -, fora capaz de desestabili-

\footnotetext{
5 Bacharel e Licenciado em Geografia pela PUCRS. Especialista em Ensino e Geografia e História (UFRGS). Especialista em Gestão da Educação (PUCRS). Professor de Geografia da Rede Jesuíta de Educação.

6 Doutora, mestre e licenciada em História pela PUCRS. Pedagoga e Especialista em Educação à Distância (Uniasselvi). Graduanda em Sociologia. Autora do livro CIGANOS: História, Identidade e Cultura. Atualmente é professora do Centro Universitário Uniasselvi e da Rede Jesuíta de Educação.
} 
zar a grande estrutura total chamada escola. Desafios se fizeram e ainda se fazem presentes a partir deste contexto iniciado em 2020, e que ainda se encontra em pleno furor, dada a não solução efetiva para o problema de saúde mundial que abalou o mundo e as grandes estruturas, dentre elas, a escolar (BARRETO; ROCHA, 2020)a volta à normalidade não apresenta soluções fáceis, a vida social, educacional e econômica estão sendo extremamente afetadas. Com a Pedagogia Pandêmica, as formas de se relacionar, de consumir, as estratégias de trabalhos e, sobretudo, o trabalho docente foram impactados. Diante desse cenário, esse estudo bibliográfico e documental objetiva tecer reflexões sobre os impactos e desafios do COVID-19 na Educação. Os resultados mostraram que muitos são os desafios e (im.

Nesse contexto desafiador, este artigo tem por objetivo refletir acerca dos impactos causados pela crise sanitária da Covid-19 no processo de ensino e aprendizagem. Objetiva-se analisar os desafios da educação perante esse contexto pandêmico. Para tanto, torna-se fundamental ressaltar que os obstáculos impostos nesse período são notórios a todos os segmentos da sociedade. No campo da educação, de maneira inesperada, grande parte das instituições de ensino sentiram-se obrigadas a implementar um modelo de ensino remoto emergencial. Não obstante, a sociedade brasileira já vinha enfrentando significativas transformações, principalmente no que diz respeito ao acesso à educação via plataformas digitais.

Observa-se uma variedade de recursos tecnológicos que possibilitam o ensino e a aprendizagem on-line, remetendo a uma evolução digital na qual a conectividade e a colaboração fazem parte do cotidiano da sociedade brasileira. No entanto, apesar dessa imposição tecnológica de adaptação por parte das escolas, a desigualdade do Brasil impõe outros desafios, que vão além do simples ato de mudar a técnica educativa, mas de perceber que nem todos têm os mesmos acessos e condições de manter uma educação mínima. Neste sentido, refletir sobre os impactos da pandemia no processo de ensino e aprendizagem também requer refletir sobre o abismo desigual que teremos ao final deste processo de readaptação e mudanças nas escolas, caso não tenhamos uma ação efetiva que abrande estas desigualdades (BARRETO; ROCHA, 2020)a volta à normalidade não apresenta soluções fáceis, a vida social, educacional e econômica estão sendo extremamente afetadas. Com a Pedagogia Pandêmica, as formas de se relacionar, de consumir, as estratégias de traba- 
lhos e, sobretudo, o trabalho docente foram impactados. Diante desse cenário, esse estudo bibliográfico e documental objetiva tecer reflexões sobre os impactos e desafios do COVID-19 na Educação. Os resultados mostraram que muitos são os desafios e (im.

Frente a esse contexto, este artigo tem por objetivo analisar a inserção do ensino remoto no processo de ensino e aprendizagem, refletindo acerca das novas possibilidades projetadas por professores e estudantes. Para isso, utilizou-se de ampla análise bibliográfica e, acima de tudo, da experiência escolar dos autores. Dada a temática recente, recorreu-se às publicações governamentais como da Unesco que já possui pesquisa sólida sobre o tema, bem como de publicações recentes acerca do assunto. Buscou-se, para tanto, fazer uma revisão integrativa e reflexiva a partir das atuais pesquisas cotejadas com o olhar e experiência dos autores.

Sendo assim, este ensaio estrutura-se em duas etapas. Na primeira, compreendem-se os impactos gerados pela pandemia da Covid-19 nos processos de ensino e aprendizagem, relacionando-os com o papel desempenhado pela escola para, na segunda parte, analisar os paradigmas nas formas de ensino e aprendizagem a partir do início da pandemia, destacando conceitos fundamentais ligados à dinâmica de adaptação e as novas possibilidades sugeridas nesse período.

\section{ENSINO E APRENDIZAGEM: REFLEXÕES SOBRE OS IMPACTOS DO ENSINO REMOTO}

Em março de 2020, quando ainda se refletia sobre a possibilidade de uma pandemia e a necessidade de uma quarentena global, o contexto midiático nos surpreendia ao apresentar diferentes panoramas daquilo que estava por acontecer. A partir disso, surgiu a necessidade de um afastamento social, e os processos de ensino e aprendizagem passaram a ocorrer de forma remota e virtual. Assim, pôde-se notar que a docência e a educação escolar sofreram sérios abalos, visto que a propagação do vírus nos forçou ao isolamento. Assim, estudantes, professores, gestores das instituições de ensino públicas e privadas, passaram a se preocupar em buscar soluções e alternativas para a continuidade dos processos educativos, visando dar assistência às necessidades de todos os envolvidos. No entanto, sabe-se que a dinâmica escolar, em sua essência, é fundamentada na convivência diária, 
no compartilhamento imediato de ideias, na construção conjunta de saberes, na "transmissão" de conteúdos e na condução de práticas educativas. Em consonância com a UNESCO (2020), podemos observar que:

Estratégias de ensino a distância: tais estratégias, em resposta ao fechamento das escolas devido à Covid-19, são um conjunto de medidas setoriais tomadas por órgãos do governo e parceiros para dar continuidade aos estudos com base nos currículos dos estudantes e a outras atividades educacionais regulares, quando escolas e outras instituições de ensino presencial estão fechadas. Para que isso tenha sucesso, as atividades de aprendizagem devem ser revisadas, e soluções alternativas para fornecer remotamente programas de ensino devem ser planejadas e ofertadas juntamente com o apoio aos professores, à comunidade educacional e em colaboração com os estudantes e suas famílias (UNESCO, 2020, p.02).

Diante disso, é possível refletir que a Covid-19 ressignificou o espaço escolar, promovendo uma zona de tensão, onde a comunidade passa a temer pela saúde daqueles que atuam nesse ambiente, uma vez que há iminente risco de transmissão, por conta da multiplicidade gerada através dos vínculos entre os jovens e demais atores dessa seara. A partir desse contexto, cabe a todos compreenderem os impactos gerados pela pandemia que afetarão os processos de ensino e aprendizagem.

É possível perceber que, ao longo do tempo, o acesso à educação e à aprendizagem vêm sendo pauta de muitas discussões. A restrição ao ambiente escolar provoca uma série de situações que, na maioria dos casos, não foram experienciadas pela comunidade educativa. Dessa forma, a sociedade vem se reconfigurando à medida que as novas práticas de ensino e aprendizagem se consolidam. Neste momento pandêmico, o papel da família é enaltecido, uma vez que os jovens necessitam de assistência para a gestão da aprendizagem. Assim, o acompanhamento familiar passou a ser incorporado no cotidiano dos estudantes de maneira ampliada, em muitas situações comparadas a situações de guerra, tendo em vista o ineditismo do contexto. Nesse sentido, MOREIRA (2020) destaca:

Uma sala de aula on-line não é um repositório de conteúdos digitais, é um espaço ativo e dinâmico onde os estudantes recebem informa- 
ções sobre as atividades on-line que devem realizar, dentro e fora da plataforma, individualmente ou em grupo, exatamente como num ambiente de sala de aula física. (MOREIRA, 2020, p. 357).

O panorama instaurado na educação revela que o ensino remoto e as demais estratégias utilizadas para suprir a necessidade dos processos de ensino e aprendizagem, aliadas às tecnologias digitais, devem seguir uma ordem de ampliação das possibilidades de ensino à distância, pois isso surge como uma resposta imediata à interrupção abrupta dos procedimentos educacionais através do fechamento repentino das escolas, resultante da pandemia da Covid-19. Essas estratégias são norteadas, de acordo com a UNESCO (2020), através da preocupação com a equidade, pois é necessário rever e determinar situações para que as desigualdades educacionais e sociais não sejam ainda mais potencializadas, em decorrência das divergências já existentes no acesso à educação.

Com a emergência de se aproximar da realidade, a comunidade escolar teve que estabelecer uma migração para os ambientes virtuais. Assim, as metodologias adotadas pelo formato on-line contrapõem as formas tradicionais de ensino e aprendizagem, tendo em vista a complexidade e a necessidade de uma inclusão digital. Diante disso, Santos Junior e Monteiro (2020, p. 5) afirmam que:

Com as suspensões das aulas, muito se fala do uso das tecnologias digitais para mediar o processo de aprendizagem remota como alternativa para não suspender as aulas. Tendo que recorrer ao $\mathrm{EaD}$, algumas instituições estão se adaptando para utilizar as plataformas digitais para fins de mediação da aprendizagem.

Nesse sentido, recursos estão sendo utilizados através das plataformas que permitem a realização de aulas síncronas como o Microsoft Teams, Zoom, Google Classroom, Google Hangout, Skype, além de o uso de plataformas para repositório de materiais como o Moodle. Alguns desses ambientes possibilitam e facilitam a dinâmica do ensino e da aprendizagem nesse período de afastamento, uma vez que a contextualização e a apresentação dos conteúdos ocorrem simultaneamente. Dessa forma, observamos que as tecnologias educacionais experimentadas nesse contexto 
pandêmico possibilitam o desenvolvimento dos objetos de conhecimento, desde que a inclusão digital ocorra de forma adequada.

No que se refere ao acesso à internet, é interessante destacar que o uso no ensino à distância foi um importante aliado na continuidade dos estudos de jovens e adultos. Entretanto, é imperativo refletir sobre a ocorrência de graves limitações em relação ao acesso para crianças, principalmente aquelas que não tiveram o desenvolvimento de uma alfabetização digital, dentre outras situações, como a própria alfabetização tradicional. Nesse contexto, destaca-se uma significativa quebra na rotina escolar desencadeada pela necessidade de um ensino remoto. Não obstante, esse período provocou uma série de preocupações relacionadas à formação dos estudantes. Nesse sentido, a instituição Todos pela Educação (2020, p. 9) discute:

Uma das medidas cruciais para se pensar de maneira consistente a introdução temporária de soluções de ensino a distância é a avaliação dos recursos tecnológicos que já estão à disposição dos estudantes ou que podem ser rapidamente providos. E isso precisa ser feito levando em conta as disparidades sociais no Brasil, que existem não só entre redes de ensino, mas também entre estudantes da mesma rede, escola ou, até mesmo, sala de aula.

Levando em consideração que muitos se encontram em etapas de aprendizagem diferentes, é necessário destacar a existência de contextos familiares com maior grau de escolarização e condições socioeconômicas privilegiadas, visto que isso resulta no acesso contínuo aos estudos por meio de ambientes virtuais consolidados. Em outra perspectiva, há ambientes familiares com menor grau de escolarização e condições de vida desfavorecidas, fatores que afetam a continuidade da aprendizagem durante e após o período de ensino remoto. Esse novo caráter de ensino aprendizagem, denominado de Ensino Remoto Emergencial (ERE), segundo Cunha (2021, p. 32), pode ocasionar uma evasão e um atraso escolar que afetará diretamente a população mais pobre:

[...] o distanciamento social e o predomínio de estratégias que dependem das tecnologias da informação e comunicação, uma parcela dos estudantes enfrentam ou enfrentarão dificuldades para acessarem e permanecerem vinculados à escola. Uma delas está relaciona- 
da ao acesso à internet. Conforme dados da pesquisa realizada pelo CETIC (2019a), no Brasil 29\% dos domicílios, aproximadamente 19,7 milhões de residências, não possuem internet. Desse montante de desconectados, 59\% alegaram não a contratar porque consideram muito caro esse serviço, outros $25 \%$ porque não dispõem de internet em suas localidades. Destaca-se, ainda, que $41 \%$ dos entrevistados alegaram não possuir computador para tal e 49\% que não sabiam usar a internet. Desse modo, os estudantes inclusos nestas estatísticas estão fora da estratégia do ensino remoto mediado pelas tecnologias digitais, que segundo Kenski (2012) quando bem utilizadas favorece ou potencializa o processo formativo pela intensificação das oportunidades de aprendizagem (CUNHA, 2021, p. 33-4).

Ainda segundo Cunha, cabe destacar que os estudantes estão inseridos em contextos diversos e, em muitos casos, com marcadores sociais de desigualdades que agravam este cenário. Neste sentido, cabe destacar que as soluções tecnológicas, apesar de necessárias, não são uma realidade plena a todos os jovens. O papel docente é de fundamental importância, pois os impactos observados até o momento sinalizam o quão desafiador está sendo e continuará após o período pós-pandemia. As práticas adotas por professores e profissionais da educação que visam qualificar o processo de ensino e aprendizagem diante do contexto são importantes, mas não suficientes, dados as desigualdades que fogem do alcance do professor. Ainda, a pandemia da Covid-19 e a necessidade do afastamento social ressaltaram a importância da interação no que se refere ao ensinar e ao aprender. Sobre isso, UNESCO (2020) aponta:

Talvez o maior desafio da atual crise ao acesso, à qualidade e à equidade da educação seja o distanciamento físico, o que torna mais difícil para os professores manter um relacionamento próximo com os estudantes, principalmente aqueles que pertencem dos grupos mais desfavorecidos. (UNESCO, p. 4, 2020).

Dessa maneira, o acesso à educação remota deve ser inclusivo, devendo considerar as singularidades de todos aqueles envolvidos na comunidade educativa. Observa-se a importância da figura do professor como aquele que prepara o sujeito para a sociedade. Assim, a docência revela o 
desenvolvimento das habilidades e competências necessárias para a emancipação dos jovens e adultos, mesmo em tempos em que o uso das tecnologias está sendo o foco do trabalho em diferentes segmentos. Portanto, destaca-se que, na prática do ensino, o professor é peça fundamental na consolidação desse processo de construção da autonomia do sujeito.

Em consonância a isso e na perspectiva da educação em ambientes virtuais, Santos (2016, p.25, apud CASTRO; MENEZES, 2011) aponta que "o professor deve estimular a aprendizagem colaborativa, em que os estudantes aprendem juntos, tornando-se corresponsáveis não apenas por sua própria aprendizagem, mas também pela aprendizagem dos colegas". Esse paradigma revela que a mediação docente é fundamental para a promoção de um ambiente de cooperação, estando caracterizada pela gestão das práticas dos estudantes na aquisição do conhecimento e na articulação dos processos necessários para a aprendizagem.

Diante dos paradigmas estabelecidos, o professor, além de realizar o desenvolvimento das habilidades e competências necessárias, é o principal responsável por orientar a aprendizagem dos educandos, independentemente da realidade. Além disso, deve ser mediador das relações pessoais e interpessoais, servindo como suporte regulador das emoções.

Em um contexto social imediatista, é possível perceber que a prática emancipadora orientada pelos educadores configura uma alternativa para a construção de uma sociedade mais crítica. Para que isso ocorra, é necessário cada vez mais o investimento no campo da educação, através da valorização dos educadores, possibilitando a profissionalização e a formação continuada desses. Em conformidade a isso, Todos pela Educação (2020, p. 5) determina que:

Mesmo a distância, atuação dos professores é central. Pesquisas apontam que, quando o assunto é ensino a distância, o trabalho dos professores tem papel significativo no sentido de assegurar uma boa experiência, independentemente da solução utilizada. Diante do cenário atual, em que são igualmente impactados pela pandemia, apoiá-los, pessoal e profissionalmente, é medida absolutamente fundamental.

Dessa maneira, é necessário que haja o desejo de uma escola que anseie por um currículo significativo, que esteja preparada para a efeti- 
vação dos processos de ensino e aprendizagem pautados na elaboração de uma política pedagógica crítica, capaz de conduzir tanto o educador quanto o educando a refletir sobre a sua história, contexto, projeções e ações, perante a sociedade em que vive. Ainda, cabe ressaltar que essa escola deve compreender e atender a todos os seguimentos da sociedade, sem a necessidade de segregar e selecionar indivíduos com maior ou menor potencial. Além disso, as instituições de ensino não devem ser um lugar de depósitos, muito menos de seres meramente ouvintes e reprodutores de uma condição opressora, diante do cenário estabelecido pela pandemia.

\section{FORMAS DE ENSINAR E APRENDER: DESAFIOS EM TEMPOS PANDEMICOS}

É interessante retomar que, na atualidade, vive-se um momento em que a sociedade brasileira afronta novos desafios, vislumbra novos espaços de atuação e abre novas áreas por meio das grandes transformações, sobretudo no cerne da educação. $\mathrm{O}$ direito à educação não perdeu e nem perderá sua essência. Nos dias atuais, praticamente, não há país no mundo que não aponte, em suas leis, o acesso à educação básica. Nessa perspectiva, a educação escolar é uma extensão social, configurada como um direito fundamental para a organização de um Estado.

Ao observar a incapacidade administrativa do Estado, é possível constatar quão negligenciada a educação vem sendo ao longo da história brasileira. Todo e qualquer avanço da educação escolar além do ensino básico foi resultado de lutas democráticas da sociedade. Compreende-se que, dessa maneira, a educação, como direito social e sua concretização em práticas sociais, converte-se em um valioso instrumento de redução das desigualdades e das discriminações, aproximando de forma pacífica os diferentes segmentos sociais. Dessa maneira, Junqueira e Pinto (2020, p. 372) apontam que:

Frágil, sem efetiva reivindicação por parte do povo, a educação brasileira se arrasta em tempos de pandemia, sob risco de retroagir e de se perder para a geração em curso. As discrepâncias entre os serviços públicos e privados se inflamam e os direitos sociais, consagrados 
como públicos e subjetivos pela Constituição Federal de 1988 se comportam de forma criticamente desigual para ricos e pobres.

O então novo período, determinado pela pandemia da Covid-19, salientou algumas incertezas, como os dogmas e a crença em uma única forma de agir e pensar. Todos que estão envolvidos com a formação de pessoas são convidados diariamente a romper com a dita zona de conforto, tendo em vista a demanda que se exige tanto do educador quanto do educando. Um dos desafios mais marcantes para a educação surge a partir da reconstrução dos espaços, em que homens e mulheres necessitam trabalhar de forma conjunta e contínua, envolvendo interesses públicos e privados.

A noção de educação remete à construção de uma sociedade organizada e baseada em uma série de temas que possuam relação com o contexto e realidade vivida das pessoas, levando à busca de respostas através da reflexão ou da ação. Para se colocar em prática uma educação integral, é necessário analisar as características que definem o contexto, ou seja, deve-se aproximar do universo desses indivíduos, coletando informações que leve à elaboração de um currículo que forneça subsídios para uma formação democrática e de qualidade. É compreensível, pois o que ocorre geralmente é a desvalorização contínua de seu papel social. Entretanto, tendo em vista a depreciação crescente do ofício educador, é necessário levar em consideração o seu potencial científico transformador a emprego do desenvolvimento do ser humano, na construção de uma comunidade global.

Sabendo que a educação compreende uma das áreas mais atingidas pela pandemia da Covid-19, é relevante levantar discussões a respeito das formas de ensino e aprendizagem durante esse período, tendo como norte a principal premissa: o afastamento social. Professores de diferentes segmentos, atuantes da rede pública ou privada, tiveram que se reinventar perante os novos desafios pedagógicos impostos. As adaptações relacionadas aos novos ambientes virtuais apontam para a constante reinvenção. Muitos docentes tiveram que realizar cursos, formações e vivências para usufruir dos recursos tecnológicos. Em conformidade com esse contexto, Neto (2020, p. 5) aponta: 
Fica evidente que a nossa relação com o tempo mudou. Mais além: a nossa relação com o tempo que tínhamos reservado para determinadas atividades, como o ensino/estudo, mudou, muda ou mudará por uma necessidade coletiva e não da individualidade. Surge um aspecto a ser considerado pelos que constroem a relação institucional 'tempo-estudo': como reajustar o 'tempo presencial' das salas de aula em 'tempo remoto' no âmbito da preservação da individualidade quando se pensa em aprender e ensinar? Debruçando-nos nesta questão, creio que nos deva surgir a vontade de promover a autoestima do estudante e conduzi-lo para o tão almejado plano da autonomia do pensamento crítico.

Dessa maneira, pode-se destacar que as formas de ensinar e aprender sofreram impactos, sobretudo nessa faixa de tempo que compreende o distanciamento social controlado. É inegável que o ensino e a aprendizagem ocorrem de maneira mais significativa quando há o convívio físico. Entretanto, o paradigma da Covid-19 trouxe formas alternativas para lidar com essas situações. O isolamento social e o fechamento das escolas resultaram em uma série de desafios. Atualmente, um dos principais questionamentos que cercam o cenário pedagógico diz respeito ao aproveitamento do ano letivo. Entretanto, vale ressaltar que as medidas adotas para minimizar os impactos na aprendizagem não podem ficar restritas à esfera tecnológica. Um ponto importante a se destacar a partir disso corresponde às transformações no que se refere à noção de tempo e espaço, uma vez que essas dimensões passaram a se caracterizar de outra maneira com a perspectiva de ensino remoto.

Com as incertezas do momento, as noções de tempo e espaço assumem uma nova condição, tendo em vista a necessidade da readaptação dos processos de ensino e aprendizagem. Estudantes e professores buscam alternativas para o convívio em rede. Assim, o ambiente virtual aproxima as partes envolvidas na aprendizagem. No entanto, revela uma complexidade quando se depara com as múltiplas formas de aprender.

As tecnologias digitais definem formas alternativas de aprendizagem, que apontam para a consolidação de um ciberespaço. Para compreendermos melhor esse conceito, Santos $(2009$, p. 4) afirma: 
O ciberespaço surge não só por conta da digitalização, evolução da informática e suas interfaces, própria dos computadores individuais, mas da interconexão mundial entre computadores, popularmente conhecida como internet. Da máquina de calcular à internet, muita coisa mudou e vem mudando no ciberespaço. Essa mudança se caracteriza, dentre outros fatores, pelo movimento do faça você mesmo. O ciberespaço é muito mais que um meio de comunicação ou mídia. Ele reúne, integra e redimensiona uma infinidade de mídias. Podemos encontrar desde mídias como jornal, revista, rádio, cinema e tv, bem como uma pluralidade de interfaces que permitem comunicações síncronas e assíncronas a exemplo dos chats, listas, fóruns de discussão, blogs dentre outros.

Frente a esse cenário, a pluralidade dos recursos utilizados nos processos de ensino e aprendizagem remete à sistematização da educação digital. Como apresentado, a interação é importante para a aprendizagem, mas a grande questão é tentar compreender como as relações serão impactadas a partir do afastamento social e do ensino remoto e quais serão os fatores fundamentais a serem projetados no período pós-pandemia. Os professores e estudantes foram desafiados a criar ou refazer seus ciberespaços, através das necessidades impostas pelas demandas de estudo e trabalho.

Associada ao conceito de ciberespaço, pode-se observar a constituição de uma cibercultura, que se define a partir do uso das tecnologias digitais, constituindo uma rede com características próprias de tempo e espaço. "Os primeiros estudos sobre cibercultura sinalizavam que esta era a cultura do ciberespaço, que é um híbrido da internet, infraestrutura tecnológica, com os seres humanos em movimento e em processos de comunicação e de redes sociais" (FONTOURA; SILVA, 2020, p.77). No que se refere à educação brasileira, observa-se um ensaio de ensino híbrido, uma vez que a aprendizagem é estendida para ambientes virtuais com o uso de plataformas repositórias de suplementos pedagógicos, revelando as diferentes possibilidades envolvidas nesse processo.

A crise estabelecida pela Covid-19 possibilitou uma série de reflexões sobre as ações e perspectivas para educação. Vale enfatizar que as experiências vividas até o momento serão o sustento para as medidas a serem consideradas na retomada do ensino presencial. Entretanto, é importante 
refletir sobre o ensino remoto não se configurar apenas na disponibilização de aulas síncronas e na oferta de materiais em plataformas repositórias. Os desafios associados à infraestrutura necessária para o prosseguimento do ensino e aprendizagem a distância conferem um significativo desafio para as instituições, durante e após esse panorama. No contexto instaurado pela crise pandêmica da Covid-19, mais do que a transmissão de informações e conteúdo, a escola possui papel fundamental na consolidação dos valores, buscando resolver as necessidades de sua comunidade. Nesse contexto, é importante o trabalho comunitário associado às realidades da economia, saúde e política.

\section{CONSIDERAÇÕES FINAIS}

A crise instaurada pela Covid-19 ressignificou as relações de ensino e aprendizagem. Nesse período de afastamento social e fechamento das instituições escolares, pôde-se notar, de forma mais ampla, como a educação atua em nossas vidas. Nesse panorama pandêmico, foi possível refletir que a educação não será a mesma de outrora. Os processos de ensino tradicional serão substituídos pelas possibilidades de aprendizagem híbrida, pois a dinâmica e a rotina escolar foram drasticamente afetadas pela então nova realidade. Os desafios impostos pela pandemia resultaram em uma nova ordem de relacionamento entre estudantes e professores, transformando o ambiente de sala de aula em um espaço virtual de aprendizagens. Diante disso, todos os atores envolvidos no ambiente escolar puderam entrar em contato com novas ferramentas e formas de ensinar a aprender, através de uma série de adaptações exigidas principalmente pela necessidade de uma educação remota emergencial.

Ainda, é possível observar que o fechamento das escolas e a prática de uma educação on-line evidenciaram muitos contrastes, principalmente aqueles que envolvem a perspectiva de uma educação inclusiva do ponto de vista socioeconômico. Perante isso, deve-se ressaltar que há uma parcela significativa da população estudantil que não possui condições de acesso aos ambientes virtuais de ensino, ressaltando com maior força as desigualdades na educação. Nesse contexto, tornou-se evidente que um grupo privilegiado economicamente deu continuidade às aprendizagens de forma remota, consolidando um importante processo de construção 
social. Enquanto isso, o grande grupo de crianças e jovens dependentes do serviço de educação pública tornou-se vítima do esquecimento governamental, uma vez que as redes estaduais e municipais enfrentaram muitas dificuldades, ou sequer deram prosseguimento no currículo escolar com aulas de forma remota.

Mediante o contexto caótico, foi possível reafirmar que os professores constituem peça fundamental no processo de ensino e aprendizagem, sendo ainda mais solicitados nessa perspectiva remota de ensino e aprendizagem. Nesse sentido, esses profissionais tiveram que multiplicar suas habilidades, reinventando-se a cada dia. As situações experienciadas provaram a necessidade de um planejamento criativo e contínuo, visando à promoção de uma aprendizagem integral. É interessante destacar a importância do trabalho associado às tecnologias de maior e menor complexidade, pois cada vez mais será necessário dominar as ferramentas que estão e serão projetadas para a educação híbrida.

A flexibilidade e o desejo pela busca de melhores condições e soluções serão fundamentais no transcorrer desse período. Muitas foram as adaptações. Certamente, em um contexto pós-pandemia, professores e estudantes estarão preparados para lidar com situações que envolvam o distanciamento e as práticas pedagógicas híbridas e remotas. Isso gera uma reflexão sobre o fato de que a educação e a formação de professores não podem parar, além de requererem construções contínuas, pois agem como potencializadoras da ação humana. As mudanças por vezes podem ser difíceis, sendo acompanhadas de situações desgastantes, resultando em desafios significativos institucionais, coletivos e individuais de adaptação. Esse cenário pandêmico exige uma política contínua docente para a assimilação digital, caracterizando um processo fluído em rede, aberto a desenvolver o fazer docente, aprimorando as múltiplas aprendizagens a serem desenvolvidas nos educandos. Nesse sentido, devem ser definidas ações que qualifiquem a educação digital tanto para o professor quanto para o estudante, permitindo o trânsito do ensino remoto emergencial para o híbrido de maneira qualificada e inclusiva.

Portanto, sem nenhuma pretensão de encerrar essas discussões, considera-se necessária a mobilização por uma educação emancipatória, inclusiva e integral. Em um contexto social imediatista, é possível perceber que a prática promotora desse ensino configura uma alternativa para 
a construção de uma sociedade crítica. Para que isso ocorra, é necessário um investimento contínuo no campo da educação, através da valorização dos educadores, possibilitando a profissionalização e a formação continuada. É necessário também que se deseje um currículo significativo, que esteja preparado para a efetivação dos processos de ensino e aprendizagem, orientados por uma política pedagógica integradora, capaz de conduzir tanto o educador quanto o educando a refletir sobre sua história, contexto, projeções e ações, perante a sociedade em que atua.

\section{REFERÊNCIAS}

ARRUDA, Eucidio Pimenta. Educação remota emergencial: elementos para políticas públicas na educação brasileira em tempos de Covid-19. Em Rede Revista de Educação a Distância, v. 7, n. 1, Minas Gerais, 2020. Disponível em: https://www.aunirede.org.br/ revista/index.php/emrede/article/view/621

BARRETO, A. C. F.; ROCHA, D. S. Covid 19 E Educação: Resistências, Desafios E (Im)possibilidades. Revista Encantar, v. 2, n. 1, p. $1-11,2020$.

COUTO, Edvaldo Souza; COUTO, Edilece Souza; PORTO CRUZ, Ingrid de Magalhães. \#Fiqueemcasa: educação na pandemia da Covid. Interfaces Científicas, Aracaju, V.8, n.3, p. 200-217, 2020.

CUNHA, Leonardo Ferreira Farias da; SILVA, Alcineia de Souza; SILVA, Aurênio Pereira da. O ensino remoto no Brasil em tempos de pandemia: diálogos acerca da qualidade e do direito e acesso à educação. Revista Com Censo: Estudos Educacionais do Distrito Federal, Brasília, v. 7, n. 3, p. 27-37, ago. 2020. Disponível em: http://www.periodicos.se.df.gov.br/index.php/comcenso/article/ view/924. Acesso em: 03 fev. 2021.

FONTOURA, Helena Amaral. DA SILVA, Marco. Práticas pedagógicas, linguagem e mídias desafios à pós-graduação em Educação em suas múltiplas dimensões. Rio de Janeiro, ANPED Nacional, 2011. Disponível em: http://www.fe.ufrj.br/ anpedinha2011/sobre.html 
JUNQUEIRA, Michelle Assato; PINTO, Felipe Chiarello de Souza. Educação em tempos de pandemia: integração da liberdade, igualdade e fraternidade para a efetivação dos direitos fundamentais. In: SOBRINHO, Liton (Org.). Covid-19 e seus paradoxos. Itajaí-SC: Univali, 2020.

MOREIRA, José Marques. Transitando de um ensino remoto emergencial para uma educação digital em rede, em tempos de pandemia. Dialogia, São Paulo, n. 34, p. 351-364, jan./abr. 2020. Disponível em: https://doi.org/10.5585/Dialogia.

NETO, Joaquim M. F. Sobre ensino, aprendizagem e a sociedade da tecnologia: por que se refletir em tempo de pandemia? Revista Prospectus, v. 2, n. 1, p. 28-38, ago-fev, 2020. Disponível em: https://prospectus.fatecitapira.edu.br/index.php/pgt/article/down$\operatorname{load} / 32 / 21$

ORGANIZAÇÃO MUNDIAL DE SAÚDE. ORGANIZAÇÃO PAN-AMERICANA DE SAÚDE. Doença causada pelo novo coronavírus. Folha informativa Covid-19 - 2020. Disponível em: https://www.paho.org/pt/topicos/coronavirus/doenca-causada-pelo-novo-coronavirus-covid-19

SANTOS JUNIOR, Verissimo Barros dos; MONTEIRO, Jean Carlos da Silva. Educação e Covid-19: as tecnologias digitais mediando a aprendizagem em tempos de pandemia. Rev. Encantar - Educação, Cultura e Sociedade, Bom Jesus da Lapa/BA, v. 2, p. 01-15, jan./dez. 2020. Disponível em: http://dx.doi.org/10.46375/encantar. v2.0011

SANTOS, Boaventura de Sousa. A Cruel Pedagogia do Vírus. Coimbra: Edições Almedina, 2020. Disponível em: http://www.abennacional.org.br/site/wp-content/uploads/2020/04/Livro_Boaventura. pdf

SANTOS, Edméa. Educação on-line para além da EAD: um fenômeno da cibercultura. Rio d Janeiro: UERJ. 2020. Disponível em: https:// www.educacion.udc.es/grupos/gipdae/documentos/congreso/xcongreso/pdfs/t12/t12c427.pdf 
TODOS PELA EDUCAÇÃO. Ensino à distância na educação básica frente à pandemia da Covid-19. Nota técnica, 2020.

UNESCO. A crise da Covid-19 e o currículo: manter resultados de qualidade no contexto da aprendizagem remoto. Nota Informativa - Setor de Educação, 2020. Disponível em: https://unesdoc. unesco.org/ark:/48223/pf0000373273_por?posInSet=1\&queryId=92659714-06f2-4168-b108-0a39831afb8b

Apoio a professores e pessoal da educação em tempos de crises. Nota Informativa - Setor de Educação. 2020. Disponível em: https://unesdoc.unesco.org/ark:/48223/pf0000373338_por

- Estratégias de ensino a distância em resposta ao fechamento das escolas devido à Covid-19. Nota Informativa - Setor de Educação. 2020. Disponível em: https://unesdoc.unesco.org/ ark:/48223/pf0000373305_por?posInSet=1\&queryId=2c9c2c48-fca9-4456-af78-d454cd849ba7 


\section{PROCESSOS DE INDUÇÃO DE PROFESSORES INICIANTES NA ESCOLA BÁSICA: UMA REVISÃO}

Aurineide Maria de Almeida Castro $^{7}$

Islane Cristina Martins ${ }^{8}$

\section{INTRODUÇÃO}

A indução profissional na educação é um período que envolve os primeiros anos, durante os quais os professores devem passar de estudantes a educadores (MARCELO et al., 2016). É um investimento na formação intencional e sistemática de iniciantes ou professores principiantes durante a inserção na carreira (CRUZ; FARIAS; HOBOLD,2020). Além disso, é o momento em que o professor iniciante tem que desenvolver seu papel específico em sua função como docente, bem como desenvolver sua identidade como professor. Essa fase de indução no ensino pode durar vários anos (VAILLANT; MARCELO, 2015).

Não é, entretanto, um conceito unificado no mundo da educação, abrangendo desde divergências relacionadas à própria terminologia até conceitos cujos fundamentos epistemológicos e ideológicos estão fora de alcance (CRUZ; FARIAS; HOBOLD, 2020). Nesse sentido, os termos "professores iniciantes" e "professores principiantes" são sinônimos, e se referem aos docentes em início de carreira, agora não mais na condição de

7 Pedagoga, Universidade Estácio de Sá-UNESA, Brasil, Especialista em Psicopedagogia Clínica e Institucional- Faculdade Boas Novas.

$8 \mathrm{Mg}$. Universidade Federal de Pernambuco. 
estudante (CRUZ; FARIAS; HOBOLD, 2020). Ou seja, são os profissionais recém-licenciados e certificados profissionalmente e que se encontram no momento de intensidade da fase do aprender a ensinar (CRUZ; FARIAS; HOBOLD, 2020).

Com disso, ser professor iniciante, por um lado, ocorre pelo processo gradual e lento na tomada de decisões no contexto de trabalho e, por outro, consiste em sua capacidade de atender às expectativas em torno de sua atuação docente (CRUZ; FARIAS; HOBOLD, 2020). É um momento no qual surgem as dúvidas, tensões; a realidade vem mostrando que nesse momento muitos professores iniciantes acabam abandonando seu trabalho por inúmeras questões (MARCELO et al., 2016). Por exemplo, Marcelo et al. (2016) apontaram baixos salários, problemas de disciplina do aluno, falta de apoio e poucas oportunidades de tomada de decisão como alguns dos principais problemas para afastamento de professores. Também há outros elementos, como a valorização social da profissão, as condições de trabalho, a infraestrutura das escolas, as formas de organização do trabalho escolar, a carreira em geral de apoio aos docentes (GATTI; BARRETO; ANDRÉ,2011).

Nesse sentido, a relação que se estabelece na formação inicial entre graduandos e professores do ensino básico é muito importante para a formulação de políticas de ingresso profissional, ou seja, políticas de inserção de jovens professores nas profissões e nas escolas. (NÓVOA, 2019). Ou seja, independentemente da qualidade do programa de formação inicial que os professores frequentaram ou as competências desenvolvidas, o início da prática tem um impacto de sobrevivência, descoberta, adaptação, aprendizagem e transição (MARCELO et al., 2016).

A justificativa deste estudo baseia-se na importância da criação de programas nos quais os professores novatos tenham um espaço de apoio e experiência prática para auxiliá-los nesse início de carreira. Para tanto, o artigo está organizado por partes: na primeira, abordamos a literatura disponível sobre o objeto, com a finalidade de compreender conceitos pelos autores; na segunda, conhecer iniciativas nacionais e internacionais sobre indução profissional; na terceira, apresentamos a mentoria como um agente de indução profissional para os professores iniciantes.

Portanto, o presente artigo tem como objetivo realizar uma revisão integrativa da literatura sobre processos de indução de professores iniciantes na escola básica uma revisão na intenção de mapear avanços e lacunas nesta área do conhecimento. 


\section{MATERIAIS E MÉTODOS}

Relizou-se um levantamento da literatura em dezembro de 2020, nas bases de dados Periódicos CAPES e Google Acadêmico. Os descritores utilizados foram: "Formação de professores" AND "Indução à docência" AND "Desenvolvimento profissional"AND "Formadores escolares" AND "Formação Docente" e, em inglês "Teacher Education" AND " Teaching Induction" AND "Professional Development" AND "School Trainers" AND "Teaching Profession" em todas as bases de dados. Foram selecionados 10 artigos, incluídos segundo os critérios de elegibilidade, conforme a Figura 1. Os critérios de inclusão foram: artigos nos idiomas inglês, espanhol e português, nos últimos cinco anos, envolvendo os processos de indução de professores iniciantes na escola básica uma revisão. Os critérios de exclusão foram artigos de revisão de literatura.

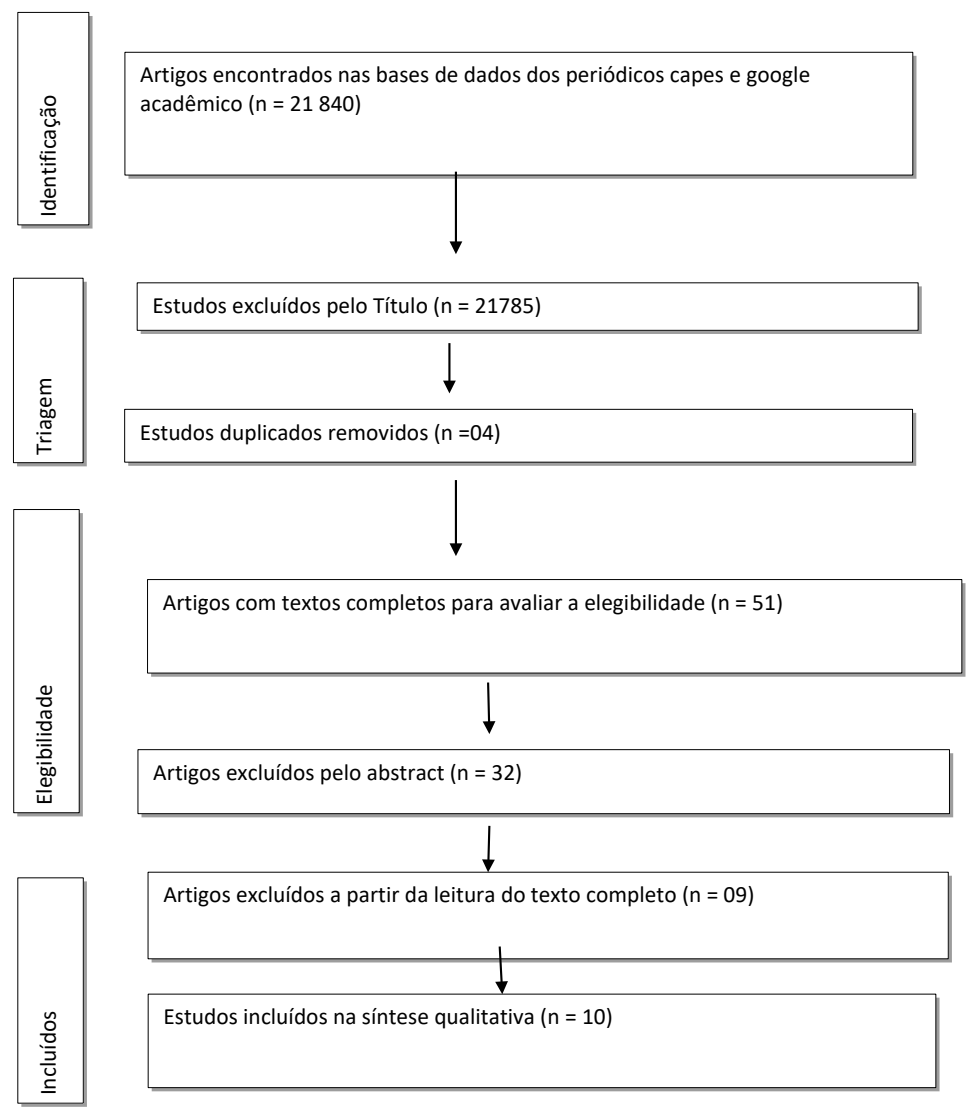

Figura 1. Fluxograma e critérios de seleção e inclusão dos artigos 


\section{RESULTADOS}

\section{Os resultados do presente estudo encontram-se na tabela 1.}

Tabela 1 - Demonstrativo dos artigos que integram a revisão integrativa

\begin{tabular}{|c|c|c|c|c|c|c|}
\hline$\# \mathbf{N}$ & Data & Título & Autores & Periódico & Objetivos & Resultados \\
\hline 1 & 2020 & $\begin{array}{c}\text { Indução } \\
\text { profissional e o } \\
\text { início do trabalho } \\
\text { docente: debates e } \\
\text { necessidades }\end{array}$ & $\begin{array}{l}\text { DA CRUZ, } \\
\text { Giseli Barreto; } \\
\text { DE FARIAS, } \\
\text { Isabel Maria } \\
\text { Sabino; DE } \\
\text { SOUZA } \\
\text { HOBOLD, } \\
\text { Márcia }\end{array}$ & $\begin{array}{c}\text { Revista } \\
\text { Eletrônica de } \\
\text { Educação }\end{array}$ & $\begin{array}{c}\text { Conceituar indução } \\
\text { profissional docente } \\
\text { problematizando-a, } \\
\text { trazendo reflexões } \\
\text { acerca das } \\
\text { possibilidades e } \\
\text { fragilidades que estão } \\
\text { presentes no início } \\
\text { da profissão docente. }\end{array}$ & \begin{tabular}{|} 
O estudo mostra que \\
o conceito de indução \\
profissional encontrado \\
na busca não deve ser \\
adicionado sem uma \\
compreensão crítica \\
em relação às condições \\
objetivas e subjetivas de \\
trabalho vividas pelos \\
professores na realidade \\
brasileira, visto que em \\
países estrangeiros são \\
bem mais apropriadas. \\
Nesse sentido considera \\
ser importante que a \\
indução profissional \\
não seja só uma \\
forma de induzir os \\
professores em início da \\
profissão, mas como um \\
constructo que aceite e \\
entenda a necessidade da \\
criação desse espaço de \\
formação, acolhimento \\
e acompanhamento de \\
sua atuacão profissional
\end{tabular} \\
\hline 2 & 2020 & $\begin{array}{l}\text { Formadores } \\
\text { de professores: } \\
\text { conceito, } \\
\text { contextos e } \\
\text { perspectivas } \\
\text { de atuação } \\
\text { em processos } \\
\text { de indução à } \\
\text { docência }\end{array}$ & $\begin{array}{c}\text { AMBROSETTI, } \\
\text { Neusa Banhara } \\
\text { et al }\end{array}$ & $\begin{array}{l}\text { Revista } \\
\text { Eletrônica de } \\
\text { Educação }\end{array}$ & \begin{tabular}{|} 
Examinar a natureza \\
e as especificidades \\
do trabalho do \\
formador escolar, \\
seu papel e as \\
perspectivas de \\
atuação desse \\
profissional \\
nos processos \\
de indução de \\
professores iniciantes \\
contribuindo assim \\
para a reflexão em \\
torno da figura do \\
formador escolar.
\end{tabular} & $\begin{array}{c}\text { A pesquisa traz nos } \\
\text { resultados a importância } \\
\text { do formador de } \\
\text { professores no processo } \\
\text { de ingresso de novatos, } \\
\text { e sua responsabilidade } \\
\text { é formular as ações de } \\
\text { acolhimento e apoio } \\
\text { necessárias para que os } \\
\text { iniciantes promovam } \\
\text { sua integração gradativa } \\
\text { na cultura e no grupo } \\
\text { profissional, bem como } \\
\text { apresenta as dificuldades } \\
\text { e relevância no processo } \\
\text { de desenvolvimento } \\
\text { profissional de } \\
\text { professores e na busca } \\
\text { pela qualificação dos } \\
\text { processos de ensino. }\end{array}$ \\
\hline
\end{tabular}




\begin{tabular}{|c|c|c|c|c|c|c|}
\hline$\# \mathbf{N}$ & Data & Título & Autores & Periódico & Objetivos & Resultados \\
\hline 3 & 2019 & $\begin{array}{c}\text { BUTT, Khadija; } \\
\text { FAROOQ, } \\
\text { Muhammad } \\
\text { Shahid }\end{array}$ & $\begin{array}{c}\text { Efeito do } \\
\text { Programa de } \\
\text { Treinamento } \\
\text { de Indução } \\
\text { na Eficácia de } \\
\text { Professores } \\
\text { no Ensino } \\
\text { Fundamental em } \\
\text { Punjab }\end{array}$ & $\begin{array}{c}\text { Paquistão Journal } \\
\text { of Education }\end{array}$ & $\begin{array}{c}\text { Pesquisar os } \\
\text { resultados que } \\
\text { o programa de } \\
\text { treinamento de } \\
\text { indução para } \\
\text { educadores do } \\
\text { ensino fundamental } \\
\text { em Punjab } \\
\text { (ESEs) na eficácia do } \\
\text { ensino. }\end{array}$ & $\begin{array}{c}\text { Os resultados do } \\
\text { estudo revelou que } \\
\text { havia uma forte relação } \\
\text { positiva entre programa } \\
\text { de treinamento de } \\
\text { indução e a eficácia de } \\
\text { ensino dos ESEs. Nas } \\
\text { áreas de treinamento, } \\
\text { justificativa (na forma } \\
\text { de ITP componentes) } \\
\text { e avaliação (na forma } \\
\text { de objetivos do PTI) } \\
\text { tiveram um efeito sobre } \\
\text { a eficácia do ensino } \\
\text { das ESEs. Apenas as } \\
\text { metodologias não } \\
\text { tiveram efeito sobre } \\
\text { Eficácia do ensino dos } \\
\text { ESEs. Embora os ESEs } \\
\text { tenham boas opiniões } \\
\text { sobre programa de } \\
\text { treinamento de indução } \\
\text { e sua eficácia de ensino, } \\
\text { mas é preciso dar } \\
\text { importância a algumas } \\
\text { áreas de treinamento } \\
\text { (comunicação com } \\
\text { pais da criança e } \\
\text { ensino multissérie), } \\
\text { valores (aprendizagem, } \\
\text { mentoria e } \\
\text { administração) } \\
\text { e conhecimento } \\
\text { de alfabetização } \\
\text { multicultural, } \\
\text { consciência global e } \\
\text { ambiental para torná- } \\
\text { los mais eficazes. }\end{array}$ \\
\hline
\end{tabular}




\begin{tabular}{|c|c|c|c|c|c|c|}
\hline$\# \mathbf{N}$ & Data & Título & Autores & Periódico & Objetivos & Resultados \\
\hline 4 & 2018 & $\begin{array}{c}\text { Mentores para } \\
\text { professores } \\
\text { iniciantes } \\
\text { como líderes } \\
\text { intermediários: } \\
\text { o trabalho } \\
\text { complicado de } \\
\text { recontextualização }\end{array}$ & WILLIS, Jill et al & $\begin{array}{l}\text { Liderança e } \\
\text { gestão escolar }\end{array}$ & \begin{tabular}{|c} 
Apresentar o \\
programa de \\
mentoria para \\
professores iniciantes \\
como líderes \\
intermediários \\
apoiado pelo governo \\
de Queensland, \\
Australia, \\
entender como os \\
professores mentores \\
negociaram e \\
atuaram em seus \\
papéis como líderes \\
intermediários \\
em escolas em \\
diversos níveis \\
de escolaridade \\
contextos \\
\end{tabular} & $\begin{array}{c}\text { A pesquisa mostrou } \\
\text { que a forma como } \\
\text { os professores se } \\
\text { posicionam como } \\
\text { mentores e como } \\
\text { os líderes escolares } \\
\text { apoiam os mentores } \\
\text { enquanto redefinem } \\
\text { seus papéis no } \\
\text { ambiente escolar } \\
\text { são componentes } \\
\text { necessários para as } \\
\text { escolas perceberem } \\
\text { os benefícios sociais } \\
\text { potenciais da } \\
\text { implementação de } \\
\text { programas formais de } \\
\text { mentores. }\end{array}$ \\
\hline 5 & 2018 & $\begin{array}{l}\text { A Pesquisa sobre } \\
\text { o trabalho do } \\
\text { professor no } \\
\text { início da carreira } \\
\text { profissional }\end{array}$ & $\begin{array}{c}\text { DE ARRUDA, } \\
\text { Maria das Graças } \\
\text { Chagas et al. }\end{array}$ & $\begin{array}{c}\text { Revista Brasileira } \\
\text { de Pesquisa sobre } \\
\text { Formação de } \\
\text { Professores }\end{array}$ & \begin{tabular}{|c} 
Apresentar o \\
Grupo de Estudos \\
e Pesquisas \\
sobre Profissão e \\
Formação Docente \\
(GEPROD/UFRJ) \\
e as pesquisas \\
realizadas entre os \\
anos de 2008 e 2017. \\
O GEPROD vem \\
se preocupando \\
com o trabalho \\
docente, sobretudo \\
no início de carreira, \\
bem como com \\
as políticas de \\
indução profissional \\
e formação \\
continuada.
\end{tabular} & \begin{tabular}{|} 
Os resultados \\
reiteraram a \\
importância de dar \\
atenção especial aos \\
professores novatos \\
e a necessidade de \\
ações sistemáticas de \\
acompanhamento \\
desses professores. Eles \\
também mostraram \\
a importância da \\
formação contínua das \\
disciplinas centradas \\
em questões práticas \\
que afetam o dia a dia \\
docente.
\end{tabular} \\
\hline
\end{tabular}




\begin{tabular}{|c|c|c|c|c|c|c|}
\hline$\# \mathbf{N}$ & Data & Título & Autores & Periódico & Objetivos & Resultados \\
\hline 6 & 2018 & $\begin{array}{c}\text { As preocupações } \\
\text { dos professores } \\
\text { principiantes, } \\
\text { as primeiras } \\
\text { experiências } \\
\text { profissionais e o } \\
\text { desenvolvimento: } \\
\text { implicações para a } \\
\text { teoria e a prática }\end{array}$ & $\begin{array}{l}\text { ZHUKOVA, } \\
\text { Olena }\end{array}$ & $\begin{array}{c}\text { Discurso e } \\
\text { Comunicação } \\
\text { para a Educação } \\
\text { Sustentável }\end{array}$ & $\begin{array}{c}\text { Investigar e fornecer } \\
\text { uma compreensão } \\
\text { do desenvolvimento } \\
\text { de professores } \\
\text { novatos à medida } \\
\text { que eles entram na } \\
\text { profissão docente } \\
\text { e desenvolvem } \\
\text { suas competências } \\
\text { pedagógicas, } \\
\text { também teve como } \\
\text { objetivo examinar } \\
\text { os fatores que } \\
\text { afetam e moldam o } \\
\text { desenvolvimento de } \\
\text { professores novatos } \\
\text { ao longo de um } \\
\text { período de dois } \\
\text { anos à medida que } \\
\text { evoluem de alunos } \\
\text { para educadores } \\
\text { profissionais. }\end{array}$ & \begin{tabular}{|} 
Os resultados deste \\
estudo sugerem \\
fortemente que o \\
sistema atual de \\
atração, recrutamento, \\
retenção e apoio \\
de professores \\
recém-qualificados \\
existentes nas escolas \\
Letônia não oferecem \\
oportunidade \\
adequada para um \\
sistema sistemático, \\
contínuo, oportuno, \\
e crescimento \\
instrucional, pessoal \\
e profissional eficaz. \\
Os resultados \\
apoiam fortemente \\
a importância \\
da orientação, \\
especialmente durante \\
a fase de indução, \\
quando professores \\
novatos passam da \\
forma de professor \\
aluno para educador \\
profissional.
\end{tabular} \\
\hline 7 & 2018 & $\begin{array}{c}\text { Programa de } \\
\text { introdução de } \\
\text { professores: } \\
\text { Primeira } \\
\text { experiência na } \\
\text { Turquia }\end{array}$ & $\begin{array}{l}\text { ÇOBANOهLU, } \\
\text { Fatma; AYVAZ- } \\
\text { TUNCEL, } \\
\text { Zeynep }\end{array}$ & $\begin{array}{c}\text { International } \\
\text { Education Studies }\end{array}$ & $\begin{array}{c}\text { Analisar as opiniões } \\
\text { de } 357 \text { professores } \\
\text { novatos sobre o } \\
\text { cumprimento das } \\
\text { metas do programa } \\
\text { de iniciação de } \\
\text { professores. }\end{array}$ & \begin{tabular}{|c} 
Os resultados \\
sugeriram que a \\
educação inicial e o \\
programa de iniciação \\
de professores \\
têm contribuições \\
semelhantes em no \\
que diz respeito ao \\
cumprimento das \\
metas do programa \\
de iniciação de \\
professores. Além \\
disso, considerando \\
o processo como um \\
todo, o mentor tem \\
um papel importante \\
no desenvolvimento \\
de professores novatos.
\end{tabular} \\
\hline
\end{tabular}




\begin{tabular}{|c|c|c|c|c|c|c|}
\hline$\# \mathbf{N}$ & Data & Título & Autores & Periódico & Objetivos & Resultados \\
\hline 8 & 2017 & $\begin{array}{c}\text { As experiências } \\
\text { dos professores em } \\
\text { início de carreira: } \\
\text { iniciativas novas e } \\
\text { problemas antigos }\end{array}$ & $\begin{array}{c}\text { SCHUCK, Sandy } \\
\text { et al }\end{array}$ & \begin{tabular}{|c} 
Desenvolvimento \\
Profissional em \\
Educação
\end{tabular} & \begin{tabular}{|c} 
Investigar as \\
experiências de \\
professores em início \\
de carreira (ECTs) \\
em New South \\
Wales, Austrália, \\
em um momento \\
em que a autoridade \\
empregadora exigiu \\
o fornecimento de \\
mentores e uma \\
redução no ensino \\
presencial para \\
ECTs. (pesquisas \\
sobre professores em \\
início de carreira \\
(ECTs))
\end{tabular} & \begin{tabular}{|} 
O estudo descobriu \\
que muitas das \\
questões do início \\
das experiências \\
dos professores em \\
início de carreira \\
permanecem \\
intratáveis, ou pelo \\
menos não resolvido \\
para alguns. A \\
pesquisa indica que \\
apesar do suporte \\
que tem exigido por \\
alguns empregadores, \\
não podemos ser \\
complacentes como \\
transição dos ECTs \\
para a profissão. Resta \\
a necessidade de \\
eliminar os elementos \\
do ambiente escolar \\
que impactam as \\
experiências das \\
ECTs.
\end{tabular} \\
\hline 9 & 2017 & $\begin{array}{c}\text { Formação } \\
\text { docente: } \\
\text { percepções } \\
\text { de professores } \\
\text { ingressantes na } \\
\text { rede municipal de } \\
\text { ensino do Rio de } \\
\text { Janeiro }\end{array}$ & $\begin{array}{c}\text { NASCIMENTO, } \\
\text { Maria das Graças } \\
\text { C.; REIS, } \\
\text { Rosemary F. Dos. }\end{array}$ & $\begin{array}{l}\text { Educação e } \\
\text { Pesquisa }\end{array}$ & \begin{tabular}{|c} 
Debater os \\
significados \\
atribuídos por \\
professores \\
principiantes na \\
profissão sobre suas \\
experiências de \\
formação inicial e \\
continuada. Bem \\
como investigar \\
como os professores \\
que ingressaram \\
na rede pública de \\
ensino do Rio de \\
Janeiro entre os \\
anos de 2010 e 2012 \\
viveram o trabalho \\
docente e o processo \\
de socialização \\
profissional.
\end{tabular} & \begin{tabular}{|} 
O resultado da pesquisa \\
demonstrou que \\
quanto a formação \\
inicial a avaliação é \\
positiva no que se \\
refere às oportunidades \\
de reflexão sobre \\
diferentes aspectos da \\
realidade educacional \\
e de participação em \\
atividades de pesquisa / \\
extensão e nos estágios \\
supervisionados. \\
No entanto, foi \\
identificada uma \\
separação entre os \\
conhecimentos \\
acadêmicos e a \\
dimensão prática da \\
formação docente, \\
Bem como, fica \\
evidente a falta de \\
política pública que \\
acolha o professor \\
iniciante , bem como \\
as formações para os \\
professores em serviço.
\end{tabular} \\
\hline
\end{tabular}




\begin{tabular}{|c|c|c|c|c|c|c|}
\hline$\# \mathbf{N}$ & Data & Título & Autores & Periódico & Objetivos & Resultados \\
\hline 10 & 2016 & $\begin{array}{l}\text { A indução do } \\
\text { corpo docente } \\
\text { iniciante na } \\
\text { República } \\
\text { Dominicana. } \\
\text { O programa } \\
\text { INDUCTIO }\end{array}$ & $\begin{array}{l}\text { MARCELO } \\
\text { GARCÍA, Carlos } \\
\text { et al. }\end{array}$ & $\begin{array}{c}\text { Revista } \\
\text { Intersaberes }\end{array}$ & $\begin{array}{l}\text { Expor o programa } \\
\text { INDUCTIO } \\
\text { que vem se } \\
\text { desenvolvendo } \\
\text { na República } \\
\text { Dominicana } \\
\text { para a indução } \\
\text { dos professores } \\
\text { iniciantes. }\end{array}$ & \begin{tabular}{|c} 
O estudo apresentou \\
o INDUCTIO o \\
programa que visa \\
facilitar a indução dos \\
professores iniciantes \\
na sua profissão \\
e assim trazer \\
qualidade à docência. \\
INDUCTIO \\
incorpora como \\
elemento principal \\
do programa a \\
figura do mentor. \\
Mas, além disso, \\
acompanha esta figura \\
com a organização \\
de círculos de \\
aprendizagem, \\
seminários de \\
trabalho, formação \\
seguindo a \\
modalidade \\
b-learning. \\
INDUCTIO faz \\
um uso intensivo das \\
tecnologias e para ele \\
foi criado um portal \\
na internet. Surgiu da \\
iniciativa do Instituto \\
Nacional de Formação \\
e Capacitação \\
do Magistério \\
(INAFOCAM) \\
da República \\
Dominicana com o \\
objetivo de favorecer \\
os processos de \\
indução profissional \\
à docência do corpo \\
docente iniciante.
\end{tabular} \\
\hline
\end{tabular}




\section{INDUÇÃO PROFISSIONAL}

\subsection{CONHECENDO INDUÇÃO PROFISSIONAL}

O objetivo do presente estudo foi realizar uma revisão integrativa da literatura sobre processos de indução de professores iniciantes na escola básica uma revisão na intenção de mapear avanços e lacunas nesta área do conhecimento. A a indução se refere ao processo de acompanhamento do professor iniciante ou principiante durante a sua inserção profissional (DA CRUZ ; DE FARIAS; DE SOUZA HOBOLD, 2020). É um período em que os docentes realizam a transição de estudantes para professores, sendo fundamental para a carreira docente (MARCELO et al., 2016).

Além disso, é um momento no qual surgem as dúvidas, tensões, em que a realidade vem mostrando que muitos professores iniciantes acabam abandonando seu trabalho por inúmeras questões (MARCELO et al., 2016). Por exemplo, Marcelo et al. (2016) apontam os baixos salários, problemas de disciplina com os alunos, falta de apoio, poucas oportunidades de tomadas de decisão como algumas questões centrais desse afastamento do professor.

Da Cruz e De Farias e De Souza (2020) mostram, em seu estudo, que o conceito de indução profissional não deve ser adicionado sem uma compreensão crítica em relação às condições objetivas e subjetivas do trabalho do professor. Por isso, a indução profissional não deve ser só uma forma de induzir os professores em início de carreira, mas um constructo que aceite e entenda a necessidade da criação de espaço de formação, acolhimento e acompanhamento de sua atuação profissional (DA CRUZ; DE FARIAS; DE SOUZA HOBOLD, 2020).

Zhukova (2018) buscou fazer uma compreensão mais profunda sobre os fatores-chave que influenciam e moldam o desenvolvimento profissional de professores novatos e desenvolvem suas competências pedagógicas, bem como o professor novato se adapta a suas novas funções no ambiente escolar aberto complexo e dinâmico. A pesquisa é enquadrada como uma análise de quatro casos de professores novatos no ensino médio de escolas públicas de Letônia (ZHUKOVA, 2018). Foram examinados os fatores que afetam e moldam o desenvolvimento de professores novatos ao longo 
de um período de dois anos à medida que evoluem de alunos para educadores profissionais (ZHUKOVA,2018).

A pesquisa revelou também que o sistema atual de retenção e apoio de professores iniciantes das escolas Letônia não oferece um sistema sistemático, contínuo de crescimento instrucional, pessoal e profissional eficaz (ZHUKOVA, 2018). Ou seja, os resultados apoiam fortemente a importância da orientação, especialmente durante a fase de indução, quando professores novatos passam da forma de professor aluno para educador profissional (ZHUKOVA,2018).

Nascimento e Reis, (2017) buscaram investigar como os professores que ingressaram na rede pública de ensino do Rio de Janeiro entre os anos de 2010 e 2012 viveram o trabalho docente e o processo de socialização profissional. Procuraram debater sobre os significados atribuídos por professores principiantes na profissão sobre suas experiências de formação inicial e continuada (NASCIMENTO; REIS, 2017). Desse modo, quanto à formação inicial, a avaliação mostrou-se positiva em diferentes aspectos da realidade educacional, como: participação em atividades de pesquisa / extensão e nos estágios supervisionados (NASCIMENTO; REIS,2017). Os autores identificaram, no entanto, uma separação entre os conhecimentos acadêmicos e a dimensão prática da formação docente, ficando evidente a falta de política pública de acolhimento ao professor iniciante, bem como as formações para os professores em serviço (NASCIMENTO; REIS, 2017).

\subsection{INICIATIVAS SOBRE INDUÇÃO PROFISSIONAL NO BRASIL E NO MUNDO}

Há um crescente número de programas educativos voltados para desenvolver políticas educativas de indução ou inserção profissional para o professor iniciante (MARCELO et al., 2016 aput ALEN; SARDI, 2009a; MARTÍNEZ, 2012). Butt e Faroq (2019) apresentam, em seu estudo, o efeito do Programa de Treinamento de Indução para os professores iniciantes e a eficácia de Ensino Fundamental em Punjab.

O treinamento de indução é um processo de apoio aos professores iniciantes para ensiná-los os conhecimentos básicos, habilidades e valores relacionados ao ensino e que se socializem com a profissão (BUTT; 
FAROOQ, 2019). Embora as os professores das escolas de ensino fundamental tenham boas opiniões sobre programa de treinamento de indução e sua eficácia de ensino, ainda é preciso dar importância a algumas áreas de treinamento (BUTT; FAROQ, 2019). Por exemplo, Butt e Faroq (2019) apontam a comunicação com pais das crianças, valores e conhecimento de alfabetização multicultural, consciência global e ambiental para torná-los mais eficazes.

De Arruda et al. (2018) trazem uma pesquisa sobre o trabalho do professor no início da carreira profissional, na qual apresenta o Grupo de Estudos e Pesquisas sobre Profissão e Formação Docente (GEPROD/ UFRJ). Esse grupo vem se preocupando com o trabalho docente no início de carreira e com as políticas de indução profissional e formação continuada (DE ARRUDA et al. 2018). As pesquisas foram realizadas entre os anos de 2008 e 2017, e os resultados mostraram a importância de dar atenção especial aos professores iniciantes e a necessidade de ações sistemáticas de acompanhamento desses professores (DE ARRUDA et al., 2018). Também mostraram a importância da formação contínua das disciplinas centradas em questões práticas que afetam o dia a dia docente (DE ARRUDA et al., 2018).

Çobanoğlu e Ayvaz-Tuncel (2018) apresentam, em seu estudo, as opiniões de 357 professores novatos sobre o cumprimento das metas do programa de iniciação de professores. O programa de indução de professores na Turquia, iniciado em 2016, foi regulamentado para treinar professores novatos por seis meses visando treinar, apoiar e proteger professores novatos (ÇOBANOĞLU; AYVAZ-TUNCEL,2018). Os resultados sugeriram que a educação inicial e o programa de iniciação de professores têm semelhanças no que diz respeito ao cumprimento das metas do programa de iniciação de professores (ÇOBANOĞLU; AYVAZ-TUNCEL,2018).

Nesse sentido, para Marcelo et al. (2016), em sua pesquisa, a indução do corpo docente iniciante apresenta o programa INDUCTIO, desenvolvido na República Dominicana para a indução dos professores iniciantes. O programa visa facilitar a indução dos professores iniciantes na sua profissão e assim trazer qualidade à docência, melhorando o contexto da sala de aula (MARCELO et al., 2016). Esse programa surgiu da iniciativa do Instituto Nacional de Formação e Capacitação do Magistério (INAFO- 
CAM) da República Dominicana, com o objetivo de favorecer os processos de indução profissional à docência do corpo docente iniciante (MARCELO et al., 2016).

\subsection{O PAPEL DO MENTOR NO PROCESSO DE INDUÇÃO PROFISSIONAL}

A mentoria constitui um componente essencial no processo de indução, mas não é o único, pois o programa INDUCTIO incorpora como elemento principal a figura do mentor (MARCELO et al., 2016). Não se trata unicamente de uma estratégia para tratar de compensar problemas, deficiências, necessidades, lacunas do novo professor, mas sim uma estratégia formativa necessária, vital e com características particulares que a faz única e específica (MARCELO et al., 2016).

A indução requer um aprendizado por parte do docente, um completo desenvolvimento profissional que se inicia ao primeiro dia em que está em sua sala de aula com seus estudantes (MARCELO et al., 2016). Além disso, considerando o processo como um todo, o mentor tem papel importante no desenvolvimento de professores novatos (ÇOBANO®LU; AYVAZ-TUNCEL, 2018). Ele acompanha na organização de círculos de aprendizagem, seminários de trabalho, formação seguindo a modalidade b-learning. INDUCTIO faz um uso intensivo das tecnologias e para ele foi criado um portal na internet (MARCELO et al., 2016).

Examinar o trabalho do formador escolar, seu papel e as perspectivas de atuação desse profissional nos processos de indução de professores iniciantes, contribuiu para a reflexão de sua prática (AMBROSETTI et al., 2020). Além disso, a figura do formador escolar é observada, e via de regra, esses profissionais são professores experientes, selecionados ou indicados para atuar em funções de orientação, coordenação ou supervisão, no espaço escolar (AMBROSETTI et al., 2020).

Ficou evidente a importância do formador de professores no processo de ingresso de novatos; sua função é formular as ações de acolhimento e apoio necessárias para que os iniciantes promovam sua integração gradativa na cultura e no grupo profissional (AMBROSETTI et al., 2020).

Igualmente, o programa de mentoria para professores iniciantes, apoiado pelo governo de Queensland, na Austrália, buscou entender 
como os professores mentores negociavam e atuavam como líderes intermediários em escolas em diversos contextos (WILLIS et al., 2018). Outro exemplo é o estudo Schuck et al. (2017), uma investigação sobre as experiências de professores em início de carreira (ECTs) em New South Wales, Austrália, momento que inicia o programa de mentores.

$\mathrm{Ou}$ seja, a autoridade local empregadora exigiu o fornecimento de mentores e uma redução no ensino presencial para ECTs (professores iniciantes), segundo Schuck et al. (2017). O estudo descobriu que muitas das questões do início da experiência dos professores em início de carreira permanecem intratáveis, ou pelo menos não resolvido para alguns (SCHUCK et al.,2017). Por outro lado, a pesquisa indica que apesar do suporte, não se pode ser complacente com a transição do professor iniciante para a profissão, necessidade ainda de eliminar elementos do ambiente escolar que impactam as experiências dos mesmos (SCHUCK et al., 2017).

\section{CONCLUSÃO}

O objetivo do presente estudo foi realizar uma revisão integrativa da literatura sobre processos de indução de professores iniciantes na escola Básica uma revisão na intenção de mapear avanços e lacunas nesta área do conhecimento. No decorrer deste estudo, foi possível observar que há uma comoção no mundo acadêmico tanto nacional como internacionalmente sobre o tema indução profissional de professores iniciantes na profissão docente.

Os estudos mostram iniciativas em muitos países, inclusive no Brasil há estudos preocupados com a formação inicial e a formação continuada do professor iniciante e principalmente com a forma como inicia sua prática pedagógica.

A mentoria vem sendo usada como uma ferramenta para ajudar os professores iniciantes, em alguns lugares tem sido feita mentoria usando líderes intermediários que são com seus pares. Ou seja, a mentoria é feita por professores com mais experiência que dão suporte a esse professor iniciante através de trocas de experiências, conversas, orientações e acompanhamento. Por outro lado, a mentoria entre professores experientes com os professores iniciantes pode trazer equívoco no modo de abordagem, 
dando à situação um ar de superioridade por parte do professor experiente que atrapalharia o mentorando.

Outro exemplo disso é que também se discuti a mentoria sendo feita pelo formador escolar (coordenação pedagógica) e, nesse sentido, seu trabalho seria dar suporte para que esse professor iniciante venha ter maior confiança diante dos problemas do dia a dia da escola.

Desse modo, as iniciativas sobre indução profissional são novas, porém muito necessárias. Fazer um mapeamento sobre indução profissional ao longo do tempo trará respostas para preenchemos as lacunas existentes sobre o tema. Além disso, propõe-se que o termo "mentoria" fosse trocado por "amigo do professor", que traria uma relação mais próxima e de confiança, porque na relação entre amigos há uma troca de experiências sem que um tenta ser maior que o outro.

Outra proposta para a indução profissional seria a utilização do coordenador pedagógico como amigo do professor, buscando preparar esse professor iniciante, porém não da forma como hoje se conhece as atribuições do coordenador pedagógico. Nesse sentido, a coordenação seria responsável pelo apoio, acompanhamento e mapeamento do trabalho do professor iniciante e as questões de conflitos entre alunos, conversas com responsáveis, dentre outras, seriam atribuições do orientador escolar.

Por fim, ao investigar esses aspectos relacionados à indução profissional, espera-se contribuir para as discussões no campo acadêmico sobre a importância do acolhimento do professor iniciante visto tantos desafios que os mesmos encontram no início de carreira. Se a indução profissional for bem-feita, terá grandes resultados tanto na qualidade de ensino como na vida profissional do professor que o mesmo inicia com medos, inseguranças que o impedem de desenvolver um bom trabalho.

\section{REFERÊNCIAS}

AMBROSETTI, Neusa Banhara et al. Formadores de professores: conceito, contextos e perspectivas de atuação em processos de indução à docência. Revista Eletrônica de Educação, v. 14, p.1-19, 2020.

BUTT, Khadija; FAROOQ, Muhammad Shahid. Effect of Induction Training Program on Teachers' Effectiveness at Elementary School 
Level in Punjab. Pakistan Journal of Education, v. 36, n. 3, p. 51-69, 2019.

CIRÍACO, Klinger Teodoro; DA COSTA, Milaine Menezes. Da formação inicial ao ingresso na carreira docente. Formação@ Docente, v. 8 , n. 1, p. 5-25, 2016.

ÇOBANOĞLU, Fatma; AYVAZ-TUNCEL, Zeynep. Teacher induction program: First experience in Turkey. International Education Studies. v. 11, n. 6; 2018.

DA CRUZ, Giseli Barreto; DE FARIAS, Isabel Maria Sabino; DE SOUZA HOBOLD, Márcia. Indução profissional e o início do trabalho docente: debates e necessidades. Revista Eletrônica de Educação, v. 14, p. 4149114, 2020.

DE ARRUDA, Maria das Graças Chagas et al. A Pesquisa sobre o trabalho do professor no início da carreira profissional. Formação Docente-Revista Brasileira de Pesquisa sobre Formação de Professores, v. 10, n. 19, p. 101-114, 2018.

GATTI, B. A., BARreto, E. S. de S. e ANDRÉ, M. E. D. de A. Políticas docentes no Brasil: um estado da arte. Brasília: UNESCO, 2011.

MARCELO, Carlos; VAILLANT, Denise. Políticas y programas de inducción en la docência en Latinoamérica. Cadernos de Pesquisa v. 47, n. 166, p. 1224-1249, out./dez. 2017.

MARCELO GARCÍA, Carlos et al. A indução do corpo docente iniciante na República Dominicana. O programa INDUCTIO. Revista Intersaberes, v. 11, n. 23, p. 304-324, 2016.

NASCIMENTO, Maria das Graças C.; REIS, Rosemary F. dos. Formação docente: percepções de professores ingressantes na rede municipal de ensino do Rio de Janeiro. Educação e Pesquisa, v. 43, n. 1, p. 49-64, 2017.

NÓVOA, Antonio. Os professores e a sua formação num tempo de metamorfose da escola. Universidade de Lisboa (ULisboa), Lisboa - Por- 
tugal. Educação \& Realidade, Porto Alegre, v. 44, n. 3, e84910, 2019 .

NÓVOA, A. Desafios do trabalho do professor no mundo contemporâneo. Palestra proferida no SIMPRO - SP, 2007. Disponível em www.scribd.com e em http://www.sinprosp.org.br/arquivos/novoa/ livreto_novoa.pdf Acesso em: dez. 2020.

SCHUCK, Sandy et al. The experiences of early career teachers: new initiatives and old problems. Professional Development in Education, v. 44, n. 2, p. 209-221, 2018.

TELES, Nayana Cristina Gomes. O Programa de Tutoria Educacional da SEMED/Manaus: contribuições ao desenvolvimento profissional de professores iniciantes. Revista Profissão Docente, v. 20, n. 45, p. 01-19, 2020.

VAILLANT, D.; MARCELO, C. A, B, C e D da formação de professores. Madrid: Narcea, 2015.

WILLIS, Jill et al. Mentors for beginning teachers as middle leaders: the messy work of recontextualising. School Leadership \& Management, v. 39, n. 3-4, p. 334-351, 2019.

ZHUKOVA, Olena. Novice teachers' concerns, early professional experiences, and development: Implications for theory and practice. Discourse and Communication for Sustainable Education, v. 9, n. 1, p. 100-114, 2018. 


\section{O IDEB E O INCENTIVO A UMA POLÍTICA PÚBLICA DESIGUAL: UMA ANÁLISE DA EVOLUÇÃO DA QUALIDADE EDUCACIONAL NAS CAPITAIS BRASILEIRAS A PARTIR DA INSERÇÃO DO NÍVEL SOCIOECONÔMICO}

Heloisa Borella Zamboim ${ }^{9}$

\section{INTRODUÇÃO}

O Brasil enfrenta as desigualdades como um fenômeno real e que gera muitas consequências práticas ao cotidiano. Em relação à educação, por se constituir um direito social, sua ausência ou oferecimento irregular gera impactos capazes de afetar a atuação do indivíduo como cidadão.

Nesse sentido, a Constituição Federal traz prioritariamente, por meio da redistribuição de recursos, a obrigação estatal da oferta do ensino obrigatório. Isto é, deve o Estado preocupar-se tanto com a universalização, quanto com a garantia da qualidade e equidade da educação, como prevê seu art. 212, \$3ํ. Partindo então da premissa que a educação necessita de condições de acesso, fornecimento e conhecimento igualitárias para con-

9 Graduanda em Direito na PUC-Campinas; bolsista PIBIC/CNPQ, desenvolvendo o projeto de iniciação científica Políticas Públicas e Direito a Educação: evolução dos gastos governamentais e eficácia de direitos fundamentais. 
quistar seu potencial transformador e reducionista das demais desigualdades, este estudo optou por abordar a sua terceira dimensão, a qual ainda se impõem grandes desafios de igualdade: a da qualidade.

Atualmente, se configura como o principal índice responsável por avaliar a qualidade de ensino básico e influir na formulação de novas políticas públicas na área da educação o Índice de Desenvolvimento da Educação Básica (IDEB). Contudo, este índice vem sendo criticado por vários autores (ALMEIDA; DALBEN; FREITAS, 2013; FIGUEIREDO et al, 2018; SILVA; SILVA; SANTOS, 2019) devido a fatores que não são observados no momento de realização de seu cálculo. Um destes fatores é o nível socioeconômico (NSE), isto é, o índice não se atém a características pertencentes ao aluno e que possuem ampla influência em seu desempenho escolar.

De modo a tentar suprir esta lacuna, este estudo buscou responder aos seguintes questionamentos: ao não incluir em suas análises o fator socioeconômico, pode estar o IDEB auxiliando a implementar políticas educacionais desiguais nas capitais brasileiras? Se a resposta for positiva, quais as prováveis consequências para o desenvolvimento da cidadania?

Para responder a estas perguntas, foi realizado estudo comparativo dos resultados obtidos no IDEB nos anos de 2007 e 2015, com os de um outro índice, o IdeA (Indicador de desigualdades e aprendizagens), que procura inserir o NSE no cálculo das aprendizagens.

Dada a amplitude de ambos os índices analisados, optou-se neste estudo por investigar um quadro mais restrito, ou seja, a presente análise se limitou a observar como se deu a evolução da qualidade educacional nos anos iniciais do Ensino Fundamental, se considerados os diferentes grupos socioeconômicos das capitais brasileiras. Ademais, considerando a interrelação entre educação, ação estatal e a sociedade, a investigação igualmente procurou, através de uma discussão teórica, refletir sobre os impactos do fornecimento desigual da educação para a sociedade.

\section{A EDUCAÇÃO COMO POLÍTICA PÚBLICA E A RELEVÂNCIA DA QUALIDADE EDUCACIONAL PARA A SOCIEDADE}

Como ponto de partida, é necessário, sobretudo, estabelecer que a compreensão da educação como política pública exige um exame sob o 
viés do fazer do Estado. Neste sentido, tem-se que a materialização da educação requer, essencialmente o reconhecimento de uma relação direta entre o Estado e os seus destinatários finais, quais sejam os alunos e professores.

De acordo com Baruffi (2009), nenhum direito é garantido com efetividade sem que exista um investimento eficaz que gere aperfeiçoamento das circunstâncias para o exercício da cidadania, ou seja, sem aprimoramentos econômicos e sociais e investimentos educacionais. A partir desta visão, extrai-se que a educação se encontra condicionada ao uso de recursos estatais e que seu investimento é vital para a prática de outros direitos, como a cidadania.

É preciso atentar, no entanto, para o fato de que não se encontra presente uma relação puramente unilateral entre o Estado e a educação. Pelo contrário, vê-se uma necessidade mútua entre o sistema educacional e a política. Nas palavras de Saviani:

A educação depende da política no que diz respeito a determinadas condições objetivas como a definição de prioridades orçamentárias que se reflete na constituição-consolidação-expansão da infraestrutura dos serviços educacionais etc.; e a política depende da educação no que diz respeito a certas condições subjetivas como a aquisição de determinados elementos básicos que possibilitem o acesso à informação, a difusão das propostas políticas, a formação de quadros para os partidos e organizações políticas de diferentes tipos etc. da infraestrutura dos serviços educacionais (SAVIANI, 2008, p. 68).

Através da apreciação dessa relação de reciprocidade, na qual a educação é capaz de influenciar novos processos políticos, verifica-se um componente determinante: o nível da qualidade educacional. Nesta conjuntura, a característica qualitativa da educação mostra-se como um referencial que possui o potencial de ampliar a visão da cidadania das crianças e adolescentes que estão em processo de aprendizagem (CURY; NASCIMENTO, 2020).

Esta perspectiva, a qual implica observar a educação como forma de aprimoramento do processo civilizatório, é também essencial para a com- 
preensão da busca por uma formação humanitária do aluno, a qual deve estar presente desde o início de sua jornada educacional. Assim, de maneira a intensificar uma atitude ativa no mundo, a qualidade, como atributo da educação, possui acepção para a construção e promoção do ser humano e a prática de uma cidadania ativa (CURY; NASCIMENTO, 2020).

Ademais, a qualidade educacional, além de ser uma característica necessária para o próprio desenvolvimento saudável da atividade educativa, constituía meta e prioridade no antigo Plano Nacional de Educação (PNE) 2001- 2010: "Em síntese, o Plano tem como objetivos: [...] a melhoria da qualidade do ensino em todos os níveis" e permanece como guia do PNE atual (2014-2024):

Art. $2^{\circ}$ São diretrizes do PNE:

III - superação das desigualdades educacionais, com ênfase na promoção da cidadania e na erradicação de todas as formas de discriminação;

IV - melhoria da qualidade da educação;

Para que sejam atingidas as metas legais e ocorra a aplicação efetiva da política educacional é necessário, portanto, que dentro do conceito do acesso esteja incluído o alcance do conhecimento, somado a uma distribuição equalitária. Assim, o acesso a um ensino de qualidade possui um papel tanto de anteparo ao direito das crianças e adolescentes, bem como em seu processo de formação e construção como cidadão.

Nesse contexto, ao enxergar a qualidade como essencial para a efetivação do direito à educação, é preciso saber se a evolução das políticas tende para um aumento qualitativo da oferta do ensino. Para tanto, vamos ao estudo do IDEB.

\section{APRESENTAÇÃO E ANÁLISE DO IDEB}

O Índice de Desenvolvimento da Educação Básica (IDEB), criado em 2007 por meio de uma iniciativa do Instituto Nacional de Estudos e Pesquisas Educacionais Anísio Teixeira (Inep), ainda continua sendo o principal índice nacional responsável por medir a qualidade educacional no país. 
Aplicado em grande escala e de modo bienal, seus resultados têm servido como parâmetro da evolução da qualidade educacional brasileira, além de ser considerado um ponto fundamental para o planejamento de novas políticas públicas na área de educação. Deste modo, entende-se o IDEB como um orientador das políticas educacionais atuais para a educação básica, pois todas as governanças do cenário local (escola, município, Estado) o usam como base referencial (SILVA; SILVA; SANTOS, 2019).

Com relação ao método para a medição da qualidade, o IDEB utiliza a junção de dois conceitos: o fluxo escolar e as médias de desempenho nas avaliações, sendo ambos aplicados no final de cada etapa de ensino, quais sejam: $5^{\circ}$ e $9^{\circ}$ ano do ensino fundamental e $3^{\circ}$ ano do ensino médio. O primeiro conceito é medido segundo os dados de aprovação escolar, encontrados no Censo Escolar; já o segundo é calculado com base nos dados obtidos no Sistema de Avaliação da Educação Básica (Saeb), o qual, por meio de uma avaliação padrão, aprecia o desempenho dos alunos nas disciplinas de português e matemática. Uma breve explicação de como é efetuado o cálculo:

O cálculo do IDEB obedece a uma fórmula em que as notas das provas de língua portuguesa e matemática são padronizadas em uma escala de 0,0 (zero) a 10,0 (dez), depois, a média dessas duas notas é multiplicada pela média (harmônica) das taxas de aprovação das séries da etapa (anos iniciais, anos finais e ensino médio), que, em percentual, varia de 0 (zero) a 100 (cem). (RESUMO TÉCNICO IDEB, 2019, p. 10).

A partir desta fórmula, é gerado um número de IDEB, o qual varia dentro de uma escala de 0 a 10. Pela composição matemática do índice, os dois conceitos utilizados devem evoluir de maneira conjunta para que se apresente um aumento no IDEB. A cada dois anos, com o objetivo de conquistar uma evolução positiva do índice e auxiliar o Brasil a atingir a média 6,0 no ano de 2022, é estabelecida uma meta diferente a ser alcançada para cada escola, município e estado. Os que possuem um índice mais alto, devem contribuir para aumentá-lo. Já com relação aos que possuem índice mais baixo, as metas são estabelecidas de maneira com que se exija um maior esforço e que se possa reduzir as desigualdades observadas 
(BRASIL, 2020). No entanto, é necessário ressaltar que essa dinâmica acaba por fortalecer na prática uma lógica de competitividade, a qual será explorada mais adiante.

\subsection{O IDEB NO CICLO DE POLÍTICAS PÚBLICAS}

No intuito de entender como o IDEB influencia na formulação de novas políticas educacionais, é preciso identificar em qual fase do ciclo de políticas públicas ele atua. Para tanto, resolveu-se adotar a divisão do ciclo de políticas públicas em quatro fases: definição da agenda; formulação e escolha das políticas públicas; implementação pelo órgão competente; avaliação (FONTE, 2015).

$\mathrm{Na}$ primeira fase, há o encontro de problemas que exigem a ação estatal. A partir disso, ocorre ainda nesta etapa a formação de uma agenda, dentro da qual são elencadas as prioridades da atuação e definido o orçamento. No que toca a educação, há uma agenda pré-estabelecida, pois, no que concerne aos municípios, a Constituição fixou o mínimo de investimento em $25 \%$ da receita que resulta dos impostos, como indica seu art. 212.

Nesse contexto, por já estar pré-definida a agenda constitucional, se vislumbra uma menor influência da atuação do IDEB nesta fase, pois a discricionariedade orçamentária somente estará presente no caso de aumento do investimento na área. Entretanto, não se entende que a atuação do IDEB nesta etapa seja insignificante, pois a futura obtenção de um índice desfavorável para o município pode representar uma grande falha do compromisso público para com o direito à educação, e, desta maneira, uma situação que deve ser evitada.

Já durante a segunda fase são identificados os objetivos, formuladas soluções e estabelecidas as probabilidades de execução para o orçamento estabelecido na agenda. É neste momento, portanto, em que as intenções dos agentes são evidenciadas e que são formuladas as bases que irão nortear o seguimento da política (SECCHI, 2013). Nesse sentido, os resultados obtidos no IDEB têm o potencial de influenciar na escolha das prioridades dos agentes públicos, pois caso a qualidade educacional tenha demonstrado uma queda ou estagnação, há a identificação de um problema que exige resposta. Contudo, mesmo que o resultado se mostre 
contrário, isto é, haja um aumento no índice, ainda continuarão a subsistir as metas estabelecidas pelo IDEB, as quais os municípios devem buscar atingi-las, no propósito de que os resultados se aprimorem ainda mais.

Quanto à terceira fase, a de implementação, é o momento em que as políticas ganham maior concretude, pois é nela que todo o planejamento efetuado nas fases anteriores passa a ser executado através da efetiva ação estatal (FONTE, 2015). É nesta etapa que passam a ser construídos os resultados da aplicação da política e é também o momento em que se torna possível coletar os dados que serão futuramente utilizados na constituição do IDEB, quais sejam o Saeb e o Censo Escolar.

Por fim, a quarta fase, que diz respeito à avaliação, é o estágio em que o procedimento de implementação e o desenvolvimento alcançado da política pública são estudados, para que se entenda melhor o estado da política e se houve redução do problema que a ocasionou (SECCHI 2013). Esta fase, portanto, se mostra fundamental para o futuro aprimoramento e, se for o caso, reformulação das políticas.

Nessa dinâmica, as ferramentas de avaliação criam um parâmetro que possibilita uma comparação do problema, tanto no aspecto temporal, como espacial (SECCHI, 2013). Aqui é onde o se localiza IDEB, pois sua função de indicador de resultados da qualidade educacional vem servindo como um instrumento de medição estatal, de modo que se pode afirmar que ele se configura como agente determinante na modificação ou constância das políticas educacionais.

Dado o exposto, mesmo enquadrando o IDEB na quarta etapa, é possível notar que o índice tem o potencial de participar e orientar os gestores das políticas educacionais nas demais fases do ciclo de políticas públicas. Demonstrada a relevância de seu estudo, vamos à análise da evolução do índice.

\subsection{ANÁLISE DO IDEB}

Investigar os resultados dos anos iniciais do Ensino Fundamental é de extrema significância, pois este período, além de participar do início da jornada educacional, abrange a fase de alfabetização de muitos alunos. Desta forma, obter um avanço positivo nas bases primordiais do ensino se constitui um bom primeiro passo para a melhoria da educação básica no Brasil. Dito isso, parte-se para a exploração dos dados: 
Gráfico 1 - Evolução do IDEB nos anos iniciais do Ensino Fundamental nas capitais brasileiras (2007-2015)

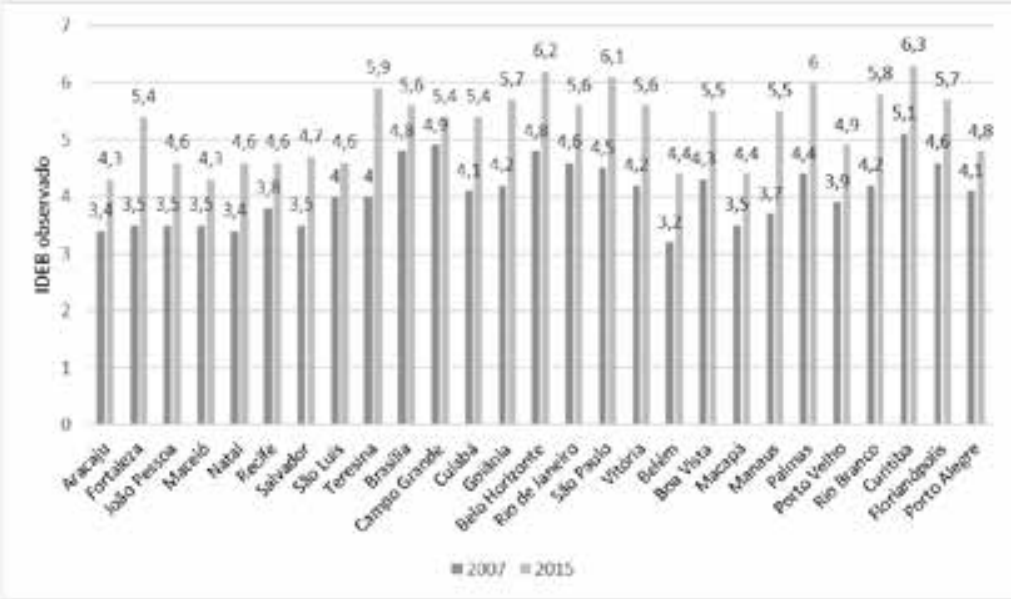

Fonte: Elaboração própria, a partir da extração de dados do IDEB na rede de ensino público dos municípios analisados.

A partir da observação do gráfico acima, repara-se que do ano 2007 para o de 2015, houve um crescimento positivo do IDEB em todas as capitais brasileiras, sem exceção. Das 27, apenas nove capitais (Aracaju, Maceió, Recife, São Luís, Brasília, Campo Grande, Macapá e Porto Alegre e Brasília) apresentaram um aumento inferior a 1,0 no período aqui analisado. Dentre as que apresentaram menor evolução estão as capitais dos estados do Mato Grosso do Sul e da Paraíba. Campo Grande obteve um aumento de 0,5 e João Pessoa, o de 0,6.

Assim, de todas as capitais, percebe-se que a grande maioria apresentou um aumento igual ou superior que 1,0 no IDEB no período aqui analisado. Destacam-se, como as que obtiveram um maior crescimento, as capitais do Piauí, Ceará e do Amazonas. Teresina e Fortaleza obtiveram um aumento de 1,9 e Manaus, o de 1,8.

A partir do exame do IDEB isoladamente, seria possível concluir que na grande maioria das capitais houve um grande salto na evolução da qualidade educacional. No entanto, uma grande crítica direcionada ao IDEB é quanto à ausência da consideração de fatores extraescolares que intercedem a vida dos estudantes, como os aspectos socioeconômicos e o capital cultural (FIGUEIREDO et al., 2018). Esta desconsideração de elementos 
externos à escola, não permite, portanto, a avalição de condições que impactam diretamente na vida dos discentes.

Por esta linha, investigar as divergências culturais e socioeconômicas têm o dever de formar um estudo que explique a diferença da desenvoltura dos alunos, uma vez que ao não as examinar presumiria, na grande maioria das vezes, dar o título de boa escola a instituições que, como singular e legítima diferenciação em comparação a outras, abrigam alunos com capital cultural e socioeconômico mais elevado (ALMEIDA; DALBEN; FREITAS, 2013). À vista disso, é necessário observar de que modo se dão as assimetrias da oferta educacional sob o viés dos diferentes níveis socioeconômicos, ou seja, enxergar o IDEB dentro de um contexto social. Partimos então, à análise das desigualdades.

\section{DIREITO À EDUCAÇÃO E AS DESIGUALDADES}

\subsection{IDEA COMO MEDIDOR DE DESIGUALDADES}

O Indicador de Desigualdades e Aprendizagens (IdeA) foi criado em junho de 2019 pela Fundação Tide Setubal e objetiva, por via da inserção de dados socioeconômicos na análise da qualidade educacional, auxiliar a criação de políticas públicas educacionais que visem a redução das desigualdades.

A partir de estatísticas formuladas para cada município brasileiro, o IdeA procura demonstrar a realidade social, de modo a possibilitar o combate a duas situações que geram a exclusão por meio do ensino, quais sejam: o baixo nível de aprendizado (alunos não aprenderam o necessário) e a desigualdade de aprendizagem entre os grupos sociais (um grupo social aprende mais que outro). (CASTILLO; ERNICA; SOARES, 2019).

Para que essa avaliação seja possível, o IdeA se vale de métodos análogos ao IDEB, ou seja, utiliza também dados concretos obtidos através da Prova Brasil (uma das avaliações que integra o Saeb e é responsável por avaliar o desempenho dos alunos da rede pública de ensino). Esse fator permitirá a realização de um estudo comparativo entre os resultados dos dois índices aqui trabalhados.

A constituição do IdeA, portanto, se dá pelo nível total de aprendizado dos alunos (dados coletados da Prova Brasil), somado à medida das desigualdades entre os grupos sociais (calculada a partir do distanciamento entre os 
grupos). Deste modo, ele permite que sejam observadas duas situações: se a aprendizagem total é equânime à referência adotada e se existem diferenças entre os grupos sociais que foram postos em análise. A referência adotada quanto ao nível de aprendizagem é alcançada da seguinte maneira:

Inicialmente, foi calculada a mudança que deveria ocorrer na distribuição da aprendizagem do conjunto dos estudantes brasileiros no PISA (Programa Internacional de Avaliação de Estudantes) para que o Brasil obtivesse desempenho igual ao de um país típico da OECD (Organização para a Cooperação e Desenvolvimento Econômico); a seguir, essa mudança foi aplicada à distribuição da aprendizagem do conjunto dos estudantes brasileiros medida pela Prova Brasil. A distribuição obtida ao final foi considerada a referência e, por isso, a meta adequada para esse momento da educação do país. (IDEA - nota técnica, 2019, p. 7).

A partir deste cálculo, é gerado um número que representa a referência utilizada no índice. Os níveis de aprendizagem são colocados em uma escala de 0 a 10 . Se o índice se apresentar de 0 a 2 indicará um nível baixo; de 2 a 2,9 médio-baixo; de 2,9 a 3,7 médio; de 3,8 a 4,8 médio alto e, por fim, de 4,8 a 10, um nível alto.

Quanto ao nível de desigualdade entre os grupos, por não haver outro referencial externo, o Idea adota o número zero $(0,0)$, que representa a igualdade perfeita. Isto indica que quanto mais próximo de zero, menor a desigualdade de aprendizagem entre os grupos e, quanto mais distante, maior a desigualdade.

Por fim, é necessário destacar que o Idea se propõe a medir a desigualdade de aprendizado entre grupos em três aspectos: o de raça, o de gênero e o de nível socioeconômico. Como já dito, neste presente estudo optou-se pela terceira abordagem, ou seja, se objetiva avaliar as diferenças no que toca às desigualdades de aprendizagens entre diferentes grupos socioeconômicos, quais sejam ricos e pobres.

\subsection{ANÁLISE DO IDEA}

Antes de se começar a explorar os dados, é preciso tecer algumas breves considerações a respeito do índice. Primeiramente, a inserção do NSE 
pelo IdeA não supre todas as necessidades no que diz respeito à mensuração da qualidade educacional, pois este índice, assim como o IDEB, utiliza dados em larga escala e, portanto, não contém todas as precisões possíveis.

O IdeA não se preocupa em trazer as particularidades de cada instituição de ensino, ou seja, o índice traz apenas as desigualdades de ensino entre diferentes grupos sociais, dentro de um mesmo município. Contudo, mesmo reconhecendo essas fragilidades, a utilização do índice será válida para este exame, pois além de aproximar mais da realidade a avaliação qualitativa da educação, o IdeA supre uma grande lacuna apresentada no IDEB, a do NSE, o que permitirá a realização de uma análise comparativa entre os resultados observados em ambos os índices. Feitas as considerações, vamos à inspeção do IdeA:

Tabela 1 - IdeA nas capitais -anos iniciais do Ensino Fundamental (2007-2015)

\begin{tabular}{|c|c|c|c|c|}
\hline Cidade & $\begin{array}{c}\text { Nível de } \\
\text { aprendizado } \\
\text { (Português) }\end{array}$ & $\begin{array}{c}\text { Nível de } \\
\text { aprendizado } \\
\text { (Matemática) }\end{array}$ & $\begin{array}{c}\text { Nível de } \\
\text { desigualdade } \\
\text { (Português) }\end{array}$ & $\begin{array}{c}\text { Nível de } \\
\text { desigualdade } \\
\text { (Matemática) }\end{array}$ \\
\hline Aracaju & 3,06 & 2,57 & 0,02 & 0,03 \\
\hline Fortaleza & 3,78 & 2,95 & 0,03 & 0,04 \\
\hline João Pessoa & 3,56 & 2,97 & 0,07 & 0,07 \\
\hline Maceió & 2,90 & 2,41 & 0,01 & 0,01 \\
\hline Natal & 3,09 & 2,54 & 0,04 & 0,05 \\
\hline Recife & 3,21 & 2,62 & 0,03 & 0,03 \\
\hline Salvador & 3,29 & 2,66 & 0,01 & 0,01 \\
\hline São Luís & 3,24 & 2,46 & 0,04 & 0,04 \\
\hline Teresina & 4,23 & 3,79 & 0,01 & 0,01 \\
\hline Brasília & 5,10 & 4,45 & 0,11 & 0,12 \\
\hline $\begin{array}{l}\text { Campo } \\
\text { Grande }\end{array}$ & 4,95 & 4,30 & 0,15 & 0,16 \\
\hline Cuiabá & 3,59 & 2,97 & 0,12 & 0,14 \\
\hline Goiânia & 4,59 & 3,64 & 0,11 & 0,12 \\
\hline $\begin{array}{c}\text { Belo } \\
\text { Horizonte }\end{array}$ & 5,59 & 4,93 & 0,22 & 0,25 \\
\hline Rio de Janeiro & 5,02 & 4,50 & 0,12 & 0,15 \\
\hline São Paulo & 4,27 & 3,85 & 0,15 & 0,16 \\
\hline Vitória & 4,33 & 3,67 & 0,20 & 0,19 \\
\hline
\end{tabular}




\begin{tabular}{|c|c|c|c|c|}
\hline Belém & 3,13 & 2,40 & 0,03 & 0,03 \\
\hline Boa Vista & 3,83 & 3,27 & 0,13 & 0,13 \\
\hline Macapá & 2,89 & 2,16 & 0,05 & 0,04 \\
\hline Manaus & 3,94 & 3,14 & 0,10 & 0,11 \\
\hline Palmas & 4,89 & 4,22 & 0,17 & 0,18 \\
\hline Porto Velho & 3,52 & 2,81 & 0,13 & 0,12 \\
\hline Rio Branco & 4,50 & 3,64 & 0,10 & 0,09 \\
\hline Curitiba & 5,35 & 5,08 & 0,19 & 0,19 \\
\hline Florianópolis & 4,68 & 4,05 & 0,27 & 0,27 \\
\hline Porto Alegre & 3,99 & 3,39 & 0,18 & 0,18 \\
\hline
\end{tabular}

Fonte: Elaboração própria, a partir dos dados extraídos do IdeA.

A primeira observação a ser feita a partir dos dados do IdeA é que as cidades altamente desiguais em uma matéria, também mantém a desigualdade alta com relação à outra. Vejamos: capitais com maior desigualdade em matemática: Florianópolis $(0,27)$, Belo Horizonte $(0,25)$; Curitiba e Vitória $(0,19)$; capitais com maior desigualdade em português: Florianópolis $(0,27)$; Belo Horizonte $(0,22)$; Vitória $(0,20)$ e Curitiba $(0,19)$.

As únicas capitais que apresentam alto nível de aprendizagem, tanto em matemática como em português (Belo Horizonte e Curitiba) se enquadram, de mesmo modo, entre as mais desiguais para ambas as disciplinas. Portanto, a tendência encontrada é: quanto mais alto o nível de aprendizado, maior tende a ser a desigualdade entre os grupos. De igual modo, para as capitais que apresentaram menor índice de desigualdade em aprendizado em uma matéria, a mesma situação se replicou para a outra. Nesse panorama, as capitais que apresentam um menor nível de desigualdade em matemática: Maceió, Salvador e Teresina $(0,01)$; Aracaju $(0,03)$ e Recife $(0,03)$; capitais que apresentam menor nível de desigualdade em português: Maceió, Salvador e Teresina (0,01); Aracaju $(0,02)$ e Recife $(0,03)$;

Por fim, quanto ao nível de aprendizagem, é possível notar que as capitais que possuem o índice mais baixo de desigualdade mantêm um nível médio-baixo para matemática e médio para português. Deste modo, a tendência mostra que quanto mais baixo o nível de aprendizado, menor é a desigualdade entre os grupos. A única exceção que foge à tendência é a cidade de Teresina, que apresenta nível médio alto para português e médio para matemática. 
Após explorar os dados encontrados no IdeA, seria possível dizer que o IDEB está auxiliando o Estado a implementar políticas desiguais? Partimos a uma análise comparativa entre os números encontrados no IdeA e no IDEB.

\section{ANÁLISE COMPARATIVA E DISCUSSÃO DOS RESULTADOS}

As capitais com maior desigualdade entre grupos no IdeA, também são cidades que apresentaram um aumento acima de 1,0 no IDEB, se comparados os anos de 2007 e 2015 (Florianópolis - 1,1; Belo Horizonte - 1,4; Curitiba - 1,2 e Vitória - 1,4). Aqui, a tendência verificada indica que as capitais que tiveram uma boa evolução no IDEB, igualmente se enquadram entre as que mais evoluíram de maneira desigual.

Já em relação às capitais menos desiguais, duas delas se encontram dentro das que evoluíram menos de 1,0 ponto no IDEB no período analisado (Maceió - 0,8; Aracaju -0,9; Salvador - 1,2; Recife - 1,2; Teresina - 1,9). Contudo, ressalva-se que apesar deste aumento se encontrar mais próximo da realidade social, não se pode dizer que estas capitais obtiveram uma evolução qualitativa plena, pois nenhuma delas se encontra em um estado de igualdade perfeita $(0,0)$.

Nesse âmbito, ao ignorar o fator socioeconômico, os aumentos positivos no IDEB estão, portanto, auxiliando a levar uma análise errônea da situação real do sistema educacional nas capitais brasileiras. Ao fazer isso, o IDEB, sendo um instrumento de comunicação que atua dentro da fase de aplicação das políticas públicas, ao invés de estar trazendo dados que estimulam a criação de políticas mais inclusivas está, por outro lado, auxiliando a apresentar uma falsa ilusão de melhora educacional qualitativa para a população.

Essa aparência de melhora decorre de o IDEB estar inserido dentro de uma lógica empresarial, a qual sua medição, realizada em larga escala, não se preocupa em analisar diversos aspectos que influenciam o ensino dos alunos, dentre eles, o NSE. Como resultado, as políticas educacionais acabam por participar de um procedimento que fomenta o exercício das atividades neoliberais (SANTOS; SANTOS; SILVA, 2019). 
Um exemplo claro desta dinâmica se mostra por meio das metas que são estabelecidas pelo índice a cada dois anos e que geram uma consequência prática: o aumento da competição entre as escolas, que buscam melhorar seu índice, sem muitas vezes observar as necessidades e particularidades de seus alunos. "Nessa lógica, a sala de aula e a escola tornam-se instrumentos para a competição, a eficiência e a eficácia, assemelhando-se às empresas que têm metas para serem cumpridas" (SANTOS; SANTOS; SILVA, 2019, p. 279).

Como o IDEB se configura como orientador de políticas no cenário brasileiro, é possível concluir que um aumento positivo no índice e o atingimento das metas pode estar auxiliando, em muitos casos, a gerar impactos negativos para o exercício saudável do ensino. À vista disso, Silva e Santos (2019) argumentam que as políticas colocadas sob a visão neoliberalista, causam a exclusão, aumentam as desigualdades, além de auxiliarem para que o Estado se desobrigue de seu papel com relação à parcela da população que mais precisa das políticas sociais.

Assim, utilizar um índice que cada vez mais se afasta da realidade, acaba por contribuir para a permanência do planejamento e aplicação de políticas desiguais nas capitais. Nesse contexto, Ruscheinsky (2008) alerta que a constante manutenção da aplicação das desigualdades gera maiores impasses, como: "o mito do progresso e a reposição das desigualdades, os direitos que prometem equidade e as exclusões na trama das relações sociais" (RUSCHEINSKY, 2008, p. 51).

Tendo que a política educacional sofre interferências políticas desde sua elaboração até sua aplicação, Azevedo (2003) considera a escola e a sala de aula como um elo final do sistema, ou seja: "espaços em que se concretizam as definições sobre a política e o planejamento que as sociedades estabelecem para si próprias" (AZEVEDO, 2003, p. 59). Nesse sentido, as permanentes políticas educacionais desiguais acabam por fazer parte de um reflexo do que a própria sociedade estipula, qual seja, um cenário marcado por exclusões.

Ademais, condicionando o equilíbrio social a uma educação de qualidade, é fundamental que sua percepção não seja somente quanto ao acesso ao conhecimento, mas acima de tudo, como essencial para o crescimento do ser humano, de modo a permitir-lhe uma formação cidadã (VIANNA, 2006). Logo, a partir do momento em que se limita a qualidade da 
educação, também se está negando outros direitos, pois a educação, para além do conhecimento, possui a capacidade de atingir a dignidade e o papel do indivíduo como cidadão.

Estabelecida esta relação de correspondência entre o ensino e a sociedade, tem-se que os ensinamentos adquiridos na escola são de vital importância na preparação do aluno para o convívio social. Dessa forma, ao se valer de um índice que perpetua desigualdades para projetar novas políticas educacionais cria-se, como consequência, um perigoso caminho para o avanço da cidadania.

Se não pensarmos na formulação do conceito de conhecimento que deve ser transmitido para os alunos, não alcançaremos esse ser humano que pensa por si, que sabe analisar e compreender o mundo em que vive e decidir frente às diferentes situações cotidianas. (OLIVEIRA et al. p. 155)

Assim, enquanto não houver um aprimoramento do IDEB, de maneira a aproximá-lo mais da realidade, corre-se o risco de o índice não resolver um ponto que necessita urgência de resolução na contemporaneidade, qual seja o alcance da formação de um ser humano com pensamento analítico, de crianças e adolescentes que estejam preparados para lidar com problemas e situações cotidianas.

\section{CONSIDERAÇÕES FINAIS}

A qualidade, vista como atributo do direito a educação, e ponto essencial para uma contribuição saudável entre Estado e sociedade, constitui uma necessidade para um bom exercício da cidadania. Dentro desta visão, o IDEB, como instrumento capaz de influenciar diretamente a grande parte do planejamento e avaliação das políticas educacionais, é munido de falhas.

Uma das imperfeições presentes no índice, qual seja, a ausência de uma análise que abriga o contexto social, deixou claro que dentro do período e locais analisados, os objetivos construídos pelo IDEB se distorcem perante as consequências de sua aplicação prática. Neste contexto, notou-se que uma realidade exclusiva gera efeitos para além da vida dos alunos, 
ou seja, também acarreta a dificuldade de se construir um Estado Social pleno e acessível a todos.

Isso indica que, enquanto não haja um Estado que enxergue de maneira mais detalhada o cenário no qual a política se insere e se atente de maneira singularizada às necessidades de cada instituição de ensino, corre-se o risco de o índice estar fadado a contribuir para a perpetuação de políticas desiguais.

\section{REFERÊNCIAS}

ALMEIDA, Luana Costa; DALBEN, Adilson; FREITAS, Luiz Carlos de. O IDEB: limites e ilusões de uma política educacional. Educ. Soc., Campinas, v. 34, n. 125, p. 1153-1174, dez. 2013. Disponível em: <http://repositorio.unicamp.br/handle/REPOSIP/24560?locale $=$ es $>$. Acesso em 10 fev. 2021.

AZEVEDO, Janete Maria Lins. A Educação como Política Pública. 3. ed. Campinas: Autores Associados, 2004. 75p.

BARUFF, Helder. Direitos fundamentais sociais: Estudos em homenagem aos 60 anos da declaração universal dos direitos humanos e aos 20 anos da Constituição Federal. Dourados, MS: UFGD, 2009. $256 \mathrm{p}$.

BRASIL. Constituição da República Federativa do Brasil de 1988.

Disponível em: <http://www.planalto.gov.br/ccivil_03/constituicao/ constituicao.htm>. Acesso em: 01 fev. 2021.

BRASIL. Lei n. 10.172, de 9 de janeiro de 2001. Aprova o plano Nacional de Educação e dá outras providências. Disponível em: <http://www. planalto.gov.br/ccivil_03/leis/leis_2001/110172.htm>. Acesso em: 17 de mar. 2021.

BRASIL. Lei no 13.005, de 25 de junho de 2014. Aprova o Plano Nacional de Educação - PNE e dá outras providências. Disponível em: <http://www.planalto.gov.br/ccivil_03/_ato2011-2014/2014/lei/ 113005.htm>. Acesso em: 12 fev. 2021. 
FIGUEIREDO,Dalsonetal. Oscavalos tambémcaem: Tratadodasinconsistências do IDEB.Ensaio: aval.pol.públ.Educ., Rio de Janeiro, v. 26, n. 100, p. 552-572, July 2018. Disponívelem: <http://www.scielo.br/scielo.php?script=sci_arttext\&pid=S0104-40362018000300552\&lng=en\&nrm=iso>. Acesso em: 10 fev. 2021.

FONTE, Felipe de Melo. Políticas públicas e direitos fundamentais. São Paulo: Saraiva, 2015.

INDICADOR DE DESIGUALDADES E APRENDIZAGENS. Consulta ao IdeA. Disponível em: <https://portalidea.org.br/ idea/>. Acesso em: 25 jan. 2021.

INEP. Consulta ao IDEB. Disponível em: 〈http://ideb.inep.gov.br/>. Acesso em: 15 jan. 2021.

INEP. Metas do IDEB. Disponível em <https://www.gov.br/inep/pt-br/areas-de-atuacao/pesquisas-estatisticas-e-indicadores/ideb/metas>. Acesso em: 14 jan. 2021.

INEP. Resumo técnico do IDEB. Disponível em: <https://www.gov. br/inep/pt-br/areas-de-atuacao/pesquisas-estatisticas-e-indicadores/ ideb/resultados>. Acesso em 10 fev. 2021.

NASCIMENTO, José Almir do; CURY, Carlos Roberto Jamil. A QUALIDADE DA EDUCAÇÃO NO HORIZONTE DA PROTEÇÃO INTEGRAL INFANTO-ADOLESCENTE. Cad. Pesqui., São Paulo, v. 50, n. 177, p. 679-697, set. 2020. Disponível em: <http://publicacoes.fcc.org.br//index.php/cp/article/view/6873/0>. Acesso em: 10 fev. 2021.

OLIVEIRA, T.; VIANA, A.P.S.; BOVETO, L.; SARACHE, M. V. Escola, conhecimento e formação de pessoas: considerações históricas. Políticas Educativas. Porto Alegre, v. 6, n. 2, p. 145-160, 2013.

RUSCHEINSKY, Aloisio. Desigualdades persistentes, direitos e democracia contemporânea. Ciências Sociais, Unisinos, v. 44, 2008.

SAVIANI, Dermeval. Escola e democracia. Campinas, SP: Autores Associados, 2008. 
SOARES, J. F.; RODRIGUES, E. C.; ERNICA, M. IDeA - Indicador de desigualdades e aprendizagens. Nota técnica. São Paulo: Fundação Tide Setubal, 2019.

SILVA, G. da, Silva, A. V. da, \& Santos, I. M. dos. (2019). O IDEB e as políticas públicas educacionais: estratégias, efeitos e consequências. Revista Exitus, v. 9, n. 1, p. 258-285. https://doi.org/10.24065/ 2237-9460.2019v9n1ID723

SECCHI, Leonardo. Políticas Públicas: conceitos, esquemas de análise, casos práticos. São Paulo: Cengage Learning, 2013. 168p.

VIANNA, Carlos Eduardo Souza Vianna. Janus, lorena, ano 3, n. 4, p. 129-138, 2006. 


\section{PROCESSOS DE}

\section{ACOMPANHAMENTO QUE POTENCIALIZAM APRENDIZAGENS: CASE DE DUAS ESCOLAS DE PORTO ALEGRE}

Fernando Degrandis ${ }^{10}$

\section{INTRODUÇÃO}

Processo normalmente está associado a algo contínuo ou continuado, com direcionamento. $\mathrm{Na}$ área educacional, trabalhamos com tempos que designam decorrência, contrapondo atos isolados, seja um segmento de ensino, como a Educação Infantil, por exemplo, ou ano letivo, ou trimestre. Também referenciamos pessoas e espaços que participam como sujeitos, como os docentes, demais educadores, estudantes e famílias. Desta forma, marca-se que na educação processo indica tanto direcionamento, relação entre ações, sujeitos e tempos.

Em outro momento (DEGRANDIS; MARQUES, 2018), já foram apresentados saberes sistematizados a partir da vivência de processo educativo em uma realidade de escola particular em Porto Alegre. Naquele

\footnotetext{
10 Licenciado em Filosofia pela Unisc; especialista em Coordenação Pedagógica pelo Isei e em Gestão Curricular Marista pela Pucrs; mestre e doutor em Teologia - Religião e educação pela Faculdades Est. Vice-diretor educacional do Colégio Marista Ipanema - Porto Alegre. Educador Maker do AuLab.
} 
momento, havia uma experiência. Na sequência, o autor, que também é gestor educacional, foi convidado pela mesma rede de ensino em que atuava, a assumir a função de vice-diretor educacional em outra unidade. Se na vivência de 2013 a 2016 o foco estava exclusivo nos anos finais do Ensino Fundamental e no Ensino Médio, na experiência seguinte houve uma ampliação para toda a escola de educação básica, da Educação Infantil ao Ensino Médio.

O objetivo deste texto é sistematizar práticas de acompanhamento a educadores e estudantes e analisar como este acompanhamento impacta nos resultados educacionais das instituições em questão. Como metodologia, será utilizado a sistematização de práticas e o diálogo destas vivências com referências.

Ao longo do texto, serão apresentados conceitos dos documentos instituições da rede de ensino em questão, o contexto das escolas, e o diálogo destes com referências de outras práticas educacionais.

\section{POR DENTRO DO CONTEXTO}

$\mathrm{O}$ autor e o gestor se confundem e se complementam, tanto neste texto, como na vivência cotidiana. O olhar técnico, de aprofundamento conceitual e de sistematização tem ajudado muito no redimensionamento das ações. Ao mesmo tempo, os principais desafios enfrentados na escola tornam-se objetos de estudo, que, sistematizados, são apresentados em forma de aprendizagens.

As escolas em questão são da mesma rede de ensino particular, ambas situadas em Porto Alegre. Há entre elas elementos comuns e outros que as diferenciam. Destaque para as especificidades são o tempo de sua existência: enquanto uma delas completa 70 anos de história em 2021, a outra completou 14 anos; aquela nos últimos anos possui em torno de 800 a 900 estudantes, já a escola mais jovem cresceu em mais de 200 matrículas nos últimos dois anos, ultrapassando os 1.200 estudantes no total. A escola mais antiga está situada em uma região da cidade de pouco crescimento populacional e estagnada quanto aos investimentos comerciais; a outra está em uma região de crescimento nos dois aspectos.

Pedagogicamente, as duas escolas no início desses processos passavam por um momento delicado. A escola mais antiga, em 2013, teve 52 repro- 
vações ao final daquele ano letivo, só considerando os anos finais do Ensino Fundamental e o Ensino Médio. Já esta não era uma dificuldade da outra escola. Contudo, ambas as instituições possuíam dois aspectos em comum: a alta rotatividade docente e os baixos resultados em avaliações externas. Sem conseguir permanecer com os professores no grupo por longo período, as escolas não conseguiam pensar em processos formativos substanciais, nem com os docentes e, consequentemente, nem com os discentes. Havia, claramente, uma falta de continuidade.

Sobre a aprendizagem, esta rede de ensino compreende que

Trata-se de um percurso orientado e inteligível, alicerçado em intencionalidades e critérios definidos, por meio dos quais se devem produzir dinâmicas próprias que auxiliem o estudante a conferir significados aos acontecimentos, experiências e fenômenos com que se depara cotidianamente e a se reconhecer como protagonista na internalização e (re)construção dos saberes. (UNIÃO MARISTA DO BRASIL, 2010, p. 58).

Havia, assim, um desafio de abordar o processo de aprendizagem com estudantes e com educadores de uma forma contínua, processual e que de fato fosse efetiva.

Em meio à vivência do autor-gestor, a rede de colégios possuía um projeto estratégico (no período 2012-2022) chamado "Reestruturação curricular". Este projeto, grosso modo, previa que todas as escolas implementassem as Matrizes Curriculares do Brasil Marista. As Matrizes, com sua primeira versão em 2012, fez a troca epistemológica e pedagógica do currículo por conteúdos para o currículo por habilidades e competências. Para a dinamização deste currículo, optou-se pelas metodologias de Sequências Didáticas e Projetos Interdisciplinares.

A reestruturação curricular em si já indicava um desafio: ressignificar práticas de ensino e a própria função do professor no ambiente escolar. Considerando que o corpo docente não havia sido preparado para tal em sua formação inicial, era preciso reaprender à dinâmica educativa na perspectiva do ensino e da aprendizagem por habilidades e competências. Aliado a esta questão, as duas escolas citadas possuíam resultados internos e externos frágeis, que indicavam necessidade de ressignificação. 
É mister destacar alguns dos objetivos das matrizes curriculares em questão:

6. orientar a formação continuada de professores, gestores e colaboradores da educação básica para o desenvolvimento de competências políticas, pastorais e pedagógicas necessárias à implementação e aprimoramento das Matrizes Curriculares;

7. qualificar a prática educativa, a gestão da aula, as situações de ensino e de aprendizagem e os processos de avaliação pedagógica, com base em referenciais teórico-metodológicos definidos como opções institucionais;

8. estabelecer referenciais estratégicos para planejar, significar, concretizar, monitorar e avaliar o currículo, que garantam a função social da escola e a missão educativo-evangelizadora da instituição marista. (UNIÃO MARISTA DO BRASIL, 2019, p. 14).

Destaca-se nestes três objetivos das matrizes curriculares o olhar para o docente, seja na sua formação continuada, seja em sua prática, de gestão de sala de aula e planejamento. Mesmo se tratando de três objetivos, sem contar os outros cinco não citados, o professor e equipe gestora é a mesma. Ou seja, não há como abordar estes elementos (formação continuada, planejamento e gestão de sala de aula) de forma separada, e sim se compreende a necessidade de ser de uma maneira integrada e orgânica.

\section{OS AVANÇOS CONQUISTADOS}

Chevallard (2013), no debate da transposição didática, afirma que não basta termos o conteúdo em si, é necessário também saber como ensiná-lo. O autor, ao fazer este debate, está pensando em especial no ensino da matemática e na relação docente-discente. O que levaria a pensar em um outro lugar na escola: quem ensina o professor a ensinar?

Sobre esta questão, vale refletir alguns aspectos. O primeiro deles é um dilema trazido pelo Chevallard (2013): ter o conhecimento em si não garante que se possa ensiná-lo. Cada conjunto de saberes exige uma dinâmica própria para ensiná-los. Há uma grande preocupação, na maior par- 
te das universidades, de preparar os futuros profissionais, capacitando-os com os conteúdos, mas pouco com o ensino do conteúdo.

Outro aspecto relevante é que a escola precisa/precisou ressignificar seu papel. Seja pelo momento social em que vivemos, seja pela constante atualização pedagógica, ou por força de lei. Em nível de Brasil, por exemplo, temos a Base nacional Comum Curricular (BNCC) aprovada em 2017. Já a rede de ensino a qual as duas escolas citadas fazem parte atualizaram seu currículo com o documento das Matrizes Curriculares em 2012. O que estes exemplos - BNCC e matrizes - têm em comum? A proposta de desenvolver competências.

[...] competência é definida como a mobilização de conhecimentos (conceitos e procedimentos), habilidades (práticas, cognitivas e socioemocionais), atitudes e valores para resolver demandas complexas da vida cotidiana, do pleno exercício da cidadania e do mundo do trabalho. (BRASIL, 2017, p. 8).

A perspectiva da escola que deixa de ensinar a memorizar e passa a desenvolver sujeitos competentes é muito diferente. Mesmo se considerarmos o documento curricular mais antigo que referenciamos, as Matrizes Curriculares do Brasil Marista, ele data de 2012. Uma recente história na educação. Em se supondo que todos os cursos de licenciatura tenham se adaptado integralmente e com excelência após estes marcos - o que em si é um desafio - há que se observar que a maioria dos docentes que hoje atuam tiveram sua formação inicial antes disso. Ou seja, poucos professores estão capacitados para ocupar este "novo" lugar na escola, do desenvolvimento de competências. O questionamento de quem ensina o professor a ensinar é mais pertinente do que nunca.

Após o processo desenvolvido na primeira escola entre 2013 e 2016, foram sistematizadas algumas práticas, em especial de formação docente e a atuação com demais setores. Estas boas práticas serão destacadas a seguir. Outros elementos apresentados por Degrandis e Marques (2018) também impactaram positivamente na outra escola, e dialogam com os aspectos que serão abordados. Contudo, considerando as ações de ambas as escolas, a formação docente e o diálogo entre os setores foram/são protagonistas em ambos os contextos. 


\subsection{CAMINHANDO EM TRILHAS JÁ TRAÇADAS}

A atenção especial para a formação continuada dos docentes foi/é uma marca desta ação, em ambas as escolas.

Com a garantia de que o grupo docente seria formado por pessoas abertas, qualificadas e identificadas com um fazer pedagógico diferenciado, fazia-se necessário ofertar espaços de formação continuada para que fossem dados passos na implementação curricular. A formação foi, assim, pensada em três frentes: formações coletivas, trocas entre os pares e acompanhamento personalizado. Em todas as frentes, considerou-se, concomitantemente, a autoformação. (DEGRANDIS; MARQUES, 2018, p. 123).

As perspectivas - individual, coletiva, entre os pares e autoformação garantem um processo a partir de vários vieses. Um deles, possivelmente o principal, é que a formação não ocorre em um único sentido, sempre da coordenação pedagógica ou equipe diretiva para com o professor. Há, sim, alinhamentos de grande grupo nos quais a equipe diretiva precisa orientar e garantir uma unidade de ação e direcionamento estratégico para a escola. Contudo, o grupo de professores participa disso e se envolve, tanto com ideias, como na contribuição ativa de se formar ou formar o outro.

Alinhamento estratégico garantido nos momentos comuns, existem necessidades de aprofundamento que são específicas da área do conhecimento ou da idade na qual atuam, e que são restritas a determinados grupos. Nestes, tanto há contribuições externas à instituição para com o grupo, como a própria entreajuda dos pares fortalece e capacita.

Há ainda aquilo que é muito específico de um docente, seja pela sua área, perfil de discente com quem atua, ou mesmo da caminhada pessoal e desenvolvimento. Se de todo o grupo, por exemplo, dois não conseguem fazer uma boa gestão de sala de aula, essas turmas terão dificuldade em sua aprendizagem, bem como os professores terão problema em sua autoestima e desenvolvimento profissional. Como não é, no exemplo, uma dificuldade de todos, mas de uns poucos, há que se atuar de maneira personalizada, tanto por indicação de textos, cursos, feedbacks, observações de aulas de forma dialogada, acompanhamento de planejamento etc. 
Ao ignorar um limite, por se tratar de um ou dois professores, perde-se a oportunidade de empoderar a todos e de atuar no aprimoramento das aprendizagens. A autoformação, incentivada pela equipe diretiva, deve ser celebrada e valorizada. Mas não cabe aos dirigentes da instituição coordenar este processo.

Estratégias como a organização prévia das reuniões pedagógicas em momentos de grande grupo, momentos coletivos por pares e seminários de boas práticas garantem a dinamicidade desses movimentos formativos. Também há uma organização na qual é realizado um feedback por semestre com cada professor. Caso algum docente apresente uma necessidade específica, estes diálogos são mais constantes.

Percebendo a escola como um grande organismo vivo e conectado, houve cada vez mais a promoção da participação de outros sujeitos para o diálogo e articulação sobre as aprendizagens. "Para além da dinâmica dos próprios professores dentro do horário semanal, havia um envolvimento grande de outros setores. Aqui merecem destaque o Núcleo de Apoio Pedagógico (NAP), a Biblioteca e a Tecnologia Educacional." (DEGRANDIS; MARQUES, 2018, p. 130).

O NAP referenciado acima é um projeto com estagiários remunerados de licenciatura que estão em sala de aula, dando suporte ao professor e que também possui alguns horários no turno inverso para auxiliar os estudantes que permanecem com dificuldades específicas para se organizar e estudar.

A partir da compreensão de que a aula/aprendizagem não se dá somente na sala de aula física, começou-se a ter a dimensão de que, se em todos os lugares se aprende, todos os ambientes e pessoas do espaço escolar precisam ser capacitadas e estar predispostas a se envolver na aprendizagem. Nas duas escolas em questão, a atuação dos estagiários, da equipe da biblioteca e setor de tecnologias educacionais foi/é um grande diferencial. Em especial pelo motivo das ações levarem a um mesmo sentido, terem um mesmo direcionamento. Os planejamentos e os objetivos das ações eram/são compartilhados, o que proporciona valorização do trabalho do outro e também entreajuda e trocas para aprimoramento.

Nota-se que o olhar personalizado para as necessidades, seja do docente ou do estudante está presente. As diretrizes institucionais precisam ser claras e ditas em diálogos francos com todo o grupo, seja de estudantes 
ou de professores. Contudo, há sempre alguns que não acompanham a dinâmica, ou mesmo têm dificuldade, seja de planejar e executar uma boa aula, no caso do docente, seja de alcançar resultados satisfatórios, no caso discente. Para isto serve este olhar particularizado, para que cada pessoa tenha a oportunidade de avançar.

Ao citar o alcance de metas, vale também destacar que esta atenção não se restringe ao olhar acadêmico. Pode ser que a fragilidade seja de organizar seus materiais, de conviver com colegas, de chegar no horário ou mesmo cumprir prazos. O acompanhamento nestes casos é partilhado com colegas de outros setores, como Orientação Educacional, Coordenação de Turno e Coordenação de Pastoral. Mas vale ressaltar que em todos os vieses, a perspectiva é de auxiliar os sujeitos a se desenvolverem.

Cruz e Loureiro (2020) trazem elementos da experiência do município de Sobral-CE, a qual, a partir de toda uma ação coletiva a rede municipal de ensino, viu seus resultados partirem de um dos piores do Brasil para o melhor IDEB (Índice de Desenvolvimento da Educação Básica) nos anos iniciais e nos anos finais do Ensino Fundamental, em menos de 20 anos. Na jornada de Sobral, os autores destacam a formação continuada, o esforço político e olhar a partir de dados. O olhar para dados e a atuação coletiva vamos poder relacionar com as escolas de Porto Alegre nos próximos parágrafos.

\subsection{DANDO NOVOS PASSOS}

$\mathrm{Na}$ sequência, serão apresentados aspectos que foram sistematizados na experiência da segunda escola, com início em 2016. Tais elementos estiveram presentes na outra instituição, mas compuseram junto com o que foi apresentado acima. Na segunda experiência, ganharam maior dimensão na medida em que o trabalho foi sendo aprimorado.

A atuação com de dados é um destes diferenciais. Também se pode observar a importância desta perspectiva na experiência de Sobral:

As avaliações continuadas do nível de aprendizado dos alunos, realizadas por meio de provas escritas e orais, sustentaram a estratégia pedagógica que visava a garantir que todos os estudantes adquirissem fluência leitora. As avaliações padronizadas de aprendizado re- 
presentam a base das estratégias educacionais adotadas em nível de município, escola e aluno. Aproximadamente um terço do tempo e dos esforços da Secretaria de Educação em Sobral são dedicados à avaliação do aprendizado dos alunos, bem como a ações relacionadas a tais avaliações. As atividades incluem a elaboração e aplicação dos exames e, mais importante, a análise dos resultados e o feedback às escolas. (CRUZ; LOUREIRO, 2020, p. 18).

No caso das escolas gaúchas referenciadas, há uma grande quantidade de dados disponíveis, alguns organizados pela coordenação da rede de escolas, outra pela própria unidade. Dentre as possibilidades de resultados educacionais, pode-se citar atendimentos disciplinares, número de faltas, rendimento acadêmico em cada avaliação interna em todos os componentes curriculares, avaliações de larga escala promovida pela rede de ensino, microdados do Exame Nacional do Ensino Médio (Enem), pesquisa de satisfação das famílias, dentre outros.

A diversidade de análises oportuniza olhar os processos educacionais de cada nível de ensino, seja na perspectiva docente, ou na condução de processos por parte das coordenações; também, com o viés do estudante, família e dos colaboradores da escola; e ainda no olhar para o todo ou de forma personalizada, para cada sujeito.

Os dados coletivos oportunizam identificar onde estão as maiores fragilidades. Após esta identificação, é importante definir ou revisar as estratégias da instituição para este aspecto. Ao mesmo tempo, o detalhamento facilita pensar as realidades específicas, seja de pequenos grupos, ou mesmo de cada pessoa.

A análise dos dados possibilita identificar quais são as prioridades da instituição. Esta definição, em primeira instância, precisa ser comunicada claramente aos envolvidos, e, na medida do possível, ser discutida com os mesmos, envolvendo-os na solução. A gestão da instituição tem neste caso não só a função de coordenar as ações pontuais para a solução dos problemas identificados, mas também envolver toda a comunidade para que a ação seja coletiva. O risco de as ações serem solitárias, mesmo que bem fundamentadas e planejadas, é que encontrem resistência ou concorrência interna, seja com outras pessoas ou mesmo com outros processos. Se não está claro qual é, ou quais são as prioridades, cada pessoa ou setor pode 
criar a sua própria lista de urgências e não necessariamente uma ação irá beneficiar a ação da outra equipe, nem mesmo ganhar um corpo coerente.

Isso não significa que todas as pessoas e departamentos precisem estar envolvidos fazendo a mesma coisa. Longe disso! A intenção é que as ações estejam em sintonia e convirjam para o mesmo lugar. Este princípio é outro que pode-se notar na experiência de Sobral:

Os resultados alcançados por Sobral derivam de sua capacidade de convergir todo o sistema educacional para a aprendizagem e da decisão de manter a política partidária longe das escolas. O sucesso da reforma educacional de Sobral não deriva de uma solução milagrosa, mas sim de um conjunto de ações estruturadas que se reforçam mutuamente, com o objetivo de garantir que todos os alunos da rede municipal concluam a educação básica na idade certa e com aprendizado adequado. (CRUZ; LOUREIRO, 2020, p. 13).

A atuação coletiva diz respeito a planos de ação bem elaborados e claros, bem como a uma cultura institucional colaborativa e do bem comum. Nesta perspectiva, cada setor e cada sujeito também se compromete com o todo e tem a dimensão de que sua ação faz parte de um todo e que o impacta, seja de forma positiva, caso em harmonia e bem-feita, ou negativa, em caso de omissão ou falta de excelência.

Aqui, se destaca a importância dos momentos de formação continuada sejam de forma coletiva, onde se pode reforçar as grandes estratégias. Da mesma forma, os diálogos individualizados podem garantir este olhar convergente, convidando cada sujeito a contribuir com os combinados.

\section{CONSIDERAÇÕES FINAIS}

Os tempos de cada uma das escolas (a primeira com Anos Finais e Ensino Médio de 2013 a 2016 e a segunda da Educação Infantil ao Ensino Médio de 2017 ao período atual) coincidiram com a presença do autor deste texto como gestor dos processos. Contudo, mais do que a atuação de um profissional de forma isolada o que este trabalho apresenta são procedimentos contínuos organizados que efetivamente geraram resultados. 
Na instituição onde a atuação estava voltada para os Anos Finais e o Ensino Médio, um dos principais resultados foi a redução do número de

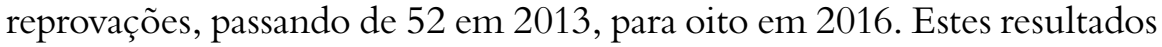
internos estiveram concomitantemente ocorrendo com resultados externos significativos, o que demonstra que não ocorreu uma mudança simplória no critério de avaliação para retenção ou promoção de estudantes, mas que estiveram alicerçados na promoção de aprendizagens.

O resultado do Índice de Qualidade da Aprendizagem (IQA) do Sima [Sistema Marista de Avaliação] (em 2013, nos Anos Finais, o resultado foi 2,2 e no Ensino Médio, 2,7; em 2016, nos Anos Finais, o resultado foi 5,1 e no Ensino Médio, 2,8). Pela primeira vez ambos os segmentos avaliados obtiveram resultados acima dos apresentados em escolas similares. (Degrandis e Marques, 2018, p. 132)

Há uma melhora significativa nestes resultados externos e que merecem ser celebrados. É inegável ainda perceber que há espaço para aprimoramento de processos que continuem gerando mais resultados. Estes indicadores foram apresentados no Prêmio Sinepe de Educação 2016, no qual a instituição foi premiada como projeto ouro na gestão pedagógica.

$\mathrm{Na}$ outra instituição de ensino, o número de reprovações se manteve baixo, de forma estável. Já os resultados de avaliações externas teve crescimento considerável. Utilizando-se dos mesmos dados da outra escola, o IQA do Sima dos Anos Iniciais foi de 6,1 em 2016 para 6,8 em 2019; dos Anos Finais foi de 4,7 para 5,5 no mesmo período; e do Ensino Médio de 2,4 para 3,7 ao longo destes anos. O Sima descontinuou a partir do ano de 2020 .

Nesta escola, os resultados do Exame Nacional do Ensino Médio tiveram grande avanço. Enquanto em 2016 a escola ocupava o 3311임 luar no ranking em nível Brasil, em 2019 já estava na $1241^{\text {a }}$ posição nacional. Até a data de fechamento do texto não havia sido divulgado o ranking nacional elaborado por veículos de comunicação com os resultados do Enem 2020.

Mesmo que não se tenham os dados de avaliações externas pós-2019 para fazer o comparativo, há de se considerar que desde março de 2020 a 
sociedade brasileira, incluindo as escolas, teve sua rotina afetada pela pandemia do coronavírus. Vale ressaltar, no entanto, que mesmo com as aulas remotas na maior parte do tempo, ou em grupos alternados em alguns meses, os processos listados acima tiveram continuidade, como a formação e acompanhamento docente, integração e diálogo entre os setores e o olhar personalizado para os sujeitos.

Planejamento com direcionamento; orientações claras; formação continuada coerente com as estratégias escolhidas; envolvimento dos públicos; análise dos dados coletivos e individuais de docentes e discentes. Esses elementos alimentam um mesmo círculo de gestão de processos.

\section{REFERÊNCIAS}

BRASIL. Ministério da Educação. Base Nacional Comum Curricular. Brasília, 2018.

CHEVALLARD, Yves. Sobre a teoria da transposição didática: algumas considerações introdutórias. In: Revista de Educação, Ciências e Matemática. Rio de Janeiro: Unigranrio, 2013.

CRUZ, Louisee; LOUREIRO, André. Alcançando um Nível de Educação de Excelência em Condições Socioeconômicas Adversas: O Caso de Sobral. In: Disponível em <http://documents1.worldbank.org/curated/en/778741594193637332/pdf/Achieving-World-Class-Education-in-Adverse-Socioeconomic-Conditions-The-Case-of-Sobral-in-Brazil.pdf>. Acesso em 22 abr. 2021.

DEGRANDIS, Fernando; MARQUES, Cíntia Bueno. Inovação curricular: um desafio possível. In: Educação Por Escrito. Porto Alegre: Pucrs, 2018.

UNIÃO MARISTA DO BRASIL. Projeto Educativo do Brasil Marista: nosso jeito de conceber a educação básica. Brasília: Umbrasil, 2010 .

UNIÃO MARISTA DO BRASIL. Matrizes curriculares de educação básica do Brasil Marista: área de linguagens, códigos e suas tecnologias. 3. ed. Curitiba: PUCPRess, 2019. 


\section{PARECER DOCENTE SOBRE A EDUCAÇÃO INCLUSIVA DE ALUNOS NECESSITADOS ESPECIAIS (NEE) NAS ESCOLAS DO ENSINO INFANTIL E FUNDAMENTAL}

Kleber Lima de Souza ${ }^{11}$

Loana Patrícia Lopes Souto ${ }^{12}$

Odvan Pereira de Gois ${ }^{13}$

Marcos Antônio Medeiros do Nascimento ${ }^{14}$

\section{INTRODUÇÃO}

A educação ministrada nas escolas brasileiras tem entendido e defendido a necessidade de inclusão dos alunos especiais na aprendizagem educacional, levando em conta que esses alunos são detentores de capacidades cognitivas, e portando, não impedidos de participar de atividades e ações desempenhadas nas escolas e em extensão na própria sociedade. Cabe aos

11 Centro Universitário de Patos - UNIFIP, Patos-PB.

12 Centro Universitário de Patos - UNIFIP, Patos-PB.

13 Centro Universitário de Patos - UNIFIP, Patos-PB; Faculdades de Integração do Sertão FIS - Serra Talhada-PE.

14 Centro Universitário de Patos - UNIFIP, Patos-PB; Faculdades de Integração do Sertão - FIS - Serra Talhada-PE; LABIMH - Laboratório de Universidade Federal do Rio de Janeiro - UFRJ. 
docentes a percepção de cada um desses alunos, de forma individualizada, a fim de compreender a melhor ação educacional que se acomoda a eles, contudo, aplicando as atividades, no máximo possível, comum a todos ao discorrer que muitas vezes esperamos exemplos que a particularidade de cada um nos mostrou servirão como um norte no dia a dia (DE ABREU et al., 2017). Corrobora o entendimento de que o conceito de inclusão sugere o desenvolvimento de processos e práticas que procuram proporcionar aos alunos com dificuldades uma educação tão comum quanto possível, evitando a sua segregação (TEIXEIRA et al., 2019)

A inclusão tenta garantir aos alunos com Necessidades Educacionais Especiais (NEE) uma educação de qualidade no ensino regular. Esse tema tem sido muito discutido nos últimos tempos, trazendo à tona o respeito ao tempo de aprendizagem de cada aluno, reconhecimento do seu potencial de forma a promover sua aprendizagem, utilizando-se da sala como ponto primordial para o desenvolvimento das atividades na escola (DE BASTOS NASCIMENTO; VALENTIM, 2020).

A inclusão não é fácil, mas não deve haver obstáculos no acesso às fases do ensino e séries da educação escolar. A inclusão de alunos com NEE nas escolas brasileira é assegurada pela Lei de Diretrizes e Bases da Educação Nacional no 9394/96 (BRASIL, 1996), bem como a capacitação dos educadores para obterem êxodo na Educação inclusiva, a fim de reduzir a exclusão e proporcionar um ensino de qualidade a todos (SILVA; CARVALHO, 2017).

Estudos comprovam que ainda é insatisfatório o número de escolas e profissionais da educação no processo NEE, o que ocorre devido à falta de compromisso de alguns gestores em investimentos e liberação de recursos para formação e qualificação dos professores para atender a esses alunos. O trabalho ora desenvolvido teve por objetivo tratar do conhecimento que detêm os professores do ensino fundamental de Patos, Paraíba, sobre o processo de inclusão dos alunos com necessidades educacionais especiais (NEE), apontando possíveis carências estruturais e de capacitação dos docentes (COUTO et al., 2018).

É imprescindível a compreensão de que esse processo é cercado de desafios objetivos e subjetivos. Através do desenvolvimento da pesquisa é possível coletar subsídios que venham a favorecer uma melhor compreensão sobre o processo de inclusão, como esse vem sendo implantado e quais 
as dificuldades que vem enfrentando, com o requisito de colaborar para uma melhor efetivação das políticas públicas educacionais.

A inclusão não é uma coisa de agora, ela já vem sendo discutida e sido amplamente projetada desde os anos oitenta, sempre buscando o respeito, influenciando para que todo cidadão absorvam a causa dos que possuem Necessidades Especiais, mobilizando e construindo uma bandeira de luta (MEDEIROS; BARRERA, 2018).

A discussão sobre os que possuem necessidades especiais tem promovido grandes debates nos três poderes constituídos e na sociedade civil, com o intuito de que haja um entendimento e que se faça cumprir o que hoje a lei garante a todos os que possuem necessidades especiais (AZEVEDO; MORGADO; DA SILVA, 2019). Hoje temos a Lei no 9.394 de 20 de dezembro, que garante a todos o direito e o acesso escolar em todos os seus níveis, destinando recursos e para as escolas e capacitando professores do ensino fundamental ao superior para que possam acolher educar e praticar a tão justa e difícil inclusão nas escolas (SILVA; CARVALHO, 2017).

Este estudo teve como objetivo realizar pesquisa para obter um parecer docente sobre a educação inclusiva de alunos necessitados especiais (NEE) nas escolas do ensino infantil e fundamental.

\section{METODOLOGIA}

Trata-se de pesquisa aplicada com abordagem quantitativa, com uma população de docentes do ensino fundamental das escolas estaduais de Patos-PB. A amostra foi composta por 110 docentes. Foram incluídos na pesquisa os docentes do ensino infantil e fundamental das escolas municipais, estaduais e particulares, tendo como critério de exclusão professores que não fossem do quadro efetivo da escola. A coleta de dados foi realizada através de um questionário semiestruturado com 18 perguntas construído pelo pesquisador, capaz de coletar informações suficientes para responder ao objetivo proposto.

Devido à pandemia da Covid 19, a coleta de dados foi realizada através da plataforma do Google Forms, enviado para os professores das escolas através de Plataformas virtuais, e-mails, redes sociais como o WhatsApp. A análise dos dados foi realizada por meio do programa Microsoft Excel 
for Windows e utilizados os procedimentos da estatística descritiva (porcentagem).

Os estudos foram aprovados pelo Comitê de Ética em Pesquisa do Centro Universitário - UNIFIP com os números dos pareceres 3.712,407, CAAE: 24724819.8.0000.5181, e 3.713,737, CAAE: 24472819.5.0000.5181, com data de aprovação em 19 de novembro de 2019.

\section{RESULTADOS}

Sendo uma entrevista realizada através de um questionário semiestruturado onde as variáveis das respostas eram talvez, regular, bom, muito bom e ótimo, foi necessário fracionar o questionário pela necessidade de tabular a porcentagem e de uma melhor compreensão.

$\mathrm{Na}$ tabela 1, apresentamos as respostas que obtiveram menor porcentagem, ou seja, com as respostas "talvez" e "regular". 
Tabela 1: Índice de MENOR (Talvez e Regular) percepção sobre a educação inclusiva dos docentes do ensino infantil

\begin{tabular}{|c|c|c|c|}
\hline Questões & Talvez & Regular & Percentual \\
\hline $\begin{array}{l}\text { 1. Tenho conhecimento suficiente para } \\
\text { atingir as necessidades educacionais de alunos } \\
\text { com deficiência. }\end{array}$ & 1 & 15 & $35,5 \%$ \\
\hline $\begin{array}{l}\text { 2. Com os conhecimentos que possuo, me } \\
\text { sinto preparado para trabalhar com alunos } \\
\text { com deficiência. }\end{array}$ & 2 & 17 & $42,2 \%$ \\
\hline $\begin{array}{l}\text { 3. Sou ou serei capaz de resolver ou controlar } \\
\text { os problemas de comportamento dos alunos } \\
\text { com deficiência. }\end{array}$ & 12 & 11 & $50,1 \% \star$ \\
\hline $\begin{array}{l}\text { 4. Sou ou serei capaz de remediar os déficits } \\
\text { de aprendizagem do aluno com deficiência. }\end{array}$ & 13 & 15 & $57,9 \%$ \\
\hline $\begin{array}{l}\text { 5. Gosto ou gostaria de ter alunos com } \\
\text { deficiência em minha aula. }\end{array}$ & 4 & 7 & $24,5 \%$ \\
\hline $\begin{array}{l}\text { 6. Já participei de cursos e palestras para } \\
\text { aumentar meus conhecimentos sobre } \\
\text { os métodos de ensino para alunos com } \\
\text { deficiência. }\end{array}$ & 2 & 10 & $26,6 \%$ \\
\hline $\begin{array}{l}\text { 7. Avalio ou avaliarei os meus alunos com } \\
\text { deficiência com os mesmos procedimentos } \\
\text { utilizados para os alunos sem deficiência. }\end{array}$ & 24 & 10 & $75,5 \% \star$ \\
\hline $\begin{array}{l}\text { 8. Sou ou serei capaz de cumprir o programa } \\
\text { de ensino proposto mesmo com a presença de } \\
\text { alunos com deficiência. }\end{array}$ & 4 & 6 & $22,2 \%$ \\
\hline $\begin{array}{l}\text { 9. Consigo ou conseguirei motivar o aluno } \\
\text { com deficiência da mesma forma que aquele } \\
\text { sem deficiência. }\end{array}$ & 7 & 6 & $28,9 \%$ \\
\hline $\begin{array}{l}\text { 10. A forma de tratamento do aluno com } \\
\text { deficiência em minha aula é diferenciada. }\end{array}$ & 7 & 5 & $26,7 \%$ \\
\hline $\begin{array}{l}\text { 11. Os alunos com deficiência vão se } \\
\text { beneficiar da interação oferecida por um } \\
\text { programa em uma classe regular }\end{array}$ & 4 & 2 & $13,3 \%$ \\
\hline $\begin{array}{c}\text { 12. Os alunos sem deficiência irão se } \\
\text { beneficiar com a inclusão de colegas com } \\
\text { deficiência nas aulas regulares. }\end{array}$ & 4 & 4 & $17,8 \%$ \\
\hline $\begin{array}{l}\text { 13. Os alunos com deficiência são aceitos } \\
\text { socialmente por seus colegas sem deficiência. }\end{array}$ & 4 & 10 & $31,1 \%$ \\
\hline
\end{tabular}




\begin{tabular}{|c|c|c|c|}
\hline $\begin{array}{c}\text { 14. Os alunos com deficiência são } \\
\text { humilhados por seus colegas sem deficiência } \\
\text { na aula regular. }\end{array}$ & 22 & 11 & $73,3 \%$ \\
\hline $\begin{array}{c}\text { 15. Existem materiais instrucionais suficientes } \\
\text { para que eu ensine os alunos com deficiência. }\end{array}$ & 5 & 22 & $60,0 \%$ \\
\hline $\begin{array}{c}\text { 16. São oferecidos pela escola todos os } \\
\text { serviços de suporte suficientes para que eu } \\
\text { ensine alunos com deficiência (médico, } \\
\text { psicólogo, fonoaudiólogo, auxiliares }\end{array}$ & 12 & 16 & $62,3 \% \star$ \\
\hline $\begin{array}{c}\text { 17. Tenho recursos suficientes da escola para } \\
\text { adquirir os materiais necessários para planejar } \\
\text { as aulas e trabalhar com os alunos com } \\
\text { deficiência. }\end{array}$ & 9 & 10 & $42,2 \%$ \\
\hline $\begin{array}{c}\text { 18. As instalações da escola em que trabalho } \\
\text { permite acessibilidade. }\end{array}$ & 4 & 3 & $15,6 \%$ \\
\hline
\end{tabular}

Fonte: Dados de Pesquisa (2019).

$\mathrm{Na}$ tabela 2, as respostas que obtiveram maior porcentagem, ou seja, com as respostas bom, muito bom e ótimo.

Tabela 2: Índice de MAIOR (Bom, Muito Bom e Ótimo) percepção sobre a educação inclusiva dos docentes do ensino infantil

\begin{tabular}{|c|c|c|c|c|}
\hline Questões & Bom & $\begin{array}{c}\text { Muito } \\
\text { bom }\end{array}$ & Ótimo & Percentual \\
\hline $\begin{array}{c}\text { 1. Tenho conhecimento suficiente para } \\
\text { atingir as necessidades educacionais de } \\
\text { alunos com deficiência. }\end{array}$ & 16 & 11 & 2 & $64,4 \% \star$ \\
\hline $\begin{array}{c}\text { 2. Com os conhecimentos que possuo, me } \\
\text { sinto preparado para trabalhar com alunos } \\
\text { com deficiência. }\end{array}$ & 19 & 3 & 4 & $57,8 \% \star$ \\
\hline $\begin{array}{c}\text { 3. Sou ou serei capaz de resolver ou } \\
\text { controlar os problemas de comportamento } \\
\text { dos alunos com deficiência. }\end{array}$ & 15 & 5 & 2 & $48,8 \%$ \\
\hline $\begin{array}{c}\text { 4. Sou ou serei capaz de remediar os } \\
\text { déficits de aprendizagem do aluno com } \\
\text { deficiência. }\end{array}$ & 13 & 2 & 2 & $42,1 \%$ \\
\hline $\begin{array}{c}\text { 5. Gosto ou gostaria de ter alunos com } \\
\text { deficiência em minha aula. }\end{array}$ & 16 & 8 & 10 & $75,6 \% \star$ \\
\hline
\end{tabular}




\begin{tabular}{|c|c|c|c|c|}
\hline $\begin{array}{l}\text { 6. Já participei de cursos e palestras para } \\
\text { aumentar meus conhecimentos sobre } \\
\text { os métodos de ensino para alunos com } \\
\text { deficiência. }\end{array}$ & 2 & 10 & 21 & $73,4 \%$ * \\
\hline $\begin{array}{l}\text { 7. Avalio ou avaliarei os meus alunos com } \\
\text { deficiência com os mesmos procedimentos } \\
\text { utilizados para os alunos sem deficiência. }\end{array}$ & 5 & 6 & 0 & $24,5 \%$ \\
\hline $\begin{array}{c}\text { 8. Sou ou serei capaz de cumprir o } \\
\text { programa de ensino proposto mesmo com } \\
\text { a presença de alunos com deficiência. }\end{array}$ & 16 & 10 & 9 & $77,8 \%$ * \\
\hline $\begin{array}{l}\text { 9. Consigo ou conseguirei motivar o } \\
\text { aluno com deficiência da mesma forma } \\
\text { que aquele sem deficiência. }\end{array}$ & 15 & 8 & 9 & $71,1 \%$ * \\
\hline $\begin{array}{l}\text { 10. A forma de tratamento do aluno com } \\
\text { deficiência em minha aula é diferenciada. }\end{array}$ & 15 & 4 & 14 & $73,3 \% \star$ \\
\hline $\begin{array}{l}\text { 11. Os alunos com deficiência vão se } \\
\text { beneficiar da interação oferecida por um } \\
\text { programa em uma classe regular }\end{array}$ & 14 & 12 & 13 & $86,7 \%$ * \\
\hline $\begin{array}{l}\text { 12. Os alunos sem deficiência irão se } \\
\text { beneficiar com a inclusão de colegas com } \\
\text { deficiência nas aulas regulares. }\end{array}$ & 10 & 10 & 17 & $82,2 \%$ * \\
\hline $\begin{array}{l}\text { 13. Os alunos com deficiência são } \\
\text { aceitos socialmente por seus colegas sem } \\
\text { deficiência. }\end{array}$ & 14 & 7 & 10 & $68,9 \%$ * \\
\hline $\begin{array}{l}\text { 14. Os alunos com deficiência são } \\
\text { humilhados por seus colegas sem } \\
\text { deficiência na aula regular. }\end{array}$ & 4 & 2 & 6 & $26,7 \%$ \\
\hline $\begin{array}{c}\text { 15. Existem materiais instrucionais } \\
\text { suficientes para que eu ensine os alunos } \\
\text { com deficiência. }\end{array}$ & 10 & 6 & 2 & $39,9 \%$ \\
\hline $\begin{array}{l}\text { 16. São oferecidos pela escola todos os } \\
\text { serviços de suporte suficientes para que eu } \\
\text { ensine alunos com deficiência (médico, } \\
\text { psicólogo, fonoaudiólogo, auxiliares }\end{array}$ & 8 & 5 & 4 & $37,8 \%$ \\
\hline $\begin{array}{c}\text { 17. Tenho recursos suficientes da escola } \\
\text { para adquirir os materiais necessários para } \\
\text { planejar as aulas e trabalhar com os alunos } \\
\text { com deficiência. }\end{array}$ & 11 & 9 & 6 & $57,7 \%$ * \\
\hline $\begin{array}{l}\text { 18. As instalações da escola em que } \\
\text { trabalho permite acessibilidade. }\end{array}$ & 8 & 10 & 20 & $84,4 \%$ * \\
\hline
\end{tabular}


Na tabela 3, é possível observar as respostas individualizadas por variável, por questionamentos, considerando que as opções (talvez e regular não contemplam com positividade, ou seja, não são satisfatórias para o objeto do estudo, sendo consideradas ideais as opções bom, muito bom e excelente.

Tabela 3: Índice de MENOR (Talvez e Regular) e MAIOR (Bom, Muito bom e Excelente) percepções sobre a educação inclusiva dos docentes do ensino fundamental

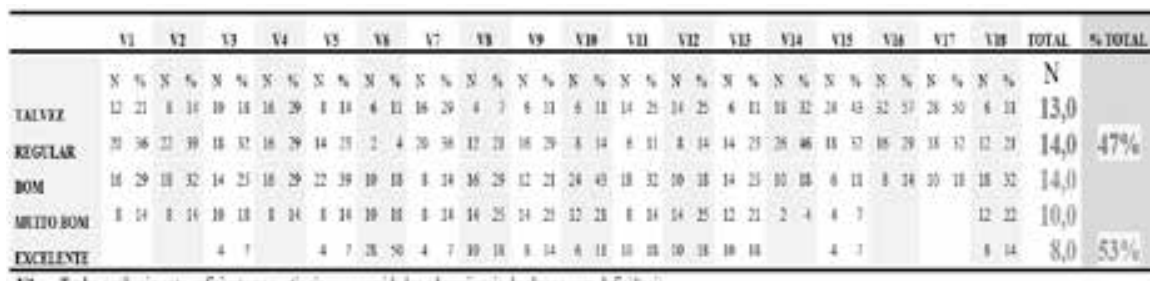

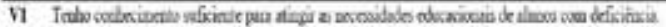

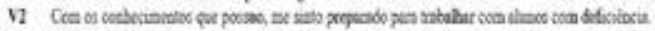

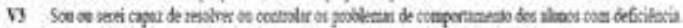

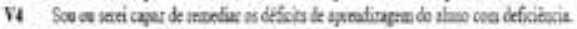

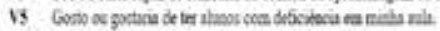

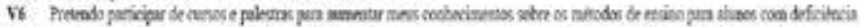

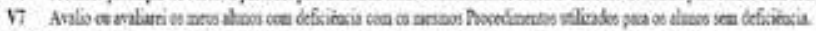

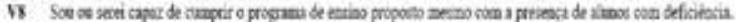

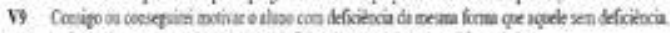

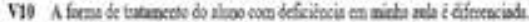

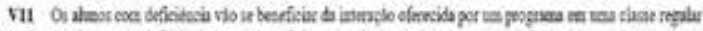

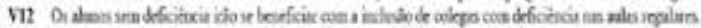

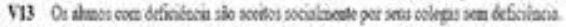

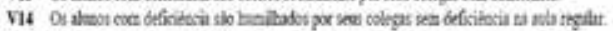

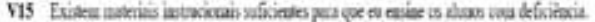

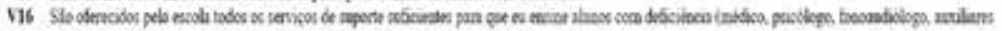

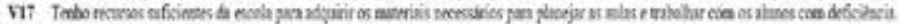

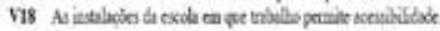

Fonte: Dados de Pesquisa (2019).

Quando computadas as variáveis consideradas acima da média, tais como bom, muito bom e excelente, encontra-se uma porcentagem de $53 \%$, conforme a tabela 4 .

Tabela 4: Respostas das variáveis do questionário semiestruturado sobre educação inclusiva dos docentes do ensino fundamental das escolas públicas estaduais

\begin{tabular}{lc}
\hline VARIÁVEIS & PORCENTAGEM \\
\hline TALVEZ & $22 \%$ \\
REGULAR & $25 \%$ \\
\hline BOM & $47 \% *$ \\
MUTTO BOM & 23,0 \\
EXCELENTE & 16,0 \\
& 14,0 \\
\hline Fonte: Dados de Pesquis & $(2016$ \\
\hline
\end{tabular}


Observando o que estabelecem as respostas e transferidas para o gráfico 1 as variáveis do questionário, constata-se que 63,1\% reúnem boa percepção sobre educação inclusiva do ensino infantil.

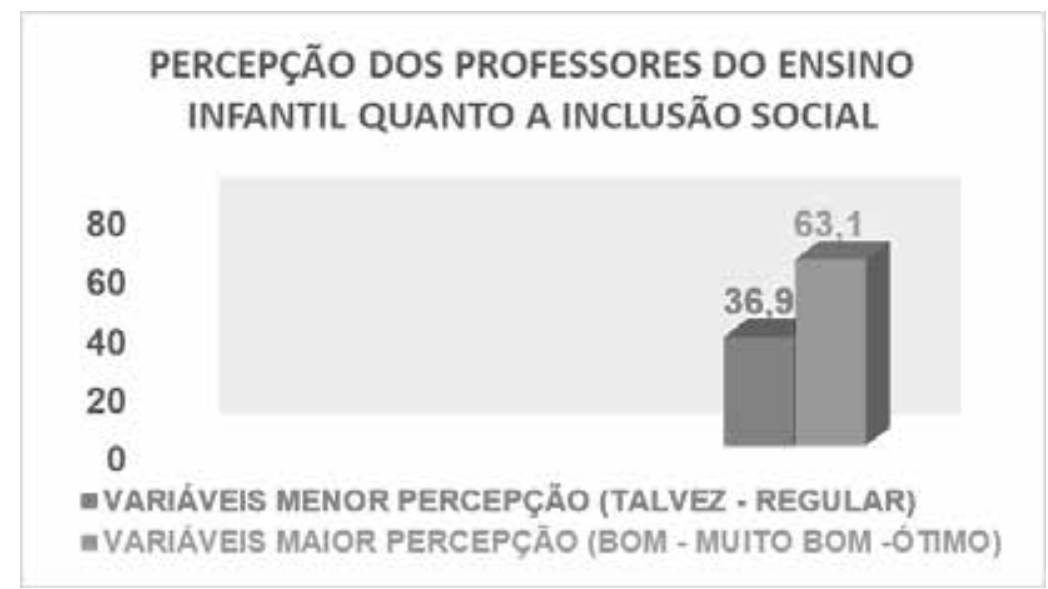

Gráfico 1: Índices gerais sobre a percepção sobre a educação inclusiva dos docentes do ensino infantil

Analisando o gráfico 2, as respostas das variáveis do questionário, constata-se que 53\% reúnem boa percepção sobre educação inclusiva do ensino fundamental.

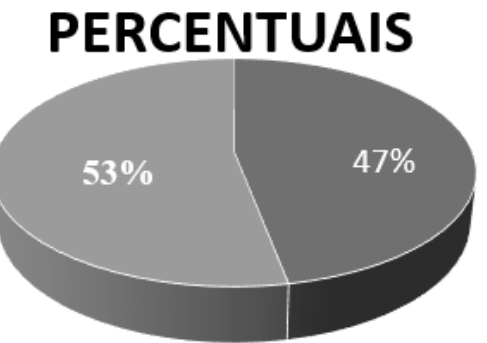

- TALVEZ / REGULAR

- BOM / MUITO BOM / EXCELENTE

Gráfico 2: Resultado das Variáveis do questionário semiestruturado sobre educação inclusiva dos docentes do ensino fundamental. 


\section{DISCUSSÃO}

A inclusão é um assunto bastante discutido atualmente; por isso, se vez necessário analisar qual a percepção dos docentes sobre educação inclusiva. Neste sentido, destaca-se a importância inclusão de alunos com deficiência na sociedade e no sistema regular de ensino, bem como conhecer as estratégias didáticas utilizadas para promover a participação e o relacionamento interpessoal desses alunos com seus colegas sem deficiência. que as políticas públicas exercem sobre a qualidade da educação adaptada, (SALLES; ARAÚJO; FERNANDES, 2015). Um olhar amplo sobre a educação inclusiva e a grande necessidade de adaptações para a efetivação deste processo aponta também a importância da presença de profissionais especializados para dar suporte aos professores, seja para confecção e adaptação dos recursos e estratégias, como para conhecer a deficiência e necessidades pessoais de cada aluno (SILVA; CARVALHO, 2017).

No âmbito escolar, observa-se que para se obter uma educação e ensino de qualidade, são necessários respaldo e valorização através de uma formação adequada aos profissionais da educação. A preparação desses profissionais para as práticas educativas é um processo que já vem sendo bastante discutido pelos órgãos públicos responsáveis. No entanto, pelo fato de o processo de inclusão ter se tornado obrigatório em todas as instituições de ensino, é imprescindível que nos apropriemos dessa temática, a fim de proporcionarmos uma educação de qualidade para todos. (FATTORI; DOS ANJOS, 2020).

Os resultados sinalizam a percepção da inclusão escolar nas perspectivas dos seus vários significados, dos aspectos legais e pedagógicos. Também se pode depreender a necessidade de capacitação dos professores que contribuam para sua qualificação no âmbito epistemológico, pedagógico e metodológico (MENEZES et al., 2016).

Destaca-se o desconhecimento dos professores sobre a política de inclusão e sobre as capacidades e limitações do aluno no que tange a deficiência e interesses pessoais, a falta de recursos oferecidos pelo poder público para efetivação de suas ações, e a falta de profissionais especializados na área de educação especial para o suporte aos professores (SILVA; CARVALHO, 2017). 


\section{CONCLUSÃO}

A partir de nossas reflexões durante a pesquisa, buscaram-se informações que contribuam para nosso conhecimento sobre a preparação de professores, visando ao processo de inclusão nas escolas, de forma a contemplar toda a diversidade de alunos inseridos na escola de ensino regular. Acredita que assim é possível incluir todos, sabendo que, no instante em que a escola se mobiliza a esse favor, há êxito e a aprendizagem ocorre de forma ampla, favorecendo a todos. O aluno comprometido nesse processo deverá ser socializado aos outros colegas, interagindo de modo que se sinta capacitada e incluído ao meio. Tal iniciativa acarretará redução da discriminação perante a comunidade escolar e, consequentemente, na sociedade.

A concepção dos professores deixa clara a falta de preparo / de sua formação, do ambiente escolar e dos recursos necessários para efetivação das propostas do Plano Nacional como a acessibilidade, espaço físico e recursos financeiros e participação da família no processo de ensino-aprendizagem dos alunos

$\mathrm{Na}$ análise dos dados a partir dos resultados, identifica-se que as concepções dos professores a respeito da inclusão escolar denotam relevante contradição entre as proposições teóricas, idealizadas da inclusão escolar e a realidade em sala de aula. Os professores apresentaram concepções claras, concisas e reais sobre a inclusão escolar, pois ao mesmo tempo em que consideram relevante e veem de maneira positiva a inclusão, sentem-se despreparados, alguns descrentes e outros desafiados. O contraste das políticas inclusivas nacionais com a realidade da escola é bastante significativa, o que revela a fragilidade das políticas existentes.

Tal perspectiva deverá contribuir para que haja formação dos professores, tornando-os aptos no atendimento dessa demanda, acarretando uma experiência maravilhosa, tanto profissional como pessoal. Portanto, entendemos que seja possível proporcionar uma educação com qualidade para todos, desde que a escola e os envolvidos nesse meio possam ter a oportunidade de serem preparados, antes e durante o processo de inclusão, para que os alunos incluídos fiquem livres de discriminações e preconceitos, pois a aprendizagem se dá através de interações entre professores e alunos tendo como base a comunicação. É fundamental e indispensável que ocorra a aproximação e aprendizagem dos conhecimentos de forma 
significativa. E assim, finalizamos nosso trabalho acreditando ter auxiliado na reflexão acerca dessa nova realidade de inclusão, deixando claro nosso objetivo, que não se finaliza nessa ou em qualquer discussão, pois ainda muito se faz necessário, mas sim, chamar a atenção para o processo de organização e adaptação necessária para a inclusão, levando em consideração o espaço e as pessoas que estão envolvidas.

\section{REFERÊNCIAS}

AZEVEDO, S. S.; MORGADO, E. M. G.; DA SILVA, L. L. F. Tecnologia e Sociedade. Políticas públicas e Inclusão como Prática Pedagógica no Brasil. Revista Internacional de Ciências, Tecnologia e Sociedade, v. 2, n. 1, p. 34-53, mar 2019.

COUTO, Mabel Rocha et al. Novas formas de intensificação do trabalho docente: um estudo sobre a implementação de políticas de regulação do trabalho do professor no ensino profissional. 2018.

DE ABREU, Fernanda Beatriz Pereira et al. Metodologias ativas: tecnologias assistivas com um novo olhar para a inclusão. Ciência AtualRevista Científica Multidisciplinar do Centro Universitário São José, v. 9, n. 1, 2017.

DE BASTOS NASCIMENTO, Simone Maria; VALENTIM, Bernadete de Fatima Bastos. Formação docente para promover a inclusão de alunos com necessidades educacionais especiais na Educação Infantil: Desafios aos cursos de Pedagogia. Série Educar-Volume 45 Educação Especial e Inclusiva, p. 56.

MEDEIROS, A. P.; BARRERA, S. D. Inclusão escolar: concepções de professores e práticas educativas. Psicologia em Revista, v. 24, n. 1, p. 191-208,2018.

MENEZES, A. L. et al. Percepções de professores da educação básica acerca do conceito de inclusão. Quaestio, v. 36, n. 1, p. 1-13,2016.

SALLES, W. DAS N.; ARAÚJO, D.; FERNANDES, L. L. Inclusão De Alunos Com Deficiência $\mathrm{Na}$ Escola : Inclusion of Students With Disabilities in School: Perception of Physical Education Teachers 
Escuela : Percepción De Profesores De Educación. Revista da Faculdade de Educação Física da UNICAMP, v. 13, n. 4, p. 1-21, 2015.

SILVA, N. C.; CARVALHO. Compreendendo o processo de inclusão escolar no Brasil na perspectiva dos professores: uma revisão integrativa. Rev. bras. educ. especial, v. 23, n. 2, p. 293-308, 2017.

TEIXEIRA, Jeisabelly Adrianne Lima et al. Inclusão de alunos com necessidades especiais nas aulas de educação física: um relato de experiência. Revista Interdisciplinar, v. 12, n. 1, p. 95-102, 2019. 


\section{ALFABETIZAÇÃO CIENTÍFICA E TECNOLÓGICA: POSSIBILIDADES NO ENSINO DA EDUCAÇÃO BÁSICA}

Lesly Diana Pimentel Yong ${ }^{15}$

Hendy Barbosa Santos ${ }^{16}$

\section{INTRODUÇÃO}

Este artigo apresenta uma reflexão sobre a importância de promover a alfabetização científica e tecnológica (ACT) na aprendizagem dos alunos nos processos formais e não formais de ensino. $\mathrm{O}$ aluno precisa compreender a ciência e os impactos que as tecnologias possibilitam no mundo em que vivemos, por isso é relevante promover a alfabetização científica e tecnológica.

Lorenzetti e Delizoicov (2001, p. 48) destacam que a “[...] alfabetização científica é um processo que tornará o indivíduo alfabetizado cientificamente nos assuntos que envolvem a Ciência e a Tecnologia, ultrapassando a mera reprodução de conceitos científicos, destituídos de significados, de sentidos e de aplicabilidade". A alfabetização científica e tecnológica pode ser promovida por meio de experiências concretas, desenvolvendo a curiosidade e criatividade do aluno.

15 Graduada em Letras/ Português/Espanhol, Mestranda em Ensino.

16 Graduado em Letras Português/ Inglês, Graduado em Artes Visuais, especialista em Língua Portuguesa e História da Arte. Mestrando em Ensino. 
Vale ressaltar que, no espaço escolar, é necessário que o professor saiba como trabalhar com temáticas que façam com que o aluno possa compreender essa relação de ciência e tecnologia e por que é importante saber essa relação. Para isso, é necessário que o professor utilize diversos espaços formais e não formais para que se promova a alfabetização científica e tecnológica do aluno. Nesse sentido, existem várias abordagens que podem ser utilizadas para alcançar esse objetivo. No artigo, apresentamos a abordagem Ciência-Tecnologia-Sociedade (CTS), que são currículos que têm "[...] como objetivo central preparar os alunos para o exercício da cidadania e caracterizam-se por uma abordagem dos conteúdos científicos no seu contexto social" (SANTOS; MORTIMER, 2002, p. 110). No decorrer do texto, apresentamos um diálogo com autores que destacam como pode ser trabalhada essa abordagem no espaço escolar e por que é importante utilizá-la no processo de ensino e aprendizagem, tendo em vista que promover a alfabetização científica e tecnológica é essencial para que o aluno possa se tornar um cidadão crítico e pesquisador.

A construção deste trabalho foi realizada por meio de uma revisão de literatura de autores que abordam a temática de alfabetização científica e tecnológica e a abordagem CTS, como Bourscheid e Farias (2014), Chassot (2003), Lorenzetti e Delizoicov (2001), Marques e Marandino (2018), Sasseron e Carvalho (2011), Santos e Mortimer (2002), Vaz, Fagundes e Pinheiro (2009), entre outros. Vale ressaltar que a leitura e análise dos textos selecionados nesta revisão contribuíram para a realização deste texto reflexivo, que trata de temáticas na área da educação que, pela importância, precisam ser enfatizadas.

\section{PROMOVENDO A ALFABETIZAÇÃO CIENTÍFICA E TECNOLÓGICA EM VÁRIOS ESPAÇOS}

Muitos estudos têm surgido abordando a relevância de promover a alfabetização científica e tecnológica no processo de ensino e aprendizagem nos diferentes níveis da educação básica. Nesse sentido, Dutra, Oliveira e Del Pino (2017, p. 58) destacam que essa alfabetização “[...] representa um conjunto de conhecimentos científicos e tecnológicos que facilitariam aos homens e mulheres fazer uma leitura do mundo onde vivem, para assim compreendê-lo e transformá-lo [...]." Nesse viés, podemos entender que 
a alfabetização científica e tecnológica é um processo em que construímos conhecimentos científicos e tecnológicos para compreender o que está ao nosso redor.

Em relação à educação, promover a alfabetização científica e tecnológica é muito importante para a formação cidadã do aluno. Sasseron e Carvalho (2011, p. 61) mencionam que, por meio da alfabetização científica, pode-se

[...] planejar um ensino que permita aos alunos interagir com uma nova cultura, com uma nova forma de ver o mundo e seus acontecimentos, podendo modificá-los e a si próprio através da prática consciente propiciada por sua interação cerceada de saberes de noções e conhecimentos científicos, bem como das habilidades associadas ao fazer científico.

Em consonância com as autoras, acredita-se que, quando os alunos começam a construir novos saberes, relacionando-os com os acontecimentos do mundo, começam a desenvolver sua alfabetização científica e tecnológica. Nessa perspectiva, Dutra, Oliveira e Del Pino (2017, p. 57) salientam que

[...] ser alfabetizado cientificamente não significa dominar todo o conhecimento científico, pois nem os cientistas dominam todas as áreas. Ser alfabetizado em ciências significa ter o conhecimento necessário para avaliar os avanços das ciências e das tecnologias e suas implicações na sociedade.

O aluno precisa compreender a ciência e os impactos que as tecnologias possibilitam no mundo em que vivemos, para que se tornem cidadãos críticos. Além disso, Milaré e Filho (2010, p. 109) também enfatizam que uma pessoa alfabetizada científica e tecnologicamente tem que ser "[...] capaz de argumentar, negociar e dialogar com outros indivíduos, de enfrentar situações diversas e concretas de maneira racional, além de saber conduzir a relação entre saber-fazer e poder-fazer".

A alfabetização científica e tecnológica pode ser desenvolvida em diferentes níveis de ensino da educação básica. Em relação às crianças do ensino fundamental, a alfabetização científica e tecnológica " [...] se cons- 
tituem num aliado para que o aluno possa ler e compreender o seu universo" (LORENZETTI; DELIZOICOV, 2001, p. 52). Nesse viés, Marques e Marandino (2018, p. 11) também apontam que,

Para a criança pequena, estar em processo de AC não implica necessariamente apropriar-se de termos e conceitos científicos, ainda que isso possa ocorrer. Estar em contato com o conhecimento científico por meio de uma visita ao zoológico ou a uma exposição, cuidando de pequenos animais na escola, observando o caminho da formiga que carrega uma folha e visualizando representações do corpo humano em uma enciclopédia já significa vivenciar o processo de AC, aproximando-se de elementos da cultura científica.

Como foi mencionado pelas autoras, as crianças, em diversos espaços formais e informais, também aprendem e estão propícias a construir sua alfabetização científica em diversas situações reais. Em relação à aprendizagem na instituição escolar, Lorenzetti e Delizoicov (2001) também argumentam que os professores podem trabalhar a alfabetização científica por meio de vídeos, documentários, excursões, aulas práticas, entre outros.

Vale ressaltar que, além dos espaços formais, como as instituições escolares, a alfabetização científica e tecnológica também pode ser trabalhada por meio de uma educação não formal (ENF). Marques e Marandino (2018, p. 13) salientam que a educação não formal "[...] é uma prática sociocultural intencional de aprendizagem e de produção de saberes, não vinculada ao sistema educacional regrado e que ocorre em diferentes espaços sociais".

Nesses espaços, as crianças podem aprender de forma descontraída e lúdica, como explicam Marques e Marandino (2018, p. 10) “Construir propostas integradoras, pautadas na brincadeira e na interação, é condição necessária à promoção de processos de $\mathrm{AC}$ que, de fato, tomem a criança como sujeito, e não como objeto.”

Ainda em relação aos espaços não formais, Jacobucci (2008, p. 56-57) menciona duas categorias para esses espaços, uma são os institucionais, onde há equipe técnica para assessorar os visitantes. Os exemplos são os "Museus, Centros de Ciências, Parques Ecológicos, Parques Zoobotânicos, Jardins Botânicos, Planetários, Institutos de Pesquisa, Aquários, 
Zoológicos, dentre outros". Esses locais são espaços que as crianças podem frequentar com os pais e familiares e que podem possibilitar diversas aprendizagens sobre ciências e tecnologias.

Além disso, Jacobucci (2008) também destaca uma outra categoria de ENF, que são os locais não institucionais, definidos como

[...] ambientes naturais ou urbanos que não dispõem de estruturação institucional, mas onde é possível adotar práticas educativas, englobam a categoria Não-Instituições. Nessa categoria podem ser incluídos teatro, parque, casa, rua, praça, terreno, cinema, praia, caverna, rio, lagoa, campo de futebol, dentre outros inúmeros espaços (JACOBUCCI, 2008, p. 57).

Como foi possível perceber, há diversos espaços não formais onde as crianças podem construir seu conhecimento científico com a interação dos adultos nesse processo de alfabetização científica e tecnológica. Vale ressaltar que, além do ensino fundamental, é essencial que a alfabetização científica também seja trabalhada no ensino médio. Nesse processo, é importante que os professores possam ensinar aos alunos temáticas em que possam relacionar a ciência e as tecnologias por meio da investigação em situações reais.

É importante ressaltar que o ensino de ciências não pode ser mais ensinado de forma mecânica e conteudista, como era ensinado há muitos anos. De acordo com Chassot (2003, p. 90), nos anos de 1980 e começo de 1990 ,

Não se escondia o quanto a transmissão (massiva) de conteúdos era o que importava. Um dos índices de eficiência de um professor ou de um transmissor de conteúdo - era a quantidade de páginas repassadas aos estudantes - os receptores. Era preciso que os alunos se tornassem familiarizados (aqui, familiarizar poderia até significar simplesmente saber de cor) com as teorias, com os conceitos e com os processos científicos. Um estudante competente era aquele que sabia, isto é, que era depositário de conhecimentos.

Como o autor menciona, não podemos mais ensinar os alunos a memorizar teorias ou conceitos científicos, é necessário que os alunos se 
tornem pesquisadores e participantes no processo de sua aprendizagem. Nessa perspectiva, Sasserom e Carvalho (2011, p. 66) também destacam que "[...] o ensino de Ciências pode e deve partir de atividades problematizadoras, cujas temáticas sejam capazes de relacionar e conciliar diferentes áreas e esferas da vida de todos nós [...]”. Dessa forma, é importante que o professor utilize em espaços formais e não formais diferentes metodologias de ensino para que os alunos possam desenvolver sua alfabetização científica e tecnológica de forma crítica e autônoma no processo de sua aprendizagem.

Ainda em relação ao ensino de ciências, Dutra, Oliveira e Del Pino (2017, p. 59) também mencionam a relevância de se desenvolver a alfabetização científica a partir do que os alunos já conhecem:

Nos dias atuais é difícil conceber propostas de ensino de ciências sem os aspectos sociais e pessoais dos estudantes, ou seja, no processo ensino aprendizagem é importante considerar os saberes populares, desenvolvendo assim uma alfabetização científica a partir do mundo que é conhecido pelos alunos e cidadãos. Considerando esse ensino a partir de novas perspectivas, surge a necessidade de reavaliar o ensino de ciências, atualmente desenvolvido na escola. Transcender este modelo de ensino é uma exigência para a escola na contemporaneidade.

Vivemos em uma época em que não há mais espaço para antigas práticas tradicionalistas, nas quais o professor era o centro do processo de ensino e detentor do saber, sendo necessário mudar esse cenário. Com a evolução da ciência e das tecnologias, é relevante que o professor se torne um mediador no processo de ensino, incentivando os alunos ao processo da pesquisa. Por meio da investigação, o professor pode propiciar a curiosidade, o desenvolvimento da argumentação e do conhecimento científico do aluno, promovendo assim sua alfabetização científica e tecnológica.

Em relação ao ensino de ciências, um movimento que se tem estudado muito é o enfoque Ciência-Tecnologia-Sociedade (CTS). A abordagem CTS teve origem em vários países, como Estados Unidos, Inglaterra e países europeus que criaram políticas no ensino de ciência e no desenvolvimento do ensino científico (CRUZ, 2001). Nessa perspectiva, 
Pinheiro, Silveira e Bazzo (2007, p. 74) esclarecem que "[...] Esse movimento tem se manifestado desde 1970, tendo sido base para construir currículos em vários países, em especial os de ciências, dando prioridade a uma alfabetização em ciência e tecnologia interligada ao contexto social”.

Em relação ao currículo com a abordagem CTS, Santos e Mortimer (2000, p. 113) destacam que os trabalhos curriculares nessa abordagem surgiram " $[. .$.$] como decorrência da necessidade de formar o cidadão em$ ciência e tecnologia, o que não vinha sendo alcançado adequadamente pelo ensino convencional de ciências". Com essa nova proposta, muitos países já incluíram em vários níveis de ensino essa abordagem. Na Espanha, por exemplo, o ensino de CTS está presente no currículo, como informa Cerezo (2002 apud PINHEIRO; SILVEIRA; BAZZO, 2007, p. 75-76):

[...] o Ministério de Educação e Cultura espanhol introduziu CTS como disciplina optativa em todos os cursos de graduação para alunos entre 16 e 18 anos (Lei de Ordenamento Geral do Sistema Educacional) e, no ensino secundário, obrigatória como complemento transversal de disciplinas de ciências para alunos entre 14 e 16 anos (Ensino Superior Obrigatório). Isso fez com que vários professores do ensino secundário e universitário buscassem aperfeiçoamento.

Como foi possível perceber, na Espanha, o ensino CTS está em vários níveis de ensino e, com essa inclusão no currículo, foi necessário que os professores tivessem formação para que pudessem também se incluir nesse processo, o que demandou investimento por parte do governo. Santos e Mortimer (2002, p. 126) assinalam que

É preciso compreender, também, o contexto dos países em que as propostas curriculares de CTS foram desenvolvidas. Por se tratar de países desenvolvidos, a estrutura social, a organização política e o desenvolvimento econômico são bastante diferentes daqueles presentes no contexto brasileiro.

No Brasil, essa abordagem começou a ser apresentada em 1990, quando surgiram as primeiras pesquisas de mestrado e doutorado abordando 
sobre a temática (SANTOS, 2008 apud DA ROSA; STRIEDER, 2018, p. 2). Além disso, nessa época, foram realizados também vários eventos e trabalhos relacionados com a ciência-tecnologia e sociedade. Santos e Mortimer (2002, p. 113-114) destacam alguns, como a

Conferência Internacional Ensino de Ciências para o Século XXI: ACT - Alfabetização em Ciência e Tecnologia”, cuja temática central foi a educação científica dos cidadãos. Pode-se considerar, também, que a atual reforma curricular do ensino médio incorpora, em seus objetivos e fundamentos, elementos dos currículos com ênfase em CTS.

$\mathrm{Na}$ área da educação, muitas pesquisas até os dias atuais vêm sendo realizadas destacando essa abordagem como uma estratégia no processo de alfabetização científica e tecnológica. A CTS é uma abordagem importante para ser incluída no currículo das escolas. Como enfatizam Bourscheid e Farias (2014, p. 31),

[...] a CTS é uma proposta pedagógica que desvincula a ideia de ciência neutra, aproxima a realidade ao aluno, trazendo significado para aquilo que é estudado, de modo que os conteúdos e o ensino de conceitos aparecem como via para dar sentido àquilo que é questionado, centrando-se em temas de relevância social.

Por meio da abordagem CTS, podem ser trabalhadas com os alunos temáticas sociais relacionadas com a ciência e as tecnologias para que o aluno possa construir seu conhecimento científico por meio da situação real vivenciada. Nesse sentido, Hofstein, Aikenhead e Riquarts (1988, p. 358 apud SANTOS; MORTIMER, 2002, p. 113) ressaltam que a "CTS pode ser caracterizado como o ensino do conteúdo de ciências no contexto autêntico do seu meio tecnológico e social, no qual os estudantes integram o conhecimento científico com a tecnologia e o mundo social de suas experiências do dia a dia".

Nessa perspectiva, Vaz, Fagundes e Pinheiro (2009, p. 106) também declaram que "[...] o enfoque CTS busca entender os aspectos sociais do desenvolvimento técnico-científico, tanto nos benefícios que esse desen- 
volvimento possa estar trazendo, como também às consequências sociais e ambientais que poderá causar".

Por meio dessa abordagem, tanto o professor como o aluno aprendem no processo de ensino se tornando pesquisadores. Como assinalam Pinheiro, Silveira e Bazzo (2007, p. 77):

Com o enfoque CTS, o trabalho em sala de aula passa a ter outra conotação. A pedagogia não é mais um instrumento de controle do professor sobre o aluno. Professores e alunos passam a descobrir, a pesquisar juntos, a construir e/ou produzir o conhecimento científico, que deixa de ser considerado algo sagrado e inviolável.

Os professores que propiciam o ensino CTS em sala de aula possibilitam aos alunos uma aprendizagem significativa e autônoma, e principalmente promovem a alfabetização científica e tecnológica dos alunos a partir das resoluções de problemas que são trabalhados em sala de aula ou em outro espaço não formal de ensino.

É importante também salientar que, ao trabalhar com essa abordagem, é necessário ter formação inicial ou continuada para saber em que consiste esse movimento e de que forma essa abordagem pode promover a alfabetização científica e tecnológica dos alunos. Nesse viés, Fontes e Silva (2004, apud FONTES; CARDOSO, 2006, p. 16) ponderam:

[...] uma das dificuldades de implementação da abordagem CTS relaciona-se com a pouca aceitação e envolvimento dos professores, uma vez que a sua formação inicial não contempla, de um modo geral, os vários aspectos desta nova abordagem para o ensino das ciências.

Como citado pelas autoras, muitas vezes a falta de formação inicial faz com que muitos professores tenham uma certa resistência para a integração dessa abordagem no currículo, mas é importante mencionar que, mesmo se muitos professores não estudaram na graduação o movimento CTS, é necessário que haja políticas de formação para que seja trabalhada nas escolas a formação continuada reflexiva com essa abordagem. 


\section{CONSIDERAÇÕES FINAIS}

Aqui, evidencia-se que a ACT, além de ser um processo contínuo, tem sua importância para além da sala de aula, ou seja, o aluno precisa aprender a transitar por outros lugares onde a ciência se faz presente e percebê-los como fontes de aprendizagem e pesquisa. Ao longo do texto, foram feitas e apresentadas considerações com várias reflexões sobre a importância de promover a alfabetização científica e tecnológica no processo de aprendizagem do aluno nos processos formais e não formais de ensino. Também mencionamos a abordagem CTS. Esse ensino, como foi mencionado anteriormente, deve estar presente nos níveis de ensino, sendo integrado ao currículo.

Os professores, ao trabalhar a CTS em sala de aula, possibilitam aos alunos uma aprendizagem significativa, incentivando a autonomia e fomentando a pesquisa. Essa abordagem é utilizada em vários países, e no Brasil também está sendo trabalhada, pois nos últimos anos muitos estudos têm surgido abordando a temática.

Por meio deste texto, também foi possível compreender como a abordagem CTS propicia aos alunos um contato maior com o mundo científico através de temáticas de abordagem social no processo de construção do seu conhecimento científico. Através dessa abordagem, tanto o professor como o aluno aprendem no processo de ensino se tornando pesquisadores. Vale ressaltar que oprofessor pode promover a alfabetização científica e tecnológica do aluno de forma que este se torne uma pessoa crítica, reflexiva e autônoma na sua formação cidadã.

Assim, a Alfabetização Científica e Tecnológica faz-se relevante por poder contribuir para que professores e alunos compreendam a importância da prática investigativa e exerçam a função de sujeitos curiosos, autônomos, críticos e responsáveis pela construção do conhecimento, assim contribuindo para uma transformação positiva da sociedade por meio da ciência e da tecnologia, para que, como citado no início deste texto, continuemos aprendendo e descortinando o conhecimento na educação.

\section{REFERÊNCIAS}

BOURSCHEID, Jacinta Lourdes Weler; FARIAS, Maria Eloisa. Revista Thema. A convergência da educação ambiental, Sustentabilida- 
de, Ciência, Tecnologia e Sociedade (CTS) e Ambiente (CTSA) no ensino de ciências. Revista Thema, Pelotas-RS, v. 11, n. 1, 2014. Disponível em: http://periodicos.ifsul.edu.br/index.php/thema/article/view/183/109. Acesso em: 10 jul. 2020.

CHASSOT, Attico. Alfabetização Científica: uma possibilidade para a inclusão social. Revista Brasileira de Educação, n. 22, jan-abr. 2003. Disponível em: https://www.scielo.br/pdf/rbedu/n22/n22a09. Acesso em: 07 jul. 2020.

CRUZ, Sônia Maria Silva Corrêa de Souza. Aprendizagem centrada em eventos: uma experiência com o enfoque ciência, tecnologia e sociedade no ensino fundamental. Tese (Doutorado em Educação) - Universidade Federal de Santa Catarina, Florianópolis, Santa Catarina. 2001. 258 f. Disponível em: https://repositorio.ufsc.br/handle/123456789/81926. Acesso em: 17 ago. 2020.

DA ROSA, Suiane Ewerling; STRIDER, Roseline Beatriz. Dimensões da democratização da Ciência-Tecnologia no âmbito da educação CTS. Revista Insignare Scientia, v. 1, n. 2, maio-ago. 2018. Disponível em: https://periodicos.uffs.edu.br/index.php/RIS/article/ view/8251. Acesso em: 10 jul. 2020.

DUTRA, Gildete Elias; OLIVEIRA, Eniz Conceição; DEL PINO, José Cláudio. Alfabetização Científica e Tecnológica na formação do cidadão. Revista Signos, v. 38, n. 2, 2017. Disponível em: http:// www.univates.br/revistas/index.php/signos/article/view/1375. Acesso em: 17 ago. 2020.

FONTES, Alice; CARDOSO, Alexandra. Formação de professores de acordo com a abordagem Ciência/Tecnologia/Sociedade. Revista Electrónica de ensenãnza de las ciencias, v. 5, n. 1, 2006. Disponível em: http://reec.uvigo.es/volumenes/volumen5/ART2_ Vol5_N1.pdf. Acesso em: 17 ago. 2020.

JACOBUCCI, Daniela Franco Carvalho. Contribuições dos espaços não-formais de educação para a formação da cultura científica. Revista Extensão, Uberlândia, v. 7, 2008. Disponível em:https://pdfs.se- 
manticscholar.org/791a/abac9b61c411df46cdea4a1501c1a32d656a. pdf. Acesso em: 17 ago. 2020.

LORENZETTI, Leonir; DELIZOICOV, Demétrio. Alfabetização científica no contexto das séries iniciais. Revista Ensaio-Pesquisa em Educação em Ciências. v. 3, n. 1, jun. 2001. Disponível em: https://www.scielo.br/pdf/epec/v3n1/1983-2117-epec-3-01-00045. pdf. Acesso em: 07 jul. 2020.

MARQUES, Amanda Cristina Teagno Lopes; MARANDINO, Martha. Alfabetização científica, criança e espaços de educação não formal: diálogos possíveis. Revista Educação e Pesquisa, v. 44, 2018. Disponível em: https://www.scielo.br/scielo.php?pi$\mathrm{d}=\mathrm{S} 1517-97022017005016102 \&$ script $=$ sci_abstract\&tlng=pt. Acesso em: 07 jul. 2020.

MILARÉ, Tathiane; FILHO, José de Pinho Alves. Ciências no nono ano do Ensino Fundamental: da disciplinaridade à alfabetização científica e tecnológica. Revista Ensaio, Belo Horizonte, v. 12, n. 2, 2010. Disponível em: https://www.scielo.br/pdf/epec/v12n2/ 1983-2117-epec-12-02-00101.pdf. Acesso em: 09 jul. 2020.

PINHEIRO, Nilcéia Aparecida Maciel; SILVEIRA, Rosemari Monteiro Castilho Foggiatto; BAZZO, Walter Antônio. Ciência, Tecnologia e Sociedade: a relevância do enfoque CTS para o contexto do ensino médio. Revista Ciência \& Educação, v. 13, n. 1, 2007. Disponível em: https://www.scielo.br/pdf/ciedu/v13n1/v13n1a05.pdf . Acesso em: 10 jul. 2020.

SANTOS, Wildson Luiz Pereira dos; MORTIMER, Eduardo Fleury. Uma análise de pressupostos teóricos da abordagem C-T-S (Ciência-Tecnologia-Sociedade) no contexto da educação brasileira. Revista Ensaio, Belo Horizonte, v. 2, n. 2, jul/dez 2002. Disponível em: https://www.scielo.br/scielo.php?script=sci_arttext\&pi$\mathrm{d}=$ S1983-21172000000200110. Acesso em: 17 ago. 2020.

SASSERON, Lúcia Helena; CARVALHO, Anna Maria Pessoa de. Alfabetização científica: uma revisão bibliográfica. Revista Investigações em Ensino de Ciências, v. 16, n. 1. 2011. Disponível em: https:// 
edisciplinas.usp.br/pluginfile.php/844768/mod_resource/content/1/ SASSERON_CARVALHO_AC_uma_revis\%C3\%A3o_bibliogr\%C3\%A1fica.pdf. Acesso em: 06 jul. 2020.

VAZ, Caroline Rodrigues; FAGUNDES, Alexandre Borges; PINHEIRO, Nilcéia Aparecida Maciel. O surgimento da Ciência, Tecnologia e Sociedade (CTS) na educação: uma revisão. I Simpósio Nacional de Ensino de Ciência e Tecnologia, 2009. Disponível em: https://ensinandoquimica.files.wordpress.com/2013/05/o-surgimento-da-cic3aancia-tecnologia-sociedade-na-educac3a7c3a3o. pdf. Acesso em: 17 ago. 2020 


\title{
OS PROFESSORES E A EDUCAÇÃO PARA O TRÂNSITO NAS ESCOLAS
}

\author{
José Carlos Teixeira Pistilli ${ }^{17}$
}

Fabiana Mabel Azevedo de Oliveira ${ }^{18}$

\section{INTRODUÇÃO}

Nas últimas décadas, o trânsito urbano transformou-se em espaço de violência, de competição, de individualismo, de intolerância que se sobrepõe ao de solidariedade e de humanidade, esgarçando a crise de valores em que vive a sociedade. O processo de barbárie vem se aprofundando nas últimas décadas e tem, nas ruas das nossas cidades, cenário privilegiado de sua manifestação (DAVIS, 1994; CLARCK; ELGELMANN, 1995; VASCONCELLOS, 1998; ZEGEER, 1998). Os atores do trânsito, no desempenho de seus diversos e alternados papéis, transgridem regras, burlam normas de segurança, culpam-se

17 Possui graduação em Engenharia Mecânica pela UFF. Trabalhou em Furnas Centrais Elétricas como engenheiro. Mestrado em Educação pela Universidade Estácio de Sá, Mestrado em Engenharia de Transportes pela UFRJ e Doutorado em Planejamento Urbano pela UFRJ. Atualmente trabalha no Colégio Brigadeiro Newton Braga (CBNB). Tem experiência na área de Educação, com ênfase em Ensino-Aprendizagem.

18 Possui graduação em arquitetura e urbanismo pela Universidade UFRJ, mestrado em arte e tecnologia pela UnB e doutorado em Urbanismo pela UFRJ. Atualmente é pesquisadora LabEspaço na UFRJ e pesquisadora no Colégio Brigadeiro Newton Braga. Tem experiência na área de gestão de projeto onde atuou como vice coordenadora do LabEspaço, também atua como arquitetura e Urbanista, e presta consultoria em tecnologia e educação, com ênfase em cidade, tecnologia, educação e sociedade. 
e desrespeitam-se mutuamente e não assumem suas responsabilidades (BRAGA, 1995). A violência no trânsito, considerada histórica, resulta em sensação de impotência e medo.

Se, por um lado, a modernidade nos disponibiliza recursos tecnológicos sofisticados em prol da segurança no trânsito, por outro lado, carecemos da dimensão educativa voltada para a formação de valores que consiste em ações, a médio e a longo prazos, visando resultados consistentes em direção à civilidade e humanização nas ruas. A educação para o trânsito nas escolas é espaço rico para essa dimensão educativa. $\mathrm{O}$ seu sucesso, assim como de qualquer projeto educativo, depende da dedicação e da integração interdisciplinar dos professores das diversas áreas do saber (FAZENDA, 1991; FAZENDA, 2013; PIAGET, 1973), desde os anos iniciais do ensino básico (fundamental). A decodificação, a interpretação e as discussões a respeito da legislação de trânsito junto aos estudantes têm papel de destaque neste processo educativo. Este, ao estabelecer limites entre direitos e deveres, permite a melhor assimilação do significado das regras de trânsito e da importância em respeitá-las como forma de se assegurar o direito mútuo à vida com dignidade.

A resolução da violência, de todo e qualquer âmbito, está atrelada à dimensão educativa, à qual todas as demais são dependentes (BRAGA; SANTOS, 1995; MIRANDA, 1979; WOLINSKI, 1993). O conhecimento e a obediência às leis de trânsito, o exercício da cidadania e o respeito à vida são alcançados por meio da educação escolar (MARTINS, 2004). A escola é o ambiente ideal e propício à criação de oportunidades para abordagens interdisciplinares de temas fundamentais voltados para a formação da cidadania e para o despertar de sentimentos de humanidade. No período entre a infância e a adolescência, nossos alunos do ensino fundamental vivem processos de transformações rumo à maturidade, motivados pela energia da curiosidade, do encantamento e, sobretudo da receptividade às informações e às atividades que tenham vínculo com suas vidas (ALVES, 1995). Qualquer distanciamento de escolas e de professores das discussões e dos trabalhos sistematizados sobre as violências no trânsito urbano, vivenciadas pelos estudantes, adia essenciais reflexões sobre as possibilidades de se construir uma cidade menos violenta. 
De acordo com a Organização Mundial da Saúde (OMS, 2013), o Brasil ocupa o $4^{\circ}$ lugar em mortes decorrentes do trânsito. Em oposição, encontramos a Suécia que possui um índice de mortes no trânsito muito baixo e está entre os países com trânsito urbano mais seguro. Este país, longe de um simples acaso, implantou o trabalho de educação para o trânsito na pré-escola, para crianças a partir de quatro anos de idade, seguindo todo o processo educativo, inclusive o universitário. Face a esse cenário, buscamos ampliar espaços para discussões dentro das escolas com seus professores sobre a importância da implantação da educação para o trânsito na matriz curricular escolar a partir do ensino fundamental. A educação para o trânsito no ensino fundamental é assegurada tanto pelo artigo 76 do capítulo VI da lei 9503 do Código de Trânsito Brasileiro (BRASIL, 1997), quanto pelo artigo 11 da resolução $n^{\circ} 638$ do Conselho Nacional de Trânsito (BRASIL, 2016).

O presente trabalho aborda a importância de um trânsito seguro em três tópicos estabelecidos na legislação (BRASIL, 2016): 1) a formação da cidadania; 2) o aprendizado de regras de trânsito; e 3) desenvolvimento do respeito à vida e ao meio ambiente. A estes, acrescentamos um quarto tópico referente à análise das estatísticas sobre acidentes no trânsito. Esta abordagem nos auxilia sondar entre os entrevistados os temas que os motivariam a ensinar educação para o trânsito na sua prática profissional.

A motivação para o presente estudo se deve ao fato de que quando a educação para o trânsito conseguir ser implantada nas escolas, teremos como resultado um trânsito mais humanizado e pessoas conscientes da importância da educação e da gentileza no trânsito, desde o período pré-escolar até sua fase adulta (GOMES, 2016).

\section{METODOLOGIA}

O trabalho foi realizado junto a docentes em escolas da rede pública municipal do Rio de Janeiro. Estabelecemos contato com as Coordenadorias Regionais de Educação (CREs) responsáveis pelas unidades escolares envolvidas para obtermos autorização para a realização de entrevistas com os professores. A coleta de dados ocorreu nos intervalos do horário de trabalho no período de março a dezem- 
bro de 2017. Foram realizadas entrevistas semiestruturadas apoiadas em questionário semiaberto, por se tratar de instrumento eficaz em pesquisas qualitativas, facilitando a liberdade de expressão dos entrevistados na exposição de seus pontos de vista (LUDKE; ANDRÉ, 1996). Assim, optamos pelo emprego de questionário que permitisse uma abordagem mista predominantemente qualitativa das respostas dos entrevistados, o qual:

[...] trabalha com o universo de significados, crenças e privilegia valores e atitudes, o que corresponde a um espaço mais profundo das relações, dos processos e dos fenômenos que não podem ser reproduzidos à operacionalização de variáveis. (MINAYO, 1994, p. 21).

Aplicando este questionário a professores do ensino básico, buscamos identificar: 1) A atuação do docente na escola nas áreas de linguagens (português, artes e educação física); de ciências humanas (história e geografia) e de ciências exatas (ciências da natureza e matemática); 2) a escolaridade do docente (graduação; pós-graduação ou mestrado/doutorado); 3) a percepção do entrevistado sobre a importância da educação para o trânsito na escola; 4) a percepção do entrevistado sobre a responsabilidade com a educação para o trânsito que cabe à sua disciplina (matéria) e a sua integração interdisciplinar com as outras; 5) a percepção do entrevistado sobre a importância dos temas: formação da cidadania, aprendizado das regras de trânsito, respeito à vida e ao meio ambiente e análise das estatísticas sobre acidentes no trânsito; 6) a percepção do entrevistado sobre as maiores dificuldades na implantação da educação para o trânsito.

Nas perguntas 3 e 4 do questionário, foram empregadas a escala bipolar linear de diferencial semântico constituída por um segmento de reta de $10 \mathrm{~cm}$ para registro das marcações de 0 a 10 atribuídas pelos entrevistados. Nas questões 5 e 6, os entrevistados atribuíram a cada item apresentado, um valor percentual de $0 \%$ a 100\%. Os entrevistados puderam, ao longo da entrevista, se expressar livremente, por escrito ou verbalmente (Figura 1). 
Figura 1 - Questionário aplicado aos professores do ensino básico

1. Qual disciplina (matéria) você leciona nesta escola?

2. Qual seu nível de escolaridade: graduação, pós-graduação, mestrado/doutorado?

3. Marque sobre a reta de 0 a 10 com um traço vertical a importância da educação para o trânsito na escola. Comente sua resposta.

0

4. Marque sobre a reta de 0 a 10 com um traço vertical a responsabilidade para com o trabalho de educação para o trânsito, no que cabe à sua disciplina (matéria) e a sua integração interdisciplinar, com as outras matérias. Comente sua resposta.

0

5. Marque de $0 \%$ a 100\% a relevância que você atribui a cada tema referente ao trabalho de educação para o trânsito, apresentado abaixo. Comente sua resposta.

(A) formação da cidadania;

(B) aprendizado das regras de trânsito;

(C) respeito à vida e ao meio ambiente;

(D) análise das estatísticas sobre acidentes no trânsito.

6. Marque de 0\% a 100\%, a influência que você atribui a cada fator como dificultador da implantação da educação de trânsito na escola, apresentado abaixo. Comente sua resposta.

(A) não exigência pelas escolas;

(B) inexistência de curso de capacitação de professores e de material didático;

(C) desinteresse dos professores.

\section{RESULTADOS}

As médias das marcações dos entrevistados sobre a reta referente às questões 3 e 4 do questionário, sintetizadas nas tabelas 1 e 2 , respectivamente, dão sinais de que os docentes, de modo geral, percebem a importância da educação para o trânsito nas escolas e a responsabilidade da sua matéria neste processo educativo. Verificamos que essa percepção foi 
maior entre os professores das disciplinas de português/ literatura, matemática e ciências da natureza (tabelas 1 e 2). Nas tabelas 1 e 2, as médias das marcações na reta, levando em consideração o nível de escolaridade, foram maiores entre docentes com graduação e pós-graduação.

Tabela 1 - Percepção da importância da educação para o trânsito

\begin{tabular}{|c|c|c|c|c|c|c|c|}
\hline \multirow{2}{*}{ Escolaridade } & \multicolumn{6}{|c|}{ Áreas } & \\
\cline { 2 - 7 } & \multicolumn{2}{|c|}{ Linguagens } & \multicolumn{2}{|c|}{ humanas } & \multicolumn{2}{|c|}{ exatas } & Tôencias \\
\cline { 2 - 7 } & $\begin{array}{c}\text { português/ } \\
\text { literatura }\end{array}$ & $\begin{array}{c}\text { arte/ } \\
\text { ed. } \\
\text { física }\end{array}$ & história & geografia & $\begin{array}{c}\text { da } \\
\text { natureza }\end{array}$ & matemática & Total \\
\hline graduação & 9,3 & 7,6 & 7,0 & 7,8 & 8,5 & 9,0 & 8,0 \\
\hline $\begin{array}{c}\text { pós- } \\
\text { graduação }\end{array}$ & 9,1 & 7,8 & 7,7 & 8,2 & 8,2 & 9,5 & 8,6 \\
\hline $\begin{array}{c}\text { mestrado/ } \\
\text { doutorado }\end{array}$ & 8,4 & 7,2 & 6,6 & 7,2 & 8,0 & 8,1 & 7,3 \\
\hline Total & 9,1 & 7,5 & 6,9 & 7,8 & 8,3 & 9,0 & \\
\hline
\end{tabular}

Tabela 2 - Percepção da responsabilidade da matéria (e sua integração interdisciplinar)

\begin{tabular}{|c|c|c|c|c|c|c|c|}
\hline \multirow[b]{3}{*}{ Escolaridade } & \multicolumn{7}{|c|}{ Áreas } \\
\hline & \multicolumn{2}{|c|}{ Linguagens } & \multicolumn{2}{|c|}{ humanas } & \multicolumn{2}{|c|}{ Exatas } & \multirow[b]{2}{*}{ tota } \\
\hline & $\begin{array}{c}\text { português/ } \\
\text { literatura }\end{array}$ & $\begin{array}{l}\text { arte/ } \\
\text { ed. } \\
\text { física }\end{array}$ & história & geografia & $\begin{array}{c}\text { ciências } \\
\text { da } \\
\text { natureza }\end{array}$ & matemática & \\
\hline graduação & 7,7 & 8,0 & 7,2 & 7,6 & 9,4 & 8,5 & 8,6 \\
\hline $\begin{array}{c}\text { pós- } \\
\text { graduação }\end{array}$ & 8,2 & 7,6 & 6,9 & 7,5 & 8,8 & 8,6 & 8,0 \\
\hline $\begin{array}{l}\text { mestrado/ } \\
\text { doutorado }\end{array}$ & 7,8 & 7,0 & 6,5 & 7,0 & 7,9 & 8,1 & 7,3 \\
\hline Total & 8,0 & 7,6 & 6,8 & 7,4 & 8,8 & 8,5 & \\
\hline
\end{tabular}

As médias dos percentuais totais atribuídos pelos entrevistados aos tópicos a eles apresentados, de modo geral, apontaram para um interesse menor pelo tópico aprendizado das regras de trânsito entre os professores das áreas exatas. No entanto, com relação ao tópico análise das estatísticas sobre acidentes de trânsito, estes mesmos professores foram os que mais o valorizaram. O tópico formação da cidadania obteve maior relevância entre os professores da área de humanas e de linguagens. Quanto ao tópico 
respeito à vida e ao meio ambiente, este foi unanimidade entre os professores de todas as áreas (tabela 3).

Tabela 3 - Registro da porcentagem média de importância dada a cada tema

\begin{tabular}{|c|c|c|c|}
\hline \multirow{2}{*}{ Tópicos } & \multicolumn{3}{|c|}{ Áreas } \\
\cline { 2 - 4 } & linguagens & humanas & exatas \\
\hline formação da cidadania & $80 \%$ & $85 \%$ & $55 \%$ \\
\hline aprendizado das regras de trânsito & $60 \%$ & $70 \%$ & $30 \%$ \\
\hline respeito à vida e ao meio ambiente & $95 \%$ & $90 \%$ & $95 \%$ \\
\hline análise das estatísticas sobre acidentes de trânsito & $65 \%$ & $60 \%$ & $90 \%$ \\
\hline
\end{tabular}

Embora muitos professores registrassem a inexistência de curso de capacitação de professores e de material didático, as médias dos percentuais atribuídos pelos entrevistados apontaram como principal dificuldade na implantação da educação para o trânsito na escola a não exigência de sua implementação pela escola. Podemos ainda verificar que poucos entrevistados acusaram o desinteresse de professores como fator dificultador na implantação da educação para o trânsito.

Tabela 4 - Maiores dificuldades na implantação da educação para o trânsito

\begin{tabular}{|c|c|c|c|}
\hline \multirow{2}{*}{ Temas } & \multicolumn{3}{|c|}{ Áreas } \\
\cline { 2 - 4 } & linguagens & humanas & exatas \\
\hline não exigência pelas escolas & $75 \%$ & $80 \%$ & $75 \%$ \\
\hline $\begin{array}{c}\text { inexistência de curso de capacitação de } \\
\text { professores e de material didático }\end{array}$ & $55 \%$ & $60 \%$ & $40 \%$ \\
\hline desinteresse dos professores & $10 \%$ & $15 \%$ & $10 \%$ \\
\hline
\end{tabular}

\section{DISCUSSÃO}

As respostas apontam o grande potencial que temos nas escolas, no material humano disposto a alavancar trabalhos interdisciplinares importantes e fundamentais para alicerçarem a efetivação e a implantação da educação para o trânsito. De modo geral, os professores mostraram-se profissionais interessados que dão importância à educação para o trânsito na escola, independente da matéria lecionada e do seu nível de escolaridade. Houve quem dissesse: "A educação para o trânsito nas escolas é 
fundamental e se isso acontecer de verdade, com entrosamento de todas as matérias, vai impactar positivamente as relações no trânsito e a cidade vai se tornar menos violenta”. Colocar em prática essa dimensão da educação, desde os anos da alfabetização até o final do processo escolar, faria com que a escola desse um passo gigantesco de contribuição para a humanização do trânsito da cidade.

Os entrevistados, em geral, percebem, ao seu modo, em função das suas áreas de atuação, a importância dos temas cidadania, regras de trânsito, meio ambiente, propostos no artigo 11 da Resolução n ${ }^{\circ} 638$ do CONTRAN (BRASIL, 2016) e da estatística sobre acidentes no trânsito. Um professor de geografia comentou que "apesar da boa vontade, nem todas as disciplinas vão ter a mesma facilidade em dialogar, em discutir questões sobre civilidade para a educação para o trânsito". Um outro docente, de português, destacou a importância de se trabalhar textos: "pois só assim, tornamos mais ricas as discussões e os diálogos interdisciplinares sobre a complexidade dos problemas do trânsito, da interpretação das suas regras e de significados de direitos e deveres”. Já outro professor, de matemática, afirmou: "me sinto capacitado em assumir esse tipo de trabalho, principalmente se for por um caminho mais quantitativo, usando tabelas, gráficos, percentagens com estatísticas do trânsito e isso vai enriquecer as outras disciplinas". Outro docente, de ciências da natureza, afirmou o seguinte: "podemos falar dos prejuízos causados pelo trânsito urbano ao meio ambiente, à saúde e à vida. Tudo isso envolve outras discussões de outros professores".

Apesar dos desafios relativos ao trabalho de educação para o trânsito trazidos pelas diversidades da formação profissional dos docentes, grande parte dos entrevistados perceberam a responsabilidade da sua matéria para com a educação para o trânsito nas escolas. Destacamos uma fala que sumariza este cenário: "As formações profissionais são diversas e os pensamentos às vezes muito divergentes e que nos trazem muitas dificuldades. Mas cada um de nós tem muito a contribuir na formação geral e multidisciplinar dos nossos alunos como cidadãos através da educação para o trânsito". As diversidades de visões e de saberes dos professores, função das suas formações profissionais, das especificidades intrínsecas e características de cada disciplina, ao contrário de traduzirem incongruências, são potencializadores de saberes interdisciplinares (MORIN, 2000). 
Nos caminhos do magistério, o aprendizado docente se dá pelas superações das adversidades cotidianas, pela comunicação interdisciplinar, pela troca, pelo diálogo de saberes, pelas capacitações, que conduzem ao aprimoramento e ao crescimento profissional (MORIN, 2002). O aprendizado docente carreia a lógica de que todos os saberes são igualmente importantes e essa importância se materializa na interação e na abertura para novos conhecimentos pelo diálogo entre os saberes, interdisciplinarmente, o que alicerça todo e qualquer processo de construção de conhecimentos escolares e extraescolares (BICALHO; OLIVEIRA, 2012). A interdisciplinaridade é considerada, pelos programas de educação para o trânsito, essencial para o processo de aprendizagem e seria mais uma oportunidade para alavancar o crescimento coletivo dos professores (FAZENDA, 1991; 1999).

Segundo a Lei de Diretrizes e Bases (BRASIL, 1996), o ensino fundamental tem como finalidade a formação do cidadão apto a viver em sociedade. Esse pensamento se completa quando entendemos que a educação deve levar o indivíduo a ser ativo como um elemento que vive com a sociedade e não apenas na sociedade. Para tanto, o educador não deve estar aprisionado à sua disciplina, mas sim aberto a interdisciplinaridade, permitindo transmitir a seu aluno uma visão crítica do mundo e articulada com a sociedade (FREIRE, 1995). A interdisciplinaridade pode ser vista como um intercâmbio mútuo e uma integração recíproca das várias áreas do saber. Os diversos saberes se articulam e quanto mais pluralidade houver nesta articulação, mais rica será a interdisciplinaridade e maior a capacidade de apreensão de conhecimentos (PIAGET, 1973).

Ao falar das maiores dificuldades na implantação da educação para o trânsito, os entrevistados apontaram para o fato de que as escolas, de modo geral, não costumam exigir as atividades educacionais relacionadas a esse trabalho, tendo em vista sua existência não estar explícita na legislação vigente. Além disso registraram, como a segunda maior dificuldade à implantação da educação para o trânsito, a carência de material didático e de cursos de capacitação de professores, tal como comentado por um entrevistado: "as apostilas são raras e confusas. Deviam ser elaboradas por nós e pelos profissionais do trânsito aqui com a gente na escola, de forma conjunta, na nossa linguagem, para a coisa não ser jogada de cima pra baixo, mas respeitar a realidade da escola, de seus alunos e de sua localização." 
Os entrevistados demonstraram interesse na implantação da educação para o trânsito, a partir das realidades das escolas e de seus estudantes, mas denunciaram o distanciamento entre o real e o ideal, entre o que está contido na lei e o que na prática acontece: "nós podemos e queremos colaborar para um trânsito menos violento, respeitando a realidade e os verdadeiros interesses da escola e de sua clientela, mas nada sai do papel e de discursos bonitos"; "a expressão educação para o trânsito não consta na lista dos temas transversais contidos na legislação. Isso dificulta sua inserção na grade escolar”.

Para melhor análise dessa questão, acrescentamos que a Lei de Diretrizes e Bases - LDB (BRASIL, 1996) não contempla o estudo do trânsito em sua base nacional de educação. Outrossim, os Parâmetros Curriculares Nacionais (BRASIL, 1998) dos ensinos fundamental e médio não referenciam o trânsito sequer como tema transversal. As falas mais reflexivas dos entrevistados abrem espaço para discussões a esse respeito, quando dão conta de que: "a educação para o trânsito não funciona porque não é clara na LDB.”; "o jeito é aproveitar as brechas da lei quando falam em trabalhar valores, cidadania, conscientização de direitos e de deveres do cidadão e respeito às realidades das nossas escolas e dos nossos alunos.". Aproveitar as "brechas na lei", valorizar a interdisciplinaridade e a transversalidade e sempre respeitar a realidade e os interesses genuínos da escola e de sua clientela são pontos fundamentais para a implantação da educação para o trânsito nas escolas.

Os PCNs referentes às disciplinas de língua portuguesa, de artes, de educação física, de geografia, de história, de ciências da natureza e de matemática dão enfoques a temas transversais tais como ética, orientação sexual, pluralidade cultural, meio ambiente e saúde (KRIGGER, 2016). Corroboramos a ideia de que a transversalidade contemplada pelos PCNs abre espaço para a inclusão de saberes extraescolares referentes a sistemas de significados construídos na realidade dos alunos, como a educação para o trânsito (CONCEIÇÃO, 2015).

Os currículos da educação infantil, do ensino fundamental e do ensino médio, de acordo com a LDB (BRASIL, 1996), deveriam ter base nacional comum a ser complementada em cada sistema de ensino e em cada estabelecimento escolar, respeitando suas características específicas. Esta lei apresenta parte diversificada, exigida pelas características regionais 
e locais da sociedade. O estudo da língua portuguesa e da matemática, o conhecimento do mundo físico e natural e da realidade social e política é abrangido por ela, mas a educação para o trânsito não é mencionada. Contudo, seu artigo 27 destaca que os conteúdos curriculares da educação básica deverão observar a difusão de valores fundamentais ao interesse social, aos direitos e deveres dos cidadãos, de respeito ao bem comum e à ordem democrática.

A criação, pelo Ministério da Educação, de um currículo plena e verdadeiramente interdisciplinar e transversal e atendendo às reais necessidades e interesses das escolas e sua clientela, iria alavancar a educação para o trânsito em todos os níveis de ensino, por meio de planejamento e ações coordenadas entre os órgãos de trânsito e educação (ARAUJO, 2016).

\section{CONCLUSÃO}

As diversidades relativas às especificidades das matérias lecionadas pelos docentes, ao contrário de serem obstáculos, podem servir ao enriquecimento do diálogo entre os saberes escolares, base para o estabelecimento da interdisciplinaridade, ponto fundamental para a superação de entraves em qualquer processo educacional.

Via de regra, os entrevistados mostraram ser um grupo de profissionais interessados e dispostos a assumir, em sua prática docente, a dinâmica da interdisciplinaridade e da transversalidade, alicerces do trabalho de educação para o trânsito e a sua inserção no currículo escolar como previsto nas legislações tanto no âmbito do trânsito, como da educação. Por outro ângulo de visão, os resultados nos levam a pensar que a educação para o trânsito, a despeito de sua importância na formação de valores e conscientização dos direitos e deveres do cidadão, pode se estabelecer como espaço privilegiado de valorização, de incentivo e de legitimação de práticas interdisciplinares diversas do trabalho docente. Existe uma direção convergente na qual, leis, diretrizes educacionais e professores estão articulados, que visa proporcionar aos alunos uma formação direcionada ao desenvolvimento da sua prática cidadã, e que encontra na educação para o trânsito, a base para discutir e ampliar esse diálogo social.

Professores enfatizaram a importância da aproximação e do diálogo interdisciplinar entre as áreas de educação e de trânsito. Essa percepção 
nos faz crer que a educação para o trânsito é terreno fértil para o estabelecimento da dinâmica interdisciplinar na escola. As falas mais expressivas dos professores convergiram para a necessidade de se contornar dubiedades nas leis e de se encontrar espaços na legislação que transitam por essas duas áreas do saber.

É preciso que se dê voz aos agentes de trânsito e, principalmente, à comunidade escolar, seus professores e seus estudantes, para que se viabilize a construção coletiva de uma educação para o trânsito que contemple as reais necessidades e interesses de cada localidade de nossa cidade. Dentro dessa lógica, a sua inserção no currículo, alicerçada e legitimada pela lei, permitirá à escola contribuir, de modo efetivo, na construção de cenários mais humanos no trânsito urbano, capazes de assegurar a todos os seus usuários, o direito mútuo à vida com dignidade.

\section{REFERENCIAS}

ALVES, Rubem. Conversas com quem gosta de ensinar. São Paulo: Ars Poética, 1995.

ARAUJO, Julyver Modesto de. Código de Trânsito Brasileiro: legislação de trânsito anotada. São Paulo: Letras Jurídicas, 2016.

BICALHO, Rute Nogueira de Moraes \& OLIVEIRA, Maria Claudia Santos Lopes. O processo dialógico de construção do conhecimento em fóruns de discussão. São Paulo: Universidade Estadual Paulista Júlio de Mesquita Filho - Interface -Comunicação, Saúde, Educação, 2012.

BRAGA, Marilita Gnecco de Camargo. Acidentes de trânsito no Brasil: agressão cotidiana ao meio-ambiente urbano. Rio de Janeiro: Revista de Administração Pública, 1995.

BRAGA, Marilita Gnecco de Camargo; SANTOS, Nilton. Educação de trânsito: alterando as regras do jogo. Rio de Janeiro: Revista Administração Municipal, 1995.

BRASIL. Código de Trânsito Brasileiro - CTB (capítulo VI do artigo 76), 1997. 
. Lei 9.394, Lei de Diretrizes e Bases da Educação Nacional - LDB, 1996.

. Parâmetros Curriculares Nacionais - PCN, 1998.

Resolução $n^{\circ} 638$ do Conselho Nacional de Trânsito CONTRAN, 2016.

CLARCK, Cynthia; ENGELMANN, Arno. Avaliação de alguns parâmetros de infrações de trânsito por motoristas e policiais. 1995. Universidade de São Paulo, São Paulo, 1995.

CONCEIÇÃO, Gislaine Fardin da. Educação para o trânsito: um estudo desenvolvido na Escola Municipal Sadao Watanabe. Mato Grosso: Revista Eventos Pedagógicos, 2015.

DAVIS, Adrian. The speed and mobility culture: the sacrifice of health and quality of life. London: Traffic engeneering and control, 1994.

FAZENDA, Ivani Catarina Arantes. Integração e interdisciplinaridade no ensino brasileiro. Efetividade ou ideologia. São Paulo: Edições Loyola, 1991.

FAZENDA, Ivani Catarina Arantes. O que é interdisciplinaridade? Rio de Janeiro: Cortez, 2013.

Práticas interdisciplinares na escola. São Paulo: Cortez, 1999.

FREIRE, Paulo. A educação na cidade. São Paulo: Cortez, 1995.

GOMES, Ordeli Savedra. Código de trânsito brasileiro comentado e legislação complementar. Curitiba: Jaruá, 2016.

KRIGGER, Ilson Idalécio Marques. O sistema trânsito: livro digital/ Ilson Idalécio Marques Krigger; design instrucional Lis Airê Fogolari. Palhoça: Unisul Virtual, 2016.

LUDKE, Menga; ANDRÉ, Marli. Pesquisa em educação: abordagens qualitativas. São Paulo: EPU, 1996. 
MARTINS, João Pedro. A Educação de Trânsito: campanhas educativas nas escolas. Minas Gerais: Autêntica, 2004.

MINAYO, Maria Cecilia (Org.). Desafio do conhecimento: pesquisa qualitativa em saúde. Rio de Janeiro: Hucitec, 1994.

MIRANDA, Orestes. Educação de Trânsito via Comunicação Social. Boletim Técnico da CET. São Paulo: Cia. de Engenharia de Tráfico, 1979.

MORIN, Edgar (Org.). A religação dos saberes: o desafio do século XXI. Rio de Janeiro: Bertrand Brasil, 2002.

Os Sete saberes Necessários à educação do Futuro. Rio de Janeiro: Cortez, 2000.

ORGANIZAÇÃO MUNDIAL DA SAÚDE. Relatório Global de Segurança no Trânsito. Genebra: OMS, 2013.

PIAGET, Jean. Problemas gerais da investigação interdisciplinar e mecanismos comuns. Lisboa: Bertrand, 1973.

VASCONCELLOS, Eduardo Alcântara de. O que é trânsito. São Paulo: Ed. Brasiliense, 1998.

WOLINSKI, Aldri. The future for road safety education; training and publicity. London: Institute of science and technology, 1993.

ZEGEER, Charles. Design and safety of pedestrian facilities. Washington: Institute of transportation engineers, 1998. 


\section{"A CAUSA SECRETA" DE MACHADO DE ASSIS: IDEOLOGIAS E COMPORTAMENTOS}

Maria Eliete Silva Pereira ${ }^{19}$

\section{INTRODUÇÃO}

Ler contos além de ser divertido, faz o leitor viajar nos acontecimentos vivenciados pelos personagens. Se considerar que esse leitor é um leitor da Educação Básica do Ensino Médio, é possível considerar que se trata de um leitor que não está muito preocupado com o contexto histórico em que o conto foi produzido, ou ao qual movimento literário pertence, o que esse leitor quer é ler um texto curto em que o faça rir ou o deixe intrigado com o desfecho, que em alguns contos, o narrador/escritor deixa o leitor tirar suas conclusões. Entretanto, este artigo tem o objetivo de trazer ao leitor uma análise mais aprofundada sobre os personagens em relação a suas ideologias e comportamentos. Para tanto, uma pergunta deve ser considerada: uma obra de ficção pode estar relacionada a questões ideológicas e comportamentais?

Para responder ao questionamento, levou-se em consideração o conto A causa secreta, de Machado de Assis, com o cuidado de uma busca sobre

19 Graduada em Letras e Pedagogia, com Pós-Graduação Lato Sensu em Literatura Brasileira Moderna e Docência do Ensino Superior. Atualmente professora Mestre, inscrita no Grupo de estudos e pesquisas Literatura Infantil e Juvenil, matriculada no Programa de Produção Acadêmica e cursando Pós-Graduação Lato Sensu em Neurociência Educacional. 
essas questões que especialistas ricamente tratam a partir de estudos feitos a respeito.

A partir do momento em que esse jovem leitor do Ensino Médio passa a considerar que os personagens dos contos não foram criados de maneira aleatória pelo escritor, que a ideia é retratar a vida cotidiana de uma sociedade, que esses personagens possuem ideologias e comportamentos que muitas vezes são regidos por discursos sociais, morais, políticos, dentre outros, esse jovem leitor compreenderá melhor a ideia central do conto e em alguns casos poderá se identificar com algum personagem, e o mais incrível desse reconhecimento é que não importa se o conto foi criado no século passado ou se foi criado recentemente.

E a ideia é justamente essa, o escritor apresenta as ideologias e comportamentos dos personagens justamente para que o leitor se envolva com a história e nela se reconheça e/ou lhe provoque indignação por algum personagem que possui ideologias e comportamentos dos quais ele - leitor - não concorda.

Ora, se os personagens não foram criados de maneira aleatória, então, não é possível desconsiderar a época literária em que o conto foi publicado, é por esse motivo que este artigo, no primeiro capítulo, traz informações sobre o período literário em que o conto $A$ causa secreta foi publicado. Porém, esse não é ponto principal e crucial.

A ideia central é levar o jovem leitor do Ensino Médio a uma leitura mais ampla, observando que cada indivíduo possui suas ideologias e comportamentos que estão relacionados a questões sociais que são abordados no segundo capítulo.

O terceiro capítulo debruça-se sobre o recurso do grotesco em cenas de sadismo, crueldade, horror, dor e sangue. Para tanto, à luz dos apontamentos teóricos de Bakhtin (1987), em A Cultura Popular na Idade Média e no Renascimento - O Contexto de François Rabelais, foram analisadas a fisionomia externa e a fisionomia interna das personagens, observando como essas construções aguçam a curiosidade do leitor a partir de sensações de nojo e repulsa.

Além de contextualizar o conto dentro do Realismo, foram feitas reflexões acerca das críticas machadianas aos desequilíbrios sociais da época e ao comportamento humano que, em sua ambiguidade, ilustram o que é a essência do grotesco: o horror e a comicidade. 


\section{O CONTEXTO LITERÁRIO EM A CAUSA SECRETA: O RETRATO DA REALIDADE}

Toda história literária envolve ficção, o que não quer dizer que o que é real é descartado, muito ao contrário. O professor Antonio Candido (2000) comenta que "a arte é comunicação expressiva, expressão de realidades, mais que transmissão de noções e conceitos."

Obras literárias produzidas em séculos anteriores estavam relacionadas a acontecimentos da época e podem se aproximar de acontecimentos nesse século XXI. Considerando que o Realismo no Brasil, teve início em 1881, que abordava conflitos internos dos indivíduos, principalmente aqueles inseridos numa sociedade burguesa regida por regras morais e comportamentais, o conto $A$ causa secreta (1885) retrata exatamente essa época, observa-se que o leitor do Ensino Médio passa por imersão na leitura ficcional de maneira superficial e acaba desconsiderando que o que o escritor traz a partir da ficção são os problemas vivenciados pelos indivíduos no seu dia a dia. Problemas que estão relacionados com a linguagem, seus comportamentos e ideologias.

Ao assumir perspectiva radical diante da condição humana, a partir de uma linguagem polissêmica, a literatura vem assegurando sua permanência e sua atemporalidade. Ao dizer de um tempo, diz de todos os tempos, integrando, unitariamente, presente, passado e futuro. (FILHO, 1993, p. 5).

Essa imersão do leitor é que faz com que o autor se comprometa com a verdade, se preocupe em retratar a vida contemporânea. Bosi assevera que

[...] é sempre válido dizer que as vicissitudes que pontuaram a ascensão da burguesia durante o século XIX foram rasgando os véus idealizantes que ainda envolviam a ficção romântica. Desnudam-se as mazelas da vida pública e os contrastes da vida íntima [...]. O escritor realista tomará a sério as suas personagens e se sentirá no dever de descobrir-lhes a verdade, no sentido positivista de dissecar os móveis do seu comportamento (BOSI, 1994, p.188). 
É importante ressaltar que nesse período o Positivismo tem como ideia central a de que o conhecimento científico devia ser reconhecido como único conhecimento verdadeiro, enquanto o Determinismo considera que tudo no universo, inclusive a vontade humana, está submetido a leis necessárias e imutáveis que leva o indivíduo a adequar-se as mais diversas situações, e o sentimento de liberdade não passa de uma ilusão subjetiva. Essas características são abordadas no conto $A$ causa secreta (1885) de forma explícita, mas que pode passar desapercebida por um leitor inexperiente.

Considerando que a ideia central desse artigo não é uma análise literária pela literatura, e sim a linguagem do discurso, ideologias e comportamentos, e "como já sabemos, que forças sociais condicionantes guiam o artista em grau maior ou menor" (CANDIDO, 2000), sequencia-se a análise, levando em consideração os comportamentos que estão atrelados a cada um dos personagens do conto. Portanto, mais adiante, é apresentada a sinopse do conto observando os comportamentos e já caminha para aproximar ao recurso do grotesco.

\section{COMPORTAMENTOS: IDEOLOGIAS INTERNA OU EXTERNA}

Com incrível maestria, o autor do conto, Machado de Assis, constrói o perfil psicológico de Fortunato, um médico respeitável de meia-idade, mas que, no fundo, não passa de um sádico extremo cujo maior prazer é presenciar a desgraça alheia. O objetivo é buscar conduzir o jovem leitor do Ensino Médio a entender, compreender que todo indivíduo segue uma ideologia, seja ela interna ou externa.

O narrador inicia o conto A Causa Secreta, traçando um perfil com características de uma família comum, Fortunato e sua esposa Maria Luísa e um amigo, Garcia. Logo no início do conto, o narrador já traz uma informação que intriga o leitor, ele informa que os três personagens estão mortos e enterrados, o que lhe permite contar a história sem rodeios. $\mathrm{O}$ discurso do narrador é provocante, instigante, convida o leitor a participar das conversas mais íntimas dos personagens, informa que em uma determinada conversa eles tinham falado de coisa tão feia e grave, que não lhes deixou muito gosto para tratar do dia e resolve então, remontar à origem da situação. 
Neste ponto, caberia uma análise sobre o narrador, porém este artigo pretende abordar somente as ideologias dos personagens, pois estas são apresentadas no decorrer da narrativa de maneira explícita, o que não requer do leitor inferências informativas em nenhum momento.

Fortunato gostava de frequentar o teatro, principalmente quando as peças traziam mortes e sofrimentos. Fortunato era capitalista, essa frequência ao teatro lhe trazia status, uma característica da sociedade burguesa da época, regida por regras morais e comportamentais. Foi numa ocasião desta que Garcia o viu pela segunda vez, a primeira foi na saída da Santa Casa. Nestas passagens os personagens não verbalizam nenhum discurso, porém Garcia estranha o comportamento de Fortunato com o interesse pelas cenas sangrentas na peça, apesar de elas não representarem a realidade, porém, esse comportamento não era o esperado pela sociedade. Conforme Althusser (1974) "Na ideologia, o que é representado não é o sistema das relações reais que governam a existência dos indivíduos, mas a relação imaginária destes indivíduos com as relações reais em que vivem".

Os personagens vão se reencontrar uma noite quando um homem (Gouvea) ferido é socorrido por Fortunato e o estudante de medicina, Garcia. Na passagem do conto em que o narrador relata que Fortunato serviu de criado, segurando a bacia, a vela, os panos para o médico fazer o curativo em Gouvea, o leitor passa a acreditar que Fortunato é um homem bom, porém, mais uma vez, o narrador deixa o leitor intrigado quando diz que Fortunato olha friamente para o ferido, que gemia muito e quando o médico sai, Garcia estava atônito, olhou para Fortunato que se sentou tranquilamente, estirou as pernas e olhou para o ferido com uma expressão dura, seca e fria.

A formação discursiva presente determina o que Garcia disse em seu pensamento e o que Fortunato disse com seus gestos. Se a língua é determinada pela ideologia, a consciência, portanto o pensamento, a "atividade mental”, que são condicionadas pela linguagem, são modeladas pela ideologia. Conforme Bakhtin (1929) "o pensamento não existe fora de sua expressão potencial e, por consequência, fora da orientação social desta expressão e do próprio pensamento".

Fortunato voltou nos dias seguintes para visitar Gouvea, mas antes que estivesse totalmente recuperado, Fortunato desapareceu friamente, 
pouco se importando se Gouvea estava ou não recuperado dos ferimentos que lhe causaram tanta dor.

Gouvea foi até a casa de Fortunato agradece-lhe pela ajuda, mas foi recebido com impaciência, e no fim de dez minutos, pediu licença e saiu. Fortunato rindo ainda lhe disse para ter cuidado com os capoeiras (os que o haviam ferido anteriormente). - "Cuidado com os capoeiras! Disse-lhe o dono da casa, rindo-se" (MACHADO, 1885). Gouvea sai humilhado, desejando deixar em sua memória apenas o benefício que o outro lhe trouxera, mas o ressentimento entrou, deixando o sentimento da ingratidão lhe tomar conta. Cabe nesse ponto, mais uma vez, citar Bakhtin:

A palavra é o fenômeno ideológico por excelência. A realidade toda da palavra é absorvida por sua função de signo. A palavra não comporta nada que não esteja ligado a essa função, nada que não tenha sido gerado por ela. A palavra é o modo mais puro e sensível de relação social. (BAKHTIN, 1992, p.36).

Tempos depois, Fortunato e Garcia se reencontram e desponta uma amizade viril. Um dia Fortunato convida o amigo para ir a sua casa jantar e conhecer sua esposa Maria Luísa. É a partir dessa aproximação que Garcia passa a conhecer e observar os comportamentos de Fortunato.

A segunda vez que Garcia foi à casa de Fortunato, percebeu que entre o casal havia alguma dissonância de caracteres, pouca ou nenhuma afinidade moral, e da parte da mulher para com o marido uns modos que transcendiam o respeito e confinavam na resignação e no temor, a mulher não age conforme suas ideias e está sempre submissa ao marido, mesmo que suas atitudes lhe causem medo e horror. Conforme Althusser,

Todo o sujeito dotado de uma consciência e crendo nas ideias que a sua consciência lhe inspira e que aceita livremente, deve agir segundo as suas ideias, deve, portanto, inscrever nos atos da sua prática material as suas próprias ideias de sujeito livre. Se o não faz, as coisas não estão bem. (ALTHUSSER,1974, p.86 e 87).

A análise que Garcia faz do casal está relacionada à contextualização das posições observadas, de princípios morais, de costumes, não deixando de fora a maneira como ele se comunica consigo mesmo, ou seja, ela- 
borando seus discursos internos. Um dia, perguntou Garcia para Maria Luísa se ela sabia da história de como ele conhecera Fortunato. Como a mulher não expressou saber como se conheceram, ele resolve contar-lhe. Maria Luísa ouviu-o espantada e gostou do que ouviu.

No fim, Fortunato contou à visita que o ferido Gouvea lhe fez. Descreveu todos os pormenores do homem, dos gestos, das palavras, dos silêncios, e a cada detalhe Fortunato ria muito. A esposa ficou desconsolada com a zombaria do marido, mas rapidamente, o médico Fortunato restituiu-lhe a satisfação anterior.

O que envolve nesse ponto são as questões ideológicas dos personagens, suas concepções de mundo, a ideologia moral.

De uma maneira geral, diz-se da ideologia religiosa, da ideologia moral, da ideologia jurídica, da ideologia política etc., que são concepções do mundo. E é claro que se admite, a menos que se viva uma destas ideologias como a verdade (por exemplo, se acreditar em Deus, no Dever ou na justiça etc.), que a ideologia de que se fala então de um ponto de vista crítico, ao examiná-la como um etnólogo examina os mitos de uma sociedade primitiva, que estas concepções do mundo são na sua grande parte imaginárias, isto é, não correspondentes à realidade. (ALTHUSSER, 1974, p. 77-78).

O compromisso do escritor em relatar o retrato da vida, utilizando como artifícios o detalhamento e a descrição minuciosa dos fatos e personagens, não se prendendo apenas a descrições externas, mas também as características internas, são observadas em cada passagem do conto, despertando no leitor o interesse de prosseguir com a leitura, aguçando a curiosidade de saber até onde esses comportamentos vão chegar.

\section{O GROTESCO: O HORROR E A COMICIDADE.}

Agora já formado em medicina, Fortunato insiste com o amigo para abrirem em sociedade, uma clínica. Tanto insistiu Fortunato que assim o fizeram. No início, Fortunato se mostrou um homem dedicado, acompanhava as operações, "não recuava diante de nada, estava sempre pronto para tudo, a qualquer hora do dia ou da noite" (MACHADO, 1885). 
Essa união levou Garcia a uma aproximação ainda maior com Fortunato, passou a fazer parte da família, jantava quase todos os dias na casa de Fortunato, e assim duplicava seu encanto por Maria Luísa. Quis expelir esse amor, mas não pôde. Pôde apenas trancá-lo. Maria Luísa percebeu esse amor e o silêncio, mas nada proferiu. "A psicologia do corpo social se manifesta essencialmente nos mais diversos aspectos da enunciação sob a forma de diferentes modos de discurso, sejam eles interiores ou exteriores" (BAKHTIN, 1992, p.43).

Com o passar do tempo, Fortunato resolveu estudar anatomia e fisiologia, e ocupava-se nas horas vagas em rasgar e envenenar gatos e cães. Como essa cena atordoava os doentes da clínica, Fortunato mudou o laboratório para sua casa. Um dia a mulher não aguentava mais essa situação, pediu para o amigo Garcia solicitar ao marido que cessasse essas experiências. Garcia atendeu à solicitação.

Neste ponto, cabe lembrar que nesse período o Positivismo tem como ideia central a de que o conhecimento científico devia ser reconhecido como único conhecimento verdadeiro. Dois dias depois, Garcia presenciou uma cena na casa de Fortunato que o deixou atônito. Fortunato cortava um rato bem devagar, uma pata de cada vez, encostava ao fogo, e retirava rapidamente para que o rato continuasse vivo. Garcia horrorizado disse-lhe: “- mate-o logo!" (MACHADO, 1885). Mas o amigo não o atendeu. E com um sorriso único, reflexo de alma satisfeita, cortou a terceira pata, e fez o mesmo movimento até a chama. E assim repetiu a cena até que o rato morresse. Fortunato, não tinha sentimento de raiva, nem ódio, tão somente um vasto prazer.

O tema ideológico de cada indivíduo está relacionado ao valor social, o que de certa forma se tornam índices individuais de valor, porém sua fonte não se encontra na consciência individual. E sobre este tema, Bakhtin menciona:

O índice de valor é por natureza interindividual. O grito do animal, enquanto, pura reação de um organismo individual à dor, é despido de índice de valor. É um fenômeno puramente natural. O grito não depende da atmosfera social, razão pela qual ele não recebe sequer o esboço de uma formalização semiótica. (BAKHTIN, 1992, p. 46-47). 
Quando Fortunato percebeu que o amigo o observava, fingiu que castigava o animal por raiva por este ter comido um papel que lhe era muito importante. Garcia o ouviu sem lhe dar crédito. Recordou de todos os atos do amigo. Fortunato tem ideias diferentes das que proclama e age segundo essas outras ideias. Ninguém é mau voluntariamente, quer cínico ou perverso. Definitivamente, o tema ideológico está relacionado ao índice de valor social.

Depois de falarem sobre outras coisas, os três foram jantar, mas Maria Luísa tossia e tossia. E não se passou muito tempo para que a doença tomasse conta da mulher. O marido assistia a tudo, a doença definhar os ossos de sua esposa. Não mediu esforços, médicos, remédios, todos os recursos, afinal amava sua mulher, a seu modo, estava acostumado com ela, mas a doença era mortal.

Nos últimos dias, Fortunato não a deixou, fitou o olho naquela decomposição lenta e dolorosa da vida, bebeu uma a uma as aflições da mulher devorada de febre e minada de morte. Não derramou uma só lágrima, faminto de sensações, não lhe perdoou um só minuto de agonia, só quando ela morreu é que ele ficou aturdido. Viu que estava outra vez só.

O pensamento que só existia na consciência de Fortunato, que não é um sistema ideológico coerente, é apenas um pensamento obscuro, passa a pertencer à esfera da realidade ao momento em que no contexto de sua consciência esse pensamento vai tomando forma e se apoiando nos sistemas ideológicos formados pelos signos ideológicos que ele formou anteriormente.

Durante o velório, Fortunato saiu para deitar-se no sofá da saleta ao lado, e logo dormiu. Garcia levantou o lenço e contemplou por alguns instantes as feições da defunta. Depois, como se a morte espiritualizasse tudo, inclinou-se e beijou-o na testa. Nesse momento Fortunato chegou à porta, não tinha ciúmes, nem inveja, mas sentiu vaidade. Garcia inclinou-se para beijar outra vez o cadáver, mas não conseguiu, não conteve as lágrimas de amor calado e irremediável desespero. "Fortunato saboreou tranquilo essa explosão de dor moral que foi longa, muito longa, deliciosamente longa." (MACHADO, 1885) Fortunato agiu segundo as suas ideias, seus atos se materializam em função daquilo que acredita. 


\section{CONSIDERAÇÕES FINAIS}

Ao fazer uma primeira leitura do conto, o leitor fica intrigado com o comportamento do protagonista da narrativa, percebe nesse personagem atitudes que contrariam as visões habituais de uma sociedade. Com uma leitura mais afinco, o leitor se depara com outros personagens que também possuem um comportamento adverso do habitual, o narrador faz questão de trazer o leitor para bem próximo dessas cenas, envolvendo-o de tal forma que, em algumas passagens, o leitor pode até se identificar com algum personagem.

O discurso do narrador é provocante, convida o leitor a participar das conversas mais íntimas dos personagens, Fortunato um homem sádico de comportamento duvidoso, a mulher Maria Luísa, submissa aos caprichos do marido e Garcia, que esconde seus sentimentos, sua ideologia interna.

Logo, registra-se que a partir das análises realizadas, as manifestações ideológicas são tão individuais quanto o comportamento do indivíduo, levando em consideração o contexto, o que a partir daí, passa a ser social. Assim, não dá para considerar que uma obra de ficção não está relacionada a questões ideológicas e comportamentais vivenciadas na época de sua criação e que não seja possível associá-la em tempos atuais.

\section{REFERÊNCIAS}

ALTHUSSER, L. Ideologia e Aparelhos Ideológicos do Estado. Lisboa: Editorial Presença, Martins Fontes, 1974.

BAKHTIN, M. Marxismo e filosofia da linguagem. São Paulo: Hucitec, 1992.

BOSI, A. História concisa da Literatura Brasileira. São Paulo: Cultrix, 1994.

CANDIDO, Antonio. Literatura e Sociedade. São Paulo: T.A. Queiroz, 2000.

FILHO, P. D. A causa Secreta. In: Os Melhores Contos de Machado de Assis. São Paulo: Global, 1993. 


\section{A BASE NACIONAL COMUM CURRICULAR (BNCC) NO ENSINO DA MATEMÁTICA ANOS INICIAIS: AVANÇO E/OU RETROCESSO?}

Heidyani Leão de Souza $a^{20}$

\section{INTRODUÇÃO}

Após um percurso trilhado ao longo da formação inicial pedagógica, com ampla pluralidade de conhecimentos acerca do campo de conhecimento da Educação, seus fundamentos filosóficos, sociológicos e psicológicos, suas implicações específicas e a relação entre as teorias fundantes e as práticas pedagógicas, para implementação daquilo que se considera como um bom ensino, instituímos as bases para a edificação desta pesquisa. Precisou-se, enquanto assunto para esta pesquisa, ainda no ano de 2017, o processo de elaboração e implementação da Base Nacional Comum Curricular - BNCC, sob a perspectiva de um grupo de docentes atuantes numa Escola de Ensino Fundamental do município de Fortaleza, identificando seus prováveis efeitos para a promoção qualitativa do ensino da matemática nos anos iniciais do Ensino Fundamental.

20 Especialista em Direito Educacional pelo Instituto Prominas (2019); graduada em Pedagogia pela Universidade Federal do Ceará (2017), pesquisadora das áreas de Educação Matemática, Formação Inicial e Continuada do Pedagogo para ensino da matemática nos anos iniciais do Ensino Fundamental. 
Esta pesquisa se sustenta num quarteto teórico-conceitual. O primeiro consiste na teoria curricular crítica (LOPES, 2004) que discute o currículo como uma construção cultural elaborado social e historicamente. O segundo esteia-se no estudo histórico da evolução dos currículos de matemática no Brasil (CARVALHO, 1998). O terceiro eixo teórico apoia-se na Transdisciplinaridade (D'AMBROSIO, 2011), como uma proposta curricular que supera a barreira imposta pela fragmentação do conhecimento em disciplinas, sustentando que a aquisição de conhecimentos ocorre de forma contínua e intermitente, emaranhando as elaborações realizadas a partir da observação da realidade e da imaginação, contribuindo para a aquisição da consciência. Ultimando, o quarto eixo funda-se no conceito da insubordinação criativa ou subversão responsável (D'AMBROSIO, 2015) com vistas a orientar a análise dos dados com o grupo de docentes selecionados, a discussão dos resultados e considerações finais.

A pesquisa tem uma duplicidade de tipificação: a primeira consiste em uma discussão de conteúdo, na medida em que parte de estudos quanto aos documentos institucionais, com base na revisão de alguns textos que integram a legislação brasileira, tais como a Constituição Federal (CF), a Lei nº 9.394/96, a Lei nº 13.005/2014 e a BNCC. A segunda contém o caráter de pesquisa social e humana, tendo em vista "a melhoria da compreensão de ordem, de grupos, de instituições sociais e éticas", como indicado por Lakatos (2016), na medida em que os estudos e os sujeitos envolvidos na pesquisa, vêm despontar modificações nos sistemas de ensino, dado as propostas contidas na BNCC.

Os procedimentos metodológicos empregados na pesquisa concerniram a uma revisão bibliográfica, uma análise documental da legislação educacional brasileira relativa aos currículos, e na aplicação de um questionário. Utilizamos a metodologia de pesquisa social Surveys (BABBIE,1999), adequado à intersubjetividade. Referida metodologia foi empregada por Karl Marx, no ano de 1880, ao enviar por correio 25 mil questionários a trabalhadores franceses a fim de verificar em qual nível ou intensidade, esses eram explorados por seus patrões. Outro exemplo de aplicação desse método é atribuído a Max Weber em seus estudos sobre a ética protestante (BABBIE, 1999, P. 78).

Envidamos o recurso da aplicação de um questionário para coleta de dados e disposição ao debate no decorrer de todo o processo, para exa- 
me de uma amostra da população com 10 professores do município de Fortaleza. Após a coleta de dados, seguiu-se com a seleção, codificação, tabulação e posterior análise e interpretação dos dados.

\section{DA ELABORAÇÃO À IMPLEMENTAÇÃO DA BASE NACIONAL COMUM CURRICULAR - BNCC}

Com a promulgação da Constituição da República Federativa do Brasil, em 1988, que recompôs os marcos legais após o período dos governos militares (1964-1985), em seguida a uma intensa movimentação social e política para modificação daquele quadro, define-se juridicamente a educação como um direito de todos e dever do Estado e da família (Art. 205). Explicita-se enquanto uma ação do Estado, a promoção da garantia da educação como direito dos indivíduos (Art. 208). Inclui o que diz respeito à fixação dos conteúdos mínimos para o ensino fundamental, de modo a afiançar a formação básica comum e respeito aos valores culturais e artísticos, nacionais e regionais (Art. 210). Determina ainda o estabelecimento de um Plano Nacional de Educação (PNE) com prazo de 10 anos, pretendendo coordenar as ações do sistema nacional de educação comparticipação dos estados e municípios, além da definição de diretrizes, objetivos, metas e estratégias, para garantir, sustentar e avultar o ensino em todos os níveis, etapas e modalidades da educação (Art. 214).

Após oito anos da publicação da CF, a Lei no 9.394/96 foi sancionada pela presidência da República, estabelecendo as Diretrizes e Bases da Educação Nacional, legislação considerada com caráter democrático e declarativa de diversos direitos. No entanto, alguns estudiosos como Bueno (2000), Frigotto (2003) e Bodião (2016), manifestam sua compreensão de que, apesar dos avanços que a referida Lei promoveu para a nação, carrega em si os traços de intensas disputas de intenções, como a substituição da proposta às vésperas de sua aprovação por um anteprojeto do senador.

No ano seguinte, o Ministério da Educação e do Desporto (MEC) consolidou os Parâmetros Curriculares Nacionais (PCN, 1997), com caráter indicativo das metas de qualidade para a promoção do ensino, os objetivos gerais do ensino, e da aprendizagem dos alunos brasileiros, contribuindo para sua atuação cidadã, de modo participativo, reflexivo e autônomo. A organização do conhecimento escolar dava-se em oito áreas - 
Língua Portuguesa, Matemática, Ciências Naturais, História, Geografia, Arte, Educação Física e Língua Estrangeira - acrescidas de cinco temas transversais: Ética, Saúde, Meio Ambiente, Orientação Sexual e Pluralidade Cultural.

O papel da Matemática no PCN consiste em apoiar uma formação humana por meio do desenvolvimento de habilidades intelectuais, estruturação do pensamento, desenvoltura do raciocínio lógico, utilidade na vida prática e atividades do mundo do trabalho, além do suporte para a construção do conhecimento em todas as áreas. Para além dos temas transversais, os PCNM indicavam a possibilidade de abordagem de outros temas, como educação do consumidor. A seleção e organização dos conteúdos contemplava quatro blocos de conteúdos, dos campos da Aritmética, Álgebra e Geometria: a) Números e Operações, b) Espaço e Forma, c) Grandezas e Medidas e d) Tratamento da Informação. O papel do professor era essencial para a tomada de decisões quanto às intervenções em sala de aula e a abordagem dos temas, favorecendo a uma aprendizagem significativa e contextualizada.

Decorrente do Art. 9, inciso IV da CF, o MEC em conjunto com a Secretaria da Educação Básica (SEB), publicaram no ano de 2013 as Diretrizes Curriculares Nacionais (DCN) nas quais estabelecem a base nacional comum, responsável por guiar a organização, a articulação, o desenvolvimento e a avaliação das propostas pedagógicas, currículos e conteúdos mínimos das redes de ensino do país. Nesse cenário e em cumprimento ao mencionado Art. 214 da CF, aprovou-se por meio da Lei no 13.005, de 25 de junho de 2014 o PNE, apresentando após os 14 artigos que integram a Lei, as metas e estratégias para a política educacional para implementação no período de 10 anos.

As primeiras 10 metas são estruturantes para a garantia do direito à educação básica com qualidade, promovendo assim a garantia do acesso, à universalização do ensino obrigatório, à ampliação das oportunidades educacionais, à redução das desigualdades e à valorização da diversidade, caminhos imprescindíveis para a equidade. Prevendo ações para a elaboração da BNCC, quatro metas relacionam-se estritamente a essa:

Meta 2. Estratégia 2.2.: pactuar entre União, Estados, Distrito Federal e Municípios, no âmbito da instância permanente de que 
trata o $\llbracket 5^{\circ}$ do art. $7^{\circ}$ desta Lei, a implantação dos direitos e objetivos de aprendizagem e desenvolvimento que configurarão a base nacional comum curricular do ensino fundamental;

Meta 3. Estratégia 3.3.: pactuar entre União, Estados, Distrito Federal e Municípios, no âmbito da instância permanente de que trata o $\$ 5^{\circ}$ do art. $7^{\circ}$ desta Lei, a implantação dos direitos e objetivos de aprendizagem e desenvolvimento que configurarão a base nacional comum curricular do ensino médio;

Meta 7. Estratégia 7.1.: estabelecer e implantar, mediante pactuação interfederativa, diretrizes pedagógicas para a educação básica e a base nacional comum dos currículos, com direitos e objetivos de aprendizagem e desenvolvimento dos (as) alunos (as) para cada ano do ensino fundamental e médio, respeitada a diversidade regional, estadual e local;

Meta 15. Estratégia 15.6.: promover a reforma curricular dos cursos de licenciatura e estimular a renovação pedagógica, de forma a assegurar o foco no aprendizado do (a) aluno (a), dividindo a carga horária em formação geral, formação na área do saber e didática específica e incorporando as modernas tecnologias de informação e comunicação, em articulação com a base nacional comum dos currículos da educação básica, de que tratam as estratégias 2.1, 2.2, 3.2 e 3.3 deste PNE (PNE, 2014).

A BNCC situa-se no contexto das políticas públicas de reformas do Estado brasileiro e integra a política nacional da Educação Básica, iniciadas nos anos 90 a partir de reuniões internacionais, a começar da promoção das conferências mundiais sobre educação por organizações internacionais, a saber, ONU, BIRD, BID e FMI. Essas conferências visavam nortear as políticas públicas ou reformas educacionais de todos os países assinantes dos termos de compromissos, sob o contexto das mudanças delineadoras da sociedade da informação e da tecnologia, decorrentes dos avanços científicos, tecnológicos e econômicos ocorridos não longo do século XX.

A área de matemática compromete-se com o letramento matemático apoiado na junção entre os cinco campos ao conjunto de ideias fun- 
damentais: Aritmética, Álgebra, Geometria, Estatística e Probabilidade. Caberá às escolas a abordagem de temas como Educação para o consumo e Educação financeira e fiscal, de modo contextualizado, transversal e integrador. A expectativa é que o aluno consiga identificar uma situação de uso para aplicar algum desses conhecimentos, podendo raciocinar, representar, comunicar e argumentar matematicamente. A construção de uma concepção de mundo, de um novo ou outro conhecimento matemático e de um outro arranjo social através dessa estrutura de pensamento não é esperada pelo documento.

Com vistas a comparar os referenciais curriculares na área de Matemática, compondo-se em introdução, história dos currículos de base comum e suas composições, comparações entre BNCC e RCNEI/PCN na área de Matemática, Veroneze (2016) comparou de modo sistêmico e global, os PCN (1998a/b e 2000) e a BNCC (2015), especialmente para a área da Matemática, buscando identificar semelhanças e diferenças, o que denominou de consensos e dissensos na composição dos currículos de base comum, no contexto da primeira versão BNCC. Identificou dez semelhanças entre os documentos quanto a: 1) elaboração dos documentos por um conjunto de atores; 2) necessidade de ensino contextualizado e interdisciplinar; 3) proposta dividida em áreas do conhecimento; 4) presença de tema transversais/integradores; 5) objetivos/competências gerais em todas as áreas do conhecimento; 6) indicação dos conteúdos mínimos em todas as escolas com a inclusão de outros conteúdos a partir do contexto escolar; 7) indicação da necessidade de diversificação dos recursos pedagógicos; 8) conteúdos agrupados, PCNM denominando de blocos de conhecimentos e a BNCC nomeando-os de eixo de conhecimento; 9) ambos salientam a relevância da matemática para a construção de uma visão de mundo e uma atuação cidadã; 10) objetivos/competências gerais semelhantes, estritamente quanto a comunicação e o uso da matemática no cotidiano.

Quanto às diferenças entre os PCNM e a BNCC identificou oito diferenças, consideradas dissensos e elencadas a seguir: 1) Os PCNM são orientadores e não-determinantes dos currículos escolares, distinguindo-se do caráter normativo da BNCC; 2) Os PCNM são enfáticos quanto à necessidade de um ensino contextualizado e interdisciplinar, enquanto a BNCC, não; 3) diferença entre os temas a serem trabalhados em todas 
as áreas, bem como de seus nomes; 4) A BNCC apresenta volume único para as três etapas da educação básica, Educação Infantil, Ensino Fundamental e Ensino Médio; ${ }^{21}$ 5) Diferença de segmentação dos blocos de conhecimento (PCNM), com números e operações; grandezas e medidas; espaço e formas; tratamento de informações e eixos de conhecimento; (BNCC) geometria; grandezas e medidas; estatística e probabilidade; números e operações; álgebra e funções; 6) Os objetivos gerais/competências para educação infantil e ensino médio são distintos nos PCNM e na BNCC; 7) Os PCN utilizam a nomenclatura "série" para o Ensino Fundamental e "ano" para o Ensino Médio, e a BNCC utiliza para o Ensino Fundamental o termo "ano"; 8) Denominações diferentes para as áreas de conhecimento, os PCNEM (2000) Linguagens, Códigos e suas Tecnologias; Ciências da Natureza e suas Tecnologias; Matemática e suas Tecnologias, enquanto a BNCC indica Aritmética, Álgebra, Geometria, Estatística e probabilidade.

\subsection{PROCEDIMENTOS DE COLETA E ANÁLISE DOS DADOS}

Investigamos as considerações dos professores quanto à proposta da BNCC, naquele instante ainda em processo de aprovação para posterior implementação, tendo como parâmetro os PCNM, empregando o questionário como a melhor alternativa para mensurar a intensidade de suas considerações, com a associação de duas técnicas.

Constituímos três dimensões de análise: a primeira refere-se ao perfil docente, estritos ao seu ciclo de atuação, a natureza da formação inicial para a atuação nos anos iniciais do EF e o tempo de atuação nesse ciclo. A segunda reporta-se aos debates sobre o currículo, tendo como parâmetros a periodicidade, o espaço, seu nível de importância, fatores fundamentais

21 Nota Explicativa: A última versão da BNCC, suprime o Ensino Médio, dado a Publicação da Portaria do MEC no 790, de 27 de julho de 2016, instituindo o Comitê Gestor da Base Nacional Curricular Comum e reforma do Ensino Médio. Referida Portaria foi publicada 10 dias após o encerramento do evento ao qual o estudo de Veroneze foi comunicado a comunidade científica - Educação Matemática na Contemporaneidade: desafios e possibilidades - ocorrido entre os dias 13 e 16 de julho do mesmo ano, na cidade de São Paulo, não invalidando a completude de seus apontamentos. 
para discussão, revisão, definição do currículo efetivado e melhoria do ensino da Matemática na escola. A terceira aborda a BNCC, tendo como referência a participação do professor no processo de elaboração, a definição de conteúdos mínimos, o caráter normativo, a concepção de professor contida na BNCC e a organização dos conteúdos para o ensino de matemática nos anos iniciais.

O questionário engloba dez questões fechadas. Integra as duas primeiras questões uma medição nominal, verificando a formação inicial e o tempo de atuação do entrevistado nos anos iniciais. A terceira questão propõe uma medição de razão, verificando a periodicidade dos encontros para debate do currículo da escola, em cada um dos espaços indicados. As sete seguintes lançando mão da técnica de medição por meio do Escalonamento de Likert, que consiste basicamente em mostrar aos respondentes uma declaração e se pergunta se eles "concordam”, "discordam” ou "discordam fortemente", podendo alterar a redação das categorias de resposta, como "aprovam" ou "desaprovam" (BABBIE, 1999, p. 233). Em nosso questionário, as categorias determinadas foram: "Pré-requisito”, "Necessário", "Alta Prioridade" e Irrelevante, nas questões de número 4 e 5. Para a pergunta de número 7, as categorias redigidas foram "altamente participativo", "participei e contribui”, "participei, mas não contribui”, "não participei”. Às questões de número, 6, 8, 9 e 10, optamos por "discordo totalmente", "discordo", "concordo", "concordo totalmente".

\subsection{O QUE OS DOCENTES DISSERAM ANTE À ELABORAÇÃO E IMPLEMENTAÇÃO DA BNCC?}

A BNCC apresenta-se como resultado de um amplo processo de debate, sustentando-se na alegação de que recebeu 12 milhões de contribuições, tanto individuais, quanto de organizações e de redes de educação do Brasil. Para além dessas, afirma ainda que diversos seminários foram realizados pelas Secretarias Estaduais de Educação, contabilizando a participação de 9 mil professores e profissionais de educação.

Indagamos, primeiramente, qual a formação inicial das professoras para atuação na Rede Pública Municipal de Ensino e observamos que 80\% do grupo é constituído por profissionais com formação em Pedagogia. Em seguida, questionamos há quanto tempo o entrevistado atua 
nos anos iniciais do Ensino Fundamental. A maioria do grupo apresenta um tempo de atuação variando entre 2 e 7 anos, 30\% com 8 a 15 anos de atuação e outra parcela com 30\% integram mais de 16 anos de atuação. Somente 10\% da amostra da população tem até dois anos de atividade, no contexto dos anos iniciais do EF.

Solicitamos que indicassem quais os espaços e o intervalo entre os encontros com o intuito de debater o currículo da escola. Os dados indicam que a discussão do currículo ocorre nos espaços assim designados: a) Secretaria Municipal de Educação (SME); b) Encontros Pedagógicos (EP) da Escola, com a participação dos técnicos da SME, o núcleo gestor da escola e os Professores; c) Reuniões entre a escola, os professores e a comunidade; d) Reunião entre os professores. Exibem ainda que nos espaços SME e EP da Escola, a maioria das professoras, consideram que o intervalo para debate do currículo é anual. Distintamente, nos espaços "c" e "d", o intervalo é semestral. Outro dado relevante é quanto a indicação de que a discussão do currículo na SME “não ocorre", por 40\% das entrevistadas.

Perguntamos às professoras seu nível de participação em alguns desses espaços, salientando que incluímos mais dois: a) possíveis reuniões internas da escola e b) promovidas pela SME, ambas para abordar a BNCC. Constatamos que apenas uma parcela dessa população, inferior a 30\%, indica que "participou, mas não contribuiu" no ambiente virtual do Portal da Base e 10\% identificam-se como participantes contributivos e participantes atuantes.

A maioria das professoras não participou do processo de elaboração da BNCC em nenhum dos espaços indicados tanto pelo MEC, quanto em dois outros espaços incluídos por esta pesquisa. As entrevistadas salientam que, quanto aos espaços para encontros presenciais, não foi dada ao professor oportunidade de conhecimento, esclarecimento e participação em todos esses ambientes. Afirmam ainda que "não participaram" dado que recordam que o assunto foi mencionado, mas sem debates. Acrescentam que as determinações do sistema educacional não favorecem a participação delas em outras atividades, para além do cumprimento da carga horária, dos planejamentos pedagógicos, processos de avaliação interna e externa e encontros com a comunidade. Alegam ainda que o desgaste físico após as aulas é intenso e ao fim de uma jornada de trabalho docente 
não estão propensas física e entusiasmadas emocionalmente, a se envolver em outra atividade, como acessar o ambiente virtual do Portal da Base e contribuir.

Prosseguindo com as questões, assinalamos que na introdução do texto da BNCC estabelece-se uma relação entre a definição de conteúdos mínimos, através dos conhecimentos específicos e competências, em uma estrutura com caráter normativo, modificando todos os currículos escolares, e ainda, que apresenta a ideia de que a BNCC se agrega aos objetivos da educação brasileira para uma formação humana integral. Dessa forma, solicitamos às professoras que indicassem seu nível de concordância quanto essa correspondência entre a oferta de conteúdos mínimos e a edificação de uma sociedade democrática e para uma formação humana integral.

Notamos que a minoria das professoras concorda ou concorda parcialmente. Registramos que o argumento das professoras quanto a concordância com essa relação, consiste no senso de que a normatização dos conteúdos mínimos, como para a matemática, iniciará um efetivo processo democrático de acesso a uma educação de qualidade, tendo um único conjunto de saberes para todos e para todas as escolas, inferindo que o processo de inclusão social, formação humana integral, disputa por melhores oportunidades no mundo do trabalho e as melhorias sociais seriam decorrentes e inevitáveis.

Distinguimos ainda que para as mesmas questões, 70\% do grupo “discorda" ou "discorda totalmente" dessa relação estabelecida pela BNCC. Justificam para tanto que a padronização mínima dos conteúdos consolida a desigualdade social e não garante uma formação humana integral, na medida em que não assegura o amplo acesso aos conhecimentos elaborados pela humanidade ao longo de seu desenvolvimento, convertendo-se numa barreira e não num ponto de partida.

A discordância da maioria das professoras quanto à relação apresentada pela BNCC, dos conteúdos mínimos e suas finalidades, concilia-se com a concepção de que essa proposta salvaguarda o discurso da cultura comum (LOPES, 2006). Dado seu caráter prescritivo, um currículo comum apresenta-se limitado em seu cerne, em suas finalidades relativas à eficiência social e formação para o mundo do trabalho, e em seu menosprezo à dinâmica do cotidiano escolar e sua capacidade de produzir, interpretar e dar sentido ao seu currículo próprio. 
A BNCC estabelece cinco unidades temáticas distintas e subdividias para a área de Matemática: Números, Álgebra, Geometria, Grandezas e Medidas e Probabilidade e estatística, cabendo às escolas a abordagem dos temas como Educação para o consumo e Educação financeira e fiscal, de modo contextualizado, transversal e integrador. Dessa forma, apresentamos duas concepções sobre essa organização da área da matemática, questionando às professoras seu nível de concordância. A primeira afirmativa indicava a concepção de que a organização da área da matemática, com a subdivisão nas referidas unidades conserva a rigidez, a fragmentação, a compartimentação, a distorção e a limitação do conhecimento matemático. A segunda alternativa, afirmava que a possibilidade de inclusão de outros temas com outras abordagens, no currículo matemático da escola pública é suficiente para responder às existentes e novas perguntas e novos problemas dos indivíduos frente a realidade.

Para a primeira alternativa, $60 \%$ do grupo concordou ou concordou totalmente com a afirmação e $40 \%$, discorda ou discorda totalmente. Na segunda alternativa, o grupo comportou-se de modo inversamente semelhante. A apreciação do grupo quanto à disposição do conhecimento matemático em unidades e sua relação com os temas integradores indica que não há unanimidade entre os professores sobre a maneira de organizar o currículo matemático para os anos iniciais do ensino fundamental. Tendo em vista que a minoria estabeleceu uma concordância quanto à subdivisão dos conteúdos matemáticos e possibilidades de abordagem de outros temas pela escola, indicando a conservação do "velho vício do ensino de Matemática com a compartimentalização” (CARVALHO, 1998, p. 121). Ainda que essas formas de disposição dos conhecimentos tenham sido necessárias, com a ênfase no detalhamento dos conteúdos, limitante e condicionador, são insuficientes para sanar diversos problemas que a humanidade enfrenta.

Os PCNM organizavam-se em quatro blocos de conteúdos-Números e operações, Espaço e Forma, Grandezas e medidas e Tratamento da Informação -, além de cinco temas transversais - Ética, Saúde, Meio Ambiente, Orientação Sexual e Pluralidade Cultural - podendo ser discutidos outros temas como a Educação do Consumidor. Por sua vez, como mencionamos, a BNCC estabelece cinco unidades temáticas distintas e subdividias para a área de Matemática: Números, Álgebra, Geometria, 
Grandezas e Medidas e Probabilidade e estatística, e os temas integradores Educação para o consumo e Educação financeira e fiscal.

Nesse sentido, as professoras foram questionadas quanto ao nível de concordância ante duas afirmativas, que concerniam em indicar se configura um avanço ou retrocesso o processo de implementação da BNCC e suas especificidades para o ensino da matemática nos anos iniciais do EF, especialmente na escola pública, comparando-se aos PCNM.

A maioria das professoras (70\%) consideram um retrocesso a efetivação da BNCC. Defendem seus posicionamentos, a começar pelo caráter regulamentar e impositivo, percebendo a possibilidade de ter um currículo fixo, sem possibilidades de mudanças e limitando a autonomia do trabalho docente. Um segundo argumento é quanto ao embaraço para discussão do tema nos espaços institucionalizados, dificultando o posicionamento da categoria sobre seu fazer pedagógico cotidiano. Terceiro argumento condiz à redução das áreas de conhecimento dos PCN de oito para quatro unidades temáticas, na medida em que as professoras receiam que o que de fato aconteça, seja um destaque maior a apenas duas áreas, Língua Portuguesa e Matemática, tendo em vista que "se reduziram de 8 para 4, quem garante que não reduzam para apenas 2, como de fato já o é, mas passando a ser lei?’”. O quarto argumento refere-se à percepção de que a modificação e redução dos temas transversais para os temas integradores e especificado por área compartimentou o que antes não era. $\mathrm{O}$ quinto argumento quanto à área da matemática é que não houve nenhuma modificação profunda, conservando a abordagem matemática em pedaços sem integrarem os conteúdos entre si nem entre as outras matérias. O sexto argumento referiu-se ao fato de que a BNCC não fala sobre a possibilidade ou prazo para uma revisão. Indicam que o cotidiano da escola é mutante e precisam incorporar novas práticas ou rever determinados assuntos que precisam ser abordados ou foram superados. Afligem-se com a probabilidade do currículo da escola fique estagnado na BNCC por tempo indeterminado. Finalizam com a perspectiva de que o "comum" contido na BNCC poderá reforçar e ampliar a diferença da qualidade na formação das crianças matriculadas nas escolas públicas e nas privadas, dado que à escola pública caberá a abordagem da Base, incorrendo ainda no risco da redução dos financiamentos em educação dado o novo cenário escolar e na consolidação de uma escola básica e mínima. 


\section{CONCLUSÕES - A IMPLEMENTAÇÃO DA BNCC PARA O ENSINO DA MATEMÁTICA: AVANÇO E/OU RETROCESSOS?}

Neste estudo, explicitamos uma concepção de educação e de currículo, bem como os marcos legais para a edificação da BNCC para a educação brasileira. Tendo como referência inicial as orientações contidas nos PCNM, investigamos em que medida a proposta da BNCC proporcionará um avanço ou retrocesso para o ensino de matemática nos anos iniciais do EF, na perspectiva de professores atuantes na Rede pública municipal.

A partir da análise da pesquisa, evidenciamos que o debate sobre o currículo na escola ainda é limitado, sobretudo na destinação dos tempos para esses, quanto na forma de abordar o currículo, com a prevalência da apresentação e não da discussão sobre currículo, no espaço da SME. Relevamos ainda a marcante discordância quanto à implementação de um currículo único para o sistema nacional, como sendo ao mesmo tempo, a via de acesso para melhorias sociais e suficiente para responder às novas questões emergentes da sociedade e propiciadora de uma formação humana integral.

Estritamente ao processo de elaboração da BNCC, constatamos que o nível de participação e contribuição, dos professores foi mínimo ou quase inexistente, tendo em vista que as condições de trabalho docente, a vultuosidade das atividades, horas dedicadas à prática pedagógica e a escassez de espaços destinado a esse tema, interferiram e ocasionaram seus distanciamentos frente ao desenvolvimento dessa política pública.

Verificamos uma objeção das professoras quanto a redução das 8 áreas de conhecimentos contidos nos PCN para apenas 4 na BNCC, especialmente quanto a organização da área da matemática, modificando-se de blocos de conteúdos para cinco unidades temáticas e sugestão de dois temas integradores, antes cinco temas transversais. A manutenção da fragmentação dos conteúdos matemáticos, resultou em um dissenso, dado que em nada modificou o que existia antes, desfavorecendo o suporte às atuais necessidades dos indivíduos frente aos desafios impostos pela sociedade do capital.

A fragilidade dessa forma de organização curricular é que a matemática permanece tratada de forma isolada, restringindo-se a questões 
e problemas fixos, limitados, com uma metodologia específica, além de provocar profundas deturpações para a educação, em dissonância a um currículo matemático essencialmente dinâmico, alcançando uma elaboração que contemple o corpus de conhecimento denominado Matemática (D’AMBROSIO, 2011, p. 39).

$\mathrm{Na}$ organização curricular da matemática, verificamos que não há uma consonância uniforme quanto à disposição dos conteúdos em unidades temáticas distintas e segmentadas, contendo em si seus objetos de conhecimento. Essa diversidade é favorável ao pensamento matemático, pois suscita outros debates e podendo conduzir a uma transição dessa forma de abordar os saberes, para uma outra mais dinâmica e integrada às outras ciências. Contribuímos com esse debate, enaltecendo a proposta de uma transdisciplinaridade versada por D’Ambrosio (2011), que suplanta as organizações internas do conhecimento em disciplinas, com prisma holístico do conhecimento, superando ainda as compulsórias limitações metodológicas e dos objetos de estudo, rompendo com o isolamento das partes de um todo. A transdisciplinaridade busca compreender a realidade integralmente, sustentando-se na retomada das múltiplas dimensões humanas, implicando a propulsão do respeito, da solidariedade e da cooperação entre os homens.

Percebemos ainda uma cisão entre o grupo de professores entrevistados, ao comparar os PCNM e a proposição da BNCC, enquanto uma norma para orientar os currículos das escolas, contendo os mínimos conteúdos a serem abordados. Os dados indicaram que 40\% das entrevistadas consideraram a BNCC um avanço e $60 \%$ sopesaram, enquanto um retrocesso para a qualidade do ensino de matemática.

Outros pontos conexos indicados pelas interlocutoras consignam informações críticas, primeiramente quanto à inexistência de um prazo para a revisão da BNCC. Notaram a expectativa da limitação do trabalho docente, restringindo-o tão somente ao que constar na BNCC. Apontaram a perspectiva da consolidação da desigualdade educacional entre as escolas públicas e privadas, visto que restará às primeiras a abordagem da BNCC e a possibilidade de outros assuntos, convertendo-se numa escola básica e mínima, enquanto na escola particular a formação tenderá a superar a mínima proposição, ampliando a formação humana das crianças. 
A partir da Resolução CNE/CP nº 2, de 22 de dezembro de 2017, o presidente do Conselho Nacional de Educação, órgão do MEC, instituiu e orientou a implantação da Base Nacional Comum Curricular, a ser respeitada obrigatoriamente ao longo das etapas e respectivas modalidades no âmbito da Educação Básica. A estrutura geral da BNCC reside na disposição das aprendizagens aplicadas às competências gerais, para a Educação Básica, estritamente para a Educação Infantil (EI) e Ensino Fundamental (EF).

Refletimos sobre esse projeto educacional que visa a uma formação comum aos diferentes brasileiros, corporificando-se na ideia da normatização dos currículos escolares, através da BNCC. Pondera-se se essa não é senão uma forma de homogeneizar um povo, de conservar seus atuais modos de conduta construídos sobre um processo histórico colonizador, de determinar o quê e o quanto um ensina e para que o outro deve aprender. A BNCC indica que os indivíduos deverão apenas ser hábeis para o uso dos conteúdos mínimos em sua vida cotidiana, sem que seja mencionado a possibilidade de construção de outros conhecimentos.

Ponderamos se a BNCC surgiu da necessidade da população brasileira, atendendo às urgentes demandas de uma nação que, ainda convive com a miséria e a fome, com a necessidade de uma revisão quanto a concentração de renda abundante para uma classe e mínima para a outra, com o aprofundamento dos conflitos sociais, e com a expansão da violência.

Provocamos uma reflexão sobre as reais intenções formativas contidas nas diretrizes e então convertemos ao cotidiano escolar e planejamento das práticas pedagógicas, atendendo aos alunos e sujeitos insertos na escola. Acreditamos, que assim, poderemos trilhar um insólito e exequível caminho para uma formação humana emancipatória, tendo como princípio a ética e o reconhecimento de si enquanto ser social capaz de transformar tais circunstâncias, em outras movidas para a paz e para a liberdade de pensamento e ação dos indivíduos brasileiros.

\section{REFERÊNCIAS}

BABBIE, Earl. Métodos de Pesquisa de Survey. Ed. UfMG. Belo Horizonte, 1999. 
BODIÃO, Idevaldo da Silva. Reflexões sobre as Ações da Sociedade Civil na Construção do PNE 2014/2024. Educação \& Realidade, Porto Alegre, v. 41, n. 2, p. 335-358, abr-jun. 2016.

BRASIL. Constituição da República Federativa do Brasil. Brasília, DF: Senado Federal, 1988.

. Lei no 9.394, de 20 de dezembro de 1996. Estabelece as diretrizes e bases da Educação Nacional. Diário Oficial [da] República Federativa do Brasil. Brasília, DF, 20 dez. 1996. Disponível em: <LeideDiretrizeseBasesNacionais>. Acesso em: 01 maio 2021.

Ministério da Educação/Secretaria de Educação Fundamental. Parâmetros curriculares nacionais: matemática. Brasília, MEC/ SEF, 1997. 142p.

. Lei no 13.005, de 25 de junho de 2014. Aprova o Plano Nacional de Educação - PNE 2014-2024 e dá outras providências. Presidência da República. Casa Civil. Subchefia para Assuntos Jurídicos. Brasília-DF, 2014.

. Ministério da Educação. Base Nacional Comum Curricular: um documento preliminar. $3^{\mathbf{a}}$ Versão. Secretaria da Educação Fundamental. Brasília, 2017. Disponível em: $<$ BaseNacionalComumCurricular> Acesso em: 22 abril. 2021.

Ministério da Educação. Plano de Desenvolvimento Nacional: razões, princípios e programas. Brasília, DF: MEC, 2007.

Ministério da Educação. Resolução no 2 de 22 de dezembro de 2017: Institui e orienta a implantação da Base Nacional Comum Curricular. Diário Oficial da União, Brasília, 22 de dezembro de 2017, Seção 1, pp. 41 a 44. Disponível em: <Resolução no 2 de 2017.> Acesso em: 01 de maio 2021.

BUENO, Maria Sylvia S. Políticas atuais para o ensino médio. Campinas-SP: Papirus, 2000.

CARVAlHO, João Bosco Pitombeira de. As propostas Curriculares de Matemática. In: Os currículos do Ensino Fundamental para as 
escolas brasileiras. Coleção formação de professores. Elba Siqueira de Sá Barreto. (Org.) São Paulo, SP: Editora Autores Associados. FCC, 1998.

D’AMBROSIO, Beatriz Silva. LOPES, Celi Espasandin. Insubordinação Criativa: um convite à reinvenção do educador matemático. Bolema, Rio Claro-SP, v. 29, n. 51, p. 1-17, abr. 2015.

D'AMBROSIO, Ubiratan. Educação para uma sociedade em transição. $2^{\underline{a}}$ ed. Natal, RN: EDUFRN, 2011. 258p.

FRIGOTTO, Gaudêncio. Educação e a Crise do Capitalismo Real. $5^{\underline{a}}$ ed. São Paulo, SP: Cortez, 2003.

LAKATOS, Eva Maria; MARCONI, Marina de Andrade. Técnicas de Pesquisa: planejamento e execução de pesquisas, amostragens e técnicas de pesquisa, elaboração, análise e interpretação de dados. $7^{a}$ ed. São Paulo: Atlas, 2016.

LOPES, Alice Casimiro. Políticas curriculares: continuidades ou mudança de rumos? Revista Brasileira de Educação. Rio de Janeiro, n. 26, maio-ago. 2004.

Discursos nas Políticas de Currículo. Currículo sem Fronteiras. v.6, n. 2, p. 33-52, jul-dez. 2006. Disponível em: <Curriculosemfronteiras> Acesso em: 01 de maio 2021.

MARX, K.; ENGELS, F. A sagrada família. São Paulo: Boitempo, 2003.

VERONEZE, Daniela Jéssica; NOGARO, Arnaldo. SILVA; Fernanda Levandoski;ZANOELLO, Simone de Fátima. Consensos e Dissensos entre os parâmetros curriculares nacionais e a base nacional comum curricular. XII Encontro Nacional de Educação Matemática. Educação Matemática na Contemporaneidade: desafios e possibilidades, São Paulo-SP, 13 a 16 de julho de 2016. 


\section{PERFIL DOCENTE NA EDUCAÇÃO INFANTIL: COMPETÊNCIA PROFISSIONAL OU QUESTÃO DE GÊNERO?}

Eduardo Gasperoni de Oliveira ${ }^{22}$

\section{INTRODUÇÃO}

O presente artigo visa buscar entendimentos ao perfil docente no segmento escolar da Educação Infantil, no sentido de refletir quais fatores devem ser levados em consideração, a fim de se afirmar se a aptidão para o magistério na Educação Infantil remonta à questão de gênero, ou se há predicativos que o educador, independentemente do gênero - deva possuir.

Por meio de adequada intervenção docente, via educação formal, independentemente do gênero, desde a tenra idade, pode acontecer a promoção de estratégias pedagógico-didáticas no intento de auxiliar no desenvolvimento, na aprendizagem e no cuidado com as crianças de 0 a 5 anos. Nesse sentido, urge por um sistema educacional que prime e valorize pela competência técnica e profissional do educador no sentido de colaborar com o integral desenvolvimento da criança no processo de

22 Mestre em Educação. Especialista em Psicopedagogia, Neurociências, Educação Infantil Gestão Escolar e Educação Especial Inclusiva. Graduado em Letras-Literatura, Pedagogia e Filosofia e Sociologia. Graduando em Música. Atua como professor universitário e gestor do segmento escolar da Educação Infantil. 
ensino-aprendizagem, possibilitando estimular os aspectos físicos, mental e sociocultural dos educandos.

É sabido que há um pequeno número de homens que atuam na Educação Infantil. Reduzido também se trata do número de pesquisas em torno dessa temática. Ao atuar no segmento escolar da infância, tanto a idoneidade, a habilidade quanto a masculinidade do educador são postas à prova.

De acordo com Tortora (2021), cabe à unidade escolar a tomada de consciência e de responsabilidade no que tange ao combate a qualquer tipo de discriminação ou preconceito. A instituição escolar necessita repensar alguns valores e dogmas do seu cotidiano, no sentido de que haja, um maior crescimento de homens atuando diretamente com as crianças da Educação Infantil. "Isso sem dúvida alguma ajudaria demais nessa missão" (TORTORA, 2021, s/p.).

A escolha dessa temática se deve não porque o proponente da pesquisa tenha sofrido, mesmo que de modo velado, algum tipo de preconceito ou situação vexatória, enquanto docente na Educação Infantil, mas sim, coloca-se na situação de modo empático, por isso trata-se de uma temática que deve ser rebatida no campo científico e profissional. Também se pauta na reflexão de Silva e Martins (2016) para justificar a realização deste capítulo no que tange à profissão docente e à relação de gêneros e masculinidade, pois a presença masculina na Educação Infantil é um assunto gerador muitos debates, que são motivados, normalmente, pelo senso comum e sua tendência no que concerne à distorção da realidade sobre essa temática.

A partir do exposto, foi pensado este capítulo que tem como problema a possibilidade de se repensar o perfil docente que atua no segmento escolar da Educação Infantil a fim de se repensar e valorizar a questão das competências que o educador ou a educadora devam possuir, abastando qualquer ranço histórico que ainda defenda que a mulher é a mais capacitada para o cuidado e para a educação das crianças. Este problema se desdobra na seguinte problematização que foi levantada em seu próprio título: "Perfil Docente na Educação Infantil: Competência Profissional ou Questão de Gênero?"

A hipótese que se defende é que, independentemente do gênero, a educação da/na Infância é muito séria e requer profissionais capacitados 
para tanto. Não se trata de dom, amor, vontade ou missão. E é na direção de busca de sua confirmação que é realizada esta pesquisa. Há diversos autores do campo da Pedagogia, sustentado pela legislação vigente brasileira e pelo próprio ramo do conhecimento da Sociologia da Infância, que enfatizam em suas obras, a relevância da atuação docente no sentido de mediar práticas pedagógicas intencionais no sentido de colaborar com o desenvolvimento global da criança, concebendo-a sob a questão biopsicomotora-social, estimulando-a a fim de que venha se desenvolver integralmente, ampliando seu repertório de vivências, descobertas e experiências.

De caráter bibliográfico, buscou-se em ideias de alguns autores não somente a confirmação desta possibilidade, mas a indicação de alguns caminhos nesta direção, ou seja, qual a relevância da atuação docente na Educação Infantil e como seu o perfil desse profissional vai sendo construído.

Em relação à sua estrutura, primeiramente, traz considerações sobre as implicações relacionadas à docência e a questão do gênero. Em seguida, abordam-se algumas legislações brasileiras que devem conduzir a atuação de educadores e de educadoras na Educação Infantil. Também são trazidos apontamentos da Sociologia da Infância, pois a atuação docente perpassa, primeiramente, com a concepção de criança e de infância que se tem. E, por fim, traz à discussão três pilares relevantes que devem fazer parte da rotina dos educadores e das educadoras quando atuam na Infância. São eles: a Afetividade, a Ludicidade e a Psicomotricidade.

\section{A QUESTÃO DO GÊNERO E SUAS IMPLICAÇÕES NA DOCÊNCIA NA EDUCAÇÃO INFANTIL}

De acordo com Almeida (apud RABELO, 2013, p. 910-911), "sendo o sexo determinado antes do nascimento por processos biológicos naturais, o gênero é um produto cultural adquirido e transmitido nas estruturas sociais".

Ao se analisar como se desenvolvem as relações de gênero na educação, principalmente no que se refere à presença masculina na docência infantil, Santos (2015) traz alguns dados do Censo educacional (2012): no montante de dois milhões de docentes da Educação Básica brasileira, para cada 4 mulheres há somente um homem. Na Educação Infantil, de 429,8 
mil professoras, somente 13,5 mil são homens. Isso demonstra o quanto a docência infantil tem sido desenvolvida predominantemente por mulheres e que pode se desenvolver um entendimento de como a educação tem sido usada como sustentáculo às "desigualdades raciais e de gênero, bem como hierarquias sociais".

Acerca do aspecto sexualidade, convém trazer as contribuições de Silva (2012, p. 2) ao dizer que diversos conceitos se fundamentam apenas no senso comum, o que pressupõe um disfarce "numa suposta igualdade" que no primeiro conflito mostra seu preconceito, tendo em vista que toda mudança nos costumes ainda está carregada de discriminações relacionadas ao gênero. E todo esse preconceito ainda tem a escola como agência colaboradora à sua formação, peculiarmente por meio do "currículo oculto". Todavia, a concepção curricular, sob "uma prática pedagógica crítica", está relacionada com a questão da diversidade "como uma questão histórica e política”, não importando somente a celebração da diferença e da diversidade, mas sim, principalmente, seu questionamento.

$\mathrm{Na}$ Educação Infantil, a presença masculina é um raro fenômeno diante do predomínio histórico do gênero feminino na atuação docente com crianças. Para Sousa (2015), quanto menor a faixa etária das crianças, menor também é o índice de homens que trabalham na Educação Infantil. Além de que, ao ingressar numa creche ou pré-escola, facilmente há a constatação da pequenez ou até inexistência masculina em relação à docência.

Saparolli (apud SILVA; MARTINS, 2016) profere que, geralmente, a predominância de mulheres no magistério brasileiro tem a explicação pautada na perspectiva mais ampla da divisão sexual laboral - componente mundialmente presente no mercado de trabalho - princípio organizador fundamentado na preexistência de relações sociais hierarquizadas entre os sexos.

No decorrer histórico, a representação de que o homem não pode tocar na criança, mesmo diante da necessidade e da obrigação da profissão, fica expresso nas falas e nas concepções acerca da atuação docente masculina na Educação Infantil. Sayão (apud GONÇALVES et al., 2015 p. 14) atenta que o "poder masculino" é concebido como principal agressor de crianças e mulheres. Todavia, é preciso bastante cautela ao generalizar o homem como aquele principal ator que oprime fisicamente a criança: 
[...] com a incorporação irrefletida dessas crenças e preconceitos perdemos na vivência das relações. Em especial quando tendemos à generalização de alguns casos divulgados pela mídia, ou não, em face do que preconceitos são criados e podem ser incorporados de maneira acrítica, inclusive no magistério (SAYÃO apud GONÇALVES et al., 2015, p. 14).

Santos (2015, p. 65) profere que há a percepção de que a participação do homem na docência da Infância se desenvolve, muitas vezes, "em meio a preconceito, estigmas e desvalorização", tendo em vista que as relações de gênero ainda permeiam as unidades escolas e isto decorre da própria história brasileira em que o patriarcalismo bem como o autoritarismo acabaram por influenciar seriamente, na história brasileira, os processos de exclusão da mulher, homossexuais, negros etc.

Isso define bem que há um preconceito ou estereótipos sobre homens e mulheres: agressivos, militaristas, racionais, para eles; dóceis, relacionais, afetivas, para elas. Em decorrência, funções como alimentação, maternidade, preservação, educação e cuidado com os outros ficam mais identificadas com os corpos e as mentes femininas, ganhando, assim, um lugar inferior na sociedade, quando comparadas às funções tidas como masculinas (SCOTT apud SOUSA, 2015, p. 65).

Gonçalves et al. (2015, p. 11) tentam entender o motivo que o magistério se tornou um setor de atuação feminina. Reportam que esta profissão, sob a aprovação da sociedade, foi uma das precursoras que se abriu para as mulheres. Todavia, elas foram conduzidas para este labor "sob a relação da tarefa educativa com a materna". A docência, tradicionalmente, é "uma profissão vista como feminina. Lidar com criança é serviço de mulher". Infelizmente, grande parte da sociedade assim pensa (NOVAES apud GONÇALVES et al., 2015, p. 6).

Historicamente, a Educação Infantil é uma profissão e atuação majoritariamente feminina. Em distinção dos outros segmentos educacionais, a Educação Infantil nasce como "campo feminino", "território de atuação das mulheres" (PEREIRA, 2016, p. 13). Assim, os profissionais homens passam por inúmeros desafios. Trata-se de "questões inviabili- 
zadas e silenciadas, questões conflitivas que permeiam o cotidiano e as relações entre a instituição e a família" (PEREIRA, 2016, p. 14), o que nos leva a reflexão.

[...] a inscrição dos gêneros - feminino ou masculino - nos corpos é feita, sempre, no contexto de uma cultura e, portanto, com as marcas dessa cultura. As identidades de gênero e sexuais são, portanto, compostas, definidas e moldadas pelas redes de poder de uma sociedade, consequentemente, são vivenciadas diferentemente, por que homens e mulheres têm papeis diferentes que lhes são atribuídos, e é no campo das relações sociais que se constroem e se reproduzem as desigualdades entre os sujeitos (PEREIRA, 2016, p. 26).

Para Gonçalves et al. (2015, p. 11), o estranhamento culmina em preconceito ao ver um homem trabalhando na docência de crianças pequenas. Isso se deve de acordo com a perspectiva das representações sociais, que é ocasionado "pelo desconhecido ou não-familiar". Indo ao encontro das reflexões de Sá (apud GONÇALVES et al., 2015, p. 11): "o estranho atrai, intriga e perturba as pessoas e as comunidades, provocando nelas o medo da perda dos referenciais habituais, do senso da comunidade e de compreensão mútua”. Toda essa estranheza pode estar relacionada com a questão das representações sociais que, na Educação Infantil também se fazem presentes, inclusive nas relações de gênero. Tal fato, pode ser explicitado pelo grande predomínio feminino de educadoras e a escassa presença masculina dentre os docentes. Talvez o motivo para tanto se deva a especificidade desta etapa educacional relacionada ao "binômio educar/ cuidar”, e que, culturamente, esta função foi atribuída à mulher (GONÇALVES et al., 2015, p. 1).

Para Rabelo (2013), nos dias contemporâneos, quando há o enfoque das vozes femininas nas investigações educacionais, pode se correr o risco de desconhecer o pensamento dos homens que se enveredam pela docência e o processo de adaptação/recriação do masculino no ambiente escolar. Nesse segmento escolar, quando se trata do olhar do homem professor, concebido como "um corpo estranho", quase não há referências à temática, "e mais, os preconceitos e discursos que frequentam a sociedade contem- 
porânea são reafirmados no cotidiano escolar" (RABELO, 2013, p. 909 -itálicos nossos).

Gonçalves et al. (2015, p. 12) trazem à discussão acadêmica a questão da importância de se ter educadores homens com a "necessidade de modelos positivos de masculinidade e com a contribuição para a diversidade e equidade de gênero na educação".

Como se pode perceber, as construções em torno do gênero se dão distintamente em meio a sociedade e, sendo a escola, uma relevante célula social, cabe que tais reflexões em torno das representações sociais e dos gêneros tenham como palco a instituição escolar no sentido de colaborar com uma educação que lute pela diversidade e pela equidade.

\section{LEGISLAÇÃO BRASILEIRA E COMPETÊNCIA DOCENTE DA INFÂNCIA}

Para abordar sobre as competências relevantes ao perfil do educador da Infância, convém recorrer à legislação vigente brasileira. Aqui serão apontadas algumas delas, enfocando as atribuições necessárias que devem constituir o perfil docente no segmento da Educação Infantil, pois:

Os objetivos propostos para a educação infantil independem do gênero do profissional, assim homens e mulheres podem desempenhar um bom trabalho na educação infantil e proporcionar à criança pequena contato aos bens socialmente construídos pela humanidade [...] (CAMPOS apud TEODORO, 2021, p. 5).

A Constituição Federal Brasileira de 1988 reconhece a educação em creches e pré-escolas como um dever do Estado a ser cumprido nos sistemas de ensino assegurado às crianças (BRASIL, 1999). Particularmente no artigo 208, incisos I e IV, a Educação Infantil: "I - educação básica obrigatória e gratuita dos 4 (quatro) aos 17 (dezessete) anos de idade; [...] IV - educação infantil, em creche e pré-escola, às crianças até 5 (cinco) anos de idade; (Redação dada pela Emenda Constitucional no 53 , de 2006)" (BRASIL, 2021 b). Percebem-se aí dois aspectos relevantes à educação das crianças: tanto a gratuidade quanto a obrigatoriedade. 
A Lei de Diretrizes e Bases da Educação Nacional nº 9.394/1996 (BRASIL, 1996) defende um novo arquétipo de Educação Infantil, etapa inicial da educação básica, "conquista histórica que tira as crianças pobres de seu confinamento em instituições vinculadas a órgãos de assistência social" (OLIVEIRA, 2001, p. 117), possibilitando a ação de distintos modos de organização e práticas pedagógicas.

No artigo 29, segundo capítulo, há uma redação que delimita a faixa etária do público-alvo da Educação Infantil, bem como a finalidade dessa etapa formativa, conforme segue:

A educação infantil, primeira etapa da educação básica, tem como finalidade o desenvolvimento integral da criança até seis anos de idade, em seus aspectos físico, psicológico, intelectual e social, complementando a ação da família e da comunidade (BRASIL, 1996).

Tendo em vista que a escola faz parte de um sistema, há que se perceber como a legislação entende o que é a Educação Infantil, para quem ela existe, o que ela representa para a sociedade e como essa mesma legislação norteia e regula os passos daqueles que se envolvem na tarefa de trabalhar com crianças de 0 a 5 anos de idade. Trata-se de relevantes informações que devem nortear à prática docente, revelando a concepção holística em que o desenvolvimento infantil deva ser concebido.

Desse modo, o educador da Infância tem como intuito auxiliar no pleno desenvolvimento das crianças, integrando a função de cuidar e educar. Essa integração é transcrita no Referencial Curricular Nacional para a Educação Infantil - R. C. N. E. I. (BRASIL, 2001), em seu primeiro volume, que traz a associação entre "cuidar" e "educar", concebidos como pilares fundamentais à prática da Educação Infantil. Valorizando tais princípios, enquanto educadores, na prática cotidiana, alcança-se uma "pedagogia mais educacional, afetiva, mais completa e humana" (OLIVEIRA, 2001, p. 24).

As Diretrizes Curriculares Nacionais para a Educação Infantil (BRASIL, 2010) descritas na Resolução CNE/CEB nº 5, de 17 de dezembro de 2009, ampliam a definição anterior no artigo 5ㅜㄹ definindo os locais de atendimento: 
Primeira etapa da Educação Básica, oferecida em creches e pré-escolas, às quais se caracterizam como espaços institucionais não domésticos que constituem estabelecimentos educacionais públicos ou privados que educam e cuidam de crianças de 0 a 5 anos de idade no período diurno, em jornada integral ou parcial, regulados e supervisionados por órgão competente do sistema de ensino e submetidos a controle social (BRASIL, 2010, p. 12).

Avançando na compreensão a respeito de Educação infantil, cabe nesse momento atentar para três aspectos e que o educador deste segmento deve estar ciente: $O$ primeiro, sobre o que é a Educação Infantil e o segundo, sobre por que ela existe, e, por fim, o terceiro, o local onde ela deve ocorrer. No que concerne ao primeiro questionamento entende-se que é uma forma de educação sistemática voltada à criança. No que consiste ao segundo aspecto apresentado entende-se que ela existe como parte estruturante da educação e da sociedade. E, finalmente, no terceiro aspecto, os locais de atendimento, inaugurando, assim, nesse segmento, a educação formal.

Concerne, pois, a uma forma de educação sistemática voltada à criança a qual, por sua vez é assim compreendida:

Sujeito histórico e de direitos que, nas interações, relações e práticas cotidianas que vivencia, constrói sua identidade pessoal e coletiva, brinca, imagina, fantasia, deseja, aprende, observa, experimenta, narra, questiona e constrói sentidos sobre a natureza e a sociedade, produzindo cultura (BRASIL, 2010, p. 12).

A Base Nacional Comum Curricular - BNCC (BRASIL, 2021 a) está alicerçada nas D. C. N. E. I. (BRASIL, 2010), que em seu artigo 9ำ, traz que os eixos nos quais são estruturadas as práticas pedagógicas da Educação Infantil trata-se das interações e da brincadeira.

A interação durante o brincar caracteriza o cotidiano da infância, trazendo consigo muitas aprendizagens e potenciais para o desenvolvimento integral das crianças. Ao observar as interações e a brincadeira entre as crianças e delas com os adultos, é possível identificar, por exemplo, a expressão dos afetos, a mediação das frustrações, a resolução de conflitos e a regulação das emoções (BRASIL, 2021 a, p. 35). 
Cabe a figura docente reconhecer as especificidades dos distintos grupos etários que formam a etapa da Educação Infantil e os objetivos de aprendizagem e desenvolvimento que são organizados em três grupos de faixas etárias em cada campo de experiências. Cada grupo concerne a uma determinada faixa etária de desenvolvimento e de aprendizado e são denominados: Bebês (de zero a 1 ano e seis meses); Crianças Bem Pequenas (de 1 ano e sete meses a 3 ano e onze meses) e Crianças Pequenas (de 4 anos a 5 anos e onze meses). Tal documento também dividiu a instituição escolar de Educação Infantil, de acordo com estes grupos etários, sendo: Creche - abrangendo de bebês de 0 a crianças de 3 anos e 11 meses e Pré-Escola - abrangendo crianças com faixas etárias de 4 a 5 anos e 11 meses de idade. "Todavia, esses grupos não podem ser considerados de forma rígida, já que há diferenças de ritmo na aprendizagem e no desenvolvimento das crianças que precisam ser consideradas na prática pedagógica" (BRASIL, 2021 a, p. 42).

Seis direitos de aprendizagem e de desenvolvimento garantem, na Educação Infantil, os meios a fim de que as crianças aprendam em circunstâncias nas quais possam desempenhar uma ativa função em ambientes que as convidem à vivência, aos desafios, às provocações e à autonomia de resolvê-los, colaborando na construção de significados sobre si, os outros e o mundo social e natural (BRASIL, 2021 a), são eles: Brincar, Conhecer-se, Conviver, Explorar, Expressar e Participar.

Como se pode perceber, nenhuma legislação brasileira trata da Educação Infantil como um campo de atuação exclusivamente feminino, mas apresenta subsídios que vão nortear a prática docente, não distinguindo homens de mulheres, trazendo importantes apontamentos sobre este segmento escolar, abrangendo desde sua finalidade, prática pedagógica intencional; sobre a infầncia e sobre a criança, o que "sustenta o saber-fazer pedagógico do professor da educação infantil” (TEODORO, 2021, p. 4).

\section{CONTRIBUIÇÕES DA SOCIOLOGIA DA INFÂNCIA PARA O PERFIL DO EDUCADOR NA EDUCAÇÃO INFANTIL}

A construção do perfil docente na Infância remete à qual concepção de criança e de infância o(a) educador(a) possui. Todavia esta concepção é complexa, pois: 
A concepção de criança é uma noção historicamente construída, que consequentemente vem mudando ao longo dos tempos apresentando concepções bastante divergentes sobre sua finalidade social. A preocupação atual reflete a ideia de que a criança desde que nasce necessita de um espaço de socialização e aprendizado abandonando a ideia de apenas assistir e cuidar. É nessa perspectiva que o atendimento das crianças de 0 a 6 anos de idade vem sendo refletido e estudado no sentido de buscar novas formas de relações na prática pedagógica desenvolvida nas instituições de atendimento às crianças pequenas. Toda essa evolução envolvendo a criança menor de 7 anos de idade vem favorecer a abertura de novos caminhos e possibilidades para a formação das intenções pedagógicas e sociais, apontando outras tendências e desafios educacionais que garantam uma prática comprometida e eficiente, promotora do desenvolvimento psicológico, intelectual e social da criança (DORIGO; NASCIMENTO, 2007, p. 16).

Santos e Lauro (2021) afirmam que o ser humano é um ser em constante construção e transformação. A fase da vida da criança apresenta algumas particularidades no desenvolvimento físico, motor e cognitivo distinto do mundo adulto. Assim, torna-se possível a compreensão de que:

[...] a criança mantém dimensões relacionais construídas nas interações entre seus pares e das crianças com os adultos, estruturando-se nessas relações formas e conteúdos representacionais distintos, elas exprimem a cultura societal em que se inserem, mas fazem-no de modo distinto das culturas adultas, ao mesmo tempo em que veiculam formas especificamente infantis de inteligibilidade, representação e simbolização do mundo (SANTOS ;LAURO, 2021, p. 5-7).

Na mesma linha de raciocínio, a nova pedagogia da infância dos dias contemporâneos concebe a criança como interativa, isto é, que interage e produz cultura:

Olhar a criança como ser que já nasce pronto, ou que nasce vazia e carente dos elementos entendidos como necessários à vida 
adulta ou, ainda, a criança como sujeito conhecedor, cujo desenvolvimento se dá por sua própria iniciativa e capacidade de ação, foram, durante muito tempo, concepções amplamente aceitas na Educação Infantil até o surgimento das bases epistemológicas que fundamentam, atualmente, uma pedagogia para a infância. Os novos paradigmas englobam e transcendem a história, a antropologia, a sociologia e a própria psicologia resultando em uma perspectiva que define a criança como ser competente para interagir e produzir cultura no meio em que se encontra (BRASIL 2006, p. 13) [itálicos meus].

É relevante trazer contribuições do campo de estudo denominado Sociologia da Infância que, desde a década de 1980, vem contribuindo para a "quebra de paradigmas sobre a infância" (DAHLBER; MOSS; PENCE apud ANDRADE, 2010, p. 66), colaborando, assim, para que se desvincule a visão adultocêntrica da criança, enquanto faixa etária, uma etapa psicológica, um adulto em miniatura, um ser passivo, um ser incompleto etc., mas sim, uma concepção construída por aspectos sócio-históricos. Portanto, a figura docente, seja homem ou mulher, não deve se esquecer de que a criança é ativa, é viva, é esperta, é curiosa, é investigativa, é influenciada pelo meio, mas também o influencia de modo inciso. Ela é protagonista que colabora com sua construção, mas também com a construção sociedade.

Em suma, sua concepção de criança e de infância está intrinsecamente relacionada com sua atuação pedagógica.

\section{OS PILARES RELEVANTES À PRÁTICA DOCENTE NA EDUCAÇÃO INFANTIL}

Neste momento, quer-se enfocar em três pilares, concebidos como relevantes para o desenvolvimento infantil e que devem conduzir a prática docente, independente do gênero de quem atua.

\subsection{A AFETIVIDADE}

Durante a vida, os acontecimentos serão experiências que passarão a fazer parte da consciência, apesar de que indivíduos diferentes vivenciam os mesmos fatos, cada um deles sentirá tais situações de modo peculiar. 
Esta singularidade em relação à forma que esses acontecimentos atingem afetam - os indivíduos, seja na família, escola ou trabalho, remete à questão da afetividade (OLIVEIRA, 2009).

Conforme o Dicionário Aurélio (FERREIRA, 1975, p. 44), a afetividade concerne ao "conjunto de fenômenos psíquicos que expressam paixões e sentimentos, acompanhados sempre da impressão de dor, insatisfação, de agrado ou desagrado, de alegria ou tristeza".

A fim de comprovar importância da afetividade ao desenvolvimento infantil, pode-se buscar subsídios teóricos na obra O Pequeno Príncipe, de Saint-Exupéry (2015). Na fábula, o principezinho se depara pelos muitos planetas com distintas personagens que vieram a contribuir para seu desenvolvimento e crescimento. Em sua jornada, também se torna amigo de uma raposa, que lhe passa muitas lições, mas, a mais importante: o amor consiste na responsabilidade perante o ser amado.

$\mathrm{Na}$ Educação Infantil, principalmente, é fundamental que educadores e educandos estabeleçam relações baseadas no diálogo, que é um potencial facilitador e motivador de troca de ideias, esclarecimentos de dúvidas e, sobretudo, a maneira mais eficaz de construção da afetividade. O diálogo possibilita que a criança e o educador se conheçam e se compreendam melhor, consolidando assim vínculos de afeto.

Cativar algo ou alguém remete ao estabelecimento e à constituição de um relacionamento e esta ação implica responsabilidade. Ao cativar sua Rosa, o principezinho foi responsável por ela. Portanto, o pequenino aventureiro faz refletir e perceber a importância do vínculo, pois "Mas, se tu me cativas, nós teremos necessidade um do outro" (SAINT-EXUPÉRY, 2015, p. 66).

Pode-se observar o trecho em que a misteriosa Raposa que criou um relevante vínculo de amizade com nosso aventureiro: "- Eu procuro amigos. Que quer dizer 'cativar'? [disse o pequenino] - Significa 'criar laços...' [respondeu a raposa]” (SAINT-EXUPÉRY, 2015, p. 65).

A ação de criar laços e criar vínculos remete à ação daquilo que ata, que liga, que possui um laço, que se relaciona, enfim, a um relacionamento. Quando se perpassa esse relacionamento ao âmbito da instituição escolar, pode-se com veemência afirmar o importante papel do educador. "Tu te tornas responsável por aquilo que cativas" (SAINT-EXUPÉRY, 2015, p. 70-72). Ou seja, ao transferir essa relação cativante ao campo 
educacional, pode-se afirmar que ao estabelecer vínculo afetivo favorável entre educador e educando, peculiarmente na Educação Infantil, colabora-se com o processo de aprendizagem e de desenvolvimento da criança.

\subsection{A LUDICIDADE}

Referencial de vida à criança e considerado um conceito que deve permear todo o fazer pedagógico na Educação Infantil, o lúdico ganha sentido especial nesta etapa da Educação Básica. O primeiro volume do R. C. N. E. I. (BRASIL, 2001, p. 13) traz: "direito das crianças a brincar, como forma particular de expressão, pensamento, interação e comunicação infantil".

O lúdico tem valores peculiares a todas as fases da vida humana, tendo finalidades essencialmente prazerosas e também pedagógicas, promovendo "um estado de inteireza, de plenitude naquilo que se faz com prazer e pode estar presente em diferentes situações da vida. É uma necessidade básica da personalidade, do corpo e da mente, faz parte das atividades essenciais da dinâmica humana" (SAMPAIO et al., 2021).

As atividades lúdicas propiciam o integral desenvolvimento da criança, já que, por meio destas, ela opera mentalmente, se desenvolve afetivamente e convive socialmente. Para tanto, a ludicidade é uma necessidade do sujeito em qualquer faixa etária e não pode ser concebida como diversão apenas. Ela é altamente educativa (GRANDIS, 2021).

\subsection{A PSICOMOTRICIDADE}

Rosa Neto e Poeta (2009) proferem que a psicomotricidade se trata da capacidade de coordenar os movimentos pressupondo o exercício de múltiplas funções psicológicas, motoras, de memorização, observação, atenção, raciocínio, discriminação etc. Pode-se perceber que a relevância sobre o aspecto do movimento para o desenvolvimento como um todo na criança, isto é, sobre seu desenvolvimento global da criança.

A educação psicomotora abrange todas as aprendizagens da criança e é indispensável às aprendizagens escolares. Quer dizer, o desenvolvimento do esquema corporal, lateralidade, estruturação espacial e orientação tem- 
poral são fundamentais às aprendizagens futuras (ROSA NETO; POETA, 2009).

\section{CONSIDERAÇÕES FINAIS}

Docência na Educação Infantil: competência profissional ou questão de gênero? $\mathrm{O}$ aporte teórico conduziu à busca de respostas para o presente capítulo. Diante do exposto e é o que se defende, a competência profissional da figura docente é mais relevante do que o gênero de quem atua. Requer estudo, dedicação, conhecimento, ser um eterno aprendiz, pois a figura docente tem parcela relevante na educação das crianças que pode potencializá-las, transformá-las ou matá-las. Para tanto, deve-se compreendê-las nesse devir, encarando-as como possibilidades de outros mundos, probabilidades de outras visões, sentidos, cores, distintas daquelas projetadas pelo adulto.

O referencial teórico colaborou no sentido de que, nos dias contemporâneos, em relação às práticas pedagógicas desenvolvidas na Educação Infantil; em suma, concernem em colaborar com o desenvolvimento da criança, sob o viés holístico, e que a figura docente, independentemente do gênero, urge por formação adequada, concebendo a criança como sujeito protagonista de sua história, como sujeito biológico, cultural, social etc.

Torna-se imprescindível a consciência de que as condições pedagógicas intencionais, visando à emancipação da criança, por intermédio de experiências de acolhida, de respeito, de diálogo, de autonomia, de cooperação, de experimentação, de descoberta, de investigação [...] farão com que ela vivencie experiências positivas e se desenvolva por completo, o que requer competência profissional para tanto, abastando o caráter relacionado a gênero.

Em vista dos argumentos apresentados, constatou-se o caráter relevante da Educação Infantil ao colaborar na transformação social, por isso a reflexão sobre a questão dos gêneros se faz relevante. Enfim, este capítulo prima em favorecer a reflexão e a discussão sobre condições de equidade entre gênero, para combater situações em torno do preconceito e do sexismo na Educação [Infantil], minimizando, assim, qualquer [pré]conceito carregado de estereótipos em torno das funções de homens e mulhe- 
res e das discriminações em torno do gênero, valorizando as diferenças no histórico das relações humanas.

Assim, poderá se pensar numa educação, de fato, democrática, equânime, justa, inclusiva, e, acima de tudo, humana.

\section{REFERÊNCIAS}

ANDRADE, L. B. P. de. Tecendo os fios da infância. Educação infantil: discurso, legislação e práticas institucionais [on-line]. São Paulo: UNESP/ Cultura Acadêmica. 2010. Disponível em: <http://books. scielo.org/id/h8pyf/pdf/andrade-9788579830853-06.pdf>. Acesso em: 16 abr. 2021.

BRASIL. Base Nacional Comum. Disponível em: <http://basenacionalcomum.mec.gov.br/\#/dia-base>. Acesso em 28 abr. 2021a.

. Constituição (1988). Constituição federal. 4 ed. São Paulo: Revista dos Tribunais, 1999.

. Constituição (1988). Constituição federal. Disponível em: <http://www.planalto.gov.br/ccivil_03/constituicao/ConstituicaoCompilado.htm> Acesso em: 11 abr. 2021b.

. Diretrizes Curriculares Nacional da Educação Infantil. Ministério da Educação. Secretaria Educação Básica. Brasília: MEC/ SEB, 2010.

. Lei no 9.394, de 20 de dezembro de 1996. Estabelece as Diretrizes e Bases da Educação Nacional. Diário Oficial da União, de 23 dez. 1996.

\section{. Parâmetros nacionais de qualidade para a educação infan-}

til. Ministério da Educação. Secretaria de Educação Básica. Secretaria de Educação Básica - Brasília. DF. v. 1. Brasília, 2006.

\section{. Referencial Curricular Nacional para a Educação Infantil.} Ministério da Educação e do Desporto. Secretaria de Educação Básica. Secretaria de Educação Básica - Brasília. DF. v. 1. Brasília, 2001. 
DORIGO, H. M. G.; NASCIMENTO, M. I. M. do. A concepção histórica sobre as crianças pequenas: subsídios para pensar o futuro. Educare et Educare - Revista de Educação. v. 2, n. 3. p. 15-32. Jan/jun. 2007. Disponível em: <http://e-revista.unioeste.br/ index.php/educereeteducare/article/download/652/544>. Acesso em 1ำ maio 2021 .

FERREIRA, A. B. de H. Novo dicionário de língua portuguesa. Rio de Janeiro: Nova Fronteira, 1975.

GRANDIS, E. D. de O. A brincadeira como mediadora no desenvolvimento da criança. Disponível em: <http://www. cefaprojuina.com/portal/index.php?option=com_content\&view $=$ article $\& \mathrm{id}=515$ : brincadeira-mediadora-desenvolvimento-crianca\&catid=57:autoria\&Itemid=71>. Acesso em: 30 abr. 2021.

GONÇALVES, J. P. et al. O trabalho de homens professores com crianças de educação infantil: as representações sociais dos gestores escolares. Itinerarius Reflections. v. 11. n. 1, 2015. Disponível em: <https://www.revistas.ufg.br/rir/article/view/35108>. Acesso em: 22 abr. 2021.

OLIVEIRA, E. G. de. A relevância da afetividade para o processo ensino-aprendizagem na educação infantil. $104 \mathrm{f}$. Monografia (especialização em Psicopedagogia) - Universidade Estadual do Norte do Paraná - UENP, Jacarezinho-PR, 2009.

OLIVEIRA, Z. de M. R. de. Educação infantil: muitos olhares. 5 ed. São Paulo: Cortez, 2001.

PEREIRA, M. A. B. Professor homem: estrangeiro na educação Infantil. Curitiba: Appris, 2016.

RABELO, A. O. Professores discriminados: um estudo sobre os docentes do sexo masculino nas séries do ensino fundamental. Educ. Pesqui., São Paulo, v. 39, n. 4, p. 907-925 out./dez. 2013. Disponível em: 〈https://www.scielo.br/pdf/ep/v39n4/aop1132.pdf>. Acesso em: 15 abr. 2021. 
ROSA NETO, F.; POETA L. S. Desenvolvimento Psicomotor. UNIASSELVI. Indaial-SC: UNIASSELVI, 2009.

SAINT-EXUPÉRY, A. de. O Pequeno Príncipe. São Paulo: Escala, 2015.

SAMPAIO, I. C. de M. et al. O lúdico nas séries iniciais do ensino fundamental. Disponível em: <http://knol.google.com/k/o-l\%C3\%BAdico-nas-s\%C3\%A9ries-iniciais-do-ensino-fundamental\#>. Acesso em: 30 abr. 2021.

SANTOS, A.; LAURO, B. R. Infância, criança e diversidade: proposta e análise. Disponível em: <www.ufff.br/virtu/2010/04/artigo-2a23.pdf>. Acesso em: 1ํ maio 2021.

SANTOS, W. S. Corpos estranhos: um estudo sobre a presença masculina na docência infantil. In: Alumni. Revista Discente da UNIABEU. v. 3. n. 5. Jan./jul. 2015. p. 65-75. Disponível em: <https:// revista.uniabeu.edu.br/index.php/alu/article/view/1812/0>. Acesso em: 22 fev. 2021.

SILVA, J. R. da.; MARTINS, V. L. O professor homem na educação infantil: um olhar acerca do preconceito. In: Revista científica Intr@ciência. 11. jun. 2016. Disponível em: <https://docplayer. com.br/27636574-O-professor-homem-na-educacao-infantil-um-olhar-acerca-do-preconceito.html>. Acesso em: 22 set. 2018.

SILVA, S. M. P. da. Gênero e sexualidade na formação docente continuada e nos espaços escolares: uma análise do Curso GDE na UFMA. In: Seminário Internacional Fazendo Gênero 10 - Desafios Atuais dos Feminismos. Florianópolis, 2012. ISSN 2179-510X. Disponível em: <http://www.fg2013.wwc2017.eventos.dype.com. br/resources/anais/20/1381507440_ARQUIVO_SirleneSilva.pdf>. Acesso em: 22 abr. 2021.

SOUSA, J. E. de. Homem docência com crianças pequenas: o olhar das crianças de um centro de educação infantil. In: 37 ${ }^{\mathbf{a}}$ Reunião Nacional da ANPEd. 4-8 out. 2015. UFSC. Florianópolis. Disponível 
em: <http://37reuniao.anped.org.br/wp-content/uploads/2015/02/ Trabalho-GT07-4232.pdf>. Acesso em: 22 abr. 2021.

TEODORO, L. G. O gênero masculino na docência da educação infantil: a convivência com professoras e diretoras face ao trabalho pedagógico In: IX Seminário Internacional de La Red Estrado. Disponível em: <http://redeestrado.org/xi_seminario/pdfs/eixo8/298. pdf>. Acesso em: 10 abr. 2021.

TORTORA, E. Professor homem na Educação Infantil: conheça os desafios e experiências. 26 jan. 2021. Disponível em: <https://novaescola.org.br/conteudo/20083/colunas-pedagogicas-21-evandro-tortora-professor-homem-na-educacao-infantil>. Acesso em: 10 abr. 2021. 


\section{CAPOEIRA: ABORDAGEM PARA UMA EDUCAÇÃO ÉTNICA-RACIAL}

Daiane Nonato de Lima ${ }^{23}$

José Morais Souto Filho ${ }^{24}$

\section{INTRODUÇÃO}

A capoeira é uma representação cultural que mistura luta e dança, caracterizada por movimentos rápidos, ágios e acrobáticos. É praticado em roda ao som de cantigas e instrumentos tocados por outros capoeiristas. Sua criação é atribuída aos negros africanos trazidos como escravos para o Brasil. Segundo Oliveira e Leal (2009), até a metade do século XVIII, a prática da capoeira era predominantemente de negros africanos. A capoeira, como luta de matriz afro-brasileira, traz consigo aspectos relacionados ao cotidiano dos negros escravos e seus descendentes. Seus costumes, crenças, relação com a terra, conflitos e opressões são alguns elementos que envolvem e influenciam as características peculiares dessa manifestação. As suas cantigas trazem letras que retratam a forma de vida, luta e reivindicações históricas dos negros brasileiros.

O termo "capoeira" refere-se à área de vegetação rasteira, onde era praticado pelos escravos brasileiros. Segundo Rego (1968), em seu livro, relata que o termo deriva do tupi: caá-apuam-era, que, traduzido, significa mato já cortado. Ora considerada luta, ora vista como dança, essa mani-

23 Mestra em Dança pela Universidade Federal da Bahia-BA.

24 Doutor em Educação Física pela Universidade Católica de Brasília-DF. 
festação foi a forma dos escravos se expressarem corporalmente "gritando" por liberdade.

A hipótese entre historiadores é que a ginga e a música na capoeira eram a forma que os negros escravos encontraram para iludir os senhores de engenho e seus capatazes, para que eles acreditassem que se tratava de uma comemoração entre os negros, e não uma forma de luta. No livro Memórias de um Sargento de Milícias, escrito por Manuel Antônio de Almeida, o escritor relata que, no Rio de Janeiro, no século XIX, bandidos e marginais eram chamados de capoeiristas. A capoeira foi extremamente reprimida, marginalizada e proibida até o século XX.

$\mathrm{Na}$ década de 1930, a capoeira já ostentava um outro status frente a sociedade. Capoeiristas chegaram a se apresentar no Palácio do Catete a convite do então presidente Getúlio Vargas. Uma nova postura intelectual e artística que buscara a valorização das tradições de matrizes africanas, interesses políticos e ideológicos também contribuíram para mudança gradativa da forma que a sociedade enxergava a capoeira. Então, a capoeira passa a ser vista como patrimônio cultural e compor a produção artística. Os mestres baianos (Pastinha e Gato) foram imortalizados nos romances de Jorge Amado (OLIVEIRA; LEAL, 2009).

De prática marginal à manifestação cultural, a capoeira retrata a transformação da ótica social sobre uma mesma manifestação. A luta retratada nessa manifestação não se trata do anseio de sobrepujar um oponente, mas sim, aspiração por liberdade e igualdade social.

A obtenção de uma sociedade plural, justa e igualitária passa por uma educação étnico-racial que reconhece e compreende os fatos históricos que contribuíram com a desigualdade social virgente. Uma questão a ser superada pela sociedade atual diz respeito ao reconhecimento da diversidade das culturas existentes como forma para a superação das tensões e conflitos (VALENTE, 1996).

A educação tem papel primordial na valorização, preservação e aprofundamento da cultura que compõe o mosaico de manifestações que legitima nossa identidade enquanto nação multicultural (GOMES, 2005). A abordagem dessas manifestações, já na educação básica, deve contribuir com a ampliação do conhecimento histórico, das lutas das minorias e a permanência das desigualdades no processo de desenvolvimento da sociedade brasileira. Pautar os processos pedagógicos de ensino-aprendizagem 
na escola em uma educação étnico-racial é efetivamente contribuir com a formação de futuros agentes sociais comprometidos em superar o racismo estrutural presente nas múltiplas esferas da sociedade brasileira.

A utilização da capoeira como instrumento para uma educação étnico-racial contempla duas das dez competências gerais apresentadas na Base Nacional Comum Curricular (BNCC). A primeira competência visa valorizar e utilizar os conhecimentos historicamente construídos sobre o mundo físico, social e cultural para entender e explicar a realidade. Por sua vez, a nona competência busca exercitar a empatia, o diálogo, a resolução de conflitos e a cooperação, fazendo-se respeitar e promovendo o respeito ao outro, com acolhimento e valorização da diversidade de indivíduos e de grupos sociais, seus saberes, identidades, culturas e potencialidades, sem preconceitos de origem, etnia, gênero, idade, habilidade/necessidade, convicção religiosa ou de qualquer outra natureza, reconhecendo-se como parte de uma coletividade com a qual se deve comprometer.

\section{ALFORRIA SOCIAL PELA EDUCAÇÃO ÉTNICA-RACIAL}

Segundo a Lei de Diretrizes e Bases da Educação nacional (LDB), educação é o processo formativo que se desenvolve na vida familiar, na convivência humana, no trabalho, nas instituições de ensino e pesquisa, nos movimentos sociais e organizações da sociedade civil e nas manifestações culturais. No art. $3^{\circ}$, parágrafo XII da LDB, o processo educativo desenvolvido no âmbito escolar deve considerar a diversidade étnico-racial (BRASIL, 2018).

Nos últimos anos, estamos presenciando um crescente comportamento de intolerância social as minorias (negras, indígenas, religiosas e de gênero). Tal comportamento vem se acentuando com a polarização política partidária latente no cenário social brasileiro desde 2018. Tais acontecimentos nos levam a refletir se de fato nosso processo educativo desempenha de forma eficaz um papel na formação de indivíduos capazes de estabelecer uma convivência humana pacífica, tolerante e democrática, respeitando as divergências culturais, étnicas e de ideias. A educação, que, segundo a BNCC, deve promover pleno desenvolvimento com foco na formação de cidadãos críticos e participativos, está especializando os jovens e os tornando cada vez mais eficazes na obtenção de notas no Exame 
Nacional do Ensino Médio (ENEM), vestibulares e outros processos avaliativos. Porém parece estar falhando no desenvolvimento da capacidade de convivência social de forma harmoniosa com a pluralidade e a diversidade que formou a sociedade brasileira.

A crise de convivência social nos leva a pensar na necessidade de ruptura epistemológica dos fundamentos e práticas que sustentam os processos pedagógicos vigentes na educação básica. É preciso refletir que o desenvolvimento de indivíduos capazes de conviver com a diversidade é tão importante quanto a formação para o mundo do trabalho. Deste modo, é preciso compreender o currículo como parte do processo de formação humana. Não se pode persistir em enxergá-lo como rol de conteúdos que preparam os estudantes para o mercado ou para o vestibular.

Uma educação étnico-racial é o processo formativo que leva o indivíduo a reconhecer a miscigenação, a diversidade cultural como elementos dissociados da formação da sociedade brasileira. É reconhecer que, independentemente da cor da pele, somos frutos de um processo de congregação de raças. Esta ampliação do entendimento da formação histórica da sociedade brasileira levará os indivíduos a compreender a gênese da desigualdade social no Brasil e perceber que não há outro caminho para uma sociedade justa e igualitária se não a de gradativamente "pagar" esta dívida histórica a gerações de negros descendentes da exploração escravocrata, que ainda hoje impacta gerações, colocando-as à margem da sociedade.

\section{CAPOEIRA: POSSIBILIDADES PARA COMPREENDER O VENTRE DO RACISMO ESTRUTURAL}

Uma das diversas possibilidades da utilização da capoeira para uma educação étnico-racial é essa manifestação ser apresentada na educação básica como tema de projeto multidisciplinar. O trabalho multidisciplinar ou colaborativo na educação é entendido como aquele realizado por múltiplos docentes (preservando as características de suas disciplinas), destinados à obtenção de um objetivo comum, compartilhando decisões e responsabilidade pelo que é produzido coletivamente (DAMIANI, 2008).

$\mathrm{O}$ trabalho multidisciplinar se mostra um importante procedimento pedagógico para ensinar desde os anos iniciais. Esta metodologia pode estimular a aprendizagem pela motivação e construção do conhecimento 
interligado às diversas áreas da aprendizagem, fazendo com que os alunos entendam as relações existentes entre as linguagens, além de possibilitar a transformação do ambiente de aprendizagem em um local de debate e pesquisa.

As letras das cantigas entoadas nas rodas de capoeira podem ser utilizadas pelo professor de português para trabalhar a oralidade, interpretação e semântica dos termos presentes e utilizados pelos negros escravos. Compreender os significados das expressões contidas nas letras possibilitará um conhecimento mais aprofundado da forma de vida imposta aos negros no Brasil colônia e suas reivindicações. Contextualizar tais reivindicações ampliará a discursão do processo de libertação dos escravos igualmente desumano ao não estabelecer, na época, uma política de inclusão social dos negros recém-libertos que agora não tinham onde viver e como manter uma vida digna sem trabalho. Restava a essas pessoas se refugiar de forma improvisada nos locais mais distantes do centro das grandes cidades, vivendo à margem da sociedade e dando origem ao que futuramente se tornaria as favelas urbanas.

Os períodos de repressão, marginalização e reconhecimento pelo qual passou a capoeira, bem como os mestres capoeiristas que deram notoriedade e contribuíram para a sua valorização enquanto cultura genuinamente brasileira, pode ser amplamente explorada e trabalhada nas disciplinas de história. O acompanhamento do transcorrer histórico da capoeira possibilitará uma viagem ao período colonial, do Brasil república até a contemporaneidade. Permite-se, então, entender os acontecimentos políticos e sociais que a sociedade brasileira passou nos diferentes períodos, ao passo que tornará possível a compreensão da forma que a capoeira era vista e entendida nesses diferentes momentos históricos.

O ritmo, a estética e plasticidade dos movimentos, dentre outros aspectos presentes na capoeira, podem ser elementos a ser trabalhados na disciplina de arte. A improvisação e a "malandragem" presentes no jogo de capoeira servirão como pano de fundo para contextualizar a necessidade do desenvolver da astúcia e interpretação para a sobrevivência durante o período de repressão e privação de liberdade vivido pelos escravos. A possibilidade do trabalho de expressão corporal e da criação das letras propicia ao professor transpor o aluno de um local de espectador da história para vivenciar em seu corpo essa reivindicação corporal e cantada pela liberdade. 
Nas aulas de educação física, a capoeira se encontra dentro do bloco de conteúdos lutas. A contextualização histórica, o desenvolvimento dos estilos de capoeira (Angola e Regional) e suas características, a confecção dos instrumentos e a recriação das cantigas podem somar-se à prática corporal, possibilitando o desenvolvimento da agilidade, flexibilidade e demais habilidades inerentes ao jogo de capoeira, superando a descontextualização dessa prática com a vida social do aluno. Compreender a capoeira como elemento da cultura corporal de movimento e sua riqueza para a identidade do povo brasileiro é, também, um objetivo a ser alcançado pela educação física no ensino básico.

Levar o aluno a refletir sobre os processos e acontecimentos históricos, sobre o período escravagista, que alicerçou o desenvolvimento econômico e contribuiu com o mosaico cultural que compõe hoje nossa identidade como nação, é dar condições ao aluno de entender de forma ativa e participativa o histórico processo de desigualdade social no Brasil vivenciado há décadas pelos negros afro-brasileiros. Ao possibilitarmos tal compreensão, damos um passo importante para além do discurso na perspectiva de uma efetiva mudança (próximas gerações) da desigualdade e do racismo estrutural ainda vigente e amplamente negado em nosso país.

\section{MUSICALIDADE E DANÇA NA CAPOEIRA: POSSIBILIDADES PEDAGÓGICAS}

Dançar é tão importante quanto ler, falar, pensar e realizar ações básicas do dia a dia; vai muito além do que apenas comunicar algo, dançar é estimular o eu-corpo com a noção de skēnos ${ }^{25}$ (AMOROSO, 2010), no intuito de expressar-se por meio de movimentos. É uma relação de conhecimentos múltiplos com o mundo, para o mundo, sobre o mundo e, acima de tudo, um conhecimento íntimo sobre si mesmo.

Para Conrado (2013, p. 178), "[a] base filosófica das danças dos povos africanos é a tradução da sua vida, da sua espiritualidade e sua maneira de comunicar, o que continuam mostrando através da linguagem corporal". A capoeira, pensando por esse viés, abriga música, dança, movimento e formas de organização, que, ao longo das vivências, são passadas pelos

25 Skēnos é a noção de corpo que a etnocenologia trabalha para argumentar pelo corpo que não separa carne e espírito, segundo o manifesto da etnocenologia. 
mestres, agregando os valores ancentrais e dialogando com o cenário atual ao qual está inserida.

Dessa forma, faz-se urgente pensar e agir pedagogicamente com base nesses saberes ancestrais; conhecer de onde vem é fundamental para entender o caminho em que se percorre e aonde se deseja chegar; entender que os nossos ancestrais vieram da nossa alteridade artística, linguística, religiosa, étnica, nos faz entender as formas de organização da sociedade (MARTINS, 1997).

Em uma sociedade historicamente marcada pela segregação de um grupo social, de apagamentos e invisibilizações das suas histórias, há a possibilidade de se trazer à tona essas memórias pela via do sensível, pela via da arte Dança, na iminência de trazer o conhecimento desde cedo, evitando a folclorização da capoeira e dando visibilidade ao corpo negro, o qual guarda, na sua memória, a arte de pertencer a um grupo que resiste (CONRADO, 2013), que sobrevive forte, acima de tudo, que mantém suas tradições como forma de contar suas próprias histórias.

Já diz Ana Mae Barbosa (2012) que não podemos conhecer a cultura de um país sem conhecer sua arte. A maneira como a cultura popular, sobretudo a capoeira, cria espaços para existir é através da educação não formal, aquela que se aprende no "mundo da vida", por meio dos processos de compartilhamento de experiências (Gohn). É imprescindível abrir esses espaços de compartilhamento também nas instituições formais de ensino, como forma de aproximar os discentes da sua cultura, possibilitando os processos de reconhecimento, pertencimento e sobretudo de continuidade. Entretanto, só é possível realizar esse trabalho com qualidade dentro da escola se for desenvolvido por profissionais especializados e pelos próprios mestres de capoeira, para não correr o risco de, mais uma vez, cair na folclorização da cultura popular, aquela que pode ser realizada por "qualquer pessoa" e de "qualquer forma", servindo apenas para realizar "dancinhas" e apresentações em datas comemorativas.

Além do mais, a vivência da dança trabalha aspectos relacionados ao ritmo, à criação, à improvisação, à sensibilidade para apreciação do seu entorno e ao desenvolvimento da motricidade, colaborando com o desenvolvimento do conhecimento corporal. 
Faz parte do processo educativo conhecer para valorizar; não se valoriza o que não conhece e não há possibilidades de desconstruir uma visão preconceituosa senão pelo entendimento da sua construção, sua articulação e forma de proliferação no mundo. A dança necessita do seu espaço na escola, sendo exercida de maneira responsável e sabendo o porquê de ela estar ocupando esse espaço, não sendo apenas uma desculpa para se trabalhar outras disciplinas, tampouco usada como lazer, recreação, relaxamento e/ou gasto de energia, mesmo sabendo que, através dela, também pode ser vivenciado tudo isso.

Conforme Silva (2014, p. 55), "[c]om um olhar atento é possível perceber a relação existente entre criança/adolescente, a dança, movimento, pensamento e aprendizagem. Essa poderia ser, também, uma das contribuições da dança na escola". Desta forma, a capoeira é uma possibilidade de vivenciar nas instituições formais de ensino da cultura popular, entendendo suas músicas, movimentos e seus modos de organização, contribuindo dessa forma para sua expansão, quebrando preconceitos e construindo uma sociedade mais igualitária, mais conhecedora dos seus processos de construção.

\section{CONSIDERAÇÕES FINAIS}

A superação do racismo estrutural, negada e amplamente praticada na sociedade brasileira, só ocorrerá quando a população conhecer e reconhecer verdadeiramente a importância do negro no desenvolvimento do país, bem como o negligenciamento social praticado repetidamente desde à "abolição". No sentido de que as futuras gerações reconheçam essa história de luta como a sua própria história e da sua nação, este processo de educação étnico-racial precisa iniciar já na educação básica. O trabalho de identificação e reconhecimento de elementos da cultura negra (comida, lutas, expressões, dentre outros aspectos) como componentes importantes para a miscigenação da cultura e identidade brasileira deve fazer parte desse trabalho educativo. Quanto mais precocemente colocarmos nossas crianças em contato com a história real do país, como também com esses elementos culturais e a diversidade étnica, maior será nossa contribuição docente para uma futura sociedade fraterna, tolerante e igualitária. 


\section{REFERÊNCIAS}

ALMEIDA, M. Memórias de um sargento de milícias. Barueri: Nobel, 2009.

AMOROSO, D. Etnocenologia: conceitos e métodos a partir de um estudo sobre o samba de roda do Recôncavo baiano. In: CONGRESSO DA ASSOCIAÇÃO BRASILEIRA DE ARTES CÊNICAS, 6.; 2010, São Paulo. Anais [...]. São Paulo, Associação Brasileira de Artes Cênicas, 2017. Disponível em: https://www.publion-line.iar. unicamp.br/index.php/abrace/issue/view/99. Acesso em: 8 jan. 2019.

BARBOSA, A. M. Arte/educação, história e práticas pedagógicas. In: Arte-educação: história e práxis pedagógicas - territórios híbridos e diálogos entre linguagens. Recife: SESC Pernambuco, 2012.

BRASIL. Lei de Diretrizes e Bases da Educação Nacional. 2. ed. Brasília: Senado Federal, Coordenação de Edições Técnicas, 2018, $61 \mathrm{p}$.

CONRADO, M. S. Percursos de resistência e aprendizagem nos cortejos de Maracatu. 2013. 273f. Tese (Doutorado em Educação) - Faculdade de Educação, Universidade Federal da Bahia, Salvador, 2013.

DAMIANI, M. F. Entendendo o trabalho colaborativo em educação e revelando seus benefícios. Educ. Rev., Curitiba, n. 31, p. 213-230, 2008. Disponível em: http://www.scielo.br/scielo.php?script=sci_ arttext\&pid=S0104-40602008000100013\&lng=en\&nrm=is. Acesso em: 8 jan. 2019.

GOMES, A. B. S. As diretrizes curriculares nacionais para a educação das relações étnico-raciais e para o ensino de história e cultura afrobrasileira e africana e a formação de profissionais da educação básica. In: Currículo: distintas abordagens epistemológicas. Ponta Grossa: Atena Editora, 2005. p. 388-416.

MARTINS, L. M. Afrografias da memória: o Reinado do Rosário no Jatobá. São Paulo: Mazza Edições, 1997. p. 191. 
OLIVEIRA, J. P.; LEAL, L. A. P. Capoeira, identidade e gênero: ensaios sobre a história social da capoeira no Brasil. Salvador: EDUFBA, 2009.

REGO, W. Capoeira Angola: ensaio sócio-etnográfico. Contagem: Editora Itapoan, 1968. 417p.

SILVA, E. C. Uma proposta para pensar a inserção da dança na educação básica. Dança: Revista do Programa de Pós-Graduação em Dança, v. 3, n. 2, p. 416, 2014.

VALENTE, A. L. Educação e diversidade cultural: algumas reflexões sobre a LDB. InterMeio: Revista do Programa de Pós-Graduação em Educação-UFMS, v. 2, n. 4, 1996. 


\section{INTERFACES DO ENSINO DE GEOGRAFIA: O CURRÍCULO E O MATERIAL OFICIAL DA REDE PÚBLICA PAULISTA DE ENSINO REGULAR - ANOS FUNDAMENTAIS}

Jefferson Luis Brentini da Silva ${ }^{26}$

\section{INTRODUÇÃO}

A Geografia é a área do conhecimento que se preocupa com questões relacionadas em nosso planeta Terra e que vão desde a sua formação, estrutura e transformações do cenário espacial, tal como é o foco da geomorfologia, contrastando tal formação com a do nosso universo. Da mesma forma, também analisa os fatores que tornam a vida neste nosso planeta possível e como ela se desenvolveu até os dias de hoje, nas relações humanas e os seus impactos na constituição, mudança e desenvolvimento do cenário espacial (KIMURA, 2008).

Como exemplo, a geomorfologia é a via do conhecimento que estuda todos os fenômenos que ocorrem, ocorreram e que são passíveis de ocorrer na Terra e os processos de formação, estruturação e desenvolvimento

26 Pós-doutorando em Educação pela Universidade Estadual Paulista "Júlio de Mesquita Filho" (UNESP-FCLAr); Doutor em Educação Escolar, Universidade Estadual Paulista "Júlio de Mesquita Filho" (UNESP-FCLAr). Professor Coordenador Pedagógico na EE "Abílio Alves Marques" - SEDUC-SP - Brasil; Grupo de Estudos e Pesquisas Filosofia para Crianças (GEPFC-CNPq) pela UNESP/FCLAr. 
de todos os processos naturais que há em nosso planeta. Vale lembrar que não conhecemos, de modo conclusivo, todos estes fenômenos, mas apenas uma ínfima parcela deles, sendo essa a tarefa de todos.

Para analisar, interpretar e discorrer acerca dos fenômenos e processos, faz-se necessário conhecer e experimentar os elementos químicos, físicos, biológicos, enfim, tudo aquilo que for possível, para que possa abranger o tema que for o enfoque, bem como a trajetória histórica de como se formaram os elementos geográficos e em que eles se transformam quando entram em contato com os demais elementos (KIMURA, 2008).

A Geografia é também uma forma bastante interessante e importante de encontrar arcabouços que se referem a questões de justiça social, sustentabilidade, cidadania, política, ética, preceitos morais, etnologia e as genealogias referentes aos conflitos entre etnias díspares, como também questões como o clima, o relevo, a fauna, a flora, e tudo aquilo que torna o nosso planeta esse grande emaranhado de condições e contradições que o fazem único e especial (CAVALCANTI, 2001).

Neste artigo serão abordados conteúdos, competências e habilidades propostas pelo Material de Apoio ao Currículo do Estado de São Paulo (SÃO PAULO, 2014) e pelo Currículo Oficial do Estado de São Paulo (SÃO PAULO, 2010), por serem os instrumentos norteadores das práticas pedagógicas dos professores da disciplina de Geografia previsto para os anos finais do Ensino Fundamental. A opção de analisar os anos finais do Ensino Fundamental foi por decorrência deste ser um período crucial para os alunos, assim como para os professores e as escolas pertencentes à rede pública paulista de ensino regular.

Esta pesquisa possui abordagem qualitativa, que utiliza como métodos e técnicas a pesquisa documental e a análise de conteúdos, que, segundo Gil (2002, p. 45-46), é muito parecida com a pesquisa bibliográfica, mas a "diferença entre ambas está na natureza das fontes”, isto é, "verifica os documentos conservados em arquivos de órgãos públicos e instituições privadas, tais como associações científicas, igrejas, sindicatos, partidos políticos".

Cabe ressalvar que os anos finais do Ensino Fundamental são um período de transição de um sistema público de ensino: do municipal para o sistema estadual; ao mesmo tempo que o indivíduo passa por uma série de 
mudanças de ordem pessoal, inclusive de ordem biológica, como a puberdade e o processo do adolescer enquanto grande parte das práticas pedagógicas, do conteúdo e do ensino tem o foco na orientação dos alunos para o mercado de trabalho, isto é, voltada para o mercado de trabalho e para o processo de profissionalização do sujeito.

Consequentemente, a opção pela análise do material de Geografia é decorrente de várias instâncias: primeiro, por conta do próprio delineamento do curso e da pesquisa e, também, pela necessidade do pesquisador de analisar as informações e conhecer o material ao qual ele, assim como muitos outros professores de Geografia, deve lecionar, enquanto professor desta rede de ensino.

Ex positis, analisar tais instrumentos regulatórios da prática do professor e que possui a ideologia da unicidade dos conteúdos produzidos historicamente pela Geografia e que são considerados como básicos para conhecer para o modelo atual de sociedade.

\section{DESENVOLVIMENTO}

A fim de tornar mais coeso este compêndio, dividiu-se este trabalho em dois tópicos, que discutem o currículo oficial e o material oficial, instrumentos norteadores para as práticas dos docentes da rede pública paulista de ensino regular descrevendo, assim, os conteúdos, competências e habilidades respectivas a cada ano letivo.

\subsection{CURRÍCULO DO ESTADO DE SÃO PAULO: CIÊNCIAS HUMANAS E SUAS TECNOLOGIAS (ENSINO FUNDAMENTAL - CICLO II E ENSINO MÉDIO)}

A Secretaria do Estado de São Paulo (SEE-SP) ${ }^{27}$ propôs, em 2008, um currículo básico para todas as escolas da rede estadual nos níveis de Ensino Fundamental (Ciclo II) e Ensino Médio. Tal processo partiu da necessidade de montar um currículo único e que suprisse aquilo que era esperado pela população, bem como um processo de regulação e regula-

27 Órgão responsável por articular, organizar, estruturar e dar funcionamento para todas as escolas pertencentes ao Estado de São Paulo. 
mentação calcado nas políticas federais e estaduais (SÃO PAULO, 2010). Além disso, tal procedimento fora estipulado a partir das experiências práticas e dos conhecimentos que já estavam pré-dispostos quanto ao tema em questão, tanto no âmbito nacional quanto mundial.

O currículo é de suma importância, também, por ser o documento aos quais todos os recursos didáticos e paradidáticos (de iniciativa pública ou privada), são voltados para a formação dos professores, inicial e continuada. Isso o torna, também, um instrumento a ser cotejado nas reuniões de professores e, em muitos casos, até o motor propulsor de muitas das reuniões docentes, tais como o planejamento e Atividade Pedagógica em Classe (ATPCs) e é a partir dos mesmos que os recursos voltados para a avaliação, reforço e recuperação precisam para sua elaboração, como é o caso, por exemplo, dos livros didáticos e do Material de Apoio ao Currículo do Estado de São Paulo (SÃO PAULO, 2014).

Além disso, é a partir dos conteúdos, competências e habilidades propostas pelo currículo que o SARESP é formulado anualmente e oferecido para mensurar a qualidade do ensino. Para tanto, o Currículo Oficial do Estado de São Paulo (SÃO PAULO, 2010) tem como objetivos principais: a escola que aprende, projetando este espaço como um ambiente de constante atualização e aprendizados, induzindo daí à ideia de que o conhecimento não é exaurido e tampouco finito, portanto, todos devem estar em constante atualização.

O currículo é também pensado como um espaço de cultura, onde são priorizados os conhecimentos considerados como necessários para conceber o convívio entre os pares dentro dos espaços simbólicos e materiais. Ele propõe que as competências como eixo de leitura e de escrita devem ser constantes e seu uso frequente no processo de formação do indivíduo, pois as pessoas que organizaram o Currículo Oficial do Estado de São Paulo (SÃO PAULO, 2010) julgam-nas competências base para toda a edificação de uma sociedade mais justa e equânime.

Por fim, a prática pedagógica deve ser calcada na contextualização do mundo do trabalho, de modo que estes conheçam o mundo do trabalho, além de sensibilizar e respeitar o seu passado, o presente e seu futuro (SÃO PAULO, 2010).

Logo, o currículo, dirigido para a área de Ciências Humanas, compreende arcabouços voltados para as áreas de Sociologia, História, Filoso- 
fia, Psicologia, Geografia, Política, Antropologia e Economia e que, por sua vez, tais vertentes do conhecimento têm como finalidade compreender, analisar, descrever e conhecer os seres humanos nas mais diversas relações internas e externas, edificadas a partir de uma imensa teia de saberes (SÃO PAULO, 2010). Para tanto, faz uso de uma série de outros recursos, campos de investigação e instrumentos elaborados historicamente pelo ser humano, apoiando-se por vezes em outras áreas do conhecimento, como a Sociologia, a Filosofia, a Física, a Economia, a Biologia, a História e mais uma série de outras, para maior concretude e coesão aos seus objetos de investigação (CAVALCANTI, 2001).

Nesse sentido, a Geografia também se apoia em diversos referenciais e apontamentos teóricos e práticos, inclusive de outras áreas e que possibilitam compreender o mundo, assim como os seres vivos, os espaços, o tempo e as interações entre eles, na tentativa de oferecer respostas cabíveis e epistemologicamente referendadas, além de propiciar momentos de reflexão e de se desprender do senso comum (CASTRO, 2005).

\subsubsection{O CURRÍCULO DE GEOGRAFIA}

No que tange à Geografia, o Currículo do Estado de São Paulo (SÃO PAULO, 2010) infere que tal vertente do conhecimento tem por objetivo o de "estudar as relações entre o processo histórico na formação das sociedades humanas e o funcionamento da natureza, por meio da leitura do lugar, do território, a partir de sua paisagem" (SÃO PAULO, 2010, p. 26). Tal pressuposto deve ter como norte a produção e reprodução de desafios e discussões que fazem parte do cotidiano e, em especial, a partir das inovações tecnológicas que permeiam a mesma, como as redes de comunicação e de levantamento de conhecimentos que existem e coexistem dentro e fora do espaço escolar, que possibilita conhecer os espaços locais, regionais e globais, simultaneamente. Para tanto, o professor de Geografia deve ser o mediador de uma série de conteúdos cuja finalidade é formar cidadãos habilitados a conhecer e reconhecer as mais diversas situações em que são e serão desafiados a conhecer, tanto na esfera espacial, quanto na esfera material e simbólica.

Durante este processo, é de suma importância a adoção de metodologias que transcendam os recursos didáticos tradicionais para que 
o docente possa sensibilizar os seus alunos quanto à disponibilidade, a difusão, a necessidade e a relevância do conhecimento e do ato de conhecer. Para isto, o professor deve estar em constante atualização dos arcabouços produzidos dentro dos enfoques geográficos, ao mesmo tempo que deve zelar e consolidar aquilo que julgar pertinente em suas práticas pedagógicas na tentativa de uma aula de excelência, de modo a utilizar com o máximo de eficiência os recursos disponíveis, físicos e mentais, na medida em que deve saber a teoria e a prática do conteúdo na vida do aluno.

Por fim, o Currículo Oficial do Estado de São Paulo (SÃO PAULO, 2014) chama a atenção sobre a necessidade do aproveitamento e da utilização do Material de Apoio ao Currículo do Estado de São Paulo (SÃO PAULO, 2014) de forma integral, ao mesmo tempo em que deve considerar as realidades e contextos dentro das especificidades de cada região, local e instituição escolar. Esse material é de suma importância, uma vez que a partir de sua utilização correta e integral, os discentes deverão estar aptos e capazes, ou melhor, terão competências e habilidades necessárias para a articulação, desenvolvimento, construção, produção e reprodução do conteúdo esperado para cada situação de aprendizagem $(\mathrm{SA})^{28}$ proposta.

\subsection{O MATERIAL DE APOIO AO CURRÍCULO DO ESTADO DE SÃO PAULO: ENSINO FUNDAMENTAL - ANOS FINAIS}

O Material de Apoio ao Currículo do Estado de São Paulo (SÃO PAULO, 2014) oferece de forma ampliada o que é previsto na matriz curricular do Estado de São Paulo em seu currículo oficial e que, por sua vez, é resultado de uma série de políticas educacionais nacionais voltadas para este enfoque.

Além disso, é este o recurso que norteia a prática docente em todas as áreas de conhecimento que são disponibilizadas pelo currículo (Língua Portuguesa, Matemática, História, Geografia, Ciências, Física, Biologia,

28 São as frações de conteúdo que são formatadas a fim de fazer com que os discentes assimilem competências e habilidades específicas, a serem ministradas para os alunos dentro de um determinado tempo previsto. 
Química, Filosofia, Sociologia, Arte, Educação Física e Língua Inglesa), que, por sua vez, atende as normas estabelecidas pela LDB (BRASIL, 1996). Este material é estruturado em etapas, com o foco na assimilação dos conhecimentos ali priorizados, na medida em que também propõe diferentes metodologias, sistemas de avaliação e a previsão de aulas que são necessárias para execução de uma parcela do currículo, as SAs.

Do mesmo modo, são sugeridas, por este material, algumas formas de recuperação, caso o discente necessite suprimir alguma defasagem e/ou dificuldade no processo de assimilação de algum conteúdo, competência e habilidades e, além disso, as considerações finais sobre a finalidade deste material e as orientações pedagógicas quanto a relevância do material tendo como base o conteúdo do Currículo Oficial do Estado de São Paulo (SÃO PAULO, 2010).

Nele é disponibilizado uma série de informações que são relevantes, entre elas, a de que o professor foi e é um grande colaborador para realização do material e que somente foi possível organizar este recurso pedagógico a partir de estudos e diagnósticos que constataram a necessidade de o professor dispor de um material que fortalecesse a articulação do currículo com a prática docente presente no dia a dia, na sala de aula de todo o Estado de São Paulo, com o auxílio do Professor Coordenador de Núcleo Pedagógico (PCNP) ${ }^{29}$ e que tal ocorrência foi (e é) basal para o aprofundamento e concretização do arcabouço, bem como da abordagem dos materiais oficiais das disciplinas.

Nesse sentido, tal material possui, como um dos objetivos, apoiar no planejamento de aulas para elas possam favorecer a assimilação por parte dos discentes das competências e habilidades:

Necessárias que comportam a construção do saber e a apropriação dos conteúdos das disciplinas, além de permitir uma avaliação constante por parte dos docentes das práticas metodológicas em

29 É uma função de excelência e de extrema importância para a formação de professores em exercício na rede pública paulista de ensino regular e, além disso, é este o profissional capaz de apontar, corrigir, monitorar e avaliar como os professores realizam a sua prática pedagógica e como poderiam vir a superá-las, de modo a suprir as reais necessidades dos alunos, escola, comunidade e região a fim de buscar melhoras substanciais na formação dos indivíduos que serão o futuro dessa nação. 
sala de aula, objetivando a diversificação do ensino e a qualidade do fazer pedagógico (SÃO PAULO, 2014, p.4).

O material foi desenvolvido por meio do programa "Educação Compromisso de São Paulo" 30 na tentativa de oferecer para os professores um instrumento para "intensificar ações de avaliação e monitoramento" (SÃO PAULO, 2014, p. 3), ou seja, tem como pano de fundo e como principal fundamento, a avaliação, a responsabilização e o monitoramento das ações pedagógicas, buscando, a partir dos resultados obtidos, condições para uma educação que esteja entre as 25 (vinte e cinco) melhores do mundo ${ }^{31}$.

Além disso, conforme o disposto no Material de Apoio ao Currículo do Estado de São Paulo (2014, p. 3), a SEE-SP “firma o seu dever com a busca por uma educação paulista de qualidade ao promover estudos sobre os impactos gerados pelo uso do material do São Paulo Faz Escola ${ }^{32}$, nos resultados da rede por meio do SARESP e do IDEB"; isto é, a partir dos resultados obtidos em avaliações externas de larga escala que o Estado se propõe a realizar, é que avaliará se o material no qual está implementado, de fato, é o mais coerente para alcançar os resultados buscados pelo programa "Educação - Compromisso de São Paulo".

É por decorrência do que está disposto neste material e pelos programas explicitados, respaldadas em algumas das políticas voltadas

30 Um programa voltado para a educação que fora anunciado pelo então governador de São Paulo Geraldo Alckmin em 2011, o qual possui como os cinco pilares que o estrutura, a saber: I) valorizar e investir no desenvolvimento do capital humano: II) mobilizar, engajar e responsabilizar a rede, os alunos e a sociedade civil; III) aprimorar ações e a gestão pedagógica como foco no resultado dos alunos; IV) lançar as bases de um novo modelo de escola e um regime de carreira do magistério mais atrativo; e, V) viabilizar mecanismos organizacionais e financeiros para operacionalizar o Programa.

$31 \mathrm{Na}$ época em que foi implantado o material na rede, em 2009, o Brasil ocupava a 53a posição e, atualmente, ocupa a 83a posição, entre os 130 países envolvidos na pesquisa. Informações disponíveis em: http://www.bbc.com/portuguese/brasil-36660930 e http://oglobo. globo.com/sociedade/educacao/pisa-2009-brasil-esta-entre-os-paises-que-mais-evoluiram-na-educacao-mas-ainda-ocupa-as-2915236. Acesso em: 02 abr. 2018.

32 Um programa de governo voltado para a educação, assim como para sua a gestão e que foi promulgado, também, pelo governo de Geraldo Alckmin que, também, propôs nos materiais oficiais. 
para a educação, que a rede pública paulista de ensino regular será, neste momento, a análise do material para a disciplina de Geografia do $6^{\circ}$ ano ao 9o ano do Ensino Fundamental e que esteve presente na rede entre 2014 até 2017.

Está análise é sintética e a pretensão é a de apontar algumas das habilidades e competências que são sugeridas como necessárias e que foram avaliadas pelo SARESP, a fim de compreender e apontar quais parcelas desse componente foram consideradas como importantes nesse período e qual a influência disso na prática docente.

\subsubsection{5a SÉRIE (6 ANO): PANORAMA GERAL}

No $6^{\circ}$ ano, os assuntos abordados fazem referência ao conceito de paisagem e às atividades econômicas que ocorrem em nosso planeta e, a princípio, o objetivo é sensibilizar a todos dos conceitos de paisagem, de modo que consigam estabelecer as diferenças entre os objetos e espaços naturais e sociais e a diferença entre o tempo da natureza e o tempo histórico. Depois disso, aborda-se a alfabetização cartográfica, intentando a ampliação do domínio dos alunos quanto a essa linguagem essencial. Exploram-se, assim, os ciclos que apontam os tempos da natureza, e que, por sua vez, produzem os objetos naturais e as diversas formas de interação entre eles. Sob essa ótica, aborda-se a história da Terra e de sua complexa teia de vidas e os resultados e consequências das ações das sociedades humanas sobre os ciclos da natureza.

Buscam-se, para tanto, as competências e habilidades que possam ser necessárias para o aprofundamento do arcabouço ligado aos fenômenos geográficos em suas várias escalas e dimensões; nesse sentido, as atividades propostas visam aprofundar o estudo dos materiais terrestres, tendo como objetivo a sensibilização dos discentes quanto aos objetos naturais que constituem as paisagens, e que, prontamente, tais paisagens possuem dinâmicas próprias e peculiares, porque estão sujeitas a modificações, dos mais variados padrões, causas e fenômenos.

Nos volumes referentes à $5^{\underline{a}}$ série $/ 6^{\circ}$ ano, abordam-se ainda como as atividades econômicas produzem, reproduzem e transformam o espaço geográfico bem como os mecanismos que atrelam os mais variados setores da economia. No ciclo fundamental são abordadas especificamente as ca- 
deias produtivas, pois é a partir deste arcabouço que poderão compreender as diversas conexões entre as atividades econômicas.

Diante da necessidade de trabalhar esses conceitos, a partir das orientações presentes no Material de Apoio ao Currículo do Estado de São Paulo (SÃO PAULO, 2014, p. 8), é fulcral desenvolver as competências voltadas à observação, à leitura e à interpretação das múltiplas paisagens que existem na superfície da Terra.

Espera-se, a partir da oferta e da consecução das situações de aprendizagens presentes nesse apanhado de volumes que os discentes demonstrem habilidade suficiente para realizar e finalizar algumas medições, dominando as variáveis dos experimentos e, também, augurando alguns resultados a partir da observação, para que os discentes também se tornem produtores de conhecimentos significativos ao identificar formas distintas do relevo terrestre e os impactos produzidos pela ação humana no relevo.

\subsubsection{6ํ SÉRIE (7ㅇANO): PANORAMA GERAL}

Durante esse período letivo, o foco reside na Geografia brasileira e espera-se que os discentes possam descobrir seu próprio país para, então, trabalhar escalas maiores, tanto a nível regional quanto a mundial. Para isto, é preciso aplicar noções básicas que foram adquiridas durante o seu percurso no $6^{\circ}$ ano, a fim de que possa fortalecer a sua competência leitora, além dos procedimentos de observação, descrição e interpretação em todas as formas distintas de linguagem, especialmente a geográfica e cartográfica.

Para dar concreção ao processo de ensino/aprendizagem, o aluno será desafiado a refletir sobre as mais variadas e distintas regiões de nosso país e, consequentemente, demonstrar as suas competências para recuperarem informações e a desenvolverem suas próprias interpretações acerca das proposições fomentadas a fim de obter como resultado a alfabetização cartográfica.

Além disso, os discentes devem construir e aplicar conceitos que possam auxiliá-los na identificação e abrangência da dinâmica das paisagens naturais brasileiras. Logo, o discente deve ser instigado a distinguir e identificar as generalidades e singularidades que distinguem as paisagens naturais brasileiras. 
Em seguida, os alunos deverão (re)conhecer os impactos provenientes das mais distintas formas de interferência humana nas paisagens naturais brasileiras, saber como identificar e distinguir a heterogeneidade morfoclimática do território brasileiro, abarcando sua importância no que tange a distribuição de recursos. Ainda terão que ser capaz de apresentar os aspectos e características da população brasileira, a partir da confecção, análise e descrição de informações extraídas dos mapas para explicar os movimentos migratórios que ocorrem pelos mais variados motivos, além de ter conhecimento suficiente sobre a distribuição territorial da atividade industrial.

Como decorrência, os discentes terão a prudência de reconhecer quando, como e por que aplicar os conhecimentos geográficos para a compreensão dos mais distintos atores sociais, o manejo de dados e de informações geográficas e sistematizar e dominar as diferentes formas de mapas e gráficos que são disponibilizados, além do refinamento da expressão oral.

Em suma, os alunos deverão se sentir desafiados a recuperar informação e a desenvolver uma compreensão geral da formação territorial além da leitura e interpretação de textos literários e espera-se que os alunos compreendam a importância da linguagem cartográfica como síntese de processos geográficos. Diante disso, o aluno deve realizar leituras, interpretações e análises de gráficos, tabelas e mapas temáticos a fim de dar uma visão mais integrada dos processos econômicos do nosso país e a repercussão desses processos no âmbito global.

As competências e habilidades prestigiadas nos volumes pertinentes ao $7^{\circ}$ ano referem-se ao desenvolvimento e domínio da linguagem, da leitura, da produção de textos contínuos (narrativas, textos expositivos e descritivos) e descontínuos (leitura e interpretação de mapas); tendo, também como finalidade, produzir, reproduzir e sistematizar uma série de informações que são dispostas em diversos lugares e espaços, ocupados ou não, pelo ser humano.

\subsubsection{7a SÉRIE ( $8^{\circ}$ ANO): PANORAMA GERAL}

No apenso de volumes referentes ao oitavo ano (sétima série) dos anos finais do ensino fundamental da rede pública paulista de ensino regular, os discentes serão induzidos a pensar sobre as variações que advieram no mundo a partir das revoluções tecnológicas. Assim como as revoluções so- 
ciais, políticas e intelectuais em nosso mundo do final do século XIV até meados de 1945, quando termina a Segunda Guerra Mundial e o mundo se volta para um sistema bipolar, ${ }^{33}$ sob a ótica da Geografia humana e da população, busca-se, a partir daí, uma forma mais acurada de descobrir a sociedade atual e o trajeto histórico que ela passou.

Para tanto, conforme o disposto no Material de Apoio ao Currículo do Estado de São Paulo (SÃO PAULO, 2014), é esperado que os discentes já estivessem aptos a elaborar atividades mais complexas e sofisticadas, utilizando da observação, interpretação, análise e síntese das atividades, bem como da realidade que o cerca. Além disso, os pesquisadores que arquitetaram este material consideram a Geografia muito mais do que um estudo de causa e efeito, e que na verdade, a grande intenção de tal componente curricular é a apreensão das situações em que as sociedades e a natureza se relacionam e, partir desta relação, como as sociedades acabam por produzir e reproduzir os seus espaços, levando em consideração as condições de cada lugar, momento e região. Para dar concreção aos objetivos propostos nesse período letivo, um dos focos é o de observar o estado de conservação da massa planetária bem como da energia que os sistemas naturais têm.

Também de suma importância e que é tratado nestes volumes, é a inquirição das condições de extração no qual os recursos naturais foram desencadeados desde os períodos mais remotos até os dias atuais. Considerando durante esse processo os aspectos voltados aos conceitos básicos de economia, tais como a oferta, a demanda e as tendências mundiais dos recursos minerais frente à insustentabilidade do modo de desenvolvimento vigente, assim como uma alternativa plausível calcada no equilíbrio social e padrões de consumo.

Por fim, almeja-se que os discentes assimilem e desenvolvam ainda mais suas competências no domínio das linguagens, da expressão oral e do pensamento lógico.

\subsubsection{SÉRIE ( 9 ANO): PANORAMA GERAL}

Inicia-se tal ano letivo com o estudo da ampliação, a nível global, das relações humanas nos quais podem vir a resultar na atual disposição de mundo globalizado.

33 Conflito ideológico, político e social entre os dois grandes sistemas que existiam na época: o Capitalismo, sob o comando dos EUA, e o Socialismo, com a URSS. 
A finalidade presente no Material de Apoio ao Currículo do Estado de São Paulo (SÃO PAULO, 2014) para este ano letivo é conduzir o discente a um arcabouço que lhe permita desvendar quais são suas possibilidades e que tais possibilidades são frutos da ação de diversas nações, sociedades, instituições e indivíduos nos mais diversos tempos históricos. A globalização é o epicentro da Geografia nesse momento, assim como as inovações e revoluções tecnológicas que vão do final do século XIV até a contemporaneidade e as consequências calcadas na heteronomia e na padronização cultural que, por sua vez, podem eventualmente intensificar o acirramento dos conflitos de qualquer natureza.

Também focará na produção e reprodução do espaço geográfico global, só que desta vez, a partir da trajetória das organizações multilaterais surgidas no contexto do final da Segunda Guerra Mundial (como, por exemplo, a ONU, a OMC, o Fórum Social Mundial e a OTAN) e as (des)ordens mundiais que surgiram neste período e que determinaram profundas mudanças no mundo, tanto no âmbito social, quanto no âmbito político e econômico.

Os conhecimentos que serão priorizados, inicialmente, são aqueles que possibilitam observar o processo de globalização e as suas significativas mudanças, tais como: lugar, espaço, região, território, mundo, escala geográfica, entre outros. Ainda, ampliar seus conhecimentos relacionados à compreensão da globalização em suas extensões econômicas e políticas.

Outro tema debatido no Material de Apoio ao Currículo do Estado de São Paulo (SÃO PAULO, 2014) do ano letivo referente à $8^{\underline{a}}$ série (9oㅜ ano) da rede pública paulista de ensino regular é o da diversidade e da desigualdade em todas as escalas, do local ao mundial, os processos históricos que fizeram com que tal situação no mundo incorresse e alguns dos porquês que ainda existe para tão lastimosa situação na contemporaneidade.

Portanto, são trabalhados conceitos relacionados à Geografia da População, em especial as relações que os indivíduos possuem e (re)produzem com o meio em que habitam, assim como os processos migratórios, a legalidade e as ilegalidades. Conforme o disposto no Material de Apoio ao Currículo do Estado de São Paulo (SÃO PAULO, 2014, p. 5), “aliado ao conteúdo conceitual e teórico considera-se de fundamental importância a 
aprendizagem de conteúdos procedimentais responsáveis por desenvolver as habilidades de leitura, escrita e de comunicação verbal”.

Enquanto competências e habilidades esperadas que sejam efetivadas nos volumes deste conjunto do material, que abordam os Parâmetros Curriculares Estaduais e é claro, Nacionais, é o de construir e aplicar conceitos, através da linguagem científica, bem como observar fatos, situações, fenômenos e lugares representativos do processo de globalização nas suas distintas dimensões (econômicas, culturais, espaciais, políticas, sociais, entre outros); além disso, os discentes são levados a identificar, reconhecer, localizar, descrever, discriminar, ordenar, medir, classificar, relacionar e comparar fatos, problemas, fenômenos, situações e lugares, como meio para compreender as disparidades que os envolvem.

A partir destas habilidades, espera-se que os discentes consigam explicar e compreender as causas e os efeitos que circunscrevem a globalização por meio de aparatos e condições suficientes para analisar a sua reprodução. Para tanto, é preciso que interpretem fatos, dados, situações, problemas e fenômenos disponibilizados na forma de textos, gráficos e mapas a fim de que assimilem diversas formas e modos de expressão e manifestação social na escala global e possibilitar ao discente a oportunidade de construir argumentos consistentes no que diz respeito às situações, causas e consequências apresentadas, assim como identificar e distinguir argumentações expressas de diferentes formas nos textos, ao mesmo tempo cotejar aspectos políticos, econômicos e sociais no mundo.

Nesse sentido, os discentes precisam erigir e sobrepor habilidades relativas ao domínio da linguagem cartográfica e ter competência para selecionar, organizar, relacionar e interpretar dados e informações dispostos de diferentes formas para construir e confrontar distintas visões de mundo, bem como identificar e distinguir diversas realidades segundo critérios comuns, como meios de arranjar informações e buscar coerência nos dados, independentemente de sua escala.

Cabe ressalvar que os discentes precisam, tanto no percurso quanto ao final do período condizente com a $8^{\text {a }}$ série ( $9^{\circ}$ ano), ter o domínio de como construir e aplicar conceitos presentes da Geografia humana e da população, comparar as mais diversas realidades e associar os padrões mundiais distintos com as condições de desenvolvimento econômico e social. 
Por fim, outros pontos colocados como basilares, no que diz respeito às competências e habilidades propostas para esse ano/série são, também, que os discentes devem discutir situações e realidades nas quais os direitos dos cidadãos, conquistados por grandes processos revolucionários, tanto em âmbito nacional quanto internacional, mas que não foram (e/ou são) usufruídos por todos os grupos que compõem a sociedade, em sua generalidade, tal como a reforma agrária, os setores basilares (saúde, segurança e educação) devendo ser oferecidos com qualidade, gratuidade, e outros.

Os alunos necessitam, também, comparar propostas e ações das instituições sociais e políticas no enfrentamento de problemas de ordem socioeconômica, e, para tanto, os discentes devem ler, analisar, interpretar e discutir textos, tabelas, gráficos, mapas, dados a fim de que possam ter uma visão diferente do senso comum sobre o que é pedido nesse final de ciclo.

A pretensão neste texto foi apresentar as demandas regulamentárias da prática pedagógica dos professores da rede pública paulista de ensino regular e, em especial, para a disciplina de Geografia. Assim, foi realizada uma análise mais apurada do Currículo Oficial do Estado de São Paulo (SÃO PAULO, 2010) e do Material de Apoio ao Currículo do Estado de São Paulo (SÃO PAULO, 2014) proposto para os anos finais do Ensino Fundamental.

Diante desta análise, foi possível perceber que o conteúdo abrange a Geografia de maneira bastante geral sobre os mais variados enfoques de pesquisa e que o foco de grande parte das atividades previstas dentro e fora da sala de aula visa fortalecer habilidades que são desenvolvidas no ensino de Língua Portuguesa e de Matemática, como a leitura e análise de textos, a confecção de quadros e tabelas a partir das informações levantadas nas mais diversas atividades, de discussão e de análise previstos pelo material e currículos oficiais.

Por fim, o material oficial é repleto de uma série de roteiros, atividades e etapas que o professor deve seguir integralmente e, em raras exceções, ele pode realizar uma atividade a partir de algum projeto que ele desenvolveu e/ ou que planeja executar baseando-se nas especificidades da escola.

\section{CONSIDERAÇÕES FINAIS}

A pretensão foi a de verificar quais são os conteúdos, competências e habilidades que são esperadas durante este percurso e como ela é oferecida 
para os alunos neste lapso de tempo. Escolheu-se tal período em decorrência de este ser um momento de transição de ensinos, do ensino municipal para o estadual, do Ensino Fundamental (anos iniciais) ao Ensino Médio, o que resulta em uma série de mudanças, inclusive de ordens estruturais e de formatação do ensino, ao mesmo tempo em que o aluno também passa por significativas transformações, já que está na fase da puberdade.

Constatou-se que o currículo e o material possuem uma série de conteúdos importantíssimos para a formação do indivíduo nesta disciplina, assim como as competências e habilidades esperadas são fundamentais para que este sujeito possa atuar com excelência dentro deste campo, ainda que não planeje atuar profissionalmente nesta área.

No entanto, o material oficial é muito extenso e organizado de maneira que nem mesmo em uma situação ideal seria possível de alcançar aquilo que é esperado pelos alunos e professores. Isso resulta, também, na precarização da educação, ao passo que se faz um enorme recorte para satisfazer a determinação de instâncias hierarquicamente superiores ou não se cumpre aquilo que é estabelecido realizar e, com isso, sofre-se pressão caso não ocorra o atingimento da meta objetivada a partir dos dados do IDESP e do SARESP.

\section{REFERÊNCIAS}

CASTRO, I. E. Geografia e Política. Rio de Janeiro: Bertrand Brasil, 2005.

CAVALCANTI, L. S. Geografia, escola e construção de conhecimentos. $2^{\underline{a}}$ ed. Campinas: Papirus, 2001.

GIL, A. C. Como elaborar projetos de pesquisa. 4. ed. São Paulo: Atlas, 2002.

KIMURA, S. Geografia no ensino básico: questões e propostas. São Paulo: Contexto, 2008.

SÃO PAULO. Secretaria de Estado da Educação. Currículo do Estado de São Paulo: Ciências Humanas e suas tecnologias/ Secretaria da Educação; coordenação geral, Maria Inês Fini; coordenação de área, Paulo Miceli. - São Paulo: SEE, 2010. 
SÃO PAULO. Secretaria de Estado da Educação. Caderno do Professor: Geografia, ensino fundamental. São Paulo: SEE, 2014. 


\section{UM BREVE RELATO DA VALORIZAÇÃO DA EDUCAÇÃO INFANTIL NA HISTÓRIA DA HUMANIDADE}

Michele Padilla Pedroso Vígari ${ }^{34}$

\section{INTRODUÇÃO}

Este artigo aborda alguns processos de valorização da criança, de geração em geração, de como ela era tratada na Idade Média, Moderna e Contemporânea, e como sua forma de tratamento da sociedade mudou através dos anos; a sociedade recebe as crianças como um ser humano físico e social. O objetivo foi apresentar a importância da valorização da criança através das gerações, desde a Antiguidade, até os dias de hoje.

\section{A HISTÓRIA DA INFÂNCIA DESDE A ANTIGUIDADE}

Segundo a perspectiva de Ariès (2006), historicamente, o papel das crianças sempre foi definido pelas expectativas dos adultos, e este mudou bastante ao longo da história, embora a família elementar e o amor tenham existido em todas as épocas.

Uma herança da Antiguidade, de acordo com Costa (2002), não é nada boa: a vida da criança no mundo romano dependia totalmente do

34 Professora Mestra em Educação, Pós-graduada em Língua Portuguesa, Direito Educacional, Letras e Pedagogia. 
desejo do pai. O poder do "pater famílias" era absoluto: um cidadão não tinha um filho, tomava-o. Caso recusasse a criança - e o fato era bastante comum - ela era enjeitada. Essa prática era tão recorrente que o direito romano se preocupou com o destino delas. E o que acontecia com a maioria dos enjeitados? A morte.

A herança da Idade Média herda da Antiguidade a cultura bárbara germânica. A tradição germânica em relação às crianças era um pouco melhor que a romana. Os germanos não praticavam o infanticídio, as mães amamentavam seus filhos e as crianças eram educadas sem distinção de posição social. O povo germânico era composto por um conjunto de lares, com dois poderes distintos: o matriarcal, exercido no seio da família, e o patriarcal, predominante na política e na organização social (COSTA, 2002)

No entanto, o destino das crianças naqueles clãs, como na cultura romana, também dependia da vontade paterna (direito de adoção, de regeneração, de compra e venda). A criança aceita ficava aos cuidados dos parentes paternos (agnatos) e o destino dos bastardos, órfãos e abandonados era entregue aos parentes maternos, especialmente aos tios e avós (COSTA, 2002)

Dessas duas tradições culturais que se mesclaram e fizeram emergir a Idade Média, conclui-se que o status da criança naquelas sociedades antigas era praticamente nulo. Sua existência dependia do poder do pai: se fosse menina ou nascesse com algum problema físico, poderia ser rejeitada. Seu destino, caso sobrevivesse, era abastecer os prostíbulos de Roma e o sistema escravista. Até o final da Antiguidade, as crianças pobres eram abandonadas ou vendidas; as ricas enjeitadas - por causa de disputas de herança - eram entregues à própria sorte (COSTA, 2002).

Nesse contexto histórico-cultural, compreendem-se a força e o impacto do cristianismo, que rompeu com essas duas tradições. Cristo disse: "Em verdade vos digo que, se não vos converterdes e não vos fizerdes como meninos, de modo algum entrareis no reino dos céus. (MT 18:3). A tradição cristã abriu, portanto, uma nova perspectiva à criança, uma mudança revolucionária.

Foi, entretanto, um processo bastante lento, um processo civilizacional levado a cabo pela Igreja. Primeiro, por força das circunstâncias. Por exemplo, dos séculos V ao VIII, na Normandia, o índice de mortalidade 
infantil era muito elevado, 45\%, e a expectativa de vida bem pequena, 30 anos. À primeira vista, esses dados arqueológicos poderiam sugerir ao historiador um sentimento de descaso para com a criança: a regularidade da morte poderia criar nos espíritos de então uma apatia, um medo de se apegar a algo tão frágil que poderia morrer à primeira doença (COSTA, 2002).

Segundo Costa (2002), paradoxalmente, ao invés disso, a documentação nos mostra que havia um grande apego dos pais, apesar da mortalidade infantil. Em sua História, Gregório de Tours nos conta o sentimento de tristeza e a lamentação de Fredegunda (concubina e depois esposa do rei dos francos Chilperico), quando havia morte de crianças. Os relatos emocionados das documentações mostram uma epidemia que começou em um mês de agosto e atacou em primeiro lugar os jovens adolescentes, provocando mortes. Perderam-se criancinhas encantadoras e queridas, que eram aquecidas no peito, carregadas nos braços e nutridas com a própria mão dos pais (COSTA, 2002).

Por sua vez, fora do mundo secular, um espaço social lentamente impôs uma nova perspectiva à educação infantil: o monacato. Os monges criaram verdadeiros "jardins de infância" nos mosteiros, recebendo indistintamente todas as crianças entregues, vestindo-as, alimentando-as e educando-as, num sistema integral de formação educacional (COSTA, 2002). As comunidades monásticas célticas foram as que mais avançaram nesse novo modelo de educação, pois se opunham radicalmente às práticas pedagógicas vigentes das populações bárbaras, que defendiam o endurecimento do coração já na infância. Pelo contrário, ao invés de brutalizar o coração das crianças para a guerra e violência, os monges o abriam para o amor e a serenidade (COSTA, 2002).

As crianças eram educadas por todos do mosteiro até a idade de 15 anos. A regra de São Bento prescreve diligência na disciplina: que as crianças não apanhem sem motivo, pois "não faças a outrem o que não querem que te façam".

Toco aqui em um ponto importante e de grande discussão na História da Educação. O paradoxo, pois o sistema medieval e monástico previa a aplicação de castigos. Na Bíblia há passagens sobre os castigos com vara que devem ser aplicados aos filhos; na Regra de São Bento, há várias passagens (punição com jejuns e varas, pancadas em crianças que 
não recitarem corretamente um salmo), e esse ponto foi muito destacado e criticado pela pedagogia moderna, que, no entanto, não levou em consideração as circunstâncias históricas da época. Por exemplo, Manacorda (autora citada por Costa, 2002) interpreta os castigos do período antigo e medieval como puro sadismo pedagógico, linha de interpretação que permaneceu ao lado da imagem do monge medieval como uma pessoa frustrada e desiludida amorosamente e que, por esse motivo, buscava a solidão do mosteiro (COSTA, 2002).

Para completar o entendimento do sentido civilizacional dos mosteiros medievais, basta confrontarmos sua vida cotidiana - de educação e disciplina voltada para uma formação ética e moral das crianças - com o mundo exterior. Por exemplo, no período carolíngio (séculos VIII a X), apesar do avanço da implantação da família conjugal simples (modelo cristão) com uma média de dois filhos por casal e um período de aleitamento de dois anos, a prática do infanticídio continuava comum, a idade média dos integrantes dos casamentos era muito baixa (entre 14 e 15 anos de idade), a poligamia e a violência sexual eram recorrentes, pelos menos na aristocracia, e ainda havia a questão da escravidão de crianças (COSTA, 2002).

Por sua vez, os bispos carolíngios do século IX tentaram regulamentar o casamento cristão, redigindo uma série de tratados (espelhos). Neles, o casamento era valorizado, a mulher reconhecida como uma pessoa com pleno direito familiar e em pé de igualdade com o marido e a violência sexual denunciada como crime grave e do âmbito da justiça pública. Para nosso tema, o que interessa é que as crianças também foram objetos de reflexão nesses espelhos: a maternidade foi considerada um valor (charitas), e o casal tinha a obrigação de aceitar e reconhecer os filhos (COSTA, 2002). Assim, a ação da ordem clerical foi dupla: de um lado, os bispos lutaram contra a prática do infanticídio; de outro, os monges revalorizaram a criança, que passou por um processo de educação direcionada, de cunho integral e totalmente igualitário - por exemplo, as escolas monacais davam preferência à criança filhas de escravos e servos, ao invés de filhos de homens livres, a ponto de Carlos Magno ser obrigado a pedir que os monges recebessem também para educar crianças filhas de homens livres (COSTA, 2002).

$\mathrm{Na}$ sociedade medieval, o sentido da infância não existia - o que não quer dizer que as crianças eram abandonadas ou despreza- 
das. O sentimento da infância não significava o mesmo que afeição pelas crianças; corresponde à consciência da particularidade infantil, esta que distingue essencialmente a criança do adulto, mesmo jovem (ARIÈS, 2006). Por essa razão, assim que a criança tinha condições de viver sem cuidados constantes da mãe ou de sua ama, ela ingressava na sociedade dos adultos. Isso ocorria logo após um desmame tardio, ou seja, perto dos seis ou sete anos de idade. Quando a criança entrava no "mundo" dos adultos, ela se integrava de tal modo que não se distinguia mais deles (ARIÉS, 2006).

Em sociedade composta de crianças e jovens de pouca idade, não se distinguiam claramente as idades; as crianças participavam de toda a atividade social: jogos, brincadeiras, aprendizes de ofícios e profissões. Não havia figuras, desenhos, artes antigas, em que as crianças pequenas e grandes não tivessem seu lugar, ou seja, abraçadas nos pescoços das mulheres, ou urinando num canto, ou trabalhando como aprendizes numa oficina, ou servindo de pajés de algum cavaleiro. (ARIÉS, 2006)

A criança muito pequenina, demasiado frágil ainda para se misturar à vida dos adultos, "não contava". Essa expressão confirma a existência da mentalidade antiquada. Já desde o século XIV procuravam os artistas exprimir arte, na iconografia e na religião, a personalidade que se admitia existir nas crianças, e o sentido poético e familiar que se atribuía à sua particularidade. Esse sentimento terminou pondo na criancinha pequena um traje especial que a distinguia dos adultos. Isso era feito geralmente pelas camadas superiores da sociedade dos séculos XVI e XVII (ARIÉS, 2006).

Essa individualização do traje das crianças, e, sobretudo dos meninos pequenos, numa sociedade em que forma exterior e o traje tinha uma importância muito grande, é uma prova da mudança ocorrida na atitude com relação às crianças (ARIÈS, 2006). Um novo sentimento da infância havia surgido, em que a criança, por sua ingenuidade, gentileza e graça tornou-se uma fonte de distração e de relaxamento para o adulto, um sentimento que poderia ser chamado de "paparicação". No começo, esse sentimento era próprio das mulheres encarregadas de cuidar das crianças, das mães ou das amas. A maneira como era a criança deve ter sempre parecido encantadora a essas mulheres. De agora em diante, porém, as pessoas não hesitavam mais em admitir o prazer provocado pelas maneiras das crianças pequenas, o prazer que sentiam em paparicá-las (ARIÈS, 2006). 
Esse sentimento da infância pode ser ainda mais bem entendido através das reações críticas que provocou no fim do século XVI e sobretudo no século XVII. Algumas pessoas ranzinzas consideravam insuportáveis a atenção que se dispensava então às crianças; sentimento novo também como que o negativo do sentimento da infância a que chamamos "paparicação". O escritor Montaigne dizia em seus escritos: "Não posso imaginar essa paixão que faz com que as pessoas beijem as crianças recém-nascidas que não têm ainda movimento na alma, nem forma reconhecível no corpo pela qual se possam tornar amáveis" (ARIÈS, 2006).

É preciso deixar claro que esse sentimento de antipatia era tão novo quanto a "paparicação", e ainda mais estranho à promiscuidade indiferente das idades na sociedade medieval. É importante observar que, no fim do século XVII, vemos formar-se esse outro sentimento da infância que inspirou toda a educação até o século XX, tanto na cidade como no campo, na burguesia como no povo. $\mathrm{O}$ apego à infância e à sua particularidade não se exprimia mais através da distração e da brincadeira, mas através do interesse psicológico e da preocupação moral (ARIÈS, 2006). A criança não era mais divertida e nem agradável, segundo um livro escrito por Balthazar Catiew em 1946, quee citou: "Só o tempo pode curar o homem da infância e da juventude, idades da imperfeição sobre todos os aspectos".

Essas observações devem ser olhadas em seu contexto da época e comparadas a outros textos para serem compreendidas; e essas mesmas já foram consideradas por alguns historiadores como uma ignorância da infância. No entanto, devemos ver nelas o início de um sentimento sério e autêntico da infância (ARIÈS, 2006).

Um erro antigo era um adulto não se acomodar à leviandade da infância. Era preciso conhecê-la melhor para corrigi-la, e os textos do fim do século XVI e XVII estão cheios de observações sobre a psicologia infantil. Tentava-se penetrar na mentalidade das crianças para melhor adaptar ao seu nível os métodos de educação, pois as pessoas se preocupavam muito com as crianças, consideradas testemunhos da inocência e da pureza batismal, semelhantes aos anjos e próxima dos santos que as havia amado (ARIÈS, 2006).

O sentimento da infầncia, caracterizado pela "paparicação", surgiu no seio familiar na companhia das criancinhas pequenas. O segundo sentimento, ao contrário, provém de uma fonte externa à família: os 
eclesiásticos e moralistas. Esses moralistas haviam se tornado sensíveis aos fenômenos outrora negligenciados da infância, mas recusaram-se a considerar as crianças como tipos de "brinquedos encantadores", pois viam nelas frágeis criaturas de Deus que era preciso ao mesmo tempo preservar e disciplinar. Esse sentimento, por sua vez, passou para a vida familiar (ARIÈS, 2006).

No século XVIII, encontramos esses dois elementos antigos, juntos a um elemento novo: a preocupação com a higiene e a saúde física. $\mathrm{O}$ cuidado com o corpo não era desconhecido dos moralistas e educadores do século XVII; tudo que se referia às crianças e à família tornava-se sério e digno de atenção (ARIÈS, 2006). Não apenas o futuro da criança, mas também sua simples presença e existência, eram dignas de todo o cuidado e preocupação: a criança havia assumido lugar central dentro da família (ARIÈS, 2006).

No fim do século XVIII, o ciclo escolar era bastante similar ao do século XIX: quatro ou cinco anos no mínimo. A criança, enquanto durava sua escolaridade, era submetida a uma disciplina cada vez mais rigorosa e efetiva, e essa disciplina separava a criança que a suportava da liberdade do adulto. Assim a infância era prolongada até quase toda a duração do ciclo escolar. (ARIÈS, 2006). De um lado, havia a população escolarizada, e de outro, aqueles que, segundo os costumes antigos, entravam diretamente na vida adulta, assim que seus passos e suas línguas ficavam suficientemente firmes. Essa divisão não correspondia às condições sociais, sem dúvida, o núcleo principal da população escolar era constituído de famílias burguesas, jovens e eclesiásticos, mas havia nobres que não frequentavam a escola. E entre artesãos e camponeses, poucos frequentavam o ambiente escolar (ARIÉS, 2006).

As meninas de boa família não eram mais instruídas do que as de classes inferiores, e podiam sê-lo até menos, pois em certos casos, as meninas do povo aprendiam a escrever com perfeição, como um ofício. A população escolar, numa época em que a escola ministrava quase a totalidade do ensino que hoje dividimos em primário, secundário e superior, coincidia muito menos do que hoje com o contorno das condições sociais, o movimento de apostolado educacional do fim do século XVII, que resultou no aparecimento dos "irmãos das escolas cristãs", não se limitava apenas aos pobres; as escolas populares eram invadidas por pequenos burgueses, 
assim como as classes inferiores dos colégios estavam cheias de pequenos artesãos ou camponeses (ARIÈS, 2006).

Os acontecimentos poderiam ter se desenrolado de tal forma que o sistema educacional se tivesse baseado na escola única; afinal, o regime antigo, até o século XVIII, praticamente só conheceu a escola única. A frequência escolar teria se estendido socialmente e geograficamente; a duração dos ciclos, por outro lado, teria variado segundo as vocações: apenas os juristas e os eclesiásticos teriam seguido até o fim dos dois ou três anos de filosofia - correspondentes a nossos anos de faculdade; os outros, os artesãos ou soldados, teriam parado no estágio anterior. (ARIÉS, 2006)

Essa era de fato a situação em meados do século XVII: os colégios ou escolas latinas estendiam uma rede circular em torno de um grande colégio com a série completa de séries de classes e a densidade dessa rede diminuía em direção à periferia. Ela era constituída de várias escolas que obrigavam apenas as classes inferiores do ciclo escolar.

Isso pode parecer surpreendente quando pensamos no rigor e na diversidade da hierarquia social do antigo regime; os hábitos de escolaridade diferiam menos segundo as condições sociais do que segundo as funções. Consequentemente, as atitudes existenciais, assim como os traços da vida cotidiana, não diferiam muito mais. Mas esse estado de coisas não durou muito, e a partir do século XVIII, a escola única foi substituída por um sistema de ensino duplo, em que cada ramo correspondia não a uma idade, mas a uma condição social: o liceu ou o colégio para os burgueses (secundário) e a escola para o povo (o primário). O secundário é um ensino longo. O primário durante muito tempo foi um ensino curto, e tanto na Inglaterra como na França, foram necessárias revoluções sociais originárias das últimas grandes guerras para prolongá-lo.

Talvez uma das causas dessa especialização social residisse justamente nos requisitos técnicos do ensino longo, do momento em que ele se impôs definitivamente aos costumes; não era mais possível tolerar a coexistência de alunos que não estavam desde o início decidido a ir até o fim, a aceitar as regras do jogo, todas, pois as regras de uma coletividade fechada, escola ou comunidade religiosa, exige o mesmo abandono total que o jogo. Do momento que o ciclo longo foi estabelecido, não houve mais lugar para aqueles que, por sua condição, pela fortuna, não podiam segui-lo nem se propor a segui-lo até o fim (ARIÈS, 2006). 
Mas há outra causa para essa evolução: a ação de homens detentores da autoridade, da razão e do saber, que já encontramos na origem das grandes transformações dos costumes entre a idade média e os tempos modernos. Foram eles que compreenderam a particularidade da infầncia e da importância tanto moral, como social da educação, da formação metódica das crianças em instituições especiais, adaptadas a essa finalidade (ARIÈS, 2006). Muito cedo, alguns deles se perturbaram com a extensão de seu próprio sucesso - um sucesso sociológico do qual nem sempre estavam conscientes. Richelieu, e depois Colbert, exprimiam seus temores de uma inflação de intelectuais e de uma crise de mão-de-obra braçal, um velho tema que as diversas gerações da burguesia conservadora transmitiram até os dias de hoje. (ARIÈS, 2006).

No século XVII, apesar de sua autoridade, esses precursores "pregavam no deserto": não puderam fazer nada para frear o sucesso dos colégios e sua penetração no campo. Mas no século XVIII, seu preconceito foi adotado por essa categoria de pessoas "esclarecidas" que, numa certa medida, aparecem em vários domínios como seus sucessores; esses homens do Iluminismo, das sociedades do pensamento, graças ao seu número e suas relações, exerceram sobre a opinião pública uma influência com que nenhum grupo de legisladores, clérigos ou intelectuais podiam ter sonhado no passado. A maioria deles propôs - a partir da expulsão dos jesuítas - limitar a uma única classe social o privilégio do ensino longo e clássico, e condenar o povo a um ensino inferior que seria exclusivamente prático (ARIÈS, 2006).

Vimos que o sentimento da infância encontrou sua expressão mais moderna nesses mesmos meios de burgueses esclarecidos. Mas os antigos gêneros da vida sobreviveram quase até nossos dias nas classes populares, submetidas por menos tempo à ação da escola. Teríamos até mesmo razão em perguntar se nesse ponto não houve uma regressão durante a primeira metade do século XIX, sob influência da demanda de mão de obra infantil na indústria têxtil. $\mathrm{O}$ trabalho das crianças conservou uma característica da sociedade medieval: a precocidade da passagem infantil para a adulta, toda complexidade da vida foi modificada pelas diferenças do tratamento escolar da criança burguesa e da criança do povo (ARIÈS, 2006).

E de acordo Áries (2006), existe, portanto, um notável sincronismo entre a classe da Idade Moderna e a classe social: ambas nasceram ao mesmo tempo, no fim do século XVIII e no mesmo meio: burguesia. 


\subsection{NA CONTEMPORANEIDADE}

Segundo Canclini (2003), os jovens atuais são a primeira geração que cresceu com a televisão a cor e o vídeo, o controle remoto e o zapping, e uma minoria com computador pessoal e Internet. De acordo com ele, entre os anos 70 e 80 se perguntava o que significava ser a primeira geração em que a televisão era um componente habitual da vida familiar. Hoje, além da TV, muitos outros meios já fazem parte do cotidiano da criança desde cedo, produzindo novas formas de aprender e refletindo na forma como crianças relacionam-se com os saberes e produzem sentidos sobre eles.

Como entender, por exemplo, a alfabetização em seu sentido estrito hoje, quando muitas das informações que dão acesso ao saber passam pelas diversas redes e tramas da imagem e das sonoridades eletrônicas?

Barbero (2002) argumenta que há hoje toda uma reestruturação das funções das práticas culturais da memória, do saber, do imaginário e da criação e, se hoje já não se escreve e nem se lê como antes, é também porque não se pode ver nem apresentar como antes.

A mudança nos protocolos e processos de leitura de que fala Barbero (2002) não significa a substituição de um modo de ler por outro, mas sim a complexa articulação de uns e outros, da recíproca inserção de uns e de outros, entre livros e quadrinhos, vídeos e hipertextos.

Canclini (2003), outro estudioso na linha dos Estudos Culturais, diz que essa mudança revela a transformação que foi configurando no decorrer do século XX e designa por "hibridação" os processos socioculturais nos quais estruturas ou práticas discretas, que antes existiam de forma separada, se combinam para gerar novas estruturas, objetos e práticas. A apropriação gera novos objetos e novas práticas diferentes das que lhes deram origem. A hibridação surge da criatividade individual e coletiva, na vida cotidiana e no desenvolvimento tecnológico. Os meios de comunicação são entendidos, então, como veículos de hibridação. Assim, quanto mais meios e tecnologias a sociedade dispõe, mais complexifica-se os processos de comunicação e os processos culturais e sociais.

Temos que considerar que, diante disso, modifica-se substancialmente o repertório de criação de histórias e personagens das crianças em função desse contexto de múltiplas "alfabetizações". 
Como Benjamin (1984) ajuda a discernir as novas formas de percepção expressam-se num "sensorium" diferente em razão da técnica, das novas tecnologias. Precisamos pensar que a relação cada vez maior das crianças com as produções da atualidade pode também modificar seus modos de produção cultural. É nesse âmbito que me proponho a investigar como a criança produz suas narrativas escritas hoje, acreditando que, diante das revoluções da cultura, também podem estar ocorrendo "revoluções" nas produções culturais da infância.

Considerando, a partir da pesquisa de mestrado de Fernandez (2006), faz a relação das crianças com os produtos culturais em geral, em seus diferentes suportes, está continuamente mediada pelas "trocas alternadas" com outros produtos, com outros diálogos, com as instituições e com os adultos e crianças com os quais entram em contato em seu cotidiano, supõe-se que tal contexto multimidiático, multirelacional traga questões cruciais para a vida das crianças, seu pensamento, seu processo de criação e sua formação. Assim, cumpre-nos o desafio de entender como pensam e produzem narrativas nesse contexto.

Fernandes (2006) ao falar sobre essa geração comenta que essas crianças vivem no mundo de excesso de informações, e por tudo isso, podemos dizer que a geração "cabeças digitais" é muito curiosa, tem mais facilidade de lidar com a diversidade, se adapta com mais facilidade às situações, é muito ágil, inquieta, com uma nova concentração. Tal geração processa a informação de forma diferente, tem uma forma própria de raciocinar (pensamento em hipertexto) e é multitarefa (faz muitas coisas ao mesmo tempo).

Green e Bigum (1995) afirmam que, nesse contexto, está emergindo uma nova geração com uma constituição radicalmente diferente e que as crianças que já nascem imersas nessa cultura da mídia já são outras crianças, com uma organização do pensamento advinda dessa nova vivência. Estudos de diferentes áreas reforçam o que foi apresentado em artigo publicado na Revista Veja em janeiro de 2006, em que se trouxe a discussão da relação das crianças com a tecnologia a partir das conclusões de alguns estudos realizados por neurologistas. O escritor americano Steven Johnson, um dos entrevistados pela revista e que acaba de lançar o livro "Surpreendente! A Televisão e o Videogame Nos Tornam Mais Inteligentes", discute a tese de que, embora o conteúdo do en- 
tretenimento, de modo geral, tenha menos informação se comparado à informação fornecida pelos livros, a forma como esse conteúdo é elaborado nos meios de comunicação exige muito mais raciocínio das crianças do que as diversões de antigamente. Segundo ele, os seriados de TV e os filmes infanto-juvenis, os videogames e os desenhos animados que antes tinham enredo simples e poucos personagens, agora trazem histórias elaboradas, cheias de tramas paralelas e com vários protagonistas. Em tese discutida pelo autor, se baseia no fato de que nas últimas duas décadas a TV passou por uma profunda transformação; os seriados de antigamente apresentavam histórias simples, lineares, com poucos personagens. A ação se desenvolvia de forma previsível. Hoje nos seriados as tramas são complexas, há uma teia de personagens principais e secundários e a história não chega pronta para o telespectador, pois exige que ele raciocine para entendê-la. Por mais que se possa discutir a natureza desses estudos não é preciso muito para se perceber que as crianças de hoje já não são mais as mesmas que fomos.

Fernandes (2006) acredita que parte dessa mudança se deve ao contato com as novas tecnologias. As narrativas criadas por meus alunos me instigavam a compreender como podiam fazer combinações tão criativas apresentadas em formatos tão originais em textos escolares, as famosas redações, quando, na verdade, escrevia-se para cumprir uma obrigação escolar, e não para reinterpretar, recriar o vivido. Muitos textos que as crianças criavam, mesmo misturando elementos de diversas mídias, trazendo num mesmo texto marcas do cinema, da propaganda, de programas humorísticos, nem sempre são bem aceitos pelos adultos ou pela sociedade, por afastarem-se dos padrões formais que a cultura letrada, normalmente, valoriza.

De acordo Fernandes (2006), devido à presença cada vez maior de estudos reiterado as mudanças e as características da infância atual nesse contexto midiático, uma questão tem instigado: seria fundamental entender melhor o contexto cultural das crianças para se ter uma percepção melhor de quando as narrativas escritas por elas trazem realmente elementos novos e criativos da linguagem e quando estes denotam uma dificuldade com a escrita que aparece sob novos formatos. Seria cabível supor que o contato maior das crianças com a tecnologia estaria motivando modos de criação de narrativas diversos dos valorizados pela escola. 


\section{CONSIDERAÇÕES FINAIS}

Este trabalho faz um breve relato de como a criança era tratada na história da infầncia desde a Antiguidade, passando pela Idade Média, Moderna e Contemporânea, mostrando um pouco do processo de desenvolvimento da criança, de geração em geração, desde os seus primórdios.

Conclui-se que, no decorrer da História, a valorização da criança foi lenta, mas com avanços significativos. E hoje percebe-se que é na infância que a criança se desenvolve socialmente e emocionalmente.

A criança precisa da família, escola, sociedade e governo, para que tenha um desenvolvimento integral com qualidade e equidade.

\section{REFERENCIAS}

ARIÈS, F. História Social da Criança e da Família. Rio de Janeiro: LTC, 2006.

BARBERO, J. M. Pistas para entrever meios e mediações. In:

Dos meios às mediações: comunicação, cultura e hegemonia. Rio de Janeiro: UFRJ, 2001.

BARROS, M. D. Educação infantil: o que diz a legislação. Disponível em http://www.lfg.com.br. 12 de novembro de 2008.

BENJAMIN, W. A obra de arte na era de sua reprodutibilidade. In: Magia e Técnica, arte e política - ensaios sobre a literatura e história da cultura. Obras escolhidas, volume I, $2^{\underline{a}}$ edição, São Paulo: Editora Brasiliense, 1984.

CANCLINI, N. G. Culturas Híbridas: estratégias para entrar e sair da modernidade. São Paulo, EDUSP, 2003.

COSTA, Ricardo. A educação Infantil na Idade Média. In: LAUAND, Luíz Jean (coord.), VIDETUR 17. Porto: Universidade do Porto / USP, 2002, p.13-20.

FERANDES, A.H. As mediações na produção de sentidos das crianças sobre os desenhos animados. Dissertação (Mestrado em Educação) - Departamento de Educação, Pontifícia Universida- 
de Católica do Rio de Janeiro, Rio de Janeiro, 2003. Disponível em: www.dbd.puc-rio.br

GREEN, B; BIGUM, C. Alienígenas na sala de aula. In SILVA, T. T. Alienígena na sala de aula - uma introdução aos estudos culturais em educação. Petrópolis: Editora Vozes, 4⿳亠丷a edição, 2002. 


\title{
REFLEXIVIDADE E PRÁTICA DOCENTE: NARRATIVAS DE PROFESSORAS ALFABETIZADORAS
}

\author{
Liliana Monteiro Carcará
}

\section{INTRODUÇÃO}

O presente artigo discute a prática alfabetizadora e a reflexão, em vista de um aprofundamento teórico sobre a temática junto aos professores alfabetizadores, suscitando o debate sobre como vêm sendo conduzidas as práticas e os processos de aprendizagem. Estabelecer processos de desenvolvimento da reflexão na prática profissional exige do professor autonomia para que possa exercer com controle o domínio técnico sobre o seu fazer docente fundamentado por uma base teórica sólida. A autonomia assegura o exercício reflexivo, a (res)significação das práticas e maior consistência quando o processo ocorre em coletividade, porque fortalece os laços e as (inter)subjetividades.

A adoção do viés reflexivo em nossa prática docente exige mudança na postura profissional que não se dá de um momento para o outro. Ela acontece em decorrência de um (re)ordenamento teórico que se configura a partir de estudos, análises, discussões e reflexões sobre o saber e o fazer docente, que vão sendo acomodadas e postas em prática, lentamente. Submerge a percepção de professor como simples transmissor de saberes e surge uma nova concepção colocando-o como profissional reflexivo, com capacidade para realizar leituras compreensivas do que é concreto e possível à prática docente. Com competência suficiente, principalmente, 
de oferecer uma nova compreensão ao saber-fazer pedagógico (BRITO, 2006).

$\mathrm{Na}$ análise da prática docente alfabetizadora, na perspectiva da reflexividade, pontuamos a reflexão como o diferencial com capacidade para promover o distanciamento das práticas reprodutivistas e mecanizadas que têm por fundamento o paradigma newtoniano-cartesiano que orientou por muitos anos a prática profissional.

A organização do trabalho pedagógico, orientado a partir de uma perspectiva reflexiva, deve levar em consideração ao que Leal et al. (2006) que, tomando como referência as afirmações de Dolz e Schneuwly, afirmam que a alfabetização na perspectiva do letramento suscita a utilização de uma diversidade de gêneros textuais, contextualizados com base nas vivências sociais dos aprendizes. Essa diversificação no trabalho docente assegura a formação do pensamento crítico e a valorização das singularidades por meio da socialização de uma multiplicidade de saberes.

\section{METODOLOGIA}

O estudo busca responder como ocorre a prática docente alfabetizadora na perspectiva da reflexividade e tem como objetivo geral investigar a prática docente alfabetizadora na perspectiva da reflexividade. A pesquisa é qualitativa narrativa. Como técnicas produção de dados, adotou-se o diário da prática e as rodas de conversa. Constatou-se, com o estudo, que algumas professoras começam se distanciar do pensar reprodutor aproximando-se do reflexivo, desenvolvendo suas atividades com autonomia.

\subsection{A REFLEXÃO COMO UMA ALTERNATIVA POSSÍVEL À PARTICIPAÇÃO SIGNIFICATIVA E FUNCIONAL NO UNIVERSO DO LETRAMENTO}

As novas perspectivas educacionais refletem as transformações do panorama mundial, que se alargam por todos os segmentos da sociedade e, na educação, faz declinar a concepção tradicional de educação abrindo espaço para um profissional com uma prática orientada para a reflexão, a autonomia e para o aprender a aprender. 
Nesse sentido, a organização do trabalho pedagógico exige um planejamento minucioso quando se almeja uma prática voltada para o desenvolvimento potencial do educando, habilitando-o às práticas sociais de leitura e escrita de forma autônoma e refletida. Esta capacidade é que vai assegurar desenvoltura em suas relações com o mundo e com os outros seres humanos. Brito (2006), ao refletir sobre a prática profissional e a organização do processo alfabetizador, pontua que a prática precisa ser intencional e estar relacionada a um contexto e a um conjunto de alunos. O estabelecimento de objetivos, a priori, denota sua intencionalidade. Para os alfabetizadores, é necessário o entendimento do processo alfabetizador como exigência não somente das técnicas de leitura e escrita, mas, acima de tudo, como uma alternativa possível de participação significativa e funcional no universo do letramento.

Ocorre que o profissional que enseja alfabetizar na perspectiva do letramento, há de ter consciência de que esse aprendizado precisa estar voltado para a formação cidadã dos educandos e que essa aprendizagem deve apresentar como devolutivas sujeitos com capacidade de realizar uma interpretação crítica da realidade compatível com desenvolvimento maturacional. Todavia, para que o docente seja capaz de alfabetizar com as habilidades e competências citadas, torna-se necessário que o ensino reflexivo potencialize a reflexão na perspectiva entendida por Zeichner (2003, p. 45) "[...] como prática social na qual o grupo de educadores apoie e sustente o crescimento de cada um dos seus membros".

Inserir o aluno no universo da leitura e da escrita por meio da alfabetização e, prazerosamente, é um grande desafio para o professor alfabetizador, porque precisa criar possibilidades metodológicas que estimulem a leitura reflexiva, além de uma formação específica e contínua em práticas de letramento.

A reflexão é indicada por Zeichner (1993) como a capacidade do professor em criar situações problemas que permitam à criança aprender fazendo, interagindo, opinando, respeitando seus limites e as suas potencialidades no sentido de estabelecer relações entre situações e objetos, serem capazes de dar contribuições à atividade em oposição à criação de situações tecnicamente estabelecidas. Entretanto, as professoras precisam criar situações, como pesquisas, para que as crianças se aprofundem mais naquilo que vão aprendendo, provoquem debates a fim de que possam 
trocar conhecimentos, tornando a aprendizagem mais interativa porque, "[...] aprendemos se nos encontramos na condição de sujeitos, porque o ser humano é vocacionado a sê-lo, e não objeto" (FREIRE, 1989). Desse modo, ao aluno precisa ser oportunizado espaços para a construção ou reconstrução do saber estando os mesmos na condição de sujeitos que refletem mediante um processo criador e recriador. Segundo Pimenta (2005), os saberes docentes são construídos no dia a dia durante o seu fazer pedagógico, resumindo experiência e saber pedagógico, consolidados na ação. A prática não é tão somente objeto de reflexão, mas também objeto de ressignificação.

\subsection{HISTÓRIAS DO SER PROFESSOR REFLEXIVO NO CICLO DE ALFABETIZAÇÃO}

As experiências vivenciadas durante o fazer docente vão se transformando em um conjunto de histórias que marcam esse fazer. Algumas são caracterizadas pela “" [...] imposição, pela submissão; outras [...] baseiam-se na vontade, no pensamento, em atitudes de questionamentos e curiosidade, na busca da verdade e da justiça" (ALARCÃO, 2001, p. 3).

As histórias do ser professor reflexivo muitas vezes acontecem, a partir de processos em que tanto o docente quanto o discente vão se formando, construindo conhecimento, aprendendo juntos e se transformando, segundo os reflexos da sociedade, também em mutação. Nesse processo de construção do saber e de gerenciamento da própria aprendizagem, independentemente de quem seja a pessoa em formação, professor ou aluno, por ser um sujeito que pensa, tem o direito a elaborar o seu conhecimento. A experiência precisa ser a fonte valorosa da aprendizagem. A metacognição como processo de conhecimento da própria metodologia do conhecer e a metacomunicação constituindo-se no processo avaliativo das interações, terminando por validar a capacidade de autogerenciamento da aprendizagem (ALARCÃO, 2001).

Por serem sujeitos históricos, docentes e aprendizes vivenciam os processos próprios da sociedade em movimento. Entretanto, é necessário que o docente esteja em constante processo de (auto) formação para que possa se apropriar do saber produzido no meio acadêmico e criar situações de aprendizagem que possibilitem aos aprendizes a aquisição desses 
conhecimentos. A socialização do conhecimento, as estratégias utilizadas, conquistas e insucessos promovem a materialização dessas experiências constituindo-as em histórias do ser professor reflexivo.

Cabe ao docente, segundo Contreras (2002), realizar uma análise crítica de sua prática numa perspectiva indagadora, partindo da análise das condições em que se desenvolvem as práticas e dos efeitos produzidos. Uma reflexão que conduza os profissionais à condição de sujeitos do fazer docente, que produz saberes e com potencial transformador. Uma reflexão que se constitua em um diálogo interior e desabroche como prática social, que no entender de Perrenoud (1993), deve ser adquirida desde a formação inicial. Nesse sentido, compreendemos que os docentes necessitam refletir sobre a prática e na prática continuamente, individual e coletivamente, pois a reflexão é condição sine qua non para o rompimento de práticas reprodutivistas e mecanicistas, que afastam os aprendizes do exercício reflexivo, transformando-os em sujeitos automatizados, preparados para dar respostas alienadas e mecânicas às indagações da sociedade em transformação.

Para a análise da prática docente alfabetizadora na perspectiva da reflexividade, pontuamos a reflexão como o diferencial com capacidade para promover o distanciamento das práticas reprodutivistas e mecanizadas que têm por fundamento o paradigma Newtoniano-cartesiano que orientou por muitos anos a prática profissional.

A organização do trabalho pedagógico, orientado a partir de uma perspectiva reflexiva, deve levar em consideração o que Leal et al. (2006), tomando como referência as afirmações de Dolz e Schneuwly, afirmam. Segundo os autores, a alfabetização na perspectiva do letramento suscita a utilização de uma diversidade de gêneros textuais, contextualizados com base nas vivências sociais dos aprendizes. Essa diversificação no trabalho docente assegura a formação do pensamento crítico e a valorização das singularidades por meio da socialização de uma multiplicidade de saberes.

Liberalli (2008) aponta características linguísticas na perspectiva de desenvolver ações que sirvam de suporte à reflexão crítica. Esse fato pode instrumentalizar os educadores para a ação e compreensão do processo de descrição, informação, confronto e reconstrução das práticas, operacionalizadas nas quatro fases, as quais apresentamos sucintamente: 
- Descrever se refere à voz do educador em expor suas ações de modo consciente, para que possa chegar a uma nova conclusão sobre o seu trabalho. Essa descrição do trabalho docente vai permitir evidenciar ações reflexivas ou rotineiras. Descrever responde diretamente às indagações sobre o que faço;

- Informar diz respeito à busca dos princípios e teorias formais que fundamentam as ações e os sentidos que alicerçam as práticas. Responde aos questionamentos relativos ao significado das nossas práticas;

- Confrontar se refere ao submeter das teorias formais, que dão embasamento ao fazer docente, bem como às ações, a um questionamento em vista da compreensão dos valores que dão sustentação ao pensar e ao agir. Nesse sentido, o confrontar assume uma conotação política que conduz a emancipação, no instante em que a criticidade é aguçada a partir do compartilhamento de vários elementos, permitindo ao docente refazer a ação de forma consciente e informada. Indaga sobre o (Como me tornei assim? Ou quero ser assim?);

- Reconstruir está relacionado a uma concepção de emancipação a qual o docente indica novos caminhos, o desenvolvimento de muitas possibilidades de ação embasadas por explicações impregnadas de fundamentos teóricos, coerentes com objetivos traçados e voltados para o atendimento das necessidades da comunidade escolar. Questiona sobre o (Como posso agir de forma diferente?).

O pensamento crítico oferece condições para que a educação seja reinventada. A superação da postura de transmissor de conhecimento, passa pela qualificação profissional a partir do reordenamento teórico da formação docente fortalecendo a autonomia do professor, rompendo com o controle técnico e a consequente valorização da sua prática (RIGAL, 2000).

\section{CONSIDERAÇÕES FINAIS}

As professoras afirmaram que iniciaram a carreira no magistério apenas com a experiência como discente, aprendendo com seus pares e a docência alfabetizadora com os conhecimentos da formação inicial. As 
professoras evidenciam, em suas falas, que não receberam nenhum tipo de formação contínua a priori, especificamente, voltada para a docência alfabetizadora. Afirmam, ainda, que o ingresso na docência alfabetizadora não foi decisão delas, muito embora algumas sentissem o desejo de se tornarem professoras em sua infância. Quanto ao ingresso no magistério, afirmam ter sido por falta de opção, pela oportunidade de emprego, mas que a vivência na docência despertou o amor a profissão.

As professoras, à medida que desenvolvem suas práticas, vão construindo sua teoria alfabetizadora e seu método de ensino. Elas evidenciam, em seus relatos, a importância de valorizar o conhecimento que acumulam em seu currículo oculto para que façam relações com a realidade e percebam o significado das aprendizagens. Compreendem que cada uma das tendências educacionais tem muito a contribuir para o desenvolvimento das potencialidades dos alunos e, portanto, devem ser analisadas e aproveitadas. Demonstram também uma preocupação com a organização do trabalho pedagógico através do planejamento e da diversificação de estratégias didáticas.

No que se refere à fundamentação teórico-metodológica da docência alfabetizadora, certificamos que as professoras necessitam de maior aprofundamento teórico, pois mesmo algumas possuindo maior tempo de serviço com a docência alfabetizadora não possuem domínio teórico que satisfaça as exigências da prática e o conhecimento relativo a alfabetização e letramento provenientes das formações oferecidas pelos programas citados por elas e nos cursos de especializações ainda são muito incipientes.

A ausência ou presença da competência técnica é o que marca a carreira das professoras como alfabetizadoras. As experiências desafiadoras as quais tiveram êxito, assim como aquelas em que fracassaram, a ausência de maturidade teórica na área em que estão atuando e a consciência de que necessitam desse amadurecimento, marcam o fazer das alfabetizadoras.

\section{REFERENNCIAS}

ALARCÃO, I. Escola reflexiva e nova racionalidade. Porto Alegre: Artmed, 2001.

BRITO, Antonia Edna. Formação do docente alfabetizador: revelando exigências e desafios, 2006. (Apresentação de Trabalho/Comunicação). 
FERREIRO, E; TEBEROSKY, Ana. Psicogênese da língua escrita. Porto Alegre, Artmed, 1999.

FREIRE, P. A importância do ato de ler: em três artigos que se completam. 15. ed. São Paulo: Cortez, Autores Associados, 1989.

GUEDES-PINTO, Ana Lúcia, LEAL, Telma Ferraz. Planejamento do ensino na perspectiva da diversidade. In: BRASIL. Secretaria de Educação Básica Diretoria de apoio a gestão educacional. Pacto nacional pela alfabetização na idade certa: projetos didáticos e sequências didáticas na educação do campo: unidade 02 . Brasília: MEC, SEB, 2012.

KRAMER, Sônia. Alfabetização: leitura e escrita: formação de professores em curso. 4. ed. São Paulo: Ática, 2006.

LEAL, Telma Ferraz; ALBUQUERQUE, Eliana Borges Correia de; MORAIS, Arthur Gomes de. Letramento e alfabetização: pensando a prática pedagógica. In: BEAUCHAMP, Janete; PAGEL Sandra Denise; NASCIMENTO, Aricélia Ribeiro de (Orgs). Ensino Fundamental de nove anos: orientações para inclusão de seis anos de idade. Brasília: Ministério da Educação, 2006.p. 71-85.

LIBERALI, Fernanda Coelho. Formação crítica de educadores: questões fundamentais. Taubaté-SP: Cabral Editora e Livraria Universitária, 2008.

RIGAL, Luís. A Escola Crítico-Democrática: uma matéria pendente no limiar do século XXI. In:

ZEICHNER, K. M. Formando professores reflexivos para a educação centrada no aluno: possibilidades e contradições. In: BARBOSA, R. L. (Org.). Formação de educadores: desafios e perspectivas. São Paulo: UNESP, 2003. p. 278-305. 


\section{LEGISLAÇÃO E POLÍTICAS PÚBLICAS PARA A EDUCAÇÃO INFANTIL: DA LEI DE DIRETRIZES E BASES DA EDUCAÇÃO (LDB 9394/96) AOS DIAS ATUAIS}

Camila Mourão Borges ${ }^{35}$

\section{INTRODUÇÃO}

O tema abordado neste artigo é de grande relevância, pois discute questões pertinentes às necessidades e aos anseios da sociedade em relação a uma educação especializada para as crianças de zero a cinco anos. Sabe-se que a mulher, com ingresso no mercado de trabalho, tem precisado contar com o Estado para garantir que as crianças, quando não estiverem na presença dos pais, estejam em lugar seguro, apropriado para o seu desenvolvimento integral. Esse lugar é a escola, que necessita ser adaptada às necessidades desse público. Segundo as Diretrizes Curriculares Nacionais, as crianças devem se desenvolver em um ambiente livre de qualquer preconceito, seja ele racial, étnico ou religioso, sendo conhecidas de maneira individualizada em um ambiente que não pode ser homogêneo, já que as crianças são únicas e singulares e têm ritmos de aprendizagem e desenvolvimento próprios.

35 Pedagoga e psicopedagoga pela Universidade Federal do Ceará (UFC). Pós-graduada em gestão, supervisão e coordenação pedagógica pela Faculdade de Educação do Piauí (FAEPI). 
Apesar de atual, essa temática já foi evidenciada anteriormente pelo psicólogo bielorrusso Lev Vygotsky (1896-1934). Em seu livro A Formação Social da Mente - O Desenvolvimento dos Processos Psicológicos Superiores, o autor "esclarece que o educador deve ter estratégias diferenciadas para atender os alunos, já que todos não detêm os mesmos conhecimentos nem aprendem de forma igual" (SANTOMOURO, 2012, on-line).

O ambiente escolar é heterogêneo, uma vez que apresenta modelos familiares diversos, realidades sociais distintas. Tal ambiente caracteriza uma realidade regional rica e diversificada, por isso a educação infantil deve possibilitar que a criança aprenda a conviver com essa diversidade, sabendo respeitar as diferenças.

É importante salientar ainda que, "como seres humanos, os alunos são singulares não somente no que se refere à personalidade, mas também porque são oriundos de uma convivência extraclasse, proveniente de uma vivência familiar e social” (DUARTE, s. d., on-line).

$\mathrm{O}$ direito à creche ainda não é um direito garantido pelo Estado, o que dificulta, para as famílias mais carentes, a atuação das mães no mercado de trabalho, exceto quando estas delegam aos avós o processo de educação das crianças para assim poderem contribuir com as necessidades econômicas familiares. A educação das crianças de 4 a 5 anos está estabelecida em lei como gratuita e obrigatória, o que garante às crianças o ingresso à escola na Educação Infantil.

A meta 1, estabelecida pelo PNE - Plano Nacional de Educação, de universalizar, até 2016, a educação infantil na pré-escola para as crianças de 4 e 5 anos de idade foi atingida satisfatoriamente na lei, mas, na prática, ainda se faz necessário muitos investimentos para garantir realmente que essa universalização atenda toda a demanda desse nível de ensino em todo o país. Quando se fala em acesso à creche, portanto, o desafio é maior, uma vez que essa meta aponta a necessidade de ampliar a oferta de educação infantil em creches de forma a atender, no mínimo, 50\% das crianças de até 3 anos.

Para a meta 1, são previstas também algumas estratégias de ações, como definir: "Em regime de colaboração entre União, Estado, Distrito Federal e Município, metas de expansão das respectivas redes públicas de educação infantil segundo padrão nacional de qualidade, considerando as peculiaridades locais" (BRASIL, 2014, p. 11). 
Tal movimento demonstraria que não se faz necessário apenas expandir as redes do ensino infantil, mas também é necessário fazer essa ampliação com qualidade como aponta mais uma das estratégias do PNE, a qual enuncia que é possível:

Manter e ampliar, em regime também de colaboração, respeitadas as normas de acessibilidade, o programa nacional de construção e reestruturação de escolas, bem como a aquisição de equipamentos, visando à expansão e à melhoria da rede física de escolas públicas de educação infantil no país (BRASIL, 2014, p. 11).

O governo federal tem apontado para o programa de vouchers para a educação. A partir dessa estratégia, seria possível aplicar a oferta desses vouchers para o acesso de crianças da rede pública a escolas creches de rede particular, uma vez que todos os outros níveis de educação no país são determinados na legislação como ensino gratuito e obrigatório, tendo que ser ofertados no serviço público educacional nacional.

A legislação nacional é clara quando sinaliza o dever do Estado também com crianças desde a mais tenra idade, porque é uma exigência da sociedade que essas crianças sejam assistidas em escolas preparadas para recebê-las, de forma a promover seu desenvolvimento integral em todas as suas dimensões (cognitiva, física, motora, afetiva). Temos que ficar atentos à proposta do homeschooling, em que as crianças aprendem em casa com o acompanhamento da família. Esse modelo de aprendizagem não pode possibilitar a negligência da oferta da educação infantil porque muitas famílias realmente necessitam de um lugar seguro para seus filhos enquanto cumprem as exigências do mercado de trabalho.

\section{CONTEXTO HISTÓRICO}

O atendimento à infância no Brasil mostra tendências diferenciadas em função das concepções de infância que orientavam os estudos em cada momento histórico. Em um primeiro período, demarcado entre o "descobrimento" até a fase de 1930, inicia-se a valorização gradativa da infância e o reconhecimento da necessidade de atendê-la. No segundo período, que vai de 1930 a 1980, concretizam-se trabalhos de assistência social à infância, tendo em vista, principalmente, o desenvolvimento nacional. 
Em um terceiro momento, evidenciam-se alguns fatos e eventos relativos à educação infantil, que ocorreram na fase de1980 até a atualidade.

Fazer um resgate da história brasileira é encarar um passado trágico, o qual fez parte da vida de milhares de meninos e meninas. $\mathrm{O}$ abandono de bebês, a venda de crianças escravas separadas de seus pais, a vida em instituições que, no melhor dos casos, significava mera sobrevivência, as violências cotidianas que não excluem abusos sexuais, as doenças, as queimaduras e fraturas que sofriam no trabalho escravo ou operário, foram situações que empurraram por mais de três séculos a história da infância no Brasil.

A trajetória da criança e do adolescente no Brasil é marcada por diversas privações e dificuldades. Ao estudá-la, evidenciam-se diversos problemas enfrentados por elas, tais como: maus tratos, abusos sexuais, mortalidade infantil, miséria, fome, falta de moradia, abandono familiar, trabalho escravo. Todos esses problemas seriam causados pela negligência do Estado, da família e da sociedade em geral (HENICK; FARIA, 2015, p. 25828).

Nossas primeiras ideias, imagens e sentimentos em relação à criança brasileira sofreram grande influência dos europeus, através dos missionários jesuítas que chegaram ao Brasil no século XVI. Aos olhos deles, a criança brasileira, índia, negra e mestiça, se assemelhava aos anjos, seres bons puros e inocentes. Elas representam, portanto, o "papel em branco" em que os jesuítas inscreviam a sua cultura, com base em fortes conteúdos de educação moral e religiosa aos quais as crianças eram submetidas antes que o "pecado" se instalasse em sua alma.

Assim, propagaram-se duas representações infantis: uma mística, repleta de fé, por meio da qual foi difundido o mito da criança santa; e outra, em que a criança é o modelo de Jesus, muito difundida pelas freiras carmelitas. Inspirados por essas imagens, que são capazes de transcender aos pecados terrenos, os jesuítas veem nas crianças indígenas "o papel em branco" que desejam escrever, antes que os adultos, com seus maus costumes, as contaminem (DEL PRIORI, s.d., p. 3).

Os jesuítas trouxeram a mentalidade europeia da criança enquanto ser gracioso e vulnerável, o que contribuiu para que enxergassem nos pequenos indígenas ou "muchachos", como os chamavam, "um inocente... mui elegante e formoso, ou ainda, mui bons e mui bonitos". O projeto 
jesuítico se afastou dos pequenos indígenas quando constataram que, ao chegarem à puberdade, eles se revoltavam contra o processo de aculturação. Para os jesuítas, "A puberdade era entendida como o momento da passagem da inocência original da infância à idade perigosa do conhecimento do bem e do mal, em que a criança assumiria o comportamento do adulto" (NETO, 2000, p. 105).

Já no período pós-colonização, mesmo havendo posicionamentos declaradamente contrários à criação de jardins de infầncia, era crescente o interesse pela infância desprotegida. Entretanto, as instituições de atendimento eram insuficientes e não havia um propósito claro para o atendimento. Por isso, a mobilização de grupos interessados no atendimento às crianças pequenas resultou na criação do Instituto de Proteção Assistência à Infância do Brasil.

O Instituto era destinado ao atendimento tanto das crianças, dos bebês das mães, quanto das amas de leite que vinham até a instituição passar pelo exame de atestação na seção denominada "Gota de Leite", que fazia a distribuição de leite esterilizado para as famílias. As amas de leite em geral recebiam baixos salários e vinham das classes mais pobres (GOLINELLI; JULIANE; MARCILIO, s.d., p. 16730).

A concepção de criança enquanto ser de cuidado e proteção fundamenta o entendimento a elas oferecido ao longo de toda a idade moderna. A partir da segunda metade do século XIX e durante o século XX, período em que se consolidou o regime republicano em nosso país, conferiu-se maior visibilidade e centralidade à infầncia, colocando em primeiro plano a problemática relativa ao cultivo das gerações mais novas e objetivando sua inserção na esfera pública. A infầncia, então, passa de um assunto periférico ao centro das atenções no que tange aos interesses governamentais, pois o investimento em seu atendimento significava benefícios políticos para o Estado.

Em meados de 70, era corrente a ideia de defender a qualidade do ensino infantil, e a culpa por sua queda parecia ser conferida à escola, que se preocupava com a nutrição e não com a educação. Nesse contexto, a educação passou a ser vista como oposto da assistência. Passou-se, então, a defender que as creches e também a Educação Infantil que atendia às classes populares precisavam de um projeto educacional. A ideia de tornar as creches e a pré-escola espaços educativos, imprimindo algo "novo" às instituições de 
Educação Infantil, acabou se tornando a tônica da reformulação de grande número de propostas de atendimento dessa faixa etária nos dias de hoje. $\mathrm{Na}$ verdade, as propostas se diziam inovadoras pelo simples fato de deixarem de ser assistencialista para se tornarem educativas. Ao longo dos anos, a discussão sobre a necessidade de integrar cuidado e educação na educação infantil tem sido feita exaustivamente na literatura acerca do assunto.

A educação da criança pequena envolve simultaneamente dois processos complementares e indissociáveis: educar e cuidar. As crianças dessa faixa etária têm necessidade de atenção, carinho, segurança, sem as quais elas dificilmente poderiam sobreviver. Simultaneamente, nessa etapa, as crianças tomam contato com o mundo que as cerca, através das experiências diretas com as pessoas e as coisas desse mundo e com as formas de expressão que nele ocorrem. Essa inserção das crianças no mundo não seria possível sem que atividades voltadas simultaneamente para cuidar e educar estivessem presentes (BUJES, s.d. apud CRAIDY; KAERCHER, 2001, p. 16).

\section{O QUE DITA O MARCO LEGAL DA EDUCAÇÃO INFANTIL NO BRASIL}

O Brasil conta com alguns marcos legais que apontam para a imensa necessidade de compreender a educação infantil como uma etapa do desenvolvimento humano com características únicas e próprias e que, por isso, necessitam de cuidados específicos, pois não é uma urgência apenas da criança, mas também dos seus pais e da sociedade. O marco principal é a lei de Diretrizes e Base da Educação Nacional.

Em 1990, o Estatuto da Criança e do Adolescente (ECA) veio para garantir os direitos das crianças e dos adolescentes, como consta no art. $4^{\circ}$, o qual determina que é dever da família, da comunidade, da sociedade em geral e do Poder Público assegurar, com absoluta prioridade, a efetivação dos direitos à vida, à saúde, à alimentação, à educação, ao esporte, ao lazer, à profissionalização, à cultura, à dignidade, ao respeito, à liberdade, à convivência familiar e comunitária, entre outros mais que asseguram a criança e adolescentes de ter seu desenvolvimento na sociedade em que vivem (DIGIÁCOMO; DIGIÁCOMO, 2013, p. 5-6). 
A Lei de Diretrizes Bases da Educação 9394/96, Art. 4º aponta que o dever do Estado com educação escolar pública será efetivado mediante a garantia de: "I - educação básica obrigatória e gratuita dos 4 (quatro) aos 17 (dezessete) anos de idade".

O Art. 29 da LDB/96 institui a educação infantil como primeira etapa da educação básica tendo como finalidade o desenvolvimento integral da criança de até 5 anos em seus aspectos físicos, psicológico, intelectual e social, complementando a ação da família e da comunidade.

O Art. 11 dita que os Municípios incumbir-se-ão de:

V - Oferecer a educação infantil em creches e pré-escolas, e, com prioridade, o ensino fundamental, permitida a atuação em outros níveis de ensino somente quando estiverem atendidas plenamente as necessidades de sua área de competência e com recursos acima dos percentuais mínimos vinculados pela Constituição Federal à manutenção e desenvolvimento do ensino.

O artigo aponta que, apesar de a educação Infantil dos 4 aos 5 anos estar garantida, em lei, sua obrigatoriedade, sua ampliação apenas se dará mediante prioridade a oferta do Ensino Fundamental. Portanto, o avanço da Educação infantil é um desafio ainda para municípios, principalmente quando se pensa em atender não apenas a pré-escola, mas o atendimento das crianças de zero aos três anos em creches.

De acordo ainda com a mesma Lei, o Art. 30 afirma que a educação infantil será oferecida em:

I - Creches, ou entidades equivalentes, para crianças de até três anos de idade;

II - Pré-escolas, para as crianças de 4 (quatro) a 5 (cinco) anos de idade.

O Art. 31 estabelece as principais diretrizes de como será organizada a educação infantil definindo as seguintes regras comuns:

I - Avaliação mediante acompanhamento e registro do desenvolvimento das crianças, sem o objetivo de promoção, mesmo para o acesso ao ensino fundamental; 
II - Carga horária mínima anual de 800 (oitocentas) horas, distribuída por um mínimo de 200 (duzentos) dias de trabalho educacional;

III - Atendimento à criança de, no mínimo, 4 (quatro) horas diárias para o turno parcial e de 7 (sete) horas para a jornada integral;

IV - Controle de frequência pela instituição de educação pré-escolar, exigida a frequência mínima de 60\% (sessenta por cento) do total de horas;

V - Expedição de documentação que permita atestar os processos de desenvolvimento e aprendizagem da criança.

Esses marcos legais, juntamente com a BNCC - Base Nacional Curricular - são documentos relevantes para a organização e estruturação da Educação Infantil no território brasileiro. Para que a Educação Infantil seja realmente incorporada como primeira etapa da Educação básica e as crianças sejam acompanhadas por profissionais especializados, considerando que os recursos financeiros ainda são limitados e que a capacidade para responder ao desafio de oferecer uma educação infantil compatível, na extensão e na qualidade, a dos países desenvolvidos, o plano nacional propõe, constante e progressivamente, prioridade segundo o dever constitucional e as necessidades sociais.

Muito ainda tem que ser feito apesar do aumento significativo no atendimento em creches e pré-escolas nos últimos anos, o que reflete uma tendência à universalização da educação infantil em contexto institucional. É importante que o governo, a escola, as famílias e a sociedade como todo possam reforçar a concepção de que a creche constitui um bem, uma conquista da sociedade, um direito não só para o filho da mãe trabalhadora, mas uma instituição educacional destinada a todas as crianças.

\section{BNCC - EDUCAÇÃO INFANTIL A ARTE DE EDUCAR E CUIDAR}

De acordo com as diretrizes Curriculares Nacionais de Educação Infantil, as propostas da educação infantil devem respeitar princípios esté- 
ticos, voltando-se para diferentes manifestações artísticas e culturais que consideram a diversidade cultural, religiosa, étnica e social do país.

As Diretrizes Curriculares Nacionais para a Educação Infantil citam a educação infantil como um espaço educacional que tem o importante papel de compartilhar, de forma indissociável, a educação e o cuidado das crianças pequenas com suas famílias.

[...] O cuidado, compreendido na sua dimensão necessariamente humana de lidar com questões de intimidade e afetividade, é característica não apenas da Educação Infantil, mas de todos os níveis de ensino. $\mathrm{Na}$ Educação Infantil, todavia, a especificidade da criança bem pequena, que necessita do professor até adquirir autonomia para cuidar de si, expõe de forma mais evidente a relação indissociável do educar e cuidar nesse contexto [...]". " [...] Educar cuidando inclui acolher, garantir a segurança, mas também alimentar a curiosidade, a ludicidade e a expressividade infantis. Educar de modo dissociado do cuidar é dar condições para as crianças explorarem o ambiente de diferentes maneiras (manipulando materiais da natureza ou objetos, observando, nomeando objetos, pessoas ou situações, fazendo perguntas etc.) e construírem sentidos pessoais e significados coletivos, à medida que vão se constituindo como sujeitos e se apropriando de um modo singular das formas culturais de agir, sentir e pensar. Isso requer do professor sensibilidade e delicadeza no trato de cada criança, e assegurar atenção especial conforme as necessidades que identifica nas crianças (BRASIL, 2006, p. 17).

A criança pequena, em primeiro lugar, se identifica com o outro para depois se diferenciar. Através da construção dos vínculos é que ela elege os modelos que vai seguir. Esses modelos serão importantíssimos para a formação da personalidade e da identidade da criança.

Os primeiros vínculos se estabelecem no ambiente familiar e somente depois da entrada na escola, por volta dos quatro anos, é que se amplia para os professores e colegas. Com a entrada cada vez mais cedo das crianças na escola, os professores devem estar atentos à construção desses vínculos e modelos no ambiente escolar. A linguagem da criança na educação in- 
fantil é afetividade, por isso o educador infantil deve estar preparado para lidar com essa demanda afetiva.

As práticas dos professores não se relacionam com o que eles sabem, com suas competências profissionais, mas com o que eles são, com o valor e o sentido que conferem à sua prática, com sua autoconsciência profissional. Trata-se de produzir, capturar e mediar pedagogicamente alguma modalidade da relação da pessoa consigo mesma com o objetivo de sua transformação (LARROSA, 2002 apud GOMES, 2009, p. 190). Segundo Oliveira:

A intencionalidade educativa presente nas interações adulto/ criança, parceiros mais/menos experientes, explicita-se sobretudo quando o adulto responsável assume o compromisso de levar ao êxito os propósitos aos quais a interação se destina, especialmente quando se trata de interações pedagógicas, ou seja, daquelas que justificam a existência de espaços institucionais (OLIVEIRA, 2010, p. 41).

Nesse sentido, aponta-se para o fato de que as atividades que envolvem essas interações são facilitadoras para o exercício da democracia, da reciprocidade, do respeito mútuo, já que, no grupo, as crianças mostram suas maneiras de pensar e consideram a maneira de pensar dos outros. Além disso, podem ocorrer disputas que devem ser resolvidas através do diálogo, provocando a intencionalidade do professor de educar para a autonomia das relações, do pensar, do agir, do sentir, interações pedagógicas que justificam a intencionalidade existente nos espaços destinados à educação dos pequeninos.

Assim, pode-se dizer que, à medida que se cuida, se educa a criança e, à medida que se educa a criança, ela é cuidada em suas necessidades. $\mathrm{O}$ compromisso com a educação das crianças pequenas vai além dos cuidados com o desenvolvimento físico, pois abrange o desenvolvimento do pensamento da linguagem, da motricidade, da autonomia e do desenvolvimento lógico.

Sendo assim, cuidar e educar as crianças de maneira indissociável e com a devida atenção para os processos é o que fará total diferença no projeto educacional adotado nas escolas de educação nacional do país. 


\section{CONSIDERAÇÕES FINAIS}

Pensar sobre a importância da educação infantil e da referência estabelecida pelos marcos legais aponta, para a sociedade, a necessidade de o país investir na ampliação de oferta desse nível de ensino, o que possibilita que as crianças, ao estarem longe da família, encontrem lugar seguro para se desenvolverem de maneira integral respeitando as suas particularidades e diferenças.

Enfrentar os problemas de abandono, desnutrição, mortalidade infantil, abusos sexuais, trabalho infantil, que ainda estão presentes em nossa realidade, somente acontecerá com um projeto educacional que coloque a criança em período integral na escola desde muito pequena. Este é um direito obrigatório e de oferta gratuita para as crianças de 4 a 5 anos que deve ser respeitado e propiciado pelos municípios com efetividade por meio de políticas públicas educacionais que assegurem a universalização da pré-escola no Brasil não apenas pela lei, mas também de maneira efetiva com acesso e democratização das crianças à escola.

É necessário que essas instituições superem o assistencialismo e a preocupação apenas de exercer os cuidados físicos de alimentação, higiênicos e descanso. A política de educação infantil, apontada pelas Diretrizes Nacionais, afirma que as crianças também possuem a necessidade de serem educadas tanto quanto cuidadas. Tal política considera, portanto, que, além dos aspectos físicos, existe todo o desenvolvimento integral, que vai desde a capacidade de pensar logicamente, a capacidade de se expressar, que vai desde o movimento do corpo à aquisição da linguagem e, por fim, a construção da autonomia, da afetividade e dos comportamentos sociais. Todos esses aspectos devem ser levados em consideração quando se pensa num projeto de construção nacional de educação infantil para o país.

Por fim, o país não pode mais negligenciar os cuidados com a primeira infância. É preciso enfrentar o problema de escassez de recursos e cuidar não apenas de universalizar o acesso, mas fazê-lo de maneira que vise a uma melhor e maior qualidade de construção das escolas que, ao mesmo tempo que precisam estar prontas para receber as crianças em suas necessidades, precisam estar também preparadas com professores capazes de trabalhar de maneira indissociável os processos de cuidado e a educação das crianças no Brasil. 


\section{REFERÊNCIAS}

BRASIL. Lei n. 9.394, de 20 de dezembro de 1996. Estabelece as diretrizes e bases da educação nacional. Diário Oficial da União, Brasília, DF, 23 dez. 1996. Seção 1, p. 27833-27841. Disponível em: http/ www.planalto.gov.br/ccvil_03/leis/9394.htm. Acesso em: 03 maio 2021.

. Ministério da Educação. Secretaria de Educação Básica. Política Nacional de Educação Infantil: pelo direito das crianças de zero a seis anos à educação. Brasília, DF: MEC/SEB, 2006. 17p. Disponível em: http://portal.mec.gov.br/seb/arquivos/pdf/pol_inf_ eduinf.pdf. Acesso em: 03 maio 2021.

Plano Nacional de Educação: para o Brasil avançar mais. Lei no 13.005, de 25 de junho de 2014. Brasília: Senado Federal, Gabinete do Senador José Pimentel, 2014.

CRAIDY, Carmen; KAERCHER. Gladis C. Educação Infantil - pra que te quero? São Paulo: Editora Artmed, 2001.

DEL PRIORI, Mary. História da criança no Brasil. In: PASSETI, Edson. As crianças brasileiras: um pouco de sua história. Texto mimeografado [s.I.: s.n., s.d.].

DIGIÁCOMO, Murilo José.; DIGIÁCOMO, Ildeara de Amorim. Estatuto da Criança e Adolescente. Curitiba: SEDS, 2013.

DUARTE, Vania. Lidando com a heterogeneidade no ambiente escolar. Brasil Escola. Goiás, 2012. Disponível em: https://educador.brasilescola.uol.com.br/sugestoes-pais-professores/lidando-com-heterogeneidade-no-ambiente-escolar.htm. Acesso em: 11 maio 2021.

GOLINELLI, Costa Rembis; JULIANE E MARCILIO, Luiza Maria. A cruzada pela infância - $\mathrm{O}$ instituto de proteção e assistência à infância do Rio de Janeiro. In: Congresso Nacional de Educação, 13, Curitiba, PR, [s.d.]. Anais [...] Curitiba, PR: PUCPR, [s.d.]. Disponível em: educere.bruc.com.br/arquivo/pdf2017/25381_14202.pdf. Acesso em: 03 maio 2021. 
GOMES, Marineide de Oliveira. Formação de professores na Educação Infantil. São Paulo: Cortez, 2009.

HENICK, Cristina Angelica; FARIA, Maria Paula. História da Infância no Brasil. In: Congresso Nacional de Educação, 12, Curitiba, PR, 2015. Anais [...] Curitiba, PR: PUCPR, 2015. Disponível em: https://educere.bruc.com.br/arquivo/pdf2015/19131_8679.pdf. Acesso em: 03 maio 2021.

MARCILIO, Maria Luiza. História Social da Criança abandonada. EDUCERE: Formação de professores, contextos, sentidos e práticas. 2 ed. São Paulo: Hucitec, 2006.

NETO, João Clemente de Souza. História da Criança e do Adolescente no Brasil. Revista Unifieo - Revista Semestral do Centro Universitário FIEO, ano 2, n. 3, 2000.

OLIVEIRA, Zilma de Moraes. Educação infantil: fundamentos e métodos. 7. ed. São Paulo: Cortez, 2011.

. Educação Infantil: muitos olhares. 9. ed. São Paulo: Cortez, 2010 .

SANTOMOURO, Beatriz. Turma heterogênea: cada um é um. E agora? Nova escola. São Paulo, 01 set. 2012. Disponível em: https:// novaescola.org.br/conteudo/1954/turma-heterogenea-cada-um-e-um-e-agora. Acesso em: 11 maio 2021. 


\section{A GESTÃO DO RISCOS NA EDUCAÇÃO BÁSICA BRASILEIRA}

Solange Feliciano Pires $^{36}$

\section{INTRODUÇÃO}

A Educação Básica compreende o primeiro ano de escolaridade até ensino médio, cuja faixa etária atende alunos de 6 a 17 anos, desde que estejam em idade série regulares, o que não inclui estimativa as desistências e reprovações que retardam a conclusão dos estudos na descrita modalidade. Partindo dessa premissa, o público atendido abarca infância e adolescência, pois de acordo o Estatuto da Criança e do Adolescente (ECA) (BRASIL, 1990) a adolescência vai dos 12 aos 18 anos.

O conceito de risco reporta a situações de vulnerabilidade que envolvem dependência por exposição a um ambiente geográfico e socioeconômico de convivência. Nesse sentido, Infância e adolescência podem ser afetados nas instâncias emocionais e físicas, requerendo dos responsáveis cuidados e atenção.

Neste artigo, analisaremos o papel da instituição escola na prevenção de riscos, abarcando a gestão local, diretores escolares e o Estado, diante das Políticas públicas de intervenção. Objetivamos identificar os discursos presentes na literatura sobre a vulnerabilidade da infầncia e da adolescência, de modo que seja traçado um paralelo com as políticas públicas criadas

36 Mestranda do Programa de Pós-Graduação em Ensino, da Universidade Estadual do Sudoeste da Bahia. Especialista em Supervisão Escolar. Graduada em História. Professora da Rede Municipal de Vitória da Conquista-BA. 
por meio da aplicação do biopoder. Nesse sentido, iniciarmos este estudo com uma análise conceitual de biopoder, sustentada nos estudos Foucaultianos, bem como mediante definições de risco e de vulnerabilidade, para que tenhamos uma melhor compreensão acerca das políticas públicas brasileiras de intervenção, bem como do papel da escola na detecção e gestão da periculosidade.

Para tanto, faremos uma análise bibliográfica da literatura contrapondo com análise nos documentos oficiais que versam sobre políticas públicas de responsabilidade do governo - criadas a partir dos anos noventa - com o objetivo de enfrentar os riscos a que estão expostos crianças e adolescentes.

\section{O BIOPODER, A VULNERABILIDADE E O RISCO NA EDUCAÇÃO BÁSICA: CONCEITOS E IMPLICAÇÕES}

O filósofo francês Michel Foucault conceitua biopoder com base nos postulados poder e saber, assim, teoriza sobre o poder não centralizado de maneira soberana em grupos hierarquicamente posicionados na ponta da pirâmide, mas reconhecendo-o como exercício que circula em múltiplas direções, associado a formas de saber. O poder atua de maneira difusa, capilar, espalhando-se pelas relações sociais por meio das instituições como família, escola, hospital e clínica. Desse modo, poder é um conjunto de relações de forças multilaterais, que circula entre todos (FOUCAULT, 1999b).

Além disso, Foucault (1999) contesta a noção de que o poder é exercido de maneira imposta arbitrariamente, para ele, o poder não é exercido por imposição e se modifica, podendo haver substituição nas relações de poder. Ou seja, o exercício do poder gera uma configuração, mas nada impede que se reconfigure.

Caminhando nessa linha de pensamento, compreendemos as análises de Foucault sobre biopoder, conceito mediante o qual ele entenderá as ações do Estado moderno direcionadas para as práticas de gestão da vida humana, em função das quais as políticas públicas são pensadas de modo a "fazer viver e deixar morrer" (FOUCAULT, 1999). Partindo da premissa de que quando mais forte a população, mas produtiva ela se torna,

[...] as disciplinas do corpo e as regulações da população, constituem os dois polos em torno dos quais se desenvolveu a organiza- 
ção do poder sobre a vida. A instalação, durante a época clássica, desta tecnologia de duas faces-anatômica e biológica-, individualmente e especificamente, voltada para os desempenhos do corpo e encarando os processos da vida, caracteriza um poder cuja função mais elevada já não é mais matar, mas investir sobre a vida, de cima para baixo (FOUCAULT, 1999, p. 152).

O referido autor conceitua biopoder como "o conjunto dos mecanismos pelos quais aquilo que, na espécie humana, constitui suas características biológicas fundamentais, vai poder entrar numa política, numa estratégia política, numa estratégia geral do poder" (FOUCAULT, 2008, p. 3). Em conformidade com essa definição, o Estado utiliza-se de estratégias de biopoder para criar políticas públicas capazes de reduzirem estatísticas, para isso, cria-se critérios de adesão e, em contrapartida, cobra responsabilidades dos contemplados.

Acrescenta-se a isso a necessidade da marcação individual para a eficácia da gestão do risco, ou seja, mesmo que se trate de população, o processo de individualização é primordial para o controle geral da periculosidade social. Nesse sentido, mesmo tendo direitos coletivos, as responsabilidades são transferidas para domínios individuais. Portanto, o objetivo da gerência da vulnerabilidade é promover no indivíduo a capacidade de autogestão, para prevenir a periculosidade.

No que diz respeito aos conceitos de vulnerabilidade e risco, os Centros de Referência de Assistência Social (CRAS), cujo objetivo é apoiar famílias em situação de risco, oferecem o Serviço de Proteção e Atendimento Integral à Família (PAIF), segundo o qual

[...] vulnerabilidade está relacionada à capacidade de contenção das forças que afetam o bem-estar da pessoa, família ou comunidade, ou seja, ao controle de ativos, incluindo recursos físicos, como moradia, bens duráveis e poupança; humanos, como trabalho, saúde e educação; e sociais, como redes de contratos e acesso à informação (BRASIL, 2012, on-line). 
Diante do exposto, podemos concluir que o estado de vulnerabilidade incapacita o sujeito de vislumbrar alteração em sua situação e na busca por direitos constitucionalmente garantidos. De acordo Benatto (2016, p. 18),

A vulnerabilidade social é preocupação de diferentes áreas, desde a saúde a movimentos sociais e identificar grupos em situações de risco exige considerar diversos aspectos e variáveis, dentre elas variáveis sociais, culturais e psicológicas. A identificação de crianças e adolescentes em situação de vulnerabilidade escolar possibilita a construção de estratégias para lidar com essa situação de conflito.

Nesse sentido, é necessário que se tenha conhecimento da situação de risco a que estão expostas as crianças e adolescentes em seu convívio. Assim, será possível desenvolver ações capazes de promover o desenvolvimento de sua aprendizagem, visto que estas situações de conflito poderão influenciar o comportamento dos sujeitos. Diante disso,

[...] a negação dos aspectos estruturantes que o sujeito precisa para sua vida, tais como: educação, saúde, lazer e cultura, desenvolvem/ criam uma situação de perigo e torna esses indivíduos mais suscetíveis a cometerem delitos e a serem expostos a situação de perigo (DOURADO, 2007, p. 11).

Portanto, são essenciais as políticas públicas de intervenção e combate à desigualdade social, sobretudo para os sujeitos em situação de vulnerabilidade social A ausência dessas gera maior dificuldade para que os sujeitos tenham seus direitos garantidos e possam, diante de uma maior consciência de sua situação, buscarem mudar sua condição e tornarem-se sujeitos participantes e independentes. Nesse ponto, concordamos:

Assim, a crise do Estado Providência não implica apenas uma série de mecanismos que enfraquecem, transformam ou suprimem fatores de integração social, como também representam um apelo à responsabilidade dos indivíduos nos processos de gestão dos riscos sociais. Trata-se de transformações do edifício social que não só alteram as percepções quanto à incerteza, mas também levam a uma relação diferente dos indivíduos com o Estado. 
Comungamos aqui com o pensamento de Michel Foucault definindo que o saber produz poder, tendo em vista que "para ele, o poder encontra-se sempre associado alguma forma de saber. Exercer o poder torna-se possível mediante conhecimentos que lhe servem de instrumento e justificação" (FURTADO; CAMILO, 2016, p. 35).

\section{POLITICAS PÚBLICAS BRASILEIRAS DE INTERVENÇÃO}

A Constituição Federal de 1988, em seu artigo 224, garante que a "política de atendimento dos direitos da criança e do adolescente far-se-á através de um conjunto articulado de ações governamentais e não governamentais, da União, dos Estados, dos Distrito Federal e dos Municípios" (BRASIL, 1988). Isso implica ações das instâncias citadas com vistas a garantir a efetivação das leis.

A noção de biopoder pode ser considerada parte do núcleo teórico mais potente do legado deixado por Michel Foucault para interrogar a experiência da modernidade. Esse termo foi por ele utilizado para referir-se a uma mesma corrente caracterizada pelo desenvolvimento de duas formas de poder: (1) uma anatomopolítica do corpo, por meio das disciplinas que atravessam a totalidade do tecido social; (2) uma biopolítica da população, centrada em uma grande variedade de controles e intervenções reguladoras do bem-estar, dirigidas à população considerada como corpo-espécie. Por meio de diferentes mecanismos e dispositivos, esse funcionamento bipolar do biopoder consegue "[...] penetrar os corpos de maneira cada vez mais detalhada e controlar as populações de maneira cada vez mais global” (FOUCAULT apud MITJAVILA, 2015, p.118).

Na medida em que uma situação de risco é detectada e evidenciada por meio de estatísticas e passa de individual a populacional, de local a geral, o governo federal intervém com intuito de diminuir a periculosidade. Nesta perspectiva, o Estatuto da Criança e do Adolescente (ECA), criado em 1990, define os Conselhos Tutelares, regulamentados, em 1990; o Programa Bolsa Família, em 2003; o Programa Saúde na escola, em 2007; o programa Mais Educação criado, em 2007. 


\section{ESTATUTO DA CRIANÇA E DO ADOLESCENTE}

Em 13 de julho de 1990 foi regulamentada a Lei n. 8.069, que criou o ECA. Considerada uma importante medida para proteção das crianças e adolescentes, pelas garantias previstas, assegura-lhes direitos, tais como: à vida, à saúde, à liberdade, ao respeito, à dignidade, à convivência familiar, à educação, à cultura, ao esporte e ao lazer. Esse último bloco está mais atrelado à escola que é nosso objeto de atenção nesse trabalho.

Assim, "a criança e o adolescente têm direito à educação, visando ao pleno desenvolvimento de sua pessoa, preparo para o exercício da cidadania e qualificação para o trabalho" (BRASIL, 1990). Essa lei assegura:

Igualdade de condições para o acesso e permanência na escola; Direito de ser respeitado por seus educadores; Direito de contestar critérios avaliativos, podendo recorrer às instâncias escolares superiores; Direito de organização e participação em entidades estudantis, e Acesso a escola pública e gratuita próxima de sua residência (BRASIL, 1990, on-line).

Em complemento, estatuto estabelece ainda os seguintes deveres do Estado, os quais devem ser efetivados:

Garantir ensino fundamental, obrigatório e gratuito, inclusive para os que a ele não tiveram acesso na idade própria; Assegurar progressivamente a extensão da obrigatoriedade e gratuidade ao ensino médio; Oferecer atendimento educacional especializado aos portadores de deficiência, preferencialmente na rede regular de ensino; Oferecer atendimento em creche e pré-escola às crianças de zero a seis anos de idade; Garantir acesso aos níveis mais elevados do ensino, da pesquisa e da criação artística, segundo a capacidade de cada um; Ofertar ensino noturno regular, adequado às condições do adolescente trabalhador; Promover atendimento no ensino fundamental, através de programas suplementares de material didático escolar, transporte, alimentação e assistência à saúde (BRASIL, 1990, on-line). 
Fica evidenciada a obrigatoriedade do ensino público e gratuito, conforme estabelecido pela constituição federal, contudo é importante ressaltar que esse direito é público e subjetivo, ou seja, se porventura não for assegurado, o cidadão pode recorrer à justiça para exigir o seu cumprimento.

\section{CONSELHO TUTELAR}

Como desdobramento do ECA, o Conselho Tutelar — órgão público de atuação municipal com caráter permanente e autônomo, cujos membros são eleitos democraticamente pela comunidade local - tem a função de fiscalizar o cumprimento dos direitos da criança e do adolescente descritos no ECA. Esse órgão averigua, atende e acompanha casos denunciados ou evidenciados, tendo a competência de acionar outros serviços para garantir o exposto no ECA, conforme descrito no Art. 136 deste, no qual também se encontram todas as suas atribuições, entre elas:

Art. 136. São atribuições do Conselho Tutelar:

I - atender as crianças e adolescentes nas hipóteses previstas nos arts. 98 e 105, aplicando as medidas previstas no art. 101, I a VII;

II - atender e aconselhar os pais ou responsável, aplicando as medidas previstas no art. 129, I a VII;

III - promover a execução de suas decisões, podendo para tanto:

a) requisitar serviços públicos nas áreas de saúde, educação, serviço social, previdência, trabalho e segurança;

b) representar junto à autoridade judiciária nos casos de descumprimento injustificado de suas deliberações (BRASIL, 1990, on-line).

São muitas as atribuições do Conselho Tutelar, em razão disso, é comum as instituições escolares receberem conselheiros tutelares para acompanharem matrícula, frequência ou mesmo requisitar crianças para atendimentos psicológicos. Nessas ocasiões, os gestores são sempre os procurados por esta instituição para prestarem esclarecimentos. Assim, firma-se parceria e torna-se comum a escola requisitar palestras de conscientização para alunos. 


\section{PROGRAMA BOLSA FAMÍLIA}

O Programa Federal Bolsa Família foi criado em outubro de 2003, e objetivou combater a pobreza e a desigualdade social por intermédio de três bases: complemento da renda familiar; acesso a direitos e estímulo ao desenvolvimento das famílias. O programa tem gestão descentralizada com atribuições nas instâncias federal, estadual e municipal.

Esse programa atende famílias com renda considerada abaixo da estatística tolerável, ou seja, entre 89,01 e 178,00 reais mensais e está condicionado às famílias com crianças e adolescentes entre 0 e 17 anos, desde que os mesmos estejam com calendário de vacinas atualizados e desde que, aqueles em idade escolar, estejam matriculados e frequentes nas escolas. Diante disso, cabe às unidades escolares enviarem relatórios mensais com esses dados.

\section{PROGRAMA SAÚDE NA ESCOLA}

Programa Saúde na Escola (PSE) foi criado por intermédio da portaria $n^{\circ} 3.696$, de 25 de novembro de 2010. Ele tem como objetivo realizar um trabalho conjunto entre educação e saúde, buscando melhoria na qualidade de vida da população brasileira, mediante a formação dos estudantes por meio de ações de promoção, de prevenção e de atenção à saúde que visam o combate das vulnerabilidades que impedem o bom desenvolvimento de crianças e jovens das escolas públicas.

O PSE atua em parceria com as escolas, para tanto oferece serviços de orientação, divulgação e serviços como vacinação e escovação. Busca atender ao púbico da educação básica, por isso os profissionais da saúde atendem aos estudantes diante de planejamento realizado junto à escola. "A Escola é a área institucional privilegiada deste encontro da educação e da saúde: espaço para a convivência social e para o estabelecimento de relações favoráveis à promoção da saúde pelo viés de uma Educação Integral” (BRASIL, 2010, on-line).

\section{PROGRAMA MAIS EDUCAÇÃO}

Tendo em vista a promoção da educação em tempo integral — da Educação Básica nas Redes Estadual e Municipal de Ensino - o Minis- 
tério da Educação criou, (mediante Portaria Interministerial no 17/2007) e regulamentou (pelo Decreto 7.083/10) o Programa Mais Educação. Tal programa visa a ampliar a carga horária das escolas para no mínimo sete horas diárias, oferecendo atividades em turno oposto ao da matrícula regular, tais atividades são optativas de acompanhamento pedagógico; educação ambiental; esporte e lazer; direitos humanos em educação; cultura e arte; cultura digital; promoção da saúde; comunicação e uso de mídias; investigação no campo das ciências da natureza e educação econômica.

Fica a cargo do gestor escolar a adesão ao programa, a escolha das atividades a serem ofertadas, a seleção dos profissionais, bem como a administração e a prestação de contas da verba recebida.

Diferentes experiências pedagógicas indicam o papel central que a escola tem na construção de uma agenda de Educação Integral articulando, a partir da ampliação da jornada escolar, políticas públicas, equipamentos públicos e atores sociais que contribuam para a diversidade e riqueza de vivências que tornam a Educação Integral uma experiência inovadora e sustentável ao longo do tempo (MEC, 2010, on-line).

Em sua constituição inicial, em 2008, o programa priorizou localidades nas capitais e regiões metropolitanas com baixo Índice de Desenvolvimento da Educação Básica (IDEB). Essa ação foi sendo ampliada progressivamente para contemplar escolas que, além do critério já citado, estivessem localizadas em locais considerados de vulnerabilidade social.

Para o desenvolvimento de cada atividade, o governo federal repassa recursos para ressarcimento de monitores, aquisição dos kits de materiais, contratação de pequenos serviços e obtenção de materiais de consumo e permanentes. De acordo com as atividades escolhidas, as escolas beneficiárias também podem receber conjuntos de instrumentos para banda fanfarra, hip hop e rádio escolar, dentre outros, conforme Manual PDDE - Educação Integral (MEC, 2010, on-line).

Por conseguinte, não podemos fazer uma leitura ingênua das políticas públicas de Educação, tendo em vista que elas são constituídas levando em 
consideração as diferenças existentes na população, sobretudo a desigualdade social. Como bem afirma Gomes (2011, p. 22-23):

[...] consideramos, porém, que a reconstrução das políticas públicas como prática discursiva é capaz de desvelar o múltiplo e complexo, e as relações contraditórias e antagônicas que as caracterizam. Como práticas discursivas, dispersas no espaço e no tempo, variadas em formas de enunciados, ressignificadas por grupos e partidos interessados que se posicionam no campo da educação disputando a hegemonia do capital específico.

De certo, cabe aos gestores um olhar crítico sobre as políticas públicas, indo além do meramente administrativo, por isso cabe uma "análise de sua coexistência, de sua sucessão, de seu funcionamento mútuo, de sua determinação recíproca, e de sua transformação independente ou correlativa" (FOUCAULT, 2004, p. 33).

Os dados apresentados nas figuras 1 e 2, a seguir, do Instituto Nacional da Educação Pública (INEP), indicam redução dos índices de evasão, apontando para um resultado positivo das políticas públicas implementadas no País e aqui descritas, no que diz respeito à matrícula e à permanência das crianças e adolescentes nas escolas.

Figura 1- Comparativo da Evasão nos anos iniciais da Rede pública de Ensino nos anos 2007 e 2014

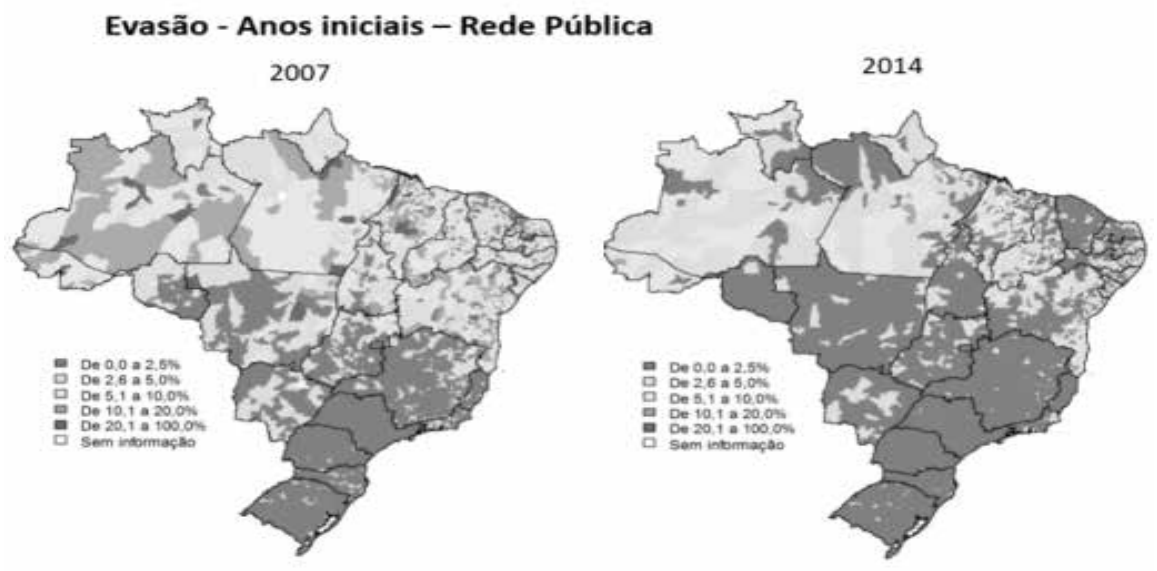

Fonte: INEP (2019). 
Figura 2 - Comparativo da Evasão no Ensino Médio da Rede pública nos anos 2007 e 2014

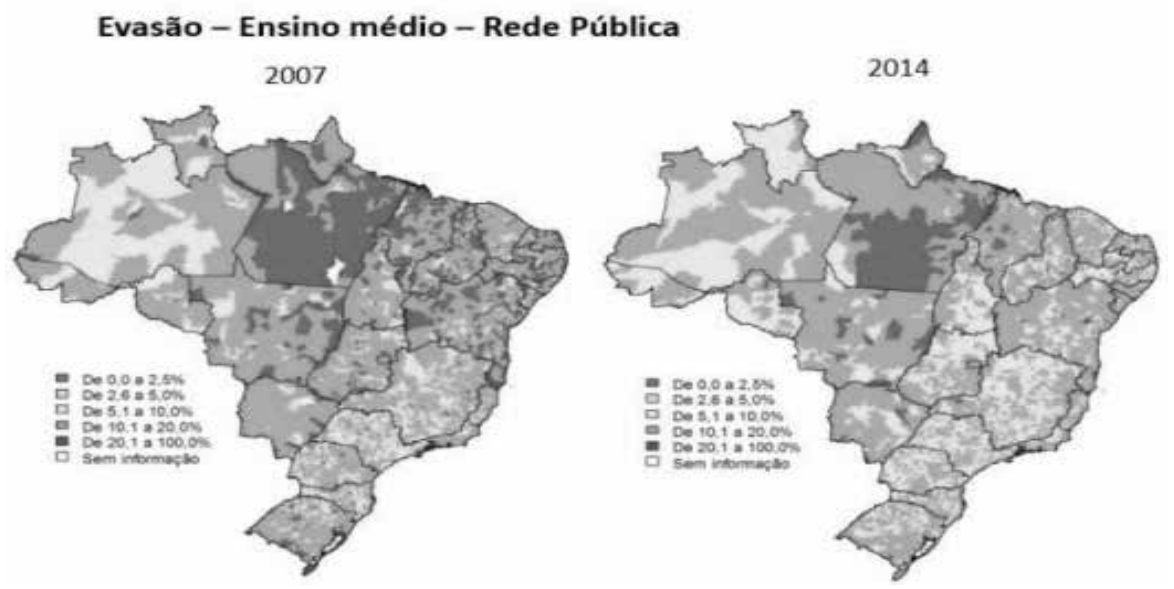

Fonte: INEP (2019).

Diante disso, é importante ressaltar que o Brasil precisa continuar avançando no cuidado com crianças e adolescentes em situação de vulnerabilidade, pois, segundo dados do Unicef (Fundo Internacional de Emergência das Nações Unidas para a Infância), apesar do Brasil ter avançado de forma significativa na redução da mortalidade infantil no período de 1996 a 2017, muitas destas crianças não chegam à idade adulta. "No mesmo período (1996 a 2017), 191 mil crianças e adolescentes de 10 a 19 anos foram vítimas de homicídio no Brasil. Ou seja: as vidas salvas na primeira infância foram perdidas na segunda década por causa da violência" (UNICEF, 2018, on-line). Tal realidade mostra a necessidade de detecção e intervenção na situação de vulnerabilidade a que estão expostos crianças e adolescentes.

\section{PAPEL DA ESCOLA NA DETECÇÃO E GESTÃO DA PERICULOSIDADE}

As políticas públicas descritas neste trabalho reforçam a importância da escola enquanto espaço de formação e intervenção social, tendo em vista que a efetivação delas está atrelada à gestão escolar. Nesse sentido, evidencia-se que apesar da intervenção do Estado no enfrentamento dos problemas sociais por meio das políticas públicas direcionadas para 
a prevenção da periculosidade de crianças e adolescentes, evidencia-se a demanda por investimento nas instituições escolares, vistas aqui em sua totalidade que perpassa desde a estrutura física até a preparação dos agentes executores, sobretudo dos gestores. Conforme preconiza Dourado, Oliveira, Santos (2007, p. 920):

[...] nesta ótica, a discussão sobre tais políticas articula-se a processos mais amplos do que a dinâmica intraescolar, sem negligenciar, nesse percurso, a real importância do papel social da escola e dos processos relativos à organização, cultura e gestão intrínsecos a ela. Portanto, é fundamental não perder de vista que o processo educativo é mediado pelo contexto sociocultural, pelas condições em que se efetiva o ensino-aprendizagem, pelos aspectos organizacionais e, consequentemente, pelas dinâmicas com que se constrói o projeto político-pedagógico e se materializam os processos de organização gestão da educação básica.

Nessa perspectiva, a escola é vista como integrada à comunidade, tendo em vista que nela grande parte das crianças e adolescentes, pertencentes a esse grupo, passam uma parte importante do seu tempo, sendo, portanto, coparticipante da sua formação e desenvolvimento. Assim, a escola tem oportunidade de detectar situações de risco e intervir, na assertiva de Luck (2013, p. 25):

[...] a gestão educacional corresponde à área de atuação responsável por estabelecer o direcionamento e a mobilização capazes de sustentar e dinamizar o modo de ser e de fazer dos sistemas de ensino e das escolas, para realizar ações conjuntas, associadas e articuladas, visando o objetivo comum da qualidade do ensino e seus resultados.

Nesse sentido, sendo a escola um direito obrigatório aos cidadãos, a estes ele deve ser garantido pelo Estado, em iguais condições de qualidade, independente da condição social, ou qualquer outra distinção, tendo em vista que o objetivo da escola é promover e assegurar ensino aprendizagem, socialização e inclusão dos estudantes, objetivando diminuir as desigualdades sociais e a vulnerabilidades das crianças e adolescentes. Desse modo, cabe aos gestores o papel de direcionar as ações educacionais nessa perspectiva, contemplan- 
do esses aspectos nas atividades educativas desenvolvidas pelo grupo pertencente ao núcleo escolar.

Em virtude disso, transparece a amplitude do papel da escola, tendo em vista o público atendido por ela, o qual pode sofrer com os impactos decorrentes da ausência desse direito nas suas condições de vida.

Por outro lado, a deterioração das condições gerais de vida, em nosso país, tem trazido consequências graves para a escola, em especial para a escola fundamental localizada nas zonas periféricas dos grandes conglomerados urbanos, que é afetada pela violência do seu entorno social, pelo tráfico e consumo de drogas, pela elevação dos índices de criminalidade etc. (BUENO, 2001, p. 106).

Deve-se considerar que as condições históricas de produção adentram o cotidiano escolar, portanto, torna-se inegável o envolvimento da escola nas situações diversificadas de vida de cada estudante, pois na maioria das vezes estes sujeitos que se encontram em situação de vulnerabilidade, perderam a esperança e a capacidade de se moverem em busca de mudança, por não acreditarem que tenham capacidade para isso.

Tal fato se torna um desafio para a escola, pois ao não terem esperança, não enxergam na educação um campo de novas oportunidade. Nessa perspectiva, cabe aos gestores escolares promoverem a articulação entre os profissionais da escola na busca por estratégias capazes de identificarem e intervirem no problema, objetivando o envolvimento das crianças e adolescentes, consequentemente, evitando fracasso escolar e a evasão. Assim, Foucault (2007, p. 13) ressalta:

[...] de que valeria a obstinação do saber se ele assegurasse apenas a aquisição dos conhecimentos e não, de certa maneira, e tanto quanto possível, o descaminho daqueles que conhece? Existem momentos na vida onde a questão de saber se se pode pensar diferentemente do que se pensa, e perceber diferentemente do que se vê, é indispensável para continuar a olhar ou a refletir (MITJAVILA, 2002, p. 131). 
Assim, crianças e adolescentes teriam a oportunidade de, mediante o saber, adquirirem total consciência de sua situação de vida, refletindo sobre o que sujeitos se tornarão, ou seja, voltariam a ter perspectivas.

\section{CONSIDERAÇÕES FINAIS}

As políticas públicas são necessárias para o combate dos problemas sociais, tendo em vista a relevância delas para o melhoramento das condições de aprendizagem das crianças e dos adolescentes em situação de vulnerabilidade. Isso porque tais condições afetam a maneira como esses indivíduos se portam junto à escola.

Contudo, o papel da gestão escolar se mostrou fundamental, não só na aplicabilidade das políticas públicas, como também na detecção dos riscos, o que cobra de tais gestores um posicionamento e direcionamento das ações pedagógicas, no sentido de enfrentar tal problemática, quer seja por meio de ações pedagógicas, palestras ou projetos. Concordamos com Lück (2013, p. 25) ao afirmar que

[...] com esse entendimento em mente, a gestão educacional corresponde à área de atuação responsável por estabelecer o direcionamento e a mobilização capazes de sustentar e dinamizar o modo de ser e de fazer dos sistemas de ensino e das escolas, para realizar ações conjuntas, associadas e articuladas, visando o objetivo comum da qualidade do ensino e seus resultados.

Com efeito, tais ações precisam objetivar não apenas a permanência das crianças e adolescentes na escola, mas sobretudo seu envolvimento na produção do saber. Isso permitirá que esses jovens se vejam como sujeitos capazes de ocuparem diferentes posições, o que evitaria os perigos a que estão expostos, em razão da vulnerabilidade.

Por fim, este estudo aponta caminhos para pesquisas mais amplas envolvendo, além da gerência da vulnerabilidade, novas perspectivas de gestão escolar exigidas pela sociedade atual, como também, o perfil de tais gestores. 


\section{REFERÊNCIAS}

BRASIL. Constituição Federal. Constituição da República Federativa do Brasil de 1988. Disponível em: http://www.planalto.gov.br/ccivil_03/constituicao/constituicao.htm. Acesso em: abr. 2021.

Lei no 8.069, de 13 de julho de 1990. Dispõe sobre o Estatuto da Criança e do Adolescente e dá outras providências. Brasília: Diário Oficial da União, 1990. Disponível em: http://www.planalto. gov.br/ccivil_03/leis/18069.htm. Acesso em: abr. 2021.

Ministério da Educação. Saiba Mais - Programa Mais Educação. Disponível em: http://portal.mec.gov.br/programa-mais-educacao/apresentacao?id=16689\#: :text=Diferentes\%20experi\%C3\%AAncias\%20pedag\%C3\%B3gicas\%20indicam\%20 o,viv\%C3\%AAncias\%20que\%20tornam\%20a\%20Educa\%C3\%A7\%C3\%A3o. Acesso em: abr. 2021.

Secretaria Nacional De Assistência Social. Desenvolvimento Social e Combate à Fome. Brasília, 2012. Disponível em: http:// agendaprimeirainfancia.org.br/arquivos/Orientacoes_PAIF_1.pdf. Acesso em: 01 out. 2016.

BUENO, J. G. S. Função social da escola e organização do trabalho pedagógico. Editora da UFPR. Educar, Curitiba, n. 17, p. 101-110, 2001.

COURTINE, Jean-Jaques. Decifrar o corpo: pensar com Foucault. Petrópolis, RJ: Vozes, 2013.

DOURADO, L.F.; OLIVEIRA, J.F.; SANTOS, C.A. A qualidade da educação: conceitos e definições. Brasília, DF: INEP, 2007.

DOURADO, Luiz Fernandes, políticas e Gestão da Educação Básica no Brasil: Limites e Perspectivas. Educ. Soc., Campinas, Vol 28, n.100 - Especial, p. 921-946, out. 2007

FOUCAULT, M. A arqueologia do saber. Tradução de Luiz Felipe Baeta Neves, 6ed. - Rio de Janeiro: Forense Universitária, 2002. 
A ordem do discurso. 5Ed - Edições Loyola: São Paulo, 1999a.

As palavras e as coisas: uma arqueologia das ciências humanas. 8 ed., São Paulo: Martins Fontes, 1999 b.

. Ditos e escritos IV. Estratégia poder-saber. Rio de Janeiro: Forense Universitária. 2006.

. Em defesa da sociedade. Curso no Collège de France (19751976). 1Ed - São Paulo: Martins Fontes, 1999c.

Em Defesa da Sociedade. São Paulo, Martins Fontes. Aula de 7 jan. 1976, p. 3-26 e Aula de 17 mar. 1976, p. 285-315, 2005.

. História da sexualidade 1: a vontade de saber. 16.ed. Rio de Janeiro: Graal, 1988.

Microfísica do poder. Rio de Janeiro: Graal, 1992.

Nascimento da biopolítica. Curso no Collège de France (1978-1979). São Paulo: Martins Fontes, 2008.

Segurança, Território, População. São Paulo, Martins Fontes, 2009. Aula de 11 de Janeiro de 1978, pp. 3-38 e Aula de 25 de Janeiro de 1978, pp. 73-104, 2009.

. Vigiar e punir: O nascimento da prisão. Petrópolis: Editora Vozes, 2004.

FURTADO, Farael Nogueira e CAMILO, Juliana Aparecida de Oliveria. O conceito de Biopoder no pensamento de Michel Foucault. Revista Subjetividades, Fortaleza, v16:34-44, dez. 2016.

GOMES, Alfredo M., Políticas Públicas e Gestão da Educação. Campinas-SP: Mercado de Letras, 2011.

INEP. Instituto Nacional de Estudos e Pesquisas Educacionais Anísio Teixeira. Inep divulga taxas de rendimento escolar; números mostram tendência histórica de melhora. Página virtual do INEP. Disponível em: http://portal.inep.gov.br/artigo/-/asset_publisher/B4AQV9zFY7Bv/content/inep-divulga-taxas-de-rendi- 
mento-escolar-numeros-mostram-tendencia-historica-de-melhora/21206. Acesso em: abr. 2021.

LÜCK, Heroisa. Concepções e processos democráticos de gestão educacional. Petrópoles, RJ: Vozes, 2013.

MOOL, Jaqueline et al. A agenda da educação integral: compromissos para sua consolidação como política pública, Caminhos da Educação Integral no Brasil: direito a outros tempos e espaços educativos. Porto Alegre: Penso, 2012.

MitJAVILA, Myriam. Medicalização, risco e controle social. Tempo Social, São Paulo, v. 27, n. 1, p. 117-137, june 2015.

MITJAVILA, M. O risco como recurso para a arbitragem social. Tempo Social. Revista de Sociologia da USP. São Paulo: USP, n. 14, v. 2 , p. 129-145, 2002.

SIERRA VM, Mesquita WA. Vulnerabilidade e fatores de risco na vida de crianças e adolescentes. São Paulo em perspec 2006, p. $148-88$.

UNICEF. Fundo das Nações Unidas para a Infância. Homicídios de crianças e adolescentes. O que fazemos. Página virtual do UNICEF, 2018. Disponível em: https://www.unicef.org/brazil/homicidios-de-criancas-e-adolescentes. Acesso em: abr. 2021. 


\section{ARTIGOS - EDUCAÇÃO PROFISSIONAL, TECNOLÓGICA E DE JOVENS E ADULTOS}





\section{CARACTERÍSTICAS PEDAGÓGICAS DAS POLITTICAS PÚBLICAS APLICADAS AO EXTENSIONISMO RURAL: UMA ANÁLISE DO ESTADO DE SÃO PAULO}

Júlia Garcia da Silva ${ }^{37}$

João Paulo Pereira Duarte 38

\section{INTRODUÇÃO}

A globalização do mundo pós-moderno trouxe consigo profundas mudanças substanciais em todos os contextos sociais, alterando as relações entre os indivíduos. A tecnologia onipresente, principalmente após a terceira revolução industrial, contribuiu com essas mudanças. O advento da nanotecnologia facilitou muito as tarefas nas quais antes exigia trabalho braçal (BRASIL ESCOLA, 2021).

No início desse período, como em toda e qualquer grande mudança, a população se tornou reticente face ao desconhecido. Um dos principais dilemas do fim do século XX até meados do século XXI era o temor de que as máquinas substituíssem o trabalho do homem. Porém, após algumas décadas, o que se pode notar é que os trabalhos apenas se transformaram, haja vista que as pessoas precisaram se adaptar, aprender novas ativi-

37 Mestranda em Planejamento e Análise de Políticas Públicas pela UNESP/Franca. 38 Mestrando em Planejamento e Análise de Políticas Públicas pela UNESP/Franca. 
dades, e lidar com essas novas tecnologias para usufruir dos seus benefícios (SILVA; CUNHA, 2002).

Uma área muito específica se destacou nessas mudanças: a área rural, que historicamente teve sua população ainda mais reticente com essas modificações tecnológicas. Outros fatores, como a preservação ambiental, complicaram um pouco mais essas mudanças.

O presente trabalho traz um apanhado desse contexto histórico, destacando a importância da educação na extensão rural para a solução desses problemas especificamente no estado de São Paulo.

Após a contextualização histórica, foram destacados vários pontos nos quais as pesquisas educacionais foram ao encontro das necessidades dessa população, contextualizando as pesquisas e suas aplicações no meio rural através dos projetos atualmente implantados com essa finalidade. Por último, foi feita uma análise crítica ligando todos os pontos citados, de modo a apontar eventual acerto e, também, onde é preciso e possível melhorar.

\section{O QUE É EXTENSÃO RURAL}

Antes de adentrar no aspecto histórico, é necessário entender o contexto e o significado de extensão rural. Como o próprio nome sugere, é o ato ou ação de estender, no caso, o conhecimento das ciências agrárias, até ao homem do campo. Há diversas características próprias dessa realidade, e uma delas é a coletividade.

É comum relatar a extensão rural como sinônimo de assistência técnica, mas essa afirmativa é refutável, uma vez que ambas exercem papéis diferentes no meio rural. A assistência técnica é mais individualista e se baseia em assistências pontuais a produtores rurais, de modo que o produtor assistido permanecerá dependente de auxílio do técnico, o qual é o único portador do conhecimento ali aplicado.

Por sua vez, a extensão rural tem caráter mais abrangente, e possui como principal objetivo levar o conhecimento e tecnologia, principalmente, a pequenos produtores, como forma de emancipação dos mesmos. Antes de tudo, possui características educacionais, alcançando mais pessoas, visando a família do ambiente rural como uma unidade de trabalho, onde se há o acompanhamento durante todo o processo e diversas avaliações acerca do desenvolvimento do que fora aplicado. 


\subsection{CONTEXTO HISTÓRICO DA EXTENSÃO RURAL}

\subsubsection{NO MUNDO}

No cenário pós Segunda Guerra Mundial e Segunda Revolução Industrial do século XX, houve o maior crescimento demográfico de toda a História. Esse fenômeno ocorreu devido ao acelerado desenvolvimento tecnológico e científico, alterando de maneira significativa as dinâmicas populacionais, uma vez que os avanços da medicina preventiva e sanitária e o controle das epidemias diminuíram significativamente os índices de mortalidade (BRASIL ESCOLA, 2021).

A sociedade agrícola começa a se transformar em uma estrutura econômica mais moderna, e à medida que se desenvolve a economia, há maior oferta de trabalho, as cidades crescem e se urbanizam, os transportes são melhores e mais rápidos causando um grande êxodo rural (BRASIL ESCOLA, 2021).

A população crescendo e saindo do campo fez com que a demanda de alimentos crescesse mais que a oferta dos mesmos, e para solucionar o problema, primeiramente nos Estados Unidos, foram adotadas políticas públicas em órgãos governamentais e incentivo a pesquisas nessa área nas grandes universidades americana. No entanto, em países subdesenvolvidos, localizados sobretudo na Ásia, América Latina e África, o campo da pesquisa rural ainda engatinhava e não era tão eficaz, fazendo com que a extensão rural nessas localidades de voltassem principalmente às iniciativas propostas pelo Ministério da Agricultura, se tornando muito mais técnica e desvinculada de pesquisas acadêmicas (MAGRINI, 2015).

\subsubsection{NO ESTADO DE SÃO PAULO}

Dada essa disparidade nos modelos econômicos, o estado de São Paulo iniciou sua própria política de extensão rural tendo como principal objetivo a produção para o mercado externo. A iniciativa contou com dois principais focos: o pequeno e o grande produtor rural; no entanto, as necessidades desses grupos se mostraram muito diferentes, causando uma certa disputa de classes, o que dificultou a implantação dessa política. 
Os grandes produtores já estavam totalmente integrados ao mercado capitalista, o que, para Queda (1987), é chamado de milagre da modernização agrícola. Envolvidos nesses ideais, os grandes produtores rurais necessitavam de auxílio tecnológico e econômico para a produção em massa, ao passo que o pequeno produtor, muito distante dessa realidade, necessitava de cuidados básicos de saneamento. Atualmente, a principal atividade extensionista em São Paulo é realizada pelo próprio estado, através da CATI - Coordenadoria de Assistência Técnica Integrada, órgão proveniente da secretaria de Agricultura e Abastecimento, que por meio de projetos e programas chega ao interior do estado.

Destaca-se entre os programas, o "Mais Leite, Mais Renda”, que visa fomentar a prática agropecuária, além de resgatar a rentabilidade e a oferta do leite produzido em São Paulo.

Outro programa de extensão com visão sustentável é o "Integra SP", que trata basicamente da aplicação de conceitos estratégicos e dinâmicos sustentáveis nos sistemas de produção e conservação do meio ambiente, aliando, assim, o conhecimento de novos modelos à tecnologia de última geração produzida para atender ao setor agrícola. Este programa possui como principais características a preservação e recuperação dos solos e recursos hídricos; melhoria de renda e qualidade no meio rural; preservação ambiental e abrandamento dos gases do efeito e estufa, e, principalmente o aperfeiçoamento na capacitação de mão de obra e na transferência de tecnologias ao produtor rural (SÃO PAULO, 2021).

Assim, infere-se que o estado caminha a passos largos em relação aos demais em nosso país, porquanto adepto de novos conceitos e tecnologia de ponta que chegam a quase todos os produtores, sobretudo pela presença de Casas da Agricultura em todos os municípios do estado que fazem o elo entre a secretaria da Agricultura e Abastecimento e o produtor (SÃO PAULO, 2021).

\section{O VIÉS EDUCACIONAL INSERTO NA EXTENSÃO RUAL}

Historicamente, a educação no meio rural não era prioritária, portanto, não havia espaço para o desenvolvimento. Com isso houve privação à população do campo, especialmente a classe trabalhadora, de ser assisti- 
da por políticas públicas e serviços públicos (SILVA JÚNIOR; NETTO, 2011). Não só a extensão rural era deixada de lado, mas também a própria escola no meio rural, que era resíduo do sistema educacional brasileiro, impedindo o avanço intelectual das gerações futuras da população rural (ARROYO; CALDART; MOLINA, 2004).

Sendo assim, devido ao forte crescimento industrial e o consequente êxodo rural, foi necessário também que se modernizassem as práticas e os sistemas de produção no campo, com a finalidade de aumentar a produção de alimentos e insumos agrícolas para satisfazer a crescente população. Nesse contexto, se faz necessário reaprender a dinâmica da vida no campo, tendo em vista que muito embora aprender seja algo natural na história da humanidade, por vezes esse processo não é fácil, principalmente associado a grandes mudanças no cotidiano, o que pode gerar desconforto e insegurança para quem faz parte desse ambiente. Por isso, é importante analisar e sistematizar esses processos educacionais, a fim de promover maior eficiência e proporcionar bem-estar para os envolvidos.

Para Navarro (2001), os principais desafios do desenvolvimento rural no Brasil estão totalmente ligados à política, ou seja, o êxito passaria por uma coalizão entre forças sociais opostas, que se diferem por suas ideologias e orientações. Observa-se, também, que a análise prévia da comunidade que se pretende implantar algum tipo de processo educacional é uma das partes mais importantes para o sucesso do projeto, uma vez que cada comunidade está inserida em um contexto sociocultural distinto. Por isso, o conhecimento prévio das necessidades dessas comunidades não pode ser ignorado, de modo que a educação deve ter caráter essencialmente construtivista.

O construtivismo, segundo Piaget (1896-1980), propõe que o aprendiz tenha participação integral na construção do seu próprio processo de aprendizagem, ou seja, a partir de suas experiências e conhecimento de mundo o indivíduo estabeleça o que é prioridade no seu aprendizado e qual a melhor maneira de adquiri-lo.

Neste mesmo contexto, o educador deve se colocar sempre na posição de aprendiz, uma vez que seu próprio conhecimento se encontra em permanente construção de valores, de atitudes e de conhecimentos. Para Coelho e Neto (1999), além de ideais é necessário prazer tanto para ensinar quanto para apreender: 
Para uma educação libertadora precisa-se ter bem claro nossos objetivos na cabeça (e no coração) é necessário descobrir a arte de aprender pela descoberta, do aprender brincando, do transformar fazendo debates, reflexões, trocando experiências, enfim, uns aprendendo com os outros. (COELHO; NETO apud Diaz-Rocha, 1999, p. 6).

O principal objetivo dos projetos de extensão rural com enfoque na educação é levar ao jovem e ao adulto morador do campo uma gama de ensinamentos sobre temas pertinentes à sua realidade, como agricultura, pecuária e economia doméstica, visando modificar hábitos e atitudes referentes aos aspectos técnicos, econômicos e sociais dessas comunidades. Dessa maneira, os produtores alcançam maior e melhor produtividade, aumento de renda e melhoramento do nível de vida em vários aspectos, além de colaborar significativamente para a economia da sua região e do Brasil como um todo, que tem um sistema econômico fortemente ligado às atividades agrícolas.

De acordo com Veiga (2001), há evidências que provam que certas regiões rurais de países mais desenvolvidos voltaram a ter dinamismo econômico, enquanto as mais urbanas estagnavam-se ou decaíam economicamente. Ou seja, é evidente o potencial do homem do campo, sobretudo quando o mesmo usufrui de todas as tecnologias e saberes existentes, de modo a influir num contexto econômico geral.

No estado de São Paulo, o órgão responsável pelos projetos de extensão rural, desde seu planejamento, execução e acompanhamento dos resultados é o CATI. O próximo capítulo será dedicado à explicação sobre o órgão e os projetos educacionais de extensão ligados a ele.

\section{A EXTENSÃO RURAL NO ESTADO DE SÃO PAULO}

O estado de São Paulo tem a maior população do país (41 milhões), sendo responsável por cerca de um terço do Produto Interno Bruto (PIB) nacional, que totaliza US\$ 550 bilhões. Embora o setor da indústria e serviços tenha maior participação econômica, a atividade agrícola é muito importante uma vez que fornece matéria prima para a indústria local, para outros estados e até outros países (CDRS, 2021). 
A coordenadoria de assistência técnica integral, representada pela sigla CATI, foi criada pela Secretaria de Agricultura e Abastecimento do estado de São Paulo, e tem como principal objetivo fomentar e promover o desenvolvimento rural sustentável, através de programas com envolvimento da comunidade, de entidades parceiras e de todos os segmentos dos negócios agrícolas (CDRS, 2021).

Presente em todos os municípios do estado paulista, em quase sua totalidade em parceria com as Casas da Agricultura, que por sua vez são em geral responsáveis pelo auxílio no sistema CAR (Cadastramento Ambiental Rural).

\section{POLÍTICAS PÚBLICAS COM CARACTERÍSTICAS PEDAGÓGICAS}

\subsection{PROJETO MICROBACIAS II E SUA VERTENTE PEDAGÓGICA}

O Microbacias II é um Projeto de Desenvolvimento Rural Sustentável realizado pelo governo do estado de São Paulo, através da secretaria de Agricultura e Abastecimento e seus membros de extensão, como a CATI (Coordenadoria de Assistência Integral) presente nos municípios, e, também, por meio da Coordenadoria de Biodiversidade e Recursos Naturais - CBRN (CDRS, 2021).

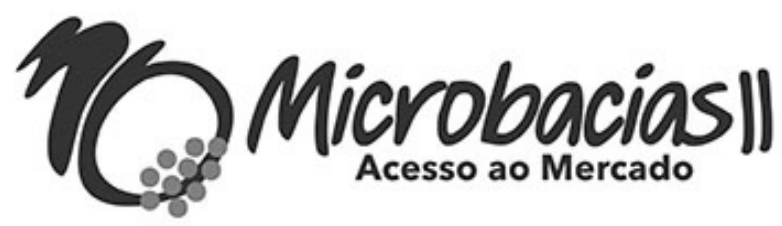

Fonte: São Paulo (2018)

O investimento financeiro é proveniente do governo do estado de São Paulo em parceria com o Banco Mundial, sendo dividido em diferentes proporções na totalidade dos casos. O principal objetivo é o de apoiar planos e iniciativas de negócios apresentados por associações e cooperativas dos produtores rurais dos municípios paulistas (SÃO PAULO, 2021) 
Outro foco bastante em pauta, divergindo da primeira fase do projeto, é o desenvolvimento sustentável e a recuperação de estradas rurais, com o intuito de facilitar a logística dos produtores para que o produto final chegue mais rápido e com menos perdas. Para isso, como visto anteriormente, foi necessário um amplo planejamento educacional para os produtores, com seminários, oficinas, visitas de intercâmbio, reuniões técnicas e cursos de capacitação para adoção e aprimoramento de práticas que tornem os processos produtivos mais sustentáveis ou que possibilitem a identificação de melhores oportunidades de acesso ao mercado (SÃO PAULO, 2021).

Os projetos de capacitação de acordo com São Paulo (2021) têm foco em:

i) promover uma ampla discussão sobre a questão da competitividade e sustentabilidade da agricultura familiar no Estado de São Paulo;

ii) permitir a identificação dos entraves e das potencialidades de cada região para o acesso dos agricultores familiares ao mercado;

iii) possibilitar a capacitação básica dos agricultores familiares, incluindo populações tradicionais, como por exemplo, povos indígenas, que os auxilie na superação dos entraves e no aproveitamento das oportunidades;

iv) facilitar a identificação de potenciais organizações e iniciativas de negócio a serem atendidas pelo Projeto;

v) promover a capacitação básica em boas práticas de gestão e produção agropecuária com ênfase no manejo adequado dos recursos naturais.

É importante destacar que, em seus editais e manuais de orientação, a CATI ressalta a importância da personalização desses treinamentos para cada comunidade atendida pelo projeto, o que o órgão julga ser de extrema importância para o melhor aproveitamento dos mesmos. Essa orientação faz com que se torne evidente o caráter construtivista da educação no campo. Inclusive para atender à maior diversidade de produtores, foram criados projetos de orientação e assistência específicos para as comunidades nativas, indígenas e quilombolas, para que se preserve a cultura e característica de produção, ou seja, os projetos educacionais visam aumentar a produção, não implementando um modelo único, mas buscando dentro da realidade de cada cultura métodos para otimizar sua produção e preservar o meio que as comunidades residem (ETNICO RACIAL, 2021). 
A orientação para os produtores se inicia na fase inicial. Ao procurar o órgão para cadastro de sua propriedade, o produtor é recebido por responsáveis que irão orientá-lo sobre o melhor projeto a ser desenvolvido, a todo momento o proprietário da terra, participa das decisões, uma vez que ninguém conhece melhor sua realidade e a realidade de sua comunidade.

Após a implantação do projeto, a Casa da Agricultura da região passa a ser responsável pelo seu acompanhamento, que vai desde orientações de execução do mesmo, até assistência técnica. Durante o andamento da proposta são feitas análises de eficiência, se preciso poderão ser realizadas adequações que otimizem o projeto.

Os responsáveis pela capacitação dos agricultores também serão capacitados ao longo do projeto, eles serão o elo entre os produtores rurais e os benefícios que o programa pode oferecer; sendo assim, eles analisam e estudam cada comunidade, toda à atividade produtiva, econômica e social da região, buscando os melhores métodos de estimular e aumentar a produção e a melhor maneira de instruir essas comunidades.

A CATI também oferece apoio para o treinamento dos responsáveis do município visando integrar de maneira mais geral a comunidade, uma vez que as propriedades rurais fazem parte do território municipal. Os insumos produzidos nas propriedades contribuem para o desenvolvimento de todo o município, não só apenas de sua comunidade, uma vez que integram a economia e geram emprego e renda para a população.

É importante também ressaltar a educação ambiental envolvida no projeto. Nos mesmos moldes das orientações para produção e desenvolvimento socioeconômico, os projetos de educação ambiental para produtores rurais têm o objetivo de difundir informações sobre tecnologias sustentáveis, temas ambientais, conhecimentos e experiências decorrentes da implantação e monitoramento do projeto. As atividades são desenvolvidas sobretudo através de cursos, eventos de avaliação de resultados e trocas de experiências.

No estado de São Paulo, algumas regiões são consideradas áreas de restrição ou de interesse ambiental, dadas as suas condições geomorfológicas, a existência de remanescentes de vegetação nativa, a suscetibilidade do solo, a importância para os recursos hídricos. Por isso nessas áreas, pequenos agricultores não têm competitividade se baseados na agricultura convencional. 
Os projetos de educação ambiental têm enfoque na diversificação econômica e geração de renda baseada na conservação e no uso sustentável dos recursos naturais para a produção (solo, água e biodiversidade) e que atenda a demandas específicas de agricultores familiares, além de contribuir para a mitigação e/ou adaptação à mudança climática. Esses projetos são importantes, pois auxiliam os produtores no desenvolvimento sustentável do agronegócio através da proteção ambiental, atividades produtivas que contribuam com a conservação e o uso sustentável da biodiversidade e dos recursos hídricos, esse tipo de desenvolvimento é necessário para a preservação do meio ambiente e dos recursos naturais necessários para a produção no campo.

De acordo com Sigam (2018), essas orientações seguirão abordagem de temas gerais e específicos relevantes para o desenvolvimento sustentável, como por exemplo:

i) Proteção da biodiversidade;

ii) Caracterização ambiental do Estado de São Paulo (em vários níveis de aprofundamento);

iii) Legislação ambiental e pagamento por Serviços Ambientais;

iv) Práticas de manejo do solo, proteção de recursos hídricos;

v) Recuperação de áreas degradadas, APPs (Áreas de Preservação Permanente), sistemas silvipastoris, sistemas agroflorestais;

vi) Turismo rural e ecológico;

vii) Produção de sementes e mudas;

viii) Proteção à fauna e à flora;

ix) Gestão ambiental em propriedades rurais - planejamento e avaliação; adequação ambiental de propriedades rurais;

x) Formação de corredores ecológicos, matas ciliares.

\subsection{PROJETOS SECUNDÁRIOS DE EDUCAÇÃO NO CAMPO}

Além dos programas oferecidos pela CATI aos produtores, existem projetos e serviços voltados diretamente para o âmbito educacional no campo. Pode-se citar a Assistência e Capacitação Técnica de Produtores rurais, onde profissionais como engenheiros agrônomos, engenheiros agrícolas, zootecnistas e médicos veterinários, levam informações e orien- 
tam os produtores em suas atividades agrícolas (CDRS, 2021). Exercem também um papel de agente de políticas públicas, bem como executores de projetos voltados especificamente para cada área no campo, onde a capacitação e o conhecimento gerado ao homem do campo são as principais vias para uma transformação mais estável e singular dos produtores rurais.

Nota-se assim, mais uma vez, o conceito educacional construtivista; ou seja, nesses projetos o conhecimento não se dá de forma unilateral, os educadores levam em consideração cada realidade encontrada, agregando para si também conhecimento e experiência. Daí a importância de o educador estar inserido nesse contexto: a vivência e o saber da realidade do homem do campo, faz-se essencial nesse panorama. Qualquer mudança sugestionada deve ter um mínimo de coerência, e conhecer os mecanismos que possam interferir na elaboração das práticas construtivas (CAPORAL, 1991). Sobretudo pelos agentes da prática, que por vezes se encontram defronte através dos limites impostos aos mesmos, e como podem ser superados (CAPORAL, 1991).

E nesse panorama educacional, as atividades assistidas, geralmente pelas Casas da Agricultura de cada município, são concomitantes aos processos pedagógicos inseridos nesse meio tantas vezes escasso de conhecimentos de educação básica. Para se ter uma ideia, o estado, de posse dessa realidade, oferece atividades que fomentam o conhecimento e a independência do produtor, expandindo o conhecimento até o campo, realizando a logística reversa da educação infantil por exemplo. Portanto, por meio dos seguintes projetos e serviços, a educação revela sua importância nesse objetivo (CDRS, 2021):

Dias de Campo: Leva-se em conta para a realização de um dia de campo, a região em que se está localizado, as culturas ali produzidas e o poder aquisitivo dos produtores. São voltados geralmente para alunos da área agrícola e principalmente para produtores daquela localidade. São realizadas apresentações utilizando-se banners, cartazes e apresentações em slides, em diferentes ambientes com diferentes assuntos. Sejam de novas técnicas e práticas ou de produtos voltados para o campo.

Unidades Demonstrativas: Há ainda unidades demonstrativas, que como o próprio nome sugere, referem-se a unidades já existentes ou montadas com a finalidade de apresentar uma nova forma de trabalhar nas diversas áreas da agricultura. 
Cursos e Palestras de Capacitação: Destinados aos produtores também em diversas áreas da agropecuária. Sejam palestras de prazo curto de tempo, ou até mesmo cursos oferecidos ao longo de meses, em parcerias com empresas privadas, SENAR e outros órgãos do governo.

Excursões: Semelhante as unidades demonstrativas, as mesmas levam os produtores a locais de capacitação que gozam de novas tecnologias para o desenvolvimento agrícola.

Em todos esses casos, não bastam apenas profissionais que possuam o conhecimento para si, mas profissionais educadores que exercem um papel importante na extensão do conhecimento. Levando em conta o grau de compreensão dos que estão sendo assistidos, a linguagem e as apresentações exigem um diálogo simples e que falem a língua dos produtores, sendo porventura, um intercâmbio cultural entre as partes. Além da compreensão dos mesmos, o convencimento é um dos desafios encontrados por parte dos profissionais, muitos produtores nascidos e criados no campo possuem uma barreira cultural natural.

É complexa, ainda, a inserção do desenvolvimento sustentável no campo. Expor a importância da conservação do meio ambiente aliado ao crescimento da produção por vezes, pode ser uma tarefa calejada que somente através de uma boa pedagogia e exemplos na prática que podem reverter esse quadro (CDRS, 2021).

\section{CONSIDERAÇÕES FINAIS}

Com base na análise tanto do programa Microbacias II, que agrega grande número de produtores rurais, e abrange todo o estado de São Paulo, como os projetos secundários, que agem de maneira mais concentrada e específica, pode-se concluir a grande importância da formação e educação de qualidade no campo, pois essas ações têm forte impacto no contexto social econômico e ambiental, não só nas comunidades rurais como em toda população ao seu redor.

Tendo em vista que no Brasil o agronegócio cria aproximadamente $37 \%$ de todos os empregos do país, sendo responsável por mais de 20\% do produto interno bruto, bem como pelo fato de que aproximadamente $61 \%$ do seu território ainda é coberto por matas originais, preparar bem quem é responsável pelo campo é essencial para o bom desenvolvimento 
do país. Assim, o principal projeto de assistência técnica do Estado de São Paulo, o Microbacias II, dá muita importância para a preparação do homem no campo, haja vista que os moradores de áreas rurais são responsáveis pela produção agrícola no país.

Outro ponto notável é a grande preocupação com a preservação da cultura de cada povo, seja ele rural, indígena ou quilombola. Diferentemente do exemplo de outros países, onde a produção foi praticamente sistematizada e mecanizada de maneira uniforme, no Brasil, muito da produção vem de agricultura familiar e dos povos nativos. O exemplo da CATI mostra o profundo respeito com dada maneira de produzir, mostrando que é possível aumentar a produção apenas potencializando os métodos de produção.

O projeto também traz uma cessão completa com projetos ambientais, que orientam os produtores a produzir de maneira sustentável, também conservando as características locais, visando à preservação dos recursos naturais (tais como: a água, o solo e o ar). A preservação desses meios é importante para a continuidade da produção a longo prazo, e, a proteção ao meio ambiente é indispensável para a preservação da vida no nosso planeta.

A prática agrícola é muitas vezes vista como a vilã do meio ambiente, e realmente há de se reconhecer seu grande impacto negativo, quando gerida e realizada de maneira errada, porém, é necessário que haja o cultivo de alimentos. Alinhar os dois interesses não é uma tarefa fácil, mas iniciativas como esse projeto tornam esse caminho mais viável.

Tanto no programa Microbacias II, quanto nos projetos de apoio é importante observar que o conhecimento prévio dos produtores é considerado o ideal construtivista muito bem empregado nos projetos, que reconhecem que as teorias e pesquisas são de suma importância para a melhoria da produção. Porém, a experiência de quem sempre viveu na terra é insubstituível, e alinhar esses dois conceitos faz com que a aprendizagem se torne mais rica para o agricultor e para o educador, que adquire experiência para difundir essa forma de conhecimento tão rica.

Nos projetos de apoio, principalmente os Dias de Campo e excursões, visam capacitar os futuros produtores, melhorando seu treinamento inicial e atraindo mais e melhores profissionais para a área. 
Atualmente, o trabalho no campo é muito diferente de algumas décadas atrás e, como visto, os meios de cultivo e produção estão sendo modernizados, a fim de aprimorar a produção para atender às necessidades atuais da crescente população. Para isso, é necessário que esse mercado seja atrativo para as futuras gerações, pois elas irão dar continuidade a essas atividades; capacitar bem esses alunos é fundamental para a qualidade da mão de obra no campo.

Neste sentido, podemos concluir que o Microbacias II foi criado para o acesso ao mercado dos pequenos e médios produtores rurais, assim como os demais projetos de apoio, porém, mais que a questão econômica, esses programas têm forte apelo social e ambiental, melhorando a vida do homem do campo e toda a comunidade envolvida no processo, além da preservação ambiental que afeta toda a população.

Por fim, projetos integrantes e abrangentes como esses, se bem executados, podem ser parte da solução para os vários pontos citados. A integração proporcionada por eles é muito importante e o projeto tem todos os requisitos para ter um bom funcionamento e cumprir bem seus objetivos. Posteriormente, após alguns anos de projeto é possível analisar se esses métodos foram tão eficientes na prática quanto são na teoria e analisar os pontos e falhas para seu aperfeiçoamento.

\section{REFERÊNCIAS}

BRASIL ESCOLA. Terceira revolução industrial. Disponível em: https://brasilescola.uol.com.br/geografia/terceira-revolucao-industrial. htm. Acesso em: 22 de mar. de 2021.

CAPORAL, F. R. (1991). A Extensão Rural e os Limites à Prática dos Extensionistas do Serviço Público. Dissertação de mestrado, Universidade Federal de Santa Maria, Santa Maria, RS, Brasil. Disponível em: https://periodicos.ufsm.br/extensaorural/article/ view/6111. Acesso em: 11 mar. 2021.

\section{CDRS. Assistência e Capacitação Técnica de Produtores Rurais.}

Disponível em: https://www.cdrs.sp.gov.br/portal/institucional/ quem-somos. Acesso em: 02 mar. 2021 
ETNICO RACIAL. Educação escolar quilombola. Disponível em: http://etnicoracial.mec.gov.br/educacao-escolar-quilombola. Acesso em: 16 mar. 2021.

GOVERNO DO ESTADO DE SÃO PAULO. Projeto de Desenvolvimento Rural Sustentável - MICROBACIAS II - Acesso ao Mercado. Disponível em: <https://www.cdrs.sp.gov.br/microbacias2/o-projeto>. Acesso em: 02 fev. 2021.

HAGE, Salomão. A importância da articulação da identidade e pela educação do campo na construção da identidade e pela luta da educação do campo. Texto apresentado no I Encontro de formação dos Educadores do Campo do Nordeste Paraense, realizado em Bragança. Abril/ 2005. http://www.cati.sp.gov.br/microbacias2/. Acesso em: 01 abr. 2021.

MARÍAS, J. História da Filosofia. São Paulo: M. Fontes, 2004.

MAGRINI, Pedro Rosas. Produção Acadêmica sobre o MST: perspectivas, tendências e ausências nos estudos sobre gênero, sexualidade, raça e suas interseccionalidades. Trabalho de Conclusão de Curso. Universidade Federal do Estado de Santa Catarina - UFSC. Centro de Filosofia e Ciências Humanas - CFCH. Programa de Pós-Graduação Interdisciplinar em Ciências Humanas - PPGICH. Florianópolis, 2015. Disponível em: https://repositorio.ufsc.br/bitstream/ handle/123456789/134927/334175.pdf? sequence=1\&isAllowed=y. Acesso em: 28 mar. 2021.

NAVARRO, Z. (2001). Desenvolvimento rural no Brasil: os limites do passado e os caminhos do futuro. Revista Estudos Avançados, São Paulo: USP, Instituto de Estudos Avançados, (V. 16, número 43). Disponível em: http://www.scielo.br/scielo.php?script=sci_arttext;pid=S0103-40142001000300009. Acesso em: 12 mar. 2021.

OLIVEIRA, Rosane Machado de. Filosofia Na Escola: A Necessidade De Um Pensar Crítico E Reflexivo Em Torno Do Ensino-Aprendizagem Em Sala De Aula. Revista Científica Multidisciplinar Núcleo do Conhecimento. Ano 03, Ed. 11, v. 7, p. 25-40, nov. 2018. 
QUEDA, O. (1987) A Extensão Rural no Brasil: da anunciação ao milagre da modernização agrícola. Tese de livre Docência, Escola Superior de Agricultura "Luiz de Queiroz", Piracicaba, SP, Brasil. Disponível em: https://www.bdpa.cnptia.embrapa.br/consulta/ busca?b=ad;id=83729; biblioteca=vazio; busca=autoria:\%22O.\%22;$\mathrm{qFacets}=$ autoria: $\% 22 \mathrm{O} . \% 22 ;$ sort $=;$ paginacao $=\mathrm{t} ;$ paginaAtual $=23$. Acesso em: 15 jan. 2021.

REIGOTA, M. (1995). Meio Ambiente e representação social. São Paulo: Cortez. Disponível em: https://www.maxwell.vrac.puc-rio. br/9419/9419.PDF. Acesso em: 23 jan. 2021.

SECRETARIA DE AGRICULTURA E ABASTECIMENTO. Coordenadoria de Desenvolvimento Rural Sustentável. Projeto Integra SP. Disponível em: 〈https://www.cdrs.sp.gov.br/portal/projetos-e-programas/projeto-integra-sp>. Acesso em: 02 abr. 2021.

SIGAM. Projeto Desenvolvimento Rural Sustentável. Disponível em: https://sigam.ambiente.sp.gov.br/sigam3/Default.aspx?idPagina=13549. Acesso em: 10 set. 2018.

SILVA, Edna Lúcia da. CUNHA, Miriam Vieira da. A formação profissional no século XXI: desafios e dilemas. Revista Ciência da Informação, Brasília, v. 31, n. 3, p. 77-82, set./dez. 2002. Disponível em: <https://www.scielo.br/scielo.php?script=sci_arttext\&pid=S0100-19652002000300008>. Acesso em: 02 abr. 2021.

SILVA JÚNIOR, A. F., Netto, B. M. (2011, novembro). Por uma educação do campo: percursos históricos e possibilidades. Entrelaçando - Revista Eletrônica de Culturas e Educação, no3 3, p. 45-60. Disponível em: file:///C:/Users/lucas/Downloads/POR\%20 UMA\%20EDUCAO\%20DO\%20CAMPO\%20-\%20percursos $\% 20$ histricos\%20e\%20possibilidades\%20_\%20Astrogildo\%20 F.\%20da\%20Silva\%20Jnior\%20e\%20Mrio\%20Borg\%20(8).pdf. Acesso em: 25 fev. 2021.

SILVA, Dyovany Otaviano da. A educação do campo e seus desafios, 2016. Disponível em: <https://centrosabia.org.br/juventude/a-educacao-do-campo-e-seus-desafios\#: :text=Autorida- 
des\%20alegam $\% 20$ que $\% 20 \mathrm{a} \% 20$ falta,existem $\% 20$ funcionam $\% 20$ como\%20classes\%20multisseriadas>. Acesso em: 18 fev. 2021.

VEIGA, J. E. (2001). O Brasil rural precisa de uma estratégia de desenvolvimento. Brasília: MDA/NEAD (Textos para Discussão, 1). Disponível em: file://C:/Users/lucas/Downloads/o_brasil_rural_ precisa_de_uma_estrategia_de_desenvolvimento.pdf. Acesso em: 21 fev. 2021.

ZEFERINO, Vânia Maria; CRUZ, Cassius. A educação do campo e seus desafios. Trabalho de conclusão de curso da Universidade Federal do Paraná, 2014. Disponível em: <https://acervodigital.ufpr.br/bitstream/handle/1884/50571/R\%20-\%20E\%20-\%20 VANIA\%20MARIA\%20ZEFERINO.pdf?sequence=1\&isAllowe$\mathrm{d}=\mathrm{y}>$. Acesso em: 05 fev. 2021. 


\title{
A FORMAÇÃO DO PROFESSOR DA EJA: A CONCEPÇÃO FREIREANA NA CONSTRUÇÃO DO PERFIL DO EDUCADOR-TRANSFORMADOR
}

\author{
Herson Conceição ${ }^{39}$ \\ Rosana Assis dos Santos ${ }^{40}$
}

\section{INTRODUÇÃO}

De acordo com a Declaração Universal dos Direitos Humanos, no artigo 26, todo homem tem direito à educação escolar e esta deve visar ao pleno desenvolvimento da personalidade humana e ao reforço do respeito aos direitos do homem e às liberdades fundamentais. A Constituição Federal também vem reforçar, no artigo 205, o princípio que toda e qualquer

\footnotetext{
39 Mestre em Educação de Jovens e Adultos - MPEJA pela UNEB - Campus I. Especialista em Educação de Jovens e Adultos pela UFBA, Psicopedagogia pela FACCEBA, Neurociências e Comportamento pela PUCRS, Neuroeducação pela Uninassau, Graduado em Pedagogia (FEBA) e Letras (UNIFACS). Gestor Escolar e professor da Rede Municipal de Ensino de Salvador - BA. Atua no Grupo de Pesquisa Gestão Organização, Tecnologias e Políticas Públicas em EJA. 40 Mestra em Família na Contemporaneidade pela UCSAL. Especialista em Educação de jovens e Adultos pela UNEB e Educação Especial pela IBPEX. Graduada em Pedagogia pela UNEB e Psicologia pela faculdade Ruy Barbosa. Atua como Coordenadora Pedagógica do ensino fundamental pela rede municipal de ensino de Salvador e realiza atendimento na clínica psicológica na Fundação de Neurologia e Neurocirurgia. Atua no grupo de pesquisa Família e Desenvolvimento Humano.
} 
educação visa ao pleno desenvolvimento da pessoa, seu preparo para o exercício da cidadania e sua qualificação para o trabalho.

A Lei de Diretrizes e Bases da Educação Nacional (LDB 96), no seu artigo 37, garante o ensino fundamental, obrigatório e gratuito, inclusive para os que a ele não tiveram acesso na idade própria. A lei garante a estes últimos a oferta de educação escolar regular, com características e modalidades adequadas às suas necessidades e disponibilidades.

As Diretrizes Curriculares Nacionais para Educação de Jovens e Adultos, no Parecer CNE/CBE 11/2000 e Resolução CNE/CEB 1/2000, estabelecem que a modalidade EJA deve considerar os perfis dos estudantes, as idades, princípio da equidade, da diferença, da contextualização das diretrizes curriculares nacionais e apropriação de metodologias próprias que atendam as especificidades desses alunos.

O estudo das metas do Estado brasileiro deixa claro o papel atribuído à educação no desenvolvimento e na potencialização nos aspectos que proporcionam o pleno desenvolvimento do ser humano. Neste sentido, o objetivo é a construção de uma sociedade aberta no país, definida como sendo aquela onde inexistam barreiras objetivas que impeçam qualquer indivíduo de realizar suas potencialidades pessoais. Outro ponto importante é a definição também pela institucionalização de um caminho adequado para a realização das potencialidades dentro da educação escolar.

Apesar das garantias da Lei - escola pública, gratuita, obrigatória e de qualidade para toda a população, numa verdadeira perspectiva de democratização, é evidente que esta não é um fator decisivo na mudança de status, já que isoladamente não é suficiente para modificar estruturas. Atrás do sistema educacional sempre há um sistema governamental que explicita ou implicitamente o suporta.

Em se tratando da EJA, a situação é ainda mais complicada e tem sido um objeto de estudo para educadores comprometidos com o direito dos jovens e adultos a um ensino de qualidade que venha ao encontro das necessidades educativas de uma clientela num contexto diferenciado do ensino regular, onde o abandono ou a infrequência torna-se um grande desafio a ser vencido.

Diante dessa realidade, o investimento na formação do professor da EJA continua sendo necessário, pois especialmente nessa modalidade, o 
perfil do educador é capaz de fazer diferença na tentativa de vencer as mazelas de uma educação pública deficitária.

$\mathrm{Na}$ construção desse perfil de educador-transformador, tomar-se-á como base as concepções de ensino de Paulo Freire, declarado patrono da educação brasileira em 2012, cujo legado é de grande valia para a formação do educador, principalmente da EJA.

\section{CONCEPÇÃO TEÓRICA-METODOLÓGICA DE PAULO FREIRE}

Neste momento, temos que nos perguntar sobre o real trabalho desenvolvido a partir das intencionalidades, inclusive ideológicas que regem cada espaço, geográfico e cultural, no qual as escolas estão inseridas. Essa concepção faz-nos questionar como os espaços tratam cada sujeito e com ele interage, se interage ou interage de forma violenta, diante das necessidades que o próprio tempo suscitam.

\subsection{EDUCAÇÃO CENTRADA NO SUJEITO}

Segundo Paulo Freire, a educação deve ser uma prática libertadora, que condicione o educando a ser reflexivo e atuante, capaz de transformar a realidade. Essa educação reflexiva que gera debate, seminários revolucionários, deve ser construída nas salas de aula a partir de intervenções próprias e se fazer presente nas decisões políticas. Esse processo de construção de posicionamento político deve ser incentivado e praticado em suas diversas perspectivas e esfera da vida do próprio sujeito-estudante, ainda mais se considerarmos que os alunos da EJA já trazem construções idiossincráticas que foram fomentadas pela experiência real com os atos externos que muitas vezes independiam de seus posicionamentos e decisões.

Afirma o autor que não existem ignorantes absolutos, nem sábios absolutos. Por ser inacabado, incompleto, o homem não sabe de maneira absoluta. Freire afirma ainda que existem graus de educação, mas estes não são absolutos. (FREIRE, 2016). Por isso, a educação tem caráter permanente, uma vez que não há seres educados e não educados e sim em processo de educação. Compreendemos que diante dessa realidade, a relação professor-aluno se estabelece de uma forma horizontal, uma via de 
mão dupla, pois quem ensina aprende ao ensinar e quem aprende ensina ao aprender. Há de se considerar, entretanto que apesar de existir uma via de mão dupla, o fluxo, intensidade e direção podem variar de forma efusiva entre o professor e o aluno e também o seu contexto. Além disso, temos que nos atentar ao grau de absorção do fluxo vindo do aluno que a escola está de fato acolhendo de forma respeitosa ou estar simplesmente descartando sem uma intervenção mais apurada de retorno e transformação da significância a partir de novos conhecimentos.

Diante da necessidade do respeito ao fluxo vindo do aluno que Freire comenta que o educador bem como os demais profissionais, devem ampliar seus conhecimentos em torno do homem com visão crítica da realidade em sua totalidade, afirmando que:

Estar no mundo sem fazer história, sem por ela ser feito, sem fazer cultura, sem "tratar" sua própria presença no mundo, sem sonhar, sem cantar, sem musicar, sem pintar, sem cuidar da terra, das águas, sem usar as mãos, sem esculpir, sem filosofar, sem pontos de vista sobre o mundo, sem fazer ciência, ou Teologia, sem assombro em face do mistério, sem aprender, sem ensinar, sem ideias de formação, sem politizar, não é possível (FREIRE, 1996, p. 64).

Ao educador, cabe buscar no aluno as várias concepções que formam aquele sujeito, a partir da compreensão que o educando é sujeito de sua própria educação, e não objeto; quanto mais autêntica a educação, mais será capaz de desenvolver no homem o ímpeto de criar e valorizar-se como ele é; sendo assim, a tarefa de uma alfabetização crítica consiste em ampliar nossa concepção acerca do mundo.

A partir dessa necessidade do educador de buscar na prática informações do histórico de vida de seus alunos, suas angústias, esperanças e visão de mundo, sua prática vai refletir de fato os anseios dos seus alunos, fazendo emergir os objetivos de cada aluno em relação à escola. A escola precisa ser o espaço que representa os desejos dos alunos, mesmo que esses sejam diversos, e de fato são. Diante desta necessidade multifocal do aluno, Freire enaltece:

Uma das tarefas do educador progressista é descobrir as possibilidades para esperança sem a qual pouco podemos fazer porque dificilmente lutamos, e quando lutamos como desesperançados ou 
desesperados é a nossa uma luta suicida, um corpo puramente vingativo (FREIRE, 2009, p. 11).

A educação para ele deve ser uma prática de liberdade e não de dominação. Uma vez que, vivemos em uma sociedade dividida em classes, na qual os privilégios de uns impedem a maioria de usufruir os bens produzidos. Despertar a criticidade do educando através de discussões da realidade social deve fazer parte da prática educativa.

Freire defende que somente uma educação ativa e dialogal ajudará o homem a desenvolver o espírito crítico, transformando-se em reais sujeitos da construção e reconstrução do saber. Para ele, o ato de conhecer é o resumo de ampliar a consciência e esta não é algo vazio como uma folha em branco onde o mundo e os outros seres imprimem imagens. A consciência se dá na relação de confronto com o mundo e com a realidade da qual ele faz parte, a qual é fruto da ação do homem e, só pode ser modificada através dessa ação. Por isso, não basta ter consciência crítica da opressão, mas é necessário ter a disposição para transformar essa realidade. Não é simplesmente responder a estímulos, porém responder a desafios.

A educação centrada no sujeito entende o ato pedagógico como um ato democrático que contraria a desigualdade social, não a aceitando, nem a naturalizando. Freire considera necessário observarmos o processo de construção da subjetividade democrática, aguçando o nosso estranhamento diante do discurso fatalista de uma realidade definitiva, sem possibilidades de mudanças. Por isso que a educação é muito mais que instrução. Ela é um processo a longo prazo e para ser libertadora precisa construir entre educadores e educando uma verdadeira consciência histórica.

\subsection{A IMPORTÂNCIA DO DIÁLOGO}

O diálogo na concepção freireana nasce de uma matriz crítica e gera criticidade, nutrindo-se de amor, de humanidade, de esperança, de fé, de confiança. Nessa relação, não há mais uma posição vertical do educador para o educando, nem mesmo uma imposição, mas uma relação dialógica, de troca. Entretanto, o diálogo não pode excluir o conflito, sob pena de ser um diálogo ingênuo alicerçado em falas que satisfazem os quereres de cada um, mas na verdade não promove o crescimento pelo processo dialético. 
E ser dialógico, para o humanismo verdadeiro, não é dizer-se descomprometidamente dialógico; é vivenciar o diálogo. Ser dialógico é não invadir, é não manipular, é não sloganizar. Ser dialógico é empenhar-se na transformação constante da realidade. (FREIRE, 1985, p. 28).

Neste sentido, ser dialógico de fato é a possibilidade de intervir na construção de novas realidades que o outro ainda não construiu pela falta de alicerces de informação ou possibilidades. A problematização passa a exercer função de extrema importância dentro dos processos de construções de conceitos, criação, recriação e transformação da significância do sujeito. Freire (2016, p.133) confirma esse processo ao relatar que "O sujeito que abre para mundo e aos outros inaugura com seu gesto a relação dialógica em que se confirma como inquietação e curiosidade, como inconclusão em permanente movimento na história".

Nesse sentido, o movimento de inconclusão, de fato torna-se um processo regimentado pelo anacronismo, pois suscita um movimento de ir e vir nos valores construídos pelo sujeito ao longo de sua vida, "confrontando" com os atuais em construção. Mas cabe atenção a este movimento à medida que não deve de forma alguma violentar os valores já construídos do sujeito, uma vez que podem estar intimamente atrelados a momentos ou pessoas de forma afetiva. O papel do educador não é o de "encher" o educando de "conhecimento", de ordem técnica ou não, mas sim o de proporcionar, através da relação dialógica educador-educando, educando-educador, a organização de um pensamento correto em ambos (FREIRE, 1985, p. 35).

Freire (1985) ainda conceitua o diálogo como sendo o encontro dos homens, mediatizados pelo mundo, para pronunciá-lo, não se esgotando, portanto, na relação eu-tu. Através do diálogo, os educandos são desafiados a pensarem na sua história social, para refletir e se posicionar diante do mundo como seres críticos e ativos.

O movimento dialógico passa a ser concebido como construção de fluxo “descontínuo", pois possibilita o encontro de valores construídos com novas possibilidades que por certo irá remodelá-los, mas pela própria construção consciente do sujeito e não pela imposição. O contraditório ou o não totalmente ocupa agora como necessários para construção dialó- 
gica e dialética, caracterizando o sujeito como de fato ser inacabado, que a todo momento se reinventa em sua relação com o outro.

\subsection{EDUCAÇÃO - UM ATO DE AMOR}

As ideias de Paulo Freire nos ensinam a ver o aluno, não como um mero objeto do ensino, mas um parceiro imprescindível no processo educativo que deve ser construído a partir dos valores que alicerçam os sujeitos, principalmente o respeito.

[...] transformar a experiência educativa em puro treinamento técnico é amesquinhar o que há de fundamentalmente humano no exercício educativo: o seu caráter formador. Se se respeita a natureza do ser humano, o ensino dos conteúdos não pode dar-se alheio à formação moral do educando. (FREIRE, 1996, p.37)

O educador e o educando são sujeitos cognoscentes, por isso estão sempre em processo de aprendizagem e por isso são inacabados à medida que nenhum homem é plenamente educado ou completo, pronto, capaz de atuar sobre os outros. A diferença do professor para o aluno está na fase de maturação que ambos se encontram, por isso, a busca do conhecimento deve ser feita em parceria, considerando que o homem não é um ser isolado, mas social.

Além de um ato de respeito, o ato educativo é um ato de amor, conforme comenta Freire:

Não há educação sem amor... o amor implica luta contra o egoísmo. Quem não é capaz de amar os seres inacabados não pode educar. Não há educação imposta, como não há amor imposto. Quem não ama não compreende o próximo, não o respeita. (FREIRE, 1982, p. 29).

O amor se revela no compromisso com os homens, como um ato de coragem. O amor não é indiferente à causa dos oprimidos, pelo contrário, onde quer que estejam esses oprimidos o ato de amor se compromete em sua causa libertária, sempre viabilizada pelo diálogo. 


\section{O EDUCADOR EM SUA CONDIÇÃO DE TRANSFORMADOR NA CONCEPÇÃO FREIREANA}

O processo educacional se caracteriza pela construção ou desconstrução de saberes, valores e comportamentos a partir da associação de novos saberes que podem vir das várias instâncias, inclusive a escola. Por isso, a multifocalização deve ser tratada pelo educador como possibilidade e não como problema. Lembremos que o produto das diferenças é justamente a soma das possibilidades e não há possibilidade de se considerar os diferentes de uma maneira única dentro de um trabalho pedagógico que tenha como objetivo a transformação. Na verdade, o primeiro que de fato deve estar aberto para as transformações é o educador que a todo instante deve colocar em discussão subjetiva suas próprias idiossincrasias.

Isso importa a necessidade de um olhar mais abrangente e contextual no aluno como sujeito de construção de sua própria identidade, onde urge, cada vez mais, a necessidade do professor se instrumentalizar para perceber especificidades do cotidiano de sala de aula sobre uma nova ótica ou sobre uma ótica menos fracionária. Tal proceder pode permitir construções relacionais mais profundas entre os atores envolvidos, o que emergirá em posturas mais reais e espontâneas, tendo como consequência maior legibilidade por parte dos professores. E é esse sujeito desejante que deve ser respeitado e livre para trabalhar com seu objeto de desejo, construindo o que lhe é informado pelo professor, em um processo de subjetivação.

Assim, o professor precisa estar atento ao sujeito e à sua fala na sala de aula para conhecer como se dá o processo do conhecimento, a partir das suas construções internas. Além disso, uma escuta sensível pode contribuir para um ambiente escolar mais harmonioso, pautado de respeito ao outro enquanto sujeito desejante, fortalecendo as relações estabelecidas de forma positiva.

Os afetos determinam as ações do sujeito, sendo ambivalentes e estruturados pelo prazer e desprazer. No que tange à relação professor-aluno, a ambivalência pode suscitar no aluno para com o professor, conscientemente ou não, sentimentos opostos: amor e ódio, prazer e desprazer, desprezo e admiração etc., dependendo das suas experiências primárias vivenciadas com seus pais na infância. A partir desse mecanismo, o aluno 
pode desenvolver uma relação de transferência com o professor, sendo ela positiva ou negativa.

\subsection{O PAPEL DO EDUCADOR NA CONSTRUÇÃO DO CONHECIMENTO}

O papel do professor, dentre outros, deve ser o de levar o aluno a refletir sobre sua realidade a partir de novos conhecimentos, procurando a causalidade profunda dos fatos e percebendo os condicionamentos criados pelos conceitos do contexto ideológico estabelecido, desvelando e transformando a realidade vivenciada.

A atuação do professor em sala de aula deve favorecer ao aluno a participação na construção do conhecimento; se o aluno é impedido de dizer o que sabe ou o que acha ou a fala é invalidada, e se não é incentivado à participação e é taxado como o que nada sabe, esse se posicionará no mundo passivamente, adaptando-se e acomodando-se à estrutura que o domina e, ainda que se sinta oprimido, não reagirá. Ou em contrapartida poderá se rebelar contra o sistema, abandonando a escola, o que talvez de fato justifique os altos índices de abandono na EJA. Neste sentido, o respeito à dignidade do educando não permite ao professor subestimá-lo ou zombar do saber que ele traz consigo para a escola. O que acontece na maioria das vezes é que esse ser oprimido acaba incorporando as atitudes do opressor e agirá da mesma maneira com os que dependem dele, consolidando um processo de reprodução pragmática.

No desafio da construção do conhecimento, o educador não pode ser um mero narrador de conceitos prontos, como se a realidade fosse algo estático, alheio à experiência do educando. Pelo contrário, deve considerar tudo o que o educando traz de sua experiência de vida para a partir desta construir novos saberes e concepções.

[...] educar e educar-se, na prática da liberdade, é tarefa daqueles que sabem que pouco sabem - por isto sabem que sabem algo e podem assim chegar a saber mais - em diálogo com aqueles que, quase sempre, pensam que nada sabem, para que estes, transformando seu pensar que nada sabem em saber que pouco sabem, possam igualmente saber mais (FREIRE, 1985, p. 15). 
A concepção problematizadora da educação considera que conhecer não pode ser um ato de uma doação do saber do educador ao educando, mas um processo que se estabelece no contato do homem com o mundo vivido, o qual não é estático e sim dinâmico e em contínua transformação. Isso se torna bem evidente na dinâmica da EJA, em que a faixa-etária é bem ampla e os alunos apresentam vivências históricas diversificadas, além de muitos virem geograficamente e culturalmente de outros ambientes.

Sendo assim, tanto o educador quanto o educando fazem parte do processo educativo, aprendendo em comunhão, mediatizados pelo mundo, por isso o papel do educador é de problematizador, jamais dissertador ou depositador. Sobre esse assunto, Paulo Freire afirma:

A educação como prática da liberdade, ao contrário daquela que é prática da dominação, implica na negação do homem abstrato, isolado, solto, desligado do mundo, assim também na negação do mundo como uma realidade ausente dos homens. (FREIRE, 1982, p.81)

Conclui-se que, nessa concepção de educação, não prevalece o educador sobre o educando, já que ninguém educa ninguém; mas um educador-educando com um educando-educador aprendendo com o outro. Identificados nessa reflexão-ação e nessa ação-reflexão sobre o mundo mediatizador, tornam-se, ambos, seres da práxis que podem assumir papel de sujeito em vários contextos.

\subsection{O EDUCADOR E A PRÁTICA PEDAGÓGICA}

A concepção metodológica freireana considera importante a problematização da situação existencial em que vive o educando, bem como a análise e síntese. Recomenda-se fazer, inicialmente, um levantamento do universo vocabular dos grupos, a fim de escolher as palavras geradoras que variam conforme o lugar, juntamente com a percepção de mundo. As palavras geradoras devem ser de riqueza fonêmica e dificuldades fonéticas, colocadas numa sequência das menores dificuldades para as maiores.

A primeira etapa é uma discussão através do diálogo baseada na palavra geradora, onde os alunos expõem suas ideias através da mediação do 
alfabetizador que faz perguntas simples. Na segunda etapa, é apresentado um outro cartaz com a palavra geradora sem o objeto a que se refere; logo após vem a apresentação da palavra, separada em sílabas, depois a visualização das famílias fonêmicas e por fim a criação de novas palavras a partir dos fonemas da palavra geradora.

Em todo esse processo, deve ser priorizada a conscientização, numa relação com a realidade através da interação dialógica.

Sobre a utilização do tema gerador Paulo Freire comenta:

É importante enfatizar que o "tema gerador" não se encontra nos homens isolados da realidade, nem tão pouco na realidade separado dos homens. Só pode ser compreendido nas relações homens-mundo. (FREIRE, 1982, p. 105).

Sendo assim, torna-se inviável separar o ensino dos conteúdos da formação ética dos educandos, pois a desconsideração total pela formação integral do ser humano, a sua redução a puro treino fortalece a maneira autoritária de falar de cima para baixo.

A prática pedagógica do educador deve desafiar o educando com quem se comunica e a quem se comunica a produzir sua compreensão do que vem sendo comunicado, usando de metodologias e estratégias de trabalho que contribuam para formação dos educandos e tornem-se pessoas ativas, participativas, sujeitos sociais de direitos, pensando no bem comum entre as pessoas e a natureza

\subsection{EDUCADOR - UM SUJEITO ÉTICO E ESTÉTICO}

A concepção freireana traz uma visão de ser humano, de mundo, de história e de educação peculiar, permeada por uma ética humanizante. Para Freire, todo educador tem uma responsabilidade ética no exercício da tarefa docente, enquanto prática formadora, devendo lutar por ela, ou seja, a ética deve ser inseparável da prática educativa, independentemente da faixa etária com quem trabalhamos, bem como a estética que traz cor e vida a sala de aula.

As obras de Freire retratam a ética universal enquanto marca da natureza humana, indispensável à convivência, como presença consciente no 
mundo. Para Freire (2016), uma educação que vise formar para a autonomia engloba necessariamente a dimensão ética e estética.

Um sujeito ético leva em consideração o respeito pelo saber "seu" e do "outro"; valoriza a lealdade; é desprovido de qualquer tipo de preconceito e julgamento; elimina a discriminação de sexo, gênero, raça, classe, idade, condição social; tem como princípio a consideração a individualidade e a diversidade; leva sempre em consideração a liberdade "sua" e do "outro"; tem sempre como pressuposto a ternura e o afeto; leva a construção de relações de solidariedade.

Um educador que valoriza a estética preocupa-se com a "boniteza" do processo de aprendizagem, manifestada nos sentimentos de esperança, solidariedade e ética, proporcionando aos educandos a valorização da expressão, comunicação e do conhecimento, visando à sensibilidade para o exercício da cidadania e convivência social.

Assim, a formação ética e estética acontece na educação, mais precisamente na sala de aula, quando a sociedade, a escola, professor e aluno lutam por uma educação transformadora, dialógica e conscientizadora. Sendo assim, um educador com essas características pode fazer a diferença na sala de aula, tornando o ambiente um espaço de construções e desenvolvimento das potencialidades do educando. Além disso, o espaço de liberdade de expressão oferece ao educando condições de fortalecer sua autoestima e autoconfiança.

\subsection{EDUCADOR - UM SUJEITO CRÍTICO E REFLEXIVO}

O pensamento freireano aponta a importância do desenvolvimento crítico e reflexivo da prática pedagógica. Um educador crítico-reflexivo possui como uma de suas grandes características a preocupação com as consequências éticas e morais de suas ações na prática social. O seu discurso está atrelado ao seu modo de ser e estar no mundo, além disso o exercício e vivência dessa prática em várias circunstâncias do cotidiano, possibilita ao educador se colocar na posição de algo concreto que represente para os alunos também valores de forma concreta.

No entanto, as representações desses valores de forma alguma podem fomentar regra de conduta ou modelo a ser seguido de forma pragmática, mas apresentar possibilidades de condutas saudáveis diante das 
muitas "insanidades" sociais que muitas vezes são apresentadas de forma forçosa no processo de aculturamento e supostos valores. Tais possibilidades de reflexões críticas não devem perpassar para a concretude sem de fato haver uma ponderação do seu meio, entendendo assim que cada instância de construção e vivência, seja ela familiar, profissional e nas várias instâncias sociais apresentam valores comuns e valores específicos. Por isso o professor deve incentivar a ponderação, mas para isso deve como condição sine qua non conhecer e reconhecer em postura empática a realidade de seus alunos.

A discussão sobre a consciência, seja ela ingênua ou crítica, suscita um processo de construção dualizada e concatenada a partir das várias interações do sujeito, caracterizando de fato a educação como um ato político. Freire (2016) destaca que o homem é consciente e, na medida em que conhece, tende a se comprometer com a própria realidade. Entretanto, um passo para a consciência crítica somente se dará vinculado a um processo educativo de conscientização e este passo exige um trabalho de promoção e construção da criticidade. "Não há para mim, na diferença e na 'distância' entre a ingenuidade e a criticidade, entre o saber de pura experiência feito e o que resulta dos procedimentos metodicamente rigorosos, uma ruptura, mas uma superação (FREIRE, 2016, p.32).

Estabelece-se um grau de exigência cada vez maior do professor com relação ao tipo específico de intervenção, numa ação dialógica, onde trazer para a sala de aula discussões que possibilitem seus alunos a reconhecerem, por si mesmos, que a realidade não é estática e sim mutável, é condição necessária.

O educador crítico considera a voz ativa dos educandos, cujos sentidos e significados de ser e estar no mundo, construídos historicamente, permeiam todas as suas ações no que se refere à sua aprendizagem, à escola e à sociedade. Seu papel seria ajudar os educandos a organizar reflexivamente o pensamento, colocando um novo termo entre o compreender e o atuar: o pensar, através de um método ativo, dialogal e participante. Para isso, o educador precisa refletir continuamente sobre sua prática, atentando para as dimensões política e pedagógica da educação.

Em se tratando da dimensão política, entende-se que a educação nunca é neutra. Tem uma intencionalidade que envolve práticas, valores, utopias que reproduzem, legitimam, questionam ou transformam as relações 
de poder prevalecentes na sociedade. Por isso, o educador da EJA precisa posicionar-se como um sujeito crítico capaz de despertar nos educandos a sua criticidade de forma consciente e comprometida com o bem comum, evitando se debruçar em concepções estritamente partidárias.

\section{CONSIDERAÇÕES FINAIS}

No decorrer deste artigo, buscou-se refletir acerca das concepções teóricas e metodológicas do educador Paulo Freire com o intuito de traçar um perfil de educador-transformador para atuar na EJA. Dentre as concepções abordadas no corpo deste trabalho, a educação centrada no sujeito se destaca nas obras de Freire, por este considerar o educando sujeito da sua educação que deve ampliar a sua percepção de mundo.

A educação proposta por Freire se dá mediante uma relação dialógica entre educador e educando, onde prevalece o respeito e a reflexão para novos posicionamentos diante do mundo. $\mathrm{O}$ autor afirma que somente $\mathrm{o}$ amor é capaz de defender uma educação para a liberdade. Ele atribui toda educação a um ato político, de luta pela causa dos oprimidos, onde através da conscientização, os educandos desenvolvem a sua criticidade, posicionando-se no mundo de forma ativa.

A prática da escrita para a alfabetização, na concepção freireana, está sempre atrelada ao universo vocabular do educando, através da interação dialógica, priorizando a conscientização. Freire considera inviável trabalhar com conteúdo desvinculado da formação integral do ser humano. Entende-se que o educador para atuar na Educação de Jovens e Adultos precisa de fato de uma formação específica de lhe proporcione ampliação de sua visão com relação a modalidade e lhe permita articular-se diante das especificidades encontradas na escola.

Observa-se também na EJA a presença de muitos alunos com dificuldade de aprendizagem ou algum tipo de transtorno no qual o poder público, praticamente não apresenta nenhum tipo de apoio ou acompanhamento. Consequentemente pela falta de oferta de formação relacionada a essa realidade em sala, muitos professores apresentam dificuldade para lidar com alunos que apresentam dificuldades de aprendizagem, o que perpassa as competências dos professores na esfera apenas metodológica, mas adentra no conhecimento psicogenético e envereda pela necessidade 
de apropriação de conhecimento que possa lhe instrumentalizar para ajudar a compreender e desenvolver um trabalho mais eficiente em sala de aula, considerando o estado afetivo e emocional do aluno.

Segundo a concepção freireana, entende-se que o educador-transformador é um sujeito ético e estético, sendo essas características indispensáveis para a convivência humana, por isso necessárias para se atuar em sala de aula, com o fim de formar seres autônomos. Num ambiente onde a ética e a estética prevalecem, há respeito pelas diferenças e valorização das diferentes formas de expressão, comunicação e conhecimento. Além da ética e da estética, o perfil do educador-transformador é embutido de criticidade e reflexividade. Essas características são importantes tanto para o professor pensar na sua prática educativa como para a formação dos educandos, pois como via de mão dupla, uma irá influenciar a outra.

As obras de Paulo Freire apresentam uma riqueza inigualável para a formação do professor-transformador, principalmente para se trabalhar com a EJA. A sua visão de formação integral do sujeito desperta o educador a buscar uma formação que vai muito além de conhecimentos técnicos. Essa formação se dá especialmente em sala de aula, na prática da escuta sensível dos educandos, buscando analisar os mundos interpessoais que constituem a subjetividade.

\section{REFERÊNCIAS}

BRASIL. Conselho Nacional de Educação. Parecer CNE/CEB no 11/2000. Diretrizes Curriculares para a Educação de Jovens e Adultos. Brasília: MEC, maio 2000.

\section{BRASIL. MINISTÉRIO DA EDUCAÇÃO. Secretaria de Educação}

Continuada, Alfabetização e Diversidade - Diretoria de Políticas de Educação de Jovens e Adultos. Disponível em http://www.ceeja. ufscar.br/legislacao-vigente-para-a-eja. Acesso em: 04 out. 2016.

FREIRE, Paulo. Educação e Mudança. 12 $12^{\underline{a}}$ ed. Rio de Janeiro: Paz e Terra, 1979.

Extensão ou Comunicação? 8르 ed. Rio de Janeiro: Paz e Terra, 1985. 
Pedagogia da Autonomia: saberes necessários à prática educativa. 53르 ed. Rio de Janeiro: Paz e Terra, 2016.

Pedagogia da Esperança - um reencontro com a pedagogia do oprimido. 4를 ed. Rio de Janeiro: Paz e Terra, 1992.

FREIRE, Paulo; SHOR, Ira. Medo e Ousadia.13. ed. São Paulo: Paz e Terra, 2011.

LDB. Lei de Diretrizes e Bases da Educação Nacional. Disponível em https://www2.senado.leg.br/bdsf/bitstream/handle/id/70320/65. pdf?sequence=3. Acesso em: 04 out. 2016.

ORGANIZAÇÃO DAS NAÇÕES UNIDAS. Declaração Universal dos Direitos Humanos. Disponível em http://www.ohchr.org/ EN/UDHR/Documents/UDHR_Translations/por.pdf. Acesso em: 04 out. 2016.

PLANEJANDO A PRÓXIMA DÉCADA. Conhecendo as 20 Metas do Plano Nacional de Educação. Disponível em http://pne.mec. gov.br/images/pdf/pne_conhecendo_20_metas.pdf. Acesso em: 05 out. 2016. 


\title{
INFOEJA: UMA PROPOSTA DE PRODUTO EDUCACIONAL NO ENSINO DE INFORMÁTICA DO CURSO DE ADMINISTRAÇÃO DO PROEJA
}

\author{
Aline Carla de Sousa Leite Cipriano ${ }^{41}$
}

\section{INTRODUÇÃO}

O Programa Nacional de Integração da Educação Básica à Educação Profissional na Modalidade Educação de Jovens e Adultos (PROEJA) foi criado pelo Decreto no $5.478 / 2005$. Este documento base logo foi alterado pelo Decreto no 5.840 , de 13 de julho de 2006. A mudança se deu em virtude de críticas que exigiam maior abrangência da iniciativa, tal como a possibilidade de oferta de ensino não apenas para o nível médio, mas também para o ensino fundamental e seu oferecimento por outros órgãos, o que requereu reformulações (BRASIL, 2007).

Um dos grandes desafios do Programa é integrar três campos da educação que historicamente não estão próximos: o ensino médio, a formação profissional técnica de nível médio e a educação de jovens e adultos. Assim, o Programa contribuiria para a melhoria das condições de partici-

41Licenciada em História, Bacharel em Direito, Pesquisadora, Professora da SEMED-Timon e SEDUC-PI, mestre em Educação Profissional e Tecnológica do Instituto Federal de Educação, Ciência e Tecnologia- IFMA - Campus Monte Castelo. 
pação social, política, cultural e no mundo do trabalho desses sujeitos, em vez de produzir mais uma ação de contenção social (MOURA; HENRIQUE, 2012).

As políticas públicas na modalidade Educação de Jovens e Adultos (EJA) foram criticadas ao longo do tempo por seus aspectos assistencialistas, voltados para cumprir as necessidades de mão de obra do mercado. Entretanto, o PROEJA vem com uma proposta diferente de integralização do currículo, observando a necessidade de formação profissional como um processo de inclusão, sendo o estado corresponsável pela evasão desses indivíduos da escola, devendo por isso ofertar o ensino àqueles que não puderam concluir na idade própria, o que representa uma política compensatória.

Destarte, em virtude do público diferenciado que integra o PROEJA, é destacada sua necessidade de escolarização integrada ao trabalho, cujas experiências e vivências exigem um tratamento específico, bem como metodologia e análise das necessidades escolares desse público. Assim, levam-se em conta os entendimentos de Arroyo (2011) sobre os sujeitos da EJA, enquanto "jovens evadidos ou excluídos da escola, antes do que portadores de trajetórias escolares truncadas, eles e elas carregam trajetórias perversas de exclusão social, vivencias trajetórias de negação dos direitos mais básicos".

Em meio ao exposto, interessante se faz questionar: como inserir os discentes do PROEJA em uma cultura digital que os auxilie na inserção no mundo do trabalho por meio da prática nas disciplinas de Informática? Essa questão norteou a proposta da dissertação do mestrado que objetivou analisar os resultados da implantação de um aplicativo educacional (AP) que auxiliasse na práxis nas disciplinas de Informática, promovendo habilidades profissionais aos discentes do Curso Técnico em Administração do PROEJA-Campus Timon-MA. Desta forma, aproximam-se as relações entre tecnologia e educação ao mundo da EJA, que deve ter como base a inserção social ampla desses sujeitos, perpassando pelo letramento digital (ARROYO, 2011).

A fim de responder a tal questionamento e aos objetivos da pesquisa, após longo período de pesquisa diagnóstica com os discentes-docentes das disciplinas do curso pesquisado, adotou-se como produto educacional a elaboração de um aplicativo que facilitasse o ensino e a aprendizagem nas 
disciplinas de Informática do curso técnico em Administração do PROEJA, possibilitando o uso didático do celular (smartphones), por ser uma ferramenta de maior acesso dos discentes.

A ideia fundamental deste artigo é apresentar um produto educacional fruto de uma pesquisa de mestrado profissional que analisou o desenvolvimento e uso do aplicativo educacional InfoEJA, auxiliando as disciplinas de Informática do curso técnico em Administração, contribuindo com a inserção desses sujeitos no mundo do trabalho e na cultura digital. Atendeu-se ao que dispõe o artigo $2^{\circ}$, do Regimento Interno do Programa de Pós-Graduação em Educação profissional e Tecnológica (ProfEPT), que visa tanto à produção de conhecimentos como o desenvolvimento de produtos, por meio da realização de pesquisas que integrem os saberes inerentes ao mundo do trabalho e ao conhecimento sistematizado (BRASIL, 2018).

A criação do produto educacional é parte das iniciativas requeridas no regimento interno do próprio curso de mestrado profissional desenvolvido; inclusive, é o principal aspecto que o diferencia do mestrado acadêmico. Assim, ambos buscam ampliar pesquisa em uma área do conhecimento, porém no primeiro há uma iniciativa de intervenção no mundo educacional, por meio da elaboração de um produto educacional, agregando valor à pesquisa.

\section{REFERENCIAL TEÓRICO}

O texto se apresenta dividido em duas seções: (2.1) O uso de aplicativos no processo de ensino aprendizagem faz uma análise sobre pesquisas que versam sobre o uso de aplicativos educacionais no processo de ensino aprendizagem; (2.2) Estrutura do aplicativo InfoEJA, na qual é apresentado a organização do App, ressaltando suas funções, objetivos e possibilidades de uso.

\subsection{O USO DE APLICATIVOS NO PROCESSO DE ENSINO-APRENDIZAGEM}

As transformações ocorridas com a III e IV Revolução Industrial, provocadas pela inserção do uso acentuado das tecnologias e a consequen- 
te troca de informações, influenciaram todos os âmbitos da sociedade, inclusive no espaço educacional, onde tais avanços promoveram impactos irrenunciáveis que propiciaram novas formas de pensar, aprender e ensinar (SOARES, 2006).

O reflexo dos impactos das tecnologias no espaço educacional é explicitado no contexto atual da pandemia da Covid-19, uma vez que a Organização Mundial da Saúde (OMS) orientou os países signatários a promoverem como medida sanitária o isolamento social, o que impediu as atividades presenciais escolares, demandando a aprendizagem por meio do ensino remoto, exigindo de professores e alunos conhecimentos e habilidades acentuados com as Tecnologias da Informação e Comunicação (TICs).

A consequente inserção e aceleração das tecnologias afetou a sociedade em vários setores, o que requereu das instituições de ensino a incorporação destas ferramentas, possibilitando o uso crescente de aplicativos educacionais como meio para desenvolver atividades financeiras, de lazer, relações sociais, transporte, culturais, de prestação e circulação de serviço, bem como adquirir conhecimentos (CITELLI, 2011).

A conversa com outros pesquisadores sobre o uso de aplicativos no espaço educacional possibilitou elencar questões pertinentes sobre as dificuldades, possibilidades e alcances de usos de Apps no espaço escolar. Desta forma, ressaltou-se e divagou-se principalmente sobre tal inserção dentro do ensino da EJA, levando em conta as especificidades e dificuldades de aprendizagem de uma geração que é considerada como "cabeças analógicas" se comparadas com as gerações mais novas e expertises nas tecnologias, nomeadas de "cabeças digitais" (PETARNELLA, 2008).

Ao versarem sobre formação continuada na EJA, Silva e Marchand (2010) reafirmam o efeito das TICs no ambiente escolar e as necessidades de incorporação das mesmas pelos professores, como forma de dinamização da aprendizagem e adequação da escola das novas linguagens digitais, que passam a codificar o mundo e exigir novos conhecimentos dos indivíduos. Isso evidencia ao estudante da EJA, que também é em suma um trabalhador, domínio e inserção neste mundo de letramento digital.

Silva e Marchand (2010) consideram que, atualmente, a utilização das tecnologias afeta e modifica significativamente nossos hábitos, fazendo-nos reconhecer a real importância e necessidade de enfrentar os desafios 
relacionados à utilização dos diversos recursos tecnológicos oferecidos. Uma vez que os instrumentos tecnológicos se fazem presentes junto às escolas, por meio de laboratórios de informática, favorecem novas possibilidades de comunicação, interação e informação advindas com a internet, provocando transformações cada vez mais visíveis em nossa sociedade.

Diante das falas de Silva e Marchando (2010), nas quais são ressaltados o impacto e as transformações promovidos pelas tecnologias que tornam o mundo cada vez mais globalizado, coaduna-se também o pensamento de Castells (2016) que ratifica e menciona o afluxo acelerado de informações nesta Era. Por isso, o conhecimento se torna ferramenta indispensável, assim a sociedade em rede se faz pela conexão, excluindo as fronteiras físicas e artificiais, impulsionando um movimento no qual o Capitalismo Informacional passa a ditar os padrões culturais imprimindo uma lógica de inclusão, mas também de exclusão daqueles que são expropriados do acesso ao conhecimento e aos meios tecnológicos (CASTELLS, 2016).

No âmbito educacional, as tecnologias no espaço escolar se inserem por meio da Informática Educativa, cuja introdução se confundiu com a origem do próprio computador nas últimas décadas do século XX. Nesse contexto, os computadores passam a ser usados como instrumentos de apoio ao ensino e aprendizagem (BALBINO, 2018). As novas tecnologias educacionais dinamizaram o ambiente de aprendizagem com sua variedade de recursos, auxiliando as práticas de ensino-aprendizagem; o uso da internet, de computadores e softwares de aprendizagem passou a facilitar as formas de conhecer.

Desta forma, corrobora Silva (2012) que os softwares educacionais passam a ter um grau bem maior de importância na promoção da aprendizagem significativa, pois funcionam como apoio às intervenções do professor, servindo como instrumentos de motivação para os alunos, na construção de conhecimentos significativos.

Esta parte fundamental do computador, o software (presente nos celulares do tipo androide), é responsável pelo controle e funções do computador, constituindo sua parte lógica e operacional. Hoje o desenvolvimento e usos de sistemas operacionais, vulgarmente chamados de Apps, se ampliaram em todas as áreas das ações humanas, a exemplo dos aplicativos bancários e de transportes, que revolucionaram as formas de prestação de serviços nestas áreas. No campo do conhecimento, vêm se destacando sof- 
twares educativos, que contribuem na autoaprendizagem, através da aquisição de informações, de forma prazerosa, lúdica e significativa.

As possibilidades das ferramentas tecnologias são ressaltadas no trabalho de Pereira e Coelho (2017), intitulado "Aplicativos móveis para fins educacionais: a utilização do aplicativo E-INST para contribuição no ensino da instrumentação industrial". Por meio de pesquisa interventiva os autores desenvolveram um $A p p$ sobre o tema citado, no qual constataram o entusiasmo dos discentes nas aulas e os resultados positivos na aprendizagem: "Diante dos resultados positivos obtidos pela pesquisa feita com os estudantes, este estudo mostra o quanto é interessante os professores utilizarem diferentes tipos de tecnologias no processo de aprendizagem, não se limitando apenas ao quadro, projetor e pincel" (PEREIRA; COELHO, 2017).

O uso acentuado de celulares de última geração, inclusive pelo público de jovens e adultos, possibilitou o redirecionamento de uma tecnologia restrita ao ambiente escolar para seu aproveitamento qualitativo nas aulas, servindo assim como tecnologia alternativa (PEREIRA; COELHO, 2017). Cabe observar que o uso de aplicativos, como demais ferramentas digitais, deve ter finalidades pedagógicas bem definidas, para que assim não se esvazie o sentido fundante de aprendizagem. A formação de professores deve ser observada como relevância neste processo, como meio para efetivação e incorporação dessas tecnologias no espaço escolar (CASTELLS, 2003).

A preparação dos docentes é mencionada nas pesquisas de Castells (2016), que ao analisar a realidade dos Estados Unidos na década de 90, menciona a carência de cursos de formação de professores para atuarem na área. Apesar das distorções, percebemos que, ressalvadas as diferenças, o Brasil também sofreu com a falta de preparação de professores, o que acabou por limitar e causar receios e proibições de professores/escolas no uso dos recursos tecnológicos, usada excepcionalmente e de forma improvisada.

Muito usado pelos professores e alvo de variadas pesquisas nas áreas de línguas, o aplicativo Duolingo, disponível de forma gratuita nas plataformas digitais, foi tema do trabalho de Pinto, Moutinho, Tavares e Bottentuit Junior (2017), intitulado "Uso da Ferramenta Duolingo no Ensino de Língua Espanhola no EJA: um estudo de caso nas turmas do CEJOL". 
Nele, os autores avaliam o uso do aplicativo como ferramenta facilitadora da aprendizagem de novos idiomas, analisando, metodologicamente, a percepção dos discentes em aulas de língua espanhola nas turmas da EJA no Centro de Ensino Jornalista João Francisco Lisboa (CEJOL), na cidade de São Luís. No caso em tela, os docentes, em vez de proibirem o uso do celular em sala de aula, passaram a usá-lo como ferramenta meio para aprendizagem de língua inglesa; assim o Duolingo, por meio dos processos de gamificação, passa a ensinar inglês de forma dinâmica e interativa, sendo orientado e aproveitado pelos professores (PINTO et al., 2017).

Pinto et al. (2017) ainda mencionam, considerando a realidade do público de jovens adultos atendidos, as concepções já cunhadas por Marc Prensky (2012), de "nativos digitais". Devido às distorções de aprendizagens entre faixa etária de estudantes, aplica-se o que defende o teórico, exigindo metodologia adequada e diversificada. Assim, a "gamificação vista com bons olhos leva o professor a dinamizar suas aulas, deixando de lado a utilização de práticas pedagógicas como a simples utilização do quadro e do discurso oral, que por hora são tidas como maçantes pelos alunos" (PINTO et al., 2017).

O uso das ferramentas tecnológicas, a exemplo da gamificação, é ressaltado por suas características lúdicas, atrativa e prazeroso dos aplicativos, algo visto nas falas dos discentes na pesquisa de Pinto et al. (2017), que afirmam que o uso do Duolingo "foi bastante positivo". Esse aplicativo também foi objeto de pesquisa de Schutz e Muller (2015), intitulado "O ensino de línguas: metodologias possíveis”, que estudou o uso da língua inglesa na EJA por meio do App Duolingo.

As contribuições das TICs assumem o espaço escolar por facilitar o acesso a anúncios publicitários orais ou escritos, músicas, artigos ou recortes de jornais, revistas e sites da internet, facilitando as relações diretas com pessoas que utilizam a língua inglesa. Essa interação faz com que o sujeito EJA desperte o interesse no ensino-aprendizagem da língua, assim como da cultura presente naquele espaço. Essas ações metodológicas são possíveis através do uso das tecnologias tornam a língua um elo de construção e produção de sentidos (SCHUTZ; MULLER, 2015).

Os autores Schutz e Muller (2015) salientam a importância da introdução das TICs no processo de ensino-aprendizagem da EJA, mencionando as várias possibilidades que as mesmas podem propiciar ao espaço 
escolar, uma vez que a língua estrangeira, assim como as tecnologias digitais, são formas atuais de leitura de mundo, necessários para nossa própria inserção no espaço digital. Usar de forma eficiente as TICs é desenhar resultados positivos, em que o interesse e mobilização dos discentes serão consequências do processo de aprendizagem.

As produções sobre o uso de aplicativos em sala de aula e demais ferramentas digitais apresentam, por meio de dados quantitativos, a relevância para alunos e professores, burlando preconceitos que proibiam o uso de celulares da sala de aula. Desta forma, há um redirecionamento no tempo sobre o uso das TICs que perpassa o ambiente social, cultural e invade a escola, exigindo habilidades necessárias aos professores que, de forma imediata, se viram tendo que desenvolver habilidades tecnológicas não apresentadas em sua formação. Surgem daí receios e frustrações que ao longo do tempo estão sendo superados por meio de ações e formações ativas, além de projetos colaborativos escolares que reforçam os usos tecnológicos.

\subsection{ESTRUTURA DO APLICATIVO INFOEJA}

O aplicativo educacional (AE) visa facilitar o ensino e aprendizagem nas disciplinas de Informática, possibilitando o uso didático do celular (smartphones) por meio de uma ferramenta digital de maior acesso aos discentes, qual seja, o celular. O objetivo almejado com a ferramenta foi contribuir nas aulas práticas de Informática do PROEJA, e sua elaboração se deveu às dificuldades de muitos discentes que não são nativos digitais. Desta forma, a aproximação com os smartphones facilitou a interação com o computador e outras tecnologias através de um (AE) que reúne acessivelmente informações e conteúdos sobre as temáticas de maior dificuldade e interesses dos discentes, observando as singularidades de aprendizagens dos mesmos.

O AE foi desenvolvido na linguagem de programação Java e no Sistema Operacional Android, o mais usado pelos discentes. Também ressaltamos que a lógica e os códigos usados foram em Kotlin, linguagem de programação para desenvolver aplicativos nativos em Android. 
A primeira vez que se usa o App, sua execução se faz pelo direcionamento do usuário a seis slides introdutórios, telas que orientam no uso e funcionalidades básicas do InfoEJA.

Figura 1. Slides introdutórios do InfoEJA (telas)

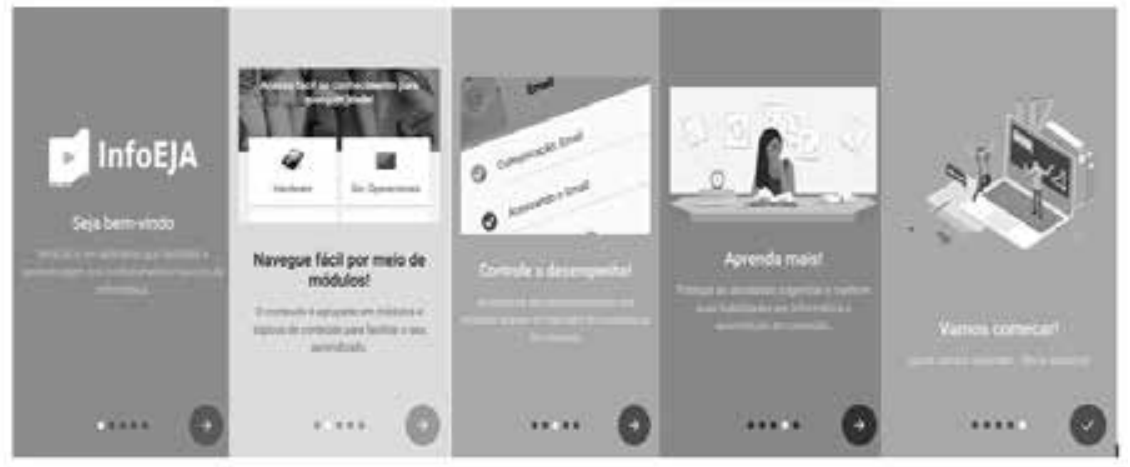

Fonte: Autora, 2020.

A tela principal apresenta um menu do lado superior esquerdo, botão usado para apresentar opções gerais do aplicativo. Na mesma tela, são apresentados os ícones que representam os módulos do aplicativo.

O primeiro slide para quem acessa pela primeira vez o InfoEJA traz uma mensagem de apresentação do produto educacional, que busca incentivar o uso do App. Já o segundo slide traz uma mensagem sobre o objetivo do produto educacional, esclarecendo a intenção do AE.

$\mathrm{O}$ terceiro slide introdutório do InfoEJA, além das imagens que orientam como usar o $A p p$, informa sobre a função de marcadores do aplicativo, que ajuda a controlar o desempenho do usuário. Já o quarto slide JA traz uma mensagem incentivadora, informando sobre as atividades do aplicativo e sugerindo seu uso como forma de fixação dos assuntos estudados.

Por fim, no quinto slide introdutório do InfoEJA, é apresentada uma mensagem de incentivo para recomeçar os estudos por meio do produto educacional, evidenciando, através de tal ferramenta de comando inicial do App, maior segurança aos discentes que estão ingressando no mundo do estudo por meio de aplicativos, uma vez que eles passam a receber instruções sobre o uso do mesmo. 
Figura 2. Estrutura do aplicativo educacional InfoEJA (telas)

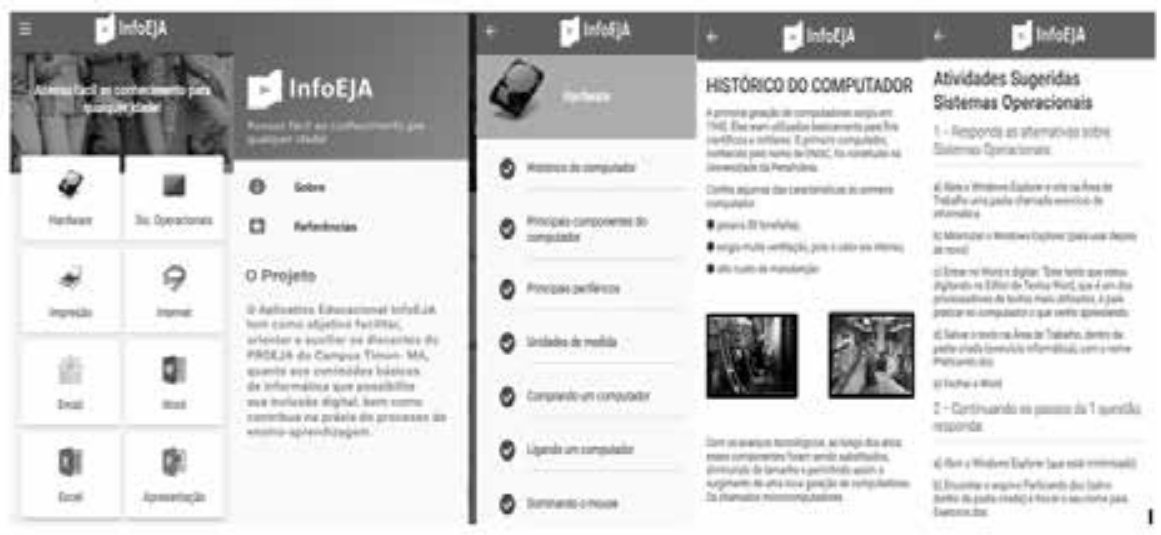

Fonte:Autora, 2020.

O ícone do menu, ao ser clicado, é direcionado para a aba "Menu Lateral", que traz uma breve apresentação do projeto no botão "Sobre", mencionando os(as) pesquisadores(as) e o desenvolvedor do App. Também está disponível o botão "Referências", que acrescenta as referências de apostila, sites e autores que contribuíram com os conteúdos do aplicativo.

Na tela principal, são apresentados os oito módulos do aplicativo, acompanhados por um ícone e nome do mesmo, sendo eles hardware, sistemas operacionais, impressão, internet, e-mail, Word, Excel e apresentação. Ao clicar no módulo, o discente é direcionado para a tela 2 , que representa a lista de conteúdos específicos referentes ao módulo. Na mesma há uma disposição didática dos assuntos para facilitar a aprendizagem. Após a leitura de todos os tópicos dos assuntos, está disponível o último tópico, que se refere ao botão "Sugestão de Atividade".

Na opção "Sugestão de Atividade", o discente é direcionado para outra tela, onde aparece a abertura de questões sobre o assunto. São atividades práticas a serem realizadas com o suporte do computador. Nessa opção, o discente poderá fixar o que aprendeu, fazendo inclusive uma revisão de tudo o que estudou. 


\section{RESULTADOS E DISCUSSÃO}

A aplicação do InfoEJA se deu no contexto da pandemia da Covid-19, sendo o isolamento social uma recomendação da Organização Mundial da Saúde por um período indeterminado. Como consequência, tivemos a suspensão de aulas presenciais a partir de março de 2020, conforme a Portaria nº 1.178, de 16 de março de 2020, do Comitê de Crise para o Enfrentamento do Coronavírus, sendo retomadas de forma não presencial no IFMA - Campus Timon a partir do dia 03 de agosto de 2020.

Por meio da plataforma Google Meet, foram desenvolvidas aulas remotas, nas quais foi aplicado o produto, por meio de aulas elaboradas pela pesquisadora, segundo o planejamento de aula e sob a tutoria dos professores(as) das turmas pesquisadas que, de forma voluntária, contribuíram com a aplicação do produto educacional.

A primeira aula foi ministrada na turma 2018 - PROEJA do curso Técnico em Administração Integrado ao Médio na modalidade EJA, no dia 14 de agosto de 2020, e contou com a participação de 18 discentes assistindo à aula de maneira remota, quando todos responderam ao questionário avaliativo do aplicativo.

A segunda aula foi ministrada na turma 2017 - PROEJA do curso Técnico em Administração Integrado ao Médio na modalidade EJA, realizada no dia 19 de agosto de 2020, com a participação de oito alunos assistindo à aula de maneira remota. Cabe mencionar que essa turma do PROEJA 2017 tem, segundo o docente, 19 discentes matriculados, porém muitos estão sem assistir aula em virtude da falta de acesso à Internet. Entretanto, apesar das dificuldades no acesso à aula, um total de 16 discentes respondeu ao questionário avaliativo, uma vez que foi dado o prazo de uma semana para a avaliação do aplicativo por meio de formulário opinativo realizado no Google Forms.

Cabe ressaltar que, após o prazo de uma semana disponível aos discentes para fazerem download do aplicativo e posterior avaliação, houve o total de 37 respondentes, ficando quatro alunos sem avaliar via questionário o App.

A avaliação do App se deu por meio de um questionário opinativo pós-aplicação do InfoEJA, elaborado por meio de sete questões fechadas, que foram respondidas pelos discentes das duas turmas pesquisadas do 
PROEJA, tendo o objetivo de analisar a qualidade e a funcionalidade do App no que se refere ao acesso, conteúdos, usabilidade, aprendizagem e possibilidades de inserção na Cultura Digital e mundo do trabalho, como pode ser visto no quadro 1.

Quadro 1. Dados do Questionário Opinativo sobre o InfoEJA aplicado aos discentes

\begin{tabular}{|c|c|}
\hline QUESTÕES & TOTAL \\
\hline $\begin{array}{l}\text { 1.Você teve dificuldades em acessar o aplicativo } \\
\text { educacional InfoEJA? }\end{array}$ & $\begin{array}{c}\text { SIM: } 50 \% \quad \text { NÃO: } 25 \% \\
\text { ÀS VEZES: } 25 \%\end{array}$ \\
\hline $\begin{array}{l}\text { 2. O aplicativo educacional InfoEJA cumpre } \\
\text { o objetivo de ser uma ferramenta auxiliadora } \\
\text { da aprendizagem, inclusive nas disciplinas de } \\
\text { Informática? }\end{array}$ & $\begin{array}{c}\text { SIM: } 88,9 \% \quad \text { NÃO: } 0 \% \\
\text { TALVEZ: } 11,1 \%\end{array}$ \\
\hline $\begin{array}{l}\text { 3. As temáticas do aplicativo educacional foram } \\
\text { selecionadas com base na indicação dos discentes } \\
\text { ao responderem o questionário. Em sua opinião, } \\
\text { os temas e conteúdos estão adequados a uma } \\
\text { melhoria na aprendizagem? }\end{array}$ & $\begin{array}{c}\text { SIM: } 94,4 \% \quad \text { NÃO: } 0 \% \\
\text { TALVEZ: } 5,6 \%\end{array}$ \\
\hline $\begin{array}{l}\text { 4. Você tem interesse em usar o aplicativo } \\
\text { educacional InfoEJA como meio de } \\
\text { aprendizagem? }\end{array}$ & $\begin{array}{c}\text { SIM: } 88,9 \% \quad \text { NÃO: } 0 \% \\
\text { TALVEZ: } 11,1 \%\end{array}$ \\
\hline $\begin{array}{l}\text { 5. O aplicativo InfoEJA é agradável e de fácil } \\
\text { usabilidade ao ponto de indicar para alguém? }\end{array}$ & $\begin{array}{c}\text { SIM: } 80 \% \quad \text { NÃO: } 8,6 \% \\
\text { TALVEZ: } 1,4 \%\end{array}$ \\
\hline $\begin{array}{l}\text { 6. Você pretende realizar as atividades práticas } \\
\text { sugeridas pelo InfoEJA? }\end{array}$ & $\begin{array}{c}\text { SIM: } 86,1 \% \text { NÃO: } 0 \% \\
\text { TALVEZ: } 13,9 \%\end{array}$ \\
\hline $\begin{array}{l}\text { 7. Na sua opinião, o aplicativo pode ajudar na } \\
\text { inserção no mundo digital e do trabalho? }\end{array}$ & $\begin{array}{c}\text { SIM: } 97,2 \% \quad \text { NÃO: } 0 \% \\
\text { TALVEZ: } 2,8 \%\end{array}$ \\
\hline
\end{tabular}

Fonte: a autora, 2020.

$\mathrm{Na}$ resposta ao primeiro item do questionário, constatamos algumas dificuldades dos discentes para baixar o aplicativo. Essa problemática foi em decorrência do link teste do App, que só foi disponibilizado nas lojas oficiais após período de teste, contendo sua versão final. Ressalta-se que algumas dificuldades dos discentes se reduzem à baixa qualidade da internet, e ao receio em operacionalizar as tecnologias digitais, o que acaba gerando dúvidas.

No segundo quesito, os discentes foram indagados quanto ao auxílio da ferramenta digital InfoEJA no processo de aprendizagem das disciplinas de Informática, ficando clara a aprovação dos mesmos, uma vez que 
88,9\% confirmaram essa possibilidade. Reforçaram, assim, as ideias de Petarnella (2008), ao mencionar a importância da introdução de aplicativos educacionais no processo de ensino-aprendizagem.

Quanto à avaliação dos discentes relacionados aos conteúdos do InfoEJA, os mesmos responderam positivamente, com 94,4\%, sobre a qualidade dos assuntos disponibilizados, e 5,6\% disseram que talvez. Tamanha aprovação se deve ao fato de consulta diagnóstica feita aos discentes na primeira fase da pesquisa do mestrado, quando puderam opinar sobre os conteúdos mais relevantes para o produto educacional. E no que diz respeito à relevância do InfoEJA como ferramenta de aprendizagem, afirmaram positivamente a possibilidade em $88,9 \%$, sendo que $11,1 \%$ disseram talvez. A acentuada estimativa mostra o entusiasmo dos mesmos ao utilizarem os recursos tecnológicos, como alternativas para aprendizagem.

Com o intuito de conhecer a experiência dos discentes com o uso do InfoEJA, questionou-se sobre a agradabilidade, facilidade e usabilidade do App, bem como sua indicação a terceiros. A resposta foi positiva, uma vez que 80\% indicaram que sim; apenas 11,4 disseram talvez; e 8,6\% indicaram que não, o que demonstra que a interface direcionada ao público atingiu seu objetivo.

A sexta questão ressalta a importância da prática por meio da resolução de questões presentes no aplicativo, recebendo uma boa aceitação dos discentes, quando $86 \%$ indicaram que realizarão as atividades práticas sugeridas no InfoEJA, bem como 13,9\% revelaram que talvez resolvam as mesmas.

No item 7 (sete), os discentes foram indagados quanto ao favorecimento do App na inserção na cultura digital e no mundo do trabalho, sendo positiva a aceitação, uma vez que 97,2 indicaram que sim e apenas 2,8 que talvez. Algo compreensível, uma vez que os aplicativos assumiram, nos dias atuais, formas de realização de serviços e satisfação de ações em diversos sentidos, com excelência as redes sociais que nos inseriram em uma nova dimensão de relação social.

Com isso, percebemos no aplicativo educacional possibilidades que podem ser ampliadas com outras pesquisas e o real aproveitamento e uso pelos docentes, transformando-se em uma ferramenta de aprendizagem que promova a autoaprendizagem, oportunizando a aquisição de conhecimentos em espaços formais e não formais. 


\section{CONCLUSÕES}

O desenvolvimento do aplicativo educacional nomeado de "InfoEJA" teve por objetivo contribuir com aprendizagem significativa, principalmente nas disciplinas de Informáticas do Técnico em Administração, promovendo habilidades profissionais aos discentes que favoreçam sua inserção na cultura digital e no ambiente de trabalho, por meio de conhecimentos tecnológicos. Para tal, foram oportunizadas práticas escolares com o uso das TICs - no caso em tela, um aplicativo, que possibilitou experiências digitais a docentes e discentes.

$\mathrm{O}$ acelerado crescimento e presença das tecnologias no ambiente escolar se fizeram com o cenário internacional da pandemia da Covid-19, que ao promover o isolamento social, impediu a realização de aula presencial por períodos indeterminados, obrigando secretarias de Educação de estados e municípios, universidades, órgão e demais instituições escolares a desenvolverem estratégias de promoção de aulas e atividades remotas, com uso cada vez mais intenso de tecnologias digitais. Em meio a este contexto, o aplicativo InfoEJA foi aplicado, oportunizando aos discentes do PROEJA alternativas de aprendizagem, nas quais os mesmos pudessem aprender de formas variadas, otimizando o tempo, ampliando os momentos de aprendizagem em ambientes formais e não formais

A aplicação do produto educacional InfoEJA se deu de forma positiva, sendo avaliada pelos discentes por meio de questionário opinativo no qual eles puderam indicar, de forma plausível, a usabilidade, o layout, possível indicação a outras pessoas e a possibilidade de inserção na cultura digital. Com isso, percebemos que a pesquisa desenvolvida, de cunho bibliográfica e interventiva, alcançou os objetivos propostos, conhecendo a realidade estudada e promovendo alterações no meio, servindo os resultados de reflexões para futuras pesquisas na temática de PROEJA e sua relação com as TICs.

Assim, a pesquisa buscou a melhoria da aprendizagem por meio da produção de um aplicativo educacional fundamentado na inserção da cultura digital, haja vista que o exercício da cidadania nos dias atuais e a efetividade dos direitos sociais estão atrelados à fruição e ao domínio dessas tecnologias; por isso, o espaço escolar deve integrar as TICs nos seus processos pedagógicos e de aprendizagens dos discentes. 


\section{REFERÊNCIAS}

ARROYO, Miguel González. Educação de Jovens e adultos: um campo de direito e de responsabilidade pública. In: SOARES, Leôncio; GIOVANETTI, Maria Amélia G. C.; GOMES, Nilma Lino (Orgs.). Diálogos na educação de jovens e adultos. Belo Horizonte: Autêntica, 2005, p. 19-50.

BRASIL. Ministério da Educação. Regulamento geral do Programa de Mestrado Profissional em Educação Profissional e Tecnológica em Rede Nacional. Brasília, DF; Ministério da Educação, 2018. Disponível em: https://profept.ifes.edu.br/regulamentoprofept/16413-regulamento13julho. Acesso em: 10 fev. 2020.

BRASIL. MEC, Secretária de Educação Profissional e Tecnológica. Programa de Integração da Educação Profissional Técnica de Nível Médio ao Ensino Médio, na Modalidade Educação de Jovens e Adultos - PROEJA. Documento Base, 2007.

CASTELLS, Manuel. A galáxia da internet: reflexões sobre a internet, os negócios e a sociedade. Rio de Janeiro: Zahar, 2003.

CITELli, A. O; COSTA, M. C. C. (org.). Educomunicação: construindo uma nova área de conhecimento. São Paulo: Paulinas, 2011.

MEDID NETO, Jorge; TEIXEIRA, Paulo Marcelo Marixi. Uma proposta de tipologia para pesquisas de natureza interventiva. Ciências educacionais, Bauru, v. 23, n. 4, 2017. Disponível em http://www. scielo.br/pdf/ciedu/v23n4/1516-7313-ciedu-23-04-1055.pdf. Acesso em: 15 nov. 2019.

MOURA, D. H. e HENRIQUE, A. L.S. Proeja: entre desafios e possibilidades. Artigo. 2012. Disponível em: http://www2.ifrn.edu.br/ ojs/index.php/HOLOS/article/view/914 Acesso em: 15 dez. 2018.

PALFREY, John. GASSER, Urs. Nascidos na era digital: entendendo a primeira geração de nativos digitais. Porto Alegre: Grupo A, 2011.

PEREIRA, G. H. de F.; COELHO, A. Aplicativos móveis para fins educacionais: a utilização do aplicativo E-INST para contribui- 
ção no ensino da instrumentação industrial. Revista Tecnologias na Educação. Ano 9. Número/Vol.19, julho 2017. Disponível em: tecnologiasnaeducaçao.pro.br/tecedu.pro.br. Acesso em: 10 jun. de 2019.

PETARNELLA, Leandro. Escola analógica: cabeças digitais: o cotidiano escolar frente às novas tecnologias midiáticas e digitais de informação e comunicação. Campinas, SP: Editora Alínea, 2008.

PINTO, A. R. C.; MOUTINHO, A. M. S; TAVARES, M. J. M.; BOTTENTUIT JUNIOR, J. B. Uso da ferramenta Duolingo no ensino de língua espanhola no EJA: um estudo de caso nas turmas do CEJOL. Revista Tecnologias na Educação. Ano 9. Número/ Vol.18- Edição Temática III- I Simpósio Nacional de Tecnologias Digitais na Educação, 2017- tecnologiasnaeducação.pro.br. Disponível em: https://repositorio.ufsm.br/handle/1/15366. Acesso em: 15 maio 2019.

Prensky, M. Digital Natives, Digital Immigrants. 2001. Disponível em: http://www.marcprensky.com/writing/prensky\%20\%20 digital\%20natives,\%20digital\%20 immigrants\%20-\%20part1.pdf. Acesso: 10 ago. 2018.

SCHUTZ, E; MULLER, G. C.K. O ensino de Línguas: metodologias possíveis. 2015. Disponível em: https://caco.ifsc.edu.br/arquivos/ proeja/ARTIGOS_ESPECIALIZA\%C3\%87\%C3\%83O_PROEJA_EAD/TC\%20Elizandra\%20Schutz.pdf. Acesso em: 16 jun. 2019.

SILVA, Antonio Mozane Teixeira da. A utilização de ferramentas da informática como instrumento pedagógico no estudo da eletricidade em uma perspectiva de aprendizagem significativa. Dissertação (Mestrado) - Universidade Federal do Ceará, Centro de Ciências, Mestrado profissional em Ensino de Ciências e Matemática. Fortaleza, 2012.

SILVA, E. A. da. MARCHAND, P. S. Formação Continuada: uso das TIC no processo educativo da EJA. In: BENVENUTI, J.; ARENHALDT, R.; MARQUES, T. B. I. (Orgs.). Refletindo sobre 
PROEJA: produções de Porto Alegre. Pelotas: Editora Universitária/UFPEL, 2010.

SOARES, Suely Galli. Educação e Comunicação: o ideal da inclusão pelas tecnologias de informação: otmismo exacerbado e lucidez pedagógica. São Paulo: Cortez, 2006. 


\section{A AÇÃO SUPERVISORA NO SUCESSO/INSUCESSO ESCOLAR DA EJAI NAS ESCOLAS MUNICIPAIS DE NINA RODRIGUES-MA}

Silvia de Fátima Nunes da Silva ${ }^{42}$

\section{INTRODUÇÃO}

Existe muita preocupação, por parte do sistema educacional e de educadores comprometidos com a educação inclusiva, sobre o grande número de insucesso escolar que tem ocorrido em nossas escolas e tem provocado uma grande reflexão e interrogação sobre o tema. $\mathrm{O}$ insucesso escolar ocorre sempre que um aluno tem dificuldades constantes em acompanhar a aprendizagem, que abandona a escola e fica reprovado. Essas dificuldades, por sua vez, ocorrem devido a fatores sociais, econômicos, familiares e culturais.

São fatores que geralmente ligados ao exterior da escola e que muito contribuem para essa onda de insucessos que temos nas escolas e também em que os supervisores podem ajudar, e como educadores todos precisam entender que cada aluno tem suas formas de receber o conteúdo, de assimilar, de registrar e de reproduzir o que foi aprendido, portanto, cabe ao professor tentar conhecê-lo individualmente para ajudá-lo a progredir. A supervisão escolar se apresenta como um instrumento de grande impor-

42 Doutora em Ciências da Educação. 
tância na qualidade da educação, pois cabe-lhe a função de planejar, avaliar e aperfeiçoar as ações, para garantir a eficácia de seus resultados.

O objetivo deste trabalho é compreender as causas do fracasso escolar e o papel desempenhado pelo supervisor pedagógico nesse contexto. A metodologia utilizada foi um estudo bibliográfico sobre o tema e uma pesquisa entre supervisores e alunos da EJAI sobre os fatores que provocam o insucesso na escola.

\section{SUCESSO/INSUCESSO ESCOLAR: CONCEITOS E INDICADORES DE INSUCESSO ESCOLAR}

Segundo Ana Benavente (1989), na década de 60, o insucesso é explicado pelas maiores ou menores capacidades dos alunos, pela sua inteligência, pelos seus dotes naturais, pela pertença social e pelo maior ou menor bagagem que os alunos dispõem, quando estes entram na escola. No entanto, nos anos 70, a autora conclui que os alunos têm capacidades diferentes, o que os obriga a ter diferentes ritmos de aprendizagem. Surge então um questionamento: quais são as principais causas do insucesso escolar?

Devem-se considerar as causas em função dos seus agentes: alunos, familiares, escola, professor, currículo, sistemas educacionais e sociedade. A razão pelas quais se pode considerar que o aluno é um dos agentes responsáveis pelo insucesso escolar deve-se à instabilidade de características da adolescência que leva o aluno a rejeitar a escola, tornar-se indisciplinado, desinteressado no estudo, e consequentemente estará em atraso no desenvolvimento econômico.

O insucesso escolar é, pois, um conceito tão relativo, quanto difícil de definir. Não menos difícil será tentar interpretar o fenômeno do insucesso escolar, analisar os fatores e os mecanismos que explicam e identificam as suas causas, por isso achamos necessário apresentar algumas definições baseadas em autores e no dicionário.

No campo educacional, o termo insucesso ou fracasso escolar é utilizado no âmbito do sistema do ensino aprendizagem, geralmente, para caracterizar o fraco rendimento escolar dos alunos que, por razões de várias ordens, não puderem alcançar resultados satisfatórios no decorrer ou no final de um determinado período escolar e, por conseguinte, reprovarem. 
Segundo Perrenoud (1999 apud SIL, 2004, p. 32, "no entanto, desde que se passou a considerar a educação como um investimento, o fracasso escolar maciço tornou-se um problema social observando-se a transformação das classes sociais e o desenvolvimento da escolarização". No que concerne a esta questão, vários estudos foram feitos no sentido de explicar as disparidades socioculturais e conhecer as reais causas e a sua natureza.

No plano social, Bourdieu e Passeron, apud. Annamaria Rangel (s/d, p. 25) mostraram que as desigualdades escolares estão ligadas a origem social e que não só os obstáculos econômicos levam a desigualdades econômicas, mas também os obstáculos culturais. Assente na teoria de reprodução social (Bourdieu apud. Marcel Crahay (1996, p:10) a escola avalia as competências dos indivíduos segundo as normas próprias das classes dominantes. Como consequência as crianças das outras classes sociais ficam a uma distância diferente da cultura escolar e tem menos sucessos do que as crianças de classes privilegiadas.

Assim, Mohamed Cherkaoui (1986, p. 43) apresenta uma conclusão a que chega todos os empíricos. "O sucesso está forte e positivamente em correlação com a origem social dos alunos”. Sejam quais forem os indicadores das duas variáveis utilizadas, quando ao nível de estatuto social da família se eleva, o êxito dos filhos aumenta igualmente. A origem social é medida em geral pela profissão dos pais, pelo seu nível ou diploma que se relaciona com o seu rendimento.

Relacionando o insucesso escolar no âmbito familiar podemos levar a cabo vários autores que apostam mais na família e no seu clima afetivo. Desses podemos salientar Mannoni (apud Oliveira; Oliveira 1996, p. 208), que insiste na influência e na qualidade relacional do filho com os pais. A síndrome do insucesso reflete fundamentalmente na má qualidade das interações intrafamiliares, denunciando a "anorexia escolar", carência e conflito na relação familiar.

Relativamente ao clima familiar e sua relação com o nível socioeconômico, não é automático. Pois, como afirma Forquin (apud Oliveira; Oliveira, 1996, p. 216), há famílias pertencentes à mesma classe social, mas com um clima efetivo e educacional muito diferente. Segundo o autor, a dificuldade em avaliar e a extrema complexidade de interações afetivas no seio da família, explica em grande parte a inconsistência dos resultados de investigação neste domínio. 


\subsection{CAUSAS DO SUCESSO E INSUCESSO ESCOLAR}

O insucesso escolar é um problema preocupante para todos os que se interessam por questões no domínio da educação, assumindo proporções e aspectos de muita gravidade. Trata se de um fenômeno muito complexo que tem manifestação à nível da escola e da sociedade através de sintomas múltiplas e diversificados (IOSIF, 2007).

$O$ fracasso escolar traz consigo a infelicidade da criança, a falta de confiança em si própria no presente e com graves reflexos futuros. $\mathrm{O}$ sufocar para sempre o desejo de maior cultura, a falta de amor pelos livros, a procura de interesses menos válida: a droga, a pornografia, a delinquência. (SILVA, 2014).

A visão que cada um tem de si próprio é marcada profundamente pelo sucesso ou insucesso. O sentimento de frustração de falta de confiança em si mesmo por vezes é tão intolerável que força o adolescente ou o jovem a procurar refúgio na droga e mesmo em caso extremo a morte. Outras vezes, o aluno procura-se afirmar se demonstrando os seus poderes através de atividades marginais A escola é considerada como culpada do agravamento da desigualdade social.

A procura de explicações para problemática do insucesso escolar tem sido uma preocupação constante ao longo das últimas décadas. Estar em situação de insucesso implica uma multiplicidade e uma enorme variedade de causas cuja localização se pode centrar ao nível do aluno, do seu ambiente restrito, ao nível da sociedade à qual pertence, ao nível da própria escola e do sistema educativo.

Existem várias pesquisas feitas na tentativa de explicar as causas do insucesso escolar. Segundo Tavares (1998), as causas do insucesso escolar estão relacionadas com vários fatores tais como: causas do sucesso e insucesso escolar, pessoal, social e econômico e escolar.

O sucesso escolar, da mesma forma que o seu oposto, o insucesso escolar, é uma matéria que preocupa todos os agentes do sistema educativo e inquieta grande parte da nossa sociedade, sendo tema de interesse para investigadores, sociólogos e pedagogos. Contudo, apesar do grande interesse que desperta esta temática, os conteúdos de sucesso e insucesso são complexos, já que, dependendo dos intervenientes educativos, o significado que lhes é atribuído é diverso, se referem que o sucesso é concebido 
com a razão entre o que se pretende conseguir (objetivos) e o que efetivamente se conseguiu (os resultados). (SILVA; DUARTE, 2012).

$\mathrm{O}$ sucesso escolar surge quando um aluno realiza um determinado percurso escolar com maior escolar com maior ou menor dificuldade. $\mathrm{O}$ insucesso escolar era "antigamente" encarado como um problema do aluno, jamais, ou muito raramente como um fenômeno que possa envolver a organização e as práticas escolares, as adequações do currículo, das metodologias, da própria estrutura organizativa as características do aluno.

Para enfrentar o insucesso escolar, o aluno deve ter confiança em si e sentir-se seguro. Para que a sua autoestima se desenvolva é importante ter uma boa relação com os familiares, professores ou outras pessoas que o rodeiam. um clima emocional estável reduz a ansiedade, a agitação desassossego. a criança precisa saber em quem pode confiar, o que pode ou não fazer e ter limites bem definidos (SILVA; DUARTE, 2012).

Quando se pensa em quem pode ajudar o aluno, surgem logo os pais ou familiares, que devem encorajar o seu filho a expressar os seus sentimentos e pensamentos; elogiar pelos seus progressos e pelo seu esforço que tem feito para ultrapassar as suas dificuldades (mesmo que não estejam totalmente ultrapassadas); explicar que os erros e as dificuldades fazem parte do crescimento humano.

De acordo com vários estudos levados a cabo por pedagogos e psicólogos a respeito deste problema, chegou-se à conclusão de que as causas podem surgir de vários fatores: no ambiente familiar e social; no ambiente cultural; na estrutura escola; nas características individuais do aluno

O combate ao insucesso escolar começa no pré-escolar, quando são desenvolvidas as primeiras aprendizagens sociais. Mas importar desconsiderar, que ainda antes disso, é relevante descurar do contexto cultural e familiar já enraizado. Traços culturais, experiência de vida, enfim, mentalidades dos pais podem constituir um indicador negativo e muitas vezes devastador do futuro dos seus filhos.

A ideia de que a escola não conhece o aluno que chega à escola com uma nova história de vida, tem se verificado ser consensual. As vezes o professor sente-se obrigado a cumprir os conteúdos e não tem tempo para estabelecer uma ligação mais consistente com os alunos. A verdade é que tem que haver acompanhamento direto ao longo de todo ensino. É preciso ter professores qualificados para enfrentar os desafios inerentes ao 
combate do insucesso escolar, neste caso, a ação do supervisor escolar é fundamental no sentido de mediar as relações entre alunos, professores e famílias.

As manifestações de insucesso escolar são múltiplas, mas três delas são particularmente referidas pela possibilidade que oferecem de se poder medir a própria eficácia do sistema educativo:

- Abandono da escola antes do fim do ensino obrigatório;

- as reprovações sucessivas que dão lugar a grandes desníveis entre a idade cronológica do aluno e o nível escolar;

- os níveis de fracasso que podem ser totais (em todas as disciplinas ou quase) ou parciais (em uma ou duas disciplinas).

É na listagem das causas onde aparecem as maiores controversas, o que se compreende já que a sua própria realização pressupõe que se identifiquem também os seus responsáveis. Neste ponto ninguém se acha inteiramente culpado, o que em sentido e mesmo verdade. A grande dificuldade desta análise reside na impossibilidade de se isolar as causas que são determinantes em todo processo, (SILVA, 2020).

\subsection{FATORES PESSOAIS DO(A) ALUNO(A)}

Ao nível pessoal, o insucesso escolar nem sempre está ligado à falta de vontade, motivação ou preguiça do aluno, além dos fatores escolares socioeconômicos e familiares, há casos em que alguma disfunção cognitiva, sensorial ou motora, muitas vezes tardiamente detectada, desvia o aluno do desempenho esperado.

Machado (2007) soma à lista de indicadores de insucesso a falta de interesse pela escola, o sentimento pessoal de fracasso do aluno, a dificuldade de inserção na vida profissional, o analfabetismo e o trabalho precoce, especialmente com alunos da EJAI. Apesar do peso destes fatores, a maioria das situações por si só não representam um aumento das dificuldades escolares com intensidade suficiente para levar o aluno ao insucesso, no entanto, há casos em que a simples aquisição de um par de óculos para a criança poderia influenciar todo o seu futuro. Para Binder \& Michaelis (2006) as perturbações precoces na aprendizagem são pequenos indicado- 
res que podem querer antever uma situação de dificuldades de aprendizagem e em casos mais graves de insucesso escolar.

Por outro lado, Miranda (2010) acrescenta que justificar o insucesso escolar somente através do baixo quociente de inteligência dos alunos é apenas uma das formas de atribuir o insucesso ao próprio aluno. Ele relembra que quando o insucesso é atribuído à escola não é necessariamente uma crítica ao edifício, ou instituição escolar, mas a toda uma envolvência desde as questões com a avaliação dos alunos, até a falta de abertura entre esta e a sociedade, ou mesmo como resultado de políticas educativas menos adequadas a cada realidade.

Marchesi (2006, p. 33) destaca que "aprender supõe esforço" e afirma que a aprendizagem tem como base a atividade mental do aprendiz, deve ser o mais consciente possível e inclusive deve ser feito um esforço por relacionar a nova informação com dados já existentes, atribuindo-lhes um significado válido.

De acordo com Gardner (cit. por Marchesi, 2006), cada pessoa apresenta um arranjo próprio de inteligência dentro das oito áreas distintas: musical, cinético-corporal, lógica-matemática, linguística, espacial, interpessoal, intrapessoal e naturalista. O diferente peso com que cada uma das áreas de inteligência está presente no sujeito, levar a ter mais apetências em algumas matérias do que noutras

No sentido de procurar potenciais situações perturbadoras para o desempenho escolar dos alunos, Carvalho (1990) identificou o álcool como sendo a substância mais utilizada pelos adolescentes e que o seu consumo entre os 11 e os 14 anos poderá potenciar futuros problemas de alcoolismo. O problema neste caso é que, assim como os comportamentos saudáveis, os comportamentos de risco (consumo de álcool e drogas) quando principiados na adolescência, tendem a persistir na idade adulta, ou mesmo agravar-se (FERREIRA; TORGAL, 2010).

Alguns estudos, como o de Jonathan et al. (cit. por Camacho \& Matos, 2006), evidenciam o fato de os jovens, que no seu grupo de pares (ou familiares próximos) se relacionam com indivíduos fumadores, estarem mais suscetíveis a adquirir também hábitos tabágicos. Na mesma linha de pensamento Sanchez; Oliveira \& Nappo (2005) e Ferreira \& Torgal (2010) entendem que a maior responsável pela iniciação do adolescente no consumo deste tipo de substâncias, como o álcool e tabaco, é a própria família. 
Formosinho (2001) considera também que o local de habitação do aluno pode influenciar a sua educação informal e por arrasto os resultados escolares. Acrescentam ainda que a cultura escolar é mais aproximada à das cidades e não tanto à cultura das zonas rurais, o que distancia as bases pré-existentes nos alunos das matérias e realidade escolar.

\subsection{FATOR SOCIAL E ECONÔMICO}

Para Guerreiro (1998), as atitudes e crenças dos pais influenciam a construção da personalidade e crenças dos filhos. Assim sendo "o valor atribuído pelos pais à escola e às aprendizagens vai influenciar a representação que os alunos fazem das mesmas". Esta ocorrência traduz-se ainda na motivação da criança perante a escola.

Machado (2011) considera que alunos oriundos de famílias de nível socioeconômico e cultural baixos apresentam valores mais notórios de insucesso e abandono escolar precoce, fundamentado através dos alunos pela necessidade de ingressar no mercado de trabalho e/ou pelas dificuldades econômicas da família.

\subsection{FATOR ESCOLAR}

Uma das explicações para a problemática do insucesso escolar tem a ver com a própria escola, com os mecanismos que operam no seu interior (BENAVENTE; CORREIA, 1980) e com seu funcionamento e organização, onde a necessidade de diferenciação pedagógica é sublinhada pela teoria socioinstitucional que evidência o caráter ativo da escola na produção do (in) sucesso escolar dos alunos.

Um dos desafios da escola é conseguir um ambiente motivacional positivo para todos os estudantes, que os incentive a aprender, que promova a curiosidade e que os leve a querer melhorar e aumentar o seu conhecimento (COVINGTON, 1996). Neste caso o objetivo não é vencer os outros, mas superar-se a si mesmo. Já Marchesi (2006, p. 11) considera que o objetivo da escola é fazer com que os alunos aprendam "o que a sociedade considera necessário num determinado momento histórico". Este acrescenta ainda que para além de instruir os alunos, a escola apresenta-se como uma refinaria onde entram produtos em bru- 
to, são moldados, acrescentam-se aditivos e depois classificados de acordo com a sua qualidade.

Porém, esta seleção natural (do melhor aluno) é segundo o autor acima mencionado, uma espécie de objetivo oculto. Benavente (1990, p. 715) lembra que as "políticas educativas, formação de professores, modelos pedagógicos, análises curriculares, dificuldades de aprendizagem, desenvolvimento cognitivo" são alguns dos fatores que influenciam os resultados escolares.

Da mesma forma, Pires (1991) apresenta seis causas do insucesso escolar:

I) desfasamento entre a escola e a realidade do aluno;

II) débil cooperação da família com a escola;

III) resposta inadequada da escola aos anseios quer dos professores e alunos, quer das famílias ou sociedade;

IV) deficiente preparação pedagógica do professor, o qual se identifica mais como docente que como professor/educador;

V) ausência de hábitos de leitura;

VI) ausências de métodos de estudo.

Neste último item, abordam-se os aspetos relacionados com a escola que podem contribuir para o (in) sucesso dos alunos. Uma vez que englobam várias áreas dentro da escola, optou-se por criar uma divisão do mesmo por tópicos, iniciando-se com a influência do professor; da avaliação; das infraestruturas, medidas políticas e administrativas; e por último o papel do diretor da escola.

\section{IMPORTÂNCIA DA SUPERVISÃO PEDAGÓGICA NO AMBIENTE ESCOLAR}

O papel do supervisor é o de auxiliar o trabalho do professor. Quando o supervisor está trabalhando junto com o professor esta ação não pode ser confundida com assessoria ou consultoria, este é um trabalho que merece e requer envolvimento e comprometimento. O objetivo de trabalho do supervisor é observar o que o professor está fazendo com seus alunos, por- 
que é através do professor que o aluno irá desenvolver sua aprendizagem e cabe ao supervisor ser o harmonizador do ambiente da escola entre todos os funcionários, e ter consciência da sua maneira de agir e ter conhecimento do Projeto Político Pedagógico da Escola.

Sobre o trabalho do supervisor, Nogueira (2005, p. 29) ressalta: "a função do supervisor educacional no contexto histórico brasileiro é, e sempre foi essencialmente política, e não técnica como tem sido vinculada [...] porque sua ação implica um exercício de tomada de decisões, embora essas sejam apenas ao nível da execução na realidade brasileira. Nesse contexto, a autora afirma que o papel do supervisor é político e não técnico como muitos educadores imaginam, pois cabe a ele ser o mediador, criar um clima de harmonia no seu local de trabalho, ter consciência de seu papel no ensino aprendizagem e ter conhecimento de tudo o que ocorre na escola para poder ajudar os educadores para haver uma aprendizagem significativa.

No Brasil, a previsão legal acerca do reconhecimento do profissional supervisor escolar ainda não ocorreu de facto, tramita no Congresso Nacional desde 2012, porém nunca foi votado para se transformar em lei, porém para que exista essa função nas secretarias de educação do país, utilizam-se do que prevê o Projeto de Lei no 4.106/2012:

- Supervisionar o cumprimento dos dias letivos e horas/aula estabelecidos legalmente;

- Orientar e acompanhar os professores no planejamento e desenvolvimento dos conteúdos;

- Planejar e coordenar atividades de atualização no campo educacional;

- Coordenar o processo de sondagem de interesses, aptidões e habilidades do educando;

- Acompanhar o desenvolvimento da proposta pedagógica da escola e o trabalho do professor junto ao aluno, auxiliando em situações adversas;

- Participar da análise qualitativa e quantitativa do rendimento escolar, junto aos professores e demais especialistas, visando a reduzir os índices de evasão e repetência, e qualificar o processo ensino-aprendizagem; e 
- Valorizar a iniciativa pessoal e dos projetos individuais da comunidade escolar; entre outras (BRASIL, 2012).

É indispensável que o supervisor da escola se expresse como educador e como especialista. O supervisor faz a transposição da teoria para a prática escolar, reflete sobre o trabalho em sala de aula, deve estudar e usar as teorias para fundamentar o fazer e o pensar dos docentes. Segundo Vasconcelos (2006) um bom supervisor deve apresentar em seu perfil as seguintes características: auxiliador; orientador; dinâmico; acessível; eficiente; capaz de resolver os mais variados problemas, produtivo; apoiar nos mais difíceis problemas que surgem no cotidiano escolar; Inovador (essa característica é fundamental no exercício da supervisão).

São muitas funções para um supervisor, porém muitos conseguem conciliar todas essas funções e se tornam indispensáveis no desenvolvimento do processo de ensino aprendizagem.

A supervisão educacional, para Ferreira, (2001) apud Rangel (2001, p. 93), é um trabalho profissional que tem como atribuição garantir os princípios de liberdade e solidariedade humana, assegurar um ensino de qualidade e garantir a formação humana nas instituições escolares. Mediar a relação professor-aluno no processo de ensino aprendizagem é o eixo central do trabalho do supervisor. É a qualificação do processo de ensino como forma de possibilitar a efetiva aprendizagem por parte de todos. Assim, algumas práticas empíricas que objetivam renovar a prática educativa podem ser utilizadas como estratégia de trabalho, entre elas podemos citar a interação com os professores, a visão estratégica e atualizada, bem como a redução do caráter burocrático ao mesmo tempo possível.

Libâneo (2002, p. 35) descreve o supervisor escolar como "um agente de mudanças, facilitador, mediador e interlocutor". Portanto, seria um profissional apto a realizar a interlocução entre direção escolar, educandos, educadores e todos os demais indivíduos que, de alguma forma, fazem parte da comunidade escolar. Teria como objetivo principal contribuir para o desenvolvimento individual, político, econômico e ético. Nesse contexto, o supervisor possui um comprometimento com a formação da cidadania dos alunos, ele precisa estar atento ao trabalho coletivo da escola, promovendo, assim, um trabalho interdisciplinar, isto é, ele preci- 
sa desenvolver um trabalho participativo e conjunto, onde todos estejam comprometidos com o processo e os resultados.

Assim, afirma Ferreira (2006, p. 179) que para o sucesso desse trabalho algumas condições são imprescindíveis: [...] manter um clima de abertura, cordialidade, encorajamento, fortalecer o sentimento grupal; trabalhar com os professores, partilhando ideias, estimulando e fortalecendo as lideranças; propiciar o trabalho em equipe; promover a troca de experiências, a reflexão sobre a prática, sugerindo, trazendo contribuições, mostrando caminhos e alternativas; estimular o desenvolvimento de experiências e seu compartilhamento com o grupo; subsidiar os docentes com informações e conhecimentos atuais sobre temas complexos.

Nesse cenário, Saviani (apud FERREIRA, 2006) acredita na possibilidade de uma nova identidade para a ação supervisora, a ser construída a partir de um trabalho coletivo, fundamentado na complexidade característica da escola, e conclui, ainda pela análise histórica, que a questão da identidade do supervisor escolar continua no contexto atual. Uma supervisão compartilhada fundamenta-se na certeza de que quanto maior for a participação dos professores nos destinos da escola, maiores possibilidades terá o "clima" gerado para contribuir para o alcance dos objetivos e metas não só da escola, como também dos supervisores e alunos.

É de relevância o fato de que o supervisor escolar atue com visão coletiva, mostrando a importância (que detêm as relações interpessoais) aos professores, alunos e a todos os indivíduos que fazem parte da comunidade escolar. Para isso é importante que tal profissional detenha as habilidades de olhar, ouvir, falar e cuidar. Somente assim, o planejamento será, de facto, coletivo (FULLAN; HARGREAVES, 2003).

Segundo Vasconcelos (2004, p. 86), mais recentemente, a supervisão escolar ganhou força e contorno legal, ou seja: "O supervisor torna-se um agente educacional que contribui para integrar e desintegrar, organizar e desorganizar o pensamento do professor num movimento de participação continuada no qual os saberes e os conhecimentos se confrontam, se defrontam, fazem sínteses. As sínteses colhidas nos confrontos são referências que sustentam o professor de sala de aula". Assim, delineada a ação supervisora, fica evidente que em seu início a supervisão escolar foi praticada no Brasil em condições que produziam o ofuscamento e não a vontade do supervisor. Esse era exatamente o objetivo pretendido com 
a supervisão que se introduzia. Silva (2004, p. 93) diz-nos: "Para uma sociedade controlada, uma educação controlada, um supervisor controlador e também controlado". Rangel (2004, p. 148) "reconhece que a consideração ao conceito de supervisão incorpora elementos da função e do trabalho do supervisor", destacando-se, assim, o seu papel de educador e, portanto, de profissional comprometido com o significado e as implicações sociopolíticas da educação.

Corroborando a discussão acerca da supervisão escolar, Ferreira (2006, p. 78) diz que "o objeto específico da supervisão em nível de escola é o processo de ensino e aprendizagem" e que a abrangência desse processo inclui: currículo, programas, planejamento, avaliação, métodos de ensino e recuperação, sobre os quais se observam os procedimentos de coordenação, com finalidade integradora, e orientação, nucleada no estudo, nas trocas, no significado da práxis.

\section{METODOLOGIA E RESULTADOS}

A contextualização metodológica deste estudo será uma pesquisa de campo, com os professores e alunos da rede municipal de ensino de Nina Rodrigues - MA, nas escolas e na Secretaria Municipal de Educação e seus resultados serão apresentados na perspectiva da análise qualitativa. Para atingir os objetivos deste estudo realizou-se uma investigação baseada em estudos bibliográficos sobre a temática e aplicação de entrevistas aos alunos da EJAI matriculados nas escolas municipais.

Este estudo trata da ação supervisora no sucesso/insucesso escolar da EJAI nas escolas municipais de Nina Rodrigues-MA. A pesquisa de campo foi realizada por meio de aplicação de questionário de sondagem aos supervisores e alunos da EJAI. Os entrevistados ficaram à vontade para identificar as causas do insucesso e a importância da ação supervisora, onde os resultados serão apresentados de forma qualitativa.

As questões analisadas foram as seguintes:

1- Você acredita que a atuação do supervisor (a)/coordenadora pode ajudar os professores e alunos a melhorar suas práticas pedagógicas e reduzir o insucesso escolar? 
2- O que a supervisão/coordenação faz para garantir o acompanhamento e orientação pessoal, social e pedagógica dos alunos da EJA no sentido de evitar o abandono da escolar?

Em relação a questão a primeira questão abordada, as afirmações dos entrevistados foram:

Supervisor 1- A orientação é realizada através de visitas periódicas nas escolas onde funciona a educação de jovens e adultos os planejamentos são realizados bimestralmente pela coordenação e supervisão na própria secretaria de educação, incentivamos as festinhas nas datas comemorativas, acompanhamos a aprendizagem desses alunos.

Supervisor 3- Sim, pois o trabalho desenvolvido na escola contribui na formação, na reflexão e tomada de consciência dos professores para melhoria do ensino aprendizagem consequentemente na diminuição do insucesso escolar.

Os alunos também contribuíram em suas opiniões:

Aluno EJAI 2- Não acredito, eu já abandonei os estudos duas vezes, os supervisores até se comunicam com a professora e com os alunos, mas o abandono acontece sempre por cansaço e falta de trabalho.

Aluno EJAI 3- Ajuda sim, a gente vem cansado para a escola, mas sempre que o nosso supervisor vem a escola traz novidades e estimula os alunos a não desistir de seus estudos. A maioria dos alunos da EJA deixam de estudar por motivos pessoais, acham as aulas chatas, acham a novela mais interessante.

Constata-se, pelas respostas acima, que o insucesso escolar é fruto de vários fatores, dentre eles se destaca: econômicos, escolares, familiares e sociais. Os supervisores afirmam que suas atuações contribuem para a permanência do aluno na escola, os alunos admitem que o trabalho dos supervisores é bom, mas não impedem os alunos de abandonar a escola. De acordo (BLANDEN et al., 2009) a educação de adultos é fundamental 
para a consecução dos objetivos globais de maior igualdade social, pois homens, mulheres e jovens com melhor educação, formação e qualificação podem melhorar suas chances profissionais.

Em relação a segunda questão sobre o que a supervisão faz no sentido de orientar e motivar os alunos a permanecerem na escola, eis as seguintes afirmações:

Supervisor 2- Atividades do ser e de conviver, como festas em datas comemorativas, aniversários, atividades culinárias, teatro, danas, enfim tudo que desperta o interesse dos alunos.

Supervisor 4 - Fazemos intervenções com os alunos que estão com dificuldades de aprendizagem, orientando o professor a desenvolver ações em sala de aula que visem a melhoria da aprendizagem.

Aluno EJAI 1- Ajuda os professores com aulas mais divertidas, a gente vem cansado, se a aula não chamar atenção eu vou embora.

Aluno EJAI 4- Os supervisores e professores fazem festinhas de aniversário aqui na escola, quando a gente deixa de ir a escola visitam os alunos.

Nesta segunda parte da pesquisa os entrevistados afirmaram que a ação do supervisor contribui sim para diminuir a evasão o que contribui muito para o insucesso escolar. Sobre isso (Silva, 2020) afirma que: "falar sobre educação de adultos provoca sérias reflexões sobre o tema, e sobre isso é fundamental conhecer e destacar o pensamento de educadores como Freire que ao longo da vida profissional dedicaram-se a alfabetizar".

\section{CONSIDERAÇÕES FINAIS}

Foi possível concluir que são muitos os fatores que contribuem para sucesso ou insucesso escolar. Entendemos que a maioria dos fatores que contribuem para o fracasso escolar dos nossos alunos dependem de fatores externos, fatores estes que independe da boa vontade do professor em oferecer as melhores e mais dinâmicas aulas. No entanto, não se deve esquecer que o sucesso escolar dos nossos alunos depende muito da atuação dos professores, são estes que com sua atuação dinâmica, responsável e comprometida podem mudar as atitudes de muitos casos de alunos cujos 
fatores externos vem de fora, como da família, da situação econômica e social e do lugar onde residem esses alunos.

Constataram-se, ainda, as situações de alunos que vivem em zonas consideradas perigosas, que não tem família que os oriente, porém conseguem obter sucesso na escolar, daí pude concluir que a escola com sua função social deve procurar desempenhá-la de forma eficaz, e os professores e gestores tem de assumir essa responsabilidade, procurando no diálogo especialmente junto às famílias para que essa onda de insucesso escolar deixe de assombrar os educadores.

\section{REFERÊNCIAS}

BENAVENTE, A. Insucesso Escolar no Contexto Português Abordagens, Concepções e Políticas. Análise Social, v. 25 (108109), p. 715-733, 1990.

Insucesso Escolar no Contexto Português - Abordagens, Concepções e Políticas. Análise Social, V. 25 (108-109), p. 715-733. 1990.

CARVAlHO, J. Comportamentos Desviantes. In Campos, B. (Ed.). Psicologia do desenvolvimento e Educação de Jovens (p.214249). Lisboa: Universidade Aberta, 1990.

FERREIRA, F. A. Fracasso e evasão escolar. Monografia. Rio de Janeiro, 2013. Disponível em: http://www2.unirio.br/unirio/cchs/ educacao/graduacao/pedagogia-presencial/CHRISTINABALBINODEOLIVEIRAFERREIRA.pdf Acesso em: 20 abr. 2021.

FERREIRA, Naura Syria Carapeto. Supervisão educacional para uma escola de qualidade. São Paulo: Cortez, 2007.

GUERREIRO, S. Insucesso e Abandono Escolar. Porto: Centro Social e Paroquial Nossa Senhora da Vitória, 1998.

IOSIF, R.M. G. A qualidade da educação na escola pública e o comprometimento da cidadania global emancipada: implicações para a situação de pobreza e desigualdade. Tese de Doutorado, Universidade de Brasília, Brasília, D.F. 2007. 
LIBÂNEO, José C. Pedagogia e Pedagogos, para quê. São Paulo: Cortez, 2005.

. Organização e gestão da escola: teoria e prática. Goiânia: Alternativa, 2004.

MACHADO, M. Família e Insucesso Escolar. Tese (Doutoramento) Faculdade de Psicologia e Ciências da Educação da Universidade do Porto. Porto, Portugal, 2007.

MARCHESI, A., \& Gil, C. Fracasso escolar: uma perspectiva multicultural. Porto Alegre: Artmed, 2004.

MEDINA, A. da S. Supervisão escolar: da ação exercida à ação repensada. Porto Alegre: AGE, 2002.

MIRANDA, C.F.N. Causas do Insucesso Escolar. Dissertação (Mestrado) - UTAD, Vila Real, Portugal, 2010. Disponível em: https:// repositorio.utad.pt/handle/10348/503 . Acesso em: 11 abr. 2021.

NOGUEIRA, M. G. Supervisão educacional: a questão política. 3. ed. São Paulo, 2005: Edições Loyola.

OLIVEIRA, M. J. V. (2014). A evasão escolar na educação de jovens e adultos na Escola Estadual Cônego José Bulhões, s/d, p. 1-16. Cadernos PDE, v. 1. Disponível: file://C:/Users/uso/Downloads/ dissertao\%20marilene\%20o\%20andrade\%20(1).pdf. Acesso em: 5 abr. 2021.

PERRENOUD, P. Novas competências para ensinar. Porto Alegre: Artes Médicas Sul, 2009.

PIRES, Maria Ribeiro. O Papel do Profissional na Escola. Revista do Departamento de Ensino do 2 Grau. SEE/MG, 1990.

RANGEL Annamaria. Insucesso escolar. Lisboa Revista Gestão O perfil do mediador de conflitos na escola: (1964. disponível no site> http://gestaoescolar.abril.com.br/comunidade/perfil-mediador-conflitos-escola-750645.shtml Acesso em: 20 jun. 2020.

RANGEL, Mary (org.). Supervisão Pedagógica: Princípios e práticas. Campinas, SP: Papirus, 2001. 
SANCHEZ, Z.; OLIVEIRA, L.; NAPPO, S. Razões para o Não-Uso de Drogas Ilícitas Entre Jovens em Situação de Risco. Revista de Saúde Pública: Rio de Janeiro, v. 39, n. 4, p. 599-605, 2005.

SAVIANI, D. Formação de professores: aspectos históricos e teóricos do problema no contexto brasileiro. Revista Brasileira de Educação, v. 14 n. 40 jan./abr, p. 1-13, 2009.

SILVA, S. de F. N. da. Evasão escolar na educação de jovens e adultos: um estudo de caso com os coordenadores/supervisores pedagógicos e educadores do município de Nina Rodrigues-Maranhão, UTAD-PT, 2020.

SILVA, S. S da. A escola e a exclusão Social: consequências do fracasso escolar nos percursos de vida de jovens e adultos pouco escolarizados dos meios populares da Zona da Mata de Pernambuco- Brasil. Universidade Lusófona de Humanidade e Tecnologias, Lisboa, 2014.

SILVA, D. M. e DUATE, J. C. Sucesso escolar e inteligência emocional, Milleniun, 42, (jan/jun) pp 67-84, 2012.

SIL, Vítor. Alunos em situação de abandono escolar. Lisboa: Horizontes Pedagógicos, 2004.

TAVARES M. V. O Insucesso Escolar e as Minorias Étnicas em Portugal. Uma abordagem antropológica da Educação, Portugal, 1998.

VASCONCELOS, C. Coordenação do trabalho pedagógico: do projeto político pedagógico ao cotidiano da sala de aula. São Paulo: Libertad, 2006. 


\section{CONCEPÇÕES DE PROFESSORES BRASILEIROS E FINLANDESES SOBRE COMUNIDADE DE APRENDIZAGEM}

Azenaide Abreu Soares Vieira ${ }^{43}$

Paula Renata Cameschi de Souza ${ }^{44}$

\section{INTRODUÇÃO}

Este estudo apresenta as inquietações provenientes da sistematização de resultados de pesquisas anteriores, fruto da cooperação entre educadores brasileiros e finlandeses, sobre a formação de professores para o desenvolvimento de saberes docentes demandados pelo contexto social e educacional.

O tema, "formação e atuação de professores em comunidade de aprendizagem (CA)", vem dos desafios vivenciados no curso de extensão ProfCAC-MAES: Comunidade de Aprendizagem Colaborativa entre Professores, ofertado em 2019 pelo IFMS Campus Nova Andradina (SOUZA, 2020; ALMEIDA, 2020). O problema que se constituiu na realização da ação de formação de professores ProfCAC-MAES diz respeito às dificuldades em desenvolver projetos colaborativos de pesquisa voltados à ressignificação da prática pedagógica, conforme o próprio grupo ProfCAC-MAES preconizava.

43 Estágio pós-doutoral pela HAMK (2019-2021) e pela UFMG (2013) e doutorado em Estudos Linguísticos na UNESP (2012).

44 Mestre em Educação Profissional e Tecnológica pelo ProfEPT/IFMS (2020). 
É sabido pela literatura que a aprendizagem em CA pode promover a melhoria do trabalho pedagógico (PACHECO, 2013) e o desenvolvimento de saberes da docência. Esse modelo de formação profissional e atuação pedagógica ancora-se no princípio do desenvolvimento da aprendizagem humana pela interação social (VYGOTSKY, 1998) e no conceito de Comunidade de Prática (CoP), de Wenger e colaboradores.

CA refere-se a um grupo, neste caso de professores em serviço, "que compartilham determinadas práticas em torno de um domínio de conhecimentos, e essa interação faz com que os membros aprofundem os conhecimentos relativos a esse domínio" (MEGA et al., 2020, p. 4). Para isso, os professores integram conhecimentos multidisciplinares de um mesmo tema, valores, crenças, saberes e ações educativas.

A cultura docente que contempla várias formas de aprendizagem em comunidade pode promover um pensamento que desenvolve riqueza de ideias, de prática e de conhecimentos sobre a prática pedagógica (GALLUCCI, 2003). Todavia, para que isso ocorra, faz-se necessário considerar que a atividade docente é interativa e relacional, mediada pela comunicação e linguagem estabelecidas nas relações do professor consigo mesmo e com outros, em diferentes contextos sociais (VYGOTSKY, 1998).

Sendo assim, interessa-nos apreender concepções e percepções sobre CA de professores brasileiros e finlandeses nos contextos de programas de formação de professores que atuam. Em nossa perspectiva, a concepção, pessoal e institucional, de aprendizagem pode justificar as escolhas dos professores e suas dificuldades diante de propostas colaborativas de formação e atuação profissional.

A hipótese é de que as concepções de professores da Educação Profissional brasileira e finlandesa, constituídas pelas vivências em processos formativos e a forma como cada instituição incentiva e organiza o trabalho docente, podem facilitar ou dificultar a constituição de CA de Professores.

Este estudo qualitativo contou com dados coletados mediante entrevista semiestruturada, gravada em áudio. Após transcrição, os dados foram categorizados e analisados com base na técnica de análise de conteúdo. Os participantes, 10 professores da Educação Profissional brasileira e nove (09) da Educação Profissional finlandesa, foram escolhidos em virtude das peculiaridades no gerenciamento de programas de formação de professo- 
res e na organização do trabalho pedagógico (VIEIRA; PARKKONEN; BARBOSA, 2020).

Ressalta-se que nossa intenção é realizar um intercâmbio de ideias acerca dos múltiplos significados de CA, de forma a enriquecer os debates sobre esse modelo de formação continuada e atuação de professores. Aspectos culturais, sociais e estruturais da Educação Profissional nos dois países, apesar de não serem o foco do estudo, são considerados fontes influenciadoras nas maneiras como os professores conceituam e percebem CA.

O estudo é guiado pelo seguinte questionamento: como professores brasileiros e finlandeses concebem CA em programas de formação de professores em seus contextos de trabalho? Para responder esse questionamento, delineamos os seguintes objetivos específicos: 1) identificar como os professores conceituam CA; 2) compreender a perspectiva dos professores quanto ao gerenciamento de CA em programas de formação de professores.

O texto traz, na primeira seção, o conceito de CA. Na segunda, os aspectos metodológicos são apresentados, seguindo para a descrição e discussão dos resultados na terceira seção. À luz dos princípios epistemológicos de CA, na quarta seção analisamos os resultados e as considerações finais da pesquisa são tecidas.

\section{CONCEPÇÕES DE COMUNIDADE DE APRENDIZAGEM}

Para chegarmos ao entendimento do conceito de CA, fez-se necessário percorrer a literatura acerca do conceito de Comunidade de Prática $(\mathrm{CoP})$. Este estudo, entretanto, não objetiva discutir amplamente estes conceitos, assim cabe apenas uma reflexão global dos dois termos. Isso porque compartilhamos do entendimento de Schlemmer et al. (2012) de que a única diferença entre $\mathrm{CA}$ e $\mathrm{CoP}$ é o fato de que nem sempre uma CA pode ser considerada uma CoP, todavia, toda CoP é uma CA. Sendo assim, diante do foco em concepções e percepções de professores em seus contextos profissionais, não faremos distinção entre os termos. No entanto, para efeito de padronização, utilizaremos o termo CA nesta pesquisa.

Os estudos sobre CA ancoram-se na teoria socioconstrutivista de $\mathrm{Vy}-$ gotsky e nos pressupostos da aprendizagem situada de Lave \& Wenger 
(1991). Para esses pesquisadores, a aprendizagem é facilitada e significativa quando há interação e colaboração, de maneira descentralizada e dialógica. Além disso, com base em Habermas e Freire, a CA tem a comunicação como fio condutor do processo de desenvolvimento humano, seja de educandos como de educadores, na escola ou em outros contextos sociais. Em relação a ação comunicativa, proposta por Habermas, a CA deve primar pela participação de todos em busca do consenso diante de uma situação-problema.

Gabassa (2009) explica que a teoria freireana da dialogicidade implica que o diálogo seja considerado igualitário, ou seja, a CA precisa considerar as vozes de todos, independentemente do cargo que ocupam, bem como valorizar a inteligência cultural de cada um. Cardoso (2019, p. 44-45) considera que a aprendizagem dialógica apreende ainda a "dimensão instrumental, criação de sentido, solidariedade e igualdade de diferenças":

A dimensão instrumental (leitura, escrita, informática) compõe-se de instrumentos de participação social e promovem interações diversificadas que, por sua vez, estabelecem vínculos solidários, como ideia de vida coletiva e, assim, criação de sentido. A partir disso, gera-se uma transformação pessoal que proporciona melhores condições para o princípio da igualdade de diferenças, que consiste na busca por justiça social e respeito às diferenças culturais.

A CA no campo da docência consiste em um grupo de professores "que compartilham determinadas práticas em torno de um domínio de conhecimentos, e essa interação faz com que os membros aprofundem os conhecimentos relativos a esse domínio" (MEGA et al., 2020, p. 4). Para isso, a CA de professores precisa integrar três elementos: domínio, comunidade e prática.

O domínio pode ser formado por uma preocupação, interesse, assunto, tema ou área compartilhada. A atuação em comunidade delineia o comportamento, crenças, relações e interações interpessoais dos profissionais que possuem o mesmo domínio de interesse, cujo intuito é de alcançar um objetivo comum mediado por ambientes de interação social. A prática não é entendida como a aplicação da teoria. Apesar de não desconsiderar os conhecimentos científicos, ela consiste na atuação do pro- 
fessor sustentada por todo conhecimento tácito construído ao longo de sua vida em situações de sala de aula (MARCOLINO; LOURENÇO; REALI, 2017). Mediante compartilhamento de experiências, diálogo e estudo autodirigido, a prática deixa de ser "o que fazer" para se constituir em "saber como fazer" melhor ou inovador. O espaço da prática abarca trocas de experiências e de construção de significados.

Sabemos pela literatura que há diferentes formas de compreender uma CA em contexto de atuação profissional. Muitas vezes, na escola, ela é entendida como um grupo de professores da mesma série ou área de atuação, um comitê escolar, um departamento de ensino, uma organização profissional nacional ou todo corpo docente de uma escola.

No entanto, Ipiranga et al. (2005) diz que há diferenças entre Comunidade de Aprendizagem, grupo de trabalho formal, equipe de projeto e rede informal. Os autores explicam que a CA "envolve muito mais do que o conhecimento técnico ou habilidade associada à obrigação de alguma tarefa" (IPIRANGA et al., 2005, p. 3). No interior de uma CA é preciso "gerar e apropriar-se de um repertório de idéias, compromissos e lembranças compartilhados e desenvolver vários recursos, tais como ferramentas, documentos, rotinas, vocabulário e símbolos que de algum modo conduzem o conhecimento acumulado" (IPIRANGA et al, 2005, p. 3).

O quadro 1, adaptado de Wenger e Snyder (2001) por Ipiranga et al (2005), sistematiza as principais diferenças de uma CA quanto a: objetivo, participantes, afinidades e duração em comparação às demais organizações grupais em contexto de trabalho:

Quadro 1. Comparação resumida de organizações de grupo

\begin{tabular}{|c|c|c|c|c|}
\hline & Objetivo & Participantes & Afinidades & Duração \\
\hline $\begin{array}{c}\text { Comunidade } \\
\text { de }\end{array}$ & $\begin{array}{c}\text { Desenvolver as } \\
\text { competências } \\
\text { dos } \\
\text { Aprendizagem } \\
\text { participantes. } \\
\text { gerar e trocar } \\
\text { conhecimentos }\end{array}$ & $\begin{array}{c}\text { Participantes } \\
\text { que se } \\
\text { autosselecionam }\end{array}$ & $\begin{array}{c}\text { Paixão, } \\
\text { compromisso } \\
\text { identificação } \\
\text { com os } \\
\text { conhecimentos } \\
\text { especializados } \\
\text { do grupo }\end{array}$ & $\begin{array}{c}\text { Enquanto } \\
\text { houver } \\
\text { interesse em } \\
\text { manter o } \\
\text { grupo }\end{array}$ \\
\hline
\end{tabular}




\begin{tabular}{|c|c|c|c|c|}
\hline & Objetivo & Participantes & Afinidades & Duração \\
\hline $\begin{array}{l}\text { Grupo de } \\
\text { trabalho } \\
\text { formal }\end{array}$ & $\begin{array}{l}\text { Desenvolver } \\
\text { um produto } \\
\text { ou prestar um } \\
\text { serviço }\end{array}$ & $\begin{array}{l}\text { Qualquer um } \\
\text { que se apresente } \\
\text { ao gerente do } \\
\text { grupo }\end{array}$ & $\begin{array}{l}\text { Requisitos } \\
\text { do trabalho e } \\
\text { metas comuns }\end{array}$ & $\begin{array}{l}\text { Até a } \\
\text { próxima } \\
\text { reorganização }\end{array}$ \\
\hline $\begin{array}{l}\text { Equipe de } \\
\text { Projeto }\end{array}$ & $\begin{array}{c}\text { Realizar } \\
\text { determinada } \\
\text { tarefa }\end{array}$ & $\begin{array}{l}\text { Empregados } \\
\text { escolhidos } \\
\text { por gerentes } \\
\text { seniores }\end{array}$ & $\begin{array}{c}\text { As metas } \\
\text { e pontos } \\
\text { importantes do } \\
\text { projeto }\end{array}$ & $\begin{array}{c}\text { Até o final do } \\
\text { projeto }\end{array}$ \\
\hline Rede informal & $\begin{array}{l}\text { Colher e } \\
\text { transmitir } \\
\text { informações } \\
\text { empresariais }\end{array}$ & $\begin{array}{c}\text { Amigos e } \\
\text { conhecimentos } \\
\text { do meio } \\
\text { empresarial }\end{array}$ & $\begin{array}{c}\text { Necessidades } \\
\text { mútuas }\end{array}$ & $\begin{array}{l}\text { Enquanto } \\
\text { as pessoas } \\
\text { tiverem um } \\
\text { motivo para } \\
\text { manterem } \\
\text { contato }\end{array}$ \\
\hline
\end{tabular}

Fonte: Ipiranga et al. (2005, p. 4).

Quanto ao objetivo, a CA distingue-se dos demais grupos pelo foco na geração e compartilhamento de conhecimentos construídos no grupo. Os participantes se autosselecionam e escolhem qual nível de participação desejam assumir, podendo estar no grupo nuclear, ativo ou periférico (MEGA et al., 2020). As afinidades são com os conhecimentos especializados do grupo, espaço onde os pontos comuns são identificados pelo diálogo e interação constante. A duração é estabelecida pela comunidade. Esta decide manter ou deixar que os participantes se dispersem.

A constituição de CA envolve "um processo de reflexão sobre a ação, um processo intencional, atrelado ao fazer, após sua ocorrência, e que demanda uma ação consequente qualitativamente diferente de uma ação rotineira" (MARCOLINO; LOURENÇO; REALI, 2017, p. 412). Constitui-se pelo engajamento de um grupo interessado em um mesmo projeto, e evolui a partir da negociação de significados. Em uma CA de professores ocorre trocas de experiências, construção de ideias para melhorar práticas de ensino, criação de estratégias e ambientes de aprendizagem centrados no estudante.

Prenger, Poortman e Handelzalts (2020) argumentam que o envolvimento de professores em CA é uma forma promissora de melhorar a qualidade da educação e consiste no trabalho coletivo desenvolvido na 
escola para melhorar os processos de ensino e aprendizagem. Essa visão é compartilhada por Gallucci (2003) ao afirmar que a interação promovida no bojo da CA favorece a criação, expansão e a troca de experiências sobre práticas profissionais, o que promove o desenvolvimento de habilidades individuais nas esferas das relações interpessoal e intrapessoal. Sendo constituída por um projeto organizado por um conjunto de ações que direcionam a transformação dos indivíduos, é formada por profissionais que interagem, modificam e planejam novas ações coletivas com vistas a aprenderem juntos algo que melhora a prática profissional.

A CA tem como características: atividades estruturadas para guiar a prática; objetivo compartilhado e foco em resultado concreto; foco coletivo na aprendizagem do estudante; conhecimento prévio e motivação individual; confiança; colaboração e participação ativa; diálogo reflexivo; liderança; apoio da gestão e de colegas; facilitações institucionais (PRENGER; POORTMAN; HANDELZALTZ, 2020)

\section{METODOLOGIA DA PESQUISA}

Participaram da pesquisa 19 professores, sendo 10 brasileiros e nove finlandeses, diretamente envolvidos em equipe de ensino em programas de formação de professores de instituições de Educação Profissional no Brasil e na Finlândia. Assim, os contextos de atuação dos participantes da pesquisa são o Instituto Federal de Mato Grosso do Sul (IFMS), localizado na região centro-oeste do Brasil, e a Universidade de Ciências Aplicadas de Häme (HAMK), localizada ao sul da Finlândia. A pesquisa foi conduzida a partir da abordagem qualitativa por envolver a coleta e análise de dados descritivos e do contato direto do pesquisador com a situação estudada, a fim de compreender os fenômenos segundo a perspectiva dos sujeitos (GODOY, 1995).

Os dados foram obtidos por intermédio de entrevista semiestruturada, gravada em áudio, composta por seis perguntas. Por se tratar de participantes brasileiros e finlandeses, aos brasileiros a entrevista foi conduzida em Língua Portuguesa, e aos finlandeses em Língua Inglesa. Em virtude da limitação de páginas, apresentamos neste artigo a análise de duas questões: "O que é Comunidade de Aprendizagem? / What is Learning Community? Como você define Comunidade de Aprendizagem em 
programas de formação de professores no Instituto Federal? / How do you define Learning Community at HAMK professional teacher training institute?”. A entrevista foi realizada presencialmente pelos autores, nas instituições de trabalho dos participantes. Os dados foram organizados e analisados a partir da elaboração de categorias, com base nos pressupostos de análise de conteúdo de Bardin (2016): pré-análise, exploração do material e tratamento dos resultados obtidos, seguido de interpretação.

$\mathrm{Na}$ fase da pré-análise transcrevemos as entrevistas e procedemos com a leitura flutuante do material transcrito. Assim, guiados pela questão central de pesquisa, a saber: "como professores brasileiros e finlandeses concebem CA em programas de formação de professores em seus contextos de trabalho?", e pelos objetivos específicos de: 1) identificar como os professores conceituam Comunidade de Aprendizagem; 2) compreender a perspectiva dos professores quanto a Comunidades de Aprendizagem em programas de formação de professores, constituímos o corpus com base na exaustividade, representatividade, homogeneidade e pertinência (FRANCO, 2003).

Seguimos para a exploração do material selecionado que melhor atendia ao objetivo central da pesquisa de: investigar concepções e percepções sobre CA de professores da Educação Profissional brasileira e finlandesa. Nessa fase, seguindo as orientações de Bardin (2016) para realização da codificação e categorização dos dados. Por fim, na terceira etapa da análise, descrevemos o resultado e, à luz da literatura, procedemos com a interpretação do mesmo e apresentação das conclusões da pesquisa, conforme seções a seguir.

\section{RESULTADOS E DISCUSSÕES}

\subsection{CONCEITOS DE COMUNIDADE DE APRENDIZAGEM}

Ao apreender como professores da Educação Profissional brasileira e finlandesa conceituam CA, mediante categorizações de análise constituídas de fragmentos discursivos registrados em entrevista, emergiram duas (2) categorias do discurso dos professores brasileiros e outras duas (2) categorias de professores finlandeses, conforme mostra o quadro 02: 
Quadro 2. Categorias e frequência da concepção de CA

\begin{tabular}{|c|c|c|c|}
\hline Participantes & Categorias & Frequência & Porcentagem \\
\hline \multirow{2}{*}{$\begin{array}{l}\text { Professores } \\
\text { Brasileiros }\end{array}$} & $\begin{array}{c}\text { Grupo } \\
\text { voluntário de } \\
\text { afinidade e } \\
\text { interesse comum. }\end{array}$ & 13 & $56 \%$ \\
\hline & $\begin{array}{c}\text { Grupo de } \\
\text { trabalho } \\
\text { constituído pela } \\
\text { instituição para } \\
\text { desenvolver algo. }\end{array}$ & 10 & $44 \%$ \\
\hline \multirow[b]{2}{*}{$\begin{array}{l}\text { Professores } \\
\text { Finlandeses }\end{array}$} & $\begin{array}{c}\text { Grupo } \\
\text { multidisciplinar } \\
\text { de ensino }\end{array}$ & 12 & $70 \%$ \\
\hline & $\begin{array}{c}\text { Grupo } \\
\text { voluntário de } \\
\text { afinidade e } \\
\text { interesse comum. }\end{array}$ & 5 & $30 \%$ \\
\hline
\end{tabular}

Fonte: os autores

O quadro 2 sistematiza as categorias, frequência e porcentagem resultantes da análise dos fragmentos discursivos dos professores quanto ao conceito de CA. Inferimos desse resultado que a maioria dos professores brasileiros compreendem CA como um grupo reunido por afinidade de domínio de conhecimento com o objetivo de compartilhar material e experiência. Em seus discursos isso se materializa da seguinte forma:

[...] de forma geral, é quando um grupo tem um interesse em comum, um objetivo e eles se unem, voluntariamente, para descobrir, para se desenvolver naquele assunto.

[...] é um espaço onde as pessoas que têm interesses em comum se juntam buscando o aprendizado por meio de troca de experiências, 
troca de dificuldades também, partilhando do que elas vêm desenvolvendo, estudando.

[...] as pessoas se encontram em grupos de afinidade na internet para estudar algum assunto, por exemplo, eu me interesso por aromaterapia, aí eu me conecto com várias pessoas que se interessam por aromaterapia e participo de um fórum de discussão ou de um grupo no Facebook.

Alguns excertos indicam que os professores brasileiros concebem CA também como um grupo organizado pela instituição para desenvolver algo, como observado nas afirmações:

[...] é um arranjo social que acontece num determinado espaço, onde a gente vai ter alguns atores que passaram por algum crivo social ou processo de formação que faz com que eles pertençam ou mereçam fazer parte dessa comunidade (ex: comunidade de professores, estudantes, pais, etc.

[...] a gente se separa em grandes comunidades de aprendizagem que são as turmas, organizadas pela nota da prova ou sorteio.

Ao olhar, especificamente, para a dinâmica de sala de aula, a concepção de CA é de grupos organizados pelo professor para realização de tarefas escolares, o que se insere na categoria de grupo organizado pela instituição para desenvolver algo:

[...] é a reunião de pessoas que buscam aprender alguma coisa em relação a um objeto do conhecimento. Por exemplo, em matemática eu posso formar uma comunidade de aprendizagem trabalhando em função do primeiro grau com os alunos, eu coloco eles para trabalhar em grupo e aí eu crio uma minicomunidade.

[...] um grupo de alunos que senta para estudar e realizar trabalho, tem os grupos permanentes (ex.: curso universitário ou do ensino médio é o mesmo grupo do início ao fim do curso)

[...] é esse trabalho em grupo, com sujeitos envolvidos para desenvolver conhecimentos referentes à disciplina. 
Com o olhar voltado para o profissional professor, os brasileiros acreditam que a CA é um grupo de professores selecionados pela instituição para compor uma equipe de trabalho ou para realizar um trabalho específico demandado pela instituição:

[...] é um grupo de profissionais diversos que de um modo geral seriam reconhecidos para trabalhar de forma colaborativa para atingir um único objetivo.

Os educadores finlandeses compreendem CA de forma similar aos brasileiros. O pensamento dos finlandeses converge com o dos brasileiros ao conceituarem CA como um grupo voluntário de afinidade e interesse comum. Nesse sentido, afirmam:

[...] é um grupo de colegas que compartilham o mesmo tipo de contexto ou os mesmos objetivos de aprendizagem ${ }^{45}$.

[...] você deve compartilhar alguns objetivos.

[...] é um grupo de atores que compartilham objetivos de aprendizagem.

Em relação a essa concepção, percebemos uma pequena alteração de sentido quando os finlandeses acrescentam a criação de algo a partir de afinidades e interesses comuns. Isso parece indicar que não basta ao grupo ter afinidade e interesses em comum para compartilhamento como percebemos no discurso dos professores brasileiros. Os objetivos precisam levar a criação de algo pelo grupo,

[...] ela pode ser grupos de estudantes, pessoas enquanto criam um produto.

[...] você deve compartilhar alguns objetivos. Então, na CA o grupo decide como alcançar os objetivos.

$45 \mathrm{Em}$ virtude do limite de palavras, não será possível trazer os excertos em inglês. 
A CA não é vista pelos educadores finlandeses como um grupo organizado pela instituição a partir de uma seleção ou para o desenvolvimento de uma demanda institucional. A maioria dos Finlandeses concebem a CA em seus contextos de atuação como um grupo multidisciplinar, um time de ensino. São times de professores responsáveis para conduzir processos de aprendizagem prescritos em um módulo do curso de formação de professores, por exemplo.

[...] é um grupo de professores responsável por planejar módulos do currículo que irá ministrar.

[...] na CA nós compartilhamos nossas experiências com os estudantes, e tentamos melhorar no ano seguinte.

[...] pode ser um time de professores trabalhando juntos no mesmo módulo, tentando decidir processos de aprendizagem para os estudantes.

[...] origina-se de pessoas que trabalham juntas para atingir algum objetivo. E estas pessoas são sempre diferentes, dependendo dos objetivos que estão trabalhando.

Em suma, a análise do conteúdo gerado pelas entrevistas realizadas com os professores brasileiros e finlandeses revela como ideia convergente a concepção de CA de ser um grupo voluntário de afinidade e interesse comum. Porém, com uma pequena divergência, pois para os professores finlandeses a CA realiza criação colaborativa e é multidisciplinar, constituída por times de ensino, team teaching.

\subsection{CONCEPÇÃO DE CA EM PROGRAMAS DE FORMAÇÃO DE PROFESSORES}

Ao pedir para os participantes da pesquisa olharem para o Programa de Formação de Professores e relatarem como acreditam que a instituição concebe Comunidade de Aprendizagem, tivemos o seguinte resultado: 
Quadro 3: CA em Programas de Formação de Professores

\begin{tabular}{|c|c|c|c|}
\hline Participantes & Categorias & Frequência & Porcentagem \\
\hline \multirow{3}{*}{$\begin{array}{l}\text { Professores } \\
\text { brasileiros }\end{array}$} & $\begin{array}{l}\text { Não há política } \\
\text { institucional }\end{array}$ & 13 & $50 \%$ \\
\hline & Ações voluntárias & 8 & $30 \%$ \\
\hline & $\begin{array}{l}\text { Prevalece } \\
\text { a cultura } \\
\text { disciplinar }\end{array}$ & 5 & $20 \%$ \\
\hline \multirow[b]{2}{*}{$\begin{array}{l}\text { Professores } \\
\text { finlandeses }\end{array}$} & $\begin{array}{c}\text { Política } \\
\text { institucional de } \\
\text { integração }\end{array}$ & 15 & $50 \%$ \\
\hline & $\begin{array}{c}\text { Processos } \\
\text { colaborativos } \\
\text { guiados por } \\
\text { projetos }\end{array}$ & 15 & $50 \%$ \\
\hline
\end{tabular}

Fonte: os autores

Os professores brasileiros percebem que não há uma política da instituição de incentivo à formação ou atuação em forma de CA, pois na maioria das vezes são iniciativas de alguns professores que buscam romper com a cultura da individualidade imposta pela organização do trabalho docente em disciplinas. De forma diferente, os educadores finlandeses percebem que existe uma política institucional de incentivo ao trabalho docente em time para promoção da integração dos conhecimentos. Disso, o resultado é o desenvolvimento de processos colaborativos, geralmente guiados por projetos de pesquisa que buscam melhorias no ensino ofertado pelo programa de formação de professores.

\section{ANÁLISE DOS RESULTADOS E CONCLUSÕES}

Os brasileiros demonstram entender CA deslocada do sentido de CoP. Por outro lado, os finlandeses compreendem que a CA envolve prática, sendo também uma CoP (SCHLEMMER et al., 2012).

Com base nas explicações de Ipiranga et al. (2005), a concepção de CA como um Grupo voluntário de afinidade e interesse comum revela que tanto professores brasileiros como finlandeses confundem o conceito 
de CA com o de rede informal, cujo objetivo é transmitir e colher informações sobre o mesmo escopo de conhecimento. A rede informal atende necessidades mútuas, mas não do coletivo, e as pessoas podem conectar-se ou desconectar-se quando quiserem. Não há o compromisso de geração de um produto, resultado, processo de interesse da comunidade (PRENGER; POORTMAN; HANDELZALTZ, 2020).

De forma sutil, os professores finlandeses pontuam a produção da CA. No entanto, não é possível afirmar que a concebem como "um processo de reflexão sobre a ação - um processo intencional, atrelado ao fazer, após sua ocorrência, e que demanda uma ação consequente qualitativamente diferente de uma ação rotineira" (MARCOLINO; LOURENÇO; REALI, 2017, p. 412).

Outra concepção identificada no discurso dos professores brasileiros foi de que a CA consiste em um grupo de trabalho formal, conforme visto na categoria "grupo de trabalho constituído pela instituição para desenvolver algo".

Para Ipiranga et al. (2005, p. 03), uma das características da CA é o desenvolvimento de "vários recursos, tais como ferramentas, documentos, rotinas, vocabulário e símbolos que de algum modo conduzem o conhecimento acumulado pela comunidade". Mega et al. (2020) reforça isso quando afirma que a CA precisa integrar três elementos: domínio, comunidade e prática. Assim, além da interação do grupo constituído em torno de um domínio comum de conhecimento, torna-se necessário a prática diferente da ação rotineira para que seja configurada uma CA.

Disso, conclui-se que os professores brasileiros não conhecem o conceito de CA, tendo em vista que confundem com rede informal e grupo de trabalho formal. Ousamos dizer também que a instituição não conhece ou reconhece o potencial da CA para efetivação dos princípios da Educação Profissional Brasileira (EPT).

De forma diferente, os professores finlandeses parecem entender a CA como um time de professores de diferentes áreas ou disciplinas curriculares, "que compartilham determinadas práticas em torno de um domínio de conhecimentos" (MEGA et al, 2020, p. 4), o que indica uma concepção próxima ao conceito de CA trazida pela literatura. Seus discursos variam entre a compreensão de CA como rede informal, equipe de projeto e time de ensino - team teaching. 
Buckley (1999) explica que time de ensino é um grupo de professores-instrutores trabalhando propositalmente, regularmente, e cooperativamente para ajudar um grupo de estudantes a aprender. Como um time, os professores trabalham juntos para definir objetivos do curso, desenhar rubricas e critérios de avaliação, preparar planos de ensino e aprendizagem e avaliar os resultados. As ações realizadas por um time de ensino convergem com as características de CA, tendo em vista ter atividades estruturadas para guiar a prática, objetivo compartilhado, foco em resultado concreto, foco coletivo na aprendizagem do estudante, conforme pontuam Prenger, Poortman e Handelzaltz. (2020).

Há também, por parte dos professores finlandeses, a percepção de que existe algo maior, institucional, guiando a organização do trabalho docente e a prática pedagógica. $\mathrm{O}$ que pode indicar influências das bases conceituais da Educação Profissional Finlandesa na forma de pensar do professor, traduzido como times de professores organizados em torno de projetos de pesquisa e ensino de interesses comuns.

Diante dos resultados, percebemos que o sistema finlandês de Educação Profissional se encontra em um estágio diferente de materialização e compreensão de CA. No entanto, tanto os professores de um como do outro país estão em processos de questionamento e ressignificação da formação e atuação docente.

\section{CONSIDERAÇÕES FINAIS}

Iniciamos a pesquisa com a expectativa de que a interação, escuta atenta e análise de concepções e percepções de professores brasileiros e finlandeses sobre CA traria algumas pistas acerca das dificuldades de professores brasileiros em desenvolver atividades colaborativas e a aprendizagem por projetos, reveladas ao longo do curso ProfCAC-MAES. Os relatos de experiências de educadores finlandeses possibilitariam a compreensão de caminhos alternativos de promoção de aprendizagem nos e pelos contextos de programas de formação continuada de professores brasileiros.

Os resultados da pesquisa indicam que tanto os professores finlandeses como os brasileiros têm duas concepções principais sobre CA, sendo uma convergente e outra divergente. Ambos entendem CA como um grupo voluntário de afinidade e interesse comum, ou seja, uma rede informal. 
Porém, em seus respectivos contextos de trabalho, os brasileiros entendem ser um grupo de trabalho constituído pela instituição para desenvolver algo de interesse institucional, o que Wenger e Snyder (2001) denominam de grupo de trabalho formal, enquanto os professores finlandeses compreendem como time de ensino - team teaching - formado por um grupo multidisciplinar para conduzir um percurso formativo. Isso traz indícios de que CA, para os finlandeses, é uma equipe de projeto ou algo bem próximo ao conceito de CoP, que também é de aprendizagem conforme afirma Schlemmer et al. (2012).

Quanto às percepções em contextos de programas de formação de professores, os brasileiros afirmam não haver intencionalidade institucional de promover CA para melhoria de processos educativos, afirmando que, muitas vezes, são ações voluntárias sufocadas pela organização do trabalho docente individual, por disciplina, turmas e tempos divididos entre as inúmeras disciplinas de um curso. Em contextos de programas de formação de professores finlandeses, a percepção é de ser uma política maior, cujo propósito é formar times de professores de áreas distintas para desenvolverem processos educativos, guiados por projetos de pesquisa aplicados ao contexto de atuação docente para sua melhoria.

A pesquisa partiu do pressuposto de que as concepções e as percepções dos professores brasileiros e finlandeses sobre CA se constituíam pelas experiências de atuação e formação que tinham, assim como, pela forma como a instituição incentiva o desenvolvimento profissional e a promoção de melhoria da prática pedagógica.

Durante a investigação verificamos que o desenvolvimento profissional e a atuação pedagógica em diferentes CA são reconhecidos e incentivados pela instituição de Educação Profissional onde os participantes finlandeses atuam, o que não ocorre no contexto de Educação Profissional dos professores brasileiros. Confirmamos ainda nossa suspeita da influência do contexto de atuação dos participantes em suas formas de pensar, ou seja, se a organização do trabalho docente mantém a lógica da divisão do conhecimento em disciplinas, estes terão muita dificuldade em desenvolver projetos coletivos e atuar de forma a promover a integração de saberes, tendo o diálogo como fio condutor.

Sendo assim, inferimos que o problema que emergiu durante o desenvolvimento do curso de formação continuada de professores ProfCAC-MAES 
tem sua casualidade na tradição educacional ainda predominante no sistema educacional brasileiro de organizar o trabalho docente em disciplinas, de tomar os conteúdos da disciplina como eixo central da prática pedagógica, fragmentando conteúdos em períodos de 45 a 50 minutos de aulas semanais, de forma que a aprendizagem é guiada por conteúdos e não projetos. O sistema educacional finlandês, por sua vez, tem: o trabalho docente multidisciplinar, projetos de pesquisa como eixo central da prática pedagógica e a aprendizagem guiada por projetos desenvolvidos no contexto de atuação.

Disso, concluímos que apesar de inúmeros pesquisadores apresentarem propostas para formação de professores dos Institutos Federais, o desenvolvimento do "ensino, pesquisa e extensão, enquanto atividades efetivamente indissociáveis, integradas, coletivas e participativas" (PACHECO, 2020, p. 19), parece estar longe de se materializar. No entanto, as concepções dos professores finlandeses nos revelam um caminho profícuo para a superação da atuação docente individual ao apresentarem a forma de atuação em equipe de projeto formado por um time de professores de diferentes disciplinas, responsáveis em desenvolver pesquisa aplicada à melhoria do ensino.

Diante da limitação de páginas, não foi possível compreender os princípios teóricos de team teaching. Ficam sem respostas os seguintes questionamentos: como o sistema de educação profissional finlandesa organiza o trabalho docente em team teaching ou equipes de projeto? Em quais aspectos o conceito de team teaching aproxima-se do conceito de CA? Ao significar team teaching como sinônimo de CA, é possível constatar que as concepções dos professores finlandeses convergem com o conceito de CA trazido pela literatura?

O que a investigação nos deixa como aprendizado é que: enquanto no contexto de Educação Profissional de professores brasileiros o ensino é o eixo central, ponte para as atividades de pesquisa e extensão dos professores, no contexto de Educação Profissional de professores finlandeses toma-se a pesquisa como organizadora de CA ou team teaching, e dos resultados das pesquisas busca-se melhoria de processos de aprendizagem dos estudantes.

\section{REFERÊNCIAS}

\section{ALMEIDA, L. C. Formação continuada docente na perspectiva in-}

tegral: uma proposta para o ensino integrado. Dissertação de mes- 
trado. Instituto Federal de Mato Grosso do Sul, 2020. Disponível em: https://sucupira.capes.gov.br/sucupira/public/consultas/coleta/ trabalhoConclusao/view TrabalhoConclusao.jsf?popup=true\&id_ trabalho=9720107. Acesso em: 25 mar 2021.

BARDIN, L. Análise de conteúdo. São Paulo: Edições 70, 2016.

BUCKLEY, F. J. Team Teaching: What, why, and how? Sage Publications, Inc. International Educational and Professional Publisher. London: New Delhi: Thousand Oaks, 1999.

CARDOSO, C. A. S. Concepções de comunidades de aprendizagem à luz de Gramsci. Revista Inova Ciência \& Tecnologia, Uberaba, p. 43-48, v. 5, n. 2, jul/dez., 2019.

FRANCO, M. L. P. B. Análise de conteúdo. Brasília: Editora Plano, 2003.

GABASSA, V. Comunidades de Aprendizagem: a construção da dialogicidade na sala de aula. Tese (Doutorado) - Programa de Pós-Graduação em Educação da Universidade Federal de São Carlos. São Carlos, 2009.

GALLUCCI, C. Theorizing about responses to reform: the role of communities of practice in teacher learning. An occasional paper. Center for the Study of Teaching and Policy, 2003.

GODOY, A. J. Pesquisa qualitativa: tipos fundamentais. RAE, v. 35, n. 3, p. 20-29, maio 1995. Disponível em: https://www.scielo.br/scielo.php?script=sci_arttext\&pid=S0034-75901995000300004. Acesso em: 28 abr. 2021.

IPIRANGA, A. S. R.; MENEZES, R. B.; MATOS, J. L. L.; MAIA, G. L. L. Aprendizagem como ato de participação: a história de uma comunidade de prática. Caderno EBAPE.BR, V. III, n. 4, dez. 2005. Disponível em: https://www.scielo.br/pdf/cebape/v3n4/v3n4a09. pdf. Acesso em: 28 abr. 2021.

LAVE, J.; WENGER, E. Situated learning: legitimate peripheral participation. Cambridge: Cambridge University Press, 1991. 
MARCOLINO, T. Q.; LOURENCO, G. F.; REALI, A. M. M. R. Isso eu levo para a vida!: aprendizagem da prática profissional em uma Comunidade de Prática. Interface. v.21, n.61, p.411-420. 2017. Disponível em: https://www.scielo.br/pdf/icse/v21n61/1807-5762-icse-1807-576220160099.pdf. Acesso em: 28 abr. 2021.

MEGA, D. F.; ARAUjO, I. S.; VEIT, E. A. Centro de Tecnologia Acadêmica da UFRGS como comunidade de prática e possibilidade de criação de espaços não formais de aprendizagem: um estudo etnográfico. Ensaio Pesquisa em Educação em Ciências, v. 22, e12139. 2020. Disponível em: https://www.scielo.br/pdf/epec/v22/ 1983-2117-epec-22-e12139.pdf. Acesso em: 28 abr. 2021.

PACHECO, J. Escola da Ponte: formação e transformação da educação. Petrópolis: Vozes, 2013.

PACHECO, E. Desvendando os Institutos Federais: Identidade e objetivos. Educação Profissional e Tecnológica em Revista, v. 4 n. 1, p. 4-22. 2020. Disponível em: https://ojs.ifes.edu.br/index.php/ept/ article/view/575. Acesso em: 18 jun. 2020.

PRENGER, R.; POORTMAN, Cindy L; HANDELZALTS, Adam. Professional learning networks: From teacher learning to school improvement? Journal of Educational Change Springer. 2020. Disponível em: https://research.utwente.nl/en/publications/professional-learning-networks-from-teacher-learning-to-school-im. Acesso em: 10 fev. 2021.

SCHLEMMER, E.; MALIZIA, P.; BACKES, L. MORETTI, G. Comunidades de aprendizagem e de prática em metaverso. São Paulo: Cortez, 2012.

SOUZA, P. R. C. Formação continuada de professores na perspectiva politécnica: uma proposta curricular. Dissertação de mestrado. Instituto Federal de Mato Grosso do Sul, 2020. Disponível em: https://sucupira.capes.gov.br/sucupira/public/consultas/coleta/trabalhoConclusao/viewTrabalhoConclusao.jsf?popup=true\&id_ trabalho=9233023. Acesso em: 25 mar 2021. 
VIEIRA, A. S. V.; PARKKONEN, V.; BARBOSA, L. L. L. Ação pedagógica híbrida em programa internacional finlandês de formação de professores: análise do alinhamento construtivo. EDUCITEC, v. 6, e152820, 2020. Disponível em: https://sistemascmc.ifam.edu.br/ educitec/index.php/educitec/article/view/1528. Acesso em: 25 mar. 2021.

VYGOTSKY, L. S. A formação social da mente: o desenvolvimento dos processos psicológicos superiores. São Paulo: Martins Fontes, 1998.

WENGER, E.; SNYDER, W. M. Comunidades de prática: a fronteira organizacional. Cambridge: Harvard Business Review, 2001. 

ARTIGOS - ENSINO SUPERIOR 



\section{ENSINO SUPERIOR PRIVADO NO BRASIL E AGENDA 2030}

André Serotini ${ }^{46}$

\section{INTRODUÇÃO}

O ensino superior, público ou privado, é altamente regulado pelo Estado brasileiro, seja para credenciamento de instituições de ensino superior, autorização de cursos, estabelecimento de diretrizes curriculares nacionais, dentre outros tantos assuntos que sempre foram objetos de infindáveis debates.

É notório que discussões sobre a qualidade do ensino superior não estão restritas apenas ao contexto brasileiro, sendo tema amplamente abordado em nível global, elevado, inclusive, à condição para que seja possível alcançar melhores índices de desenvolvimento econômico e social, a ponto de ser incluído como meta relacionada ao Objetivo de Desenvolvimento Sustentável (ODS) 4 - Educação de Qualidade, da Agenda 2030.

A pesquisa leva em consideração que, em 2019, das 2.608 instituições de ensino superior no Brasil, 88,42\%, ou seja, 2.306, são privadas. Em graduações presenciais, de 6.153.560 de matrículas, 4.231 .071 (68,76\%) foram realizadas em instituições privadas. E, do total de 934.037 alunos que concluíram a graduação em 2019, 694.831 (74,39\%) são egressos de instituições privadas (INEP, 2019). Buscou-se estabelecer uma relação

\footnotetext{
46 Docente do Curso de Direito e do Programa de Mestrado em Ciências Ambientais da Universidade do Estado de Minas Gerais - UEMG | Frutal. Líder de Pesquisa do Núcleo de Pesquisa (Des)Envolvimento: Direito, Pós-Modernidade e Sociedade de Consumo.
} 
entre o sistema de aferição de qualidade adotado pelo Ministério da Educação (MEC), o papel das instituições de ensino superior privadas e a possibilidade de se atingir a meta que dispõe sobre a necessidade de assegurar a igualdade de acesso para todos os homens e mulheres à educação técnica, profissional e superior de qualidade, a preços acessíveis, incluindo universidade (NAÇÕES UNIDAS, 2015).

$\mathrm{O}$ artigo está organizado em três partes, a primeira apresentando o Objetivo de Desenvolvimento Sustentável relacionado à educação. A segunda 2 apresenta dados sobre o ensino superior brasileiro obtidos através da análise do Censo da Educação Superior. E a última aborda o Sistema Nacional de Avaliação da Educação Superior, objetivando a melhoria dos índices de qualidade, principalmente focados nas instituições privadas de ensino.

Nas considerações finais, apresenta-se a contribuição desta pesquisa ao afirmar que as instituições privadas têm importante participação para o cumprimento das metas estabelecidas na ODS 4. Verificou-se, no entanto, que há carência de indicadores oficiais para o acompanhamento das referidas metas, sugerindo, desta forma, que o Sistema Nacional de Avaliação da Educação Superior seja considerado um dos possíveis indicadores de qualidade.

\section{OBJETIVOS DE DESENVOLVIMENTO SUSTENTÁVEL - EDUCAÇÃO DE QUALIDADE (ODS 4)}

Em 2015, os Estados-membros na ONU, reunidos em Nova York, reconhecendo que a erradicação da pobreza em todas as suas formas e dimensões, incluindo a pobreza extrema, é o maior desafio global e um requisito indispensável para o desenvolvimento sustentável e, buscando solucionar tal problemática, adotaram a Agenda 2030, comprometendo-se a tomar medidas para a promoção do desenvolvimento sustentável para os 15 anos seguintes - por isso a denominação “Agenda 2030” (NAÇÕES UNIDAS, 2015).

Sucintamente, essa agenda compreende um plano de ação para as pessoas, o planeta e a prosperidade, buscando fortalecer a paz universal, indicando 17 Objetivos de Desenvolvimento Sustentável (ODS), com 169 
metas visando erradicar a pobreza e promover vida digna para todos, dentro dos limites do planeta.

As ações previstas nesta Agenda estão alicerçadas em áreas consideradas de importância crucial para a humanidade e para o planeta focando nas Pessoas, com o objetivo de acabar com a pobreza e a fome e garantir dignidade e igualdade, em um ambiente saudável; Planeta, visando proteger o planeta da degradação; Prosperidade, no intuito de assegurar que todos os seres humanos possam desfrutar de uma vida próspera e de plena realização pessoal, e que o progresso econômico, social e tecnológico ocorra em harmonia com a natureza; Paz, promovendo sociedades pacíficas, justas e inclusivas, livres de medo e da violência; e, Parceria, mobilizando os meios necessários para implementar esta Agenda por meio de uma Parceria Global para o Desenvolvimento Sustentável (NAÇÕES UNIDAS, 2015).

É importante destacar o item 25 da Agenda que traz a Educação como um dos instrumentos necessários para atingir tais objetivos, vejam:

Comprometemo-nos a fornecer a educação inclusiva e equitativa de qualidade em todos os níveis - na primeira infância, nos ensinos fundamental, médio, superior, técnico e profissional. Todas as pessoas, independentemente de sexo, idade, raça ou etnia, e pessoas com deficiência, migrantes, povos indígenas, crianças e jovens, especialmente aqueles em situação de vulnerabilidade, devem ter acesso a oportunidades de aprendizagem ao longo da vida que os ajudem a adquirir os conhecimentos e as habilidades necessários para explorar oportunidades e participar plenamente da sociedade. Nós nos empenharemos para proporcionar às crianças e aos jovens um ambiente que propicie a plena realização dos seus direitos e de suas capacidades, ajudando nossos países a colher dividendos demográficos, inclusive por meio de escolas seguras e de comunidades e famílias coesas (NAÇÕES UNIDAS, 2015).

Dentre os objetivos está a "Educação de Qualidade" (ODS 4), pautado em assegurar a educação inclusiva e equitativa de qualidade, e promover oportunidades de aprendizagem ao longo da vida para todos (NAÇÕES UNIDAS, 2015). 
Engana-se ao pensar que este objetivo está focado apenas na educação básica. Pelo contrário. Contempla todos os níveis de educação entendendo como fundamental a promoção de uma educação inclusiva, igualitária e baseada nos princípios de direitos humanos e desenvolvimento sustentável (NAÇÕES UNIDAS, 2015).

Uma das metas do ODS 4, a 4.3, dispõe que até 2030 deverá estar assegurada a igualdade de acesso para todos os homens e mulheres à educação técnica, profissional e superior de qualidade, a preços acessíveis, incluindo universidade (NAÇÕES UNIDAS 2015)

Obviamente, as metas, bem como os próprios objetivos devem ser interdependentes para que seja possível cumprir a finalidade da Agenda 2030 e, neste sentido, é importante, também, destacar a meta 4.7 ao trazer que até 2030 é necessário

[...] garantir que todos os alunos adquiram conhecimento e habilidades necessárias para promover o desenvolvimento sustentável, inclusive, entre outros, por meio da educação para o desenvolvimento sustentável e estilos de vida sustentáveis, direitos humanos, igualdade de gênero, promoção de uma cultura de paz e não-violência, cidadania global, e valorização da diversidade cultural e da contribuição da cultura para o desenvolvimento sustentável (NAÇÕES UNIDAS, 2015).

Ao reconhecer, portanto, o ODS 4 - frisa-se, novamente, que tem como tema "Educação de Qualidade" -, como fundamental para o desenvolvimento sustentável e para que os demais ODSs também sejam alcançados, percebe-se que existem alguns fatores indicativos de aferição de qualidade, que devem ser verificados, como questões relacionadas com estilos de vida sustentáveis, direitos humanos, igualdade de gênero, promoção de uma cultura de paz e não violência, cidadania global, e valorização da diversidade cultural e da contribuição da cultura para o desenvolvimento sustentável.

Necessário ainda apontar que, embora o ODS 8 não seja especificamente relacionado à Educação de qualidade, traz dentre suas metas (8.6) a redução substancial (que era até 2020), da proporção de jovens sem emprego, educação ou formação, como forma de promover o crescimento 
econômico sustentado, inclusivo e sustentável, emprego pleno e produtivo, e trabalho decente para todos (NAÇÕES UNIDAS, 2015). Mais uma vez destaca-se, portanto, a importância de uma educação de qualidade para atingir os objetivos previstos na Agenda 2030.

Obviamente, para atingir metas e cumprir com os compromissos estipulados deve existir um diagnóstico da situação que possibilite o seu devido acompanhamento. Também em 2015, no Brasil, o Programa das Nações Unidas para o Desenvolvimento - PNUD, elaborou um catálogo para o acompanhamento da Agenda 2030, elencando os subsídios iniciais sobre a identificação de indicadores nacionais referentes aos objetivos de desenvolvimento sustentável, priorizando fontes estatísticas oficiais ou registros administrativos ou ambos, bem como as lacunas existentes no conjunto de indicadores atualmente disponíveis no Brasil (PNUD, 2015).

Sobre o acompanhamento do ODS 4, o instrumento citado informou que no Brasil já havia sido aprovado no ano anterior (2014) o Plano Nacional de Educação - PNE, com 20 metas a serem alcançadas em 10 anos, abrangendo desde a educação infantil até a pós-graduação dos profissionais do magistério e, tendo como meta específica a qualidade da educação e a avaliação da aprendizagem, demonstrando, portanto, o esforço do pais em universalizar com qualidade a educação básica e de expandir seus quadros superiores, em forma e conteúdo, antecipando a integralização das metas do ODS de educação para 2024 (PNUD, 2015).

As fontes de informações balizadoras para o acompanhamento do ODS 4 são as próprias metas do PNE, referenciadas pelos dados da Pesquisa Nacional por Amostra de Domicílios - PNAD e o censo demográfico, ambos realizado pelo IBGE e, dos dados obtidos através dos Censos da Educação Básica e da Educação Superior, realizados pelo Instituto Nacional de Estudos e Pesquisas Educacionais Anísio Teixeira - INEP (PNUD, 2015).

Os indicadores da meta 4.3 são os seguintes: 1) razão entre as taxas de escolarização líquida de mulheres e homens por nível de ensino (técnico-profissional e superior); e, 2) percentagem de docentes com formação em nível superior lecionando na educação profissional. O documento informa que não há indicador disponível sobre equidade no acesso e na gratuidade, sugerindo-se que seja elaborado estudo para viabilizar a criação destes indicadores (PNUD, 2015). 
Já, ao tratar da meta 4.4, que objetiva aumentar substancialmente o número de jovens e adultos que tenham habilidades relevantes, inclusive competências técnicas e profissionais, para emprego, trabalho decente e empreendedorismo, destacam-se como indicadores: 1) média de anos de estudo da população de 15 a 24 anos; 2) média de anos de estudo da população de 15 a 29 anos; 3) percentagem da população com ensino médio concluído; e, 4) percentagem da população com formação em nível superior concluído (PNUD, 2015).

Então, ao tentar responder se o sistema brasileiro de educação superior, especialmente privado, consegue atender a tais condicionantes para que seja possível alcançar um índice integral de qualidade, percebe-se que pelos indicadores apresentados, não há qualquer balizamento para uma boa resposta. Desta forma, na sequência, apresentam-se e analisam-se dados sobre o ensino superior privado e sistema de avaliação, com o intuito de auxiliar na determinação de referências de qualidade a ser considerado para o acompanhamento das metas.

\section{ENSINO SUPERIOR NO BRASIL}

De acordo com o Censo da Educação Superior de 2019, organizado e realizado pelo INEP - Instituto Nacional de Estudos e Pesquisas Educacionais Anísio Teixeira, autarquia federal vinculada ao MEC - Ministério da Educação, responsável pelas avaliações e exames, pelas estatísticas e indicadores, e pela gestão do conhecimento e estudos educacionais, divulgado em 2020, de um total de 2.608 instituições de ensino superior no Brasil, 88,42\%, ou seja, 2.306, são privadas. Em graduações presenciais, de 6.153.560 de matrículas, 4.231.071 (68,76\%) foram realizadas em instituições privadas. E, do total de 934.037 alunos que concluíram a graduação em 2019, 694.831 (74,39\%) são egressos de instituições privadas (INEP, 2019). Estes dados demonstram, claramente, a importância da iniciativa privada, partindo da premissa de ser a educação superior um dos mecanismos de promoção de emancipação e no processo de desenvolvimento pessoal, profissional, econômico e social no Brasil.

Ao comparar os dados atuais com os dados de 2010, quando se teve início o censo, verifica-se que quanto ao número de instituições de ensino superior, partiu-se de 2.378 (2010), para 2.608, em 2019 e, em relação às 
privadas, foram de 2.100 (2010) para 2.306, em 2019 - praticamente, a diferença apresentada neste período se deu em razão ao aumento de instituições privadas. Todavia, quando se analisa o número de matriculados, observa-se que em 2010 havia 6.449.120 matrículas em cursos presenciais, sendo deste total, 3.987.424 em cursos ofertados em instituições privadas. Já, em 2019, verifica-se que o total de matriculados caiu para 6.153.560, enquanto nas instituições privadas aumentou para 4.231,071 (INEP, 2019).

De certa forma, estes números corroboram a importância e o impacto que o ensino superior privado tem provocado na sociedade brasileira. Em partes, podemos atrelar o aumento do número de instituições privada e do número de matriculados nestas instituições a forte política de democratização do acesso aos cursos superiores, tendo o Estado oportunizando abertura de novas instituições de ensino superior públicas e, em especial e maciçamente, privadas, potencializada por incentivos econômicos como programas de financiamento estudantil.

Apesar de inúmeras críticas a respeito da qualidade do ensino superior privado, não podemos esquecer que, embora vivendo num Estado em que esperamos que o Poder Público possa dar conta de todas as necessidades sociais, o art. 209, da Constituição Federal de 1988, dispõe que o ensino é livre à iniciativa privada, desde que haja cumprimento das normas gerais da educação nacional e, se submeta à autorização e avaliação de qualidade pelo Poder Público. Desta forma, resta evidente que a atividade de educação está sob controle direto por parte do Estado, o qual criou uma série de órgãos e mecanismos para realização deste mister (BRASIL, 1988).

A Constituição brasileira traz em seu art. 214, inciso III, a obrigatoriedade de se haver um plano nacional de educação, de duração decenal, objetivando articular o sistema nacional de educação em regime de colaboração, definindo diretrizes, objetivos, metas e estratégias de implementação visando, dentre outras questões a melhoria da qualidade de ensino (BRASIL, 1988). Desta forma, é patente a necessidade de adequação das instituições privadas de ensino às normativas expedidas e que venham a ser expedidas pelos órgãos estatais, vinculados ao Ministério da Educação, possibilitando que a estas sejam concedidas as autorizações para seu funcionamento.

Atualmente, das normativas que regulam a oferta de cursos superiores, destacam-se a Lei no. 9.394, de 20 de dezembro de 1996, deno- 
minada Lei de Diretrizes e Bases da Educação Nacional - LDB, e a Lei n⿳⺈.10.861, de 14 de abril de 2004, a qual institui o Sistema Nacional de Avaliação da Educação Superior (SINAES), além, obviamente, de uma série de atos normativos como pareceres e resoluções do Ministério da Educação (MEC), expedidos pelos Conselho Nacional de Educação (CNE).

Em paralelo, temos vinculada ao MEC a Secretaria de Educação Superior (SESu), responsável por planejar, orientar, coordenar e supervisionar o processo de formulação e implementação da Política Nacional de Educação Superior, bem como a manutenção, a supervisão e o desenvolvimento das instituições públicas federais de ensino superior (IFES) e a supervisão das instituições privadas de educação superior, conforme a Lei de Diretrizes e Bases da Educação Nacional (LDB).

\section{SISTEMA NACIONAL DE AVALIAÇÃO DA EDUCAÇÃO SUPERIOR}

A Lei n⿳o. 10.861, de 14 de abril de 2004, institui o Sistema Nacional de Avaliação da Educação Superior (SINAES) agregando a avaliação das instituições, dos cursos e do desempenho dos estudantes. Desta forma, o SINAES, de acordo com o $\int 1^{\circ}$, do art. $1^{\circ}$, da referida Lei, tem por finalidade:

[...] a melhoria da qualidade da educação superior, a orientação da expansão da sua oferta, o aumento permanente da sua eficácia institucional e efetividade acadêmica e social e, especialmente, a promoção do aprofundamento dos compromissos e responsabilidades sociais das instituições de educação superior, por meio da valorização de sua missão pública, da promoção dos valores democráticos, do respeito à diferença e à diversidade, da afirmação da autonomia e da identidade institucional (BRASIL, 2004)

Para que tais finalidades sejam alcançadas, o sistema deve assegurar:

[...] I - avaliação institucional, interna e externa, contemplando a análise global e integrada das dimensões, estruturas, relações, com- 
promisso social, atividades, finalidades e responsabilidades sociais das instituições de educação superior e de seus cursos;

II - o caráter público de todos os procedimentos, dados e resultados dos processos avaliativos;

III - o respeito à identidade e à diversidade de instituições e de cursos;

IV - a participação do corpo discente, docente e técnico-administrativo das instituições de educação superior, e da sociedade civil, por meio de suas representações. (BRASIL, 2004).

Ainda com base na Lei do SINAES, os resultados da avaliação institucional, interna e externa, constituirão referencial básico dos processos de regulação e supervisão da educação superior, compreendendo, neste campo, o credenciamento e a renovação de credenciamento de IES, a autorização, o reconhecimento e a renovação de reconhecimento de cursos de graduação. Desta forma, podemos constatar a existência de processos de avaliação relacionados à Instituição de Ensino Superior (credenciamento e renovação de credenciamento) e, processos relacionados à avaliação de Cursos de Graduação (autorização, reconhecimento e renovação de reconhecimento).

O objetivo das avaliações de IES, que contam com autoavaliação e avaliação externa in loco, de acordo com o art. 3ํㅡㄹ da Lei do SINAES é a identificação de seu perfil e o significado de sua atuação, por meio de suas atividades, cursos, programas, projetos e setores, considerando, dentre outras dimensões institucionais, a missão e o plano de desenvolvimento institucional (PDI); a política para o ensino, a pesquisa, a pós-graduação, a extensão e as respectivas formas de operacionalização; a responsabilidade social da instituição; a comunicação com a sociedade; as políticas de pessoal, as carreiras do corpo docente e do corpo técnico-administrativo, bem como as condições de trabalho; organização e gestão da IES; infraestrutura física; planejamento e avaliação, especialmente os processos, resultados e eficácia da auto avaliação institucional; política de atendimento aos estudantes; e, sustentabilidade financeira, tendo em vista o significado social da continuidade dos compromissos na oferta da educação superior (SEROTINI, 2016). 
De outro lado, a avaliação dos cursos de graduação, realizada mediante visitas por comissões especializadas nas respectivas áreas de conhecimento, seguindo o disposto no art. $4^{\circ}$, da Lei do SINAES, tem por objetivo identificar as condições de ensino oferecidas aos estudantes, levando-se em consideração o perfil do corpo docente, as instalações físicas e a organização didático-pedagógica.

Em paralelo aos procedimentos avaliatórios acima dispostos, temos a avaliação do desempenho dos estudantes dos cursos de graduação, realizada mediante aplicação periódica do Exame Nacional de Desempenho dos Estudantes (ENADE), que, de acordo com o art. 5ํㅡㄹ da Lei do SINAES, tem como objetivo, como o próprio nome sugere, aferir o

[...] desempenho dos estudantes em relação aos conteúdos programáticos previstos nas diretrizes curriculares do respectivo curso de graduação, suas habilidades para ajustamento às exigências decorrentes da evolução do conhecimento e suas competências para compreender temas exteriores ao âmbito específico de sua profissão, ligados à realidade brasileira e mundial e a outras áreas do conhecimento. (BRASIL, 2004).

Com base nas informações apresentadas até este ponto é possivel inferir que as instituições de ensino que contabilizam os totais do Censo da Educação Superior são aquelas que cumpriram os requisitos cabíveis e alcançaram padrões mínimos de qualidade que permitiram os seus funcionamentos e ofertas de cursos.

\section{CONSIDERAÇÕES FINAIS}

Ao discorrer sobre o Objetivo de Desenvolvimento Sustentável (ODS 4), almejando Educação de Qualidade e apresentando dados sobre o ensino superior geral e, em especial, privado no Brasil, buscou-se verificar quais os indicadores que são utilizados para o acompanhamento das metas deste ODS.

Analisando os indicadores oficiais (PNUD, 2015) como: 1) razão entre as taxas de escolarização líquida de mulheres e homens por nível de ensino (técnico-profissional e superior); 2) percentagem de docentes com 
formação em nível superior lecionando na educação profissional; 3) média de anos de estudo da população de 15 a 24 anos; 4) média de anos de estudo da população de 15 a 29 anos; 5) percentagem da população com ensino médio concluído; e, 6) percentagem da população com formação em nível superior concluído, constata-se que são insuficientes para a aferição da qualidade do ensino superior, impossibilitando, assim, o correto acompanhamento das metas do ODS 4.

Já ao analisar o Sistema Nacional de Avaliação da Educação Superior (SINAES) e o trabalho que vem sendo realizado como avaliações periódicas, inclusive, in loco, nas instituições de ensino superior, considerando critérios como formação, qualificação e experiência do corpo docente; estruturas e instalações necessárias para funcionamento; análise de projetos institucionais e pedagógicos, bem como perfil de egresso, dentre outros, constata-se que estes poderiam ser indicadores de qualidade utilizados para o acompanhamento das metas.

Desta forma, este artigo apresenta contribuições no sentido de se considerar os resultados das avalições realizadas pelo SINAES como indicadores oficiais para o acompanhamento das metas relacionadas ao Objetivo de Desenvolvimento Sustentável 4, no sentido de se alcançar uma plena educação de qualidade com potencial de atender as demandas trazidas pela Agenda 2030.

\section{REFERÊNCIAS}

BRASIL. Constituição (1988). Constituição da República Federativa do Brasil. Brasília, DF, Senado, 1988. Disponível em: http://www. planalto.gov.br/ccivil_03/constituicao/constituicao.htm. Acesso em: 9 abr. 2021.

Lei Federal no 9.394, de 20 de dezembro de 1996. Estabelece as diretrizes e bases da educação nacional. Brasília/DF: Diário Oficial da União, 23 dez. 1996. Disponível em: http://www.planalto. gov.br/ccivil_03/leis/19394.htm. Acesso em: 9 abr. 2021.

Lei Federal no 10.886, de 14 de abril de 2004. Institui o Sistema Nacional de Avaliação da Educação Superior - SINAES e dá outras providências. Brasília/DF: Diário Oficial da União, 15 abr. 2004. 
Disponível em: http://www.planalto.gov.br/ccivil_03/_ato20042006/2004/lei/110.861.htm. Acesso em: 9 abr. 2021.

FILGUEIRAS, Carlos Alberto. Ganhar o Jogo no Mercado Educacional. In: Competitividade e mudanças no DNA institucional: construindo a educação superior do futuro. São Paulo: Editora de Cultura, p. 113-121, 2014.

GRIBOSKI, Claudia Maffini. Competitividade, Rankings e o Impacto do SINAES. In: Competitividade e mudanças no DNA institucional: construindo a educação superior do futuro. São Paulo: Editora de Cultura, p. 122-134, 2014.

MATIAS, Lisandra. Um Retrato do Guia do Estudante da Editora Abril. In: Competitividade e mudanças no DNA institucional: construindo a educação superior do futuro. São Paulo: Editora de Cultura, p. 144-151, 2014.

MENEGHINI, Rogério. Uma Visão sobre Rankings e a Experiência do RUF. In: Competitividade e mudanças no DNA institucional: construindo a educação superior do futuro. São Paulo, Editora de Cultura, p. 135-143, 2014.

NAÇÕES UNIDAS. Transformando Nosso Mundo: A Agenda 2030 para o Desenvolvimento Sustentável. ONU, 2015. Disponível em: http://www.itamaraty.gov.br/images/ed_desenvsust/ Agenda2030-completo-site.pdf. Acesso em: 14 abr. 2021.

Programa das Nações Unidas para o Desenvolvimento (PNUD). Acompanhando a agenda 2030 para o desenvolvimento sustentável: subsídios iniciais do Sistema das Nações Unidas no Brasil sobre a identificação de indicadores nacionais referentes aos objetivos de desenvolvimento sustentável/Programa das Nações Unidas para o Desenvolvimento. Brasília: PNUD, 2015. 250 p. Disponível em: http://www.undp.org/content/dam/brazil/docs/ agenda2030/undp-br-Acompanhando-Agenda2030-Subsidios_iniciais-Brasil-2016.pdf. Acesso em: 16 abr. 2021. 
REIS, Fábio Garcia (Org). Competitividade e mudanças no DNA institucional: construindo a educação superior do futuro. São Paulo, Editora de Cultura, 2014.

SÁ, Henrique Luís. Desenvolvimento Ético e Responsabilidade. In: Competitividade e mudanças no DNA institucional: construindo a educação superior do futuro. São Paulo, Editora de Cultura, p. 101-112, 2014.

SEROTINI, André. Compliance como prática de gestão de instituições de ensino superior privadas. Multiciência. São Carlos, v. 15, p. 9-21, 2016. 


\section{A EXPANSÃO DO SABER: O PAPEL DA MÚSICA EM UNIVERSIDADES CONFESSIONAIS}

Jetro Meira de Oliveira ${ }^{47}$

INTRODUÇÃO

O aumento no número de instituições de ensino superior (IES) particulares no Brasil é um fato registrado e discutido nas últimas décadas. O significante número de dois terços de todas as matrículas do ensino superior no Brasil pertencem a IES particulares. Inseridas neste contexto, temos as IES confessionais que estão ligadas a ou são sustentadas por alguma religião e, de alguma forma, refletem a filosofia e práxis dessa religião. As primeiras IES confessionais no Brasil foram as Católicas, mas hoje há uma variedade de IES ligadas a diferentes religiões (DURHAM, 2003; TAVARES, 2009, ROTH et al., 2013). Na maioria das religiões cristãs, a música tem papel preponderante e isto se reflete em suas IES.

Este texto tem o objetivo de ponderar sobre o papel da música dentro de uma IES confessional, especialmente considerando a ideia de monocultura religiosa predominante e sua influência no desenvolvimento de uma cultura universitária. O conceito de "universalidade" inerente na própria palavra "universidade" e a expressão latina da qual a palavra universidade é derivada, universitas magistrorum et scholarium, traduzida como "comunidade de professores e pesquisadores" norteiam a discussão. Con-

47 Doutor em Artes Musicais. 
juntamente, o conceito de desenvolvimento integral do ser humano é empregado contemplando as quatro dimensões humanas: física, emocional, intelectual e espiritual.

\section{MONOCULTURA RELIGIOSA}

Observamos um crescimento exponencial nas religiões evangélicas e pentecostais no Brasil desde o final do século XX até os dias atuais (ZYLBERKAN, 2020; MENDONÇA, 1995). Paralelamente, a Igreja Católica brasileira tem experimentado a popularização de seu movimento de Renovação Carismática (VALLE, 2004). Unindo todos os cristãos, até mesmo os católicos (BALLOUSSIER, 2019), está a cultura gospel, caracterizada por ser uma forma de vida baseada na tríade música-consumo e entretenimento (SANTOS et al., 2017; FERREIRA, 2016; ROSAS, 2015). A cultura gospel é um reprocessamento religioso de culturas midiáticas, mercadológicas e urbanas. Estudos contemporâneos revelam que o crescente movimento gospel tem a aparência de modernização da religião, apresentando novas formas de culto e a relativização de costumes. Entretanto, permanecem, nesta cultura religiosa moderna, características historicamente associadas com as religiões evangélicas, tais como, dificuldade com a pluralidade de expressões culturais e religiosas, e em particular o anti-intelectualismo (PICOLI et al., 2020), que ganhou projeção com os movimentos neoconservadores atuais (CUNHA, 2004).

A cultura gospel estabeleceu-se como uma monocultura dominante no cenário religioso cristão contemporâneo, trazendo certa padronização musical, uma espécie de McDonaldização das igrejas (WEINGÄRTNER, 2001, p. 72). O principal aspecto negativo de qualquer monocultura é a formação de bolhas epistêmicas e câmaras de eco que resultam em isolamento intelectual, social e cultural. Em bolhas epistêmicas, importantes contribuições de alguns são excluídas por omissão, geralmente sem má intenção, em um processo social e comunitário de seleção. Em muitos casos, estas estruturas sociais e comunitárias se tornam um "filtro epistêmico de autorreforço, que deixa de fora visões contrárias e aumenta ilegitimamente nossa autoconfiança epistêmica ${ }^{48}$ " (NGUYEN, 2018, p. 2). O processo

48 "self-reinforcing epistemic filter, which leaves out contrary views and illegitimately inflates our epistemic self-confidence". 
de câmaras de eco é diferente do que se observa em bolhas epistêmicas. Câmaras de eco são criadas pelo descrédito ativo de vozes relevantes. Neste caso, o modo operacional é o isolamento sistemático dos membros de uma determinada câmara de eco de todas fontes epistêmicas externas (JAMIESON; CAPPELLA, 2008, p. 163-236).

O resultado destes processos nutridos em bolhas epistêmicas e câmaras de eco é isolamento e a incapacidade de interagir com ideias diferentes. A Psicologia chama de imunização cognitiva ou epistêmica quando crenças se tornam realidades impenetráveis, mesmo que desafiem a lógica. Frequentemente, crenças são ligadas a fortes emoções que contribuem no estabelecimento destas crenças, mesmo a níveis irracionais. O processo de imunização de crenças depende muito da repetição das crenças selecionadas (SMITH, 2016). "Esta discrepância pode ser descrita como sendo entre saber e simplesmente sentir que sabe ${ }^{49 "}$ (BERTOLOTTI, 2015, p. 230).

Naturalmente, as características presentes em qualquer monocultura são opostas aos valores básicos de qualquer ambiente universitário. A Universidade, mesmo a confessional, existe para ampliar a capacidade intelectual, cultural e artística de sua comunidade acadêmica. Esta comunidade acadêmica inclui não somente alunos e professores, mas também funcionários da IES e também a comunidade em geral para quem são destinados, comumente, programas culturais de extensão universitária. A preponderância dada à cultura gospel cria uma monocultura que empobrece a comunidade de uma Universidade confessional.

\section{CULTURA UNIVERSITÁRIA}

Existem diferentes modelos de conceito de Universidade (CHARLE, 1996; DRÈZE, 1983). No Brasil transitamos entre práticas nas quais a Universidade é vista como monopólio de instrução pública, catalizador de pesquisa, e um conceito amplo de saber como instrumento de ação, valorizando princípios democráticos. Em raros casos, a Universidade no Brasil é concebida como instrumento para a formação moral e intelectual com o propósito de educar a mente, sem necessariamente ter um objetivo profissionalizante (NUNES GIMENEZ, 2021).

49 "This discrepancy could be described as the one between knowing and simply feeling of knowing". 
As IES confessionais necessitam ser, por sua própria vocação, confrontadas com a necessidade de se colocarem na sociedade justamente na função de instrumentos de formação moral e intelectual (WHITE, 2015; TYE, 2000, p. 10-12; PAZMIÑO, 2008; ELIAS, 2002). Neste sentido, o conceito anglo-saxônico de educação nas "artes liberais" se torna um proveitoso ponto de partida para esta discussão (NUNES GIMENEZ, 2021, p. 5). É no amplo conceito de educação nas "artes liberais" que a música encontra sua melhor justificativa como parte de uma cultura universitária. O conceito precisa ser amplo e ir além da tradicional cultura humanista, herança dos séculos XVII e XVIII, de um ser humano culto ou cultivado (MOLES, 1974, p. 10-13). Não basta apenas produzir connoisseurs capazes de apreciar a "grande arte", como foi defendido no passado (HIRSCH et al., 1988, p. 155-189; HIRSCH, 1988, p. 18). São necessárias oportunidades para exercer pensamento crítico, demonstrar criatividade e desenvolver percepção estética (MESA, 2009, p. 58).

\section{MULTICULTURALISMO E MÚSICA NA UNIVERSIDADE CONFESSIONAL}

A presença da arte em geral, mas, especialmente da música, na sociedade contemporânea exige uma apropriação de aspectos do conceito de multiculturalismo, e como esse conceito pode elucidar uma educação estética. Multiculturalismo pressupõe a coexistência de diferentes grupos no mesmo sistema social. Em muitas situações, esta coexistência é improvável se deixada apenas para acontecer como fenômeno natural. Sendo assim, multiculturalismo implica "diversidade cultural". Para que haja diversidade cultural, é necessário que os diferentes grupos tenham oportunidades econômicas, políticas e educacionais similares (PRATTE, 1979, p. 6 e 141). Ao mesmo tempo, uma boa Educação Multicultural não procura interferir na ou suplantar a transmissão de noções abrangentes da Educação Cultural tradicional (ELLIOTT, 1990, p. 152).

É importante destacar a armadilha que existe em uma compreensão permeada pelo viés do neoliberalismo sobre diversidade cultural e multiculturalismo. Frequentemente estes termos são usados para defender a ideia do homem individual em uma cultura laissez-faire de tolerância e paz. Esta cultura de valoração do indivíduo é mediada pelo Relativismo 
Cultural, que possui um irônico caráter padronizador ao fazer uma defesa mercadológica da diversidade que resulta na afirmação de nichos de consumo. A triste realidade é que sob esta falsa bandeira de diversidade o ser humano é reduzido, limitado em suas concepções de si mesmo e do coletivo. Já em um processo educacional enriquecedor as diferenças servem de impulso, estímulo para se encontrar algo maior e mais abrangente (MALANCHEN, 2016, p. 81-93).

Mihalyie Csikszentmihalyi sintetiza a importância de uma interação contextualizada com a música e elucida seu processo de preservação.

Nós não podemos estudar criatividade ao isolarmos indivíduos e suas obras do meio social e histórico onde suas ações foram desenvolvidas. Isto porque aquilo que chamamos criativo nunca é o resultado de ação individual isolada; é o produto de três principais forças modeladoras; um conjunto de instituições sociais, ou área/campo de atividade, que seleciona das variações produzidas por indivíduos aquelas julgadas dignas de serem preservadas; um domínio cultural estável que irá preservar e transmitir para as gerações seguintes as novas ideias selecionadas ou formas que merecem preservação; e finalmente o indivíduo, que traz alguma mudança no área/campo de atividade, uma mudança que a área/campo de atividade vai considerar criativa $^{50}$ (CSIKSZENTMIHALYI, 1988, p. 325).

A música, tal qual outras manifestações e expressões da cultura, nunca é apenas aquilo que aparenta ser, neste caso, música. "Da mesma maneira que cultura não é simplesmente uma coleção de objetos que pessoas têm mas algo que as pessoas fazem, "música" é uma forma específica de

50 "We cannot study creativity by isolating individuals and their works from the social and historical milieu in which their actions are carried out. This is because what we call creative is never the result of individual action alone; it is the product of three main shaping forces; a set of social institutions, or field, that selects from the variations produced by individuals those that are worth preserving; a stable cultural domain that will preserve and transmit the selected new ideas or forms to the following generations; and finally the individual, who brings about some change in the domain, a change that the field will consider to be creative". 
atividade humana"51 (ELLIOTT, 1990, p. 153). A prática musical dialoga intensamente com vários aspectos da existência humana, especialmente com modos de pensar e viver, criando um metadiscurso contextual.

A música não pode ser tratada apenas como assunto de especialistas. Toda a sociedade interage com a música, quer queira, quer não. Gastamos em média 3 horas e meia por dia ouvindo música, 90\% da programação das rádios consiste de música, filmes e programas de TV têm sua trilha sonora. É justamente em função desta presença inevitável, desta pervasividade da música em nossa vida que existe a necessidade de uma educação que contemple explicações "de como as práticas musicais se relacionam com a cultura e a sociedade, incluindo abordagens da semiótica, acústica, negócios em música, psicologia, sociologia, antropologia [e] estudos culturais" (TAGG, 2011, p. 7-9).

Traduzindo isto em termos práticos para IES confessionais que tenham a predominância de uma cultura gospel, é necessário conceber um ambiente musical que contemple os conceitos-chave do multiculturalismo. De maneira específica as IES confessionais devem garantir que a cultural gospel dominante não se torne uma ferramenta de massificação.

Outra consequência negativa de uma monocultura, e consequentemente, de um processo de massificação, é o controle do gosto musical desta comunidade. Existem estudos que apontam como a exposição repetitiva a um repertório musical limitado molda o gosto musical das pessoas (SEREN, 2011, p. 52, 56-58; SOUTO, 2013; OLIVEIRA, 2012; FEIXA-PAMPOLS, 2004; RONSINI, 2007; CASAGRANDE, 2009; MORAIS, 2015). Isto é um triste depauperamento do ser humano que causa o distanciamento e a dificuldade de comunicação entre diferentes grupos. Verdadeiras ilhas de isolamento cultural e religioso são criadas neste processo. As pessoas que vivem em monoculturas musicais são incapazes de perceber o valor, a beleza e o significado de qualquer outra manifestação musical diferente daquilo que aprendeu a gostar através de um processo de massificação. O processo de massificação é negativo em si mesmo, independente daquilo que é massificado. Mesmo a massificação de algo historicamente aceito e estabelecido, como a música de Johann Sebastian Bach, traz graves consequências já que impede o ouvinte a de-

51 "In the same way that culture is not simply a collection of objects that people have but something that people do, "music" is a specific form of human activity" 
senvolver a cognição, a compreensão e a apreciação de qualquer outra manifestação musical. E se este é o caso com Bach, que é considerado algo excelente em termos estéticos, culturais e espirituais, quanto mais ainda se o repertório em questão é grandemente dependente da impressão sensorial causada em seus ouvintes.

\section{ACESSIBILIDADE CULTURAL}

Isto traz ao primeiro plano a questão de acessibilidade cultural. A acessibilidade cultural está intimamente ligada a missão e função da Universidade em seu papel de centro de criação, transmissão e difusão de cultura, assim como promotora de intercâmbios culturais (SÁ-CHAVES, 2007, p. 10). A Universidade confessional contemporânea precisa não somente promover uma interação informada com manifestações de cultura midiática, por exemplo, a cultura gospel, mas também oferecer experiências musicais e culturais que normalmente seus alunos e comunidade em geral não costumam ter acesso. E neste sentido é muito importante dar espaço para o tradicional e histórico, que frequentemente são esquecidos em ambientes de cultura gospel predominante. A rejeição do conhecimento da totalidade e os valores universais é uma herança negativa da globalização e do Pós-modernismo (WOOD, 1999). Isto muitas vezes se reflete no tratamento da música em IES confessionais através do descarte ou menosprezo do histórico e tradicional. Simplesmente as atividades musicais que fundamentam a razão da Educação acabam sendo consideradas um desnecessário acessório, e assim sendo, o acesso a este tipo de enriquecimento cultural é bloqueado a muitas pessoas. Paradoxalmente, é dada primazia à cultura popular, ao saber espontâneo, cujo acesso não depende da Educação formal (SAVIANI, 2001, s.p.).

Um dos principais papeis da Educação é o de mediador entre a vida cotidiana e as esferas não cotidianas da vida humana (DUARTE, 2016, p. 67). Consequentemente, é necessário provisionar ao aluno experiências musicais que suplantem o seu cotidiano. Apenas uma pequena parcela da população estudantil de IES confessionais tem acesso "cotidianamente" a recitais, concertos e programas musicais. Justifica-se então a evidente necessidade de prover este tipo de experiência musical, seja com convidados ou através da ampliação do repertório de grupos musicais da própria insti- 
tuição: corais, orquestras, bandas e outros. É imprescindível levar aos alunos e comunidade universitária em geral música que represente as formas mais desenvolvidas historicamente em razão do conhecimento. E isto se coloca em oposição ao relativismo epistemológico e cultural que permeia grande parte das práticas de Instituições de Ensino Superior (DUARTE, 2016, p. 66-67). Há aqui um importantíssimo diálogo que expande a mente e a cultura. $\mathrm{O}$ acréscimo de novos conhecimentos e experiências enriquecem a experiência anterior, que de forma alguma é excluída.

Ao contrário, o saber espontâneo, baseado na experiência de vida, a cultura popular, portanto, é a base que torna possível a elaboração do saber e, em consequência, a cultura erudita. Isso significa que o acesso à cultura erudita possibilita a apropriação de novas formas através das quais se pode expressar os próprios conteúdos do saber popular. Mantém-se, portanto, a primazia da cultura popular da qual deriva a cultura erudita que se manifesta como uma nova determinação que a ela se acrescenta. Nessa condição, a restrição do acesso à cultura erudita conferirá, àqueles que dela se apropriam, uma situação de privilégio, uma vez que o aspecto popular não lhes é estranho (SAVIANI, 2001, s.p.).

É de suma importância que a Universidade confessional amplie os quadros referenciais conceituais de seus atores (SÁ-CHAVES, 2007, p. 14). A sociedade contemporânea reconhece a crescente necessidade de uma educação em artes liberais para a formação de indivíduos dotados de flexibilidade cognitiva e a capacidade de aprendizado contínuo (LEWIS, 2018 , p. 15). Isto promove o autoconhecimento e o conhecimento do outro, proporcionando enriquecimento social, cultural e intelectual do indivíduo e do coletivo. Pertence também a Universidade confessional a responsabilidade de preparar seus alunos para viverem em uma sociedade cosmopolita e multicultural fazendo com que tenham consciência da variedade de culturas existentes e da necessidade de saberem comunicarem eficientemente através de diferenças culturais (LEWIS, 2018, p. 19). É essencial que o trabalho educacional promova o encontro do universal do gênero humano com o singular (MALANCHEN, 2016, p. 95). 
Isso permite que o trabalho de reconhecimento do outro imediatamente diante de mim seja constante, assim como traz a chance de reconhecimento do outro que não está presente na relação interpessoal direta. Afinal, as obras-primas da humanidade não são um conjunto de conhecimentos autônomos; são produções humanas, fruto das mãos de muitas pessoas que viveram em diversos tempos; gerações participaram e participam de sua construção. Apropriar-se desse saber é, de alguma forma, entrar em contato com esse sujeito histórico que também nos constitui. Nesse sentido, pelo acesso ao conhecimento elaborado, podemos construir uma via solidária e fraterna de encontro com sujeitos empíricos e históricos! (FONTE, 2012, p. 18).

\section{O ESTUDO ACADÊMICO DA MÚSICA}

Na cultura gospel existe a tendência de olhar a música poeticamente como produto de processos biológicos naturais naqueles que foram abençoados com talento. Em contrapartida a este pensamento ingênuo, a Universidade confessional precisa promover o estudo acadêmico da música (ALMEIDA FILHO, 2007). Neste estudo acadêmico, encontramos a realidade de que o desenvolvimento musical de um indivíduo depende muito mais de um conjunto de fatores do que meramente de uma bênção da fada da música. A concepção de que a música é um dom divino acaba afastando as pessoas de uma interação mais informada e edificante com a arte sonora (SCHROEDER, 2004; SCHROEDER, 2005; ELIAS, 1993).

Zorzal elucida através de pesquisa como o ambiente cultural é mais determinante do que talento natural ou genética para o bom desempenho musical.

1. Em várias culturas estudadas por antropólogos há um grande número de pessoas que atingem um nível de expertise musical acima das normas de nossa própria sociedade. Isso sugere que fatores culturais, e não biológicos, limitam a difusão da expertise musical em nossa sociedade. 2. A realização musical nem sempre segue a árvore genealógica familiar. Crianças cujas famílias não possuem antecedentes musicais e que recebem oportunidades apropriadas 
e encorajamento podem atingir resultados excelentes. 3. A maioria dos mais aclamados músicos profissionais não foram crianças prodígios. $\mathrm{Na}$ verdade, estudos revelam que pouquíssimos desses músicos mostraram quaisquer sinais de promessa musical especial na infância, ou ainda, após os primeiros anos de aprendizado no instrumento que os consagraram. 4. Não há exemplos claros de excelentes realizações em composição ou performance musical que não foram precedidos por muitos anos de intensa preparação e prática. No caso de crianças prodígios, seus níveis de prática precoce excedem os de um músico (ZORZAL, 2012 p. 205).

A música é para todos! O fazer musical não depende de talento nato ou de um dom místico concedido somente a alguns. Esta verdade é uma grande contribuição proporcionada através do estudo acadêmico de música!

Outro aspecto que o estudo acadêmico de música esclarece é o propósito do aprendizado e envolvimento com repertório estabelecido na história e tradição. Não entramos em contato com este repertório apenas para cultuá-lo como obras-primas da sociedade (GIROUX, 1999, p. 108). O objetivo maior, neste caso, é oferecer a comunidade universitária a apropriação de formas socialmente desenvolvidas de expressão e sentimento, e não apenas a disseminação ou reprodução de sentimentos já experimentados no cotidiano. Tais experiências permitem ao indivíduo um processo de superação das expressões cotidianas de reação emocional. A música “emprega material extraído da vida cotidiana, mas lhe dá uma configuração diferente, que produz nos indivíduos sentimentos que normalmente não são vivenciados no cotidiano" (DUARTE, 2016, p. 68-70).

Por meio do estudo acadêmico de música, podemos compreender um pouco mais sobre o que a música é. Não podemos olhar a música apenas como uma palavra de seis letras de difícil definição. Somos capazes sim de ter uma conceituação de música que educa nossa interação com esta arte. A música é um fenômeno acústico percebido somente no cérebro. A música pode ser usada para expressar sentimentos e ideias e tem efeitos neurológicos, psicológicos e fisiológicos no ser humano (OLIVEIRA, 2015, p. 42-45). 


\section{DESENVOLVIMENTO INTEGRAL DO SER HUMANO}

As Instituições de Ensino Superior confessionais devem presar pelo desenvolvimento integral do ser humano. Isto implica um desenvolvimento harmonioso das dimensões física, intelectual, emocional e espiritual do ser humano (HINTZ, 2012, p. 43; WHITE, 2015, p. 14; KNIGHT, 2018, p. 175). A própria Bíblia indica este desenvolvimento integrado do ser humano ao descrever o crescimento de Jesus: "Jesus ia crescendo em sabedoria, estatura e graça diante de Deus e dos homens" (Lucas 2:52, NVI).

Existe uma íntima relação entre as quatro dimensões humanas e nossas práticas musicais. A música se relaciona com cada uma destas dimensões e pode ser um catalizador da integração destas dimensões. É fácil compreender a relação da música com nossa dimensão física. Há músicas que simplesmente nos levam ao movimento físico. É muito revelador quando observamos a reação física de crianças pequenas em resposta a estímulos musicais. A relação da música com nossa dimensão física pode ser mais sutil do que isso, quando estamos sob a influência de uma música que tem o propósito de aumentar nossa frequência cardíaca e respiratória para a prática de exercícios em uma academia ou aula de hidroginástica. No caminho inverso, a musicoterapia faz uso de certos tipos de música precisamente para diminuir a frequência cardíaca e respiratória do paciente. Já a relação da dimensão emocional com a música é um pouco mais complexa. Podemos ter experiências emocionais relacionadas a música em diferentes níveis. Algumas experiências podem ser superficiais e outras mais profundas, e estas não são dependentes exclusivamente da música em si. Existe aquilo que podemos chamar de "significado emocional" que muitas vezes é determinado em associação a eventos extramusicais. Mas, de qualquer forma, é inegável que a música pode despertar emoções no ser humano.

A relação entre música e a dimensão mental/intelectual está presente quando a música exige do ouvinte um exercício de raciocínio para que este possa compreendê-la. Nesta perspectiva, este tipo de música não é feito para consumo imediato. É um tipo de música que precisa ser degustada em um amplo processo cognitivo. Este processo cognitivo comumente exige conhecimento histórico, contextualização, relações de memória com experiências anteriores, reflexões dos sentimentos e ideias 
evocados, e a formulação de julgamentos de valor. Naturalmente este processo cognitivo não é um processo espontâneo. Ele precisa ser mediado. Este papel de mediador de experiências musicais intelectuais pertence a Universidade confessional.

A música, por sua própria essência imaterial, é a mais espiritual de todas as artes. A música existe, de fato, somente no momento no qual ela é apresentada, executada. Mesmo uma gravação não é essencialmente a própria música, mas apenas uma representação desta (OLIVEIRA, 2015, p. 42). Esta qualidade temporal da música faz dela essencialmente uma arte espiritual. As definições secular e religiosa da dimensão espiritual humana, apesar de distintas, possuem convergências. Em tempos recentes tem emergido uma linha de pensamento que

[...] sugere que existe uma dinâmica central e universal no desenvolvimento humano que merece ser movida ao centro do palco nas ciências desenvolvimentistas, ao lado e integrada com os outros bem conhecidos fluxos de desenvolvimento: cognitivo, social, emocional e moral. O nome comumente dado a esta dimensão é desenvolvimento espiritual. E é hipotetizado de ser o manancial do qual emergem a busca por significado, conexão com os outros e o sagrado, propósito, e contribuições, cada e todas das quais podem ser abordadas pela religião ou outros sistemas de ideias e crença ${ }^{52}$ (ROEHLKEPARTAIN et al., 2005, p. 5).

A música "possibilita a imaginação humana e assim também a imaginação religiosa a entender e experimentar o transcendente em uma maneira única e espiritualmente valorizada" ${ }^{53}$ (FOLEY, 2015, p. IX). É em

52 " [...] suggests that there is a core and universal dynamic in human development that deserves to be moved to cen- ter stage in the developmental sciences, along- side and integrated with the other well-known streams of development: cognitive, social, emotional, and moral. The name commonly given to this dimension is spiritual development. And it is hypothesized to be a developmental wellspring out of which emerges the pursuit of meaning, connectedness to others and the sacred, purpose, and contributions, each and all of which can be addressed by religion or other systems of ideas and belief".

53 "[...] enables the human imagination and thus the religious imagination to grasp and experience the transcendent in a unique and spiritually prized manner". 
sua relação com a dimensão espiritual que a música pode melhor expressar um sentido profundo.

Som, a essência da música, atribui a arte musical suas características de transitoriedade, dinamismo, intangibilidade, envolvimento e presença. Um quadro está em exibição em uma determinada galeria e ocupa espaço físico. No entanto, a música não está fixa em nenhum lugar. A música é temporal: ela é no momento de sua execução, não foi antes e não será depois. As ondas sonoras viajam a $337 \mathrm{~m} / \mathrm{s}$ em uma temperatura de $25^{\circ} \mathrm{C}$. Esta velocidade é lenta o suficiente para humanos perceberem o som e a música como movimento. A música é intangível e não pode ser percebida pelo tato, visão ou olfato. Outras formas de arte utilizam materiais, mármore, tintas, papel, mas a música está somente no movimento das ondas sonoras.

\section{PENSAMENTOS FINAIS}

O desafio de uma educação universitária enriquecedora é grande. A tentação existe da formação de profissionais altamente especializados, no entanto compartimentalizados, incapazes de uma ampla interação com a sociedade. As exigências do mundo contemporâneo requerem cidadãos de sólida e ampla formação capazes de contribuir para a construção histórico-social da sociedade.

A Universidade confessional, por sua própria vocação, pode e deve contribuir para uma educação que possa nutrir seus alunos e comunidade com o que há de melhor no que já foi feito e está sendo produzido pela humanidade. De maneira específica, a Universidade confessional deve evitar o estabelecimento de monoculturas. Especialmente em relação a presença da música na Universidade confessional deve assegurar uma ampla educação que contemple o tradicional e histórico. A música também deve ser estudada com seriedade, e não apenas considerada um passatempo.

Pertence a Universidade confessional alimentar e desenvolver as dimensões humanas que não são espontaneamente aprimoradas, assim como integrar as 4 dimensões humanas. Isto não quer dizer que expressões musicais das dimensões emocional e física devem ser extintas ou negligenciadas. No entanto, é a vocação da Universidade confessional focar no desenvolvimento intelectual e espiritual de sua comunidade de alunos, professores e agregados. 


\section{REFERÊNCIAS}

ALMEIDA FILHO, Naomar de. As Três Culturas na Universidade Nova. Ponto de Acesso, v. 1, n. 1, 2007.

BALLOUSSIER, Anna Virginia. Carismáticos católicos se aproximam de evangélicos nos ritos e em Bolsonaro. Folha de São Paulo on-line, 03 de novembro de 2019. Disponível em: <https://www1. folha.uol.com.br/poder/2019/11/carismaticos-catolicos-se-aproximam-de-evangelicos-nos-ritos-e-em-bolsonaro.shtml?origin=uol> Acesso em 09 de março de 2021.

BERTOLOTTI, Tommaso. Patterns of rationality: recurring interferences in science, social cognition and religious thinking. New York: Springer, 2015.

CASAGRANDE, Jaques Luis. Influências da Indústria Cultural nas preferências musicais de adolescentes do ensino fundamental e médio: Estudo de caso. Tese (Doutorado em Psicologia) - Universidade Federal do Ceará, 2009.

CHARLE, C.; VERGER, J. História das universidades. Tradução de Élcio Fernandes. São Paulo, SP: UNESP, 1996.

CSIKSZENTMIHALYI, Mihalyi. Society, Culture, and Person: A System's View of Creativity. In: STERNBERG, R. J. (Ed.). The Nature of Creativity: Contemporary Psychological Perspectives. New York: Cambridge University Press, 1988.

CUNHA, Magali do Nascimento. "Vinho novo em odres velhos". Um olhar comunicacional sobre a explosão gospel no cenário religioso evangélico no Brasil. Tese (Doutorado em Ciências da Comunicação) - Universidade de São Paulo, São Paulo, 2004.

DRÈZE, Jacques H.; DEBELLE, Jean. Concepções da Universidade. Tradução Francisco de Assis Garcia e Celina Fontenele Garcia. Fortaleza: UFC, 1983.

DUARTE, Newton. Os Conteúdos Escolares e a Ressurreição dos Mortos: Contribuição à Teoria Histórico-crítica. Campinas: Autores Associados, 2016. 
DURHAM, Eunice R. O ensino superior no Brasil: público e privado. In: Seminário sobre Educação no Brasil. Centro de Estudos Brasileiros; Departamento de Estudos Educacionais da Universidade de Oxford, 11 mar. 2003. Disponível em: <https://sites.usp.br/nupps/wp-content/uploads/sites/762/2020/12/dt0303.pdf> acesso em $25 / 4 / 2021$

ELIAS, John. A History of Christian Education: Protestant, Catholic, and Orthodox Perspectives. Malabar, FL: Krieger Publishing, 2002.

ELIAS, Norbert. Mozart, Sociologia de Um Gênio. Rio de Janeiro: Jorge Zahar, 1995.

ELLIOTT, David J. Music as Culture. The Journal of Aesthetic Education, v. 24, No. 1, Special Issue: Cultural Literacy and Arts Education. Spring, 1990.

FEIXA-PAMPOLS, C. A construção histórica da juventude. In: CACCIABAVA, A.; FEIXA-PAMPOLS, C.; CANGAS, Y. Jovens na América Latina. São Paulo: Escrituras, 2004.

FERREIRA, Manuela Lowenthal. Mercado e discurso na igreja neopentecostal Bola de Neve. Revista ESCRITAS, V. 8 n. 1, 2016.

FOLEY, Edward. Music and Spirituality-Introduction. In: Music and Spirituality. Basel: MDPI, 2015.

FONTE, Sandra Soares Della. Escola, Unidade e Diversidade. In: Anais da Reunião Anual da ANPED, 35, Porto de Galinhas, 2012. Disponível em <http://35reuniao.anped.org.br/images/stories/trabalhos/GT17\%20Trabalhos/GT17-1717_int.pdf> Acesso em: 21 mar. 2021.

GIROUX, Henry A. Praticando estudos culturais nas faculdades de educação. In: SILVA, Tomaz Tadeu da. (Org.). Alienígenas em sala de aula: uma introdução aos estudos culturais em educação. Petrópolis: Vozes, 1995.

HINTZ, Matthew. Paradise Found: Religiosity and Reform in Oberlin, Ohio, 1833-1859. Master Thesis, Clemsom Universi- 
ty, 2012. Disponível em <https://tigerprints.clemson.edu/all_theses/1338> Acesso em: 22 mar. 2021.

HIRSCH, E. D. Cultural Literacy. New York: Vintage Books, 1988.

HIRSCH, E. D.; KETTA, Joseph F.; TREFIL, James. The Dictionary of Cultural Literacy. Boston: Houghton Mifflin, 1988.

JAMIESON, Kathleen Hall; CAPPELLA, Joseph N. Echo Chamber: Rush Limbaugh and the Conservative Media Establishment. Oxford: Oxford University Press, 2008.

KNIGHT, George R. Filosofia e Educação: Uma Introdução da Perspectiva Cristã. Engenheiro Coelho, SP: UNASPRESS, 2018.

LEWIS, Pericles. Globalizing the Liberal Arts: Twenty-First Century Education. In: Higher Education in the Era of the Fourth Industrial Revolution. Singapore: Palgrava MacMillan, 2018.

MALANCHEN, Julia. Cultura, Conhecimento e Currículo. Campinas: Autores Associados, 2016.

MENDONÇA, Antonio Gouvêa. O Celeste Porvir: a inserção do protestantismo no Brasil. São Paulo: ASTE, 1995.

MESA, Carlos Alberto (Coord.). Pedagogia Adventista. Tatuí, SP: Casa Publicadora Brasileira, 2009.

MOLES, Abrahm Antoine. Sociodinâmica da cultura. Tradução de Mauro W. Barbosa de Almeida. São Paulo: Perspectiva (USP), 1974.

MORAIS, Tatyane Pereira. Educação, mídias e indústria cultural: a (de)formação do sujeito na atualidade. 37aㅡ Reunião Nacional da ANPEd, Florianópolis, out. 2015.

NGUYEN, C. Thi. Echo chambers and epistemic bubbles. Episteme: Sep 2018.

NUNES GIMENEZ, Ana Maria; Machado Bonacelli, Maria Beatriz. Repensando o Papel da Universidade no Século XXI: Demandas e Desafios. Revista Tecnologia e Sociedade, v. 9, n. 18, 2013. Dispo- 
nível em: <https://www.redalyc.org/articulo.oa?id=496650340006> Acesso em: 09 mar. 2021.

OLIVEIRA, Jetro Meira de. Massificação musical e a perda da individualidade: implicações para a educação musical. Anais do XXII Congresso da Associação Nacional de Pesquisa e Pós-Graduação em Música - João Pessoa - 2012.

OLIVEIRA, Jetro Meira de. Natureza e Implicações da Música para a Adoração. In: REIS, Emilson; FOLLIS, R.; CARMO, F. (Org.). Bases Bíblicas da Adoração. Parousia, v. 3. Engenheiro Coelho, SP: UNASPRESS, 2015.

PAZMIÑO, Robert W. Foundational Issues in Christian Education: An Introduction in Evangelical Perspective. Grand Rapids, MI: Baker Academic, 2008.

PICOLI, Bruno Antonio; RADAELLI, Samuel Mânica; TEDESCO, Anderson Luiz. Anti-intelectualismo, neoconservadorismo e reacionarismo no brasil contemporâneo: o movimento escola sem partido e a perseguição aos professores. Rev. FAEEBA, Salvador, v. 29, n. 58, p. 48-66, abr-jun. 2020.

PRATTE, Richard. Pluralism in Education. Springfield, IL: Charles C. Thomas, 1979.

ROEHLKEPARTAIN, Eugene C. et al. (Eds). The Handbook of Spiritual Development in Childhood and Adolescence. Thousand Oaks, CA: SAGE Publications, 2005.

RONSINI, Veneza V. Mayora. Mercadores de Sentido: Consumo de Mídia e Identidades Juvenis. Porto Alegre: Sulina, 2007.

ROSAS, Nina. Cultura evangélica e "dominação" do Brasil: música, mídia e gênero no caso do Diante do Trono. Tese de doutorado em Sociologia. UFMG. 2015.

ROTH, Leonardo et al. A estrutura do ensino superior no Brasil. Revista Gestão Universitária na América Latina - GUAL, v. 6, núm. 3, sept. 2013. Disponível em: <https://www.redalyc.org/ pdf/3193/319328457006.pdf> Acesso em: 25 abr. 2021. 
SÁ-CHAVES, Idália. Cultura, Conhecimento e Identidade: Universidade e contemporaneidade. Saber (e) Educar 12, 2007.

SANTOS, Douglas Alessandro Souza; SILVA, José Lucas da; MORENO, Pedro Augusto Caregatti. Chamados ao Entretenimento: A Estratégia do Evangelicalismo Pentecostal na Busca por Espaço no e por Mercado Brasileiro. Áskesis, v.6, n.1, jan-jun. 2017.

SAVIANI, Dermeval. A Educação Musical no Contexto da Relação Entre Currículo e Sociedade. Artigo on-line no site do autor. 2001. Disponível em <https://www.fe.unicamp.br/dermeval/texto2001-6.html> Acesso em: 21 mar. 2021.

SCHROEDER, Sílvia Cordeiro Nassif. O músico: desconstruindo mitos. Revista da ABEM. Porto Alegre, n. 10, p. 109-118, 2004.

SCHROEDER, Silvia Nassif. Reflexões sobre o conceito de musicalidade: em busca de novas perspectivas teóricas para a educação musical. 2005. Tese (Doutorado em Educação), Faculdade de Educação, Universidade Estadual de Campinas. Campinas, 2005.

SEREN, Lucas. Gosto, Música e Juventude. São Paulo: Annablume, 2011.

SMITH, Aaron C. T. 5 reasons why people stick to their beliefs, no matter what. Psychology Today, 28 Mar 2016. <https://www.psychologytoday.com/us/blog/true-believers/201603/5-reasons-why-people-stick-their-beliefs-no-matter-what> Acessado em: 22 jan. 2020.

SOUTO, Sara. A Importância do Tribalismo da Nova Era do Marketing. Revista de Comunicação e Marketing, 5 (1), 2013.

TAGG, Philip. Análise musical para "não-musos”: a percepção popular como base para a compreensão de estruturas e significados musicais. Per Musi, Belo Horizonte, n. 23, 2011.

TAVARES, Sergio Marcus Nogueira. Governança em Universidades Confessionais no Brasil: Modelo em Construção. Educação \& linguagem, v. 12, n. 19, p. 219-238, jan-jun. 2009.

TYE, Karen. Basics of Christian Education. Nashville: Chalice Press, 2000. 
VALLE, Edênio. A Renovação Carismática Católica. Algumas observações. Estudos avançados, v. 18, n. 52, 2004.

WEINGÄRTNER, Martin. A confessionalidade luterana e a questão carismática. Estudos Teológicos, v. 41, n. 3, 2001.

WHITE, Ellen G. Educação: Um Modelo de Ensino Integral. Tradução Flávio Lopes Monteiro. Tatuí: Casa Publicadora Brasileira, 2015.

WOOD, Ellen Meiksins. O que é a agenda "pós-moderna"? In: Wood, E. M.; Foster, J. B. (Org.). Em defesa da história. Rio de Janeiro: Jorge Zahar, 1999.

ZORZAL, Ricieri Carlini. Uma Breve Discussão sobre Talento Musical. Revista Música Hodie, Goiânia, v. 12, n. 2, p. 201-209, 2012.

ZYLBERKAN, Mariana. Evangélicos devem ultrapassar católicos no Brasil a partir de 2032. Veja on-line, 04 de fevereiro de 2020. Disponível em: <https://veja.abril.com.br/brasil/evangelicos-devem-ultrapassar-catolicos-no-brasil-a-partir-de-2032/> Acesso em: 09 mar. 2021. 


\section{AFETIVIDADE E EDUCAÇÃO: A NECESSIDADE DO ENSINO AFETIVO NA EDUCAÇÃO UNIVERSITÁRIA}

Walfrido Monteiro Júnior ${ }^{54}$

\section{INTRODUÇÃO}

Este artigo apresenta reflexões teóricas e práticas sobre a necessidade de introdução de metodologias e estratégias com foco na afetividade na formação universitária do professor. A maior dificuldade apresentada pelos professores do ensino básico é compreender a importância de utilizar os comportamentos de acolhimento, afetividade, prática da escutativa com os estudantes, sensibilidade e compreensão justamente pelo fato de não terem esses temas na formação universitária. Se o professor se interessar por esses assuntos, deverá realizar cursos específicos de pós graduação (lato sensu) por conta própria, ou participar de pequenas formações desenvolvidas pela Secretaria de Educação ou pela Diretoria de Ensino no formato de aulas gravadas, sem a interação entre aluno e professor.

Nota-se que não é possível separar a educação universitária da educação básica, principalmente pelo fato de que é na formação do profissional da educação que atuará no ensino fundamental ou médio que precisará

54 Graduado em Letras (UNIB), graduado em Filosofia (UNIMES), especialização em Gestão Escolar (FALC), especialização em Arqueologia (UNISA), mestrado em processo: Educação Universitária (UNR) e doutorando em Ciência da Educação Superior (UNR). 
obter conhecimentos teóricos e práticos de como se relacionar com a nova geração de alunos (BAUMAN, 2000).

Para a elaboração deste artigo, foi realizada a análise do pensamento complexo do autor Edgar Morin, que aborda de forma atual as necessidades de mudanças de via (caminho) que a educação também deverá passar, principalmente considerando o conceito de mundo complexo. Essas obras serão utilizadas para a fundamentação de que a prática educativa no curso superior deve passar por um processo urgente de adequações; o professor deve se relacionar com o aluno, utilizando da sensibilidade, da amabilidade, da comunicação não violenta, da relação entre o cognitivo e da afetividade, de acordo com (CUDA, 2018).

Outro ponto a destacar que impermeabiliza tais mudanças é a crença de que, na universidade, o cognitivo está separado ou soberano sobre a afetividade e mesmo que poucos trabalhos acadêmicos sejam desenvolvidos ou encontrados nas bases de dados, é possível perceber que já existem estudos que relacionam e potencializam o cognitivo e a afetividade como responsáveis no processo saudável da aprendizagem.

Não somente a fragmentação dos processos de aprendizagem em se separar o afetivo do cognitivo, mas também a aula tradicional, que pode ser encontrada em universidades públicas, em que o aluno é apenas o ser que absorve aquilo que o professor quer ensinar. Se o universitário se posiciona de forma contrária, poderá sofrer com perseguições, já que a relação professor-aluno é vertical, de cima para baixo.

O referencial teórico utilizado é o pensamento complexo de Edgar Morin e, como o próprio autor em seus livros defende, a educação precisa ser holística, respeitando as diversidades culturais, a natureza, a relação de respeito, de sensibilidade, de compreensão e principalmente uma educação humana, com práticas humanísticas para criar um ambiente harmonioso, propício para a aprendizagem saudável.

A metodologia utilizada foi a pesquisa qualitativa, análise bibliográfica, aplicação da enquete com professores da rede estadual de São Paulo, universitários e a conversa informal com professores universitários. Visou-se verificar a compreensão da importância da educação afetiva na universidade e a diferença das respostas por idade, confrontando o pensamento da geração dos nascidos na década de 70,80 com a atual geração de adolescentes universitários e a pesquisa exploratória em três instituições 
acadêmicas, FECAF, UNR e UFABC, que implantaram a afetividade em suas ações pedagógicas.

\section{REFERENCIAL TEÓRICO}

Sobre a definição de afetividade no campo da educação, segundo Cagnin (2008), o assunto pode ser abrangente, pois compara as emoções ou a demonstração de humor como um estado de afetividade. Sobre a importância da afetividade na educação, segundo Cuda (2018), de acordo com os estudos da Neurociência, o ser humano possui duas reações quando está diante de situações agressivas ou de ameaça; ou ele ataca como uma forma de se proteger ou ele foge, por isso a importância de o professor utilizar recursos afetivos para construir um ambiente seguro, de confiança entre professor-aluno.

Como já mencionado, uma das razões encontradas para a exclusão da afetividade ou da educação afetiva no mundo acadêmico é a premissa defendida pelo viés científico de que os processos do intelecto ou do conhecimento devem ser desprovidos de sentimento (MATOS, 2008). No entanto, para Morin (2020a), tanto para o mundo mamífero como para o ser humano, o desenvolvimento da inteligência é inseparável da afetividade. $\mathrm{Na}$ Conferência Internacional Sobre os Sete Saberes Necessários à Educação do Presente, realizada em Fortaleza de 21 a 24 de dezembro de 2010, foram criados vários consensos sobre os principais passos para a educação do futuro, podendo ser expandida desde a educação infantil à educação superior. Em uma dessas recomendações, destaca-se:

São necessárias novas práticas pedagógicas para uma educação transformadora que esteja centrada na condição humana, no desenvolvimento da compreensão, da sensibilidade e da ética, na diversidade cultural, na pluralidade de indivíduos, é que privilegie a construção de um conhecimento de natureza transdisciplinar $[\ldots]$ (MORIN, 2010, p. 13).

Várias são as tentativas de blindagens por parte de professores universitários para não associarem a importância do processo cognitivo com o afetivo. De acordo com Matos (2008), os professores titulares e antigos das 
instituições educativas superiores são professores da geração anterior de 70, 80, e não aprenderam a trabalhar de forma afetiva; ou são educadores substitutos que não possuem o intuito de criar afinidades com os estudantes. Já os professores das universidades particulares mais atenciosos, principalmente pelo fato de não perderem alunos ou o seu emprego.

Para Morin (2020), um dos grandes problemas da educação, seguindo a tradição de Descartes, é a fragmentação do conhecimento, das disciplinas, dos saberes, construindo assim a invisibilidade do contexto, do global, do multidimensional e do complexo. Ou seja, para esta investigação, o professor do futuro ou que possui a missão de ensinar, motivar, transmitir confiança e obter ações de sensibilidade, compreensão e afetividade deverá construir um novo olhar perante os seus alunos; ele precisa entender de forma holística a realidade, as defasagens, as dificuldades, as culturas e principalmente as diversidades do ser humano.

Por isso a necessidade da transformação do ensino superior fragmentado em uma educação planetária, global e complexa, já que as relações humanas são complexas. Segundo Morin (2020a, p. 34): "Unidades complexas, como o ser humano ou a sociedade, são multidimensionais: assim o ser humano é ao mesmo tempo, biológico, psíquico, social, afetivo e racional". Portanto, a relação professor universitário-universitário não pode ser uma relação entre polos em que se apenas transmite um conhecimento para alguém que pode ou não compreender, que pode ou não estar passando por problemas psicológicos, como o estresse, o medo, a ansiedade ou a depressão.

Essa é a importância do contexto, do olhar holístico, colocar-se no lugar do outro, perceber que o ser humano é psíquico, biológico, afetivo (MORIN, 2020), que possui suas frustrações, limites, medo, raiva, mas que também é dotado de capacidades; e que o professor, seja ele do ensino básico ou do ensino universitário, deve agregar a suas práticas pedagógicas a sensibilidade, a compreensão e a afetividade.

Sobre a relação entre afetividade e cognição, para Almada (2014), quando o ser humano está ou se sente acuado, com medo, inseguro, pode apresentar reações diversas; uma delas é o congelamento. Este, trazido para a realidade da sala de aula, é o comportamento de não participação, de não exposição, pois teme ser ridicularizado, exposto, agredido. Já para Cuda (2018), é importante a reação agradável, harmoniosa e 
afetiva entre professor-aluno, pois a confiança contribui para a melhoria na aprendizagem.

A pedagogia da presença defendida por Costa (1991) possui congruências em relação às premissas defendidas por Morin, no sentido de que o professor constrói uma nova forma de olhar o alunado, de educador transmissor de conteúdos e detentor do conhecimento. O professor passa a ter um olhar mais humanizado, compreendendo a realidade social e psicológica, sem julgamentos, construindo uma relação horizontal, que segundo Morin (2020b), é a desconstrução de posicionamentos egoístas e egocêntricos.

Essa integração entre afetividade e cognição também é defendida por Mahoney (2005, p. 15) que afirma:

O motor, o afetivo, o cognitivo, a pessoa, embora cada um desses aspectos tenha identidade estrutural e funcional diferenciada, estão tão integrados que cada um é parte constitutiva dos outros. Sua separação se faz necessária apenas para a descrição do processo. Uma das consequências dessa interpretação é de que qualquer atividade humana sempre interfere em todos eles. Qualquer atividade motora tem ressonâncias afetivas e cognitivas; toda disposição afetiva tem ressonâncias motoras e cognitivas; toda operação mental tem ressonâncias afetivas e motoras. E todas essas ressonâncias têm um impacto no quarto conjunto: a pessoa, que, ao mesmo tempo em que garante essa integração, é resultado dela.

A importância da não dissociação entre o racional e o afetivo ficou evidente com o surgimento da pandemia em 2020, pois para Morin (2020b), fomos surpreendidos em 2020 com o surgimento da Covid-19. Estávamos acostumados com a nossa vida, com os nossos costumes e em março desse ano, tivemos que reaprender a viver, com as nossas dores e convivendo com a dor do outro. Segundo Morin (2020b, p.27): “O isolamento nos tornou subitamente reclusos dentro de nossa própria casa e às vezes dentro de nós mesmos".

Sobre a importância da relação não agressiva nas interações humanas, nas relações professor-aluno, a missão de educar deve ser não somente como uma mera transmissão, mas no escopo de ajudar o outro na sua própria 
evolução, na sua aprendizagem, na sua construção. No entanto, de acordo com Morin (2020b), a reforma é pessoal, cada professor escolhe a maneira que deve ensinar, a sua postura e a sua relação com os alunos, conforme a citação a seguir:

Solidariedade e responsabilidade são imperativos não só políticos e sociais, mas também pessoais. Desde já deveríamos entender que reforma da sociedade e reforma pessoal são inseparáveis. Gandhi escreveu: "Sejamos a mudança que queremos ver no mundo". Ora, muitos de nós vivem numa separação total entre ideias altruístas e comportamentos egoístas. Como quer ter acesso a um mundo de compreensão, benevolência e solidariedade quem não é compreensivo, benevolente e solidário? Como pode edificar um mundo de relações humanas melhoradas quem continua egoísta, vaidoso, invejoso, mentiroso?

Diante disso, Morin afirma (2020b) no final de seu livro, que é hora de mudarmos de via lições do coronavírus, descreve a sua preocupação sobre o retorno das pessoas a uma condição anterior da pandemia, perdendo o senso de solidariedade, do processo de escutativa (ouvir o outro sem a construção de prejulgamentos), sensibilização, altruísmo. Por tanto esse é o momento da revolução, de se construir, mesmo que usando a analogia do trabalho de formiguinhas, a educação planetária, complexa para assim poder compreender o mundo complexo, desfragmentado e afetivo. Que a universidade e principalmente os professores agreguem em suas aulas a afetividade, a sensibilização, a compreensão; e que a razão fria, insensível, o conhecimento pelo próprio conhecimento seja substituído pela razão sensível. Morin (2020b, p. 87) define com maestria:

Mais ainda: a razão sensível precisa integrar o amor em si mesma. O amor é a mais forte e mais bela relação intersubjetiva que se conhece. $\mathrm{O}$ amor na humanidade extrapola as relações entre indivíduos, irriga o mundo das ideias, da seiva à ideia de verdade, que nada é sem o amor à verdade; é o único complemento possível da liberdade, pois sem ele a liberdade se torna destrutiva. $\mathrm{O}$ amor deve ser introduzido, em relação indissolúvel e complexa, 
no princípio da racionalidade. Deve construir um componente da racionalidade complexa.

Nota-se a importância da reformulação ou, como prevê Morin, a reforma da educação, tanto de baixo para cima como de cima para baixo, pois todos esses níveis são relacionados. O universitário que cursa o mestrado ou o doutorado, terá duas escolhas, lecionar para a formação de professores ou apenas se tornar pesquisador, se escolher a primeira opção, terá a responsabilidade de preparar os professores para a educação básica, e os seus alunos terão a sua postura, a sua condução na aula como uma inspiração.

Não basta somente ensinar sobre História, Filosofia, Língua Portuguesa, mas preparar esses futuros profissionais a compreender a alma humana, a aplicar o olhar sensível, a usar a comunicação não violenta, e utilizar a afetividade e a motivação em suas aulas, criando um espaço agradável, que poderá contribuir no processo de ensino e aprendizagem.

\section{METODOLOGIA}

A metodologia utilizada nesta pesquisa foi a análise bibliográfica utilizando os principais conceitos do pensamento complexo de Edgar Morin sobre a utilização da afetividade ou da educação afetiva no ensino superior. Analisou-se a parceria entre o Instituto Ayrton Senna e a Secretaria de Educação do Estado de São Paulo, sobre a realização de cursos e formações sobre a educação socioemocional. No caso para a educação básica, tal situação pode ser desenvolvida por universidades a partir de Congressos, incentivos à publicação de artigos científicos ou propostas de linhas de pesquisas para o mestrado e doutorados.

Para ampliar o horizonte da possibilidade de aplicação da educação afetiva ou afetividade nas universidades públicas ou privadas, foi realizada a pesquisa exploratória em três instituições de educação. Verificou-se a possibilidade da utilização da afetividade, da motivação, do diálogo não violento em espaços universitários. A primeira foi o curso de Medicina da UNR, Universidade Nacional de Rosario na Argentina; a segunda, FECAF, instituição privada de educação, localizada em São Paulo, Taboão da Serra e a terceira: UNIFABC, Universidade Federal do ABC, localiza- 
da na região do $\mathrm{ABC}$, mais especificamente em São Bernardo do Campo. Nas duas primeiras instituições de educação, foram aplicadas a entrevista e a conversa informal com alunos.

\section{CURSO DE MEDICINA DA UNR - ARGENTINA}

Localizada na região de Santa Fé, em Rosario, universidade possui um número significativo de estudantes brasileiros, principalmente nos cursos de Medicina e Educação Superior. No caso do primeiro curso, o ingresso é automático, não precisando realizar o vestibular, apenas um minicurso MIU - Modulo de Inclusão Universitária ou como os próprios alunos chamam de: "período de adaptação"

Para esta pesquisa, 10 estudantes de Medicina dessa instituição foram entrevistados, sendo nove brasileiros e um argentino. As questões foram enviadas pelo WhatsApp, as principais questões levantadas foram sobre a relação professor-aluno, sobre o curso, a metodologia do curso e o nível de satisfação dos estudantes. Todos os entrevistados afirmaram que se não fosse pela iniciativa da Argentina de possibilitar que brasileiros estudem sem a mensalidade e sem o vestibular, dificilmente poderiam cursar Medicina.

A metodologia, segundo os alunos, é desfragmentada, ou seja, eles precisam primeiramente entender sobre o problema do paciente e depois recorrer a todos os conhecimentos, que se completam, para assim pensar em uma ação médica. O método muito usado por essa instituição é o PBL, aprendizagem baseada em problemas.

Sobre a relação entre professor e aluno, todos disseram que os professores são muito respeitos, mas exigentes. Se por acaso um aluno encontra alguma dificuldade, ele pode recorrer a um professor que irá sanar todas as dúvidas. Um dos entrevistados havia estudado o curso de Direito no Brasil e disse que estranhou muito tal possibilidade de ajuda. Nas palavras do entrevistado: "lá no Brasil, quando o aluno está com dúvidas, é cada um por si"; o aluno argentino disse que é comum essa postura entre os professores, que sabem ser exigentes com respeito, e um dos princípios mais respeitados na Argentina é a ética.

A última pergunta foi sobre a questão da utilização da afetividade nas aulas, como os brasileiros percebiam a condução da aula. Uma entrevista- 
da, relatou que no início houve o estranhamento, primeiro por conta da diferença da língua, depois sobre a postura dos professores, fala da entrevistada: "são muito responsáveis com o horário da aula, alguns são divertidos, outros são mais sérios, porém muito respeitosos, conversam com carinho e são preocupados em saber se realmente estamos aprendendo, se algum aluno brasileiro não consegue entender a pronúncia, eles falam com mais calma".

Outra característica que se destaca é a interdisciplinaridade; como explicam os próprios alunos, não basta saber um pouco sobre cada disciplina, é necessário saber resolver um determinado problema.

As aulas e disciplinas são separadas por ciclos de áreas do conhecimento, esses alunos também possuem orientações sobre questões sociais, outro ponto que se destaca, pois não é só formar um profissional, mas formar um perfil profissional com responsabilidade social, ética e com respeito às diversidades e principalmente à afetividade com os pacientes.

Como já mencionado, a estrutura e utilização diferente da abordagem de aula tradicional se estende a todos os cursos da UNR, como se pode verificar no Estatuto da Universidade aprovado em 22 de junho de 1998 e modificado em 12 de outubro de 1998. 2001 e 25 de setembro, 2007. Segundo os entrevistados, os princípios fundamentais que se defende no curso de medicina: Qualidade de vida para todos, respeito entre profissional e paciente, formação ética, respeito aos direitos humanos, cidadania, afetividade, holística visão dos problemas de saúde, no que diz respeito à diversidade e multiculturalismo, princípios e valores humanos que se também são defendidos no pensamento complexo.

\section{FACULDADE FECAF - FACULDADE CAPITAL FEDERAL}

Esta é localizada na região de Taboão da Serra e é mantida por grupos de empresários com o intuito de proporcionar qualidade na educação e preços acessíveis para a população. Foi realizada a pesquisa exploratória em campo para perceber a relação dos professores e alunos, dois alunos participaram da pesquisa e da entrevista, sendo que foram eles que mostraram o prédio.

Segundo os universitários, a premissa defendida pela instituição é o uso da afetividade em todas as repartições da instituição, principalmente 
na relação professor e aluno, a instituição conta com laboratórios de química, biologia, artes cênicas e arte visual, os universitários aprendem na prática, e se apresentarem dúvidas sobre o conteúdo é comum o professor estar disposto para ajudar, esse também é um critério para a contratação do profissional.

\section{UNIFABC - UNIVERSIDADE FEDERAL DO ABC}

Esta universidade foi fundada em 2005, considerada nova na história das universidades federais no Brasil, porém apresenta três pontos inovadores que contribuem para esta pesquisa. O primeiro a destacar é a interdisciplinaridade entre os cursos: o estudante que estuda Direito pode realizar disciplinas vinculadas a outras áreas do conhecimento, é a única universidade federal do Brasil a possuir todos os professores doutores, e considerada uma das melhores, ocupando o $1^{\circ}$ lugar entre as universidades brasileiras no Ranking SCImago nos quesitos "Excelência em Pesquisa", "Publicações de alta qualidade" e "Impacto normalizado das suas publicações".

Outro diferencial é a relação professor-aluno: de acordo com a análise exploratória e análise de caso, é defendida na universidade a utilização da afetividade como meio para construir um ambiente agradável e que promova o bem-estar dos professores e alunos. Ressalta-se que se os estudantes apresentarem dificuldades de aprendizagem, existe a possibilidade de agendamento com os professores para sanar as dúvidas. Outra preocupação da instituição é em relação a ansiedade e depressão, existem aulas e eventos típicos que abordam sobre esses temas.

Sobre as aulas, foi analisada a aula de pós-graduação (mestrado) em Filosofia. Foi utilizada a metodologia dialógica e nas apresentações de trabalhos, os estudantes expõem pesquisas realizadas na educação básica, destaca-se a forma de comunicação calma e afetiva dos professores com os universitários e a sua reciprocidade, criando um ambiente harmonioso.

Esta pesquisa exploratória serviu para evidenciar que é possível a implantação da afetividade, da educação não violenta ou da educação afetiva; precisa-se transformar o ambiente que forma os futuros profissionais da educação, não importando se atuarão em escolas públicas ou privadas. Como Morin define (2020), a missão do professor tem que ser além da 
mera transmissão de informações, segundo Matos (2008, p. 17) sobre a relação professor-aluno:

O modelo de professor é aquele que expõe; o de aluno é passivo, memorizador. Em geral, reforçam-se relações individualistas, competitivas e não dialógica entre docentes e alunos, alunos-alunos, quando o correto deveria se relações do tipo aprender-a-aprender, garantindo pensamentos críticos criativos, construtores de novas soluções para os novos problemas da sociedade.

Este é o professor chamado de linear ou reducionista, compreende apenas que a sua função é formar trabalhadores, segundo Matos (2008), essa prática é muito comum nas universidades, e tal posicionamento se relaciona com o mito do professor detentor do conhecimento e se relaciona com Morin (2020b) sobre a cegueira do conhecimento. O professor que possui essa postura nem se preocupa em conhecer o aluno, saber dos seus gostos, das suas intenções com o curso, apenas é um ser ouvinte, como define Matos (2008, p. 18):

Esse professor não se preocupa com uma aprendizagem significativa; a vida do aluno, seus sentimentos e emoções, suas dificuldades não lhe tocam. Enquanto não houver uma profunda reforma do pensamento, a universidade não será uma instituição, com o escopo maior de colaborar para a mudança social.

No entanto, existem instituições como foram mostradas nesta pesquisa, que mesmo que isoladas, estão tentando criar suas próprias revoluções na educação. É fundamental quebrar o paradigma de que a universidade e suas práticas devem perpetuar a sistematização de aulas frias, congeladas, com regras que mais servem para humilhar, ofender, diminuir os estudantes, como será visto a partir da aplicação da enquete realizada com professores da rede pública de educação básica, universitários e professores universitários.

Sobre essa necessidade de mudança, segundo Matos (2008), tais propostas contribuem para a construção de um espaço que não só privilegia o intelectual, mas também o emocional e o afetivo. Preparar boa aulas, estabelecer relações agradáveis em que todos possuem o direito da comu- 
nicação, da relação de confiança, de ser acolhido, respeitado, admirado e incentivado a buscar caminhos melhores, pois segundo Mora (2013), as pessoas somente podem aprender aquilo que elas amam.

Foi realizada a aplicação da enquete com 66 participações divididas entre professores e universitários, após o registro do questionário dividido em nove perguntas. As pessoas que responderam "sim" na primeira questão foram entrevistadas, principalmente para aprofundar as respostas apresentadas. No entanto, somente 20 permitiram que suas respostas fossem informadas neste artigo. Mesmo considerando o número de participantes, o importante foi analisar de forma qualitativa o quanto as ações em sala de aula podem gerar frustrações, mal-estar, estresse e até depressão.

\section{RESULTADOS E DISCUSSÕES}

\section{VOCÊ JÁ FOI MAL TRATADOIA EM SALA DE AULA POR PROFESSOR UNIVERSITÁRIO? $0 / 66$ retpostas cocretas}

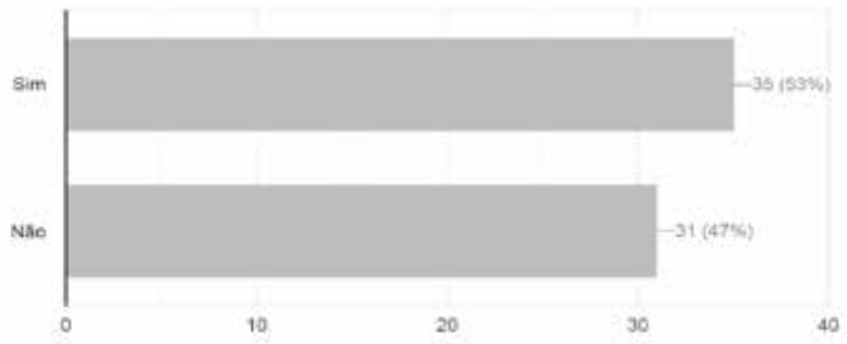

Enquete realizada pelo Google Forms, por conta da pandemia e da quarentena ocorrida em São Paulo, 2021.

Nota-se que se for considerado o número de entrevistados e a diferença entre as respostas sim e não é insignificante. No entanto, o objetivo da aplicação da enquete foi perceber que de 66 pessoas, 35 passaram por alguma situação de maus-tratos. Considerando portanto, a compreensão da qualidade do problema, essa resposta passa a ser significativa. Vinte participantes responderam a questão aberta - 2 sobre como se sentiram diante da situação vivida, 15 participantes solicitaram que as declarações não fossem informadas nesta pesquisa, por conta da gravidade das situações. A questão 2 será utilizada no final do artigo. 
3. CONTINUANDO A PERGUNTA DE NÚMERO 2, DIANTE DESSA SITUAÇÅO, VOCÊ PENSOU EM DESISTIR DO CURSO?

$0 / 66$ respostas corretan

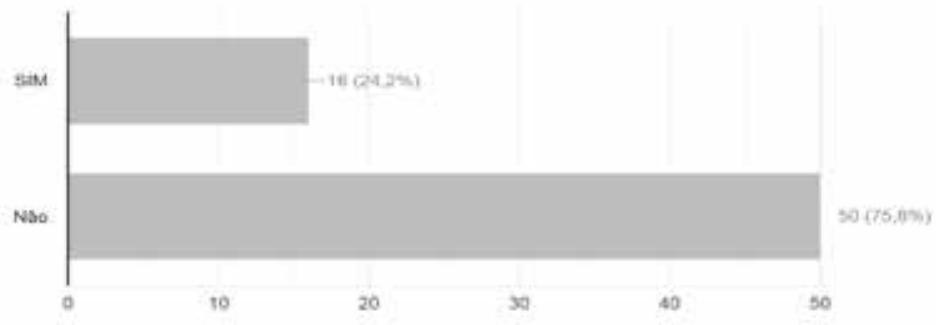

Sobre a questão 3, os participantes que informaram que não desistiriam do curso por causa da relação curso e profissão. Muitos professores iniciam a prática docente estando no início da graduação e para que não percam as aulas, eles precisam estar cursando um curso de educação superior. Atualmente na rede pública estadual, essa regra foi alterada, para que o professor participe da atribuição de aulas, necessita apresentar comprovação de 50\% da realização do curso superior, o que prejudica a desistência. Relataram também que a troca de universidade é uma tarefa difícil, pois muitas vezes as grades das disciplinas não são iguais.

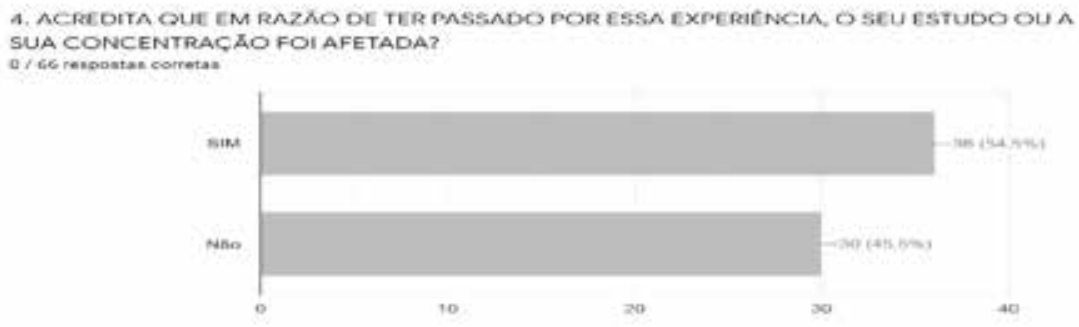

Um dos entrevistados declarou: "sabe aquela frase - engole o choro e continua". Compreende-se que tal postura do professor ou o ocorrido não teria acontecido se o professor tivesse preparo socioemocional ou aplicasse em suas aulas o conceito da afetividade. 


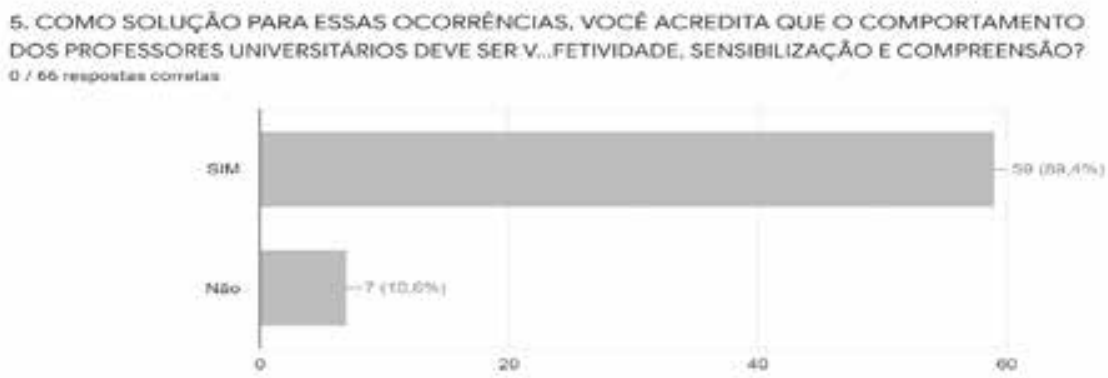

Apenas sete responderam que não, ou seja, fica evidente a importância da aplicabilidade dessas posturas ou formações, que já são conhecidas na rede estadual de São Paulo. Na realidade das Universidades, a afetividade, sensibilização e compreensão ainda não são inseridas nos programas de formação de professores, graduações e pós-graduações (mestrado e doutorado) ou muito menos exigidas pela instituição a ação dos professores.

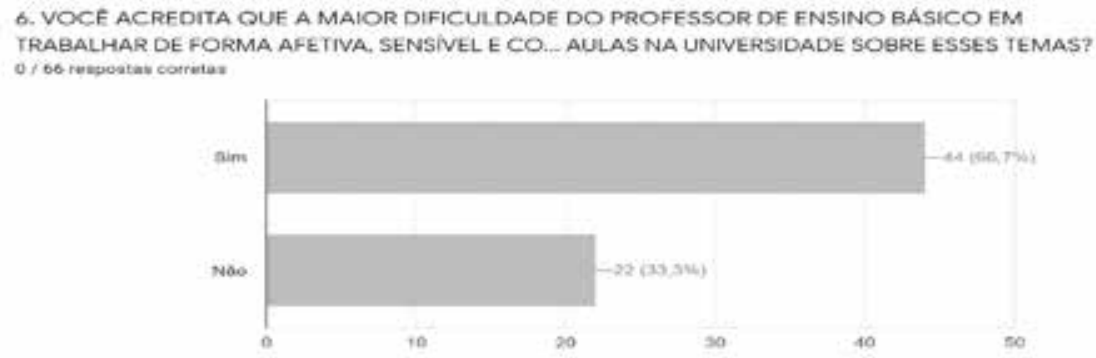

A questão 6 questiona se a maior dificuldade do professor de ensino básico em trabalhar de forma afetiva está na ausência de formação da universidade. Nota-se que é uma escolha pessoal a transformação, pois muitos professores ainda defendem o ensino tradicional. 
7. VOCE PREFERE TER AULAS COM PROFESSORES OUE SÃO AGRADÁVEIS NA COMUNICAÇĀOO. PACIENTES, COMPREENSIVEIS E MOTIVADORES?

$0 / 66$ respoatas corretas

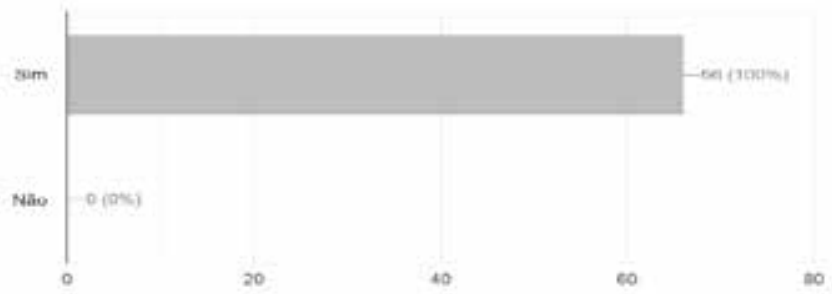

6. (PANDEMIA - 2020 E 2021 ) A AUSENCIA DE AFETIVIDADE, SENSIBILIZAÇĀO E MOTIVACĀO POR PARTE DOS PROFESSORES UHIVERSITARIOS EM AULAS REMOTAS OU HIBRIDAS PODE CONTRIBUIR RARA O DESESTIMULO DO ALUNO OU ATRAPALHA LO NO ENTENDIMENTO DO CONTEUDO?

0) 06 inspostas sorretas

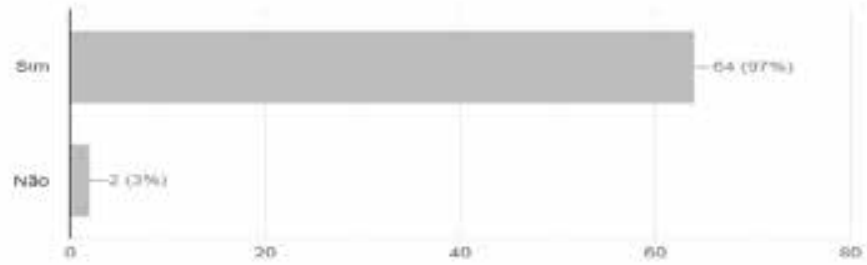

9. DUAIS SAOOAS PRINCIPAIS MUDANGAS PEDAGOGICAS CUE A UNIVERSIDADE PRECISA REALIZAR?

60 inspostas

Precisa ser maso humana

Conscienuzar os professores e todo o corpo acadernico sobre os efeitos colaterais, puncipalmente na saude mental do alunos, como consequencia dos maus tratos

Aboutaueros diferentes com as plataformas utilizadas, pmmatir que o aluno exerca monitorias

Realizar workshops para alunos e peofessores sobre afetividode e campreensăo nesses tempos dificeis de pandermis

O que muitas das vezeo acontece que o profodeor se torno um especialieto em uma determinada area $\mathrm{e}$ nao te trabalha o tado pedagogico que trabalha essas aree palcosecelol

investir em uma formaça de qualidade, cobrar e nao certificar pessoas que nao tem condiçao nenhuma de estar em uma sala de auta como protestor, educador. infedizmente a educaço esta sucateada devido a pessima formagaso dessec educadotes.

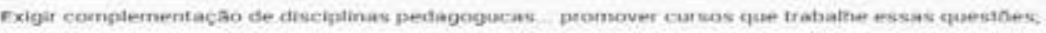




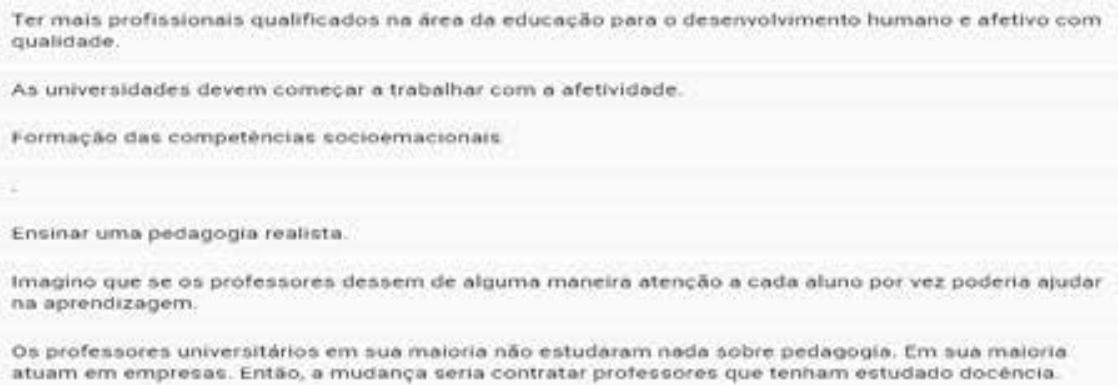

Os professores universitabitos em sue maioria nóo estudaram nada sobre pedaoogio, Em sub maiorie

Abaixo estão as respostas autorizadas para serem inseridas na pesquisa, remetendo à questão 2. Se a sua resposta for "sim", para a questão anterior, como você se sentiu?

"Me senti incapaz de continuar o curso".

"Me senti desmotivada a continuar. Acredito que ninguém tem o direito de fazer o outro se sentir mal. "Em sala de aula pior ainda, pois a pessoa está em busca de conhecimento, muitas vezes está pagando por isso, mas independente de pagar ou não, o tratamento deve ser respeitoso para todos. Alunos são cristais a serem lapidados e que privilégio um professor tem de saber que todos as pessoas que se tornam profissionais vêm do saber passado por ele".

"Péssima, pensei em desistir, chorei por dois anos"

"Envergonhada, me sentindo inferior, inútil"

"Triste e desmotivada".

"Impotente"

"Humilhada"

"Com medo, acuada"

"Senti muita raiva, e disse a mim mesma que ele nao me intimidaria”.

"Triste e deprimida"

"Humilhado"

"Muito mal" 


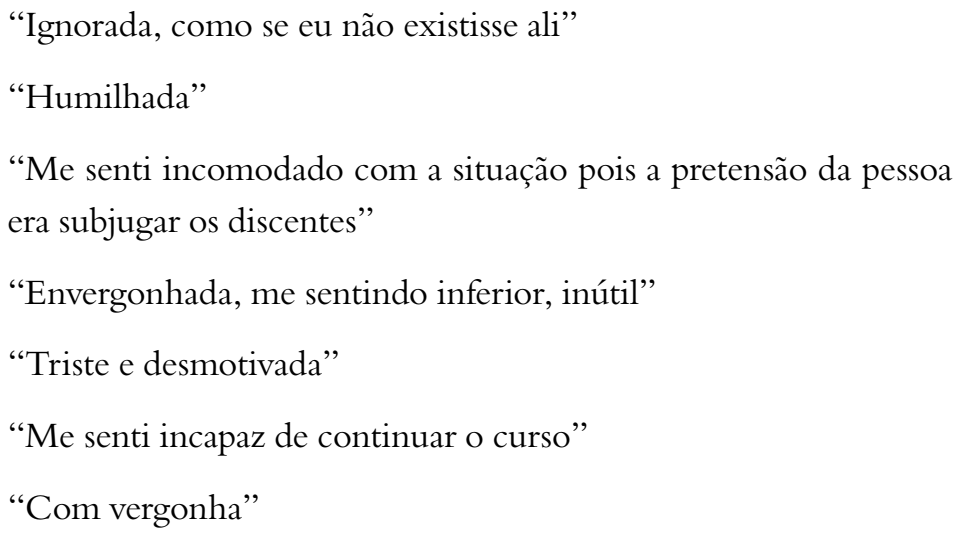

\section{CONSIDERAÇÕES FINAIS}

Ao finalizar a pesquisa, lança-se a reflexão sobre a importância da inserção de práticas afetivas ou a educação afetiva na educação superior como forma de garantir a formação sadia e a construção do ambiente saudável que propicia a aprendizagem. Nota-se que é uma escolha pessoal, o professor decide qual a maneira de trabalhar com a sua turma. É preciso compreender que a educação tradicional tende a transmitir conhecimentos de forma engessada e que sem a presença da afetividade, da comunicação não violenta e da construção de um espaço harmonioso, agradável e que permita o bem-estar, a relação professor-aluno será afetada e poderá também afetar as condições psicológicas do universitário contribuindo para o prejuízo da aprendizagem.

Tudo o que foi exposto corrobora a construção de novas pesquisas sobre a educação significativa, afetiva, motivadora e transformadora. Mesmo considerando que, no Brasil, existem poucos trabalhos sobre a importância da afetividade na educação superior, pôde-se apresentar três instituições que estão buscando, cada uma com a sua forma particular, melhorias na educação. Isso é significativo para os estudantes, e por se destacarem ou serem diferentes, essas instituições estão também construindo uma história de sucesso.

Não cabe mais a aula tradicional em uma sala de aula, seja em que nível for; o conhecimento deve ser ensinado, mas o respeito ao próximo é imprescindível, tudo é uma questão de possibilidade. Tem-se como exemplo também a ação do Instituto Ayrton Senna em conjunto com a 
Secretaria de Educação do Estado de São Paulo, que propôs algo novo: formar professores para a educação do futuro, mais humana, sensível e compreensiva.

Por conta das respostas dos participantes, percebe-se a necessidade gritante de mudança, e no caso na rede estadual de educação, a intervenção é mais fácil, por ser uma rede e uma proposta única de ação. Ou seja, os professores deverão trabalhar dessa forma, principalmente por conta da pandemia e das diversas realidades em que os professores precisam lidar, pais desempregados, muitos dos alunos tiveram que trabalhar para garantir o sustento da família, as notícias de falecimento de parentes e familiares dos estudantes - então, era o momento da transformação.

No caso da universidade, a situação é mais complexa, já que tal ação ocorrerá por escolha do professor e trabalhará de forma isolada, ou será uma decisão da instituição de mudar sua prática educativa. Este foi o caso da FECAF, UNR e da UNIFABC, que além de acrescentar a afetividade, a comunicação não violenta em todas as aulas, também é a primeira e única universidade a trabalhar de forma interdisciplinar, e todos ganham com essas alterações.

\section{REFERENCIAS}

ALMADA, Leonardo Ferreira. A neurociência afetiva como modelo explicativo das emoções básicas. Psicologia Argumento, dez. 2014. Disponível em: https://www.academia.edu/

BAUMAN, Zygmunt. Modernidade líquida. Rio de Janeiro: Jorge Zahar Ed., 2000.

BRUNER, Jerome. Cultura, mente y educación. In: La educación, puerta de la cultura. Madrid: Aprendizaje Visor, 1996.

CAGNIN, Simone. Algumas contribuições das neurociências para o estudo da relação entre o afeto e a cognição. Estudos e Pesquisas em Psicologia, ago. 2008. Disponível em: http://www.redalyc.org

CUDA, Mariela. Neurociencias, Didáctica, y Pedagogía: aportes de la escuela de hoy. 1ํㅡㄹ ed. Ciudad Autonoma de Buenos Aires: Bonum, 2018. 
CURRÍCULUM de Medicina de la Universidad Nacional de Rosario www.unr.edu.ar. Estatuto de la U.N.R - www.unr.edu.ar

GARDNER, H. (2001). Inteligência: um conceito reformulado. (Silva, A.C., Trad.). Rio de Janeiro: Objetiva. (Original publicado em 1999).

Mentes que mudam. Porto Alegre: Bookman, Artmed, 2005.

GOLEMAN, D. La Práctica de la Inteligencia Emocional. Barcelona: Kairós, 1998.

MACLEAN, P. Triune brain: archipalium (reptilian brain), paleopalium (mammal brain), neopallium (rational brain), 1997. Disponible en: http://www.phys.uni.torun.pl/ duch/ref/00 -how-brain/

MATOS, Sandra Maria S. Afetividade e educação: a dimensão afetivo-vivencial na relação professor-aluno em manifestações de formandos do curso de pedagogia, um estudo sobre o prisma do pensamento complexo. / Sandra Maria Sousa Matos. São Paulo, 2008.

MORA, Francisco. Neuroeducación: solo se puede aprender aquello que se ama, 2013. Alianza editorial. Disponível em: https://www. amazon.com.br/

MORIN, Edgar. É hora de mudarmos de via: lições do coronavírus. Rio de Janeiro: Bertrand Brasil, 2020.

. Educação e complexidade: os sete saberes e outros ensaios.São Paulo: Cortez, 2007.

. Introducción al pensamiento complejo. Gedisa, 1996.

. La vía. Para El futuro de la humanidad. Espasa Libros, 2011.

PÉREZ LINDO, Augusto, ¿Para qué educamos hoy? Filosofía y teoría de la educación. Buenos Aires: Biblos, 2010.

SIQUEIRA, Vinicius. Modernidade Líquida. Mauá, SP: Edição do Autor, 2017. 


\section{OS DESAFIOS DO ENSINO JURÍDICO E O PROFESSOR COMO MEDIADOR EM TEMPOS DE COVID-19}

Gabrielle Apoliano Gomes Albuquerque Pearce ${ }^{55}$

Luiz Alberto Gomes Barbosa Neto ${ }^{56}$

\section{INTRODUÇÃO}

Em virtude da pandemia causada pelo novo coronavírus (Covid-19), houve diversas transformações na sociedade. Uma delas foi a necessidade de isolamento social a fim de diminuir e evitar o contágio dessa nova doença. Com isso, diversos serviços tiveram que se adaptar, dentre eles, a categoria do ensino superior.

Os cursos de Direito que eram realizados apenas de forma presencial passaram a ocorrer imediatamente na modalidade remota ${ }^{57}$, a fim de não prejudicar o processo de ensino aprendizagem. Como em toda mudança surgem desafios, neste caso não foi diferente. A formação dos professores

55 Mestre em Direito, com ênfase em Direito Privado; Juíza leiga vinculada a Turma Recursal dos Juizados Especiais do Estado do TJCE; Advogada inscrita na OAB/CE; Docente do Curso de Graduação em Direito no Centro Universitário INTA - UNINTA e na Faculdade de Tecnologia do Nordeste - FATENE.

56 Mestre em Políticas Públicas e Sociedade. Advogado. Especialista em Planejamento, Implementação e Gestão de EAD. Especialista em Direito, Políticas Públicas e Controle Externo. Docente do Curso de Graduação em Direito do Centro Universitário INTA (UNINTA).

57 Modalidade de ensino que o professor e alunos se relacionam através de uma sala virtual, síncrona em tempo real. 
e a realidade dos alunos da área jurídica eram direcionadas ao ensino presencial, mas houve uma imposição abrupta da aprendizagem por meio da tecnologia com respaldo do Ministério da Educação. Nesse novo cenário, a mediação, que essencialmente é conhecida como método de solução de conflito, pode ser um instrumento que auxilie na adaptação dos alunos ao ensino desenvolvido neste novo modelo.

Por isso, este trabalho busca responder à seguinte pergunta: quais desafios surgiram no ensino jurídico em virtude da imposição do uso da tecnologia durante a pandemia causada pelo novo coronavírus e como as técnicas de mediação de conflitos poderia auxiliar neste processo de ensino-aprendizagem em meio remoto?

O objetivo desta pesquisa é esclarecer e expor as transformações e dificuldades enfrentadas no ensino superior nos Cursos de Direito em tempos de Covid-19. Tem como justificativa esclarecer e apresentar o assunto para a sociedade, instigando o aprofundamento e a qualificação do debate na área. Ademais, a importância do trabalho para a comunidade acadêmica está refletida no sentido de fomentar e contribuir com as pesquisas na temática, uma vez que existe uma situação nova para todos os envolvidos.

Para tanto, inicialmente, será analisado o ensino do Direito antes da pandemia, analisando a pedagogia e andragogia. Ato contínuo, será apresentada a reflexão sobre a utilização das técnicas de mediação de conflitos como um instrumento de facilitação da aprendizagem, a fim de avaliar se elas podem ser utilizadas também no ensino remoto durante a pandemia para, ao final, expor os desafios do ensino do direito durante a pandemia e a atuação do professor como mediador.

\section{PARADIGMA DE ENSINO DO DIREITO ANTES DA PANDEMIA: A TRANSIÇÃO NECESSÁRIA ENTRE A PEDAGOGIA E A ANDRAGOGIA}

O Brasil é o país que mais tem faculdades de Direito no mundo. $\mathrm{Na}$ década de 1990, havia 225 instituições de ensino jurídico e, em 2021, tem-se mais de 1.500. Existem, até o ano de 2021, mais de um milhão e trezentos mil advogados registrados na OAB; e mais de um milhão de estudantes de Direito no país. Fora uma quantidade de aproximadamente dois milhões de bacharéis em Direito. 
Embora tenhamos todo esse "exército de operadores do Direito" no país, o ensino jurídico vem sendo criticado há décadas e continua sendo criticado por diversos professores e pesquisadores, dentre os quais: Roberto Lyra Filho (1980), Luis Alberto Warat (1982), José Eduardo Faria (1987), Horácio Wanderlei Rodrigues (1988), Antonio Alberto Machado (2009), Alexandre Morais da Rosa (2013), Lenio Luiz Streck (2014 e 2017), Francisco Soares Campelo Filho (2017) dentre outros. A maioria das críticas gravitam em torno de dois pontos: 1) o modelo de ensino medieval que é praticado em quase todo as faculdades jurídicas nacionais sem grandes modificações, salvo raras exceções e 2) o paradigma educacional ainda bastante baseado na pedagogia e não na andragogia.

Sobre o primeiro ponto, infelizmente, o modelo de ensino jurídico não mudou muito desde a criação dos dois primeiros cursos de Direito no país em 1827, em Olinda, no Estado de Pernambuco e em São Paulo, capital. Tal modelo já era inspirado nas faculdades medievais europeias, principalmente, na de Coimbra, onde a maioria dos bacharéis da elite da época se formavam antes da criação dos citados cursos (VENANCIO FILHO, 2011).

O foco do ensino se dava pelas aulas magistrais dos grandes professores e mestres das letras jurídicas da época. O paradigma da aula expositiva fundamentado na autoridade do professor/palestrante sobre o assunto tratado, o que foi descrito e criticado por Paulo Freire como sendo um tipo de educação "bancária", na qual o docente deposita os conteúdos aprendidos anteriormente na cabeça dos discentes, sem a participação concreta e significativa destes, ou seja, a relação entre docente-discente se dá de forma narrativa ou dissertativa, e não pelo diálogo:

A narração, de que o educador é sujeito, conduz os educandos à memorização mecânica do conteúdo narrado. Mas ainda, a narração os transforma em "vasilhas", em recipientes a serem "enchidos” pelo educador. Quanto mais vá "enchendo" os recipientes com seus "depósitos", tanto melhor educador será. Quanto mais se deixem docilmente "encher", tanto melhores educando serão. Desta maneira, a educação se torna um ato de depositar, em que os educandos são os depositários e o educador, o depositante. Em lugar de comunicar-se, o educador faz "comunicados" e depósi- 
tos que os educandos, meras incidências, recebem pacientemente, memorizam e repetem. Eis aí a concepção "bancária" da educação, em que a única margem de ação que se oferece aos educandos é a de receberem os depósitos, guardá-los e arquivá-los. (FREIRE, 2018, p. 80)

Essas relações se perpetuaram e ainda se perpetuam no ensino jurídico brasileiro, devido aos efeitos prolongados dos fenômenos da "concursocracia", da "simplificação", da "esquematização", da "estandartização" e da "pedagogia da prosperidade", descritos pelo professor Lenio Luiz Streck (2017), e aprofundados pela expansão desenfreada das vagas de cursos de Direito no país.

O segundo ponto crítico apontado é o paradigma educacional voltado para a pedagogia ao invés de um paradigma andragógico que existe desde a década de 1970 e, ainda, é pouco discutido e implementado no ensino superior brasileiro. Esse paradigma educacional se fundamenta na situação de ensino de pessoas com uma idade mais avançada, geralmente, no ensino superior, numa situação totalmente diferente do discente das séries escolares do ensino fundamental e médio.

Para esse tipo de ensino, buscam-se aplicar técnicas voltadas para esses discentes que buscam uma aplicação prática efetiva do que aprendem nos cursos superiores, e a utilização de metodologias ativas como a laboratórios de laboratórios de aplicação prática (cultura maker), gamificação (cultura gamer), sala de aula invertida, simulações de situações reais (role- play) estratégias baseadas em times ou de resolução de problemas reais, utilização de aplicativos como kahoot e socrative que incentivam o uso do celular para resolver questões ou realizar competições individuais ou em coletivas.

Portanto, a andragogia pode ser utilizada através das seguintes estratégias:

1) possibilitam a utilização do conhecimento e das experiências que os aprendizes possuem como base para novas aprendizagens;

2) envolvem o exercício pleno da criatividade, desde as elaborações cognitivas, tais como: resumos de textos, avaliação crítica, pesquisas e apresentações sobre determinado assunto, autoavaliação; bem 
como de: simulações, construções coletivas de jogos de aprendizagem, dramatizações, criações de poesias, músicas, danças e tantos outros contextos artísticos diversos. (CONCEIÇÃO NETO; MOURA, 2019, p. 47)

Como falado, esse paradigma educacional foi difundido na década de 1970 por autores como Carl Rogers e Malcolm Knowles. Knowles, influenciado pelas ideias de Rogers, fez uma comparação entre os paradigmas educacionais da pedagogia e andragogia:

[...] onde ser vê uma ideia clara de que a andragogia desenvolve o senso crítico, a criatividade e a autonomia. O aluno sente-se cidadão do mundo, participante da construção do seu processo do saber e do aprender. Quando o aluno desenvolve a capacidade de conhecer o mundo através dos seus próprios referenciais de interpretação, como ser pensante e reflexivo, pode transformar esse mundo (CONCEIÇÃO NETO; MOURA, 2019, p. 48)

O grande obstáculo é o próprio modelo de ensino superior; os docentes não recebem uma formação específica para a andragogia, exigem-se apenas diplomas de pós-graduação na modalidade de mestrado ou doutorado para poder se tornar professor do ensino superior. Assim,

Livros, teses, revistas especializadas, e até mesmo debates nas redes sociais em relação a EaD, no Brasil e no mundo são inúmeros e todas convergem para a real necessidade de rever currículos, práticas e metodologias, apontando para a real importância da inserção da Andragogia nos currículos, para que esses professores, além de dominar os seus princípios, tenham maior capacidade para inseri-la em seus planejamentos e possam executar com mais propriedade as atividades do ensino-aprendizagem, sobretudo via AVA. (MENDES, LOPES, SOUZA et al, 2012, p. 1345)

Apesar dessas dificuldades, o ensino jurídico teve oportunidade de mudar ao longo do tempo, mas como demonstrado acima não houve muitas alterações. Contudo, a pandemia causada pelo novo coronavírus apresentou uma necessidade de mudança imediata, sem que fosse possível 
um período para a adaptação. Desta forma, a mudança paradigmática que deveria ter ocorrido com o passar do tempo ocorreu de forma brusca, em especial, pela mudança do ensino presencial para o on-line (remoto), causando muitos conflitos entre todos os envolvidos na situação.

\section{A MEDIAÇÃO COMO UM INSTRUMENTO DE APRENDIZAGEM}

O direito do acesso à justiça, princípio consagrado Constituição $\mathrm{Fe}-$ deral de 1988 (CF/88), representa a preocupação do ordenamento jurídico brasileiro com a efetiva solução dos conflitos. Existem, contudo, alguns obstáculos à efetivação deste princípio. Dentre eles, podem ser citados a situação econômica das partes, dado os custos elevados do processo, além de honorários advocatícios e eventuais despesas, como honorários periciais e taxas cartorárias, o desconhecimento dos direitos previsto na legislação resulta que as pessoas não visem reivindicá-los (MARASCA, 2007, p. 42) e, ainda, a falha na prestação jurisdicional.

Todas essas razões motivam as partes envolvidas a buscarem outras formas de solucionar suas lides, sem enfrentar as dificuldades acima elencadas, a exemplo dos meios alternativos de solução seus conflitos, como a conciliação, a mediação e a arbitragem, previstos no CPC/15. Estes meios, que possuem como características a cooperação, a confidencialidade, a ênfase no futuro e a economia de dinheiro, tempo e energia, (KLUNK, 2021, p. 77) buscam a solução dos litígios de maneiras diversa do processo civil tradicional, mas seguindo os mesmos princípios.

Apresentam-se, ainda, como reflexo da dignidade da pessoa humana, pois garante ao indivíduo a possibilidade de solução do conflito por meio da comunicação mútua entre as partes envolvidas compartilhando sentimentos, problemas, soluções e mudanças de atitudes para a pacificação do mesmo. ${ }^{58}$

58 Conforme o entendimento de Sidney Guerra e Lilian Emerique, a dignidade humana é um princípio que "impõe um dever de abstenção e de condutas positivas tendentes a efetivar a proteger a pessoa humana". GUERRA, Sidney; EMERIQUE, Lilian Márcia Balmant. O Princípio da Dignidade da Pessoa Humana e o Mínimo existencial. Revista da Faculdade de Direito de Campos, ano VII, n. 9, dez., 2006, p.7-8. Nesse sentido, pode-se concluir que as condutas em prol do acesso à justiça, a exemplo dos meios alternativos de solução de conflitos, por serem 
Com base nestes preceitos, surgiu a mediação como um meio de resolução do conflito. Este ideal foi buscado na elaboração do novo CPC, ao destacar a importância deste método. Nesse contexto, é possível afirmar que a mediação é um método já utilizado desde a antiguidade, mas que teve destaque no ordenamento jurídico brasileiro a partir de 2015, com o Novo Código de Processo Civil. A Comissão de Juristas do Senado Federal, responsável pela elaboração do projeto de lei do CPC argumento que esta norma "proporcione à sociedade o reconhecimento e a realização dos direitos, ameaçados ou violados, que têm cada um dos jurisdicionados".

Como citado, um meio de solução alternativa de conflito é a mediação, onde o terceiro envolvido se chama mediador e busca ajudar as partes omitindo-se de expressar opinião ou juízo de valor, devendo somente proporcionar aos litigantes a oportunidade de abordar sobre os problemas do conflito por meio do diálogo e, se assim desejarem, acordarem em uma solução (REIS, COUTINHO, 2018, p. 17).

Apesar da semelhança entre a mediação e a conciliação, a diferença está no fato de que o mediador tem uma posição menos ativa, não refletindo superioridade, mas sim, igualdade entre as partes, o que transmite confiança para buscar auxílio com o mediador, que oportuniza as partes a buscarem a solução para o caso em tela. O mediador "é um facilitador que estimula as partes a encontrar uma solução harmônica para o litígio, enquanto o conciliador tem o papel mais propositivo, e quanto necessário oferece às partes alternativas por ele próprio desenvolvidas para a solução do litígio" (CHIMENTI, 2015, p. 89).

Como se percebe-se, a mediação é um método que auxilia na resolução dos conflitos. Contudo, pelas características que lhe são próprias, seria possível aplicá-la no ensino jurídico remoto que ocorre durante a pandemia da Covid-19, na figura do docente como mediador. Veja-se que a mediação possui diversas características que podem ser utilizadas pelo professor-mediador:

[...] os efeitos potenciais da mediação são o reforço à capacidade das pessoas de tomar decisões sozinhas (empowerment) e de verem e considerarem as perspectivas dos outros (recognition)

condutas positivas em auxiliar os litigantes a buscar solução de seus conflitos de forma justa, apresentam-se como reflexo do respeito ao princípio da dignidade da pessoa humana. 
Suas principais características são:

(i) A descrição do papel e dos objetivos do terceiro em termos baseados na capacitação (empowerment) e no reconhecimento (recognition);

(ii) o apoio a um contexto que se desenvolva por meio da autoria e dos esforços das próprias partes;

(iii) a ausência de julgamento dos pontos de vista e das decisões das partes;

(iv) a postura otimista em relação à competência e aos motivos das partes, sem julgamentos sobre as pessoas e seu caráter;

(v) a emoção como parte integrante do conflito, e não algo a ser evitado ou redirecionado;

(vi) a exploração da ambiguidade das partes;

(vii) a concentração no momento presente da interação do conflito;

(viii) a possibilidade de tratar acontecimentos passados em busca do seu valor para o presente;

(ix) a possibilidade de flexibilização da sequência da interação do conflito; e

a sensação de êxito se o empowerment e o recognition são observados. (ALMEIDA; PANTOJA; PELAJO, 2016, p. 42).

Além destas, há uma técnica aplicada na mediação que pode ser um instrumento a ser utilizado pelo professor: a escuta ativa.

Por meio da escuta ativa, todos os envolvidos na mediação devem escutar com atenção as preocupações, manifestações e perspectivas de cada uma das partes. O Manual de Mediação do Conselho Nacional de Justiça explica que:

Ouvir ativamente significa escutar e entender o que está sendo dito sem se deixar influenciar por pensamentos judicantes ou que contenham juízos de valor - ao mesmo tempo deve o ouvinte demonstrar, inclusive por linguagem corporal, que está prestando atenção ao que está sendo dito. Isso não quer dizer que o media- 
dor deva concordar com a parte. Recomenda-se que apenas deixe claro que a mensagem que foi passada por compreendida. Muitas vezes, uma parte que se apresenta inicialmente com semblante fechado e postura não cooperativa pode adotar uma postura bastante produtiva, apenas porque sentiu que não foi ouvida com atenção. Isso porque ser ouvido significa ser levado a sério (BRASIL, 2016, p. 202-203).

Considerando as considerações acima expostas e os desafios surgidos no ensino do Direito durante a pandemia da Covid-19, importante analisar como as características da mediação podem ser utilizadas pelo professor frente as dificuldades encontradas. Este tema será discutido no tópico a seguir.

\section{DESAFIOS DO ENSINO DO DIREITO DURANTE A PANDEMIA ENTRE O REMOTO (ON-LINE) E O EAD E O PROFESSOR-MEDIADOR}

Diante da situação excepcional causada pela Covid-19, os cursos presenciais tiveram que se adaptar, de forma imediata, às aulas realizadas remotamente. Considerando que "a educação é, acima de tudo, o meio pelo qual a sociedade renova perpetuamente as condições da sua própria existência" (DURKHEIM, 2014, p. 103), é necessário que as instituições de ensino superior e os professores mantenham-se no papel de auxiliar na educação para que a sociedade continue existindo e evoluindo.

Como apresentado acima, a mediação apresenta-se como um instrumento a ser utilizado no processo de aprendizagem diferenciado imposto pelo novo coronavírus. Desta forma, o professor apresenta-se como mediador nesse processo, sendo uma figura central que buscará propiciar aos discentes um ensino efetivo e andragógico.

Para adaptar-se a este novo modelo, uma possível estratégia é a adoção de aulas remotas. Nesta modalidade, o ensino presencial físico é transposto para o ensino por meios digitais, com mesmo currículo, metodologias, práticas pedagógicas, e com o mesmo tempo "ou seja, a aula ocorre num tempo síncrono seguindo princípios do ensino presencial”. O docente ministra a aula por meio de webconferência de forma que "a presença 
física do professor e do aluno no espaço da sala de aula geográfica são substituídas por uma presença digital numa sala de aula digital" (MOREIRA; SCHLEMMER, 2020, p. 9). Neste sentido, um dos desafios para este novo modelo de ensino é a implantação de uma plataforma virtual para intermediar o contato com alunos e professores, pois por meio deste instrumento há "uma comunicação de mão dupla entre as partes" (OLIVEIRA; SANTOS, 2020, p. 15).

Nos cursos de Direito presenciais, como em qualquer outro curso que possua apenas a modalidade de ensino presencial, pode ser que a instituição de ensino superior não possua esse tipo de sistema ou plataforma o que pode dificultar a mudança para o novo modelo. Contudo, o objetivo das aulas remotas deve ser fornecer o acesso temporário e rápido do ensino, e não proporcionar um ecossistema on-line robusto (MOREIRA; SCHLEMMER, 2020, p. 9). Neste diapasão, não se deve exigir a elaboração de uma plataforma extremamente bem elaborada, mas permitir que o ensino continue mantendo os ideais do ensino presencial.

Nesse sentido, é possível que se utilizem as ferramentas disponíveis na rede mundial de computadores que proporcionem aos discentes uma sala de aula virtual. Existem plataformas virtuais como o Zoom e o Google Meet, em que é possível se conectar com um vasto número de pessoas em uma sala de virtual. Na utilização destas, o professor deve utilizar as técnicas de mediação, como a escuta ativa, a fim de aproximar as partes envolvidas no processo de ensino-aprendizagem. Destaca-se que esta aproximação é um dos objetivos da mediação como solução de conflitos que pode ser utilizada no ensino.

$\mathrm{Na}$ implantação desta plataforma, outro desafio que pode surgir é como capacitar os docentes para utilizá-la. Importante ressaltar que em virtude do isolamento social causado pela pandemia do novo coronavírus, tal capacitação também deve ser realizada de forma remota. Esta capacitação é importante para auxiliar os docentes a compreender a nova realidade, dado que os professores precisam desenvolver, constantemente, seu pensamento crítico. Frente a isto é que os docentes serão "capazes de formar criticamente seus alunos” (SILVA; CARVALHO, 2019, p. 168), inclusive neste novo modelo.

Em pesquisa realizada com 34 professores que trabalham com ensino à distância, constatou-se que 10\% dos entrevistados não havia formação 
para esta modalidade e 29\% apresentaram que a ausência de qualificação é um assunto que dificulta o trabalho docente (ABREU; NOVAES; ZARRO, 2020). Ressalta-se que a pesquisa trata do ensino à distância, e não do ensino remoto em específico. Porém, considerando a semelhança do ambiente virtual utilizado para os dois modelos de ensino, é importante expor que é uma dificuldade a ausência de capacitação no ensino à distância, o que também pode ser vislumbrado no ensino remoto.

A necessidade de uma capacitação objetiva é importante diante do pouco tempo para a adaptação do modelo presencial para o remoto. Todavia, nada impede que continuem a acontecer ciclos de formação dos professores paralela a ocorrência de aulas remotas, abordado sobre a mediação no processo de ensino à medida que os docentes forem vivenciando as demandas no ensino remoto. Logo, ao passo que o docente adquirir conhecimentos, irá executá-los de imediato.

Os alunos do curso do Direito possuem disciplinas práticas onde aprendam a elaborar petições, realizam atendimento ao público e lidam com processos judiciais reais. A realização dessas aulas práticas é outro desafio a ser enfrentado, pois é importante para a formação do discente o trato com o público, simulando uma situação real que possa ser vivenciada após o fim do curso.

É importante salientar que deve haver autorização do órgão responsável, qual seja, o Ministério da Educação para que se realize tais atividades de forma remota. Porém, a realização de tais atividades práticas se mostra possível pois grande parte dos processos judiciais são eletrônicos. Desta forma, poderia haver um meio de comunicação em que público entrasse em contato informando seu caso, tal fato seria encaminhado ao professor responsável pela disciplina prática e este realizaria a divisão de processos aos discente. Todo esse processo seria realizado de forma remota.

Salienta-se que esta proposta seria uma mudança no processo de ensino dessa disciplina prática. Porém, a pandemia exige a adoção de novos procedimentos de ensino. Aqui, mais uma vez, a mediação pode ser inserida. Neste caso, além do professor como mediador, o docente deve ensinar aos alunos técnicas de mediação para que estes apliquem com os assistidos. Estes também estarão participando de um procedimento diferenciado por meio de instrumentos tecnológicos, o que pode fazer com 
que se sintam receosos. Assim, a mediação pode auxiliar aos assistidos a ter confiança nos discentes e no processo.

Outra dificuldade a ser enfrentada é captar a atenção do aluno quando se está cercado de mídias e tecnologias. Para solucionar esta questão, deve haver uma mudança cultural alterando a visão de que o aluno deve ter atenção do professor para o fato de que o professor deve ganhar à atenção dos discentes (FILATRO, 2019, p. 83). Logo, o professor, com base na capacitação realizada pela instituição de ensino superior, deve se utilizar de instrumentos que capte a atenção do aluno, tornando a aula mais interativa e lúdica e, assim, facilitar o processo de ensino aprendizagem.

Uma mediação entre professores e alunos realizada pelos meios tecnológicos de informação, por meio de chat, fórum ou videoconferência, promove uma aprendizagem colaborativa e significativa (COSTA, 2017, p. 72). Estas são ferramentas que o docente pode se utilizar para obter a atenção do docente, pois proporciona um aprendizado mais dinâmico.

É importante ressaltar que, assim como qualquer âmbito educacional, no ensino nas instituições de ensino superior, presencial ou à distância, é necessário que seja estabelecido como o conteúdo será apresentado, os materiais didáticos a ser utilizados, bem como a escolha da metodologia e, ainda, o canal de contato dos discentes com os professores e a instituição. Juntos, estes elementos "fundamentam a construção e a reconstrução constante do sentido atribuído pelas pessoas envolvidas ao processo de ensino-aprendizagem" (FILATRO, 2018, p. 26).

Expor ao discente como o conteúdo será exposto, esclarecendo os materiais a ser trabalhados e a metodologia ser utilizada poderá trazer uma segurança para o aluno de como a disciplina ocorrerá de forma remota, o que fortalece a credibilidade de que o ensino naquele modelo seguirá os ditames do ensino presencial.

\section{CONCLUSÃO}

Para os cursos de Direito realizados apenas na forma presencial houve uma mudança significativa, em tempos de Covid-19, ao ter que adaptar-se ao modelo de ensino para que ele fosse ofertado por meio de plataformas digitais. Apesar de ser um novo modelo de ensino, os ideais da mediação, método de solução de conflito já conhecido e difundido em diversas áreas 
do conhecimento como o Direito, podem auxiliar na relação entre os alunos e o professor, apresentando-se este como verdadeiro mediador.

Dentre os desafios encontrados, constatou-se que a formação do docente, quanto à utilização destas ferramentas e quanto ao conhecimento das técnicas da mediação, como uma dificuldade, dado que o professor do ensino presencial não tem familiaridade com os instrumentos do ensino à distância ou do ensino remoto e, por vezes, não havia recebido capacitação em técnicas mediativas. Para solucionar este ponto, é possível a realização de cursos formativos contínuos, ainda que em paralelo a execução das aulas remotamente. Desta forma, os ensinamentos da formação podem ser implantados de imediato.

Há, ainda, a dificuldade de implantação de uma plataforma a ser utilizada, na medida em que as instituições de ensino superior podem não ter um sistema virtual, dado o ensino ser apenas presencial. Contudo, considerando a situação excepcional, não se deve exigir uma plataforma completa, mas apenas uma que possibilite a interação entre os docentes e discentes a fim de não prejudicar o processo de ensino-aprendizagem.

$\mathrm{Na}$ execução das aulas por tais instrumentos, outra dificuldade a ser enfrentada é conseguir manter a atenção dos alunos. Neste aspecto, o professor deve interagir com os discentes por meio de ferramentas virtuais, como chats ou fórum, a fim de proporcionar um ambiente virtual mais dinâmico e atrativo, aproximando os discentes e docentes como ensina à mediação ao buscar o estabelecimento de laços entre os envolvidos.

Constata-se que apesar da mediação ser utilizada no curso de Direito como um método de solução de conflito, percebe-se que ela também pode ser aplicada como um instrumento que auxilie no procedimento de ensino aprendizagem diferenciado durante as aulas remotas impostas pelo isolamento social causado pelo novo coronavírus.

A escuta ativa é uma técnica que deve ser aprimorada ainda mais nas aulas remotas, pois como a comunicação ocorre por meios virtuais, e muitas vezes em aulas gravadas, o discente pode ficar receoso de se expressar. Assim, o professor, como mediador, deve ter atenção neste momento a fim de aprimorar a comunicação entre as partes e compreender os interesses dos envolvidos.

Além disso, a aproximação entre os discentes e o docente deve ser um objetivo a ser alcançado. O estabelecimento de laços entre as partes envol- 
vidas no processo mediativo é um foco do mediador. Nas aulas remotas, o professor, como mediador, deve buscar estabelecer laços entre ele e os discentes para que estes se sintam acolhidos nesse modelo de ensino diferente do que estão habituados. Isto será essencial para que o ensino, de fato, ocorra. Assim, o professor, além de ser um facilitador da aprendizagem, apresenta-se com verdadeiro mediador no processo de ensino.

\section{REFERÊNCIAS}

ABREU, Enoque; NOVAES, Maria Angélica; ZARRO, Maria Izadora Mendonça. Desafios na formação dos professores para atuação na EAD. Paidéi@, Revista Científica de Educação à distância, v. 12, n. 21, 2020. Disponível em: https://periodicosunimes.unimesvirtual.com.br/index.php/paideia/article/view/939/923. Acesso em: 15 mar. 2021.

ALMEIDA, Diogo Assumpção Rezende de; PANTOJA, Fernanda Medina; PELAJO, Samantha. A mediação no Novo Código de processo civil. 2. ed. São Paulo: Forense, 2016.

BRASIL. Conselho Nacional de Justiça. Azevedo, André Gomma de (Org.). Manual de Mediação Judicial. Brasília: CNJ, 2016. Disponível em: https://www.cnj.jus.br/wp-content/uploads/2015/06/ f247f5ce60df2774c59d6e2dddbfec54.pdf. Acesso em: 15 mar. 2021.

CAMPELO FILHO, Francisco Soares. O advogado e a sua formação: é preciso (re)pensar o ensino jurídico no Brasil. 2017. Disponível em: https://www.conjur.com.br/2017-ago-19/campelo-filho-preciso-repensar-ensino-juridico-brasil. Acesso em: 10 mar. 2021.

CHIMENTI, Ricardo Cunha. A conciliação e a mediação no novo Código de Processo Civil e nas leis n. 13.129/2015 e 13.140/2015. Cadernos Jurídicos da Escola Paulista da Magistratura, São Paulo, ano 16, n. 41, jul./set., 2015, p. 89-108.

CONCEIÇÃO NETO, Vera Lúcia da, MOURA, Guilherme Lima. Práticas andragógicas criativas no ensino superior de administração: efetividade à aprendizagem ou "mise em scène"? Revista Gestão Or- 
ganizacional, v. 17, Edição 1, 2019, p. 46-57. dx.doi.org/10.21714/ 1679-18272019v17Ed. p.46-57.

COSTA, Adriano Ribeiro da. A educação a distância no Brasil: concepções, históricos e bases legais. Revista Científica da FASETE, Paulo Afonso, ano 11, n. 12, p. 59-74, jul. 2017. Disponível em: https://www.unirios.edu.br/revistarios/media/revistas/2017/12/a_educacao_a_distancia_no_brasil_concepcoes_historico_e_bases_legais. pdf. Acesso em: 15 mar. 2021.

DURKHEIM, Émile. Educação e Sociologia. Lisboa: Edições 70, 2014.

FARIA, José Eduardo. A reforma do ensino jurídico. São Paulo: Sergio Antonio Fabris, 1987.

FILATRO, Andrea. Metodologia Inovativas na educação presencial, a distância e corporativa. São Paulo: Saraiva, 2018.

FREIRE, Paulo. Pedagogia do oprimido. 65 ed. Rio de Janeiro: Paz e Terra, 2018.

KLUNK, Luzia. O conflito e os meios de solução: reflexões sobre mediação e conciliação. In: SPLENGER, Fabiana Marion; SPLENGER NETO, Theobaldo (Orgs.) Mediação enquanto política pública: o conflito, a crise da jurisdição e as práticas mediativas. Santa Cruz do Sul: EDUNISC - Editora UNISC, 2012, p. 77.

LYRA FILHO, Roberto. O direito que se ensina errado. Brasília: Centro Acadêmico de direito da UnB, 1980.

MACHADO, Antônio Alberto. Ensino jurídico e mudança social. 2 ed. São Paulo: Expressão Popular, 2009.

MARASCA, Elisângela Nedel. Meios alternativos de solução de conflitos como forma de acesso à justiça e efetivação da cidadania. Revista Direito em Debate, Ijuí, ano XV no 27, 28, jan-jun/ jul-dez. 2007.

MENDES, M. C.; LOPES, V. C.; SOUZA, H. A.; VIANA, D. G.; BUENO, S. V. ANDRAGOGIA, MÉTODOS E DIDÁTICA DO 
ENSINO SUPERIOR:: NOVO LIDAR COM O APRENDIZADO DO ADULTO NA EAD. Revista Gestão \& Saúde, [S. l.], v. 3, n. 1, p. 1366-1377, 2017. Disponível em: https://periodicos. unb.br/index.php/rgs/article/view/165. Acesso em: 15 mar. 2021.

MOREIRA, José Antônio; SCHLEMMER, Elaine. Por um novo conceito e paradigma de educação digital on-line, Revista UFG, v. 20, 2020, p. 2-35. In: https://www.revistas.ufg.br/revistaufg/article/ view/63438. Acesso em: 15 mar. 2021.

OLIVEIRA, Francisco Ariclene; SANTOS, Ana Maria Sampaio dos. Construção do conhecimento na educação a distância: descortinando as potencialidades da Ead no Brasil. EaD em Foco, v. 10, e. 799, 2020. Disponível em: https://eademfoco.cecierj.edu.br/index.php/ Revista/article/view/799/504. Acesso em: 15 mar. 2021.

REIS, Marcos Aurélio; COUTINHO, Patrícia Martins Rodrigues. A prática da mediação e o acesso à justiça: por um Agir Comunicativo. Disponível em: <file://C:/Users/User/Downloads/ARTIGOCIENTIFICO_MEDIACAOUNIEURO.pdf> Acesso em: 29 mar. 2018. p. 17.

RODRIGUES, Horácio Wanderlei. Ensino jurídico: saber e poder. São Paulo: Autêntica, 1988.

ROSA, Alexandre Morais da. McDonaldização do Processo Penal e analfabetos funcionais. 2013. Disponível em: https://www.conjur.com.br/2013-out-19/diario-classe-mcdonaldizacao-processo-penal-analfabetos-funcionais. Acesso em: 10 mar. 2021.

SILVA, Déborah Fernanda da; CARVALHO, Letícia dos Santos. O lugar da reflexão na formação inicial de professores. Revista Educação e Debate, Fortaleza, ano 41, n. 80, set./dez., 2019, p. 155-171. Disponível em: http://www.periodicosfaced.ufc.br/index.php/educacaoemdebate/article/view/918/493. Acesso em: 15 mar. 2021.

STRECK, Lenio Luiz. Hermenêutica jurídica e(m) crise: uma exploração hermenêutica da construção do Direito. 11. ed. rev., atual. e ampl. Porto Alegre: Livraria do Advogado Editora, 2014. 
Resumocracia, concursocracia e a "pedagogia da prosperidade”. 2017. Coluna Senso Incomum da Conjur. Disponível em: https://www.conjur.com.br/2017-mai-11/senso-incomum-resumocracia-concursocracia-pedagogia-prosperidade. Acesso em: 11 mar. 2021.

VENÂNCIO FILHO, Alberto. Das Arcadas ao bacharelismo: 150 anos de ensino jurídico no Brasil. São Paulo: Perspectiva, 2011.

WARAT, Luis Alberto. Saber crítico e senso comum teórico dos juristas. Sequência, Florianópolis, v. 3, n. 5, 1982. Disponível em: https:// periodicos.ufsc.br/index.php/sequencia/article/view/17121/15692. Acesso em: 10 mar. 2021 


\section{A BASE NACIONAL COMUM CURRICULAR E A EDUCAÇÃO FINANCEIRA}

Jefferson Florencio Rozendo ${ }^{59}$

\section{INTRODUÇÃO}

É cultura do povo brasileiro passar por dificuldades financeiras, com efeitos colaterais em outros processos do viver. Muitos tentam de todas as maneiras sair da crise, mas isso não é tão fácil; é preciso criar o hábito, mudar a cultura, educar, fazer esforço e ter dedicação e perseverança. $\mathrm{O}$ tema da educação financeira tem se tornado destaque entre todas as mídias. O Youtube, por exemplo, é a mídia social onde mais se fala sobre esse tema. Vários especialistas na área começaram a fazer vídeos explicando sobre educação financeira e formas de investimentos. Mas essa ideia de poupar, equilibrar as contas, conhecer a importância do dinheiro, tanto para uma família como para uma nação, tem que ser cultivada já na infância, repetimos.

59 Doutorando em Ciências da Educação, (ACU) Absoulute Christian University - Florida USA. Mestre em Ciências da Educação, (ACU) Absoulute Christian University - Florida - USA. Mestrando em Educação Profissional e Tecnológica (ProfEpt / IFCE), Licenciatura Plena em Educação Física (UEVA), Bacharel em Direito (FAFOR), Licenciado em Pedagogia (UNYLEYA), Especialista em Segurança Pública (UNICE), Esp. em Tecnologias Digitais para a Educação Básica (UECE), Esp. em Alfabetização e Multiletramentos (UECE), Esp. em Docência do Ensino Superior e Tutoria de Educação a Distância (IPEMIG). 
Já existe projeto que tramita no Congresso Nacional, desde 2016, para implantar na base comum curricular a disciplina de educação financeira. É de extrema importância ensinar desde cedo as crianças e os jovens o que fazer com o dinheiro, como utilizá-lo, para que no futuro obtenham bons resultados, como adultos livres de dívidas e com melhor qualidade de vida, além de contribuir para com o próprio país.

A educação financeira está entre os temas da atualidade sugeridos para compor a Base Nacional Comum Curricular (BNCC). Trata-se do conjunto de conhecimentos entendidos como essenciais para o fortalecimento da cidadania e voltados para ajudar a população a tomar decisões financeiras mais autônomas e conscientes. A BNCC definirá os conteúdos que deverão fazer parte dos currículos das escolas de educação básica nos próximos anos, por determinação do Plano Nacional de Educação (PNE).

O tema da educação financeira ganhou destaque na arena política global com a crise econômica mundial, em 2008. Especialistas de organismos internacionais, como a Organização para a Cooperação e Desenvolvimento Econômico (OCDE) voltaram a atenção para a importância das questões associadas à educação financeira.

Nesse contexto, a educação financeira é definida como o processo mediante o qual os indivíduos e as sociedades melhoram sua compreensão em relação aos conceitos e produtos financeiros, de maneira que, com informação, formação e orientação, possam desenvolver os valores e as competências necessários para se tornarem mais conscientes das oportunidades e dos riscos neles envolvidos. De modo geral, significa que a educação financeira pode ajudar as pessoas nas escolhas mais acertadas e responsáveis sobre o planejamento das finanças pessoais, familiares, empresariais e governamentais.

No Brasil, a educação financeira vem conquistando espaço como política de Estado a partir da publicação do Decreto no 7.397, de 22 dezembro de 2010, que instituiu a Estratégia Nacional de Educação Financeira (ENEF). Desde então, ações acerca da temática são compartilhadas de forma integrada, por órgãos e entidades públicas e da sociedade, nos âmbitos federal, estadual e municipal.

A concretização da ENEF é realizada por meio do Comitê Nacional de Educação Financeira (CONEF) e do Grupo de Apoio Pedagógico (GAP), colegiado criado para assessorar o comitê e apreciar, revisar 
e validar conteúdos e metodologias pedagógicas relacionadas à educação financeira.

O GAP é presidido permanentemente pelo Ministério da Educação e desempenha funções de caráter deliberativo e consultivo ao avaliar e validar todo o material didático utilizado e disseminado no Programa Educação Financeira nas Escolas - Ensino Fundamental e no Programa Educação Financeira nas Escolas - Ensino Médio. Esses programas são operados pela Associação de Educação Financeira do Brasil (AEF-Brasil), com sede em São Paulo e instituída por meio de convênio firmado junto ao CONEF. A AEF-Brasil é também responsável pela execução das ações aprovadas nas reuniões deste colegiado.

O Brasil é o único país cujo Ministério da Educação tem papel predominante na estratégia nacional de educação financeira, afirma Sueli Teixeira Mello, assessora da Diretoria de Currículos e Educação Integral (DICEI), da Secretaria de Educação Básica (SEB), do MEC. Ela explica que a educação financeira está incluída no documento preliminar da BNCC como tema integrador denominado consumo e educação financeira, ou seja, é trabalhado de forma transversal nas disciplinas curriculares da educação básica.

Entre 2011 e 2012, cerca de 900 escolas públicas de ensino médio das redes estaduais do Ceará, Minas Gerais, Rio de Janeiro, São Paulo, Tocantins e do Distrito Federal participaram de projeto-piloto voltado para avaliar o impacto do uso do material didático produzido, com resultados muito satisfatórios. Em 2015, escolas públicas do ensino fundamental das redes municipais de ensino de Joinville (SC) e de Manaus deram sequência à experiência. Antes de trabalhar a educação financeira em sala de aula, os professores das secretarias de educação que aderiram ao programa e que participaram dos projetos-piloto são capacitados pela AEF-Brasil.

Por meio da DICEI/SEB, o MEC licitou e imprimiu os livros didáticos de educação financeira para o ensino médio. O conjunto de materiais distribuído às escolas, no âmbito do Programa Educação Financeira nas Escolas - Ensino Médio compõe-se de nove livros: três livros do aluno, três cadernos de atividades do aluno e três livros do professor. Foram impressos 1,9 milhão de exemplares, beneficiando 2.969 escolas e 47 secretarias de Educação, estaduais e municipais. 
A Educação Financeira é o processo pelo qual os indivíduos e a sociedade aprimoram sua concepção acerca de conceitos e produtos financeiros, visando facilitar suas decisões cotidianas (OCDE1, 2005). Busca-se ter um modo mais consciente de pensar sobre as oportunidades e os riscos que estamos cercados e, assim, exercer escolhas bem-feitas que acabem por repercutir no futuro.

A Educação Financeira, quando tratada de forma pedagógica e reflexiva, exerce uma importante função sobre as crianças, os adolescentes e sobre os adultos na construção de bases para uma vida saudável, equilibrada e promissora, em relação às finanças. Através do ensino da Educação Financeira, é possível conscientizar as pessoas para que aprendam a lidar com o dinheiro, fruto do seu trabalho, estimulando que se gaste menos do que se ganha. Logo, elas poderão ter um futuro mais tranquilo, menos incerto e menos dependente de programas, como a previdência social, que ao longo dos anos vem se mostrando cada vez mais insuficiente para uma vida digna. Sendo assim, não basta ter uma boa formação e emprego para que se tenha uma boa estabilidade financeira. Domingos (2012a, p. 8) relata que "suas conquistas dependerão - e muito - da sua capacidade de lidar bem com o dinheiro. [Isso] porque, o dinheiro sempre foi, e continuará sendo, a mola que move o mundo."

Ao longo da vida, a sociedade depara-se seguidamente com a frase: "educação vem de berço", para Domingos (2012a), esse pensamento está atrelado à questão da Educação Financeira e não se limita às questões éticas, pois também reflete o modo pelo qual o indivíduo deve se portar conscientemente, frente às suas tomadas de decisões. Dessa forma, a maneira que irá manusear seus próprios recursos financeiros também é determinada pelos ensinamentos que recebe. Assim, seria possível supor que, caso fosse abordado a relevância deste assunto para os jovens através da inserção do tema da Educação Financeira nos currículos escolares, o aluno sairia do Ensino Médio com um importante grau de conhecimento sobre como se organizar financeiramente. Além disso, estes ensinamentos possibilitariam aos jovens terem uma visão positiva sobre seu futuro, incentivando-os para que alcancem seus tão desejados sonhos com organização financeira.

Todavia, muitos dos pais também não obtiveram acesso a informações sobre como realizar o planejamento financeiro, e é justamente por 
isso, que se torna importante a inserção da discussão deste tema em sala de aula desde o início da vida escolar de cada jovem. Sendo assim, quando se tornar um adulto, terá capacidade de transferi-los para as gerações futuras. Isso irá impactar positivamente no desenvolvimento do país, diminuindo as taxas de inadimplência e levando a população a ter uma melhor qualidade de vida.

D’Aquino (2008) frisa em seu trabalho qual a melhor maneira de educar as crianças, explicando aos pais como devem se portar frente a diversas situações do cotidiano, além de desenvolver uma ordem sobre como apresentar o assunto da Educação Financeira com o passar dos anos. A função da Educação Financeira na vida das crianças é criar bases para que na vida adulta eles possam ter uma boa relação com o dinheiro, e, além disso, responsabilidade. Conforme D’Aquino (2008), o propósito de educar financeiramente os jovens em relação a como lidar com o dinheiro foca-se na construção de uma maturidade financeira.

Em detrimento das questões ressaltadas, passa a ser evidente o quão meritório é inserir o estudo da Educação Financeira desde o início do processo educacional dos jovens. Passa-se, então, a ser este o motivo de tamanha aspiração de muitos autores, para estudar e focar na implementação da disciplina de Educação Financeira nas escolas do Brasil.

\section{EDUCAÇÃO FINANCEIRA}

A Educação Financeira refere-se a um meio pelo qual é possível que o indivíduo aprenda a fazer bom uso do dinheiro, ou seja, que saiba tomar decisões conscientes e sustentáveis financeiramente. Isso pode gerar impactos econômicos, sociais e ainda, ambientais, através, por exemplo, do consumo consciente de produtos de higiene ou limpeza gerando menores custos, menos desperdício, maior duração e menos lixo.

É imperativo destacar que é necessária a atenção dos indivíduos sobre as forças do mercado afetando suas decisões de consumo, que muitas vezes acabam induzindo o consumidor a comprar determinado produto, através de promoções e do marketing. Sendo assim, os indivíduos devem analisar suas escolhas e, consequentemente, os impactos que poderão obter. Essas decisões podem vir a comprometer o seu futuro financeiro, por isso é de suma importância que a população apresente um discernimento quanto 
as decisões individuais e familiares em relação aos recursos disponíveis. Dessa maneira, a Educação Financeira visa a uma equilibrada relação entre indivíduos e dinheiro, ampliando suas decisões e suas escolhas a curto, médio e longo prazos. Em decorrência disso, a Educação Financeira como Modernell (2011, p. 22) destaca " [...] deve ser vista como um conjunto de hábitos financeiros saudáveis que contribuam para melhorar a situação, o proveito e as perspectivas financeiras das pessoas."

Segundo a Organização para a Cooperação e Desenvolvimento Econômico (OCDE, 2005), a Educação Financeira consiste no processo pelo qual os indivíduos e as sociedades melhoram seu entendimento acerca dos conceitos e produtos financeiros. Para tal, analisam três grupos de abordagens: informação, formação e orientação, para que os indivíduos possam desenvolver valores e competências que passam a ser primordiais para se tornarem mais conscientes das oportunidades e riscos envolvidos. Concomitantemente, poderão manifestar escolhas bem-informadas, saberão onde procurar ajuda e ainda, praticar ações que irão melhorar o seu bem-estar. A OCDE (2005), ainda destaca que, deste modo, esses indivíduos contribuirão com responsabilidade e permanecerão comprometidos com o futuro.

A falta de acesso e de informação acerca do conhecimento financeiro acaba por gerar consequências indesejadas: erros na tomada de decisões, falta de planejamento financeiro e falta de informação acabam inviabilizando a vida de grande parte da população. Por outro lado, quando os indivíduos manifestam uma noção, mesmo que inicialmente básica, passam a pensar mais sobre suas decisões e seu futuro. Pelo fato de ter uma significativa importância, há uma crescente quantidade de notícias e matérias jornalísticas referentes ao planejamento financeiro e é deste modo, que a população terá a oportunidade de ampliar seus conhecimentos e preparar para se envolverem neste complexo mundo financeiro.

Grande é o número de indivíduos que, pelo fato de não terem tido um contato com as questões relacionadas ao planejamento financeiro, ou seja, não terem acesso a este tipo de educação, acabam por se envolver em situações complicadas, obtendo obrigações maiores do que a sua capacidade financeira. Isso explica o porquê do aumento crescente dos níveis de inadimplência. O número de pessoas com o nome sujo ou com dívidas em atraso alcançou 63 milhões em março de 2019 segundo dados da Serasa 
Experian, é o maior patamar desde o início da série histórica, iniciada em 2016. Com isso, 40,3\% da população adulta está inadimplente no Brasil.

\section{EDUCAÇÃO FINANCEIRA NO BRASIL}

A recente ascensão econômica de milhões de brasileiros coloca o cidadão em contato com novas situações e operações financeiras pouco familiares para muitas pessoas. Somado a isso, o aumento das possibilidades de consumo torna necessário promover a educação financeira para despertar a consciência da população quanto às suas decisões individuais e familiares relacionadas a seus recursos.

Adotar decisões de crédito, investimento, proteção, consumo e planejamento que proporcionem uma vida financeira mais sustentável gera impactos não só a vida de cada um, como também no futuro do nosso país. A educação financeira convida a todos para ampliar sua compreensão a respeito dessas escolhas, sendo um conhecimento que possibilita o desenvolvimento de uma relação equilibrada com o dinheiro.

Brasil é um dos poucos países do mundo que possui uma Estratégia Nacional de Educação Financeira (ENEF), criada para promover ações de educação financeira gratuitas e sem qualquer interesse comercial. A ENEF brasileira é resultado de uma articulação entre 11 instituições de governo e da sociedade civil e, por este diferencial, valoriza ações que integrem a iniciativa privada, a sociedade civil e o governo.

\section{EDUCAÇÃO FINANCEIRA INFANTIL}

A educação financeira infantil é a base para criarmos filhos mais conscientes e evitar que, no futuro, eles desenvolvam uma ansiedade que os leve à indisciplina e a más escolhas financeiras. Não adianta nada ter um discurso eficiente sobre o bom uso do dinheiro se você não tem controle sobre seus gastos. Suas atitudes influenciam mais do que seus discursos. Por isso, dar o bom exemplo é fundamental. E isso deve começar o quanto antes.

Desde a mais tenra idade, a criança já percebe que há uma diferença entre ela e os adultos, que existem papéis para cada um. E são as suas atitudes que o filho irá usar inconscientemente como inspiração para se 
construir como indivíduo na sociedade. Quando a criança chega aos seis anos, mais ou menos, vale a pena intensificar o costume de aproximação com o dinheiro. Uma pequena mesada já pode ser aplicada, para ajudá-la a desenvolver a noção dos pequenos gastos, do funcionamento do orçamento doméstico e do bom planejamento financeiro.

\section{EDUCAÇÃO INTEGRAL}

Em 1942, com o objetivo de uniformizar o dinheiro em circulação, durante o Estado Novo, houve a adoção da moeda nacional Cruzeiro. D’Aquino (2008, p. 8) frisa que "[...] o Brasil foi palco de pelo menos duas décadas de um inacreditável pesadelo inflacionário." Entre 1942 e 1994, houve oito mudanças de moeda, sendo que seis aconteceram num intervalo de vinte anos. Para Pregardier (2015), o professor apresenta uma posição privilegiada no que tange a formação de hábitos, pois trabalha com crianças e adolescentes em um estágio no qual esses estão desenvolvendo conexões entre o seu comportamento e suas experiências vivenciadas. Domingos (2016) enfatiza que o ensino da Educação Financeira não se apoia apenas na matemática, cálculos e planilhas, sendo o tema muito mais do que isso, mesmo considerando que estas são ferramentas importantes a serem utilizadas. Também é importante considerar que os hábitos e costumes da vida diária afetam o modo como se utiliza o dinheiro, ou seja, é base para a Educação Financeira.

Dessa forma, faz-se necessário o desenvolvimento da educação dos indivíduos de forma integral para que haja uma unificação da ação educadora, como enfatiza Perissé (2014). Como esses temas acabam resgatando tópicos da vida real, é importante que os professores busquem interligá-los com o contexto de cada disciplina. A autora também relata que a interdisciplinaridade acabará por criar um grau de curiosidade dos alunos acerca dos temas relacionados. Esse sentido de integridade que o autor descreve refere-se aos professores que têm conhecimentos sobre diversas áreas, e que ao mesmo tempo são capazes de associá-los, ou seja, possuem "[...] uma visão 'religadora' de saberes." (PERISSÉ, 2014, p. 6). John Kenneth fala "Nada estabelece limites tão rígidos a liberdade de uma pessoa quanto a falta de dinheiro." Isso é uma verdade, vivemos em um mundo onde o dinheiro é quem manda, tantas pessoas sofrem pela falta do mesmo, pois 
o dinheiro compra praticamente tudo, uma saúde de qualidade, uma boa educação e tantas outras coisas que a classe mais pobre não pode desfrutar, por isso é importante conhecer sobre o dinheiro e os benefícios que ele pode nos gerar, para assim ter o interesse de administrá-lo melhor.

Outro aspecto a ser analisado é o entendimento do quão importante e benéfica é a comunicação sobre o tema financeiro entre pais e filhos. Levando em consideração que este tema é recente e que são poucos os pais que obtiveram contato quando eram crianças, é necessário conhecer e aplicar na vida diária, como reflexo das necessidades demandadas no seu dia a dia. Isto posto, pode-se constatar que uma pequena minoria dos jovens e adolescentes discorrem sobre o assunto da Educação Financeira com seus pais. Sobre a questão de acesso a informações acerca do tema, também é uma minoria que tem alguma noção sobre Educação Financeira em revistas, jornais, televisão, internet, dentre outros. No contexto estudado, verificou-se que a escola consiste em um ambiente adequado para tratar-se sobre o assunto da Educação Financeira.

\section{CONCLUSÃO}

As abordagens teóricas que fundamentam o estudo demonstram o quão importante é o desenvolvimento do tema da Educação Financeira, tanto para a sociedade em geral, quanto para as crianças, para os adolescentes e para os adultos, desde o início de suas vidas, através do ambiente escolar. Em sala de aula, os alunos iniciam o processo de formação de hábitos e, em razão do contato com o tema da Educação Financeira, passam a desenvolver tais conhecimentos em seus comportamentos cotidianos. Deste modo, espera-se que possuam consciência acerca de como planejar-se financeiramente de maneira adequada e visionária sobre seu futuro. Assim, este estudo buscou descrever a inserção do tema da Educação Financeira de forma transversal nas disciplinas curriculares da escola pública e verificar a contribuição do tema na formação dos alunos, no que se refere ao desenvolvimento de conhecimento, competências e habilidades.

Conclui-se, portanto, que a Educação Financeira, como tema transversal, acaba oferecendo vantagens às crianças, aos adolescentes e adultos, mostrando a eles o quão importante é ter uma vida financeira equilibrada 
e que o ato de poupar de hoje refletirá na capacidade de conquistar algo almejado no futuro.

\section{REFERÊNCIAS}

AEF. ENEF: Estratégia Nacional de Educação Financeira. São Paulo, 2015. Disponível em: <http://www.vidaedinheiro.gov.br/index. php>. Acesso em: 08 jan. 2020.

CERBASI, G. A complexa educação financeira. 2012. Disponível em: <http://www.maisdinheiro.com.br/artigos/4/91/a-complexa-educacao-financeira>. Acesso em: 08 jan. 2020.

DOMINGOS, R. Livre-se das dívidas: como equilibrar as contas e sair da inadimplência. São Paulo: DSOP Educação Financeira, 2012.

DOMINGOS, R. Terapia financeira: realize seus sonhos com educação financeira. São Paulo: DSOP Educação Financeira, 2012.

GIL, A. C. Como elaborar um projeto de pesquisa. 4. ed. São Paulo: Atlas, 2002.

OCDE. Recommendation on Principles and Good Practices for Financial Education and Awareness. Paris, 2005. Disponível em: <http://www.oecd.org/ daf/fin/financial-education/35108560.pdf>. Acesso em:08 jan. 2020.

PREGARDIER, A. P. M. Educação financeira: jogos para sala de aula: uma abordagem lúdico-vivencial de formação de hábitos. Porto Alegre: AGE, 2015.

PERISSÉ, G. Formação integral: educação financeira como tema transversal. São Paulo: DSOP, 2014. 


\section{A EDUCAÇÃO E A PSICANÁLISE NA GESTÃO DOS CONFLITOS}

Jefferson Florencio Rozendo ${ }^{60}$

\section{INTRODUÇÃO}

A educação é a base para a formação do indivíduo. Desde cedo, a criança é inserida no contexto escolar para dar os primeiros passos para o seu desenvolvimento pessoal e intelectual. Sabemos que, ao chegar na escola, a criança já vem com uma leitura de mundo e essa leitura entra em choque com a leitura da palavra. Durante esse processo, há uma convergência entre as normas e regras que são estabelecidas no contexto familiar com as que são apresentadas no contexto escolar. Há uma diferenciação nas relações que são próprias da educação familiar e da educação escolar. Enquanto na família, na maioria dos casos, a afetividade é predominante, assim como os valores nela estabelecidos, a escola apresenta uma outra configuração.

A criança se depara com novos saberes, aprende além dos conteúdos, novos valores. Aprende a conviver em sociedade e com as diferenças. A escola é um contexto mais amplo, de formação do ser humano como pro-

60 Doutorando em Ciências da Educação, (ACU) Absoulute Christian University - Florida USA. Mestre em Ciências da Educação, (ACU) Absoulute Christian University - Florida - USA. Mestrando em Educação Profissional e Tecnológica (ProfEpt / IFCE), Licenciatura Plena em Educação Física (UEVA), Bacharel em Direito (FAFOR), Licenciado em Pedagogia (UNYLEYA), Especialista em Segurança Pública (UNICE), Esp. em Tecnologias Digitais para a Educação Básica (UECE), Esp. em Alfabetização e Multiletramentos (UECE), Esp. em Docência do Ensino Superior e Tutoria de Educação a Distância (IPEMIG). 
tagonista da sua própria história. Partindo desse pressuposto, quem educa é a família, pois sempre será a base para o comportamento do indivíduo em formação na sociedade. Cabe à família orientar sobre certas responsabilidades, como o diálogo sobre sexo, drogas, o respeito e relacionamento interpessoal. A escola não se exime dessas obrigações, no entanto, a estrutura deve vir de casa. Na escola, novos conceitos serão transmitidos e as relações interpessoais (sociais e afetivas) irão criar novas estruturas.

$\mathrm{Na}$ esfera das relações, será inserida nesse contexto a relação professor-aluno, que muitas vezes segue por caminhos tortuosos. Podem ser crianças com histórias de vida familiar desestruturada, com traumas provenientes dessa relação e professores neuróticos que acabam descarregando suas dores na vivência escolar, principalmente na sala de aula.

O objetivo deste trabalho é discorrer sobre a importância da inserção da psicanálise no contexto escolar como forma de colaborar para o equilíbrio das relações entre professores e alunos, no processo educativo e relacional.

\section{A ESCOLA COMO AMBIENTE DE APRENDIZAGEM E CONFLITOS}

A escola é um ambiente de aprendizagem, mas também de conflitos. Apesar de ser uma instituição fundamental para a construção do indivíduo, evolução da sociedade e da humanidade. É também um espaço de desenvolvimento e aprendizagem complexo, pois envolve as relações entre vários segmentos como os padrões relacionais, culturais, sociais e familiares, que irão contribuir para que essas relações sejam saudáveis ou não. É nesse contexto que surgem os problemas enfrentados na escola, nas relações que envolvem o professor, o aluno e a família.

A criança, antes de ir para escola, nasce em um ambiente familiar diverso. Não existe um padrão de família. Desde o seu primeiro contado com o mundo exterior, a criança já começa a aprender e a apreender com tudo que a cerca, as sensações e as emoções. E é o resultado desse primeiro contato que ela leva para a escola. Ela não nasce sabendo e não estamos falando apenas dos conhecimentos escolares.

Ela leva consigo os valores culturais e sociais que vivenciou em casa que poderão ser positivos ou negativos, se a família na qual está inserida 
seja desestruturada emocionalmente. Acrescentamos a isso as informações absorvidas por outros meios, como, por exemplo, a televisão.

Crianças pequenas não chegam mais à escola sem base alguma de conhecimento científica e social, dado que têm outras fontes de cultura do cotidiano. (CORTELLA, 2015, p. 49).

A aprendizagem escolar depende da compreensão de tudo o que envolve as relações humanas em todo o seu contexto, não somente da parte dos alunos e das famílias, mas também dos professores e de todos os profissionais da escola, tendo em vista que as questões emocionais, decorrentes das experiências vividas desde a tenra idade são fundamentais na construção do indivíduo. E a psicanálise poderá atuar profundamente estabelecendo um diálogo entre o saber psicanalítico e a prática educativa.

Os educadores devem avançar, nesse sentido, adquirindo o conhecimento necessário a um olhar a um olhar crítico que lhes possibilite mante a fidedignidade aos reais conceitos psicanalíticos, tendo em vista o aperfeiçoamento do fazer educativo. (ASSIS, 2012, p. 17).

A psicanálise, a partir do pensamento de Freud ${ }^{61}$, oferece os conceitos fundamentais e essenciais para a prática educativa escolar e as subsequentes consequências das relações que envolvem esse espaço. Apesar de não ser pedagogo, Freud exerceu grande influência na Educação com alguns conceitos da psicanálise e contribuições para a parte clínica psicanalítica. A psicanálise, na sua abordagem, enfatiza os impulsos do inconsciente e seus efeitos sobre o nosso comportamento e exerceu grande impacto no estudo do desenvolvimento e suas teorias revolucionaram a concepção que a psicologia tinha a respeito da infância e a adolescência.

Todo ser humano, durante o seu desenvolvimento, atravessa etapas que irão estruturar a sua personalidade futura. Nesse contexto, Freud observou que o desenvolvimento da personalidade da criança e do adolescente está associado ao que ele chamou de pulsão sexual, que é um impulso energético interno que direciona o comportamento do indivíduo. $\mathrm{O}$

61 Médico neurologista e psiquiatra criador da psicanálise. 
comportamento gerado pelas pulsões diferencia-se daqueles gerados por decisões, por ser gerado por fontes internas inconscientes.

Em "Pulsões e destinos das pulsões", Freud define a pulsão como "conceito limite entre o psíquico e o somático, como representante psíquico dos estímulos que provêm do interior do corpo e alcançam a psique, como medida da exigência de trabalho imposta ao psíquico em consequência de sua relação com o corpo". (Freud, 2004, p. 148).

Ao contrário de outras teorias, cuja ênfase se dá no desenvolvimento cognitivo, Freud procura explicar por que os seres humanos não se comportam sempre de maneira lógica e como o conteúdo do pensamento não se limita apenas ao desenvolvimento cognitivo.

\section{A SEXUALIDADE INFANTIL}

Como já mencionado, o desenvolvimento psicossexual do indivíduo é fundamental para a formação de sua personalidade. Freud percebeu que as crianças ainda bebês, apesar da crença de que ela somente se manifesta na puberdade, possuem sexualidade, no entanto, diferente da sexualidade de um adulto porque ainda não está desenvolvida.

Na concepção popular do instinto sexual, ele está ausente na infầncia e desperta somente no período da vida que designamos como puberdade. Esse não é um erro qualquer, mas de grandes consequências, pois principalmente a ele devemos nosso atual desconhecimento das condições fundamentais da vida sexual. (FREUD, 2016, p. 73).

A sexualidade infantil é um assunto polêmico que desafia pais e professores pela bagagem rica em crenças que a mistifica e não a trata como aspecto natural e intrínseco ao humano. A censura produz distorções sobre a sexualidade e pode provocar danos na vida sexual adulta. De acordo com suas percepções, as características apresentadas por um adulto são resultado do processo de desenvolvimento da criança. Algumas características apresentadas por ele como as suas neuroses, vicissitudes e, por ou- 
tro lado, as características saudáveis são mero resultados desse processo de desenvolvimento mal ou bem estruturado.

As fases do desenvolvimento psicossexual ainda são vistas como tabu em muitas comunidades, mas não podemos negar que elas são de extrema importância para o desenvolvimento da personalidade. A sexualidade já se manifesta no bebê e vai evoluindo na sua forma e expressão ao longo de toda a vida. Isto é, o desenvolvimento psicossexual é um processo complexo e sutil, sujeito a diversos acasos, à medida que o ser humano passa pela infância, adolescência, idade.

Em cada etapa da vida, as pessoas a sexualidade se manifestam de formas diferentes, estando esta, sujeita à influência de diversos fatores internos e externos, interferido no desenvolvimento psicoafetivo de cada pessoa. A forma como se processa o desenvolvimento sexual em um indivíduo afetará no seu comportamento socioemocional quando adulto.

O desenvolvimento sexual é o elemento central da teoria freudiana, que as divide em cinco fases distintas. Se a criança experimenta frustração sexual em relação a qualquer estágio do desenvolvimento psicossexual, poderá desenvolver na vida adulta algum tipo de transtorno mental, ansiedade ou neurose.

A primeira fase é denominada como fase oral; estende-se de 0 a 1 ano e tem como característica o prazer através da sucção. Além do alimento, transfere esse prazer para outros objetos que a cerca. O ato de sugar é considerado uma manifestação sexual infantil e é determinado pela busca do prazer. A criança encontra satisfação sugando ritmicamente numa parte da pele. Sendo mantida além do considerável, por exemplo, poderá transformar-se em adultos apreciadores de beijos, fumantes e tendência ao consumo de álcool. Caso haja algum tipo de repressão nessa fase, a possibilidade de distúrbios alimentares também pode ser considerada.

$\mathrm{Na}$ fase anal, quando a criança já controla os esfíncteres anal e uretral, sente uma certa satisfação em executar esse controle e relaciona ao poder de agradar ou desagradar a mãe, por meio da retenção de suas fezes. Freud considera tanto a zona labial quanto a zona anal de fundamental importância para o desenvolvimento da sexualidade em outras funções do corpo que estão relacionadas às satisfações da criança. $\mathrm{O}$ modo de como a criança se relaciona consigo mesma e com os outros está diretamente relacionado à maneira de como suas necessidades são satisfeitas. 
$\mathrm{Na}$ fase fálica, a criança começa a dar importância aos órgãos genitais. Nesse momento, a criança percebe a presença ou a ausência dos órgãos genitais, no menino, o pênis (falo) e, na menina, a vagina, configurando-se na fase do Complexo de Édipo ${ }^{62}$ e, em decorrência, o Complexo de Castração ${ }^{63}$ e o processo de identificação. É um momento conflituoso para a criança por ter como rival o progenitor do sexo oposto e por, ao mesmo tempo, amá-lo.

A fase de latência, quando a prioridade da criança passa a ser o conhecimento do ambiente que a cerca. É a fase da aprendizagem. A criança direciona sua pulsão no desejo de aprender. A sexualidade da criança torna-se ora reprimida, ora sublimada, centrando-se em atividades e aprendizagens intelectuais e sociais, como jogos, escola, e estabelecendo vínculos de amizades que irão fortalecer a identidade sexual de ambos, ou seja, as características femininas e masculinas.

Com a chegada da puberdade, momento em que a produção hormonal é bastante acentuada, a sexualidade assume o papel de protagonista, com predominância dos órgãos genitais. Os conflitos originários da fase edipiana se tornam mais conflituosos. É o momento da busca da identidade.

\section{O DESENVOLVIMENTO DA SEXUALIDADE HUMANA}

O período de desenvolvimento da sexualidade humana é que irá determinar a personalidade do adulto. Nelas, estão situadas as causas tanto das neuroses infantis quanto das futuras neuroses na fase adulta, muitas vezes, decorrentes da falta de preparo dos pais, no que diz respeito familiar e das escolas, na forma de conduzir e desconsiderar aspectos indispensáveis para o processo de aprendizagem. Muitos pais não sabem como lidar com as perguntas embaraçosas que as crianças costumam fazer e acabam por fantasiar, oferecendo respostas descontextualizadas, correndo o risco

62 o Complexo de Édipo foi criado por Freud e inspirado na tragédia grega Édipo Rei designa o conjunto de desejos amorosos e hostis que o menino enquanto ainda criança experimenta com relação a sua mãe.

63 O Complexo de Castração diz respeito a uma experiência inconsciente na qual a criança rompe a ideia de onipotência da existência fálica através da diferenciação dos sexos. 
de futuramente se tornarem desacreditados, levando-os à busca de informações verdadeiras de outras formas.

Devemos considerar que a dificuldade dos pais em relação à educação sexual dos filhos é um reflexo de uma educação moralista, centrada nos valores religiosos que há muito tempo se perpetua na sociedade, impossibilitando que o indivíduo tenha a oportunidade de conhecer a si próprio, seus desejos e anseios numa repressão interna que certamente contribuirá para possíveis neuroses na vida adulta. Os professores, por sua vez, não se distanciam dessa realidade, pois passaram pelo mesmo processo de desenvolvimento psicossexual e provavelmente estiveram sujeitos a equívocos e à interpretação dos pais, em relação a cada fase, resultando em possíveis traumas, frustrações, seus anseios, seus medos e seus conflitos internos.

De ambas as partes, no educador e no educando, o equilíbrio emocional é fundamental na composição da aprendizagem escolar. Portanto, a constituição psíquica saudável está diretamente ligada às fases do desenvolvimento psicossexual e não podem ser desconsideradas, muito menos ignoradas no processo educativo. Uma escola saudável é aquela que oferece ao aluno o desejo do saber, mas que principalmente conheça as necessidades dos alunos, envolva-se com suas famílias e que nesse processo se utilize de uma metodologia que vá além das práticas pedagógicas convencionais, mas que valorize os aspectos afetivos, sociais e culturais de cada um. Tal afirmação é válida para todos os envolvidos no trabalho educativo.

Nesse sentido, a psicanálise poderia atuar positivamente, junto com a psicologia e a psicopedagogia. Esses três elementos são indispensáveis para proporcionar o equilíbrio no fazer pedagógico. Mais precisamente, a psicanálise seria uma forte aliada na orientação de como lidar com os diversos conflitos de ordem emocional na relação professor e aluno. Essa relação é bipolar e irá depender da construção emocional de cada envolvido.

\section{RELAÇÕES INTERPESSOAIS}

As relações interpessoais no contexto escolar, como já mencionado, podem apresentar configurações distintas. $\mathrm{O}$ educando pode desenvolver em relação ao educador empatia ou antipatia no âmbito do inconsciente. Poderá transferir para o professor sentimentos carinhosos ou agressivos que poderão estar associados à relação familiar. Assim como os pais, 
o professor possui e utiliza a ascendência sobre o aluno, para transmitir ensinamentos, valores, inquietações. $\mathrm{O}$ aluno, ao perceber, relaciona ao contexto familiar e dá a sua resposta emocional de acordo como tal, que poderá ser uma relação de amor ou de ódio, ou poderá transferir o amor que gostaria de receber em casa para o professor, quando percebe nele sentimentos de afeição e dedicação.

O mesmo pode se dar ao contrário. Um professor que não consegue lidar com suas próprias dores não terá uma resposta positiva de seu aluno. Isso explica o fato de recordarmos dos professores que mais nos seduziram. $\mathrm{Na}$ escola, como na vida, aprendemos por amor a alguém. Grande parte dos educadores não tem a percepção de que sua postura em sala de aula pode ser consequência de algo bem ou mal resolvido, em determinado momento da sua vida e que reflete diretamente na sua prática pedagógica.

A psicanálise pode ser entendida como uma teoria do desenvolvimento, assim como outros teóricos como Piaget ${ }^{64}$ e Vigotsky ${ }^{65}$ deram destaque às fragilidades dos recém-nascidos humanos e as consequências dessa singularidade, que nos acompanha desde recém-nascidos à fase adulta. Piaget e Vigotsky manifestaram interesse em estudar o desenvolvimento cognitivo das pessoas, desde o momento do nascimento, considerando que a aprendizagem nunca cessa e que é fundamental para o desenvolvimento humano nas relações com ele mesmo e com a sociedade. Diferenciando na forma de como isso acontece. Enquanto para Piaget o desenvolvimento passa por etapas em idades estabelecidas para todos, Vigotsky defende a interação social como parte do processo.

Apesar de não ter elaborado nenhuma teoria específica acerca do desenvolvimento humano, Freud defendeu que é a dinâmica afetiva que nos permite sobreviver à fragilidade com que viemos ao mundo. Cabe aos pais ou a quem couber os primeiros cuidados, amar o recém-nascido, criando uma espécie de jogo de satisfação e de desejos. A partir daí, o indivíduo vai estruturando sua subjetividade de acordo coma suas fantasias, de ser ama-

64 Jean Piaget (1896-1980) foi um psicólogo, biólogo e pensador suíço. Sua teoria e pensamentos contribuíram para o entendimento do desenvolvimento infantil e a aprendizagem das crianças.

65 Lev Vygotsky (1896-1934) foi um psicólogo bielorrusso, autor da psicologia cultural-histórica. O pensador enfatizava o papel da linguagem e do processo histórico social no desenvolvimento intelectual do indivíduo. 
do ou desejado ou ter suas necessidades funcionais satisfeitas. A frustração dessas fantasias gera forças inconscientes que seriam tão mais abundantes quanto as conscientes que estariam sempre ocultas devido às sanções morais e o medo da recriminação social, colocando os nossos desejos mais profundos ao crivo da moralidade e da adequação social.

O homem se torna neurótico porque não pode suportar a medida de privação que a sociedade lhe impõe, em prol de seus ideais culturais, e concluiu-se então que, se estas exigências fossem abolidas ou bem atenuadas, isto significaria um retorno a possibilidades de felicidade. (Freud, 2010, p.45).

\section{A CONTRIBUIÇÃO DE FREUD PARA A EDUCAÇÃO}

A contribuição de Freud para a Educação não foi dizer como ensinar as crianças, mas de compreender como somos levados ao conhecimento. Nesse aspecto, a contribuição de Freud foi relevante para entendermos por que desejamos aprender, por que aprendemos com algumas pessoas e não com outras e no que consiste a posição do professor.

Por que desejamos aprender pode ser respondido com o conceito de sublimação. Freud defendeu que a busca por satisfação e amor assim como a tentativa de evitar a dor e o desprazer são tudo que move o ser humano. Freud pegou emprestado da física o termo sublimação ${ }^{66}$ usado para designar a passagem direta de um estado físico a outro tem um estágio intermediário na psicanálise.

Sublimação é a passagem do desejo à sua satisfação sem expressar na consciência seu conteúdo naturalmente erótico. Nesse caso, é como se a dimensão de prazer e de satisfação física do desejo sublimado fosse desviada para algo não relacionado a libido. Temas socialmente vistos como mais elevados ou importantes tais como a arte e conhecimento, a religião que são em geral os mais eleitos para sublimação. Por que aprendemos com algumas pessoas e não com outras, Freud nos ajuda com dois princípios,

66 A sublimação é um tipo de mecanismo de defesa maduro, no qual impulsos ou idealizações socialmente inaceitáveis são transformados em ações ou comportamentos socialmente aceitáveis, possivelmente resultando em uma conversão a longo prazo da pulsão inicial. 
um deles é chamado de transferência ${ }^{67}$ e foi descoberto por ele durante sua prática clínica, quando percebeu que muitas pacientes acreditavam se apaixonar por ser psicanalista. Freud se deu conta de que isso acontecia porque elas se projetavam afetos infantis na figura do terapeuta.

O que isso tem a ver com educação é que da mesma maneira que para nos deixarmos analisar por um terapeuta; é necessário um vínculo capaz de provocar afetos infantis inconscientes. Para que aprendamos com alguém, muitas vezes é necessário termos uma criança inconsciente de que aquela pessoa sabe muito ou que pode nos ensinar algo. Ou seja, que sem a sua ajuda, não conseguiríamos aprender. Esse tipo de crença é a mesma que a criança tem em relação aos pais, eles sabem tudo e conhecem a verdade do mundo. Os pais e os professores se tornam de certa forma líderes carismáticos, dos quais seus filhos e alunos renunciam dos próprios prazeres em prol de suas vontades.

Freud explica que este é um fenômeno inconsciente em que os alunos se identificam com certos professores, de tal maneira que querem fazer as tarefas que eles pedem como se satisfazê-los fosse satisfazer a si próprio. Podem até tentar copiar seu estilo e seu jeito de se expressar. Porém, no ambiente escolar, as relações entre docentes e discentes podem ocorrer de forma distorcida. O professor não pode corresponder aos afetos envolvidos na transferência como se ele fosse de fato o destinatário deles. Ao contrário, é apenas frustrando esses afetos que o sujeito pode vir a ter uma perspectiva mais madura sobre eles.

O professor tampouco pode se deixar confundir com figuras afetivas como os pais, tios e muito menos como namorados ou amantes. Um bom professor por sua vez também deve esperar que cada um aluno seja capaz de abandoná-lo e superá-los e se o caminho do conhecimento superar as gerações anteriores.

\section{CONCLUSÃO}

Está inteiramente nas mãos dos professores a formação dos estudantes, pois a criança, antes de chegar na escola, traz consigo uma bagagem

67 A transferência ocorre na relação entre paciente e psicanalista, analista ou terapeuta. Nela, o desejo do paciente, advindo de sua infância, se apresenta atualizado durante o processo de terapia. 
de conceitos, preconceitos, sentimentos e ressentimentos absorvidos pela experiência relacional vivida com a família e por outros meios, como, por exemplo, a mídia que são verdadeiros veiculadores e reforçadores de forma distorcida. Para isso, é necessário o equilíbrio emocional dos dois lados. O professor também carrega consigo, em alguns casos, esses valores distorcidos que necessitam ser trabalhados.

A psicanálise, associada à educação, seria uma forte aliada para atenuar as tensões emocionais existentes na escola, especificamente na sala de aula, proporcionando ao professor e ao aluno a possibilidade de verbalizar suas tensões emocionais. Dessa forma, a psicanálise pode ajudar, permitindo a possibilidade de uma compreensão em profundidade do sujeito, no que ele tem de mais pessoal e de mais íntimo.

Para tal, é necessário que a escola não considere o professor como mediador do saber e considere sua condição humana, mantenha, e que não coloque o aluno numa relação de submissão passiva à autoridade do professor como receptor do saber, mas como um ser em construção. O professor, deve compreender as dificuldades encontradas pelo aluno, pode estar associadas 'questões emocionais, muitas vezes inconscientes, assim como as próprias. A relação professor-aluno depende, em grande parte, da maturidade afetiva do professor. Se esta lhe permite resolver suas próprias dificuldades, ele poderá ajudar ao aluno e ao professor resolverem ou aliviarem suas tensões emocionais inconscientes com todas as suas frustrações e recalcamentos de seus dramas interiores, com seus desejos, suas histórias, exprimindo-se pela sua simbolização.

O ambiente escolar é heterogêneo. Professores e alunos são os personagens principais nesse contexto e há a necessidade de uma atenção especial no processamento dessas relações. Antes de tudo, não esquecer que nesse contexto estão indivíduos que carregam consigo as marcas deixadas durante o desenvolvimento psicossexual. Positivas ou não, essas marcas irão se concretizar em ações. Essas ações, quando não observadas, não consideradas e não trabalhadas são as responsáveis por grande parte da desarmonia nas reações entre professores e alunos. Os professores, já com a personalidade formada e alunos em formação.

A psicanálise é uma possibilidade de condução para a equalização do ambiente escolar, contribuindo para a compreensão dos processos repri- 
midos pelo inconsciente que geram sintomas de ansiedade, interferindo no processo de ensino e aprendizagem.

\section{REFERENCIAS}

ASSIS, Arbila Luiza Armindo. Influências da psicanálise na educação: uma prática psicopedagógica. 1 ed. Curitiba: InterSaberes, 2012 .

CORTELLA, Mario Sérgio. Não nascemos prontos! Provocações filosóficas. 19 ed. Petrópolis: Vozes, 2015.

FREUD, Sigmund. As pulsões e seus destinos. Obras incompletas de Sigmund Freud. 1ํㅡㄹ ed. Belo Horizonte: Autêntica, 2013.

1901-1905. Obras completas, v. 16: Três ensaios sobre a teoria da sexualidade, análise fragmentária de uma histeria ("O caso Dora”) e outros textos (1901-1905). 1 $1^{\underline{a}}$ ed. São Paulo: Companhia das Letras, 2016.

1912-1914. Obras completas, v. 11: Totem e tabu, contribuição à história do movimento psicanalítico e outros textos (1912-1914). 1 a ed. São Paulo: Companhia das Letras, 2012.

1923-1925. Obras completas, v. 16: O eu e o id, "autobiografia” e outros textos (1923-1925). 1ª ed. São Paulo: Companhia das Letras, 201I.

1923-1936. Obras completas, v. 18: O mal-estar na civilização, novas conferências introdutórias à psicanálise e outros textos (19301936). 1a ed. São Paulo: Companhia das Letras, 2010.

PIAGET, Jean, 1896-1980. Para onde vai a educação? / Jean Piaget; tradução lvette Braga. - 20.ed. - Rio de Janeiro: José Olympio, 2011.

TAILlE, Yves de La; OLIVEIRA, Marta Kohl de; DANTAS, Heloysa. Piaget, Vigotski, Wallon: Teorias psicogenéticas em discussão. $29^{a}$ ed. São Paulo: Summus, 2019. 
RESUMOS 



\section{O ALUNO NÃO É O PROBLEMA: O PROTAGONISMO DA TERAPIA OCUPACIONAL EM EDUCAÇÃO JUNTO À COMUNIDADE ESCOLAR}

Victor Matheus Marinho Dutra ${ }^{68}$

\section{INTRODUÇÃO}

A educação brasileira recebe parecer anual através de instrumentos avaliativos, como a Prova Brasil, Exame Nacional do Ensino Médio, Sistema de Avaliação da Educação Básica, dentre outros. No entanto, as avaliações usam critérios quantitativos, que apresentam dados escassos, ignorando as condições mais estruturais de autoavaliação da escola, condições de trabalho dos profissionais, ambiente escolar, métodos de ensino e aprendizagem (DE OLIVEIRA et al., 2017).

Não identificar as gêneses dos problemas educacionais perpetua o fracasso escolar. Ainda, ignorar o histórico de vida e fatores social e econômico do aluno é não desenvolver estratégias efetivas na aprendizagem, pois tais fatores influenciam significativamente. Dessa forma, faz-se necessário conhecer o contexto familiar, fatores de riscos, moradia e nível de formação dos responsáveis. O ambiente escolar pode

68 Graduando de Terapia Ocupacional da Universidade do Estado do Pará. 
ter inúmeros desafios, mas um lar hostil, que não oferte condições agradáveis de apoio pedagógico e sem capacidade de instruir o desempenho escolar do menor, torna-se um agravante a formação acadêmica (AVELINO; MENDES, 2020).

É neste cenário de realidades parcialmente concretas das dificuldades enfrentadas pelos alunos, das multiplicidades dos fatores de vida do sujeito, que a Terapia Ocupacional projeta sua relevância. Por ser uma profissão que atua no Contexto Escolar, levando em conta as atividades cotidianas, como o brincar, lazer, participação social, Atividades de Vida Diária, Atividades instrumentais de Vida Diária, descanso e sono, a educação (COFFITO, 2O18).

O terapeuta ocupacional também elabora atividades que facilitem a aprendizagem e participação do aluno no ambiente escolar. Podendo planejar espaços que melhorem o desempenho ocupacional, promover mecanismos para a acessibilidade dos ambientes externos e internos à escola. Buscando estratégias à evasão escolar e conclusão das disciplinas, com capacitação e orientação dos profissionais, reuniões com a família, especialistas e a equipe para acompanhar o aluno, ou encaminhá-lo para demais serviços (COFFITO, 2018).

Dessa forma, a partir do repertório de conhecimento e formação do terapeuta ocupacional, este contribui em problemas relevantes à sociedade em diversos contextos, como o da educação pública (PEREIRA, 2018). Exposto isto, este trabalho tem como objetivo relatar a experiência no estágio curricular de Terapia Ocupacional no contexto educacional, o qual realizou-se o acompanhamento de alunos com demandas prejudiciais a seu engajamento escolar.

\section{DESCRIÇÃO DA EXPERIÊNCIA}

O Projeto Escola situa-se no município de Belém-PA, cuja sua finalidade é ofertar às crianças de baixa-renda reforço educacional, serviços em saúde e empreendedorismo para geração de renda familiar. A equipe de Terapia Ocupacional é inserida nesse contexto, por meio da implementação do estágio de prática em educação. Precisa da observação apurada e de ações para organizar e estruturar as atividades do estágio. 
Na primeira semana, os estagiários acompanharam a rotina das crianças no projeto, no sentido de compreender sua rotina, bem como sua organização, relações interpessoais e analisar os elementos que compõem o desempenho ocupacional dos alunos. Nessa ocasião, foi possível observá-los na aula de música, no karatê, no refeitório e na sala de aula. Por tal aproximação, os alunos estabeleceram vínculo com a equipe de Terapia Ocupacional, sendo importante no processo de acolhimento.

Assim, buscou-se fazer parte do contexto de cada criança, participar dos grupos, interagir e quando solicitado, auxiliá-los na execução das atividades a partir dos comandos da pedagoga responsável pela turma. Por tal contato, foram observadas demandas relacionadas à aprendizagem, como transtorno da aprendizagem, as habilidades sociais e demandas comportamentais. Foi desenvolvido, através disso, o plano terapêutico para atender às habilidades que necessitavam de maior atenção em cada criança.

Nos atendimentos individuais, foram realizadas avaliações através das atividades expressivas, objetivando conhecer as rotinas das crianças, suas relações nos contextos e eventuais demandas. Está oportunidade permitiu a identificação de: relações familiares fragilizadas, havendo queixas de participação família, pouco envolvimento no brincar, baixa qualidade nessas relações, falta de suporte nas atividades curriculares, uso demasiado do celular; reduzidos vínculos interpessoais, onde existiam poucas amizades no projeto, relacionamentos fragilizados com os colegas; e vulnerabilidade social, a partir de moradias com cômodo único para famílias grandes, ambiente onde eram presenciadas violências, dentre outros fatores.

Reuniu-se com a equipe, composta também por psicólogo, assistente social e pedagogo, buscando formalizar um diálogo interprofissional, com a troca de informações a respeito dos alunos. Esse espaço é também relevante para que a equipe possa aproximar diálogos e formas de intervenção, além de objetivos a serem alcançados com as crianças. Nesse espaço de construção coletiva também é possível consolidar junto aos demais profissionais o papel do terapeuta ocupacional na educação.

\section{ANÁLISE E DISCUSSÃO}

A instituição oferta oportunidade de esporte, arte, apoio pedagógico e assiste nas condições básicas a criança. No entanto, por ser no 
contraturno e não oportunizar ao menor o brincar livre, prejudica o equilíbrio ocupacional, levando o mesmo a praticá-lo dentro da sala de aula, lugar não adequado e que pode promover acidentes. $\mathrm{O}$ brincar faz parte da vida infantil, proporcionando que a criança conheça as relações com os pares e aprenda brincando. Não proporcionar esta experiência à criança, acarreta prejuízos em sua autonomia e na construção da identidade (LORO, 2016).

O projeto poderia ainda, por meio da equipe pedagógica, facilitar este processo, revisando o conteúdo aprendido e ajudando nas tarefas escolares. Assim, seria possível deixar o turno da noite livre para que a criança desempenhe atividades de seu interesse.

No que tange às demandas relacionadas ao transtorno da aprendizagem e comportamentais, em grande parte, tornam os alunos excluídos e estigmatizados, levando a baixa autoestima e construindo limitações à educação desses alunos. Crianças com histórico escolar marcado pelo fracasso, podem desacreditar de seu potencial em tarefas significativas (BERNARDI, 2006). As escolas precisam buscar meios de tornar o aprendizado mais satisfatório, tornando didático e metodológico a toda diversidade de aluno (MURA; ZURRU, 2016).

A família é fundamental na formação escolar do indivíduo. Contudo, os responsáveis que desempenham o papel de facilitadores das tarefas escolares, ao chegarem do trabalho à noite, encontravam-se exaustos. Tal situação culmina na transferência de responsabilidade do educar unicamente à instituição de ensino. Cabe à divisão de tarefas ao educar do aluno, não delegando somente a um integrante da família. A escola e a família são instituições fundamentais, precisando que funcionem por meio de parceria. Este processo deve ser de forma frequente e simultânea, a forma de participação da família pode acarretar prejuízos, ou não, ao escolar (COSTA; SOUZA, 2019).

Portanto, a família precisa entender seu papel na formação escolar da criança, provendo-o de afeto, paciência e auxiliando na aquisição do conhecimento. Responsabilizar apenas a escola, é negligenciar o compromisso familiar de suporte à educação do estudante. A família não deve estar alheia ao aprendizado dos filhos na vida escolar, precisando que se estimule e participe da educação formal da criança (FIRMAN; RAMOS, 2015). 
No mais, a Terapia Ocupacional busca analisar as atividades desempenhadas, de forma a contribuir para o bem-estar e a independência dos indivíduos. Assim, o reconhecimento do trabalho e as trocas com os demais profissionais foram fundamentais para afirmar a profissão não apenas no campo da saúde, mas ao contexto educacional. Toda instituição de ensino busca a aprendizagem do aluno e a família possui um papel fundamental neste processo, podendo contribuir ou não com o desenvolvimento dos educandos.

\section{CONSIDERAÇÕES FINAIS}

A Terapia Ocupacional, ao adentrar no espaço educacional, desenvolve estratégias para que a comunidade escolar possa desempenhar seu papel de fomentadora da educação. Portanto, atua como mediadora da escola e família, no enfoque ao aluno. Além disso, atua no sentido de possibilitar que o aluno se desenvolva com autonomia e independência, a partir do equilíbrio de suas ocupações e desempenho escolar. Nessa perspectiva, é fundamental conhecer a rotina e fazer-se parte da mesma, para melhor percepção da realidade do aluno.

Por fim, é imprescindível que a equipe estabeleça diálogos permanentes, de modo a convergir ações e refletir estratégias que procurem o melhor desenvolvimento e desempenho acadêmico do estudante.

\section{REFERENCIAS}

AVELINO, Wagner Feitosa; MENDES, Jessica Guimarães. A realidade da educação brasileira a partir da Covid-19. Boletim de Conjuntura (BOCA), v. 2, n. 5, p. 56-62, 2020.

BERNARDI, Jussara. Alunos com discalculia: o resgate da autoestima e da autoimagem através do lúdico. Dissertação de Mestrado. Pontifícia Universidade católica do Rio Grande do Sul, 2006.

COSTA, Emanuelle Lourenço; SOUZA, Jane Rose Silva. FAMÍLIA E ESCOLA: AS CONTRIBUIÇÕES DA PARTICIPAÇÃO DOS RESPONSÁVEIS NA EDUCAÇÃO INFANTIL. Khóra: Revista Transdisciplinar, v. 6, n. 7, 2019. 
COFFITO, 2018. Reconhece e disciplina a especialidade de Terapia Ocupacional no Contexto Escolar, define as áreas de atuação e as competências do terapeuta ocupacional especialista em Contexto Escolar e dá outras providências. Disponível em: https://www.coffito.gov.br/nsite/?p=10488/ Acesso em: 03 out. 2020.

DE ARAÚJO FIRMAN, Josiane Aparecida; SANTANA, Sylvia Caroline Russi; RAMOS, Marcos Lupércio. A importância da família junto à escola no aprendizado formal das crianças. Colloquium Humanarum, p. 123-133, 2015.

DE OLIVEIRA, J. F.; LIBÂNEO, J. C.; TOSCHI, M. S. Educação escolar: políticas, estrutura e organização. Cortez Editora, 2017.

LORO, Aline Rafaela. A importância do brincar na educação infantil. 2016.

MURA, Antonello; ZURRU, Antico Luigi. Riqualificare i processi inclusivi: un'indagine sulla percezione degli insegnanti di sostegno in formazione. Edizioni Centro Studi Erickson, 2016.

PEREIRA, Beatriz Prado et al. Terapia ocupacional e educação: as proposições de terapeutas ocupacionais na e para a escola. 2018. 


\section{PROFESSORES DE EDUCAÇÃO FÍSICA E BNCC: ALGUMAS REFLEXÕES}

Anderson José de Oliveira ${ }^{69}$

\section{INTRODUÇÃO}

O presente trabalho traz o resultado parcial de uma pesquisa que objetiva saber o nível de conhecimento de um grupo formado por sete professores(as) de Educação Física a respeito da implementação da Base Nacional Comum Curricular - BNCC (BRASIL, 2017). Para embasar tal discussão foram trazidas obras/autores(as) clássicos da área, como Coletivo de autores (1992) e Marcos Garcia Neira (2016) além de serem referendados alguns elementos contidos nessa base.

Sendo a BNCC um documento de implementação obrigatória, é necessário conhecer/entender como ela integrará a prática dos professores brasileiros. Torna-se importante saber que conhecimentos estes professores possuem em relação a ela.

\section{FUNDAMENTAÇÃO TEÓRICA}

Os PCN (BRASIL, 1997) específicos da disciplina Educação Física já especificava na época de sua publicação, que coexistem diferentes abordagens para a Educação Física escolar brasileira que articulam co-

\footnotetext{
69 Graduado em Educação Física pela Universidade Federal de Juiz de Fora e Graduando em Pedagogia pelo Centro Universitário Faveni. Professor das redes municipal e estadual da cidade de Juiz de Fora.
} 
nhecimentos advindos de diferentes áreas como psicologia, sociologia e filosofia. Estas correntes têm ampliado o campo de ação e reflexão, além de aproximar a educação física das ciências humanas. Dentre essas perspectivas, existem aquelas embasadas em uma linha de estudo crítica, fundamentadas em teorias marxistas. Estas propõem uma reflexão e trabalho nas escolas em que o principal marcador social seja a luta de classes. Como exemplo tem-se a Metodologia Crítico Superadora, escrita por um coletivo de autores na década de 1990 (COLETIVO DE AUTORES, 1992).

Seguindo uma linha pós-crítica está Marcos Garcia Neira. Tal autor propõe um trabalho que para além da categoria classe social sejam considerados também o gênero, a etnia, dentre outros marcadores sociais (NEIRA, 2016). O referido autor propõe um currículo cultural da educação física.

Para além das teorias curriculares no trato do conhecimento vinculado à Educação Física enxerga-se, assim como apontado pelos PCN (BRASIL, 1997) e por Maia et al. (2019), que nas escolas ela ainda é tratada como marginal. Como exemplo dessa característica podem ser citadas as aulas colocadas em horário diferente daquele em que os estudantes frequentam a maioria dos outros componentes curriculares e a ausência do professor de educação física no planejamento e discussão do trabalho desenvolvido no ambiente escolar.

Em 2017, mesmo não havendo políticas públicas significativas para mudar essa realidade descrita nos PCN (BRASIL, 1997), entrou em cena mais um elemento na construção da Educação Física nas escolas brasileiras: a Base Nacional Comum Curricular. Tal documento, de implementação obrigatória, servirá de base para a construção de todos os currículos no território nacional. A BNCC (BRASIL, 2017) propõe uma educação embasada em competências e habilidades e divide o conhecimento nas seguintes áreas: linguagens (formada pelos conteúdos educação física, artes, língua portuguesa e língua inglesa), matemática, ciências da natureza, Ciências humanas (subdividida nos conteúdos história e geografia) e ensino religioso.

Em relação ao componente curricular Educação Física, ele está organizado em seis unidades temáticas: brincadeiras e jogos, danças, esportes, ginásticas, lutas e práticas corporais de aventura. 


\section{METODOLOGIA}

Para a realização da pesquisa, foi utilizada uma abordagem de cunho qualitativo. Foram correlacionadas fontes bibliográficas/documentais com relatos de professores(as) de Educação Física. Esses relatos se deram através de um contato inicial com um grupo de estudos vinculado a Universidade Federal de Juiz de Fora. Tal grupo foi escolhido por discutir assuntos vinculados à Educação Física. Sete docentes responderam através de aplicativo de mensagem ${ }^{70}$ a um questionário que continha a seguinte questão: que conhecimentos você possui em relação à BNCC?

Os profissionais foram separados em duas categorias: "atuantes" (composto por três docentes) e "não atuantes" (composto por quatro docentes). $\mathrm{O}$ primeiro relacionado aos que trabalham como professores na área escolar e o segundo por outros que não atuam nessa área ainda. Todos (as) autorizaram que suas falas fossem utilizadas na confecção de um trabalho acadêmico.

\section{RESULTADOS E DISCUSSÃO}

Inicialmente, foi percebido que mesmo sendo publicada em 2017, tal base não foi estudada pela maioria da mostra de professores(as) não atuantes no sistema de ensino. Grande parte disse ter conhecimentos superficiais em relação à mesma e um(a) professor(a) disse não possuir conhecimento nenhum. Um número considerável de docentes abordou questões políticas em relação à base como sua vinculação com o movimento "escola sem partido", mas aspectos estruturais da BNCC não foram comentados.

O fato de essa base ser um documento obrigatório que regula os currículos no Brasil era conhecido por todos. Tal característica foi semelhante no grupo dos professores(as) que atuam no sistema educativo. Entre três docentes, somente um(a) falou sobre aspectos estruturais da BNCC. Este(a) professor(a) falou sobre os conteúdos da educação física, as habilidades a serem desenvolvidas nesse componente curricular e como a base se organiza em relação ao mesmo.

70 Tal metodologia foi utilizada devido à dificuldade de um contato presencial com tais professores por conta do isolamento social que é necessário em tempos de Pandemia da Covid 19. Os questionários foram aplicados no fim do ano de 2020. 


\section{CONCLUSÕES}

Se a BNCC será o pilar dos currículos na educação nacional, é necessário haver mais investimentos pelo setor público e privado de ensino em sua divulgação. Apesar de se tratar de um recorte de uma pesquisa em andamento, percebe-se que a BNCC ainda é algo distante da realidade da maioria dos (as) professores (as) de educação física dentro do grupo pesquisado. Somente um (a) docente dentro de um grupo com sete pessoas conhecia a BNCC mais detalhadamente.

Devido às limitações do presente trabalho, não foi possível abordar os motivos desse distanciamento, mas pode-se afirmar que tal conhecimento será necessário na prática pedagógica desses (as) docentes dentro das escolas públicas e privadas do Brasil.

\section{REFERENCIAS}

BRASIL. 1997. Parâmetros Curriculares Nacionais (1aa a $4^{\mathbf{a}}$ séries). Brasília: MEC/SEF, 10 volumes.

BRASIL. Ministério da Educação. Secretaria da Educação Básica. Base Nacional Comum Curricular. Brasília-DF; MEC; CONSED; UNDIME, 2017.

COLETIVO DE AUTORES. Metodologia do ensino de Educação Física - São Paulo: Cortez, 1992.

NEIRA, Marcos Garcia. O multiculturalismo Crítico e suas contribuições para o currículo da Educação Física. Temas em Educação Física Escolar. Rio de Janeiro. v.1 jan/ jun. 2016.

SAVIANI, Demeval. Pedagogia Histórico-crítica primeiras aproximações. 3ํㅡㄹ ed. - São Paulo: Cortez: Autores Associados, 1992. 


\section{RELAÇÕES ÉTNICO-RACIAIS E AUTOCONHECIMENTO NO ENSINO FUNDAMENTAL II: COMO OS EDUCANDOS PERCEBEM/SENTEM O RACISMO ESTRUTURADO (ESTUDO DE CASO)}

Vitor Martins Graciliano ${ }^{71}$

\section{INTRODUÇÃO}

Buscamos fomentar a reflexão e o debate sobre a significação das disciplinas de Ensino Religioso Projeto de vida e as demais disciplinas que trabalham com o tema "autoconhecimento", analisando o racismo estrutural tendo como referencial ou pondo de partida o livro de Silvio Luiz de Almeida, Racismo estrutural (2019).

Almejamos o enriquecimento da prática docente e a apresentação de novas ou melhores formas de abordagem de temas que muitas vezes não são abordados de forma coerente e efetiva, deixando de alcançar suas reais possibilidades. Assim, perdem muitas vezes seu significado ou motivos de serem temas interdisciplinares ou integradores que têm como função ampliar o aprendizado e expectativa de maior significação que outros conteúdos.

71 Bacharel em Direito, licenciado em Geografia, especialista em Psicopedagogia e Educação Ambiental; pesquisador da área de Educação: currículo, práticas escolares e relações étnico-raciais. 


\section{FUNDAMENTAÇÃO TEÓRICA}

Racismo é apresentado pelo autor Silvio Luiz de Almeida como sendo "sempre estrutural, ou seja, de que ele é um elemento que integra a organização econômica e política da sociedade. Em suma, o racismo é a manifestação normal de uma sociedade, e não um fenômeno patológico ou que expressa algum tipo de anormalidade. (ALMEIDA 2019, p. 15)

No entanto, muitos buscam negar a importância de se refletir, discutir e debater sobre raça e consequentemente sobre racismo, argumentando que tais ideias não fazem parte da política estrutural da sociedade. Ao atentarmos para as construções sociais e políticas, entendemos que todas são derivadas de práticas discursivas permeadas por relações de poder que se originam a partir de uma construção psicossocial.

Conforme demostrado pela antropologia surgida no início do século XX e a biologia - especialmente a partir do sequenciamento do genoma -, não existem diferenças biológicas ou culturais que justifiquem um tratamento discriminatório entre seres humanos. A verdade é que a noção de raça ainda é um fator político importante, utilizado para naturalizar desigualdades e legitimar a segregação e o genocídio de grupos sociologicamente considerados minoritários. (ALMEIDA 2019)

\section{METODOLOGIA}

Metodologicamente, segundo a classificação de pesquisas de Gil (2002), a mais adequada para os fins almejados é a pesquisa exploratória a partir de estudo de caso. Segundo Chizzotti (2008), esta tem o objetivo de reunir dados relevantes do objeto estudado para que, dessa forma, se obtenham conhecimentos mais amplos acerca dele, esclarecendo as dúvidas e questões pertinentes que instruam ações futuras.

Por se tratar de uma pesquisa cuja abordagem principal é qualitativa, foram utilizados como procedimentos de coleta/produção de dados: o desenvolvimento de "redes de conversações" (CARVALHO; HOLZMEISTER, 2013), com questionários pré-preparados de coletas de dados de forma virtual, a pesquisa documental e revisão de literatura. 


\section{RESULTADOS E DISCUSSÃO}

A partir das redes de conversas, análises e reflexões dos dados obtidos/ produzidos, conseguimos traçar um perfil predominante, relacionado à temática em pauta, dos educandos da comunidade escolar em análise. A partir desse projeto, apresentaremos possíveis caminhos que poderão servir de bases para a construção de novos materiais, conteúdos, abordagens ou norteadores de novas percepções, possibilitando que novos olhares sejam despertados, para novos horizontes, que ressignificarão as relações, estudos e desenvolvimento do autoconhecimento em todos os âmbitos, principalmente no combate a toda forma de racismo.

\section{CONCLUSÕES}

Em meio à grande diversidade de uma sala de aula e suas múltiplas personalidades, como educadores somos cada vez mais desafiados ao desenvolver uma sequência didática, ainda mais quando se trata de um eixo tão complexo quando o autoconhecimento. Nesse contexto, os estudos que buscam discutir essa temática apresentam-se como uma oportunidade de reflexão, debate e amplificação das possibilidades de diálogo e disseminação de saberes e conhecimento de uma forma extraclasse, ultrapassando até mesmo os muros das escolas e dos lares, e conseguindo permear os centros acadêmicos, circuitos de discussão e implementação de políticas públicas. Devem ser capazes de sensibilizar os responsáveis, para o diálogo e a integração democrática da sociedade aos currículos e documentos norteadores da educação pública.

O maior objetivo que acreditamos ter alcançado é a ressignificação do autoconhecimento, que muitas vezes causa sofrimentos e nos limitam, e o semear de novas perspectivas para todos que de qualquer forma entraram em contato com este trabalho.

\section{REFERÊNCIAS}

ALMEIDA, Silvio Luiz de. Racismo estrutura. São Paulo: Sueli Carneiro; Pólen, 2019. 264 p. (Feminismos Plurais).

FORDE, Gustavo Henrique Araújo; VALENTIM, Silvani dos Santos. Práxis pedagógica antirracista e afirmativa como princípio norteador 
dos currículos da Educação Profissional e Tecnológica. In: FRANCO, Sebastião Pimentel; SÁ, Nicanor Palhares (Org.). Gênero, etnia e movimentos sociais na história da educação. Vitória ES: EDUFES, p. 61-73, 2011. Disponível em file://C:/Users/User/ Documents/47-Texto\%20do\%20artigo-240-1-10-20121125.pdf. Acesso em: 20 mar. 2021.

MACHADO Adilbênia Freire. Filosofia Africana para descolonizar olhares: perspectiva para o ensino das relações étnico-raciais. Tear revista de Educação, Ciência e Tecnologia, Canoas, v. 3, n. 1, p. 1-20. 2014. Disponível em: https://periodicos.ifrs.edu.br/index.php/ tear/article/view/1854/1438. Acesso em: 20 mar. 2021.

MBEMBE, Achille. Crítica da razão negra. São Paulo: N-1, 2018. Achille. Necropolítica. São Paulo: N-1, 2018. 


\section{MULTICULTURALISMO, RELAÇÕES ÉTNICO-RACIAIS: UMA POSSIBILIDADE DE INTERVENÇÃO NO COMPONENTE CURRICULAR EDUCAÇÃO FÍSICA}

Anderson José de Oliveira ${ }^{72}$

INTRODUÇÃO

O presente trabalho traz um relato de experiência relacionado a intervenções pedagógicas no componente curricular Educação Física com turmas do fundamental 1 em uma escola municipal de Juiz de Fora-MG. Objetivou-se, através de uma abordagem multiculturalista e um olhar voltado para a diversidade étnico racial no Brasil, desenvolver atividades nas temáticas contidas na Base Nacional Comum Curricular dentro do componente curricular acima referendado. As atividades foram desenvolvidas através do Whats App devido à necessidade de um trabalho através do ensino remoto, tendo em vista mudanças nas escolas com a pandemia da Covid 19.

\section{FUNDAMENTAÇÃO TEÓRICA}

Para fundamentar esta intervenção, utilizou-se uma base teórica embasada em pressupostos contidos no multiculturalismo e também em au-

72 Graduado em Educação Física pela Universidade Federal de Juiz de Fora e Graduando em Pedagogia pelo Centro Universitário Faveni. Professor das redes municipal e estadual da cidade de Juiz de Fora. 
tores que versam sobre a diversidade étnico racial e questões relacionados ao negro e sua inserção no ambiente escolar. Primeiramente, será abordado o multiculturalismo.

\section{MULTICULTURALISMO}

Hall (2003), em sua obra Da diáspora: Identidades e mediações culturais, faz uma distinção entre multicultural e multiculturalismo. Segundo ele, multicultural está relacionado a características sociais e possíveis problemas de governabilidade que acontecem em todas as sociedades em que estão juntas distintas comunidades culturais que buscam edificar uma vida em comum concomitantemente ao fato de manterem características vinculadas as suas origens. Já o termo multiculturalismo está vinculado a estratégias e políticas que objetivam administrar questões vinculadas a diversidade e multiplicidade nascidos no seio das sociedades multiculturais.

Hall (2003) segue dizendo que ao mesmo tempo que existem diferentes sociedades multiculturais, existem também multiculturalismos distintos. Existem o multiculturalismo conservador, o multiculturalismo liberal, o multiculturalismo crítico ou revolucionário, dentre outros.

Em relação à última versão do multiculturalismo, mostrada anteriormente, na visão de Kincheloe e Steeinberg (2012) citados por Neira (2016), a pedagogia multicultural crítica não objetiva a neutralidade. Ela se diferencia em relação a outros enfoques multiculturais devido à demarcação de valores que orientam suas práticas, estando o multiculturalismo crítico vinculado ao igualitarismo e dissipação do sofrimento humano. Neira (2016) diz que os multiculturalistas críticos ratificam o princípio de que um ensino de qualidade é aquele que leva em consideração as vivências dos alunos considerando a diversidade de etnias, classes sociais e gêneros dos discentes.

Tendo em vista o exposto até aqui, penso ser necessário adotar uma perspectiva multicultural crítica no trato do conhecimento vinculado à educação escolar. É necessário considerar as diferentes culturas que constituem a sociedade brasileira, valorizando a contribuição para nossa história de grupos que foram excluídos durante muito tempo no ambiente escolar. 
Sendo assim, foi dado enfoque ao multiculturalismo e a cultura afro-brasileira no trabalho com o conteúdo Educação Física no ambiente escolar. No entanto, antes de entrar especificamente na discussão de atividades que foram desenvolvidas, convém falar um pouco sobre questões étnico raciais.

\section{RELAÇÕES ÉTNICO-RACIAIS E A ESCOLA}

Gomes (2003) enxerga a escola como um local no qual é aprendido e compartilhado além de conteúdos e saberes escolares, valores, crenças e hábitos, bem como preconceitos dos mais diferentes tipos como os raciais, de gênero, classe e de idade. Essa visão permite compreender os caminhos pelos quais se dá a construção da identidade negra. A autora entende essa identidade como uma produção social, cultural e plural, que envolve a construção do olhar de indivíduos pertencentes a um mesmo grupo étnico racial, em relação a si mesmos, tendo como ponto de partida a relação com o outro. A identidade negra é construída também durante sua trajetória escolar. "Nesse percurso, os negros deparam-se, na escola, com diferentes olhares sobre o seu pertencimento racial, sobre a sua cultura, sua história, seu corpo e sua estética" (GOMES, 2003, p. 172).

Segundo Santos (2002), no Brasil, o corpo do indivíduo se impõe de maneira aparente, sendo comum privilegiar a aparência como critério principal de objetivação e julgamento. Assim, em terras brasileiras, ser negro é cotidianamente ser objeto de um olhar enviesado. "A chamada boa sociedade parece considerar que há um lugar predeterminado, lá embaixo, para os negros e assim tranquilamente se comporta" (SANTOS, 2002, p. 161).

No entanto, segundo Gomes (2003), não se pode deixar de levar em conta que a escola brasileira na atualidade tem edificado representações sociais mais positivas em relação ao negro e a sua estética, fato esse decorrente da ação da comunidade negra organizada em movimentos sociais, de grupos culturais negros, entre outros agentes sociais.

Dessa forma, pretendo contribuir com esse movimento citado por Gomes, agregando elementos para essa construção positiva em relação ao negro, trabalhando com atividades que remetem a sua herança cultural relacionada as músicas, aos costumes, dentre outros aspectos. 


\section{METODOLOGIA}

Para realizar a presente intervenção, foi utilizada uma abordagem de cunho qualitativo. Utilizaram-se fontes bibliográficas/documentais para montagem de atividades relacionadas ao componente curricular Educação Física para alunos do ensino fundamental 1 em uma escola pública do município de Juiz de Fora. Foram trabalhados conteúdos relacionados a Dança e também a Jogos e Brincadeiras, que são unidades temáticas da Educação Física dentro da Base $\mathrm{Na}$ cional Comum Curricular. Esta também serviu como um norte para organização das atividades juntamente como o currículo da rede municipal da referida cidade. As aulas foram dadas através do aplicativo de mensagem (WhatsApp) devido ao período que estamos vivendo relacionado à pandemia da Covid-19 em que as aulas estão sendo realizadas através do ensino remoto.

\section{RESULTADOS E DISCUSSÃO}

A partir da fundamentação teórica vinculada ao multiculturalismo, foi pedido que os alunos realizassem jogos e brincadeiras comuns à sua comunidade, ou seja, atividades que as crianças realizavam dentro de seu contexto cultural. Os alunos trouxeram para as aulas, dentre outras, as seguintes brincadeiras: amarelinha, pular corda, empinar pipa, jogar bola, bolinha de gude, pique-esconde. Em um segundo momento, foi pedido que os estudantes vivenciassem as atividades que seus colegas expuseram. Os alunos demonstraram grande interesse nas atividades propostas, pois elas estavam vinculadas ao cotidiano deles e a cultura do local em que vivem/convivem. Concomitante a esse processo, foram trabalhados também elementos vinculados à cultura afro-brasileira. Foi falado, dentre outras, sobre a brincadeiras da "amarelinha africana" e também um jogo conhecido como "terra-mar".

Em relação à temática dança, após um trabalho mostrando música e danças que possuem uma matriz afro-brasileira, como o maracatu, o samba e o funk, foi pedido aos estudantes que realizassem performances nos ritmos/danças trabalhadas durante as aulas. O funk foi o estilo musical mais citado, seguido pelo samba (pagode). Foram propostas perfor- 
mances pelos alunos em que eles cantavam, dançavam ou imitavam seus cantores favoritos.

\section{CONCLUSÕES}

Foi percebido que o trabalho com atividades vinculados ao universo cultural em que as crianças convivem se mostrou produtivo, pois os alunos demonstraram bastante interesse em realizar as dinâmicas propostas. Foi percebido que os estudantes se identificaram com o que foi trabalhado, pois era algo que fazia parte de seu cotidiano. Alguns responsáveis realizaram as atividades ensinando/vivenciando com seus filhos algo que fez parte de sua infância.

É necessário, assim como o proposto no presente trabalho, valorizar a cultura dos estudantes brasileiros. Assim, eles poderão ser levados a valorizar suas raízes e construir um mundo em que a diversidade cultural e racial do Brasil seja respeitada em suas inúmeras dimensões e que esse respeito se transforme em igualdade e oportunidades a todos, independentemente de sua origem, costumes ou etnia.

\section{REFERÊNCIAS}

GOMES, Nilma Lino. Educação, identidade negra e formação de professores/as: um olhar sobre o corpo negro e o cabelo crespo. Educação e Pesquisa, São Paulo, v. 29, n. 1, p. 167-182, jan-jun. 2003.

HALL, Stuart. Da diáspora: Identidades e mediações culturais. Organizacao Liv Sovik; Belo Horizonte: Editora UFMG; Brasília: Representação da UNESCO no Brasil, 2003.

HALL, S. A centralidade da cultura: notas sobre as revoluções de nosso tempo. Educação e realidade, Porto Alegre, v. 22, n. 2, p. 15-46, jul-dez. 1997 Disponível em https://seer.ufrgs.br/educacaoerealidade/article/view/71361/40514

NEIRA, Marcos Garcia. O MULTICULTURALISMO CRÍTICO E SUAS CONTRIBUIÇÕES PARA O CURRÍCULO DA EDUCAÇÃO FÍSICA. Temas em Educação Física Escolar, Rio de Janeiro, v. 1, n. 1, jan-jun., p. 3-29, 2016. 
SANTOS, Milton. Ser negro no Brasil hoje. São Paulo: Publifolha, p. 157-161, 2002. Disponível em <http://inculturacao.salesianos. br/wp-content/uploads/2012/08/Ser-negro-no-Brasil-hoje-Milton-Santos-materia-da-Folha-de-S-Paulo.pdf> Acesso em: 20 abr. 2014. 


\section{O CONTEXTO DE PRODUÇÃO DA BNCC E SEUS REFLEXOS PARA A EDUCAÇÃO BÁSICA: APONTAMENTOS HISTÓRICOS}

Luan Tarlau Balieiro ${ }^{73}$

\section{INTRODUÇÃO}

Quando se pensa na noção de currículo escolar, é pertinente observar que há uma relação de poder efetivamente demarcada no campo da educação. Como bem ressaltou o sociólogo Bourdieu (2002), o sistema de ensino se constitui em uma das formas pelas quais as estruturas sociais são propagadas. Tais estruturas estão inseridas em um campo repleto de discursos, de simbologias, de condutas a serem naturalizadas. No campo da educação, ainda mais nas políticas educacionais curriculares, a Base Nacional Comum Curricular (BNCC) se apresenta como um projeto construído em meio a um contexto permeado por embates, sobretudo se focalizar as suas versões e os debates em torno delas.

Assim, seleciona-se a BNCC como o objeto de estudo deste trabalho. A fim de compreender o seu contexto de produção, objetiva-se apresentar uma visão histórica a respeito dessa política curricular, a qual permitirá adentrar em algumas especificidades concernentes aos rumos que a

73 Mestrando em Educação pela Universidade Estadual de Maringá (UEM). Especialista em Docência na Educação Superior e em Libras pelo Centro Universitário Metropolitano de Maringá (UNIFAMMA). Licenciado em Letras pela UEM. 
Base propicia à educação básica brasileira. A inquietação parte do seguinte questionamento: tem-se um exemplo de uma política curricular que aponta veridicamente para uma oportunidade de emancipação do sujeito? Por mais que se possa ter uma resposta predefinida, justifica-se a necessidade de tecer reflexões a partir desse questionamento, reportando-se a uma visão histórica sobre o documento.

\section{FUNDAMENTAÇÃO TEÓRICA}

No ano de 1988, instaura-se a Constituição Federal. Com essa promulgação, são retomadas as discussões sobre a necessidade de se pensar os caminhos da educação brasileira. É a partir desse período que se nota o compromisso da sociedade em prol da luta e defesa de uma escola pública de qualidade para todos, sem diferenças de classes. Além da Constituição Federal de 1988, salienta-se outro referencial que contribuiu para a progressão da educação no sentido de estimular a formação de sujeitos críticos: a Lei no 9.394/1996, a Lei de Diretrizes e Bases (mais conhecida como LDB). Com base nesse contexto sócio-histórico, outros referenciais norteiam a elaboração e a construção da BNCC, a saber: os Parâmetros Curriculares Nacionais (PCNs) para o Ensino Fundamental, provenientes dos anos de 1997 e 1998; as Diretrizes Gerais para a Educação Básica, provindas de 2010; e o Plano Nacional da Educação iniciado em 2014, com metas e estratégias a serem atingidas até 2024.

Com o transcorrer do tempo, as políticas educacionais no Brasil foram determinadas de diversas maneiras, justamente por evidenciar um aspecto de padronização do Estado que abarca interesses políticos das mais variadas naturezas. Pondera-se que essas políticas devem ser norteadas pela sociedade em geral, ao assegurar os direitos individuais e, por consequência, preservar o bem comum. É pertinente destacar, nesse contexto, que o processo de elaboração de uma política pública deve envolver todo um país, de modo a enfatizar suas reais necessidades e objetivos.

Ademais, menciona-se que a precaução por determinar conteúdos com os quais os educandos serão ensinados já estava delineada, por exemplo, no "Manifesto dos Pioneiros da Educação Nova", de 1932. A necessidade de uma base nacional já se evidenciava na própria Constituição de 1988; encontrava-se, inclusive, na Lei de Diretrizes e Bases da Educação, sendo que a pri- 
meira LDB é proveniente de 1961, a segunda corresponde ao ano de 1971 e a atual aponta para o ano de 1996, a qual passa por alterações ao longo do tempo em muitos aspectos. Tal precaução também se demarca no Plano Nacional de Educação (PNE). A partir do exposto, depreende-se que há uma necessidade por normatizar os conteúdos a serem ensinados aos educandos.

Neste momento, é prudente centrar o olhar em algumas informações a respeito das versões da BNCC. De acordo com Aguiar (2018), no ano de 2015, o I Seminário Interinstitucional para a Elaboração da Base reuniu assessores e especialistas. A Portaria no 592, de 17 de junho do ano já mencionado, instituiu a Comissão de Especialistas para a elaboração de proposta da BNCC. A crise no governo de Dilma Rousseff suscitou a substituição no Ministério da Educação. No mês de setembro, destituiu-se o ministro Renato Janine Ribeiro e o movimento das bases se colocava em desenvolvimento com a vinda de especialistas ingleses e australianos a se manifestar de forma favorável. Em meio a esse contexto, Aloízio Mercadante assume o Ministério da Educação. Assim, no mês de outubro do ano em questão, inicia-se a consulta pública para a construção da primeira versão da BNCC com contribuições da sociedade civil, de organizações e entidades científicas.

Conforme expõe Aguiar (2018), o Governo Federal começou as discussões para elaborar a Base em 2015, com a primeira versão apresentada em março do mesmo ano. As propostas passaram por análises com especialistas e, posteriormente, apresentaram-se para reformulações à população por meio dos conselhos municipais e estaduais de Educação. A primeira versão recebeu as seguintes críticas: houve lacunas em áreas como História e Literatura, uma vez que estas não evidenciavam conteúdos programáticos. O texto não contemplava, por exemplo, o trabalho com conteúdos em relação às Revoluções Industrial e Francesa, assim como quanto a culturas de povos egípcios e de civilizações gregas.

Dessa maneira, a segunda versão da Base foi apresentada no mês de maio de 2016, recebendo 12 milhões de contribuições, de acordo com dados do MEC. No mês de junho, realizaram-se seminários com professores, gestores e especialistas abertos à participação pública por todo o Brasil com o intuito de debater a segunda versão da BNCC. No mês de agosto, começou a ser elaborada a terceira versão, em um processo participativo por intermédio da segunda versão. Já no mês de abril de 2017, o Ministério da Educação encaminhou a versão final da BNCC ao Con- 
selho Nacional de Educação (CNE), sem considerar, porém, a etapa do Ensino Médio.

\section{METODOLOGIA}

Opta-se por uma abordagem qualitativa por meio de revisão bibliográfica (FREIRE, 1996; BEISIEGEL, 2010; AGUIAR, 2018) e estudo documental a partir da Base Nacional Comum Curricular (BRASIL, 2017).

\section{RESULTADOS E DISCUSSÃO}

Ao analisar o texto da BNCC, é possível notar que sua proposta de elaboração recorre a aspectos significativos, como a expansão e a melhoria na qualidade do sistema educacional brasileiro. Contudo, historicamente, o Brasil não cumpriu e tampouco está cumprindo com as metas propostas em seus documentos que visam às políticas educacionais de práticas efetivamente concretas. Ademais, na BNCC, observa-se que há aspectos não aplicáveis à realidade educacional da sociedade brasileira. Por exemplo, tem-se a concepção de educação pautada, ainda, em um tradicionalismo pedagógico, de maneira a estabelecer que o docente deva assumir a função de um mero transmissor de conteúdo, quando, na verdade, ele deveria construir o conhecimento junto com os educandos, ao contribuir para uma autonomia e conscientização, o que, de fato, não se evidencia na BNCC, constatando-se um certo retrocesso face à criticidade proposta pela LDB proveniente de 1996. A esse respeito, recorre-se a Freire, a partir de Beisiegel (2010), que apresenta uma passagem bem pertinente no tocante à relação entre educação e conscientização:

[...] Paulo Freire também expõe demoradamente suas reflexões sobre as modalidades de consciência e sobre as características de uma educação comprometida com o processo de conscientização. Seriam duas as posições que o brasileiro vinha assumindo diante da existência. Uma primeira, a da consciência intransitiva, seria caracterizada pela forma quase vegetativa de vida, voltada para os desafios da sobrevivência biológica, destituída de historicidade, de homens 
"demitidos da vida", ou "inadmitidos à vida”, em situação de "um quase incompromisso entre o homem e a sua existência". [...] Esta seria a consciência predominante nas áreas mais rústicas, distantes das regiões mais urbanizadas e desenvolvidas. Uma segunda posição, a da consciência transitiva, predominante nas regiões economicamente mais desenvolvidas, estaria acima dos interesses meramente vegetativos, o homem teria horizontes mais largos, enxergaria mais longe, suas preocupações seriam marcadas por alto teor de espiritualidade e historicidade (BEISIEGEL, 2010, p. 32-33, grifos do autor).

Assim, reflete-se que o conhecimento não é um produto, mas, sim, um processo; logo, faz-se preciso parar com o sistema de educação bancária (FREIRE, 1996), pois não existe uma transferência de conhecimento. Educar é construir um ambiente onde o conhecimento possa ser produzido, circulado, apreendido e debatido. Parece que essas considerações não se fazem presentes nas políticas educacionais curriculares.

Ao se centrar nos aspectos ideológicos e condicionantes das políticas públicas educacionais, abrangendo as curriculares, especificamente a Base Nacional Comum Curricular, compete a reflexão de qual será o resultado efetivo dessas políticas e, especialmente, da BNCC para a Educação Básica brasileira. Tendo em vista o seu contexto de influência, volta-se ao questionamento proferido na seção introdutória deste texto: trata-se de uma política curricular que aponta veridicamente para uma oportunidade de emancipação? Na tentativa de respondê-lo, vê-se que os reflexos da Base Nacional Curricular Comum para a Educação Básica, de uma forma geral, têm como resultado a característica de serem amplamente gerenciados. Na realidade, acredita-se que, para alcançar uma oportunidade efetiva de emancipação, é preciso superar a cultura burguesa, com vistas a propiciar um frutífero desenvolvimento intelectual, que conduzirá o sujeito a uma formação, de fato, emancipatória. Notoriamente, esse processo ocorre por intermédio da educação como uma ferramenta de luta, de um progresso social e humano.

\section{CONCLUSÕES}

No que concerne ao exposto, depreende-se que o processo de construção da Base Nacional Comum Curricular é repleto de especificidades históricas circunscritas em um contexto de interesses, de relações de po- 
der e de discursos bastante questionáveis. Não se pode deixar de destacar que a formação humana integral está correlacionada ao exercício de cidadania do sujeito e há o reconhecimento de que a BNCC propõe, em determinados momentos, o ato de se trabalhar o conhecimento a partir de uma concepção democrática.

Todavia, não é por meio dessa concepção que a BNCC passa a engendrar o seu pensamento, ou seja, de se formar um sujeito crítico e reflexivo em uma sociedade demarcada por um jogo de ambições. O intuito continua a ser que o sujeito seja operacionalizado por esse jogo. Indo além: de um sujeito que não demonstre iniciativa, reportando-se a uma evidente passividade, sem indagar sobre a sua real condição, a fim de não entrar em embates contrários ao sistema capitalista vigente na sociedade, de forma a impedir modificações no transcorrer da história.

\section{REFERÊNCIAS}

AGUIAR, Márcia Angela da Silva. Relato da resistência à instituição da BNCC pelo Conselho Nacional de Educação mediante pedido de vista e declarações de votos. In: AGUIAR, Márcia Angela da Silva.; DOURADO, Luiz Fernandes (Org.). A BNCC na contramão do PNE 2014-2024: avaliação e perspectivas. Recife: ANPAE, 2018. p. $8-25$.

BEISIEGEL, Celso de Rui. Paulo Freire. Recife: Massangana, 2010. Disponível em: http://www.dominiopublico.gov.br. Coleção Educadores. Acesso em: abr. 2021.

BOURDIEU, Pierre. Entrevista concedida à Maria Andréa Loyola. Rio de Janeiro: UERJ, 2002.

BRASIL. Ministério da Educação. Base Nacional Comum Curricular. Educação Infantil e Ensino Fundamental. Versão homologada por Mendonça Filho. Brasília, DF: MEC, dezembro de 2017. Disponível em: http://download.basenacionalcomum.mec.gov.br/. Acesso em: abr. 2021.

FREIRE, Paulo. Pedagogia da Autonomia: saberes necessários à prática educativa. São Paulo: Paz e Terra, 1996. 


\section{ENSINO E APRENDIZAGEM EM GEOGRAFIA: REFLEXÕES A PARTIR DA PANDEMIA DA COVID-19}

Diego Neves Sampaio ${ }^{74}$

\section{INTRODUÇÃO}

Nesse espaço e tempo em que se estabeleceram as relações dentro e fora da sala de aula, torna-se cada vez mais importante a reflexão sobre a aproximação entre o mundo escolar com a vida cotidiana dos estudantes. Para além da história, pode-se perceber que a realidade estudantil se caracteriza como um produto social contemporâneo. Perante a expansão das tecnologias educacionais, percebe-se que sua utilização facilita o campo da comunicação entre a escola e o público.

\section{FUNDAMENTAÇÃO TEÓRICA}

A crise instaurada pela Covid-19 ressignificou as relações de ensino e aprendizagem. Nesse período de afastamento social e fechamento das escolas, pôde-se notar, de forma mais ampla, como a educação atua e ressignifica nossas vidas. Diante do panorama, é possível refletir que a educação não será a mesma de outrora. Sendo a escola um espaço geográfico, de acordo com Castrogiovanni (2006), devemos compreender esse

74 Bacharel e Licenciado em Geografia pela PUCRS. Especialista em Ensino e Geografia e História (UFRGS). Especialista em Gestão da Educação (PUCRS). Graduando de Ciências Biológicas. Professor de Geografia da Rede Jesuíta de Educação. 
lugar através da função que exerce, ou seja, promover o desenvolvimento individual e o poder das relações, interações e trocas, resultando na consolidação do saber, caracterizando uma relação entre desafio e equilíbrio.

O objeto de estudo da Geografia é constituído e fundamentado a partir das diferentes bases conceituais filosóficas, atrelados às diversificadas manifestações culturais presentes na sociedade. Nesse sentido, em relação à formação do espaço e suas características, é definido como "um conjunto indissociável, solidário e também contraditório, de sistemas de objetos e sistemas de ações, não considerados isoladamente, mas como o quadro único no qual a história se dá." (SANTOS, 2006, p.39).

O espaço está relacionado ao tempo, diferenciando-se de acordo com a sua forma, estrutura e evolução histórica. Dessa maneira, Santos (2012) considera o espaço como um distinto conjunto de elementos de diferentes épocas, que resume a evolução da sociedade e explica as situações da atualidade social; logo, é indissociável a noção de espaço, em relação à noção de sistemas temporais. No entanto, sabe-se que a dinâmica escolar em sua essência é fundamentada na convivência diária, no compartilhamento imediato de ideias, na construção conjunta de saberes, na transmissão 6 de conteúdos e na condução de práticas.

Assim, é possível refletir que a Covid-19 ressignificou o espaço escolar, promovendo uma zona de tensão, onde a comunidade passa a temer pela saúde daqueles que atuam nesse ambiente, uma vez que há um eminente risco de transmissão, por conta da multiplicidade gerada através dos vínculos entre os jovens e demais atores dessa seara. A partir desse contexto, cabe a todos compreenderem os impactos gerados pela pandemia que afetarão os processos de ensino e aprendizagem.

A Geografia, sendo um componente curricular, deve instrumentalizar estudante para uma melhor compreensão do mundo. Dessa maneira, o desenvolvimento dos conteúdos no âmbito escolar, devem promover a formação do cidadão, fazendo com que haja o devido reconhecimento do contexto no qual está inserido, compreendendo o seu papel enquanto ator da sua história, sociedade e espaço (CALLAI, 2001, p.134). Um dos principais potencializadores da educação corresponde ao convívio social. Os seres humanos aprendem através das trocas de experiências com aqueles que estão a sua volta. Ao explorar o mundo, coloca-se em constante aprendizado. Ainda, estando na escola, concretiza-se essa exploração no 
encontro com o outro, formando um universo contínuo de desenvolvimento social.

Quando a educação é projetada para a mudança, podemos observar a significação dos objetos de estudo. Para tal, Freire (1987) destaca que o trabalho educativo deve estar estruturado no respeito ao diálogo, e na união entre 7 ação e reflexão, ou seja, a práxis. Entretanto, em tempos onde o ensino remoto fez parte do cotidiano dos estudantes, podemos refletir a real significação dos objetos de estudo desenvolvido ao longo do período pandêmico. Muito se discute sobre as diferentes concepções da educação, as possibilidades diversas em que podem ocorrer a aprendizagem, entretanto, nota-se que a prática docente ainda em sua essência, traduz parcialmente aquilo que é criticado por Freire. Levando em consideração que a propagação da Covid-19 ocasiona uma mudança no comportamento humano, gerada pela adoção de medidas de prevenção e cuidados individuais, o isolamento social surgiu como estratégia eficaz contra a transmissão desse vírus.

Através dos aspectos citados pelo autor, nota-se que Vigotsky traz a interação como fundamento central na formação do sujeito, levando em consideração que o homem se caracteriza por estabelecer relações de cunho primário dentro das suas raízes sociais. Diante desse cenário, vale retomar que os autores citados resgatam a importância de se analisar o ensino e aprendizagem de forma geral e aplicada a geografia. A exploração dos conceitos de espaço geográfico, espaço virtual, ensino, aprendizagem, tempo, ensino remoto e híbrido e isolamento social, serão de fundamental importância para o transcorrer dessa pesquisa. Ainda assim serão necessários os olhares de autores como Jean Piaget através de suas pesquisas sobre a teoria construtivista, o arcabouço de Edgar Morin através da teoria do pensamento complexo e também Antônio Nóvoa, escritor português que traz à tona situações que desafiam a educação.

\section{METODOLOGIA}

O presente estudo visa analisar como o estudo da Geografia no ensino fundamental II possibilita a significação dos objetos de estudos de forma que os estudantes sejam capazes de compreender seus mundos, durante a pandemia da Covid-19, comparando as práticas desenvolvidas 
no ensino público e privado. Para tanto, torna-se fundamental ressaltar que os obstáculos impostos nesse período são notórios a todos os segmentos da sociedade. No campo da educação, de maneira inesperada, grande parte das instituições de ensino sentiram-se obrigadas a implementar um modelo de ensino remoto emergencial evoluindo para um ensino e aprendizagem híbridos.

Para conduzir o estudo, optou-se por realizar uma revisão de literatura sobre os desafios da educação no período pandêmico, atrelado com o ensino e a aprendizagem em Geografia no Ensino Fundamental II em livros, artigos, dissertações e teses (documentais e eletrônicas) e análise dos principais conceitos atrelados ao problema de pesquisa.

O tipo de pesquisa caracteriza-se por ser aplicada, pois objetiva resolver um problema específico, ou seja, significar os objetos de estudo da Geografia escolar no período pandêmico. A abordagem do problema transcorrerá de forma mista, de maneira quantitativa e qualitativa. Do ponto de vista quantitativo, gera uma classificação dos dados levantados, já a abordagem qualitativa aborda o universo de significados, de motivos, de aspirações, de crenças, de valores e de atitudes, o que corresponde a um espaço mais profundo das relações, dos processos e dos fenômenos Minayo (2001).

A coleta de dados ocorrerá através da realização de questionário misto, utilizando o software Microsoft Forms. Já as entrevistas serão semiestruturadas e aplicadas de forma individual. Para fomentar a pesquisa será realizada a prática da pesquisa de campo nas escolas selecionadas, para a viabilização de um estudo comparativo. Para a pesquisa empírica pretende-se selecionar seis escolas, três da rede pública e três da rede particular de ensino de Porto Alegre/RS, mas essa definição específica dos objetos de estudos será combinada posteriormente com o professor orientador da dissertação.

Na busca de uma melhor compreensão dos objetivos específicos, será necessário um estudo de caso em turmas do Ensino Fundamental II, para contextualizar o ensino de Geografia na rede pública e privada de Porto Alegre/RS, observando os desafios impostos pela contemporaneidade associados ao distanciamento social e a prática do ensino remoto emergencial. Ainda assim, será necessária a investigação dos planejamentos bem como os recursos utilizados nas aulas durante o contexto pandêmico, com 
o intuito de refletir e propor soluções para um ensino e aprendizagem em Geografia mais significativo associado ao mundo atual.

De suma importância para o prosseguimento dessa proposta, será realizada uma comparação entre as diferentes estratégias utilizadas pelos professores da rede púbica e privada, com a intensão de analisar as diferenças entre os processos de ensino e aprendizagem em Geografia, levando em consideração que o fazer pedagógico deve estar associado ao novo, visando práticas criativas atuais, e não na reprodução (CASTROGIOVANNI, 2006, p. 24).

Na sequência, será realizada uma análise para compreender o contexto escolar no qual o estudante está inserido, para melhor compreender a aprendizagem, pois segundo Castrogiovanni (2012) a Geografia escolar deve ser estruturada a partir da compreensão integral do espaço geográfico, permeando as representações e concepções de vida dos estudantes, pois é fundamental ofertar situações de aprendizagem que contemplem as referências dos alunos em relação ao seu espaço vivido. Ainda assim, será necessário refletir novas práticas de ensino em Geografia para reduzir as lacunas existentes entre o ensino público e privado, uma vez que o contexto, a organização e a estrutura do espaço escolar interferem diretamente nos processos de aprendizagem.

Por fim, serão propostas novas abordagens didático-metodológicas para a significação dos objetos de estudo da Geografia escolar, a partir da realização de oficinas pedagógicas e atividades associadas ao ambiente virtual, para que os estudantes possam buscar soluções para o seu cotidiano, percebendo a Geografia como parte de suas vidas.

\section{RESULTADOS E DISCUSSÃO}

O então novo período, determinado pela pandemia da Covid-19, salientou algumas incertezas, como os dogmas e a crença em uma única forma de agir e pensar. Todos que estão envolvidos com a formação de pessoas são convidados diariamente a romper com a dita zona de conforto, tendo em vista a demanda que se exige tanto do educador quanto do educando. Um dos desafios mais marcantes para a educação surge a partir da reconstrução dos espaços, em que homens e mulheres necessitam trabalhar de forma conjunta e contínua, envolvendo interesses públicos 
e privados. A noção de educação remete à construção de uma sociedade organizada e baseada em uma série de temas que possuam relação com o contexto e realidade vivida das pessoas, levando a busca de respostas através da reflexão ou da ação. Perante o contexto pandêmico causado pela crise sanitária da Covid-19, faz-se necessário refletir sobre o papel do ensino da Geografia na concepção do mundo atual em relação aos objetos de estudos desenvolvidos nas escolas.

Nesse sentido, Calai (2001) contribui afirmando que o atual ensino da Geografia, assim como os demais componentes curriculares, deve considerar a crítica sobre aquilo que a escola representa na atualidade, para que haja uma compreensão do contexto político e socioeconômico do mundo, fundamentalmente do Brasil. Ao refletir sobre isso, podemos problematizar até que ponto há uma real significação dos conteúdos tratados em sala de aula? De que maneiras a pandemia pode ter ressignificado o ensino e a aprendizagem da Geografia? O ensino geográfico é igualitário quando analisado a sua prática em instituições de ensino públicas e privadas? A insurgência de um ensino remoto emergencial evoluído para um ensino híbrido, pode ter causado algum impacto no ensino da Geografia? Os objetos de estudo da Geografia escolar, estão sendo significados ao ponto de fazerem sentido no cotidiano dos estudantes, para compreenderem o contexto socioespacial da atualidade? Tais indagações permeiam o campo desta proposta de pesquisa, uma vez que a essência do ensino da Geografia, deve ser pautada em discussões que levem o sujeito a ler o espaço geográfico relacionando-o com outros tempos e espaços (GIORDANI, 2014, p. 7).

\section{CONCLUSÕES}

Com as incertezas do momento, as noções de tempo e espaço assumem uma nova condição, tendo em vista a necessidade da readaptação dos processos de ensino e aprendizagem. Nessa perspectiva, estudantes e professores buscaram alternativas para o convívio em rede. Assim, o ambiente virtual aproxima as partes envolvidas no processo educativo. No entanto, revela uma complexidade quando se depara com as múltiplas formas de aprender. As tecnologias digitais definem formas alternativas de aprendizagem, remetendo a estruturação de um ciberespaço, que para Lévy 
(1999, p.92) corresponde ao espaço de comunicação aberto pela interconexão mundial dos computadores e das memórias dos computadores. Perante essa definição, podemos estabelecer uma relação de ressignificação, pois o ciberespaço está inserido nas relações socioespaciais, estabelecidas no espaço geográfico.

Portanto, a grande questão é tentar compreender como as práticas associadas ao ensino e aprendizagem em Geografia, serão impactadas a partir do afastamento social, do ensino remoto emergencial e ensino híbrido e quais serão os fatores fundamentais a serem projetados no período pós-pandemia. Para isso, Rego (2007, p.16) nos ajuda a compreender que a Geografia é uma forma de refletirmos sobre a nossa existência, uma forma de ler e pensar de maneira filosófica aquilo que influencia o nosso dia-a-dia.

\section{REFERÊNCIAS}

CAStrogiovanNi, Antonio Carlos et al. Ensino da Geografia: Caminhos e Encantos. 2. ed. rev. Porto Alegre: EDIPUCRS, 2006.

Antonio Carlos; COSTELLA, Roselane Zordan. Brincar e Cartografar com os diferentes mundos geográficos: a alfabetização espacial. 2. ed. rev. Porto Alegre: EDIPUCRS, 2011.

CALLAI, H. C. A Geografia e a escola: muda a geografia? Muda o ensino? Revista TerraLivre, São Paulo, ano 1, n. 16, p. 133-152, 2001.

Ensino de Geografia: Práticas e textualizações no cotidiano. 10. ed. Porto Alegre: Editora Mediação, 2012.

FREIRE, Paulo. Educação como prática da Liberdade. Rio de Janeiro, Paz e Terra, 1980.

. Pedagogia do Oprimido. Rio de Janeiro; Paz e Terra, 2005.

GIORDANI, Ana Claudia et al. Aprender a ensinar Geografia: a vivência como metodologia. 1. ed. rev. Porto Alegre: Evangraf, 2014. 
IVIC, Ivan. Lev Semionovich Vygotsky / Ivan Ivic; Edgar Pereira Coelho (org.).

Recife/PE. Fundação Joaquim Nabuco, Editora Massangana, 2010. Disponível em: http://www.dominiopublico.gov.br/download/texto/ me4685.pdf

LEVY, Pierre. Cibercultura. 2. ed. São Paulo: Editora 34, 1999.

MINAYO, M. C. S. (Org.). Pesquisa social: teoria, método e criatividade. Petrópolis/RJ: Vozes, 2001.

SANTOS, Milton. Espaço e Sociedade. Vozes, Petrópolis/RJ, 1979.

Metamorfose do espaço habitado: Fundamentos teóricos e metodológicos da geografia. Hucitec. $3^{\underline{a}}$ ed. 1994, São Paulo/ SP.

A Natureza do Espaço: Técnica e Tempo, Razão e Emoção. São Paulo: Edusp, 1996.

Espaço e Método. São Paulo: Edusp, 2012.

SCHAFFER, Neiva Otero et al. Um globo em suas mãos: práticas para a sala de aula. 3. ed. rev. Porto Alegre: Penso, 2011.

UNESCO. Estratégias de ensino a distância em resposta ao fechamento das escolas devido à Covid-19. Nota Informativa - Setor de Educação. 2020. Disponível em: https://unesdoc.unesco.org/ ark:/48223/pf0000373305_por?posInSet=1\&queryId=2c9c2c48-fca9-4456-af78-d454cd849ba7 


\title{
DESAFIOS DA EDUCAÇÃO BÁSICA EM TEMPOS DE ENSINO REMOTO
}

\author{
Laiane Michele Silva Souza
}

\section{INTRODUÇÃO}

O presente trabalho pretende destacar alguns desafios enfrentados por professores(as) e alunos(as) da educação básica nesse contexto de pandemia, no qual impediu que as aulas presenciais continuassem. No entanto, para que o processo formativo não fosse muito prejudicado pelo tempo de duração das medidas de distanciamento social aplicadas para conter a proliferação do novo coronavírus, optou-se por utilizar o ensino remoto como estratégia educacional para todos os níveis, com destaque para o básico que é o foco deste trabalho.

Diante da atual realidade, é lúcido considerar que o ensino remoto deve perdurar por mais alguns meses; além disso, essa modalidade de educação tende a permanecer através das instituições de Educação à Distância, entre outras, o que faz das reflexões desta pesquisa oportunas para o pós-pandemia também, pois ela pretende dar subsídios para que o ensino remoto revise e repense algumas problemáticas.

\section{FUNDAMENTAÇÃO TEÓRICA}

A pandemia da Covid-19 não é a primeira que assola o planeta, e é evidente que ela traz especificidades por estar em um contexto sócio-histórico diferente das outras. O próprio vírus é novo, mas como todo momento histórico que altera a "normalidade" da vida das pessoas, esse tam- 
bém deixará consequências para educação, saúde, relações sociais, para o modo como se encara a realidade etc.

Em termos de educação, pode-se considerar que o ensino remoto ou on-line, que já existia, sobretudo na modalidade de Educação à Distância (EaD), agora ganhou outra proporção pela urgência de sua adoção no período da pandemia. Houve a chance de se consagrar de vez como uma possibilidade de estratégia educacional, sendo utilizada, senão inteiramente, pelo menos de maneira híbrida, aliada a educação regular, ou seja, coexistindo com as aulas presenciais. No entanto, para que isso ocorra, é importante considerar a realidade do país, onde há grande desigualdade social; com isso, para a consolidação de qualquer alteração na educação, sobretudo, pública, é preciso minimizar essa situação, e em última instância, extingui-la.

Não se deve deixar de levar em consideração que a globalização, de alguma forma, proporcionou que a sociedade do século XXI conseguisse ter um isolamento social criativo, com as inúmeras vias de acesso à informação e de conexão entre pessoas. Enfim, é um avanço social considerável conseguir ficar isolado em casa mas ao mesmo tempo não se isolar completamente das pessoas e do que está acontecendo nas diversas sociedades espalhadas pelo globo, tendo, para isso, a possibilidade de acessar vídeos, filmes, textos, músicas, dentre tantas outras coisas, na Internet. No entanto, esse avanço social não alcançou um contingente considerável de pessoas que não têm esse acesso aos seus benefícios, incluindo, conseguir ter aulas em casa via internet. No que se refere ao ensino remoto, ou seja, on-line, é preciso levar alguns fatores em consideração:

As desigualdades sociais também são acompanhadas de exclusão digital [...] A pesquisa TIC Domicílios apontou que enquanto 92\% da classe média está conectada, apenas $48 \%$ da população de baixa renda, Classes D e E, têm algum tipo de acesso à Internet, quase sempre via celular (TIC DOMICÍLIOS, 2019). Os desafios para a inclusão digital ainda são imensos no País. (COUTO; COUTO; CRUZ, 2020, p. 210).

Para reforçar esses dados, cita-se Cunha e Costa (2021) que em seu relatório de pesquisa, mais especificamente, no gráfico construído com base 
nas respostas de 726 professores da educação básica baiana para a seguinte questão: "Você compreende que as estratégias utilizadas possibilitam um ensino igual para todos os educandos?”, 542 professores escolheram a alternativa "não". É preciso dar destaque a esses dados, ainda mais que na pesquisa de Cunha e Costa (2021), a maioria dos professores que responderam ensinam na rede pública; $87 \%$ dos professores entrevistados nessa pesquisa são desse seguimento, o que deixa evidente que ainda há muito o que se fazer para que o ensino on-line se efetive de maneira equânime, sobretudo na pandemia, quando é o meio mais seguro de fazer as aulas acontecerem.

$\mathrm{Na}$ educação formal, as experiências no uso das TICs possuem resultados muito diferenciados no contexto pandêmico da Covid-19, dependendo primeiramente das assimetrias nas condições infraestruturais e individuais de acessibilidade, bem como, em segundo lugar do nível de ensino (fundamental, básico e superior), idade dos discentes e graus de capacitação digital dos professores, sempre levando em consideração as condições pré-existentes (SENHORAS, 2020, p. 133)

Há um ponto salientado pelo autor que também precisa de atenção especial nesse momento de educação remota e diz respeito à capacidade (ou falta dela) que os professores têm de lidar com as tecnologias de informação e comunicação (TICs). De acordo o relatório de pesquisa apresentado por Cunha e Costa (2021), quando perguntados se os professores baianos possuíam equipamentos e domínio suficiente de informática para conseguir ministrar suas aulas on-line, 65\% assinalaram a opção "não". Isso evidencia que, para esse tipo de ensino, os(as) professores(as) da Bahia não estavam preparados e tiveram que se adaptar no decorrer do processo ensino-aprendizagem. Evidentemente, há alunos que também encontram essas dificuldades, sendo um elemento indicativo para uma possível queda na aprendizagem, que aliás é sentida pelos professores baianos (CUNHA; COSTA, 2021).

\section{METODOLOGIA}

Para a realização da pesquisa, utilizou-se como metodologia a análise de dados do Relatório de pesquisa: os desafios de ser professor(a) durante a pan- 
demia da Covid-19 na Bahia, organizado por Cunha e Costa (2021). Utilizou-se, ainda, a revisão bibliográfica de educadores que se debruçaram sobre a temática: educação em tempos de pandemia, entre eles Couto; Couto; Cruz (2020) e Senhoras (2020), que ofereceram panoramas importantes sobre os desafios do ensino remoto.

\section{RESULTADOS E DISCUSSÃO}

Considera-se a problemática da exclusão digital no país a mais urgente de ser solucionada, pois se uma parcela considerável dos alunos não tem condições de acessar as aulas porque não possuem equipamentos e Internet necessária, o ensino remoto não se torna a estratégia mais pertinente para dar continuidade as aulas no contexto pandêmico, tendendo a ser muito problemática.

A Constituição Federal, em seu art. 206, inciso I, referente à educação, prevê "a igualdade de condições para o acesso e permanência na escola” (BRASIL, 1988). Ora, se é preciso continuar o processo formativo do aluno e a educação está vivendo uma situação atípica, em que a "escola" está integrada à casa dos alunos. É preciso então que o Estado intervenha, já que ele compartilha esse dever com as famílias e algumas destas não conseguem proporcionar TICs e internet de qualidade para que seus membros acompanhem as aulas, tornando-se seu dever ofertar essas ferramentas.

Há outra intervenção que o Estado precisa fazer nesse período de ensino remoto, que diz respeito a capacitar os professores para que estes consigam lidar com as TICs e os softwares utilizados pelas escolas para poderem prosseguir com o processo de ensino-aprendizagem.

Faz-se necessário salientar que, antes de começarem com o ensino remoto, os gestores deveriam ter ofertado um período de formação aos professores para que, minimamente, eles pudessem estar familiarizados com as ferramentas utilizadas e conseguissem orientar seus alunos.

Subtende-se pela resposta dada pelos professores da pesquisa de Cunha e Costa (2021), que na maioria dos casos não houve essa formação e se houve não foi suficientemente satisfatória, já que o dado indica que a maioria não sabia lidar com essas tecnologias. 


\section{CONCLUSÕES}

Para todos os desafios que a educação básica enfrenta, especialmente nesse período de educação remota, e não só os que foram apontados na presente pesquisa, é pressuposto básico para sua resolução colocá-los em pauta, não apenas no contexto escolar, mas também em ambientes políticos e sociais. Quanto mais desvelados estiverem e postos em debate, mais aberto estará o "caminho" para solucioná-los.

Este trabalho, por exemplo, cumpre esse papel, ao evidenciar alguns fatores problemáticos que surgem na educação on-line no contexto brasileiro, propondo que eles sejam debatidos e refletidos. Não se coloca entre os objetivos encerrar as discussões sobre o tema, pois seria presunção e estaria contradizendo o argumento de que é importante valorizar o diálogo visando a um consenso como método para solucionar os problemas. Há outros desafios centrais, que precisam ser colocados em pauta o quanto antes, para que sejam debatidos e gerem um efetivo e equânime processo de educação nesse momento de pandemia, e que seus efeitos se reverberem para o pós-pandemia.

\section{REFERENCIAS}

BRASIL. Constituição da República Federativa do Brasil. Brasília, DF: Senado Federal: Centro Gráfico, 1988.

CUNHA, Ana Luiza Salgado; COSTA, Glauber Barros Alves (org.). Relatório de Pesquisa: Os desafios de ser professor (a) durante a pandemia da Covid-19 na Bahia. 1 ed. Caetité: UNEB - Universidade do Estado da Bahia, 2021.

COUTO, E. S.; Couto, E. S.; CRUZ, I. de M. P. \#FIQUEEMCASA: Educação na pandemia da Covid-19. Educação, v. 8, n. 3, p. 200-217, 2020. Disponível em: https://doi.org/10.17564/2316-3828. 2020v8n3p200-217. Acesso em: 02 maio 2021.

SENHORAS, Eloi Martins. Coronavírus e educação: análise dos impactos assimétricos. Boletim de Conjuntura (BOCA), v. 2, n. 5, p. 128-136, 2020. Disponível em: http://doi.org/10.5281/zenodo.3828085. Acesso em: 02 maio 2021. 


\title{
EJA NO SISTEMA PRISIONAL BRASILEIRO
}

\author{
Lanita Helaine S. N. Sizanosky ${ }^{75}$
}

O presente trabalho foi elaborado no decorrer do programa de Pós-Graduação em Educação e Novas Tecnologias, o qual possibilitou novas experiências pedagógicas para esta pesquisadora. A educação é um ato transformador e sua efetivação permeia um compromisso político e social de pessoas que tem por objetivo a transformação da sua realidade da comunidade onde vive (FREIRE, 1996). No sistema penitenciário, conforme relata Julião (2007), a escola, ainda que localizada em um espaço repressor, é o único local que possibilita e estimula processos educativos, contribui na reconstrução da identidade e na reintegração social dos reclusos.

O objetivo geral desta pesquisa é trazer à tona a importância da EJA no sistema prisional, suas características e sua atuação neste processo reflexivo. Analisar a EJA na educação prisional, sob um olhar da Lei de Execução Penal (LEP) e do Decreto n⿳⺈ 7.626/2011, que oferta esta demanda educacional, é um dos objetivos específicos desta pesquisa. Demonstrar, por meios de pesquisas já realizadas, as restrições e limitações que este ambiente recluso impõe ao processo educacional e o papel da educação como forma de contribuir no tratamento penal, é outro objetivo específico.

75 Pedagoga há 31 anos, formada pela UFPR. Mestre em Educação e Novas Tecnologias (UNINTER), Doutoranda em Educação (UNILOGOS University International). Atua como Penal na Casa de Custódia de São José dos Pinhais- Paraná- Brasil. 
Historicamente, a Educação de Jovens e Adultos foi marcada por muitos embates para que esta modalidade de ensino fosse reconhecida no país e houvesse investimentos necessários. Pensar na EJA no país traz à tona a palavra exclusão. Segundo Haddad e Pierro (2000), grande parte do perfil dos jovens inseridos na modalidade de ensino da EJA é composta por jovens excluídos do ensino regular, os quais carregam o estigma de alunos-problemas.

Na história educacional do país, a Educação de Jovens e Adultos é algo recente, pois data de 1925, tendo sido sempre influenciada pelos períodos políticos que a utilizaram para legitimar o poder do Estado. Foi por meio da Educação Popular, direcionada pelo educador Paulo Freire, que surge não apenas uma metodologia de combate ao analfabetismo, mas uma proposta politicamente humana, que contempla uma consciência transformadora da realidade vivida, por meio de uma leitura histórica social.

A Lei de Execução Penal (LEP), nº 7210/84 em seu art. 10, declara que é dever do Estado a assistência educacional aos detentos, como forma de prevenir o crime e reorientá-lo a sociedade, mas foi por meio do Decreto $n^{-}$7.626/2011 que a oferta de educação para jovens e adultos em estabelecimentos penais foi associada às ações complementares de cultura, esporte, inclusão digital, educação profissional, fomento à leitura e a programas de implantação, recuperação e manutenção de bibliotecas destinadas ao atendimento à população privada de liberdade, inclusive as ações de valorização dos profissionais que trabalham nesses espaços.

O princípio fundamental que deve ser enfatizado e exigido é que a educação no sistema penitenciário não pode ser entendida como privilégio, benefício ou, muito menos, recompensa oferecida em troca de um bom comportamento. Entende-se que a educação é um direito previsto constitucionalmente. Entretanto, Oliveira (2013, p. 961) alerta por meio de pesquisa de campo, realizada na prisão de Uberlândia (MG) que nem sempre este direito é respeitado já que para o acesso ao ensino formal é avaliado "a conduta de cada preso, o qual se transforma o direito de todos à educação em um benefício individual e algo a ser conquistado", entende-se, portanto, ser este um benefício para poucos. A imperfeição do sistema obriga as unidades penitenciárias a realizarem uma triagem para a escolha dos presos que terão acesso ao ensino formal, isto porque ao 
construir as unidades penitenciárias não se pensava no tratamento penal, ou seja, não se planejava o atendimento escolar.

Mesmo havendo elementos comuns à EJA fora do ambiente carcerário, Onofre (2007) e Oliveira (2013), entre outros, alertam quanto ao trabalho prático diferenciado neste ambiente recluso, em virtude das restrições que o ambiente prisional impõe ao processo educacional.

Para atingir o objetivo proposto neste trabalho de pesquisa, a metodologia utilizada será a exploratória e apresenta uma abordagem qualitativa. Quanto à estratégia, este trabalho é constituído por meio de pesquisa bibliográfica e documental, pois pretende-se realizar a análise de materiais impressos e on-line, bem como documentos que possibilitem analisar o tema.

Ser um educador atuante na educação de jovens e adultos para privados de liberdade é um grande desafio, pois trazer à sala de aula temas problematizadores que incentivem a autonomia reflexiva nem sempre é visto com simpatia em um ambiente repressor.

Pensar na EJA nos traz à mente a palavra exclusão; para os privados de liberdade, este sentimento é uma realidade. É na escola que o aluno encarcerado se percebe como alguém mais próximo a quem ele era quando em liberdade.

Quanto às características educacionais no ambiente prisional, menciona-se a rotatividade dos alunos para outros presídios, no decorrer do processo de ensino, em virtude de progressão ou regressão de regime carcerário. Outra característica a ser discutida é a arquitetura das unidades prisionais do país, as quais, quando planejadas, muitas não contemplam o espaço educacional.

Uma unidade prisional que não investe em uma ação educativa decreta aos detentos que nela estão inseridos, ações reincidentes na criminalidade.

\section{CONCLUSÕES}

A educação no sistema penitenciário não pode ser entendida como privilégio, benefício ou, muito menos, recompensa oferecida em troca de um bom comportamento.

Trabalhar com jovens e adultos é estar aberto a repensar sua prática escolar diariamente, pois o aluno adulto possui conhecimentos e capaci- 
dade reflexiva que não pode ser desprezada. Para o sucesso do processo educativo é necessário que se fomente, no ambiente escolar, diálogos participativos e democráticos, mediado por um professor que propicie um compartilhamento de informações contextualizado e invista em reflexões, possibilitando ao aluno encarcerado construção de saberes, que gerem senso crítico e autonomia reflexiva.

Investir na autonomia reflexiva do educando é investir na sua formação ou reconstrução social e este processo pode alterar não apenas o futuro de uma pessoa, mas de uma sociedade. Contrariamente a este investimento educativo, pode ocorrer um fator inverso ao proposto nas assistências elencadas na Lei de Execução Penal (LEP) e no egresso à sociedade. Esse detento pode apresentar comportamento institucionalizado ao vivido no ambiente prisional, abrindo ou aprofundando o abismo no espaço sócio familiar e o fracasso do tratamento penal poderá ser percebido por meio das reincidências criminais.

\section{REFERENCIAS}

BRASIL. Ministério da Justiça - Lei de Execução Penal 7.210. Disponível em: <http://portal.mec.gov.br/index.php?option=com_docman\&view $=$ download \&alias $=10029-$ lei-7210-11-julho-1984\&category_slug=fevereiro-2012-pdf\&Itemid=30192>. Acesso em: 10 nov. 2018.

FREIRE, PAULO. Pedagogia da Autonomia - Saberes necessários à prática educativa. 2. ed. São Paulo: Paz e Terra, 1996.

HADDAD, Sérgio; PIERRO, Maria Clara Di. Escolarização de Jovens e Adultos. Revista Brasileira de Educação, n. 14, p.108-130, maio-ago. 2000. Disponível em: <http://www.scielo.br/pdf/rbedu/ n14/n14a07.pdf>. Acesso em: 03 nov. 2018

JULIÃO. Elionaldo Fernandes. EJA e Educação Prisional - Educação para Jovens e Adultos Privados de Liberdade: desafios para a Política e Reinserção Social. Ministério da Educação. Projeto Salto para o Futuro. Boletim n. 06, maio de 2007. 
OLIVEIRA, Carolina Bessa Ferreira de. A educação escolar nas prisões: uma análise a partir das representações dos presos da penitenciária de Uberlândia (MG). Educ. Pesqui., São Paulo, v. 39, n. 4, p. 955-967, out./dez., 2013. Disponível em: <http://www.scielo.br/ pdf/ep/v39n4/aop894.pdf>. Acesso em: 02 nov. 2018.

ONOFRE, Maria Cammarosano. Educação Escolar entre as grades. São Carlos: EDUFSCAR, 2007. 


\section{UTILIZAÇÃO DO DIÁRIO DE BORDO PARA DESENVOLVIMENTO DE COMPETÊNCIAS E AUTONOMIA COM ALUNOS DO PROEJA}

Leonardo do Monte Rabelo ${ }^{76}$

\section{INTRODUÇÃO}

Os alunos participantes do PROEJA chegam ao programa com histórias de vida, em sua maioria, difíceis e conturbadas juntamente com grande predominância de baixa autoestima e falta de estímulo para estudos. Pela própria característica do programa, circunstâncias da vida impediram a conclusão do ensino médio desses alunos. Segundo Paulo Freire (1996), se alguém não é capaz de sentir os outros, é que lhe falta ainda muito que caminhar, para chegar ao lugar de encontro com eles. Neste lugar de encontro, não há ignorantes absolutos, nem sábios absolutos: há homens que, em comunhão, buscam saber mais.

Tendo em vista que os alunos do PROEJA são adultos, entende-se a necessidade da utilização das bases da andragogia por respeito aos conhecimentos prévios trazidos por estes e para elevação da autoestima no processo de construção do conhecimento eficaz. O presente trabalho teve

\footnotetext{
76 Mestre em Consumo, Cotidiano e Desenvolvimento Social pela UFRPE (2016), Pós-graduado em Logística Empresarial (MBA) pela FCAP/UPE (2012) e Didática e Metodologias Ativas pela Uniamérica (2020), Graduado em Administração pela FBV (2007), Psicanalista pela ABEPE (2021), Professor do IFPE.
} 
por objetivo desenvolver a autonomia e elevação da autoestima dos alunos visando ao desenvolvimento de competências por meio de um diário de bordo. Foi possível perceber o grande impacto social e nas vidas dos alunos, pois a maioria trabalha durante o dia e chega ao programa, em período noturno, com algumas expectativas como melhorar seu desempenho profissional, conseguir empregos e terminar a educação básica.

Foi possível entender que a falta de uma educação formal mais abrangente que vá além do técnico, e atinja algumas competências comportamentais exigidas pelo mundo do trabalho, mas não ensinadas no fundamental e nem mesmo em muitos técnicos, justificam este trabalho. A educação profissional não se restringe ao aprendizado de técnicas, mas também ao desenvolvimento integral do ser humano.

\section{FUNDAMENTAÇÃO TEÓRICA}

A escrita é uma forma de os alunos expressarem suas ideias e raciocínios, bem como ampliar sua compreensão em todas as disciplinas. A capacidade de expressar os pensamentos propicia a possibilidade de reelaborações de conceitos para construção do conhecimento, muito bem expresso por Freire (1996) quando explica o processo de construção do conhecimento pela alfabetização.

Para que o indivíduo venha a ser interferente no seu contexto, é necessário o exercício da autonomia na fase adulta. Segundo Knowles (1980), nessa etapa da vida a aprendizagem é predominantemente autodirigida, objetiva e centrada na vida. A capacidade de aprender não se fundamenta apenas na capacidade racional e no nível acadêmico alcançado. Ela é bastante influenciada pelas vivências e pelos aspectos subjetivos e emocionais. A história de vida pode facilitar ou prejudicar a abertura ao novo. Portanto, a utilização de um diário bordo se mostra como uma abordagem metodológica de grande impacto. Segundo, Oliveira, Gerevini e Strohschoen (2017) o conteúdo do diário de bordo é de cunho inteiramente pessoal, onde os estudantes podem usar um plano de pesquisa para formular seus métodos, devem escrever da maneira como veem o mundo, suas indagações e estar de acordo com o momento que vivem o processo de aprendizagem diária. A comunicação pessoal e a grupal são componentes interligados e inseparáveis no processo de aprender conti- 
nuamente, mais profundamente num mundo cada vez mais complexo e imprevisível (MORAN, 2014).

Para que se possa perceber a evolução no processo, o diário de bordo pode ser alinhado com a metodologia Writing Across the Curriculum (escrita por meio do currículo). Segundo Dalporto (2013), a escrita através do currículo é projetada para ajudar a impulsionar as habilidades de pensamento crítico e exigir que os alunos não apenas escrevam durante as artes da linguagem, mas também durante disciplinas como matemática, estudos sociais e ciências.

\section{METODOLOGIA}

Para execução do projeto, foi escolhida a escola estadual Madre Iva Bezerra de Araújo, situada no município de Cabo de Santo Agostinho-PE, que oferta as modalidades EJA e PROEJA, sendo este último em convênio de cooperação técnica com o Instituto Federal de Educação de Pernambuco (IFPE) para os componentes curriculares técnicos. Estão matriculados cerca de 70 alunos no PROEJA e 80\% destes com idades entre 30 e 60 anos. Por se tratar de adultos, os princípios da andragogia que sustentam essa proposição: clima de confiança e respeito nas aulas, valorização da experiência adquirida e das novas vivências; participação dos alunos em todas as etapas da aprendizagem, interesse e aplicabilidade dos conteúdos (KNOWLES, 1980).

Com as característica dos alunos do PROEJA, a escrita não deveria extensa, mas sim, alguns parágrafos relatando três pontos principais: 1 - os conteúdos aprendidos na disciplina; 2 - Como se pode aplicar na rotina diária e 3 - Como tem sido os sentimentos e percepções pessoais. Esses parágrafos deveriam ser escritos ao final das aulas dos componentes técnicos, ministradas pelos professores do IFPE. Na aula subsequente, os alunos que se sentiam à vontade podiam ler suas produções para a turma, podendo ser realizada uma roda de conversa sobre as aplicabilidades dos conteúdos nas rotinas de todos.

Com a evolução do calendário e das disciplinas no período letivo, realizaram-se a releitura e análise das produções, para que se percebessem as mudanças no padrão da escrita, conhecimentos construídos, motivação, autoestima e autoimagem. Ao final do semestre letivo, o estudantes fize- 
ram uma produção escrita relatando todo o processo passado, vivências pessoais e quais mudanças foram percebidas.

\section{RESULTADOS E DISCUSSÃO}

A coleta e leitura das produções textuais mostraram não só um desenvolvimento da escrita e capacidade de expressão, como um melhora significativa na emoções e autoimagem. Foi possível perceber uma diferença grande da capacidade de expressão oral e escrita, sendo essa última bem inferor. Quando se liam os textos escrotos, percebia-se dificuldade de expressar ideias e pensamentos no início da atividade, o que não ocorrida na fala. Com a prática de pequenos textos, pôde-se perceber a melhora significativa. Muitos relatos dos alunos atestam as observações como os seguintes, preservando os nomes:

Tenho aprendido com mais facilidade os assuntos, por exemplo: como posso usar a técnica do almoxarifado na organização da minha casa. Tá sendo muito bom esse aprendizado. É algo que vou levar para vida realmente, que é inesquecível (W.F.L. - 28 anos).

No início do curso eu estava muito desmotivado. Só vim para escola por conta do emprego que pediu o ensino médio. Mas com o contato com os colegas e a ajuda dos professores eu fui criando mais vontade de aprender e procurar um emprego melhor (A. M. -33 anos).

O que aprendi na aula de ontem ajuda muito no trabalho, muito boa. Outra coisa, abre uma outra ideia sobre a vida. Cada dia nessas aulas a gente vai aprendendo mais e criando novas ideias, se possível for, do que a gente for entendendo (C. S. -58 anos).

A análise dos dados mostrou que um aprofundamento do projeto com a interdisciplinaridade com a disciplina de português irá potencializar a aplicação e implementação do diário de bordo. As produções textuais pequenas (entre três e cinco linhas) inicialmente se mostraram mais eficazes no envolvimento dos alunos. A cada aula ia se pedindo que aumentassem mais uma linha, pois se fosse pedido que escrevesse um texto a recusa era maior. 


\section{CONCLUSÕES}

Esse projeto de intervenção almejou resgate da autoestima, autonomia e desenvolvimento de competências de expressão dos alunos do PROEJA do Campus Cabo de Santo Agostinho do IFPE. A utilização do diário de bordo se mostrou bastante eficaz devido à facilidade de aplicação e à baixa complexidade na execução, porém com grandes resultados positivos.

A capacidade de expressão oral e escrita são consequências do desenvolvimento cognitivo e pessoal. Esses fatores são fundamentais para a empregabilidade e desenvolvimento profissional por serem competências essenciais no mundo do trabalho. As dificuldades de escrita e expressão estão presentes na maioria dos estudantes matriculados nos programas de educação de jovens e adultos, mas que suas bagagens de experiência de vida não podem ser negligenciadas no processo educativo; pelo contrário, se fazem necessárias para o bom processo de construção do conhecimento no modelo andragógico de educação.

A intervenção apresentou um efeito positivo de grande impacto na vida e no resgate da autoestima dos alunos. Os relatos apresentados mostraram o quanto a necessidade de expressão pode ter um efeito libertador.

\section{REFERÊNCIAS}

DALPORTO, Deva. Writing Across the Curriculum: What, How and Why. WeAreTeachers.com. Disponível em: www.weareteachers.com/Writing-Across-the-Curriculum-What-How-and-Why Acesso em: 03/09/2020

FREIRE, Paulo. Pedagogia da Autonomia: saberes necessários à prática educativa. São Paulo: Paz e Terra, 1996.

KNOWLES, Malcolm S.; The modern practice of adult education from pedagogy to andragogy. New York: The Adult Education Company, 1980.

MORAN, José. Autonomia e colaboração em um mundo digital. Revista Educatrix, n. 7, p.52-37, Editora Moderna, 2014. 
OLIVEIRA, Aldeni Melo de; GEREVINI, Aalessandra Mocellin; STROHSCHOEN, Aaparecida Gumarães. Diário de bordo. Revista Tempos e Espaços em Educação, São Cristóvão, Sergipe, Brasil, v. 10, n. 22, p. 119-132, mai./ago. 2017. http://dx.doi. org/10.20952/revtee.v10i22.6429. 


\section{POLÍTICAS PÚBLICAS PARA EDUCAÇÃO DE JOVENS E ADULTOS: UM ESTUDO SOBRE A IMPLANTAÇÃO EM GOIÁS}

César de Araújo Pires ${ }^{77}$

Daniella Couto Lôbo ${ }^{78}$

\section{INTRODUÇÃO}

Este trabalho é parte de uma pesquisa em desenvolvimento que tem como temática: Cenários da Educação de Jovens e Adultos (EJA), uma leitura crítica das políticas educacionais em Goiás nos últimos 05 anos. O objetivo é compreender, a partir do levantamento bibliográfico, as políticas públicas referentes à Educação de Jovens e Adultos, adotadas nos últimos 05 anos de forma crítica e reflexiva. Os objetivos específicos são: identificar como se procedeu a implantação dos programas desenvolvidos no ensino noturno pela Secretaria de Estado da Educação; analisar a estrutura curricular e sua influência na construção de uma identidade escolar.

A pesquisa foi idealizada a partir da experiência enquanto gestor de uma escola pública da região metropolitana de Goiânia. Durante um pe-

\footnotetext{
77 Mestrando em Educação - FacMais, Especialista em Docência do Ensino Superior - FABEC, Licenciado e Bacharelado em História - PUC/GO, Professor FacCidade e da Rede Estadual de Ensino de Goiás.

78 Doutora em Educação e professora do curso de pedagogia da PUCGOIÁS e professora do quadro permanente do Mestrado em Educação da Faculdade de Inhumas (FACMAIS).
} 
ríodo de mais de oito anos, percebeu-se a necessidade de pensar a prática pedagógica direcionada aos jovens e adultos, principalmente aqueles que frequentavam o ensino noturno.

Sabe-se que o ensino noturno é marcado pelo expressivo número de evasão escolar. Isso se dá em função de diversos problemas sociais que envolvem a unidade escolar e pelas altas taxas de reprovação, fatores motivadores desta investigação. Os estudos sobre a Educação e Juventude no Brasil de autores como Alves (2016; 2018) e Feffermenn (2006) têm permitido compreender o perfil do alunado da EJA e, ainda, problematizar sobre políticas públicas, as intenções e contradições que a circundam da proposição à implantação.

Para alcançar esses objetivos, primeiramente realizou-se um levantamento bibliográfico sobre a temática em artigos científicos, jornais de circulação na cidade, livros de autores que trabalham com a temática do ensino noturno e, por fim, na documentação emitida pelo Conselho Estadual de Educação e Secretaria de Estado da Educação.

O estudo teórico sobre a temática permitiu verificar, até o momento, a problemática do ensino noturno, o perfil dos sujeitos atendidos nesse turno e a questão dos trabalhadores/estudantes. Os estudos realizados até o momento mostraram a questão da violência que assola o alunado do período noturno, o que reforça a necessidade de um olhar analítico para o ensino destinado à EJA.

Dados da avaliação externa da unidade escolar demostram uma queda nos índices avaliação do Índice de Desenvolvimento da Educação Básica (IDEB) e do Índice de Desenvolvimento da Educação de Goiás (IDE$\mathrm{GO})$, queda que pode ser atribuída ao ensino noturno devido às altas taxas de evasão e reprovação. Nesse contexto, é que se propõe o estudo das políticas públicas para a educação de jovens e adultos em Goiás nos últimos 05 anos, bem como a implantação de programas neste período.

\section{FUNDAMENTAÇÃO TEÓRICA}

A partir da análise de documentos emitidos pelo Conselho Estadual de Educação de Goiás (Resoluções, Portarias e Pareceres) acerca dessa temática, bem como dos documentos emitidos pela Secretaria de Estado da Educação de Goiás, fomentou-se a curiosidade em conhecer teoricamen- 
te as políticas educacionais que nortearam a educação de jovens e adultos em Goiás. Ainda nesta perspectiva, observou-se nos estudos de Libâneo (2008) uma análise do currículo que vem sendo apresentado e estudado na rede estadual de ensino de Goiás, principalmente na educação de jovens e adultos. A leitura da obra de Apple (2006) impulsionou uma investigação acerca da concepção impregnada na proposta curricular da educação de jovens e adultos, propiciando a formulação de novos entendimentos.

Ao analisar os documentos emitidos pelo Conselho Estadual de Educação e pela Secretaria de Estado da Educação - SEDUC, percebeu-se a necessidade de realizar um estudo sobre os currículos dos programas que atendem à educação de jovens e adultos em Goiás. Para isso, pretende-se utilizar os estudos de Arroyo (2013) para entender como a estruturação curricular proposta nos vários programas que atendem a educação de jovens e adultos da rede de ensino de Goiás têm sido percebidos pelo público alvo do programa.

O estudo teórico está sendo fundamentado em Paiva (2015), que estabelece uma linha cronológica para a implementação das políticas públicas para a educação de jovens e adultos. A leitura de Reis (2017) nos propicia um maior entendimento sobre a formação do perfil dos alunos da educação de jovens e adultos. Para entender o processo de evasão escolar pretende-se utilizar a discussão estabelecida Alves (2018) em seus diversos artigos-envolvendo a temática de jovens, violência e estudos no turno noturno. Por meio da leitura de Feffermann (2006) é possível elencar um dos prováveis elementos para a evasão escolar na educação de jovens e adultos, que seria o comércio do tráfico envolvendo os alunos desta modalidade. E, em Spósito (2014) observa-se uma análise dos desafios da reflexão sociológica na educação de jovens e adultos no noturno e outros que também tratam dessa temática.

O intuito é fundamentar o levantamento histórico das políticas educacionais dando ênfase à educação de jovens e adultos no Brasil de 1930 a 2020, nas políticas implementadas na última década e as causas dessa evasão escolar no turno noturno.

Foi realizada uma revisão bibliográfica em teses e dissertações, cujos autores se dedicaram a refletir a temática proposta, com o objetivo de subsidiar um estudo teórico que possa se alcançar uma resposta ao problema suscitado na pesquisa. 


\section{METODOLOGIA}

A pesquisa, ainda em desenvolvimento, tem sido realizada sob a perspectiva exploratória e qualitativa de cunho bibliográfico e documental. Para atingir os objetivos estabelecidos, optou-se pelo levantamento bibliográfico sobre a educação de jovens e adultos em Goiás, bem como os índices de evasão e reprovação, verificando também como a questão da violência e do tráfico contribuem para a elevação das taxas de evasão. Tem sido utilizado como fonte de pesquisa: livros, periódicos, teses e dissertações produzidas nos últimos dez anos.

$\mathrm{Na}$ análise documental utilizou-se documentação emitida pelo Conselho Estadual de Educação de Goiás e Secretaria de Estado da Educação de Goiás, bem como os dados dos últimos 05 anos referentes à Educação de Jovens e Adultos (EJA) e aos programas: Programa de Fortalecimento do Ensino Noturno (PROFEN), Novo Ensino Médio Noturno e Educação de Jovens e Adultos a Distância (EJA TEC), modalidade de ensino a distância.

\section{RESULTADO E DISCUSSÃO}

Fundamentados na leitura dos artigos de Alves (2018), Feffermann (2006) e Sposito (2014), pode-se perceber que uma das possíveis causas da evasão do turno noturno está interligada com as temáticas da violência na região da escola e sua relação com o perfil do alunado.

A discussão sobre currículo, ainda em processo, será fundamentada pelos estudos de Arroyo (2013), Libâneo (2008), Vasconcelos (2009), Cavalcante (2009) e Gomez (1998). Serão analisados, a princípio, o que os teóricos supracitados discutem sobre currículo e sua construção no âmbito escolar e sua aplicabilidade na EJA. Em uma análise preliminar dos teóricos supracitados, foi possível elencar algumas possibilidades de falhas que podem ter desencadeado os baixos resultados dos programas propostos pela Secretaria de Estado da Educação de Goiás - SEDUC. Programas que já nasceram condenados ao fracasso, como o Programa de fortalecimento do Ensino Noturno - PROFEN, sendo finalizado no final do segundo ano de desenvolvimento, mostrou a falta de estruturação curricular e a falta de enraizamento das concepções pedagógicas. 
Torna-se inevitável analisar os impactos da pandemia da Covid-19 na educação, enfatizando o ensino noturno e, em especial, a educação de jovens e adultos - EJA, estabelecendo um elo entre a evasão escolar e o contexto pandêmico como uma das causas que agravaram a evasão.

\section{CONCLUSÕES}

Diante do levantamento bibliográfico realizado pode-se fundamentar a escrita do primeiro capítulo da pesquisa. Nesse sentido, observou-se a necessidade de uma contextualização histórica das políticas educacionais no Brasil e, em especial, em Goiás, com ênfase no ensino da EJA e EJA TEC.

As leituras realizadas em Paiva (2015) e em artigos, dissertações e teses, possibilitaram entender o processo de implantação das políticas públicas para a educação de jovens e adultos no Brasil e em Goiás, que aconteceu de forma lenta e tardia, fator que pode ter sido agravado pelos períodos de turbulência vividos no Brasil em várias épocas (golpe varguista, ditadura militar de 64, etc.) e a forte influência neoliberal na estruturação das políticas educacionais.

Serão objetos de estudo também as propostas em curso e o ensino remoto, com ênfase na pandemia da Covid-19, quando as aulas remotas (síncronas e assíncronas) desencadearam um aumento da evasão escolar, já que boa parte dos alunos não possuem condições financeiras para acessarem as aulas on-line.

\section{REFERENCIAS}

APPLE, Michael W. Ideologia e Currículo. Porto Alegre: Artmed, 2006.

ARROYO, Miguel G. Currículo, território em disputa. 5 ed. Petrópolis, RJ: Vozes, 2013.

GOIÁS. Programa de Fortalecimento do Ensino Noturno "PROFEN". Superintendência de Ensino Médio - Gerencia de PROFEN/EJA. 2017. 
GOIÁS (CEE). Resolução CEE/CLN no 030 de 25 de novembro de 2018. Dispõe sobre a Autorização do Programa de Fortalecimento do Ensino Noturno - PROFEN, como curso experimental através da Secretaria de Estado da Educação, Cultura e Esporte e dá outras providências.

GOIÁS (estado). Diretrizes da Educação de Jovens e Adultos do Estado de Goiás (Minuta para discussão). Secretaria de Educação. 2010. (prelo). 


\section{A FALTA DA EDUCAÇÃO FINANCEIRA E MARKETING NOS CURSOS DE DIREITO EM SERGIPE}

Lavínia de Almeida Souza ${ }^{79}$

\section{INTRODUÇÃO}

O ensino superior tem como principal objetivo a educação de indivíduos em determinado ofício. As faculdades e universidades desenvolvem um currículo acadêmico, contendo as matérias necessárias para que o aluno ao concluir seu curso, consiga sucesso em sua carreira profissional. Contudo, no curso de direito, no estado de Sergipe, o ensino superior é falho em prover o básico de educação financeira e de marketing. O saber conteudista é de fato importante para a prática de um bacharel em direito, contudo o mesmo precisa ser cumulado de outros fatores para alcançar o sucesso. O marketing ensina o básico da autopropaganda e também de como saber cobrar pelos seus serviços, em contrapartida a educação financeira, garante um aprendizado sobre investir e gerenciar o dinheiro obtido com o seu trabalho, ambos importantes não só durante a vida laboral, mas também na aposentadoria. Sendo assim, o presente trabalho teve como impulsionador investigar o currículo acadêmico das Universidade e Faculdades de Direito, constando se há o oferecimento de matérias que dis-

79 Graduada em Direito pela Universidade Tiradentes (SE); Mestranda em Direitos Humanos pela Universidade Tiradentes (SE); Pós-Graduanda em Direito Tributário e Planejamento Tributário pela Faculdade 8 de julho 
corram sobre marketing e educação financeira, como também demonstrar a importância de inserir entres na grade curricular.

\section{FUNDAMENTAÇÃO TEÓRICA}

O mercado de trabalho encontra-se cada vez mais competitivo, dominar o assunto não é mais suficiente para que o profissional consiga obter sucesso ou até mesmo almejar um crescimento. O labor jurídico torna-se mais do que cumprir obrigações, é preciso mostrar diferencial para poder se destacar dos demais.

Existem em Sergipe 19 instituições que fornecem o curso de Direito; formam-se, aproximadamente, a cada ano, 1.394 bacharéis. Sendo assim, temos a anualmente uma enorme quantidade de pessoas que, em tese, possuem o mesmo conhecimento. Logo, a pergunta é o que diferencia ela das demais.

A interdisciplinaridade foi introduzida no mundo acadêmico depois de longos debates que proporcionaram o entendimento que é preciso abranger as barreiras para que o conteúdo passado em sala de aula converse com a realidade do mundo.

G odim, em seu trabalho Perfil profissional e mercado de trabalho: relação com a formação acadêmica pela perspectiva de estudantes universitários, conseguiu identificar as habilidades básicas que os alunos deveriam possuir sendo elas: dominar outro idioma e conhecer; informática (habilidades técnicas); ter visão mais ampla do contexto de trabalho e da organização (habilidade cognitiva), trabalhar em equipe e ser multiprofissional (habilidades atitudinais e comportamentais); saber argumentar e comunicar-se; saber administrar; trabalhar com imagem institucional; ser versátil e ético. Contudo, sob o enfoque da carreira jurídica foi considerado uma habilidade importante saber trabalhar com marketing de causas. (GODIM, 2002, p. 304).

Diante do exposto, conseguimos ver quais seriam o conjunto de habilidades necessárias para tornar-se um indivíduo em um profissional completo, contudo, as grades curriculares, em específico, do curso de direito, ainda é falha em prover matérias ou desenvolver atividades que permitam que seus alunos possam obter ou aflorar o conjunto de ferramentas para o auxiliarem no exercício de sua atividade laboral.

Silva Venoso (2007) irá afirmar que as faculdades e universidades precisam adaptar seus currículos académicos a fim de atender as novas 
demandas do mercado, irá inclusive exemplificar que o advogado moderno nem sempre é aquele com um perfil de tribuno. Logo, vemos que é preciso repaginar os cursos de Direito para que se possa preparar os futuros bacharéis para a realidade que irão enfrentar.

Sendo assim, segue-se o próprio exemplo de Godim (2002), que afirma que uma habilidade crucial para o direito é o saber trabalhar com marketing de causa, uma matéria que deveria ser apreciada seria Noções de Marketing.

O marketing vai além da propaganda, ele é um processo que envolve planejamento e execução de uma ideia a fim de satisfazer objetivos individuais e organizados (BOONE; KURTZ, 1998). Sendo assim, sabemos que não adianta dominar o conteúdo ensinado em sala de aula, é importante saber vender esse conhecimento, habilidade esta que pode ser desenvolvida em aulas voltadas para o marketing pessoal. Além do marketing, uma matéria de extrema importância é a educação financeira, saber administrar seu dinheiro e ser capaz de organizar um orçamento são habilidades importantes na vida adulta.

A educação financeira é o estudo sobre finanças, uma vez que através deste pode-se desenvolver a compreensão a respeito de conceitos e produtos financeiros de modo que trabalha na conscientização de oportunidades e riscos de sua ação (ESCOLACONQUER, 2017).

A importância da educação financeira está relacionada ao controle que o indivíduo possuirá sobre seu dinheiro. Prova desta importância é demonstrada de maneira especial neste momento de crise: a Folha de São Paulo constou que somente 38\% das famílias constituíram reserva em 2019 e foi graças a essa reserva que estão conseguindo passar pela pandemia, uma vez que estão administrando seu dinheiro de maneira consciente.

Sendo assim, temos mais uma vez a prova que não basta fornecer conhecimento e conteúdos no ensino superior, é preciso permitir que o aluno desenvolva habilidades que o ajudem tanto na vida profissional como na vida pessoal.

\section{METODOLOGIA}

O trabalho desenvolvida trata-se de uma pesquisa de corte que contou com o método quali-quantitativo, uma vez que além da revisão bi- 
bliográfica (livros, artigos científicos, dissertações de mestrado e teses de doutorado), utilizou-se da coleta de dados. A obtenção de dados baseou-se na pesquisa da grade curricular de Universidade e Faculdades, públicas e privadas, a fim de identificar se havia ou não o fornecimento de matérias que abordassem marketing ou educação financeira. As Universidades pesquisadas se resumiram em: Universidade Federal de Sergipe (UFS) e Universidade Tiradentes (UNIT), entre as faculdades podemos citar: Maurício de Nassal, 8 de Julho, FASE, FANESE e Pio Décimo.

Durante a pesquisa, também foi analisada as diretrizes determinadas pelo MEC no tocante ao curso de Direito e se haveria previsão da possibilidade de existir o oferecimento de matérias como marketing e educação financeira.

\section{RESULTADOS E DISCUSSÃO}

O Estado de Sergipe conta com 19 instituições de ensino superior, cujas quais oferecem o curso de direito. Dentre elas foram analisadas as seguintes instituições: Universidade Tiradentes, Universidade Federal de Sergipe, Faculdade Maurício de Nassal, Faculdade 8 de Julho, FASE, FANESE e Pio Décimo. No grupo amostral delimitado consegue-se identificar que nenhuma delas possuía na grade curricular, do curso de Direito, matérias que visassem ao ensino de noções de marketing e muito menos de educação financeira. Ficou constado que este fato decorre da inexistência de diretrizes do MEC que incentivem a inserção dessa interdisciplinaridade. Sendo assim, vemos que o ensino do direito em Sergipe ainda é voltado para um método exclusivamente conteudista e voltado somente para o mundo jurídico.

\section{CONCLUSÕES}

A interdisciplinaridade é uma importante prática no ensino superior, ela não somente humaniza o aluno para questões sociais que vão além do que existe no livro, como também permite a conversa entre diversos campos do conhecimento.

O mundo mudou, tornou-se tecnológico e com isso abriu-se novas portas no mercado de trabalho, não mais basta apenas o conteúdo é preci- 
so saber pôr em prática e acima de tudo, com um mercado de trabalho tão competitivo é mais do que necessário possuir um diferencial.

O marketing pessoal e profissional é importante quando queremos vender um produto, no caso do direito, o conhecimento jurídico, por isso o aluno precisa aprender a habilidade da autopropaganda, como mostrar seu trabalho, como alcançar potenciais clientes, tudo isso fazem parte do que transforma o indivíduo em um profissional completo.

A educação financeira é um adicional a estratégias e marketing, pois saber administrar o dinheiro é o princípio mais básico para obter sucesso, a má administração financeira pode por anos de trabalho em perigo, por isso, saber investir, guardar, aplicar e manejar suas finanças é tão importante.

Vemos que existe uma falha no tocante ao ensino superior, mas especifico, no curso de direito que precisa ser revista. Reconhecer a importância da inserção de matérias como marketing e a própria educação financeira, torna-se de extrema importância, pois é preciso educar, ensinar e preparar profissionais capazes de lidar com a competição e realidade do mercado de trabalho.

\section{REFERÊNCIAS}

BOONE, L.; KURTZ, D. L. Marketing contemporâneo. Rio de Janeiro, LTC, 1998.

\section{ESCOLACONQUER. O Que é Educação Financeira e Qual a} sua Importância. 2020. Disponível em: https://escolaconquer. com.br/blog/o-que-e-educacaofinanceira/?gclid=CjwKCAjwpKCDBhBPEiwAFgBzj3jxQIfA29d2x9MZevtwGgPSxxq9jEIT6evuCzintT70OYdYCW48KBoCcDkQAvD_BwE. Acesso em: 31 mar 2021.

GODIM, Sônia Maria Guedes. Perfil profissional e mercado de trabalho: relação com a formação acadêmica pela perspectiva de estudantes universitários. Revista Estudos de Psicologia, n. 7, 2002.

VENOSA, Silvo de Salvo. Reflexões Sobre Direito e Advocacia. Carta Forense, n, 44, 2007. 


\section{ESTABELECIMENTO E DESENVOLVIMENTO DA MICROBIOTA INTESTINAL EM IDADE PEDIÁTRICA}

Amanda do Nascimento Souza $a^{80}$

\section{INTRODUÇÃO}

O estabelecimento de uma microbiota intestinal saudável nos primeiros anos de vida é essencial para saúde da criança e posteriormente para o adulto, já que desempenha diferentes funções no hospedeiro humano, entre elas a proteção contra patógenos, modulação do sistema imune e absorção de nutrientes (HOUGHTELING; WALKER, 2015). Sabe-se que a composição e função da microbiota em idade pediátrica é modulada por diversos fatores, tais como: o tipo de parto (cesáreo ou normal), a amamentação, composição da microbiota materna, alimentação e uso de medicamentos (TADDEI; FEFERBAUM, 2017). Portanto, a estabilização e manutenção completa de um intestino saudável desde infância é de grande importância para o desenvolvimento de uma microbiota com baixo potencial patogênico.

\section{FUNDAMENTAÇÃO TEÓRICA}

A microbiota intestinal se refere à população de microrganismos vivos que habita o trato gastrointestinal. Ela é considerada um dos ecossistemas

80 Bacharel em Nutrição. 
mais complexos, sendo o parto, a primeira fonte de microrganismos para a colonização inicial do trato gastrointestinal (GONÇALVES; MELLO, 2014). A microbiota intestinal das crianças abrange menos espécies e com menor estabilidade, se comparado a microbiota de um adulto. A estabilização completa dessa microbiota infantil só se dá por volta dos 2 e 3 anos de idade e permanece relativamente estável na vida adulta. (MORAES et al., 2014). Dessa forma, cada criança irá apresentar um padrão único e variável de colonização, isso dependerá das condições as quais cada uma foram submetidas nos seus primeiros anos de vida (TADDEI; FEFERBAUM, 2017).

\section{METODOLOGIA}

Esta pesquisa compreende uma revisão de literatura em artigos científicos, que foram publicados nos bancos de dados Scielo (Scientific Eletronic Library On-line), Google acadêmico, Pubmed (National Library of Medicine) e Lilacs (Literatura Latino-americana e do Caribe em Ciências da Saúde). Com os seguintes descritores: microbiota intestinal, disbiose intestinal e microbiota do recém-nascido. Foram considerados estudos publicados na língua portuguesa e inglesa e que trataram da microbiota intestinal na fase pediátrica.

\section{RESULTADOS E DISCUSSÃO}

Diversos estudos vêm demostrando uma associação direta da microbiota intestinal com a manutenção da saúde durante a infância. No estudo feito por Felippo e colaboradores (2010), comparando-se a microbiota fecal de crianças da Itália urbana e da África rural, constatou-se que o grupo de crianças africanas por terem uma dieta basicamente vegetariana, composta pelo baixo consumo de proteínas animais e baixo consumo de gorduras apresentaram uma maior colonização por bactérias benéficas em comparação às crianças que viviam na região da Itália, com uma dieta tipicamente ocidental, com pouca fibra e muita gordura, tendo assim a alimentação um papel importante no desenvolvimento da microbiota. Já no estudo Penders e colaboradores (2005), crianças que foram amamentadas apresentaram uma microbiota benéfica com maior quantidade 
de bififobactérias e menos Clostridium difficile e Escherichia coli, Visto que leite materno é um importante modulador da composição da microbiota. Kalliomäki e colaboradores (2008) analisaram os principais grupos de bactérias em crianças com sobrepeso/obesidade e crianças eutróficas, constatando que crianças com sobrepeso e obesidade apresentaram maiores quantidades de bactérias patogênicas, demostrando uma importante influência do peso sob a colonização da microbiota intestinal.

\section{CONCLUSÕES}

Diante do exposto, conclui-se que a microbiota intestinal exerce grande influência na saúde do hospedeiro, e sendo assim, a estabilização e manutenção completa de um intestino saudável desde a infância até a vida adulta é imprescindível para o desenvolvimento de uma microbiota com baixo potencial patogênico.

\section{REFERÊNCIAS}

ALMEIDA, Luciana et al. Disbiose intestinal. Revista Brasileira de Nutrição Clínica, São Paulo, v. 24, n. 1, p. 58-65, jan. 2009. Disponível em: <file://C:/Users/Amanda/Documents/TCC/artigos\%20 em\%20inglês/Referências/ALMEIDA\%20et\%20al,\%202009. pdf>. Acesso em: 7 jul. 2019.

BARBOSA, Flávio et al. Microbiota indígena do trato gastrintestinal. Revista de biologia e ciência da terra, v. 10, n. 1, p.78-93, jun. 2010. Disponível em:<https://www.redalyc.org/pdf/500/50016930008. pdf>. Acesso em: 15 jul. 2019.

PENDERS, John et al. Quantification of Bifidobacterium pp., Escherichia coli and Clostridium difficile in faecal samples of breast-fed and formula-fed infants by real-time PCR. FEMS Microbiol Lett. Maastricht, v. 243, n. 1, p. 141-147, fev, 2005. Disponível em:<https:// academic.oup.com/femsle/article/243/1/141/434494>. Acesso em: 4 ago. 2019. 


\section{EFEITOS DOS NUTRIENTES ANTIOXIDANTES NO ESTRESSE OXIDATIVO INDUZIDO PELO EXERCÍCIO FÍSICO}

Amanda do Nascimento Souza $a^{81}$

\section{INTRODUÇÃO}

A adoção de uma alimentação equilibrada associada à prática de atividade física desempenha uma importante relação, pois proporciona benefícios na melhora do desempenho e rendimento físico do organismo, além de ajudar no gerenciamento do peso e na prevenção de diversas doenças (SOMMER et al., 2019). Durante a prática de exercício físico, ocorre o aumento do consumo de oxigênio, levando à formação de radicais livres, sobretudo quando os limites fisiológicos não são levados em consideração. Esses radicais livres são capazes de gerar efeitos deletérios nas células e tecidos, com implicações relevantes sobre a etiologia de inúmeras doenças. Portanto, a nutrição desempenha um papel muito importante, à medida que protege contra os danos oxidativos, através dos nutrientes denominados de antioxidantes (PINHO; SILVA, 2013).

\section{FUNDAMENTAÇÃOTEÓRICA}

O oxigênio molecular $(\mathrm{O} 2)$ é imprescindível ao metabolismo energético, principalmente durante os exercícios físicos, quando a demanda de oxi-

81 Bacharel em Nutrição. 
gênio é maior. Através desses processos metabólicos oxidativos, formados os radicais livres. Estes são definidos como espécies moleculares que apresentam elétrons desemparelhados em uma órbita atômica, sendo muitos deles altamente reativos e instáveis (LOBO et al., 2010). A produção excessiva desses radicais livres em detrimento da velocidade de remoção gera um estresse oxidativo. Este está associado à etiologia de várias doenças crônicas, como: câncer, obesidade, diabetes, aterosclerose, doenças neurodegenerativas e problemas cardiovasculares. Os radicais livres, quando não neutralizados corretamente, podem alterar a absorção dos alimentos, pois afetam diretamente as células do intestino, provocando inflamação nas articulações capazes de oxidar as moléculas de LDL, contribuindo para obstrução das artérias; atacam o material genético das células, destroem as células nervosas, além de danificar o esperma, levando à esterilidade (BRAGA, 2009). A alimentação tem papel importante na preservação do dano causado pelo estresse oxidativo, ao interagir com as espécies reativas de oxigênio (EROs). Desta forma, os nutrientes atuam de maneira cooperativa na preservação do estresse oxidativo e, consequentemente, na preservação de várias doenças (PINHO; SILVA, 2013; COLOMBO, 2013).

\section{METODOLOGIA}

Esta pesquisa é uma revisão de literatura em artigos científicos, originais e de revisão, com ênfase nos últimos 10 anos, quando foram publicados nas seguintes bases de dados: RBNE (Revista Brasileira de Nutrição Esportiva), Scielo (Scientific Eletronic Library On-line), Pubmed (National Library of Medicine) e Lilacs (Literatura Latino-americana e do Caribe em Ciências da Saúde). Os descritores selecionados para a pesquisa incluíram: antioxidantes, atividade física, estresse oxidativo e radicais livres. Foram considerados estudos publicados nos idiomas português e inglês e que continham, pelo menos, um dos descritores selecionados, bem como aqueles que abordassem a temática. Foram selecionados 17 artigos, dentre os cerca de 50 consultados.

\section{RESULTADOS E DISCUSSÃO}

A nutrição desempenha papel importante para proteção contra o estresse oxidativo induzido pelo exercício físico, através dos compostos antioxidantes dietéticos, tais como: carotenóides, vitamina 
C, vitamina E, zinco, cobre e selênio. Esses nutrientes são imprescindíveis para o funcionamento adequado de enzimas antioxidantes que constituem o principal sistema de defesa antioxidante do organismo, à medida que controlam os níveis intracelulares de radicais livres (PINHO; SILVA, 2013).

Colombo (2013) relata que os carotenoides são capazes de bloquear a carcinogênese, inibindo o crescimento de células tumorais pelo seu papel antioxidante, além de serem capazes de protegerem moléculas como lipídios, LDL, proteínas e DNA.

Diversos estudos também vêm relatando o papel da vitamina $\mathrm{C}$ e da vitamina E no estresse oxidativo. Segundo Murakami e colaboradores (2006), a vitamina C participa do mecanismo de proteção contra peroxidação lipídica por regenerar a vitamina E. O papel simbiótico da vitamina $\mathrm{C}$ e da vitamina $\mathrm{E}$ é bem esclarecido, elas interagem de maneira efetiva na inibição da peroxidação dos lipídios, bem como na proteção do DNA diante do estresse oxidativo ocasionado pelo exercício físico.

De acordo com Wessells et al. (2010), a suplementação de 10 a 20 $\mathrm{mg} /$ dia de zinco em na forma de sulfato de zinco durante 5 dias foi eficaz sobre o sistema antioxidante e imune, reforçando seu papel importante contra o estresse oxidativo no exercício físico. Akil e colaboradores (2011) observaram que a administração intraperitoneal de selênio $(6 \mathrm{mg} / \mathrm{Kg} / \mathrm{dia})$, durante quatro semanas em ratos que foram submetidos a uma sessão aguda de exercício de natação, elevou a concentração plasmática de enzimas antioxidantes associadas com a proteção do dano oxidativo, como GPx e SOD. E Pinho e Silva (2013) mostram que o cobre é essencial para a manutenção dos processos biológicos, à medida que o exercício físico e a dieta podem afetar o equilíbrio deste mineral e interferir nas ações pró e antioxidantes, em especial de atletas, devido ao elevado estresse oxidativo.

\section{CONCLUSÕES}

O estresse oxidativo pode contribuir para o surgimento de diversas doenças por meio de complexos mecanismos celulares e moleculares. Portanto, neutralizar a produção excessiva desses radicais livres é imprescindível na prática de exercícios físicos. Sendo assim, uma nutrição adequada, contemplando a ingestão de antioxidantes, principalmente através 
do consumo de vegetais e frutas, permite modular o estresse oxidativo e produzir uma ação efetiva e protetora, prevenindo e atenuando os danos celulares.

\section{REFERÊNCIAS}

PINHO, Wendel Luiz; SILVA, Adriana Pederneiras Rebeiro. Efeitos do exercício físico sobre a formação de espécies reativas de oxigênio e os compostos antioxidantes da dieta. Rev. Bras. de Nutr. Esportiva, São Paulo, v. 7, n. 37, p. 77-87, 2013. Disponível em:<http://www. rbne.com.br/index.php/rbne/article/view/369/361>. Acesso em: 05 jan. 2021.

SCHNEIDER, Cláudia Dornelles; OLIVEIRA, Alvaro Reischak de. Radicais livres de oxigênio e exercício: mecanismos de formação e adaptação ao treinamento físico. Rev Bras Med Esporte, Niterói, v. 10, n. 4, p. 308-313, 2004. Disponível em<http://www.scielo.br/scielo.php?script=sci_arttext\&pi$\mathrm{d}=\mathrm{S} 1517-86922004000400008 \& \operatorname{lng}=\mathrm{en} \& \mathrm{nrm}=\mathrm{iso}>$. Acesso em: 10 abr. 2021.

SILVA, Wallison Junio Martins da; FERRARI, Carlos Kusano Bucalen. Metabolismo mitocondrial, radicais livres e envelhecimento. Rev. bras. geriatr. gerontol., Rio de Janeiro, v. 14, n. 3, p. 441-451, 2011. Disponível em: $<$ http://www.scielo.br/scielo.php?script=sci_arttext\&pid=S1809-98232011000300005\&lng=en\&nrm=iso>. Acesso em: 10 abr. 2021. 


\section{PERSPECTIVAS COM O LETRAMENTO DIGITAL E REMOTO NA PRÁTICA PROFISSIONAL JURÍDICA INTRODUZIDA PELA RESOLUÇÃO № 2 DO CNE/CES}

Thiago de Souza Modesto ${ }^{82}$

\section{INTRODUÇÃO}

A Resolução no 2, de 19 de abril de 2021, do Conselho Nacional de Educação - Câmara de Educação Superior (CNE/CES), alterou o artigo 5ำ da Resolução nº 5/2018 do CNE/CES, trazendo novas disposições às Diretrizes Curriculares Nacionais dos Cursos de Direito. O objeto do presente resumo é analisar os possíveis impactos da alteração constante no artigo $1^{\circ}$ que alterou o inciso III do artigo $5^{\circ}$, referente à formação prático-profissional, especificamente no que tange à inclusão de "estudos referentes ao letramento digital, práticas remotas mediadas por tecnologias de informação e comunicação". O tema se justifica na medida em que a alteração do paradigma da prática jurídica presencial para a eletrônica gera impactos no processo ensino-aprendizado e na vida prática-profissional do aluno.

82 Mestrando em Direito Público e Evolução Social e especialista em Direito Civil e Processo Civil pela Universidade Estácio de Sá - UNESA. Coordenador do Núcleo de Práticas Jurídicas e professor do Centro Universitário de Barra Mansa - UBM. 


\section{FUNDAMENTAÇÃO TEÓRICA}

Em que pese a forma de exercício da advocacia e das carreiras jurídicas ter sido significativamente alterada ao longo dos tempos, podendo ser citado o processo eletrônico em substituição ao processo físico e as audiências virtuais em grande parte dos Tribunais do país, os cursos de Direito mantinham-se voltados às práticas jurídicas presenciais, até porque o curso de Direito sempre teve a tradição de ser predominantemente presencial. Antes da alteração apontada, boa parte das faculdades já contavam com disciplinas na modalidade on-line, fazendo com que o aluno buscasse o manuseio das ferramentas digitais. No entanto, é com a alteração nas Diretrizes Nacionais do Curso de Direito, no que se refere à prática-profissional, que tem ocorrido grande movimentação para atender a esta formação da maneira almejada pelo Ministério da Educação.

Nesse contexto, surgem as seguintes indagações: 1) Quais as possíveis barreiras a serem enfrentadas para a satisfatória implementação do letramento digital na prática jurídica remota? 2) Quais as expectativas de benefícios aos bacharéis em Direito, no longo prazo, com a mudança de paradigma da exclusividade de práticas jurídicas presenciais pelas práticas eletrônicas?

A Resolução em estudo enaltece a necessidade de formação do discente com conhecimento digital em duas frentes: inclui o Direito Digital como disciplina obrigatória na formação técnico-jurídica e abrange a necessidade do letramento digital e práticas remotas mediadas por tecnologias de informação e comunicação na formação prático-profissional.

No mundo contemporâneo e globalizado, é inimaginável a vida sem internet, redes sociais e recursos tecnológicos, especialmente para fins recreativos, educativos e profissionais. Esta nova era gera inúmeras possibilidade e novas formas de ensinar e aprender. Segundo Coscarelli (2014), "podemos e devemos usar o computador como meio de comunicação, como fonte de informação, que ajudará os alunos a responder suas pergunta, a levantar novos questionamentos, a desenvolver projetos e a confeccionar novos produtos".

Tal caminho não é diferente para o futuro operador do Direito que será colocado em constante necessidade de manejar recursos digitais, cabendo a este profissional se aperfeiçoar. Portanto, nada mais justo e realista que o 
ensino já enfoque os desafios que serão colocados na vida profissional do discente, considerando que a academia deve preparar o bacharelando nas três perspectivas formativas: geral, técnico-jurídica e prático-profissional.

No campo jurídico, a tramitação processual por meio eletrônico é uma iniciativa que busca a celeridade na prestação jurisdicional, além da economia com papel e espaço físico aos Tribunais que adotam.

Sobre a necessária atualização em consonância com a evolução da sociedade, uma possível tendência de resistência do educador precisa ser enfrentada:

Os professores ainda estão num modelo criado no século XIX, o de prisão e igreja, no qual o professor é um pregador e a interatividade é mínima. Mas a era polifônica obriga que o ambiente seja interativo. Eles precisam se abrir para as novas tecnologias e novas formas de pluralidade. (CECCHETTINI, 2011, p. 03)

A crítica feita não reflete a atuação da maioria dos profissionais de educação, havendo cada vez mais aplicação de metodologias ativas em sala de aula, objetivando um conhecimento interdisciplinar e pautado no diálogo entre educador e educandos.

Considera-se ainda uma grande mudança na realidade vivenciada pelos professores, desde o ano de 2020, os efeitos da pandemia da Covid-19, pois alteraram a forma pela qual as aulas são ministradas, mesmo nos ditos cursos integralmente presenciais. A rotina de aulas on-line, criação e disponibilização de links para acesso síncrono aos encontros, postagem de material de apoio nos ambientes virtuais de aprendizagem, utilização das mais variadas plataformas de ensino, fazem, desde então, parte do cotidiano de professores e alunos no ensino superior.

Outro problema a ser enfrentado é a falta de acesso a internet, que fatalmente prejudica a realização de atividades síncronas e o letramento digital. Um estudo do IPEA (Instituto de Pesquisa Econômica Aplicada) realizado no ano de 2020, apontou:

Seis milhões de estudantes brasileiros, da pré-escola à pós-graduação, não dispõem de acesso domiciliar à internet em banda larga ou em rede móvel 3G/4G para acompanhar aulas e outras atividades 
on-line. Destes, cerca de 5,8 milhões frequentam instituições públicas de ensino no país. (IPEA, 2020).

A conta da breve fundamentação tecida é de se observar que são possíveis estabelecer hipóteses de benefícios ao letramento digital nas práticas profissionais remotas no Curso de Direito, que acontecem por meio de atividades no Núcleo de Práticas Jurídicas (NPJ) e também de desafios a serem trabalhados para minimizar prejuízos e inefetividade a esta modalidade necessária e urgente de se desenvolver profissionalmente.

\section{METODOLOGIA}

Trata-se de pesquisa exploratória e qualitativa, realizada por meio de revisão bibliográfica e documental, especialmente tendo por base as Resoluções n⿳o 2/2021 e no 5/2018 do CNE/CES. Além disso, o resumo é fruto da experiência empírica do autor. Objetiva-se o levantamento de hipóteses para responder às perguntas propostas, a fim de se vislumbrar uma perspectiva sobre a recente alteração promovida pelo Ministério da Educação.

\section{RESULTADOS E DISCUSSÃO}

Como resultados, encontraram-se algumas possíveis respostas às indagações formuladas na fundamentação teórica, obtendo, em caráter preliminar:

1. Uma possível barreira a ser superada é a necessidade de buscar alternativas para os alunos que não possuam conectividade com a internet ou tecnologia em suas residências possam exercitar em condições de igualdade com os demais acadêmicos. Para tanto, são necessários laboratórios de informática com profissionais capacitados para atenderam as demandas nas Faculdades. Os professores devem estruturar as atividades de maneira que se torne possível a efetiva simulação do exercício real das profissões jurídicas, como é o caso da elaboração de processos simulados na sua íntegra, fixando-se prazos e regras, tal qual a prática forense exige do profissional. Por fim, deve haver um apoio pedagógico aos professores do Curso de Direito, especialmente para aqueles que tenham maior resistência ou falta de familiaridade com os recursos tecnológicos, a fim de que 
o processo de ensino-aprendizagem na modalidade remota não se torne uma mera retórica.

2. No longo prazo, a expectativa é a de que os bacharéis em Direito, já no exercício profissional, sintam uma menor distância entre o que se aprendeu na Faculdade e o que lhe é colocado no mercado de trabalho. A aproximação entre o estudo e a prática - da maneira mais realista possível - só tem a contribuir com a completa formação que se busca de um profissional da área jurídica, profissional este que necessita aprender e pôr em prática muitos conhecimentos que vão bem além do aprendizado dogmático. As carreiras jurídicas caminham no sentido de uma constante modernização e superação da imagem do Poder Judiciário abarrotado de papéis e pessoas pelos Fóruns. Esta mudança já vem ocorrendo gradativamente, tendo se fortalecido no momento de pandemia.

\section{CONCLUSÕES}

Observa-se que as mudanças no processo ensino-aprendizagem devem acompanhar a própria evolução da sociedade e a forma como esta recebe os bacharéis em Direito na vida profissional. Não mais se justifica um ensino preso ao tradicionalismo dos tempos de outrora, eis que não irão contribuir de forma efetiva com as perspectivas formativas propostas pela Resolução no 2/2021 do CNE/CES. A transição entre o ensino da prática jurídica presencial para virtual já está ocorrendo neste momento de pandemia, porém ainda não há segurança para atestar como as faculdades trabalharão o letramento digital de forma definitiva, cabendo às instituições de ensino pensarem nos desafios que possam se colocar.

Repensar a forma de transmitir o conhecimento prático-profissional deve ser feito a partir das constatações factíveis do que o bacharel encontrará no mercado de trabalho, sabendo-se que cada vez mais este exige expertise aos meios tecnológicos, situação que a Resolução em análise buscou contemplar na formação prático-profissional e na formação técnico-jurídica.

\section{REFERÊNCIAS}

BRASIL. Ministério da Educação. Resolução no 2, de 19 de abril de 2021. Disponível em: http://portal.mec.gov.br/index.php?option=- 
com_docman\&view=download\&alias=181301-rces002-21\&category_slug=abril-2021-pdf\&Itemid=30192. Acesso em: 02 maio 2021.

CECCHETTINI, Eliane El Badouy. Introdução. In: VERAS, Marcelo et al. (Org). Introdução: Inovação e métodos de ensino para nativos digitais. São Paulo: Atlas, 2011. p. 1-18.

COSCARELLI, Carla. Alfabetização e letramento digital. In: COSCARELLI, Carla et al. (Org). Letramento digital: aspectos sociais e possibilidades pedagógicas. Belo Horizonte: Ceale; Autêntica Editora, 2014. p. 31-40.

IPEA. Ipea analisa estratégias para universalizar o ensino remoto na pandemia. Disponível em:https://www.ipea.gov.br/portal/ index.php?option $=$ com_content\&view $=$ article\&id $=36560$. Acesso em: 02 maio 2021.

TJRJ. Processo eletrônico. Disponível em: http://www.tjrj.jus.br/web/ guest/processo-eletronico/apresentacao. Acesso em: 02 maio 2021. 


\title{
A PERCEPÇÃO DOS PROFESSORES UNIVERSITÁRIOS SOBRE O TRABALHO REMOTO: LIMITES E POSSIBILIDADES
}

\author{
Otília Maria A. N. A. Dantas ${ }^{83}$ \\ Lidiane Oliveira Eduardo Mota ${ }^{84}$ \\ Pauliane Duarte de Almeida ${ }^{85}$ \\ Rafael Rodrigues de Melo ${ }^{86}$
}

\section{INTRODUÇÃO}

Este resumo expandido se propõe a compreender a percepção dos professores universitários sobre o trabalho remoto, seus limites e possibilidades. Serão abordados os desafios referentes ao acesso à universidade e à evolução do ensino a distância, modalidade que teve seu processo acelerado em virtude da pandemia de Covid-19, culminando no ensino remoto.

83 PhD em Educação pela Universidade de Brasília. Doutora e mestre em Educação pela Univerdsidade Federal do Rio Grande do Norte. Graduada em Pedagogia. Professora permanente dos PPGE da Faculdade de Educação da Universidade de Brasília.

84 Mestranda do Programa de Pós-graduação em Educação, Modalidade Profissional pela Universidade de Brasília. Graduada em Pedagogia pela Universidade de Brasília.

85 Mestranda do Programa de Pós-Graduação em Educação, Modalidade Acadêmica pela Universidade de Brasília. Graduada em Pedagogia pela Faculdade Michelangelo.

86 Mestrando do Programa de Pós-Graduação em Educação, Modalidade Profissional pela Universidade de Brasília. Graduado em Farmácia pelo Centro Universitário Euroamericano. 
Para entender como vem ocorrendo o trabalho dos docentes no contexto das universidades em tempos de pandemia e os desafios frente a essa nova realidade, foi elaborado um formulário on-line para professores dos Programas de Pós-Graduação da Faculdade de Educação da Universidade de Brasília, modalidade acadêmica e profissional.

\section{FUNDAMENTAÇÃO TEÓRICA}

A trajetória da educação superior brasileira é marcada por sucessivas reformas e conquistas de movimentos sociais. Morhy (2014) aponta os desafios da pós-graduação, que passou a apresentar progressos significativos a partir da década de 80. Dentre os quais, podemos citar o marco inicial e pioneiro que aconteceu na Universidade de Brasília, a implantação do Programa de Ensino a Distância (PED) na Faculdade de Educação. Na época a UNB recebeu um grande número de alunos para fazer cursos à distância e essa implementação da nova modalidade se mostrou um grande desafio a ser enfrentado pela academia.

Historicamente as Universidades no Brasil passaram e ainda passam por desafios significativos, dentre os quais a implementação do ensino à distância, decorrente do avanço das tecnologias e mudanças sociais, por meio de políticas públicas de expansão do ensino, que permitiu o acesso às universidades, de estudantes em vulnerabilidade social e baixa renda. Em 2019, a ANDIFES (Associação Nacional dos Dirigentes das Instituições Federais de Ensino Superior) divulgou uma pesquisa que traçava o perfil socioeconômico dos estudantes das universidades federais, e a constatação foi que 70\% dos estudantes são oriundos de famílias de baixa renda (ANDIFES, 2019). Entretanto, o ano de 2020 trouxe um desafio nunca vivido por essa geração: a pandemia da Covid-19 causada pelo coronavírus. Essa doença vem causando impactos epidemiológicas em escala global, não se restringindo à área da saúde, mas com consequências sociais, econômicas, políticas, históricos. $\mathrm{Na}$ educação, não foi diferente. No ensino superior, o reflexo disso foram as universidades fechadas e os alunos distantes da sala de aula. O distanciamento, o isolamento social e a suspensão das aulas presenciais obrigaram os gestores da educação a buscar meios de inovar e dar andamento ao ensino, especialmente no segundo semestre de 2020. 
Diante do exposto, a pesquisa que realizamos teve como objetivo compreender a percepção de professores universitários sobre o trabalho remoto, considerando seus limites e possibilidades. Como objetivos específicos destacamos: delinear questões referentes ao acesso à universidade e à evolução do ensino a distância; analisar os desafios do ensino à distância e do ensino remoto; desvelar, com base nas perspectivas dos docentes universitários, os limites e possibilidades do ensino remoto.

\section{METODOLOGIA}

Para analisar os desafios do ensino à distância e do ensino remoto, foi aplicado um formulário on-line, por meio do Google Forms, a professores universitários dos Programas de Pós-Graduação da Faculdade de Educação da Universidade de Brasília, modalidades acadêmica e profissional. O questionário continha sete perguntas, sendo três objetivas e quatro subjetivas. O Termo de Consentimento Livre e Esclarecido foi incorporado ao formulário, contendo todas as informações como objetivos e funcionalidade do questionário, além do contato das pesquisadoras. Ao todo, cinco professores participaram. Esse número, embora pequeno, nos traz apontamentos para compreender a percepção de professores universitários sobre o trabalho remoto, considerando seus limites e possibilidades.

Vale salientar que para garantir o anonimato dos docentes daremos os seguintes signos a estes: DES01, DES02, DES03, DES04 e DES05.

\section{RESULTADOS E DISCUSSÃO}

Os professores pesquisados nos apresentaram um olhar bastante significativo sobre o ensino remoto e a educação à distância. Iremos, no entanto, apresentá-los primeiro. Sobre a situação funcional, a maioria desses docentes universitários são efetivos na Universidade de Brasília (figura 1). 
Figura 1. Situação Funcional dos docentes universitários

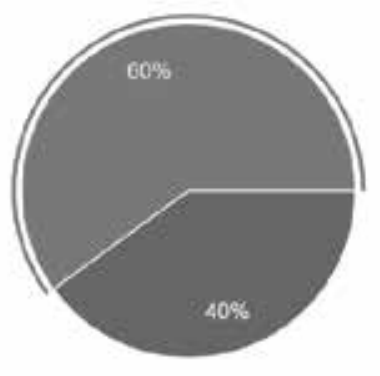

DOCENTE ASSOCIADO

DOCENTE TITULAR

DOCENTE SUBSTITUTO

DOCENTE COLABORADOR

Fonte: elaborado pelos autores.

Com relação ao tempo de atuação, estes docentes possuem mais de 20 anos de trabalho na docência superior (figura 2).

Figura 2. Tempo de docência no ensino superior

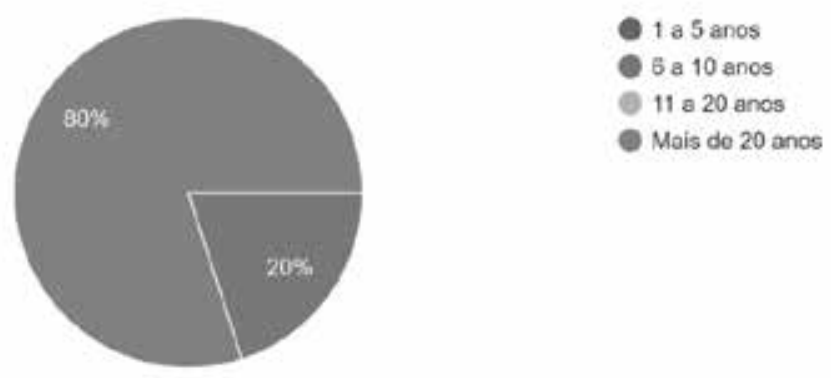

Fonte: elaborado pelos autores.

No que diz respeito à formação, parte dos professores são doutores e outra parte tem $\mathrm{PhD}$.

Ao serem questionados sobre a percepção que possuem sobre o trabalho remoto antes da pandemia, os docentes, de uma forma ou de outra, consideram que o trabalho poderia ser viável pois:

Antes da pandemia já trabalhava na EaD. Sempre achei o trabalho remoto viável, sempre que consideradas suas características: 
necessidade de organização e planejamento da rotina de trabalho, disciplina em relação a essa organização, domínio de ferramentas diversas etc. (DES01).

Que seria possível interagir com qualidade, mas muito limitado (DES03).

Sempre utilizei o contexto remoto como parte da disciplina presencial (DES05).

Deste modo o ensino remoto sempre esteve inserido nos diferentes tempos/espaços de formação, mesmo antes da pandemia, embora de modo ocasional e pouco explicito.

Quando indagados sobre os principais desafios encontrados na modalidade de ensino remoto, os docentes responderam que:

O fato de que os discentes não tiveram preparação nem escolha (DESO2).

A organização do tempo por parte dos estudantes e dos diferentes grupos de trabalho. Uso de muitos recursos sem a formação necessária, é difícil dominar adequadamente, em pouco tempo, todas as ferramentas de trabalho disponíveis. Adequação de rotinas de trabalho presencial em pouco tempo (DES04).

O acesso dos alunos. A falta de infraestrutura de rede do país. Ainda que pagando por uma internet de qualidade o serviço dá muito problema preparar o material didático e organizar atividades de interação (DES01)

Para estes docentes o suporte tecnológico e adaptar o pedagógico a este suporte de qualidade duvidosa foi desafiador para realização do ensino remoto e a efetivação da aprendizagem.

Ainda questionamos sobre a percepção que estes docentes possuem sobre o ensino remoto hoje. Uma das repostas chamou atenção pelo discurso que resume bem o atual cenário:

Que há plataformas muitos robustas, as quais oferecem muitas ferramentas interessantíssimas; que algumas práticas digitais se popu- 
larizaram muito rápido, assim como algumas ferramentas como, por exemplo, a streamyard, e outras de palestras ao vivo. Tudo isso veio a acrescentar ao trabalho docente e educativo. Mas, ainda assim, é necessário um investimento muito grande na parte de estruturação do processo pedagógico e uma equipe muito bem qualificada para a gestão dos processos de aprendizagem remotos. Não é um tipo de trabalho para um professor sozinho. Há que se pensar colaborativamente. É uma outra concepção de práticas e processos. Além do mais, há que se investigar mais sobre os processos de aprendizagem dos educandos e pensar como as interações podem ser mais dialógicas e não tão unidirecional. (DES04)

Como bem citou o docente acima, não basta a vontade política e pedagógica para se desenvolver o ensino remoto hoje; é preciso haver um forte investimento em infraestrutura, bem como formação continuada destes docentes no intuito de traduzir o pedagógico no tecnológico considerando, principalmente, os diferentes estilos de aprendizagem.

\section{CONCLUSÕES}

Por meio das percepções dos docentes universitários percebe-se que há o reconhecimento do ensino remoto como modalidade de ensino, pois viabilizaram o trabalho docente de modo criativo e dinâmico. No entanto, verificou-se ainda que, para se tornar algo de fato eficaz, muito deve ser feito em relação à infraestrutura, planejamento pedagógico, acesso com qualidade e, principalmente formação continuada destes docentes universitários no que se refere ao uso das TICs, principalmente na superação da desigualdade social.

De fato, os progressos educacionais realizados pelo Brasil na segunda metade da década de 80 foram notáveis. Mesmo assim, esses avanços não foram suficientes para satisfazer adequadamente às demandas existentes tendo em vista que as exigências da sociedade mudaram devido as transformações tecnológicas, sociais e epidemiológicas.

\section{REFERÊNCIAS}

ANDIFES, Associação Nacional dos Dirigentes de Instituições Federais de Ensino Superior. V Perfil socioeconômico e cultural dos 
estudantes de graduação das Instituições Federais de Ensino Superior. 2019.

BEHAR, Patrícia Alejandra. O ensino remoto emergencial e a educação à distância. In: www.ufrgs.br. Diponível em: https://www.ufrgs. br/coronavirus/base/artigo-o-ensino-remoto-emergencial-e-a-educacao-a-distancia/. Acesso em: 03 dez. 2020.

MORHY, Lauro (Org.). Universidade no mundo: universidade em questão, v.2. Brasília: Editora UnB, 2004. p 25-60. 



\section{EDUCAÇÃO: VISÕES E ESTRUTURAS}

Cristina Rolim Wolffenbüttel, Janilton de Lima Almeida, José Morais Souto Filho, Karina Medeiros Pirangy de Souza (orgs.)

Tipografias utilizadas:

Família Museo Sans (títulos e subtítulos)

Bergamo Std (corpo de texto)

Papel: Offset $75 \mathrm{~g} / \mathrm{m} 2$

Impresso na gráfica Trio Studio

Setembro de 2021 